\title{
Tensile and Creep-Rupture Evaluation of a New Heat of Haynes Alloy 25
}

February 2007

Prepared by

John P. Shingledecker, Principal Investigator

with Darryl B. Glanton, Ralph L. Martin, Brian L. Sparks, and Robert W. Swindeman

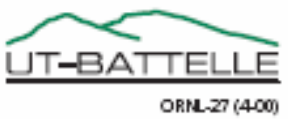




\section{DOCUMENT AVAILABILITY}

Reports produced after January 1, 1996, are generally available free via the U.S. Department of Energy (DOE) Information Bridge:

Web site: http://www.osti.gov/bridge

Reports produced before January 1, 1996, may be purchased by members of the public from the following source:

National Technical Information Service

5285 Port Royal Road

Springfield, VA 22161

Telephone: 703-605-6000 (1-800-553-6847)

TDD: 703-487-4639

Fax: 703-605-6900

E-mail: info@ntis.fedworld.gov

Web site: http://www.ntis.gov/support/ordernowabout.htm

Reports are available to DOE employees, DOE contractors, Energy Technology Data Exchange (ETDE) representatives, and International Nuclear Information System (INIS) representatives from the following source:

Office of Scientific and Technical Information

P.O. Box 62

Oak Ridge, TN 37831

Telephone: 865-576-8401

Fax: 865-576-5728

E-mail: reports@osti.gov

Web site: http://www.osti.gov/contact.html

This report was prepared as an account of work sponsored by an agency of the United States Government. Neither the United States government nor any agency thereof, nor any of their employees, makes any warranty, express or implied, or assumes any legal liability or responsibility for the accuracy, completeness, or usefulness of any information, apparatus, product, or process disclosed, or represents that its use would not infringe privately owned rights. Reference herein to any specific commercial product, process, or service by trade name, trademark, manufacturer, or otherwise, does not necessarily constitute or imply its endorsement, recommendation, or favoring by the United States Government or any agency thereof. The views and opinions of authors expressed herein do not necessarily state or reflect those of the United States Government or any agency thereof. 
ORNL/TM-2006/609

Tensile and Creep-Rupture Evaluation of a New Heat of Haynes Alloy 25

\author{
John P. Shingledecker ${ }^{1}$, Principal Investigator \\ with \\ Darryl B. Glanton ${ }^{1}$, Ralph L. Martin ${ }^{1}$, Brian L. Sparks ${ }^{1}$, Robert W. Swindeman ${ }^{2}$ \\ ${ }^{1}$ Oak Ridge National Laboratory, Materials Science and Technology Division, Oak Ridge, TN, USA \\ ${ }^{2}$ Retired, Oak Ridge National Laboratory, Metals \& Ceramics Division, Oak Ridge, TN, USA
}

February 2007

Prepared by

OAK RIDGE NATIONAL LABORATORY

P.O. Box 2008

Oak Ridge, Tennessee 37831-6285

managed by

UT-Battelle, LLC

for the

U.S. DEPARTMENT OF ENERGY

under contract DE-AC05-00OR22725 



\section{CONTENTS}

Page

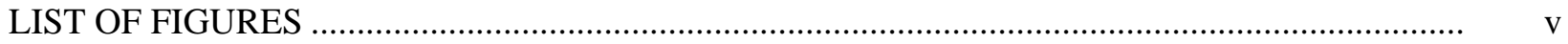

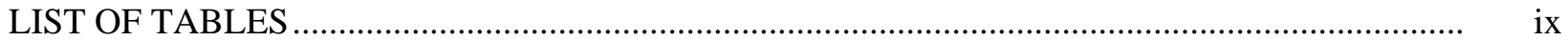

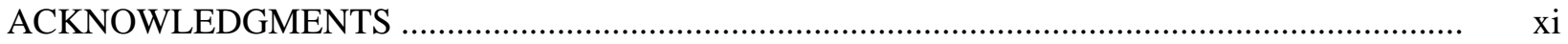

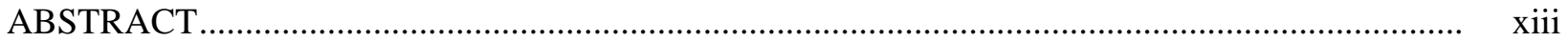

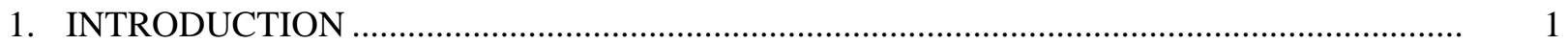

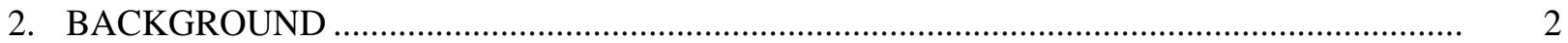

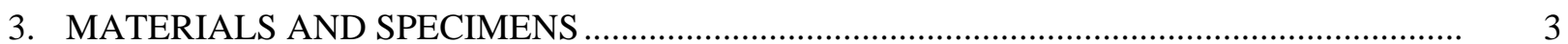

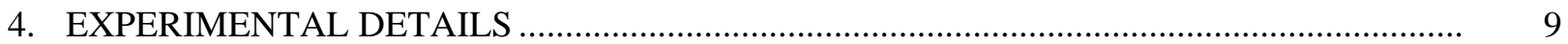

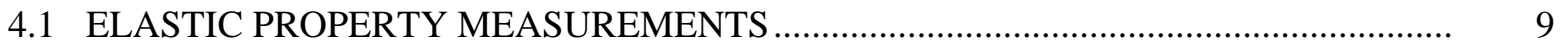

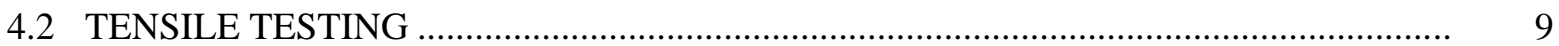

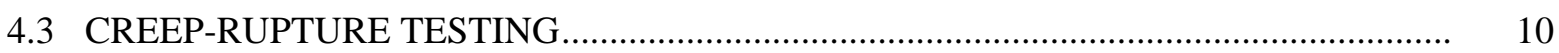

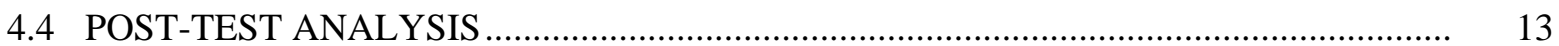

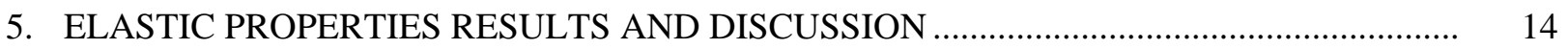

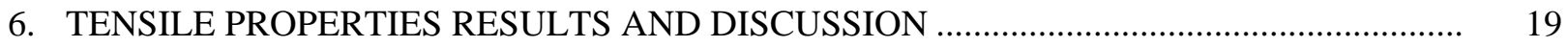

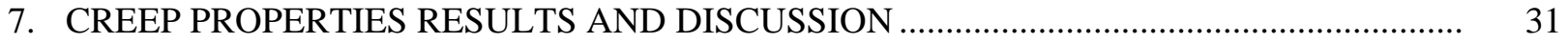

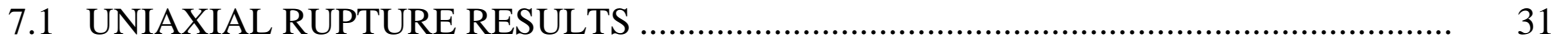

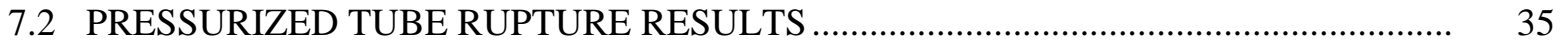

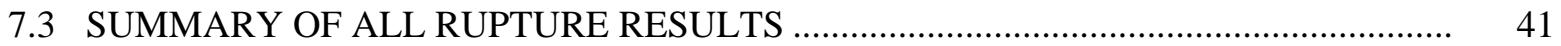

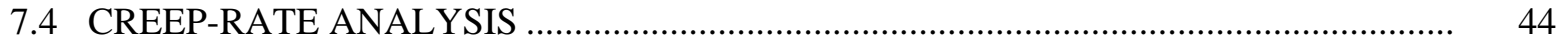

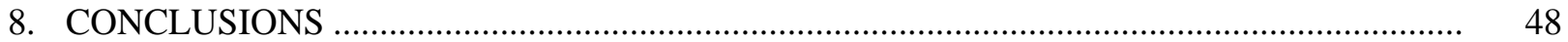

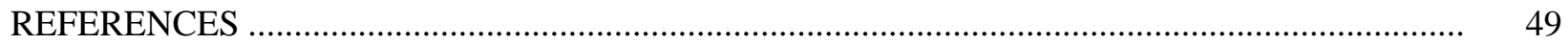

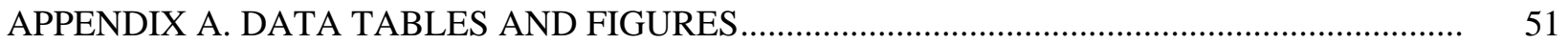

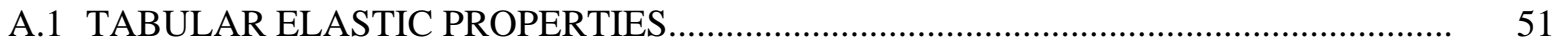

A.2 TABULAR TENSILE PROPERTIES ................................................................................. 52

A.3 TABULAR UNIAXIAL CREEP AND CREEP-RUPTURE DATA .................................. 54

A.4 TABULAR PRESSURIZED TUBE RUPTURE DATA …............................................... 57

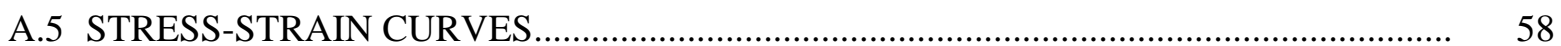

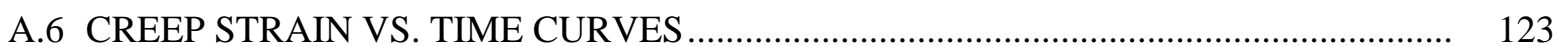

A.7 HISTORICAL SUMMARY OF HAYNES 25 TENSILE DATA …................................. 179

A.8 HISTORICAL SUMMARY OF HAYNES 25 CREEP-RUPTURE DATA....................... 188 



\section{LIST OF FIGURES}

Figure

Page

3.1 Metallographic images of the alloy 25 as-received material ...............................................

3.2 Specimen drawing for alloy 25 plate creep and tensile specimens .................................... 5

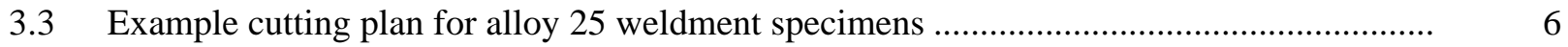

3.4 Uniaxial weldment specimens taken from tubular machined bar ................................... 7

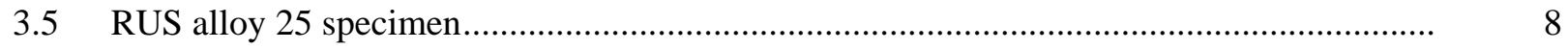

4.3.1. Schematic of pressurization and control system for high-temperature pressurized creep testing of tubular specimens.

4.3.2 Furnace detail for high-temperature pressurized creep testing showing the tubular specimen, the thermocouple placement, the stainless steel canister, the gas inlet and outlet, and the pressure stem

5.1 Plot of elastic modulus vs. temperature for this heat of alloy 25 (aged $=$ aged at $675^{\circ} \mathrm{C}$ for 6,000 hours) and compared to the Haynes Datasheet data [15]

5.2 Plot of shear $(\mathrm{G})$ and bulk (K) modulus vs. temperature for this heat of alloy 25 (aged $=$ aged at $675^{\circ} \mathrm{C}$ for 6,000 hours)

5.3 Plot of Poisson's ratio vs. temperature for this heat of alloy 25 (aged $=$ aged at $675^{\circ} \mathrm{C}$ for 6,000 hours).

5.4 Reconstructed TTT diagram for Haynes alloy 25.

6.1 Measured Yield Strength (YS) and Ultimate Tensile Strength (UTS) as a function of temperature for base metal (BM) and weldments (WM) of Haynes alloy 25 sheet and cross-weldments of Haynes alloy 25 bar product in the as-received condition and after aging at $675^{\circ} \mathrm{C}$ for 6,000 and 12,000 hours ..........

6.2 Measured ductility, elongation (EL) and reduction of area (RA), as a function of temperature for base metal (BM) and weldments (WM) of Haynes alloy 25 sheet and cross-weldments of Haynes alloy 25 bar product in the as-received condition and after aging at $675^{\circ} \mathrm{C}$ for 6,000 and 12,000 hours

6.3 Tensile Elongation and the difference in Uniform Elongation and Elongation as a function of temperature for alloy 25 unaged and aged sheet and bar products.

6.4 Room temperature strength and ductility as a function of aging time at $675^{\circ} \mathrm{C}$ for alloy 25

6.5 Strength and ductility at $650^{\circ} \mathrm{C}$, as a function of aging time at $675^{\circ} \mathrm{C}$ for alloy $25 \ldots \ldots \ldots \ldots . . . .25$

6.6 Room temperature tensile properties as a function of 1,000 hour aging temperature .......... 26 
6.7 Measured Yield Strength (YS) and Ultimate Tensile Strength (UTS) for Haynes alloy 25 sheet (as-received, no aging) as a function of temperature compared to the historical database for annealed alloy 25

6.8 Measured ductility for Haynes alloy 25 sheet (as-received, no aging) as a function of temperature compared to the historical database for annealed alloy 25

6.9 Measured Yield Strength (YS) and Ultimate Tensile Strength (UTS) for Haynes alloy 25 sheet weldments (no aging) as a function of temperature compared to the historical database for alloy 25 weldments

6.10 Measured ductility for Haynes alloy 25 sheet weldments (no aging) as a function of temperature compared to the historical database for alloy 25 weldments

7.1 Larson-Miller Parameter (LMP) vs. Stress (log scale) for all material conditions

7.2 Larson-Miller Parameter (LMP) vs. Stress (log scale) for all material conditions and the historical database

7.3 Actual life versus predicted life (LMP analysis)

7.4 Rupture ductility as a function of rupture time for all material conditions compared to the historical database

7.5 Creep curves (time vs. creep strain) for the four material conditions tested at $800^{\circ} \mathrm{C}$ and $103 \mathrm{MPa}(15 \mathrm{ksi})$

7.6 Actual vs. predicted life for pressurized tube creep-rupture tests analyzed using the Von Mises (VM) stress criterion for the inner (ID) and outer (OD) diameter elastic (Lame) and steady-state creep (Bailey) solutions

7.7 Actual vs. predicted life for pressurized tube creep-rupture tests analyzed using the stress intensity (SI) stress criterion (Tresca) for the inner (ID) and outer (OD) diameter steady-state creep (Bailey) solutions and for the reference stress solution (Tresca) .............

7.8 Typical micrograph of a region near the creep fracture of a pressurized tubular creep specimen

7.9 Quantitative metallographic results for crack depth (left) and crack spacing (right) as a function of test temperature and location (ID and OD) for selected tubular specimens

7.10 Plots of isothermal rupture data from 650 to $750^{\circ} \mathrm{C}$

7.11 Plots of isothermal rupture data from 800 to $900^{\circ} \mathrm{C}$

7.12 Plots of isothermal rupture data at 925 and $950^{\circ} \mathrm{C}$

7.13 Minimum creep rate versus stress for various temperatures 
7.14 Activation energy determination plot of inverse absolute temperature versus minimum creep rate divided by stress $\wedge$ n $(n=8)$.......

7.15 Stress versus diffusion compensated minimum creep rate (min. creep rate / $\mathrm{D}_{0} \exp$ (-Q/RT) for all material conditions ... 



\section{LIST OF TABLES}

Table

Page

1. Composition of Haynes alloy 25 used in this study .......................................................

2. Calculated kinetic constants for alloy 25 strength and ductility aged at $675^{\circ} \mathrm{C} \ldots \ldots \ldots \ldots \ldots \ldots . . . . . . . . . .23$

3. Standard error of estimate* (SEE) for tube rupture results ............................................... 40

A.1.1 Elastic properties of Haynes alloy 25 (Heat \# 1860-8-1391) before and after aging at

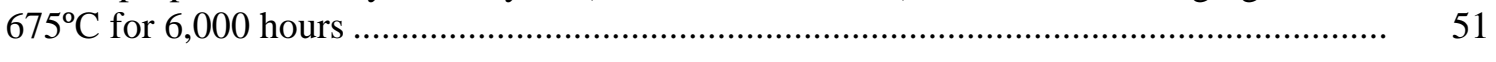

A.2.1 Tensile properties of Haynes alloy 25 (Heat \# 1860-8-1391) ............................................. 52

A.2.2 Tensile properties of Haynes alloy 25 GTA weldments .................................................. 53

A.3.1 Creep and stress-rupture data for Haynes alloy 25 (Heat \# 1860-8-1391)........................... 54

A.3.2 Creep and stress-rupture data for Haynes alloy 25 weldments (Heat \# 1860-8-1391)........... 56

A.4.1 Rupture data for Haynes alloy 25 pressurized creep tests on tubes .................................. 57

A.7.1 Alloy 25 (L-605) historical tensile data for annealed material........................................ 179

A.7.2 Alloy 25 (L-605) historical tensile data for welded material .......................................... 183

A.7.3 Alloy 25 (L-605) historical tensile data for aged material .................................................. 185

A.8.1 Alloy 25 (L-605) historical creep and stress-rupture data.............................................. 188

A.8.2 Alloy 25 (L-605) historical creep and stress-rupture data for weldments............................ 194 



\section{ACKNOWLEDGEMENTS}

The authors would like to acknowledge the contributions of James F. King for his leadership on the program, Peyton Moore for his past leadership of the program, Roger Miller and Edgar Lara-Curzio for reviewing this report, Tim McGreevy for helpful discussions, Tom Geer for his assistance with metallography, Chris Stevens for performing some of the tensile tests, personnel from INL and LANL for providing the materials used in this study, Laura Riester for help with the elastic property measurements, and Christine Goudy for spending countless hours formatting this report. 



\begin{abstract}
From 1999 to 2006, a program was undertaken within the Materials Science and Technology Division, formerly the Metals and Ceramics Division, of Oak Ridge National Laboratory to characterize the tensile and creep-rupture properties of a newly produced heat of Haynes alloy 25 (L-605). Tensile properties from room temperature to $1100^{\circ} \mathrm{C}$ were evaluated for base material and welded joints aged up to 12,000 hours at $675^{\circ} \mathrm{C}$. Creep and creep-rupture tests were conducted on base metal and cross-weldments from 650 to $950^{\circ} \mathrm{C}$. Pressurized tubular creep tests were conducted to evaluate multiaxial creep-rupture response of the material. Over 800,000 hours of creep test data were generated during the test program with the longest rupture tests extending beyond 38,000 hours, and the longest creep-rate experiments exceeding 40,000 hours.
\end{abstract}





\section{INTRODUCTION}

Haynes alloy 25 (alloy 25), originally referenced as L-605, is a cobalt-based superalloy with good fabricability, high-temperature strength, and corrosion resistance. Most of the high-temperature data required for design of Haynes alloy 25 components, creep and tensile properties of base material and weldments, were summarized in 1970 by Swindeman [1]. All of the available literature was again reviewed by Swindeman in 1998 [2], and it was concluded that additional long-term data on a new heat of material would be needed for improved design and material analysis. Furthermore, it was recognized that new data on multiaxial creep effects would be useful, and therefore it was proposed that internally pressurized creep tests on tubular specimens of varying wall thicknesses be conducted. Based upon these recommendations, a test program to evaluate the tensile and creep properties of a new heat of alloy 25

was started. This report summarizes the results of this program, and an appendix containing the historical data (based largely on the summaries by Swindeman) and the data produced on this program is included. 


\section{BACKGROUND}

A summary of the historical database for alloy 25 is provided in appendix subsections A.7 and A.8. Section A.7 contains the tensile data and section A.8 contains the stress and creep-rupture data. The tensile data are taken from the review of Slunder [3]. The data from Slunder's work includes references $[1,4,14,15,16]$. The stress and creep-rupture data are taken from Simmons and Cross [4], Baughman [5], Green et al. [6], Sandrock et al. [7], Conrad et al. [8], Flagella and McCullough [9], Yukawa and Sato [10], and Widmer et al. [11,12]. Stress-rupture data for weldments were included in some of the references: [1,4,5, and 8]. In general, the stress and creep-rupture data were of short duration. Only Widmer provided creep data beyond 10,000 hours. Over 200 tests are included in the historical database, but the total test durations for these tests are less than 200,000 hours.

A new heat of alloy 25 material was obtained for this study (details in section 3.0). Plate and bar product were evaluated. Dynamic elastic properties from room temperature to $1100^{\circ} \mathrm{C}$ were measured for the heat in the as-received mill-annealed condition and after aging at $675^{\circ} \mathrm{C}$. Tensile tests from room temperature to $1100^{\circ} \mathrm{C}$ were performed on base metal and weldments aged up to 12,000 hours at $675^{\circ} \mathrm{C}$. Creep and stress-rupture tests were conducted on base metal and weldments; this included aged material in addition to material in the as-received mill annealed condition. Creep-rupture test temperatures ranged from $650^{\circ} \mathrm{C}$ to $950^{\circ} \mathrm{C}$ for times in excess of 38,000 hours. Pressurized creep-rupture tests on tubular specimens were also conducted for two sizes of tubes at similar creep conditions. 


\section{MATERIAL AND SPECIMENS}

The alloy 25 base metal material was received from Babcock \& Wilcox of Ohio, Inc (Mound Laboratories) as 0.14-in. (3.3-mm) thick plate processed to meet the AMS 5537C specification. The vendor chemistry and the nominal composition of the alloy are given in Table 1 . The vendor reported the following tensile properties: $67.5 \mathrm{ksi}$ (465 MPa) yield strength, $114 \mathrm{ksi}$ (786 MPa) ultimate strength, and $52 \%$ elongation. Additional alloy 25 bar material, machined into the form of tubes, from the same heat of material was received from Idaho National Laboratory (INL) and Los Alamos National Laboratory (LANL). The grain size of the plate and the machined bar product were measured as an ASTM No. 4-5 (60-90 $\mu \mathrm{m})$ and No. 7-8 (23-32 $\mu \mathrm{m})$, respectively. Metallographic images of the asreceived materials are shown in figure 3.1. Although the bar product had a finer average grain size than the plate, a number of larger grains similar in size to the plate grain size were observed in the bar material. Twining was evident within most grains, and in some areas it was difficult to differentiate grain boundaries from twin boundaries. All materials were received in the solution annealed condition, and the purchase specification required that the material have an ASTM grain size number of four or greater to reduce the materials susceptibility to hot cracking during welding.

Table 1. Composition of Haynes Alloy 25 used in this study

\begin{tabular}{|c|c|c|c|c|c|c|c|c|c|c|}
\hline \multirow[b]{2}{*}{ ID } & \multicolumn{10}{|c|}{ Element (wt\%) } \\
\hline & C & $\mathrm{Cr}$ & $\mathrm{Fe}$ & $\mathrm{Mn}$ & $\mathrm{Ni}$ & $\mathrm{P}$ & S & $\mathrm{Si}$ & W & Co \\
\hline $\begin{array}{c}\text { Haynes Heat \# } \\
1860-8-1391\end{array}$ & 0.11 & 20.23 & 2.34 & 1.51 & 10.32 & 0.008 & 0.002 & 0.16 & 14.77 & Bal. \\
\hline $\begin{array}{c}\text { AMS 5796C } \\
.035 ” \text { Dia.Weld } \\
\text { Wire Heat \# } \\
\text { 1860-8-1362 }\end{array}$ & 0.12 & 20.13 & 2.51 & 1.46 & 10.58 & 0.012 & 0.003 & 0.22 & 15.43 & Bal. \\
\hline $\begin{array}{c}\text { Nominal } \\
\text { Composition }\end{array}$ & 0.10 & 20 & $3^{*}$ & 1.5 & 10 & --- & --- & $0.4^{*}$ & 15 & $\begin{array}{c}51 \\
\text { (Bal) }\end{array}$ \\
\hline
\end{tabular}

*Maximum 

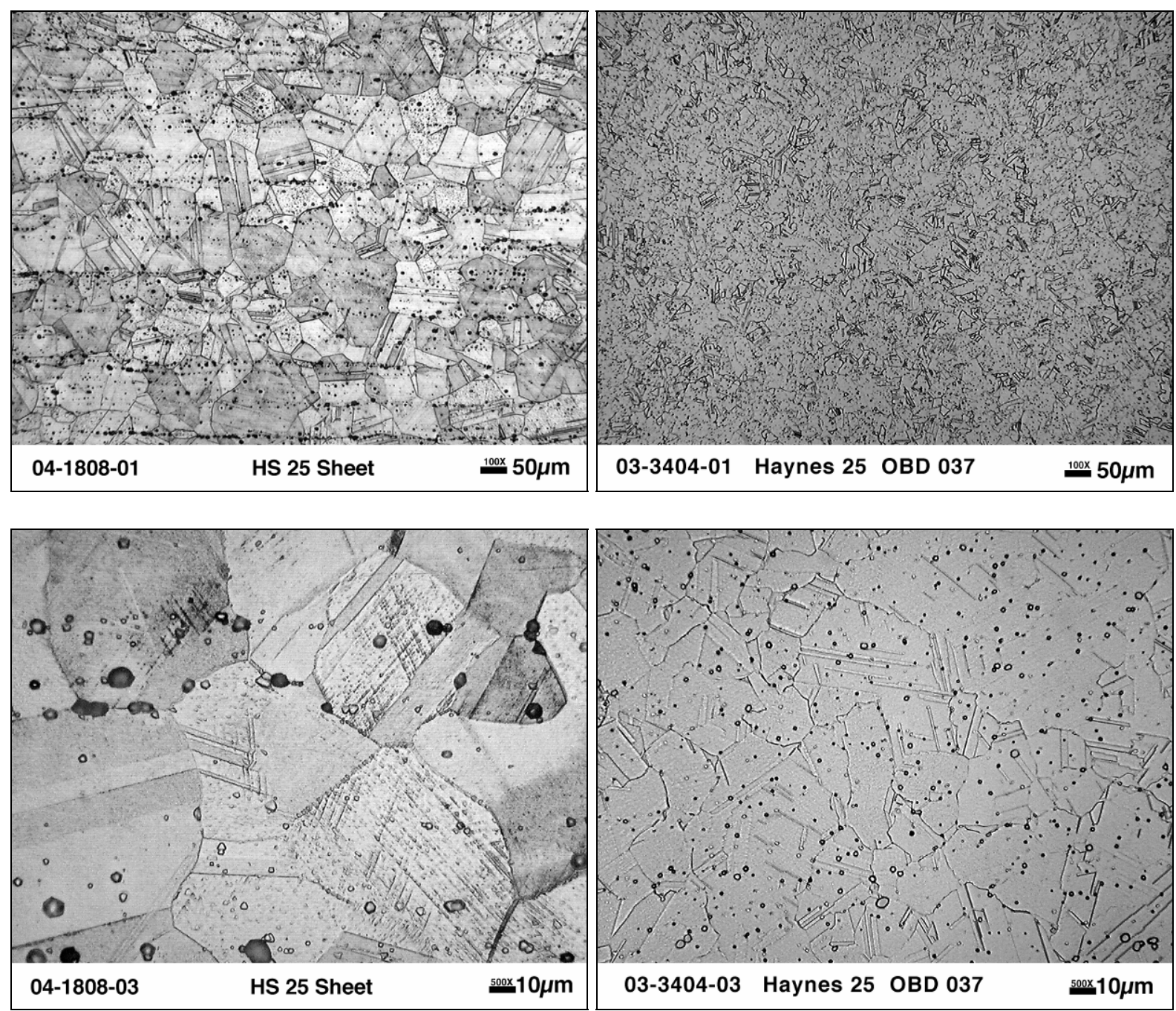

Figure 3.1. Metallographic images of the alloy 25 as-received material. sheet - left, machined bar (tube) - right.

The plate was sheared into several pieces and coupons were cut for the preparation of tensile and creep testing specimens. Plate-type specimens were machined with the uniform gage section parallel to the primary rolling direction of the sheet with dimensions shown in figure 3.2. 


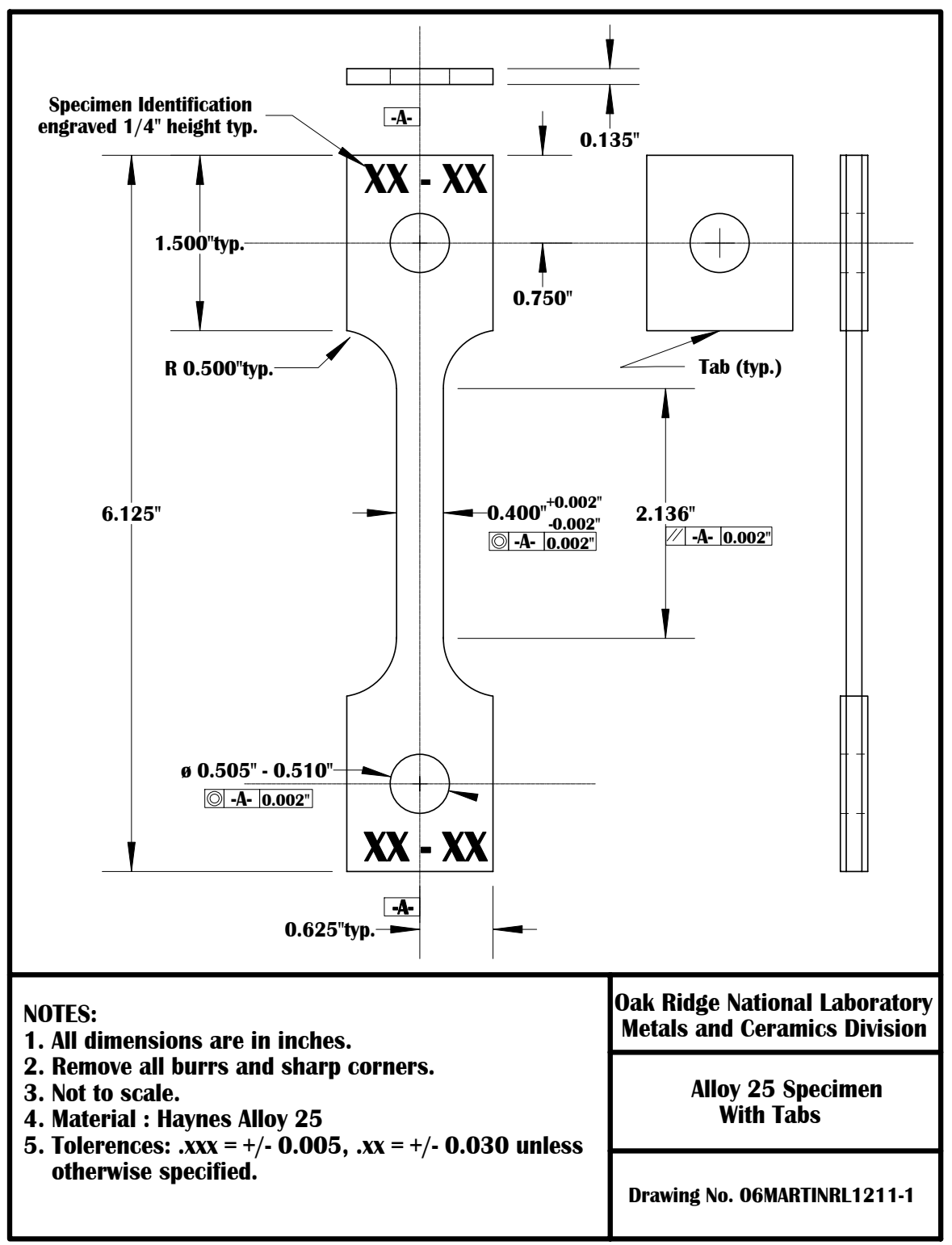

Figure 3.2. Specimen drawing for alloy 25 plate creep and tensile specimens.

Welded plate was received from Mound Laboratories as 0.14-in. (3.3-mm) thick sheet. This was the same plate material as supplied for base metal testing but containing a matching composition multi-pass gas tungsten arc weld (GTAW) transverse to the primary rolling direction. The weld filler metal heat met the AMS 5796C specification, and its composition is included in Table 1 . Ten plates each $10 \mathrm{in}$. (250 mm) by $7 \mathrm{in.}(178 \mathrm{~mm})$ were supplied. The plates exhibited a slight angular distortion after welding. Coupons were cut from the plates oriented to place a transverse weld in the center of the reduced section of the plate specimen as shown in the example cutting plan in figure 3.3. The specimen design was the same as that used for testing the base metal with the exception of the weldment in the center of the gauge. Specimens were machined so that the pin-hole in each shoulder was perpendicular to the end of the sheet, and the weldment crown was not removed. After machining, specimens were placed in a three-point loading bend devise with the weldment crown resting on the center bend bar. The angular distortion was removed by flattening the specimens in the 3-point fixture. Tensile tests were performed on the flattened 
bars. Short-term heat-treatments at $800^{\circ} \mathrm{C}$ did not cause significant changes in the room temperature tensile behavior indicating a minimal effect of flattening on tensile properties.

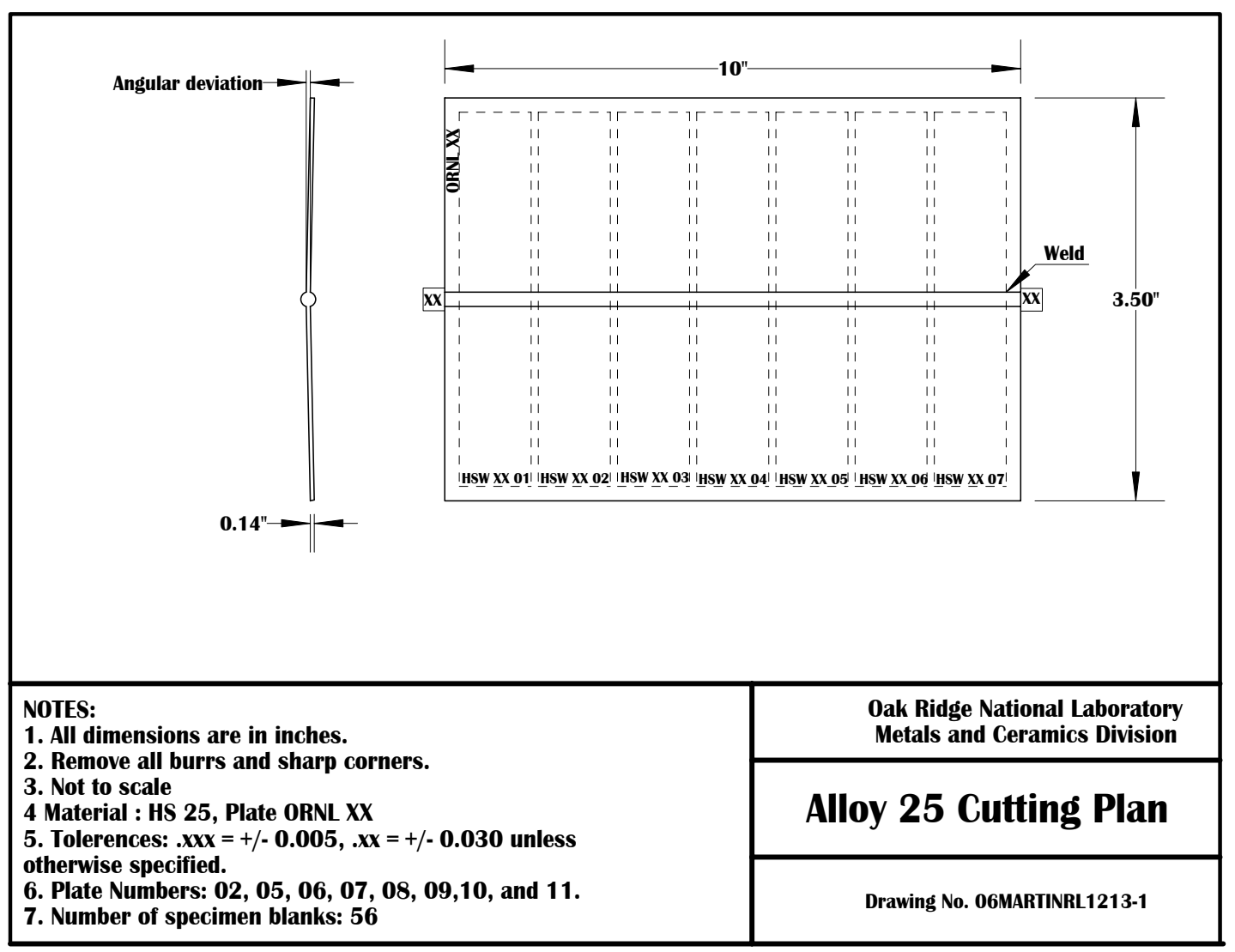

Figure 3.3. Example cutting plan for alloy 25 weldment specimens.

Tubular specimens machined from bar-stock were supplied by INL and LANL. Uniaxial weldment specimens for tensile and creep testing were machined in a similar configuration to the plate specimens as shown in figure 3.4. These specimens contained a matching filler metal multi-pass GTAW orbital weldment in the center of the gauge. The same heat of filler metal used in the plate specimens was used by both INL and LANL for these specimens. Due to the size of the bar stock, some specimens were machined with a $1.000 \mathrm{in}$. (25.00 mm) gauge length while others were similar to the plate specimens with a $2.140 \mathrm{in}$. (54.35 mm) gauge length. The curvature of the tube was left intact, as it was not practical to flatten the specimen without imparting a significant degree of cold work, and specialized grips were produced for long-term creep testing. 


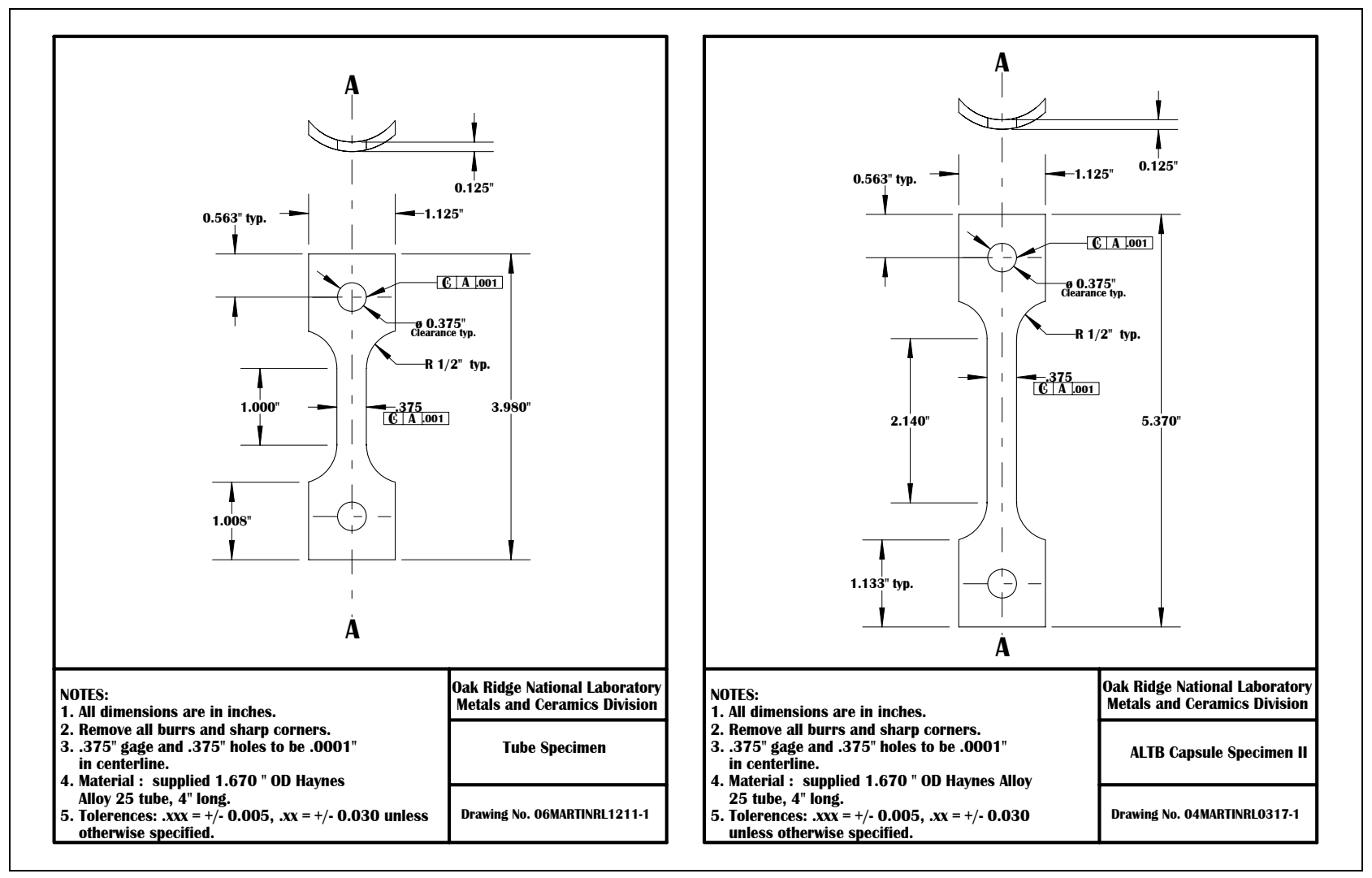

Figure 3.4. Uniaxial weldment specimens taken from tubular machined bar. Weldment crown was in center of gauge section similar to uniaxial plate specimens. The gauge length of some specimens was 1.000 in. $(25.40 \mathrm{~mm})$ as shown in the figure on the left, and other specimens were machined with a gauge length of $2.140 \mathrm{in}$. $(54.35 \mathrm{~mm})$ as shown on the right, depending on available material.

Tubular specimens machined from bar-stock for pressurized stress and creep-rupture testing were supplied by INL and LANL. Two sizes of tube with diameter (dia.) to wall thickness ( $\mathrm{t}$ ) ratios of dia/t = 10.76 and 13.15 were evaluated. Hemispherical end caps were welded on the ends of the tubes. A pressure stem was fabricated from Haynes 25 bar stock and welded into a hole in one of the caps to apply and control the pressure within the capsule. The length of the tubes between the weldments was approximately 3.5 to 4.5 times the nominal diameter of the tube.

Elastic property measurements of alloy 25 were performed using Resonant Ultrasound Spectroscopy (RUS). The RUS specimen configuration was a disc $0.708 \mathrm{in.}(18 \mathrm{~mm}$ ) in diameter and $0.118 \mathrm{in}$. ( $3 \mathrm{~mm}$ ) in thickness as shown in figure 3.5. 


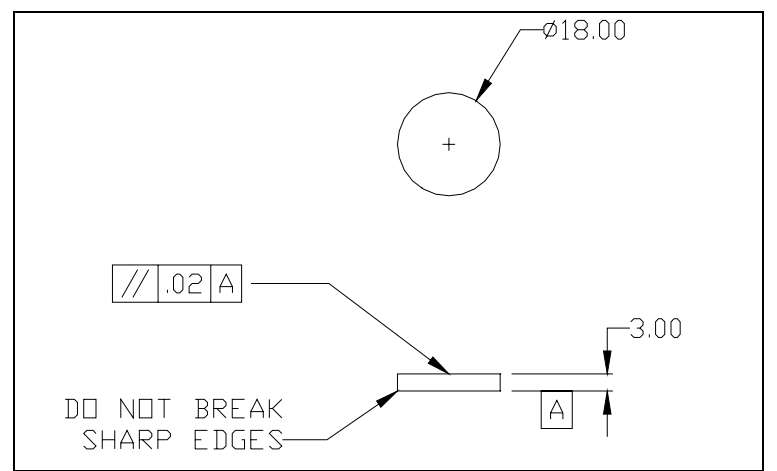

Figure 3.5. RUS alloy 25 specimen (dimensions in $\mathbf{m m}$ ).

For aging studies, the machined specimens and fabricated tubular specimens were placed in quartz capsules, evacuated, and back-filled with a partial Ar-5\%He atmosphere ( 1/3 atm.). The quartz capsules were inserted into box furnaces and aged at various temperatures under close temperature control for up to 12,000 hours. 


\section{EXPERIMENTAL DETAILS}

\subsection{ELASTIC PROPERTY MEASUREMENTS}

To determine the elastic constants (elastic modulus, shear modulus, and Poisson's ration) for this heat of alloy 25, Resonant Ultrasound Spectroscopy (RUS) testing was performed in an Argon atmosphere starting at room temperature $\left(25^{\circ} \mathrm{C}\right)$ and at isothermal conditions at the following temperatures: 150,300 , $500,650,800,900,1000$, and $1100^{\circ} \mathrm{C}$ for specimens removed from the as-received plate and plate aged for 6,000 hours at $675^{\circ} \mathrm{C}$ [17]. For each test, the specimen was heated to the desired temperature and a spectrum was obtained after soaking at that temperature for 30 minutes. The temperature was then raised and the process repeated. After completing the entire temperature range, the specimen was cooled to $25^{\circ} \mathrm{C}$ and another spectrum was obtained. The peak-fitting routine used to analyze the RUS spectrum determines a best-fit value for the elastic modulus (E) and the shear modulus (G) [18]. From these values, Poisson's ratio ( $v$ ) was determined by the relationship:

$$
E=2 G(1+v) \quad \text { equation } 1
$$

Although the atmosphere was inert, a small oxide layer was visible after testing. Depending on its thickness, an oxide layer may affect the elastic measurements. Calculating the elastic constants after cooling (when the oxide layer is present) and comparing it to the initial room temperature constant is a standard method for determining the extent of an oxide layer effect. The difference between the pre- and post-test calculated elastic moduli were 2.2 and 1.0 percent for the unaged and aged material respectively, and no change was observed for Poisson's ratio. This indicates that the oxide layer had a negligible effect on the determined constants.

\subsection{TENSILE TESTING}

Tensile tests were performed on alloy 25 base metal (plate and bar product forms/specimens) and weldments in the as-received condition and after aging for various times and temperatures. The room temperature and elevated temperature tensile tests conformed to ASTM E8-00 and E 21-92, respectively. Tests were performed in electromechanical tensile machines equipped with digital data acquisition. All tests on the plate and plate weldment specimens were performed in extension control mode with an extension rate of $0.107 \mathrm{in} / \mathrm{min}$, which corresponded to a nominal strain rate of $0.05 / \mathrm{min}$ on the specimen gauge section. For the bar cross-weldments, the tensile tests were performed in extension control with a nominal strain rate of $0.005 / \mathrm{min}$. After yielding (one to two percent strain), the extension rate was increased to give a nominal strain rate of $0.05 / \mathrm{min}$, and the test specimen was taken to failure. An ASTM class B1 or B2 extensometer was attached to the gauge section of the specimens for accurate measurement of strain. Yield strength (YS) was determined using the $0.2 \%$ offset method, the proportional limit was calculated by visual inspection of the tensile curve, ultimate tensile strength (UTS) and ultimate strain (strain at UTS) were calculated by the computer data acquisition system, and final elongation (EL) and reduction of area (RA) were determined by post-test measurements. 


\subsection{CREEP-RUPTURE TESTING}

The creep-rupture testing procedures conformed to ASTM practice E139. For creep-rupture testing, dead-load and lever-arm machines were used with a maximum capacity of $22 \mathrm{kN}$ (5,000 lbs). For temperatures of $800^{\circ} \mathrm{C}$ and lower, type $\mathrm{K}$ (Chromel-Alumel) thermocouples were used for temperature control and readout. For temperatures above $800^{\circ} \mathrm{C}$, type $\mathrm{S}$ (Platinum-Platinum/Rhodium) thermocouples were used for control but type $\mathrm{K}$ thermocouples were sometimes used for set-up at the start of the test. Load cells were used to set and maintain the load within $0.5 \%$ of the target load for all creep-rupture and creep tests. Machine loads were adjusted when needed to accommodate potential changes due to the effect of lever arm travel. An extensometer was attached to the center 2 inches $(50 \mathrm{~mm})$ of the reduced section of the specimens. Depending on the test requirements, the ASTM extensometer type ranged from Class B-1 to Class C (ASTM E 83). Most testing was performed with extensometers calibrated to the Class B-2 category. The Class C extensometer was sometimes used for the weldment samples since the influence of the cross weld in the gage length produced some uncertainty as to the significance of the measured displacement. For tests above $900^{\circ} \mathrm{C}$, oxidation of the specimen may have a significant influence on the creep-rupture properties, so testing at these conditions was performed in a flowing 99.99\% purity Argon atmosphere. After testing, the specimen surfaces were tinted a light-green in color, which is indicative of a thin chromia based oxide scale typical in this alloy system. In contrast, the specimens tested in air all exhibited a dark black oxide layer after creep testing, which is evidence of a thicker oxide layer. For testing in Argon gas, the retort system excluded the use of typical creep extensometers for strain measurement and the high-temperature precluded the use of other strain measurement options. Thus, load-line displacement readings were taken manually at 48 to 72 hour increments and used to estimate the creep strain.

Several types of extension sensors were used on the extensometers. All were electronic and provided signals that could be read by a data acquisition system. For most tests, load and extension data were collected on a computer data acquisition system. Manual dial gage readings of the load line displacement were made on a weekly basis. Generally, these readings indicated larger displacements than readings from extensometers. The difference was attributed to creep strains accumulated in the shoulders of the specimens and displacement of the loading pins. Post test readings of the displacement on the specimen reduced sections generally confirmed the accuracy of the extension measurements.

For pressurized creep testing of the tubular specimens (removed from bar stock), the ORNL pressureburst facility was used. Figure 4.3.1 shows a schematic representation of one test rig in the facility. A high-pressure oil-less pump supplied Ar-0.5\%He gas to the test facility. A 7,500 psi safety pressure relief valve was used to limit pressure in case of an emergency. Specimen pressure was controlled manually using a series of valves. A digital pressure transducer, in line with the specimen, was used to monitor pressure at all times. In order to maintain a constant pressure within the capsule throughout the test, an accumulator was used so the system could be isolated from the supply pump. The main pump was only used during the test when the pressure deviated from the target pressure by more than $+/-50$ psi.

Generally, this was not needed because the accumulator had sufficient volume to keep the tube pressure within the specified range. Fluctuations in room temperature could also cause increases or decreases in the test system pressure. Insulating the accumulators reduced these fluctuations, and only in the case of the very long-term tests were one or two manual changes in pressure to the accumulators required. 


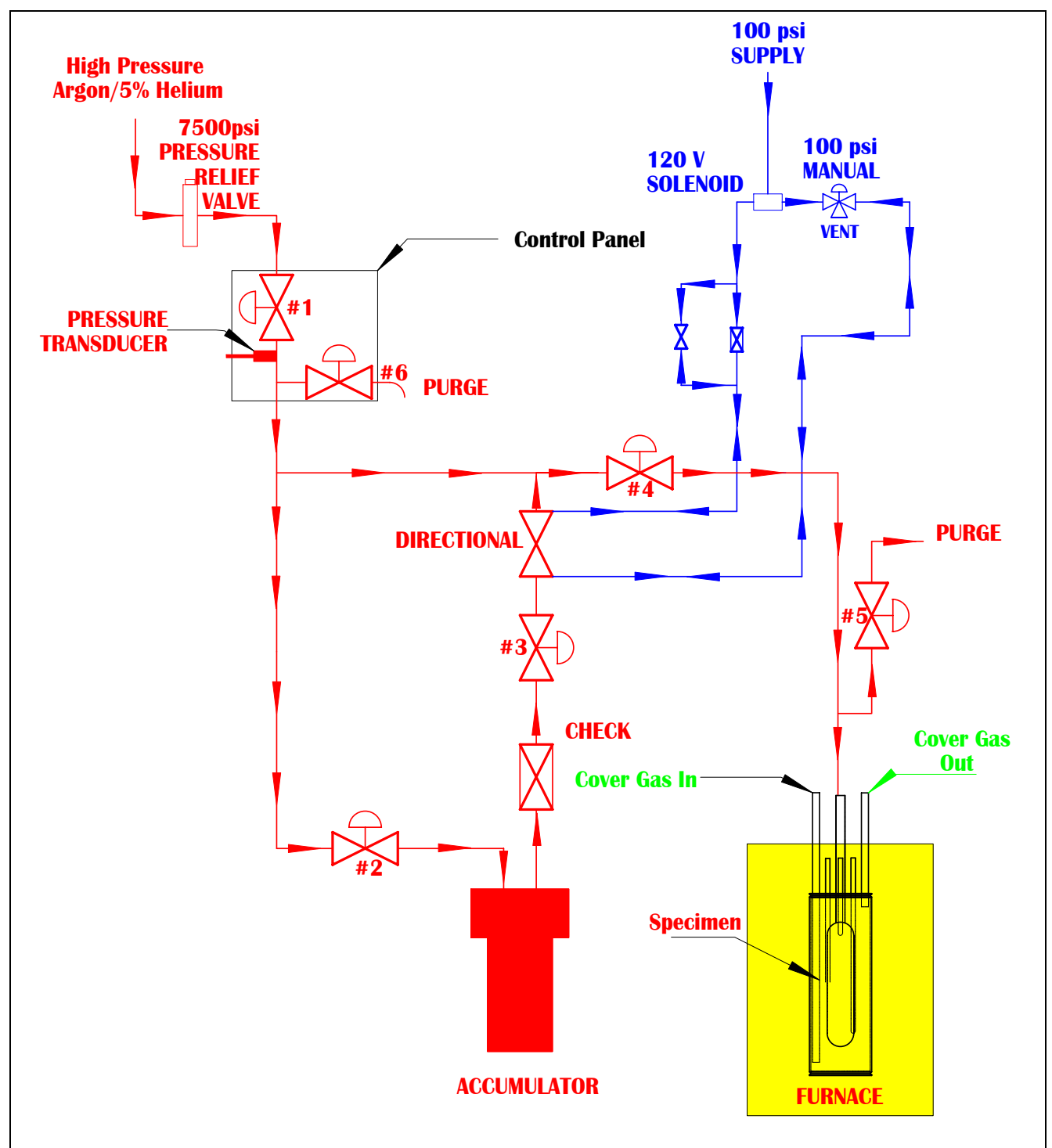

Figure 4.3.1. Schematic of pressurization and control system for high-temperature pressurized creep testing of tubular specimens.

A detailed schematic of the set-up within the furnace is shown in figure 4.3.2. A 304L stainless steel can was used to hold the specimen during the test. The can was used for three reasons: (1) to allow for the use of an inert cover gas (99.99\% Ar) to minimize oxidation effects when testing at high temperature; (2) to protect the furnace and heating elements in case the specimen ruptured; (3) to assist in providing uniform temperature across the entire specimen. A Haynes 25 pressure-stem was welded (fillet weld) with Haynes 25 filler metal (GTAW process) to the can lid. This pressure-stem was welded to standard stainless steel high-pressure tubing to connect to the system outside of the furnace. The stainless steel lid was sealed to the can using 308L stainless steel wire. 


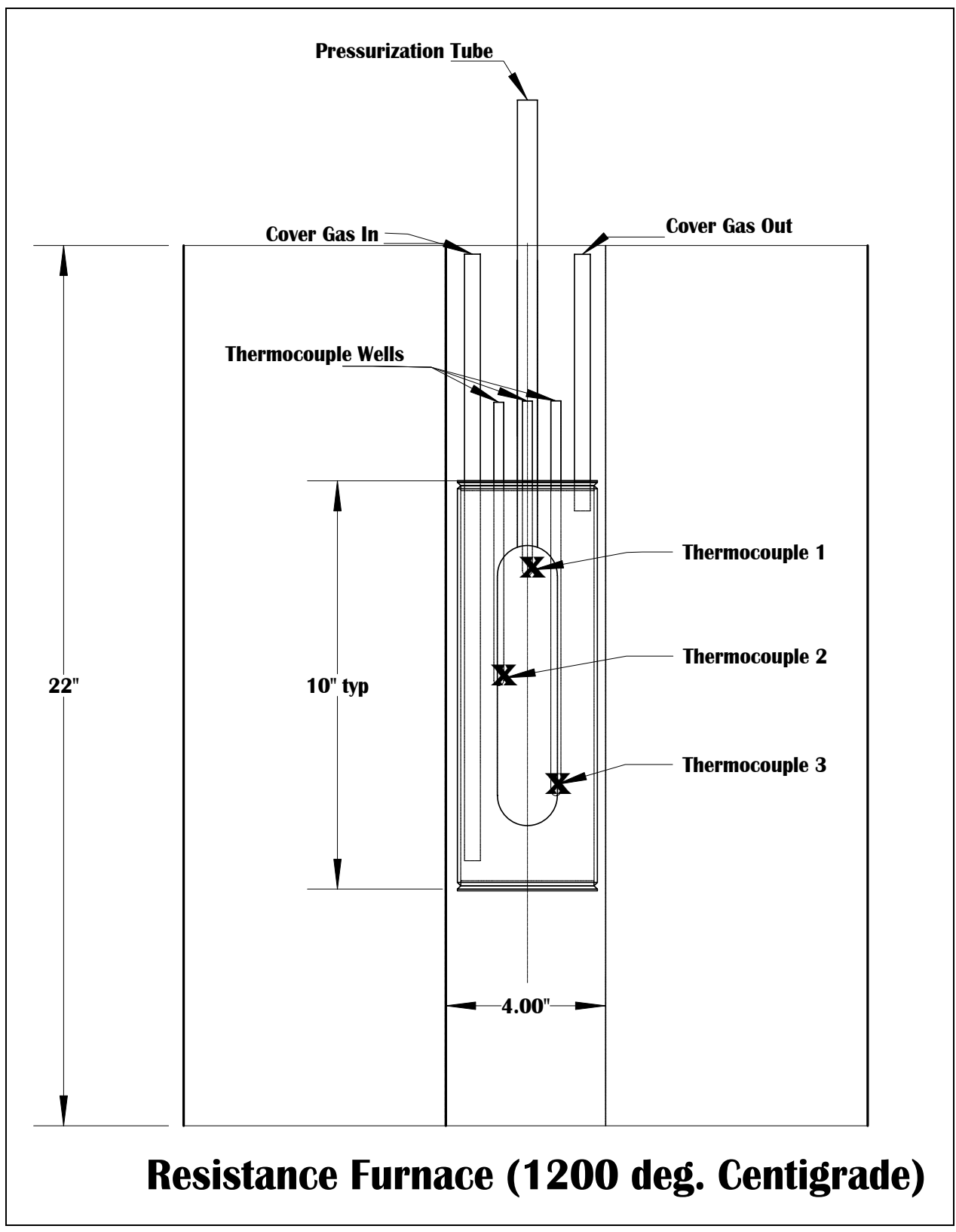

Figure 4.3.2. Furnace detail for high-temperature pressurized creep testing showing the tubular specimen, the thermocouple placement, the stainless steel canister, the gas inlet and outlet, and the pressure stem.

Metallic sheathed thermocouples were fed into the stainless steel canister through Swagelok fittings and ceramic-insulated thermocouples were fed in through stainless steel wells which were bent to touch the specimen surface. The difference in temperature readings between the sheathed thermocouples and the thermocouples in the stainless steel wells were less than $1^{\circ} \mathrm{C}$. For these tests, three sheathed and three ceramic-sheathed thermocouples (two placed in each location as indicated in figure 4.3.2), were used to measure temperature. As with the uniaxial tensile testing, type K (Chromel-Alumel) thermocouples were used for temperatures of $800^{\circ} \mathrm{C}$ and lower while type S (Platinum-Platinum/Rhodium) thermocouples were used for testing at $850^{\circ} \mathrm{C}$ and above. In a few cases, tests of short duration (less than 200 hours) at $850^{\circ} \mathrm{C}$ were performed using type $\mathrm{K}$ thermocouples where temperature drift is not significant. A computer data acquisition system recorded the temperature (six thermocouples), the pressure, and time at 
$0.1 \mathrm{hr}$ intervals. This data collection rate was increased when the pressure dropped below a predetermined value to record the rupture or leak rate. An accumulator shut-off valve was closed at this point so the entire gas volume of the accumulator did not leak through the specimen on rupture. When these events happened, the system sent an alarm to a staff member to manually check the system for specimen rupture.

The test procedure used was as follows. After the specimen was welded to the can top, the specimen was pressurized at room temperature to the test pressure and held for 24 hours to check for leaks. If a leak was detected, the welds and fittings were evaluated for leaks, the problem was corrected, and the process was repeated. After successful pressurization, the specimen was de-pressurized and the can lid was welded onto the can sealing the specimen inside the canister. The system was purged and the specimen was pressurized with Ar- $0.5 \% H e$ gas again for 24 hours. During this time, flowing Argon gas was introduced into the can. After 24 hours, the pressure in the capsule was lowered a minimum of 1000 psi below the intended test pressure, the data acquisition system was started, and the furnace was started. The temperature was gradually raised and the pressure adjusted to stay a minimum of 1000 psi below the test pressure. Once the capsule had reached the test temperature and the total temperature gradient was less than $5^{\circ} \mathrm{C}\left(<+/-2.5^{\circ} \mathrm{C}\right.$ intended test temperature $)$, the pressure was raised to the test pressure and the test was started. In addition to the computer data acquisition system, the data was also recorded on a chart recorder and periodic manual readings were made. The pressure drop limit was set at 50psi; that is when the pressure dropped 50psi below the test pressure, the data acquisition rate was increased, the supply from the accumulator was stopped, and an alarm was sent out. If the pressure continued to decrease, then this point was taken as the rupture time.

To measure the rupture strain of the tubular specimens, the diameter of the specimen was measured after testing. This worked well for small longitudinal ruptures along the tube axis, but in some cases the specimen had a 'fishmouth' type rupture with a large opening. In these cases, the largest circumference was measured and the final diameter was calculated.

\subsection{POST-TEST ANALYSIS}

A select number of specimens (sheet and tubes) were visually examined using a digital stereo microscope. Others were sectioned and areas of interest were prepared metallographically by mounting the sectioned samples in epoxy, grinding using 220 and $600 \mathrm{SiC}$ grit sandpaper, and polishing using 6, 3, and $1 \mu \mathrm{m}$ diamond paste. Samples were etched for metallographic examination using glyceregia. 


\section{ELASTIC PROPERTIES RESULTS AND DISCUSSION}

The measured elastic constants as a function of temperature for alloy 25 before and after aging at $675^{\circ} \mathrm{C}$ for 6,000 hour are tabulated in the appendix (A.1). The elastic modulus (E) for these two material conditions is plotted along with the dynamic modulus data from the Haynes 25 product brochure [19] in figure 5.1. The shear modulus $(\mathrm{G})$ and bulk modulus (K) are plotted as a function of temperature in figure 5.2, and Poisson's ratio (v) values for the two conditions are plotted in figure 5.3.

The RUS measured elastic moduli are slightly higher than the Haynes data over the entire temperature range. The difference in modulus is generally less than $4 \%$, which is small considering a different measurement technique and/or product form was likely used for generating the Haynes data. The plot also shows that the elastic modulus for aged material is 2 to 3 percent higher below $650^{\circ} \mathrm{C}$ compared to the unaged material. This difference is smaller above $800^{\circ} \mathrm{C}$. The small change in elastic modulus for the aged material at the lower temperatures may be due to a change in the matrix composition between the unaged and aged material. Examination of the TTT diagram, figure 5.3, for Haynes 25 shows that aging for 6,000 hours at $675^{\circ} \mathrm{C}$ results in the precipitation of the $\mathrm{Co}_{3} \mathrm{~W}$ and $\mathrm{Co}_{2} \mathrm{~W}$ phases in addition to carbide phases. Precipitation of the intermetallic phases may appreciable change the bulk composition of the Co matrix resulting in a slight change in elastic properties. In addition to differences in elastic modulus, some small differences are observed in Poisson's ratio at the lower temperatures. Above the aging temperature, especially at 900 to $1100^{\circ} \mathrm{C}$, both the elastic modulus and Poisson's ratio do not show noticeable differences. Closer examination of figure 5.2 shows that the differences in Poisson's ratio and elastic modulus below $800^{\circ} \mathrm{C}$ are the result of small changes in the shear modulus, which is consistently higher for the aged material at low temperatures. No trends are observed for bulk modulus for the unaged and aged conditions. This indicates that any possible aging effect on elastic properties (due to long-term exposure at $675^{\circ} \mathrm{C}$ ) is small and restricted to temperatures below $650^{\circ} \mathrm{C}$. 


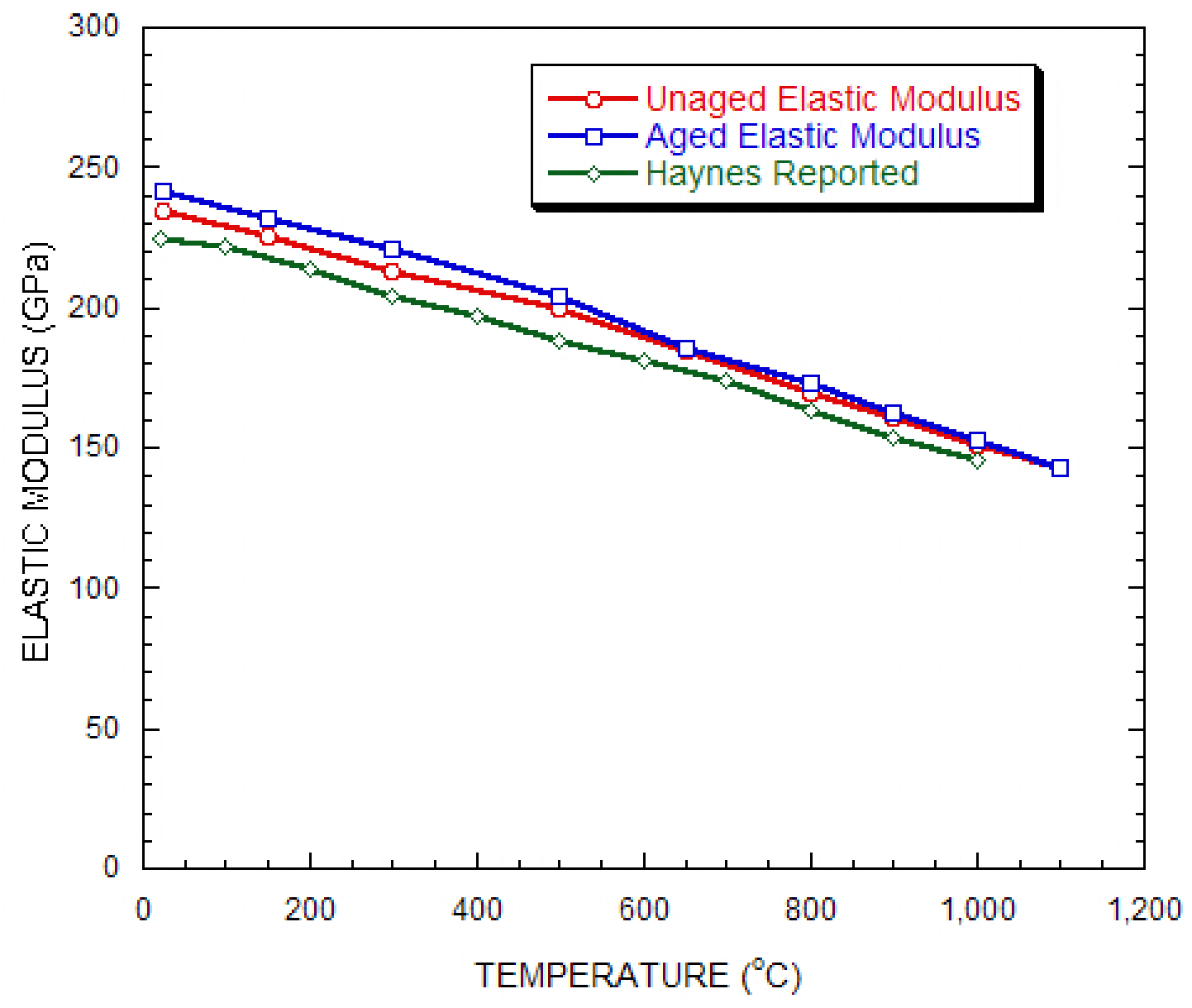

Figure 5.1. Plot of elastic modulus vs. temperature for this heat of alloy 25(aged $=$ aged at $675^{\circ} \mathrm{C}$ for 6,000 hours) and compared to the Haynes Datasheet data [15]. 


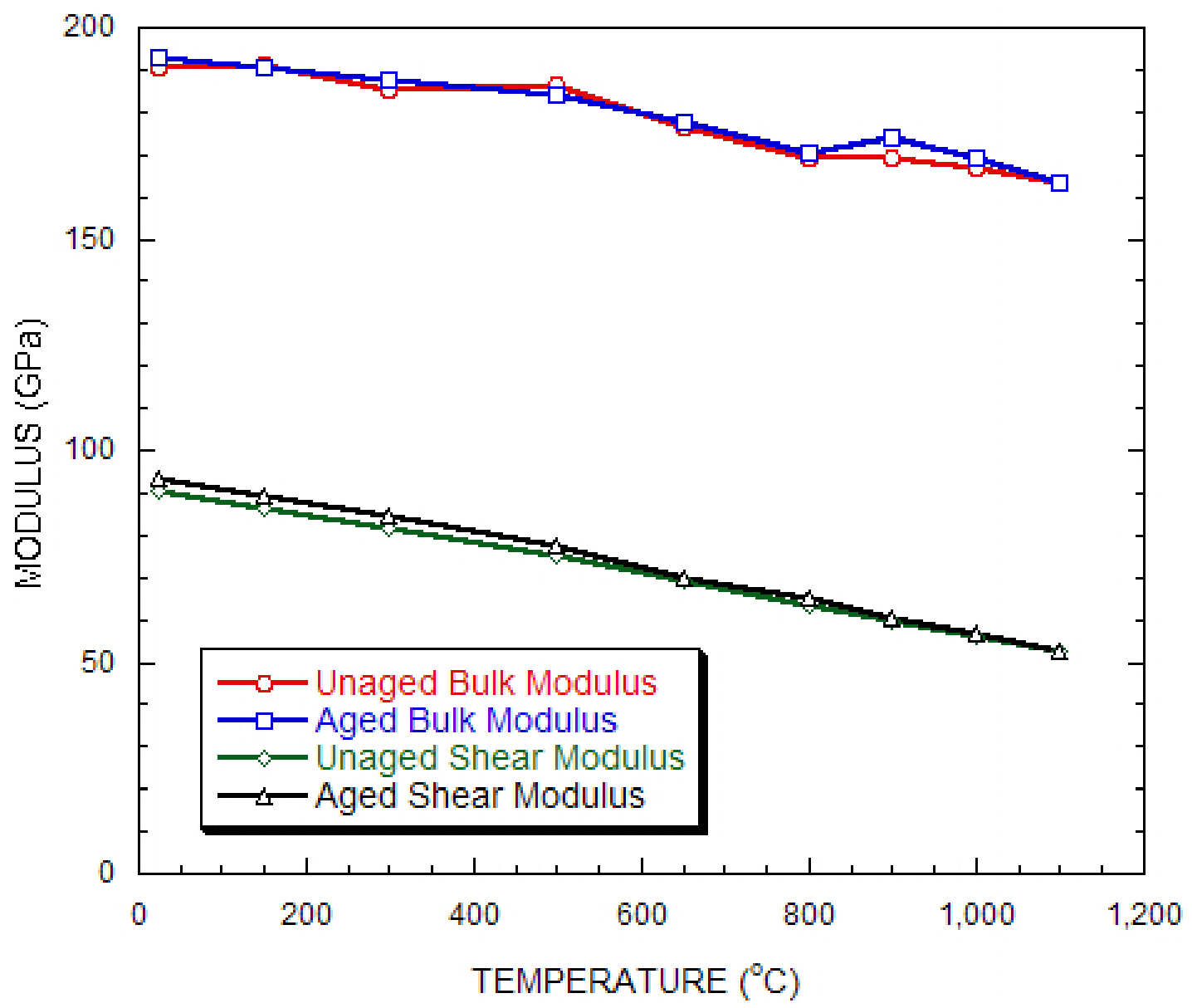

Figure 5.2. Plot of shear (G) and bulk (K) modulus vs. temperature for this heat of alloy 25 (aged $=$ aged at $675^{\circ} \mathrm{C}$ for 6,000 hours). 


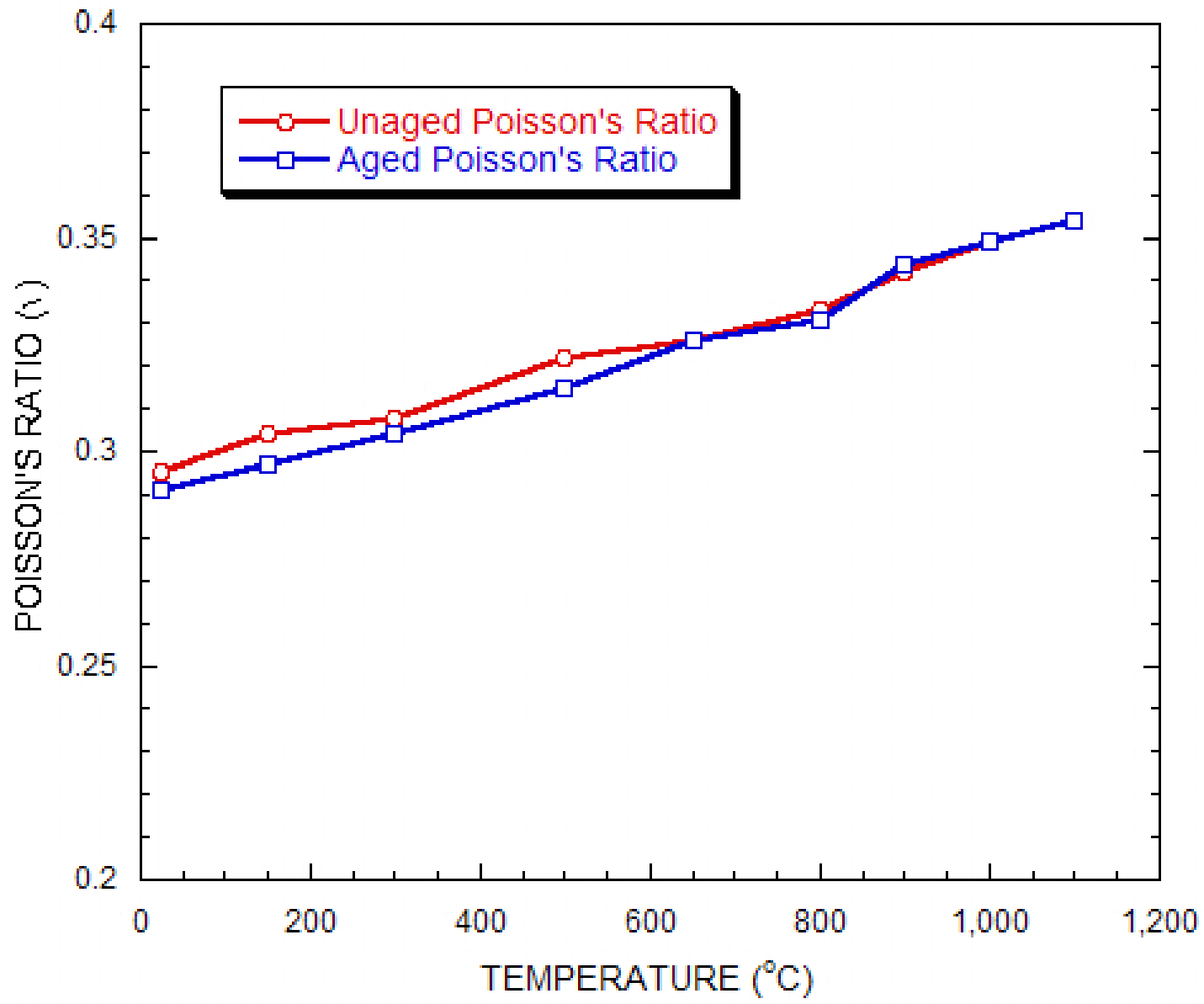

Figure 5.3. Plot of Poisson's ratio vs. temperature for this heat of alloy 25 (aged $=$ aged at $675^{\circ} \mathrm{C}$ for 6,000 hours). 


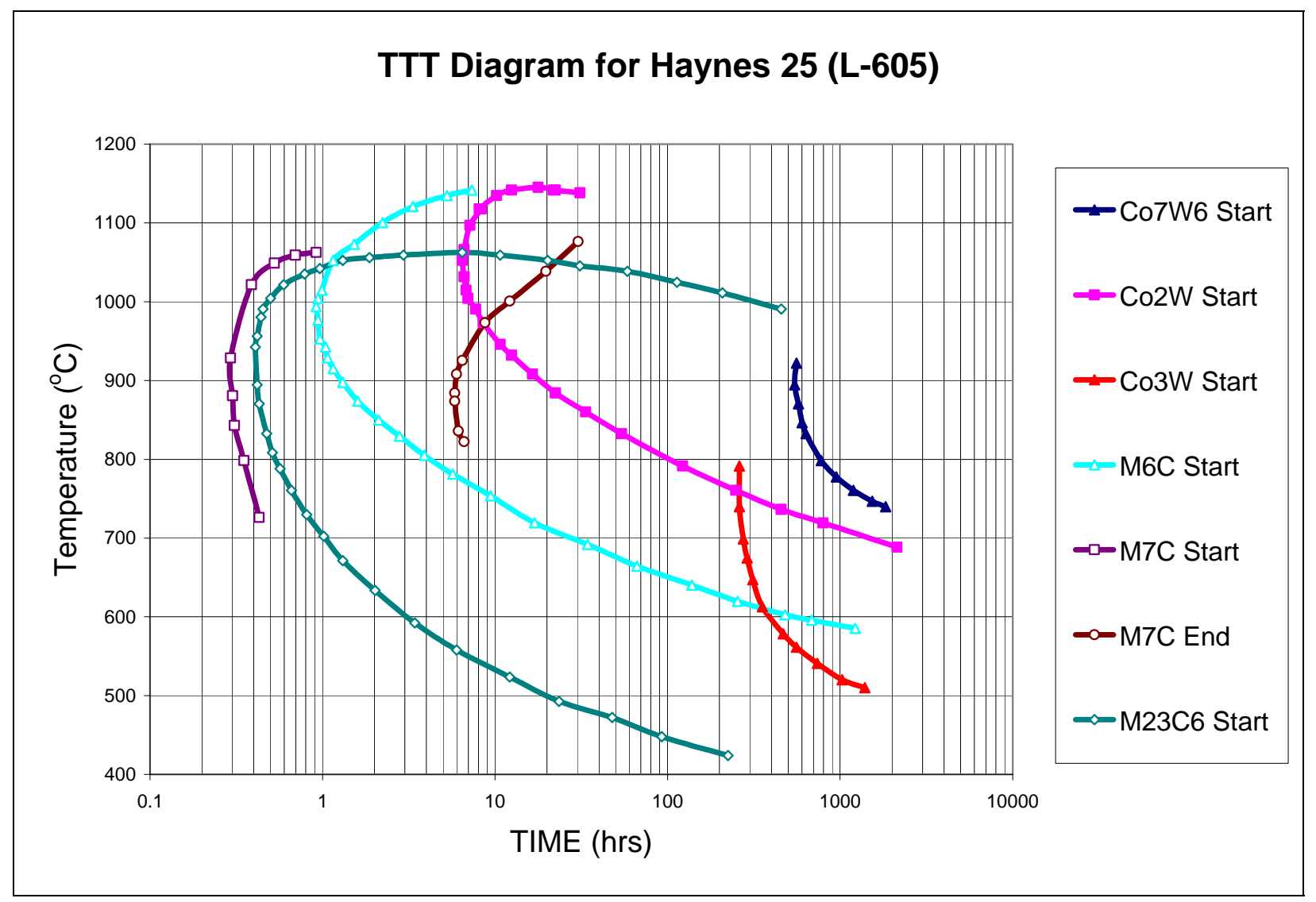

Figure 5.4. Reconstructed TTT diagram for Haynes alloy 25. Data taken from ref [10]. 


\subsection{TENSILE PROPERTIES RESULTS AND DISCUSSION}

Tensile properties were measured on sheet (base metal: BM), sheet cross-weldment (WM), and bar crossweldment (bar WM) specimens in the as-received (annealed or as-welded) condition and in various aged conditions. The tabular tensile data can be found in the tables of appendix A.2. Table A.2.1 gives the tensile properties of the base metal while Table A.2.2 contains the weldment data. The most prominent aging conditions were 6,000 and 12,000 hours at $675^{\circ} \mathrm{C}$. These conditions were chosen, in part, on the TTT diagram (figure 5.3) to cause precipitation of the $\mathrm{M}_{23} \mathrm{C}_{6}$ and $\mathrm{M}_{6} \mathrm{C}$ carbides as well as the $\mathrm{Co}_{3} \mathrm{~W}$ intermetallic phase. The formation of the $\mathrm{Co}_{2} \mathrm{~W}$ Laves phase has also been reported at $700^{\circ} \mathrm{C}$ for short times and extension of this curve of the TTT diagram suggests this condition would precipitate this phase as well. The precipitation of the carbide and intermetallic phases has long been known to embrittle alloy 25 causing a decrease in the tensile and impact ductility [13-16]. However, most of these studies investigated short-time aging conditions at temperatures of $760^{\circ} \mathrm{C}$ and higher, and thus a lower temperature longer-time aging condition at $675^{\circ} \mathrm{C}$ was chosen for this study.

Figure 6.1 shows the yield strength (YS) and ultimate tensile strength (UTS) as function of temperature for alloy 25 base metal and weldments including aging at $675^{\circ} \mathrm{C}$ for 6,000 and 12,000 hours.

Examination of the plot shows that for each aging condition, the sheet base metal (BM) and the weldment (WM) had the same properties. Since all of the sheet weldment test specimens broke in the base metal, it is expected that the base metal will govern properties. In the machining of the specimens, the weld crown was not removed, thus the weld metal was essentially mechanically reinforced due to a larger crosssectional area. However, the heat-affected zone (HAZ) of the weldment is not reinforced. Therefore, the tensile data show that welding does not degrade the room and high-temperature tensile properties of Haynes alloy 25. A few tests on the bar weldments (Bar WM) were conducted at room temperature and at $650^{\circ} \mathrm{C}$. In general, these showed the YS and UTS were slightly higher compared to the as-received and aged sheet products, but one data point fell slightly below the data for the sheet pieces. In contrast to the data for sheet pieces, the non-aged bar materials failed in the weldment, so these data are measures of weldment strength. The higher yield strength of the bar material may be due to a grain size effect. The grain size of the bar is finer, figure 3.1, compared to the sheet material. Generally, finer grain size, for the same material, results in higher low-temperature yield strength. Under this assumption of higher strength in the bar, the initial yielding of the bar specimen may have occurred in the weldment region eventually causing failure in the weldment whereas initial yielding in the sheet weldment was in the base metal leading to failure in the base metal. After aging, the bar weldments failed in the base metal similar to the sheet product. All of the data fell within typical scatter for tensile data. Thus, the data suggest that the bar product may have slightly better unaged tensile properties compared to sheet product, but there are no sufficient data to determine whether or not these differences are statistically significant.

Figure 6.1 also shows the dramatic effect aging has on alloy 25 strength. Aging at $675^{\circ} \mathrm{C}$ for 6,000 hours improves the YS of the material by about $300 \mathrm{MPa}$ from room temperature to $650^{\circ} \mathrm{C}$. The magnitude of this effect decreases with further increasing temperature and no difference in YS is observed at $1,000^{\circ} \mathrm{C}$. A similar but less dramatic effect is observed for the UTS. At room temperature, little difference is observed, but the UTS is improved in the range of 300 to $800^{\circ} \mathrm{C}$ by about $100 \mathrm{MPa}$. As with YS, aging at $675^{\circ} \mathrm{C}$ has no effect on UTS at $1,000^{\circ} \mathrm{C}$ and above. Also, aging for 12,000 hours at $675^{\circ} \mathrm{C}$ does not cause further changes in YS and UTS. 


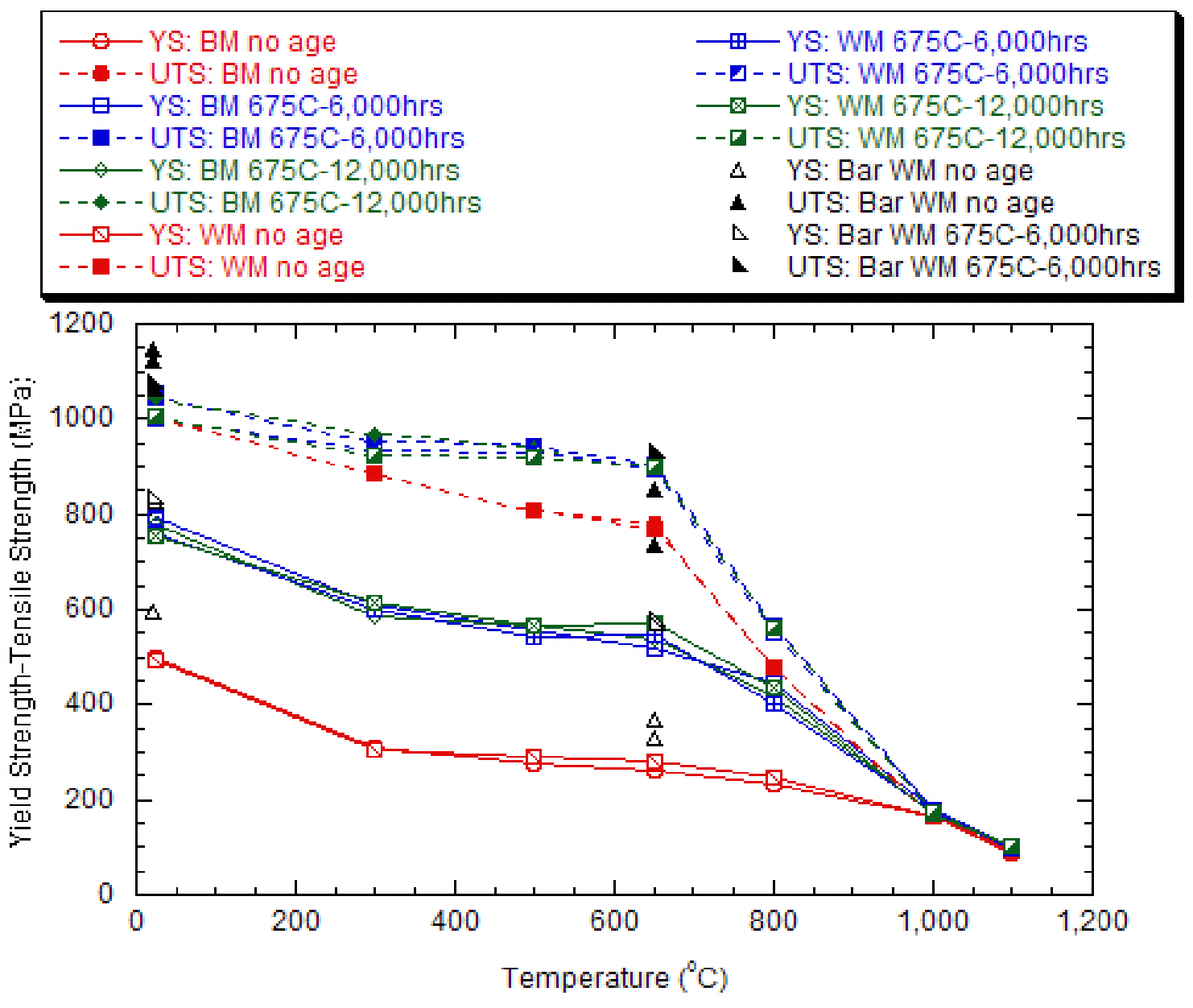

Figure 6.1. Measured Yield Strength (YS) and Ultimate Tensile Strength (UTS) as a function of temperature for base metal (BM) and weldments (WM) of Haynes alloy 25 sheet and cross-weldments of Haynes alloy 25 bar product in the as-received condition and after aging at $675^{\circ} \mathrm{C}$ for 6,000 and 12,000 hours.

Figure 6.2 is a plot of the tensile ductility, elongation (EL) and reduction of area (RA), for the all the material conditions. Similar to the strength data, no difference is observed for any aging condition between sheet BM and WM. However, the Bar WM does show lower ductility for the as-welded condition, which is due to localized failure in the weldment. After aging, the Bar WM is equivalent to the $\mathrm{BM}$ and WM. In the unaged condition, alloy 25 has good tensile ductility with EL above $45 \%$ and RA above $35 \%$ for all temperatures tested. However, after aging at $675^{\circ} \mathrm{C}$ for 6,000 hours, the tensile ductility at room temperature to $800^{\circ} \mathrm{C}$ is significantly reduced below $20 \%$. Unlike strength, further aging for 12,000 hours at $675^{\circ} \mathrm{C}$ shows slightly more loss of ductility below $800^{\circ} \mathrm{C}$, generally less than $15 \%$. The effect is most pronounced at room temperature where ductility is less than $10 \%$. At $1000^{\circ} \mathrm{C}$ and above, the aging effect is less with all ductilities measuring beyond $25 \%$. 


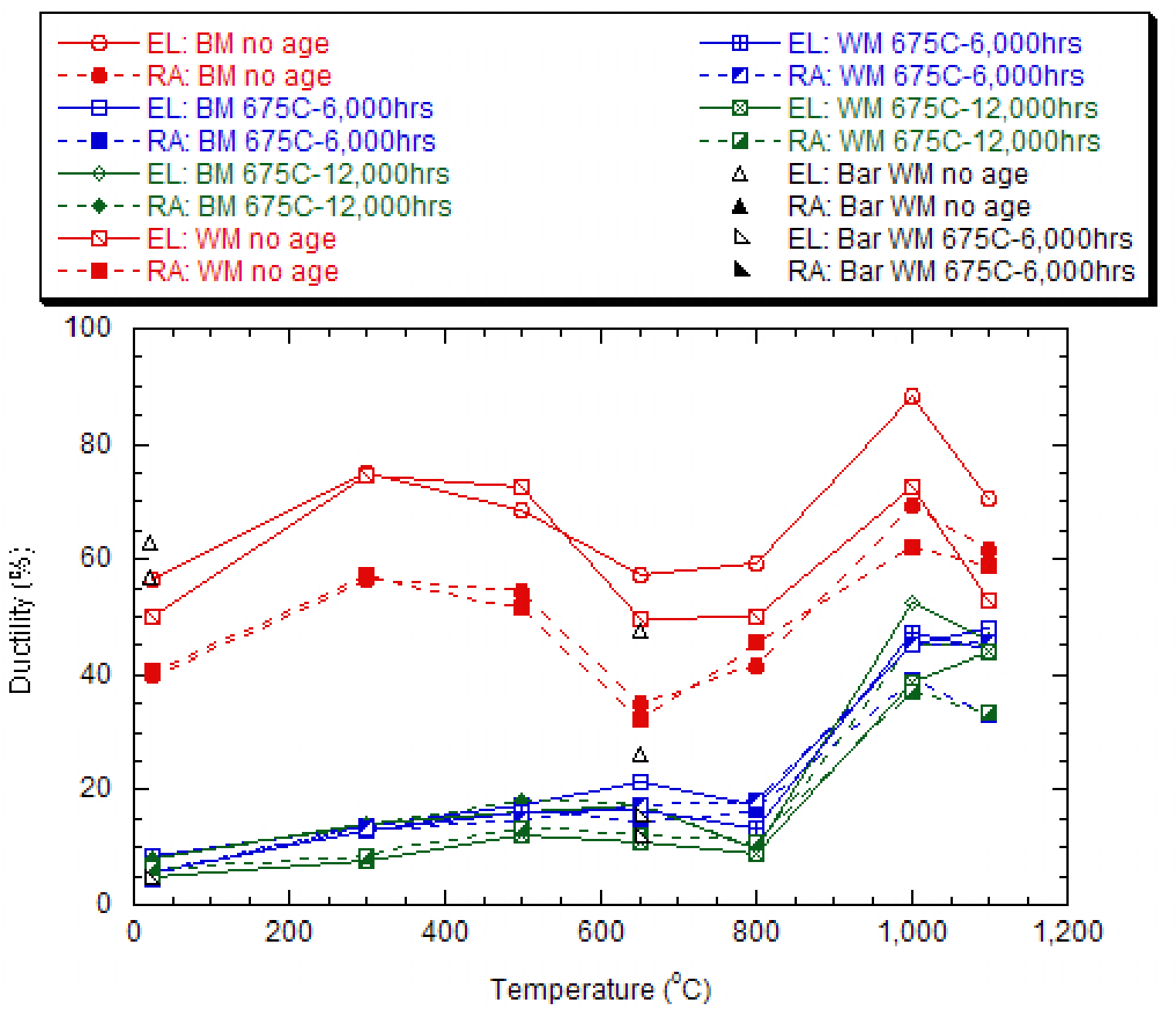

Figure 6.2. Measured ductility, elongation (EL) and reduction of area (RA), as a function of temperature for base metal (BM) and weldments (WM) of Haynes alloy 25 sheet and crossweldments of Haynes alloy 25 bar product in the as-received condition and after aging at $675^{\circ} \mathrm{C}$ for 6,000 and 12,000 hours.

In addition to total elongation (EL), the uniform elongation (strain at the UTS) is also tabulated in the appendix. The difference in EL and uniform EL can be used as a measure of tensile behavior by the equation:

$$
\text { Difference }(\%)=\frac{E L-\text { UniformEL }}{E L} 100
$$

equation 2

When the difference between EL and uniform EL is very small (less than 10\%), the material breaks at or near the UTS, and the material behavior is characterized as strain hardening. When the difference is close to $100 \%$, all deformation is due to strain softening (after yielding, the strength begins to drop).

Examination of the stress-strain tensile curves, individually plotted in appendix A.5, show that alloy 25 can show both types of behavior. Figure 6.3 is a plot of EL for all material conditions (aged and unaged) and the difference in EL and uniform EL (\%) for these test data. Regardless of the value of EL (which varies significantly due to aging as already shown), the difference is only a function of testing 
temperature. From room temperature to $650^{\circ} \mathrm{C}$, the difference is less than $10 \%$, which shows alloy 25 exhibits strain hardening without strain softening. At 1000 and $1100^{\circ} \mathrm{C}$, the $\mathrm{EL}$ and difference are close to the same value showing strain softening dominates. At $800^{\circ} \mathrm{C}$, the material exhibits a mixture of strain softening and strain hardening.

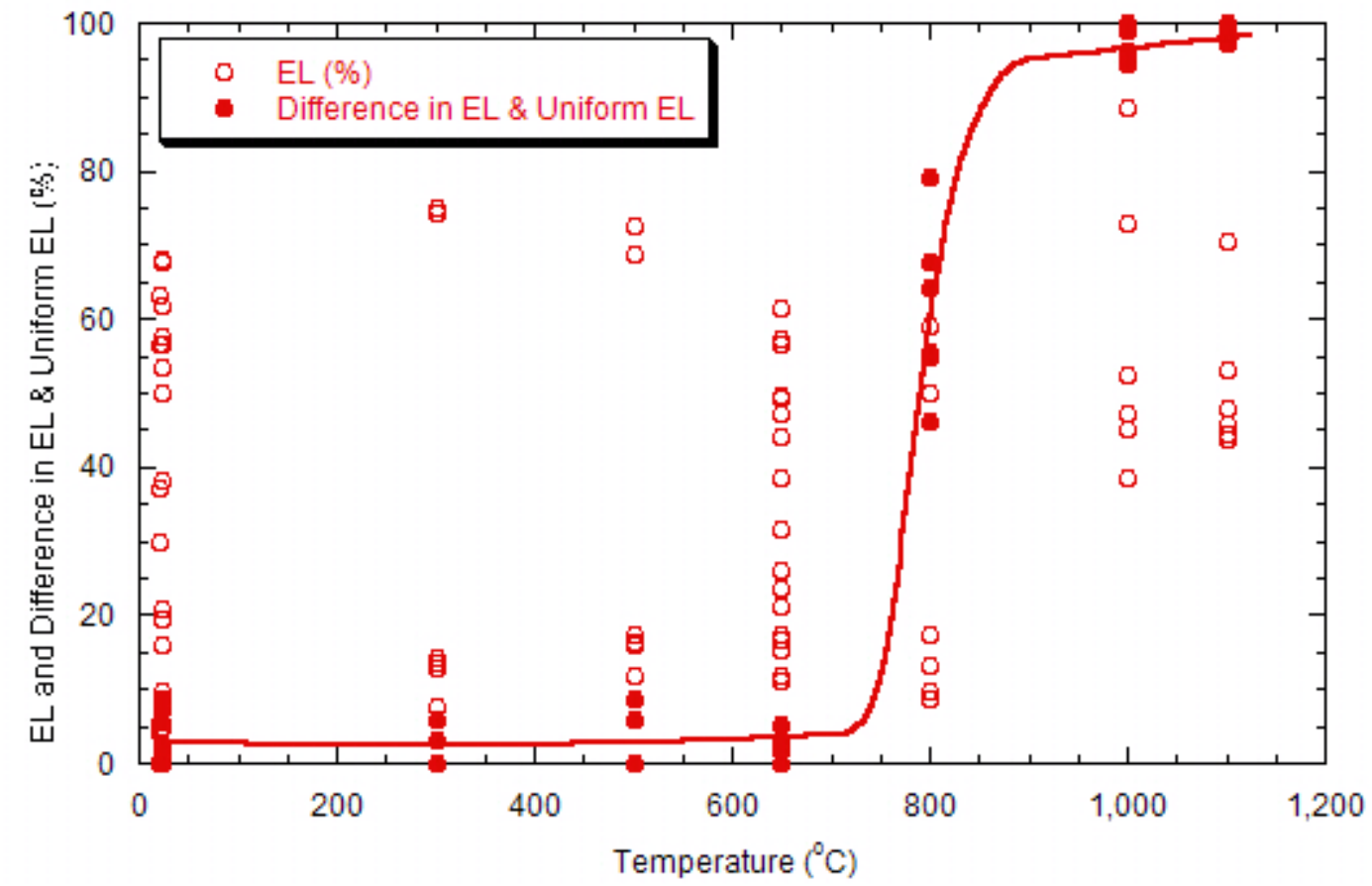

Figure 6.3.Tensile Elongation and the Difference in Uniform Elongation and Elongation as a function of temperature for alloy 25 unaged and aged sheet and bar products. The difference in EL and uniform EL is a measure of deformation due to strain softening. $0 \%=$ no strain softening (strain hardening), $100 \%=$ only strain softening (no strain hardening).

Shorter-term aging experiments were conducted at $675^{\circ} \mathrm{C}$ (in addition to the 6,000 and 12,000 hour aged material) on sheet BM to evaluate the kinetics of strength and ductility change. Figure 6.4 shows the room temperature tensile strength and ductility changes with aging time at $675^{\circ} \mathrm{C}$. Figure 6.5 shows the tensile strength and ductility at $650^{\circ} \mathrm{C}$ after aging at $675^{\circ} \mathrm{C}$ for various times. Bourgette conducted room temperature and $650^{\circ} \mathrm{C}$ tensile tests after aging at $650^{\circ} \mathrm{C}$ [14]. These data are included on the plot for comparison. A general Johnson-Mehl-Avrami (JMA) type equation [20] was fit to the strength (S) and ductility (D) data as a function of time (t) as follows:

$$
\begin{aligned}
& \frac{S-S_{\text {Max }}}{S_{\text {Max }}-S_{\text {Min }}}=1-\exp \left(k t^{n}\right) \\
& \frac{D-D_{\text {Max }}}{D_{\text {Max }}-D_{\text {Min }}}=1-\exp \left(k t^{n}\right)
\end{aligned}
$$

equation 3

equation 4

where the strength or ductility is bounded by maximum and minimum values (subscript Max or Min) and the kinetics of the change depend on the power law terms $\mathrm{k}$ and $\mathrm{n}$. The calculated values for $\mathrm{k}$ and $\mathrm{n}$ for YS, EL, and RA are listed in Table 2. The $n$ values for EL and RA are negative (inverse JMA) since ductility decreases with aging time. The n-value was found to be 1.1 to 1.2 for room temperature YS, EL, and RA, 1.1 for $650^{\circ} \mathrm{C} \mathrm{YS}$, and 0.7 to 1.0 for $650^{\circ} \mathrm{C}$ EL and RA.

Table 2. Calculated kinetic constants for alloy 25 strength and ductility aged at $675^{\circ} \mathrm{C}$ 


\begin{tabular}{c|cc|cc|cc}
\hline Test Temp & \multicolumn{2}{|c|}{ YS } & \multicolumn{2}{c|}{ EL } & \multicolumn{2}{c}{ RA } \\
\hline & $\mathrm{k}$ & $\mathrm{n}$ & $\mathrm{k}$ & $\mathrm{n}$ & $\mathrm{k}$ & $\mathrm{n}$ \\
23 & $-6.003 \mathrm{E}-04$ & 1.1052 & -515.15 & -1.1835 & -789.80 & -1.2280 \\
650 & $-4.643 \mathrm{E}-04$ & 1.1016 & -77.14 & -0.7374 & -764.38 & -0.9949 \\
\hline
\end{tabular}

Examination of figures 6.4 and 6.5 and the kinetic constants show that the major change in room temperature and elevated temperature strength and ductility occurs from $\sim 100$ to 400 hours at $675^{\circ} \mathrm{C}$. The TTT diagram for Haynes 25 shows this is the time when the $\mathrm{Co}_{3} \mathrm{~W}$ intermetallic forms. Additionally, the $\mathrm{M}_{6} \mathrm{C}$ carbide is predicted to start its formation at $\sim 50$ hours at this temperature as well. Thus it is not possible to determine the exact cause of ductility loss at $675^{\circ} \mathrm{C}$ without a more detailed study of the microstructure. McKamey and George have studied the impact ductility of Haynes 25 at $675^{\circ} \mathrm{C}$ and have concluded that observed increases in hardness and decreases in ductility are due to the formation of carbides and intermetallics, but the two phenomena are not directly related. Their work suggests that grain boundary precipitates affect ductility while intragranular precipitates effect hardness [21]. The kinetic constants in Table 2 suggest that different precipitates (or the same precipitates that precipitate at different location and times) are responsible for changes in strength and ductility. The value of n should be independent of temperature for the same nucleation mechanism. The n-values for YS, EL, and RA are the same for room temperature and YS at $650^{\circ} \mathrm{C}$, but ductility at $650^{\circ} \mathrm{C}$ is governed by a different n-value suggesting a different precipitate (or location) is contributing to the loss of high-temperature ductility. Current work is being undertaken to carefully examine these specimens to better characterize the precipitates, their morphology, and location as a function of time and temperature.

The data plotted from Bourgette in figures 6.4 and 6.5 show much lower strength and higher ductility at room temperature for alloy 25. At room temperature, these data do show a small increase in strength and loss of ductility with aging time that is similar to the data in this study. These data are shifted to slightly longer times, which may be due to differences in chemistry, thermal history, and aging at $650^{\circ} \mathrm{C}$ instead of $675^{\circ} \mathrm{C}$. Unfortunately, the high-temperature data are too limited to infer any trends.

Short-term 1,000 hour aging treatments were carried out at 700 and $750^{\circ} \mathrm{C}$ in addition to the aging studies conducted at $675^{\circ} \mathrm{C}$. Room temperature tensile tests were performed on the 1,000 hour aged material and are compared to the 1,000 hour aged data from the historical database in appendix A.7 (Table A.7.3). Figure 6.6 is a plot of these data. In general this heat of material shows higher room temperature YS and UTS after aging compared with the historical dataset. The ductility appears to fit the trend of the historical database with EL and RA measurements lower than lower-temperature aged material and higher than higher-temperature aged material after 1,000 hours. 

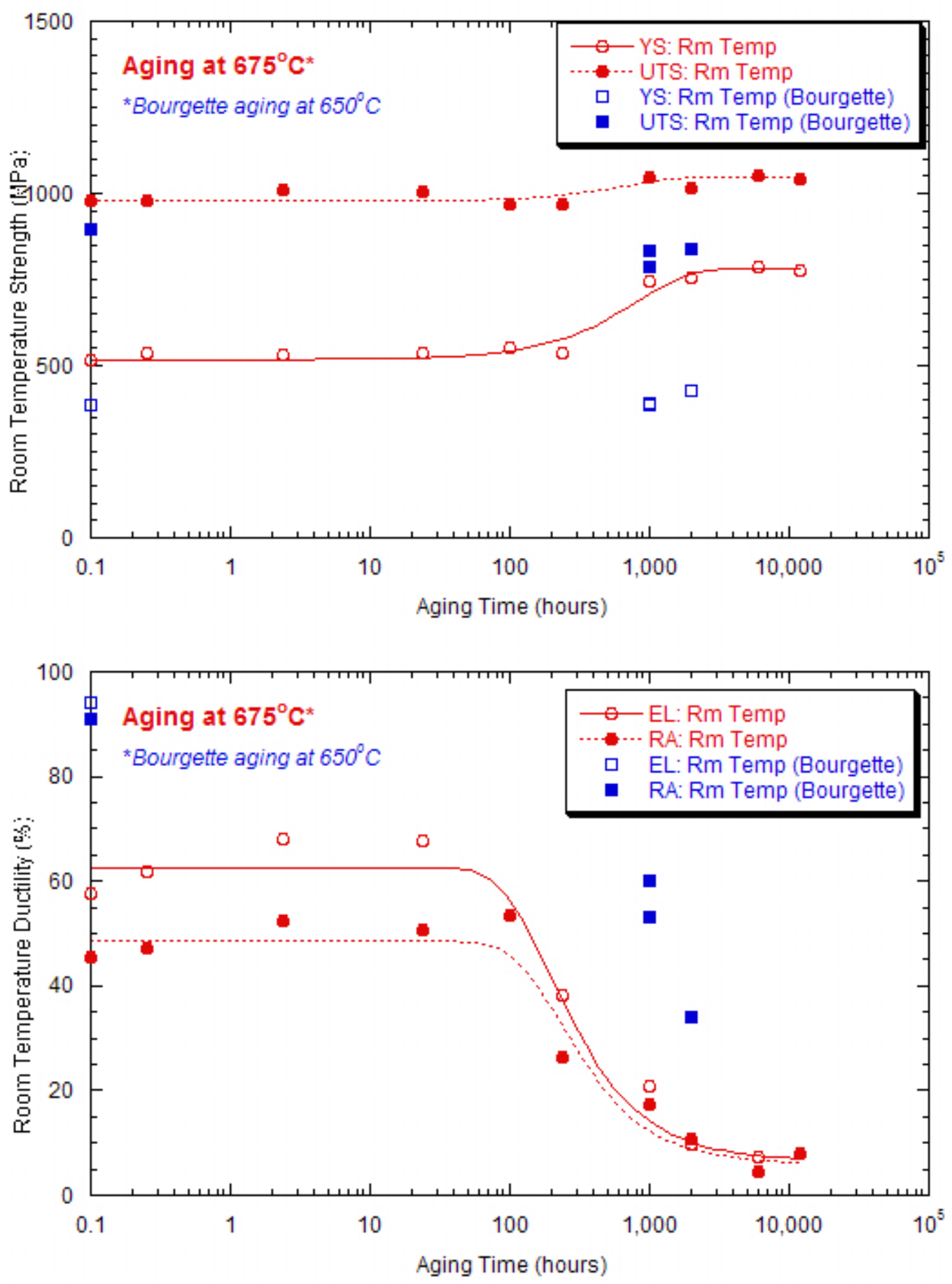

Figure 6.4. Room temperature tensile strength and ductility as a function of aging time at $675^{\circ} \mathrm{C}$ for alloy 25. Data from Bourgette aged at $650^{\circ} \mathrm{C}$ is plotted for comparison [14]. 

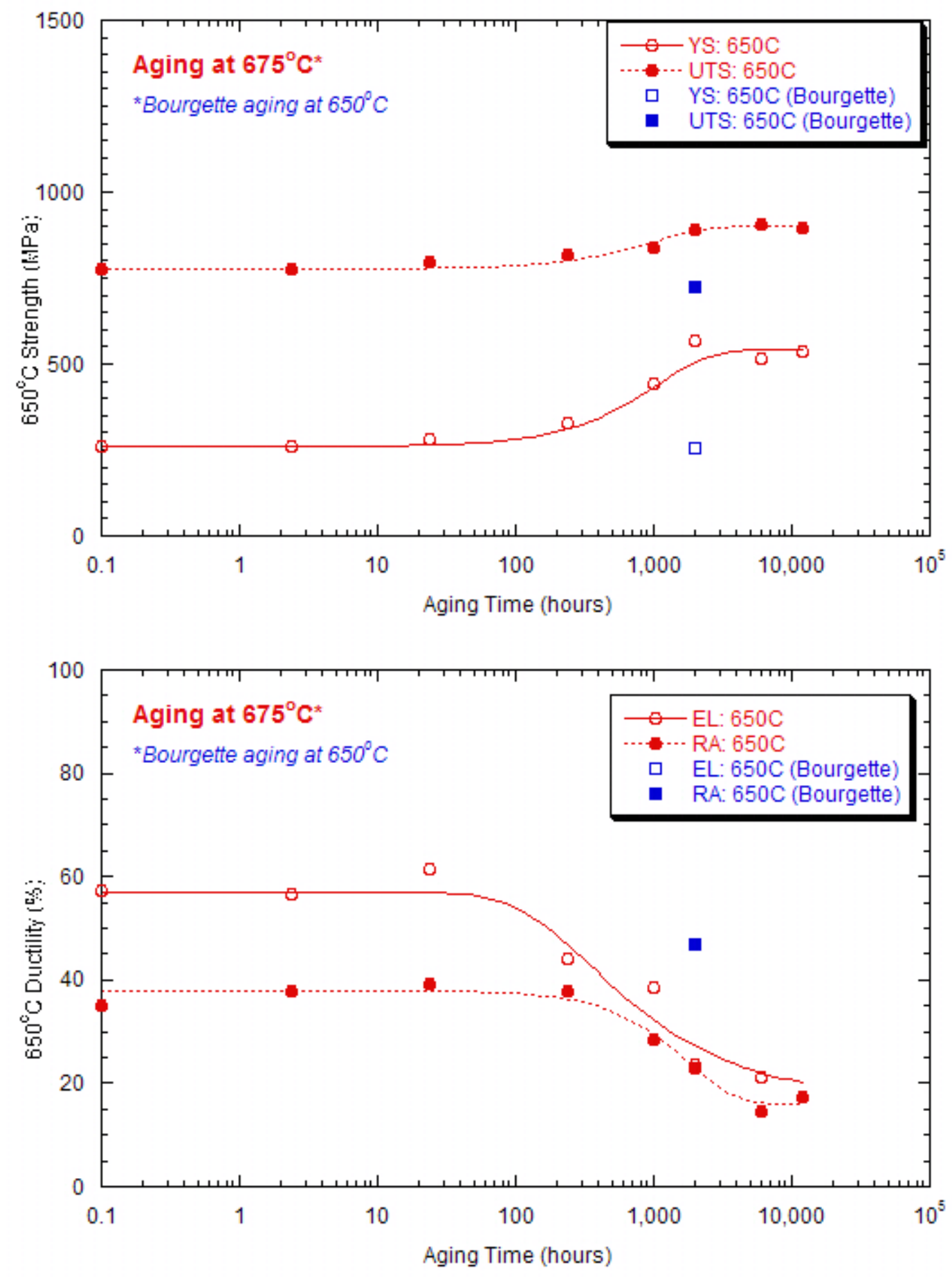

Figure 6.5. Tensile strength and ductility at $650^{\circ} \mathrm{C}$, as a function of aging time at $675^{\circ} \mathrm{C}$ for alloy 25. Data from Bourgette aged at $650^{\circ} \mathrm{C}$ is plotted for comparison [14]. 

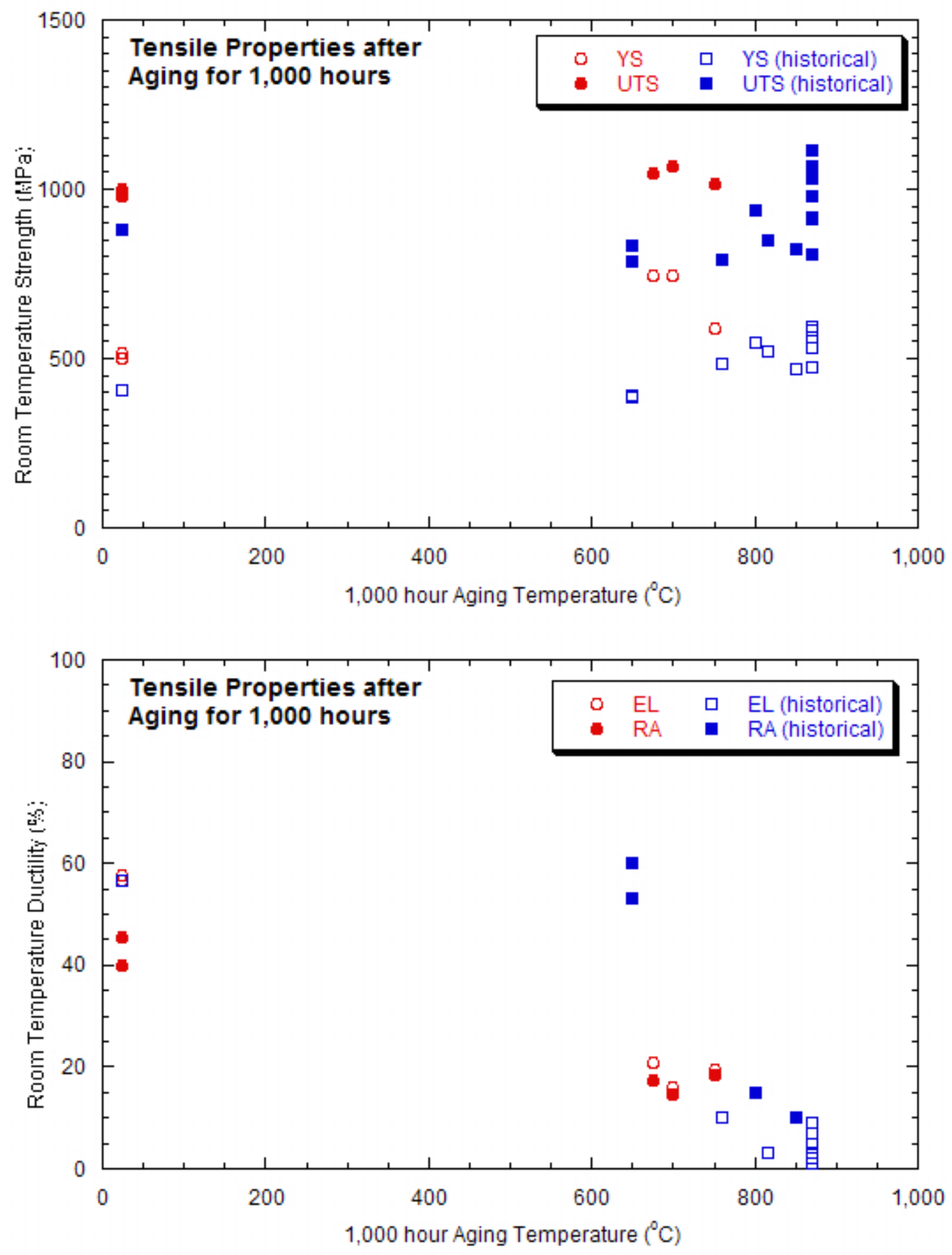

Figure 6.6. Room temperature tensile properties as a function of 1,000 hour aging temperature.

Figures 6.7 and 6.8 compare the measured tensile properties of the unaged sheet to the annealed historical database in appendix section A.7 (Table A.7.1). For YS and UTS, the current heat of material followed the general trend of the database. The strength values were average or slightly higher than average from room temperature to $650^{\circ} \mathrm{C}$. At $800^{\circ} \mathrm{C}$ to $1100^{\circ} \mathrm{C}$, the YS and UTS data fell within the scatter of the historical dataset. 

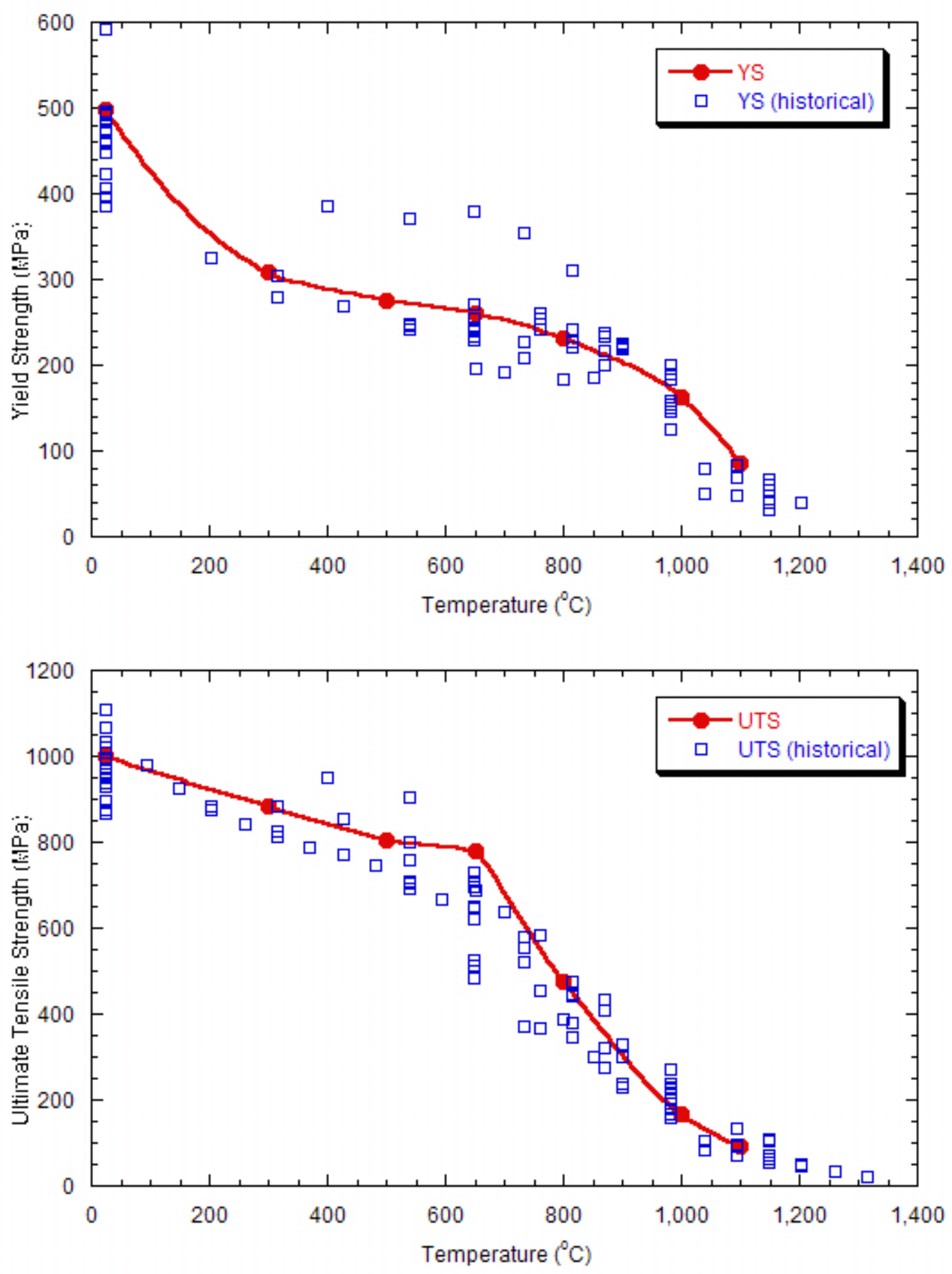

Figure 6.7. Measured Yield Strength (YS) and Ultimate Tensile Strength (UTS) for Haynes alloy 25 sheet (as-received, no aging) as a function of temperature compared to the historical database for annealed alloy 25.

Elongation (EL) values for this heat followed the typical trend in the historical database up to $650^{\circ} \mathrm{C}$, but EL values at $800^{\circ} \mathrm{C}$ to $1100^{\circ} \mathrm{C}$ were higher than any others reported in the historical database. Although the historical database does not contain RA values, the RA was plotted for this heat of material in figure 6.8, and the RA showed the identical trend to EL. Since EL is not specimen geometry independent (EL 
for the same material may vary depending on GL), RA is generally a better measure of ductility. Since both ductility measures show the same trend, the EL result is not due to specimen design. The reason for improved high-temperature ductility without a corresponding decrease in strength is not obvious, but improved melting practices and heat-treatments to produce a finer grain size, compared to older airmelting practices and coarse grain sizes in the historical database, may be reasons for the discrepancy with the historical dataset. The ductility data are consistent with a number of individual studies on alloy 25, summarized in ref [28], which show the material does exhibit a tensile ductility minimum around $760^{\circ} \mathrm{C}\left(1400^{\circ} \mathrm{F}\right)$. This is attributed to fracture behavior. "At low temperatures below the ductility minimum, crack propagation is transgranular in nature whereas at the minimum it is intergranular in nature failing by wedge-shaped voids and grain boundary shear. At higher temperatures the intergranular fracture mode continues but thermal recovery allows for blunting of the crack tips and improves ductility [28].”

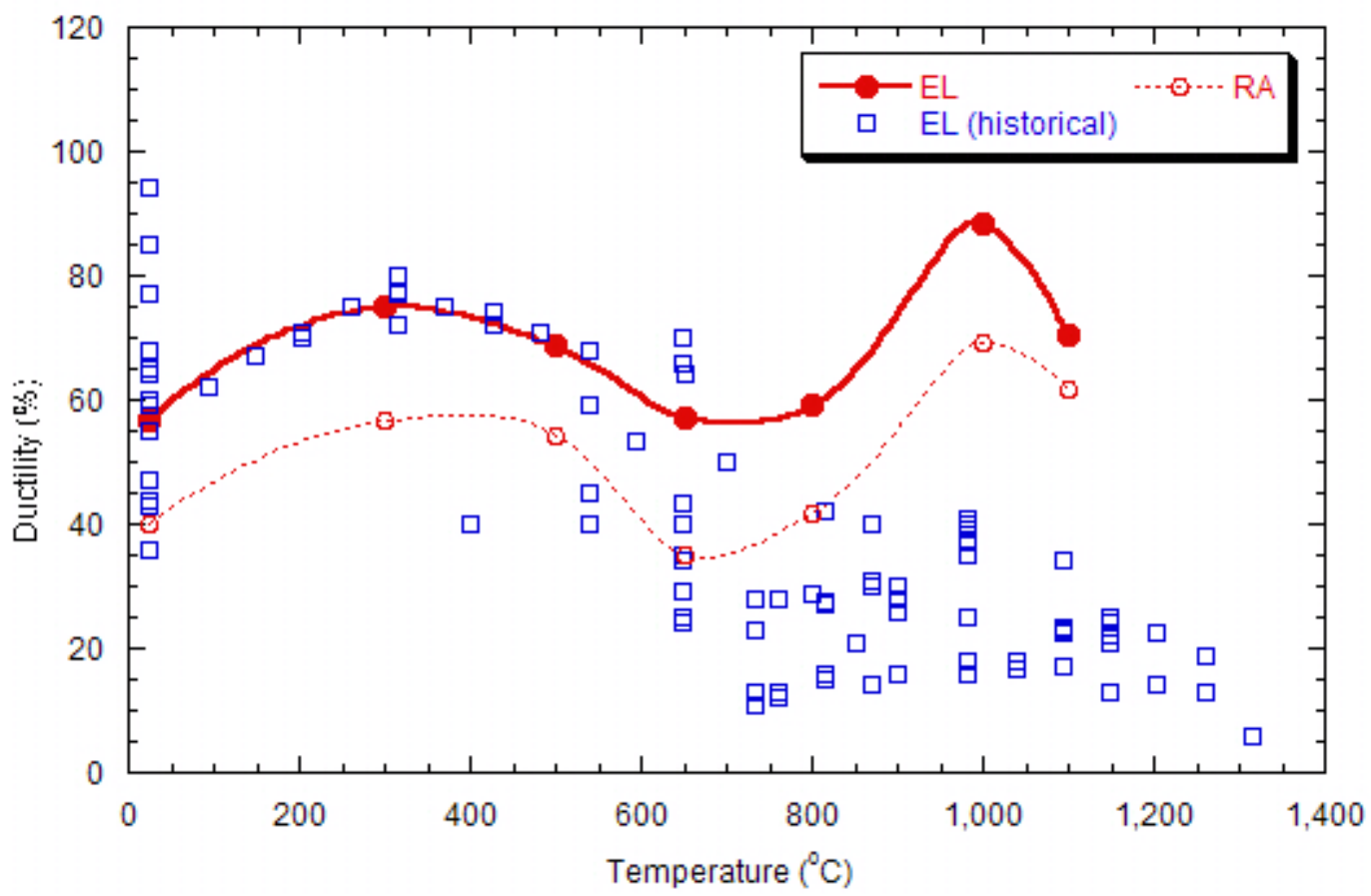

Figure 6.8. Measured ductility for Haynes alloy 25 sheet (as-received, no aging) as a function of temperature compared to the historical database for annealed alloy 25.

The historical dataset contains data on weldments (Table A.7.2). These data are for thinner sheet product and all reported failures occurred in the weld metal. For the current sheet and bar weldment, most failures were in the base metal, although a few of the bar data were in the weld. As discussed previously, this is mainly due to the mechanical reinforcement provided by the weldment crown (which was not removed). Thus, a comparison with the historical weld data is not appropriate. However, no HAZ failures were found in the current tensile dataset which does indicate the welding process did not have a detrimental effect on tensile properties. Figures 6.9 and 6.10 compare the weldment tensile data to the historical database. As expected, these data shows better YS and UTS compared to the historical data for the entire temperature range. For EL and RA, the trend is similar; at $650^{\circ} \mathrm{C}$ and above, the current welded sheet and bar show better ductility compared to the historical data. 

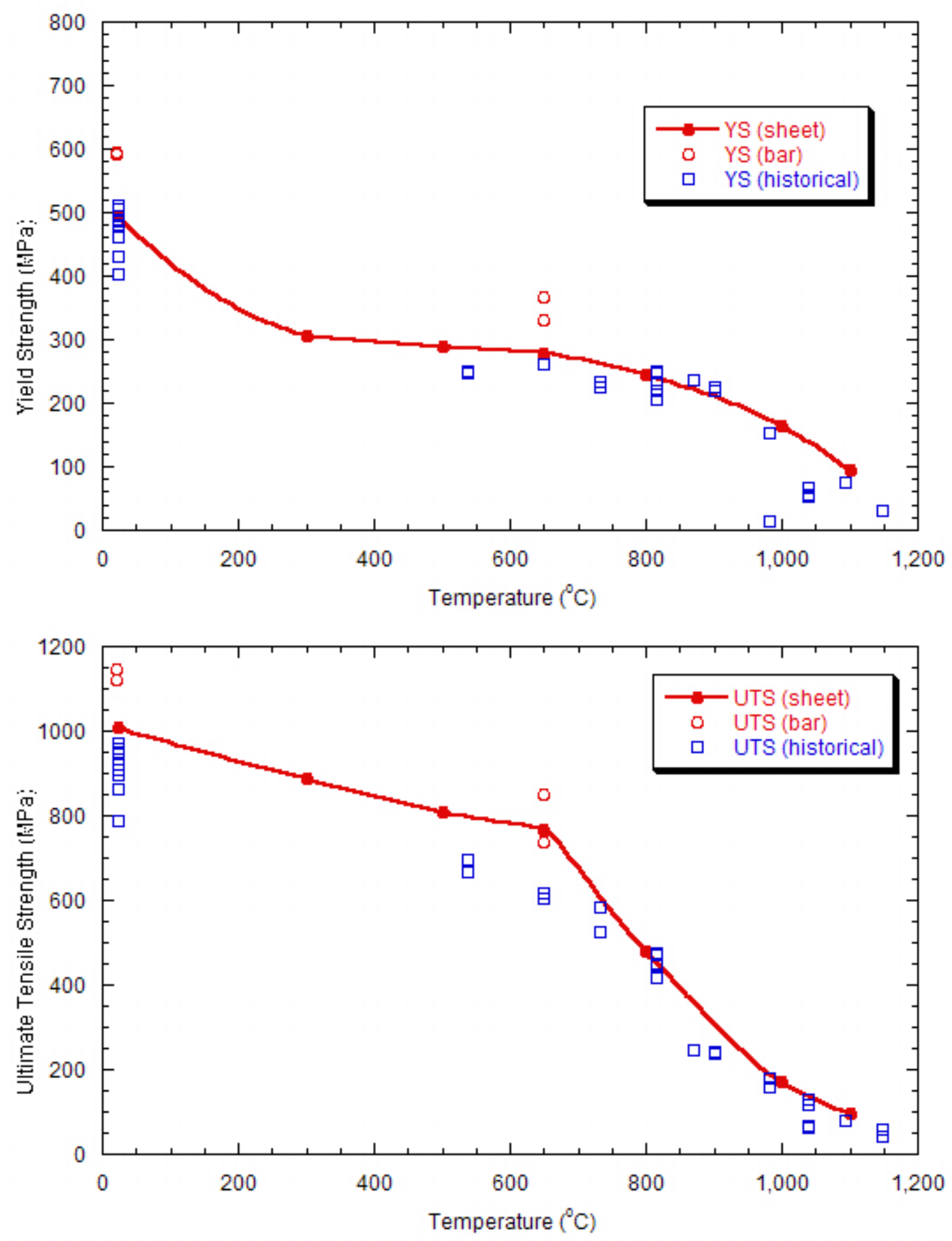

Figure 6.9. Measured Yield Strength (YS) and Ultimate Tensile Strength (UTS) for Haynes alloy 25 sheet weldments (no aging) as a function of temperature compared to the historical database for alloy 25 weldments. 


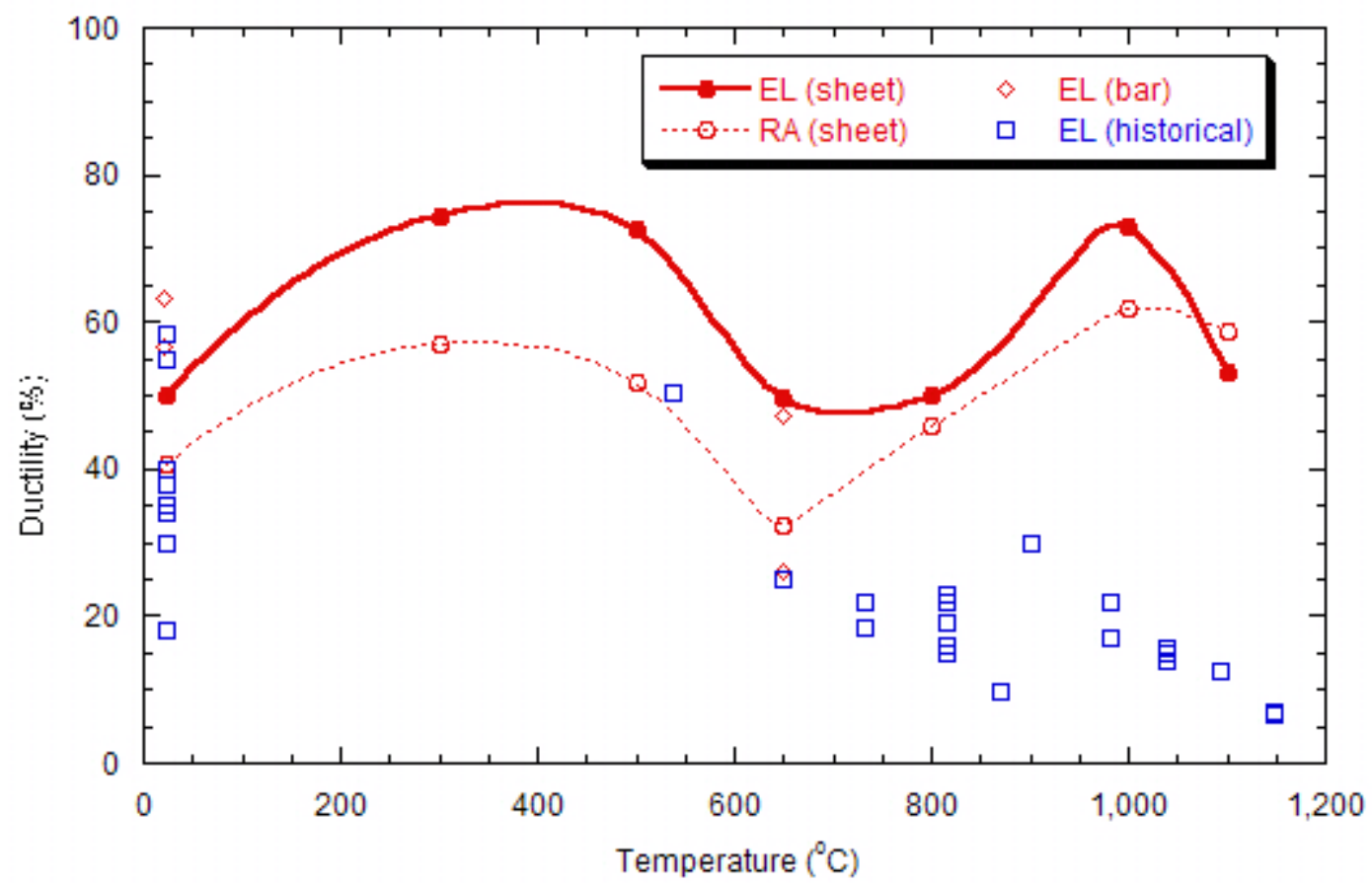

Figure 6.10. Measured ductility for Haynes alloy 25 sheet weldments (no aging) as a function of temperature compared to the historical database for alloy 25 weldments. 


\section{CREEP PROPERTIES RESULTS AND DISCUSSION}

Uniaxial creep and creep-rupture tests were performed on alloy 25 sheet and weldments in the unaged and aged for 6,000 hour at $675^{\circ} \mathrm{C}$ condition and alloy 25 bar weldments in the unaged condition. Tests were conducted from $600^{\circ} \mathrm{C}$ to $950^{\circ} \mathrm{C}$ for times exceeding 40,000 hours. The results of these tests are presented in tabular form in appendix section A.3 (Tables A.3.1 and A.3.2). The corresponding creep strain versus time curves are included in appendix A.6. Tubular creep-rupture tests (internally pressurized tubular specimens machined from bar stock) were conducted from $675^{\circ} \mathrm{C}$ to $950^{\circ} \mathrm{C}$ for times exceeding 22,000 hours. Internal pressures ranged from 8.3 to $42.7 \mathrm{MPa}$ (1,200 to 6,200 psi).

\subsection{UNIAXIAL RUPTURE RESULTS}

The uniaxial rupture results for all material conditions; unaged sheet (Base Metal or BM), sheet pre-aged before testing for 6,000 hour at $675^{\circ} \mathrm{C}$ (Aged Base Metal or BM-Aged), sheet or bar weldments (Weld Metal or WM), and sheet weldments pre-aged before testing for 6,000 hour at $675^{\circ} \mathrm{C}$ (Aged Weld Metal or WM-Aged), are plotted using the Larson-Miller Parameter (LMP) approach in figure 7.1. The LMP is defined as follows, where $\mathrm{t}_{\mathrm{r}}=$ rupture life (hours), $\mathrm{T}=$ temperature $\left({ }^{\circ} \mathrm{C}\right)$, and $\mathrm{C}=$ constant:

$$
\mathrm{LMP}=(273+\mathrm{T})\left[\log \left(\mathrm{t}_{\mathrm{r}}\right)+\mathrm{C}\right] \quad \text { equation } 5
$$

Previous work has shown the historical HS-25 database to be best fit using a constant between 16.7 and 17.5 [2]. A constant of $\mathrm{C}=17$ was used for the plot in figure 7.1. This gave a standard error of estimate (SEE) in the difference between the log time calculated from the LMP and the actual time to rupture of 0.18. Evaluation of the rupture data in figure 7.1 shows no obvious trend in rupture life as a function of material condition. All data fall in a tight scatter band with overlapping data for each material condition. Thus it was concluded that aging at $675^{\circ} \mathrm{C}$ and welding have no deleterious effects on the rupture strength of alloy 25.

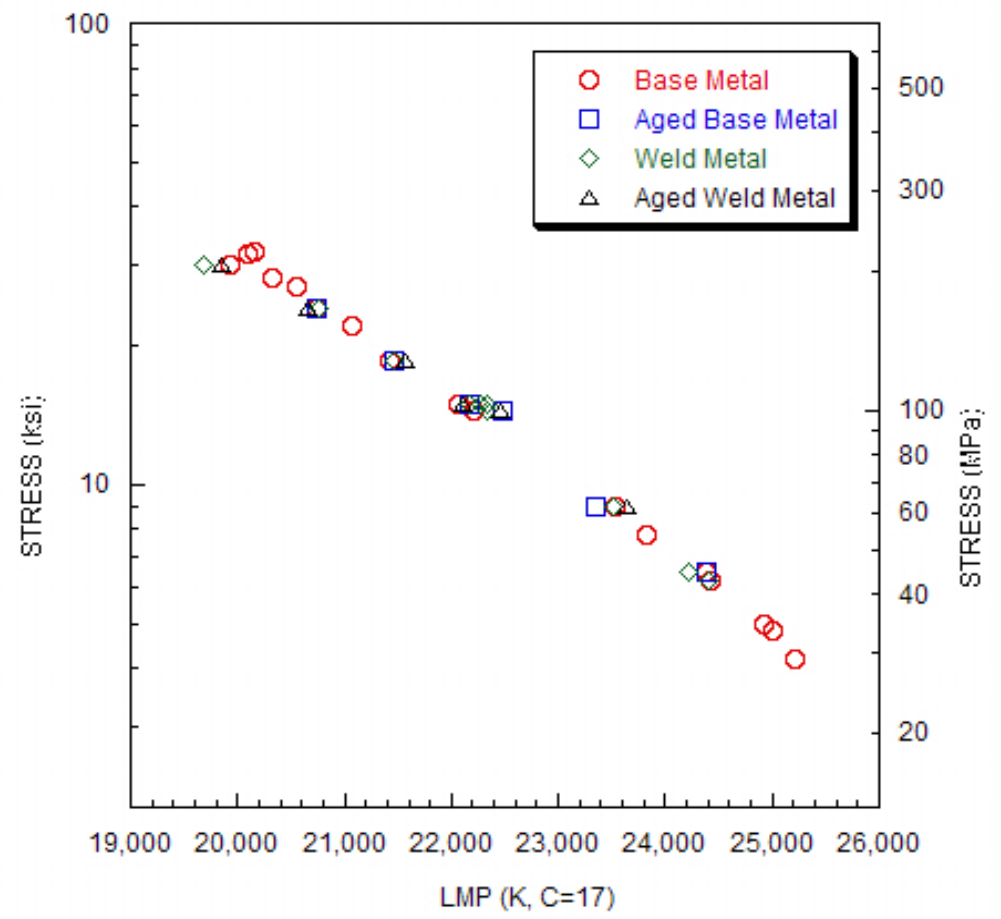

Figure 7.1. Larson-Miller Parameter (LMP) vs. Stress (log scale) for all material conditions. 
Figure 7.2 is a LMP plot for the current uniaxial dataset and the historical rupture dataset. A second order polynomial is fit through all of the data on the plot. The historical dataset shows significant variation about this best fit line, but the current heat of tested material shows a good correlation to the line with only slight deviations for the highest and lowest stress tests conducted on this heat of alloy 25 . These data are re-plotted in figure 7.3 as actual rupture life versus predicted rupture life by the LMP method. A one to one (straight line) correlation is an exact fit. Dotted lines are included in the plot to indicate the bounds for data within a factor of \pm 2 in life. Most data points for all material conditions fall within the plus or minus factor of two in life while many data points in the historical dataset fall outside of this range. The entire range of actual versus predicted times for the historical dataset is about plus or minus a factor of thirty (range of over two log cycles) in life. From this plot, it is concluded that an LMP fit of all the uniaxial rupture data, including the historical dataset, shows very good correlation with current heat of alloy 25, but using the historical dataset for design may be problematic due to the large variations in rupture times.

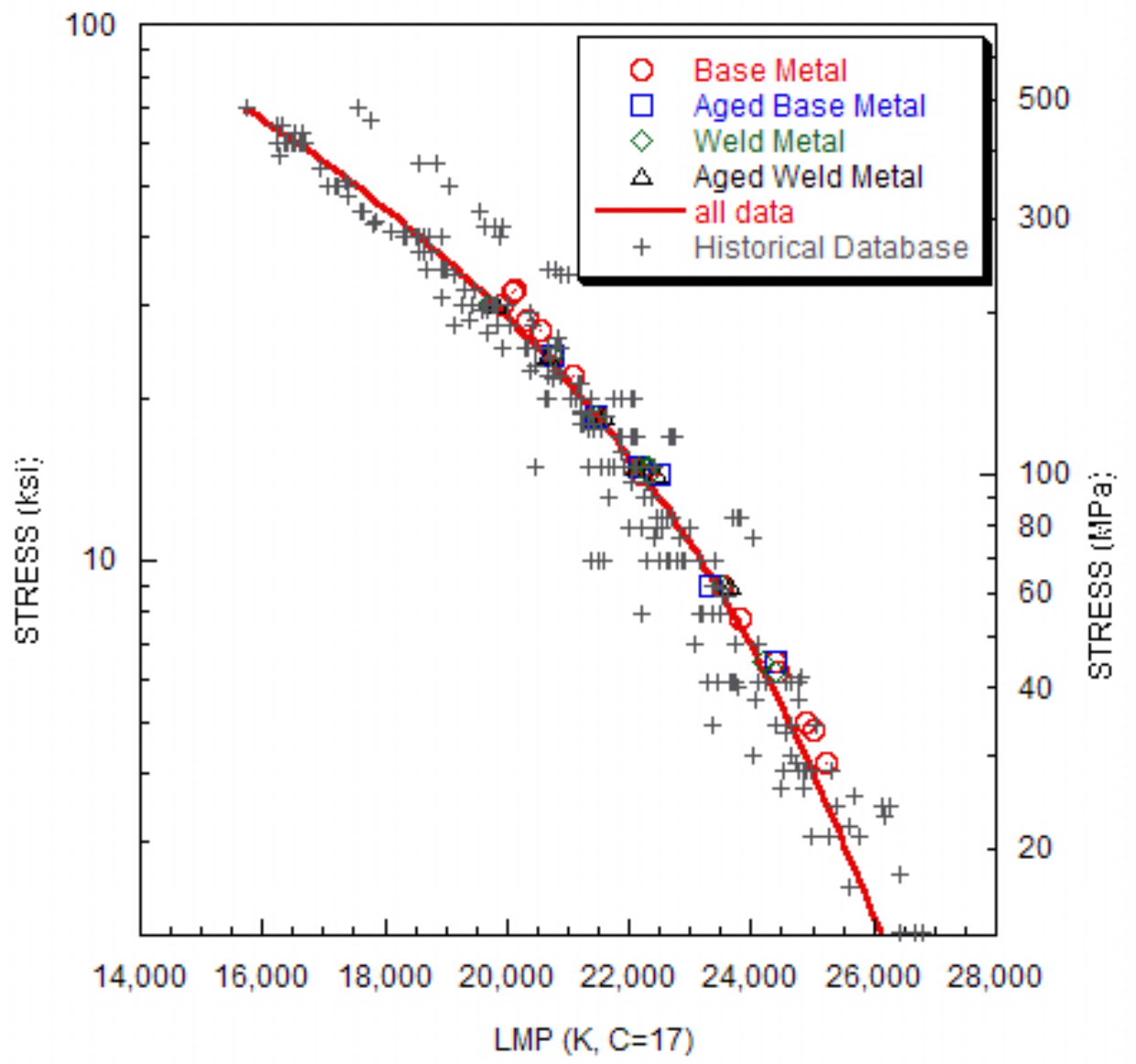

Figure 7.2. Larson-Miller Parameter (LMP) vs. Stress (log scale) for all material conditions and the historical database. 


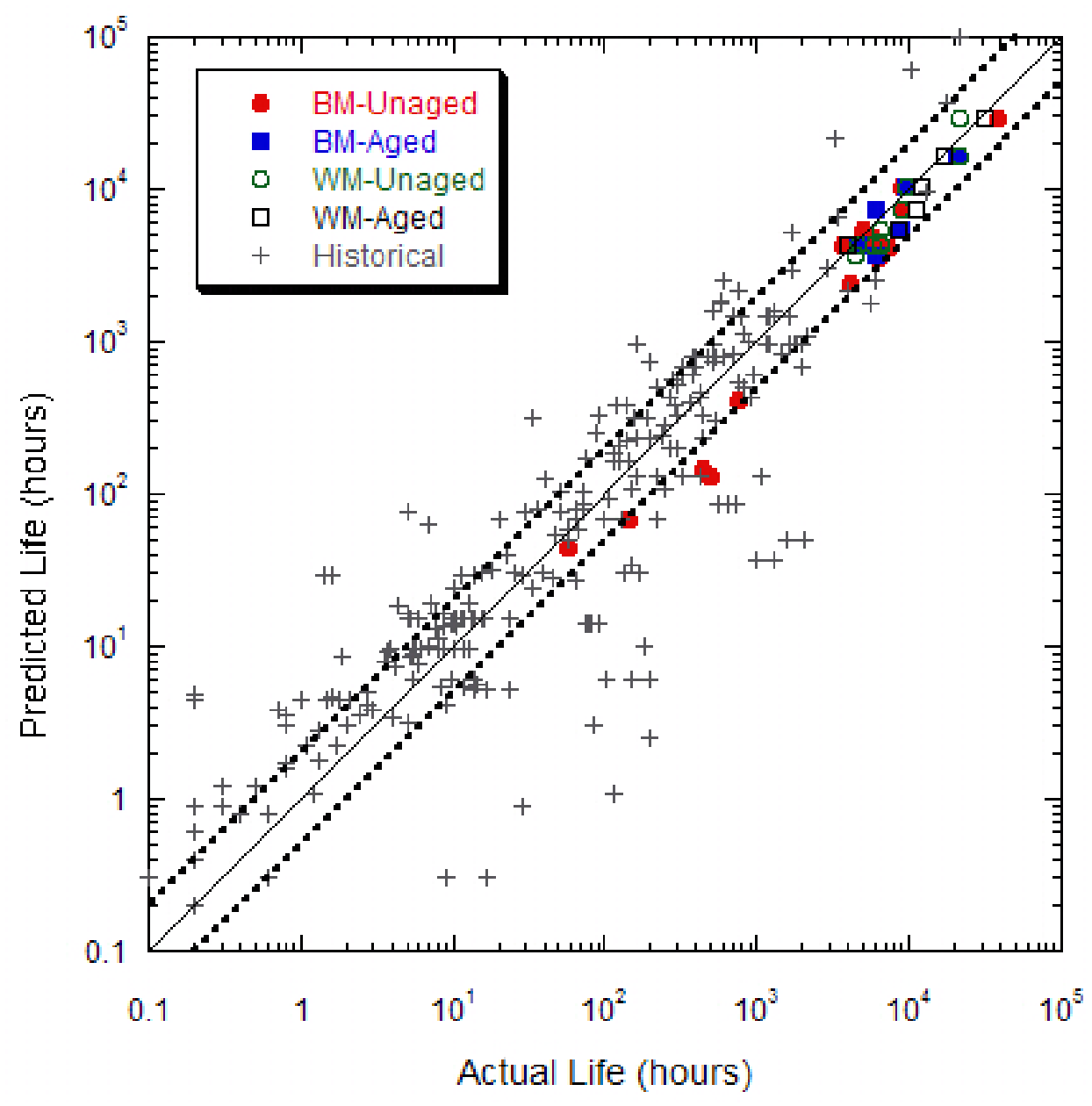

Figure 7.3. Actual life versus predicted life (LMP analysis). Dotted lines are plus or minus a factor of two on life.

Rupture ductility (post-test elongation) as a function of rupture life is plotted for all material conditions and the historical dataset in figure 7.4. Most of the historical dataset is based on short-time data, which gives highly variable results in terms of rupture ductility. For test times of 0.1 to 1,000 hours, the ductility of the historical dataset ranges from 2 to $35 \%$, and the few rupture points beyond 1,000 hours the range is 2 to $15 \%$. The current heat of material shows similar behavior where 100 hour tests gave $50 \%$ elongation, 1,000 hours gave 20 to $30 \%$ elongation, 5,000 to 10,000 hour tests resulted in 5 to $15 \%$, and ruptures beyond 10,000 hours resulted in ductilities of 2 to $6 \%$.

In figure 7.4, the rupture elongation measurements for each material condition overlap one another and no effect can be seen. However, examination of creep curves in the appendix A.6, revealed a few noticeable trends. The general trend for all the data is captured in figure 7.5. First, as already stated by LMP analysis, rupture life was not significantly affected by material condition (less than a factor of two in life). Second, when comparing base and welded material (either comparing unaged to unaged or aged to aged) the weld specimen showed slightly less creep strain for a given time. This is attributed to increased resistance to creep deformation in the cross weldment location. The strength of the weldment is a function of both weldment mechanical properties and geometry. As with the tensile tests, the weldment was mechanically reinforced because the weld crown was not removed which contributes to a portion of the gauge length having improved creep resistance. The third trend observed is the aging effect. Aging at $675^{\circ} \mathrm{C}$ for 6,000 hours reduces the minimum creep rate and lowers the creep strain at a given time 
compared to identical tests on unaged material. The degree of this effect is a function of testing temperature. Generally, the effect is large (large differences between creep rates and strains) at low temperatures near or below the aging temperature, but the effect is minimal at the highest temperatures tested.

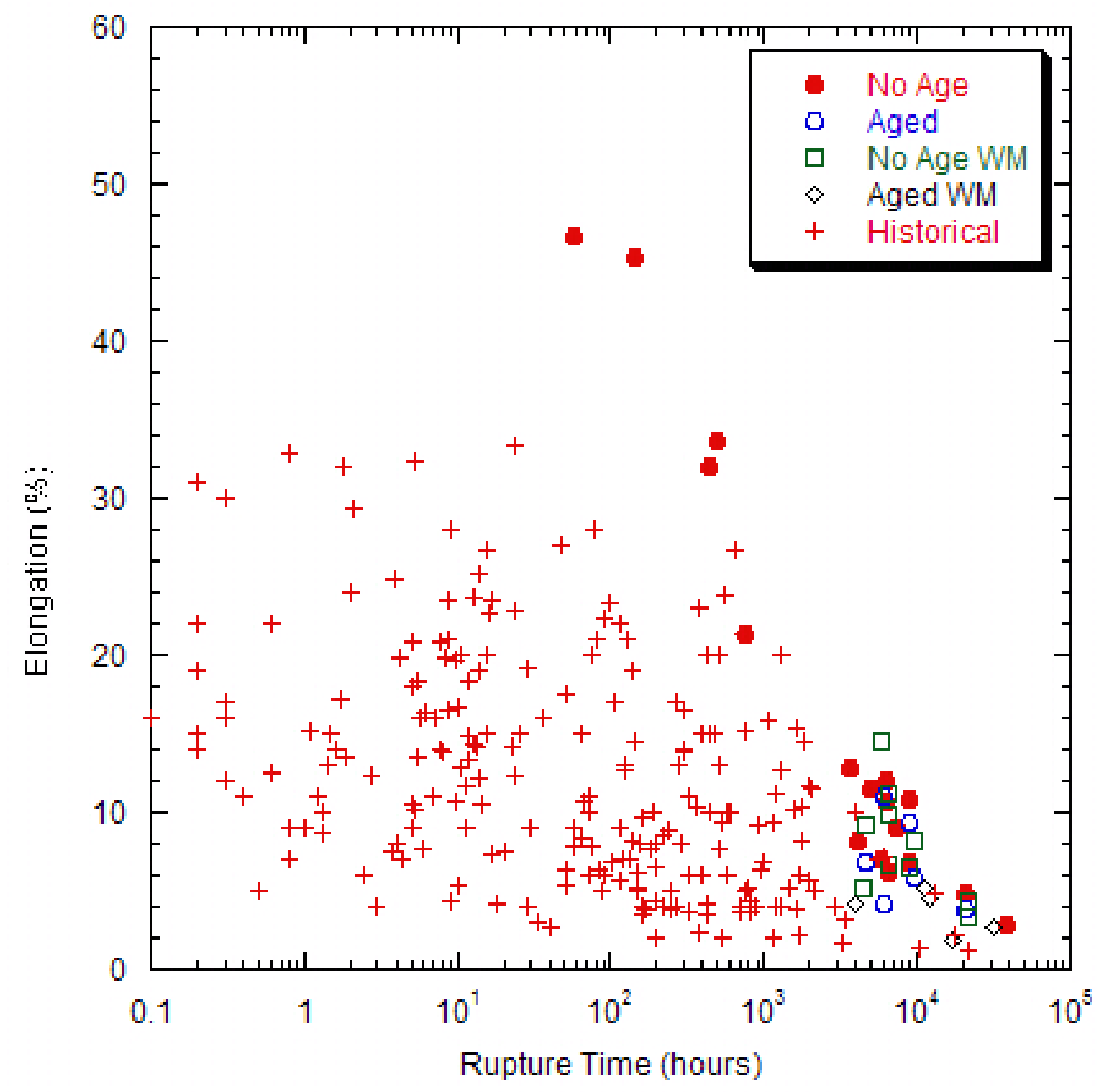

Figure 7.4. Rupture ductility as a function of rupture time for all material conditions compared to the historical database. 


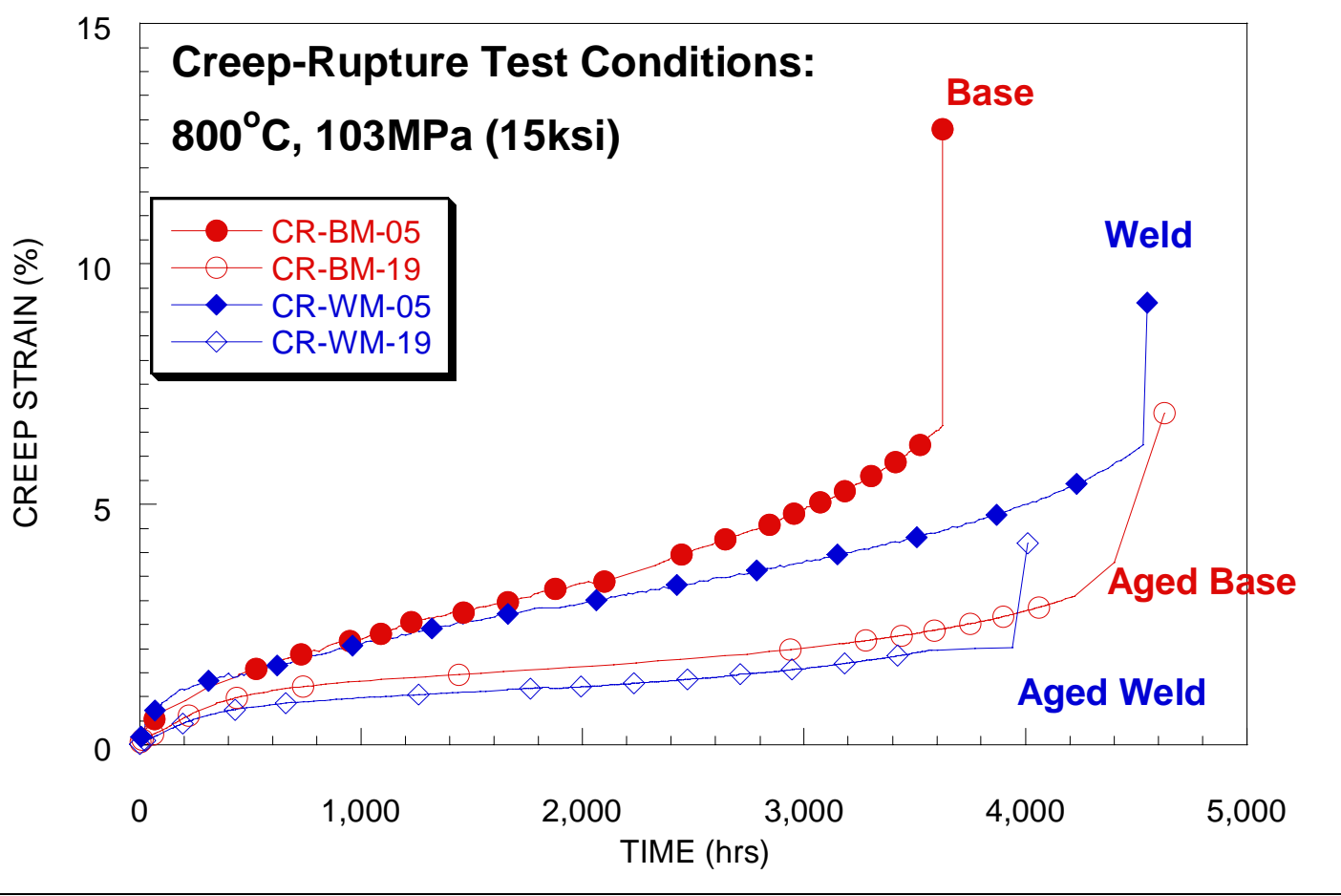

Figure 7.5. Creep curves (time vs. creep strain) for the four material conditions tested at $8^{\circ}{ }^{\circ} \mathrm{C}$ and $103 \mathrm{MPa}(15 \mathrm{ksi})$.

\subsection{PRESSURIZED TUBE RUPTURE RESULTS}

To evaluate the internally pressurized tube creep-rupture test results, the rupture life of the capsule was compared to the expected life using the fit of the rupture data in figure 7.2 and assuming the stress distribution in the tubular specimen could be modeled as an infinitely long tube. For a thick-walled tube with an internal pressure $P$, an internal radius $R_{i}$, and an external radius $R_{0}$, the elastic hoop stress ( $\sigma_{\text {hoop }}$ ), axial stress $\left(\sigma_{\text {axial }}\right)$, and radial stress $\left(\sigma_{\text {radial }}\right)$ were calculated at any radial location $(r)$ by Lame, per the following equations [22]:

$$
\begin{aligned}
& \sigma_{\text {hoop }}=P \times \frac{R_{i}^{2}}{R_{o}^{2}-R_{i}^{2}}\left(1+\frac{R_{o}^{2}}{r^{2}}\right) \\
& \sigma_{\text {axial }}=P \times \frac{R_{i}^{2}}{R_{o}^{2}-R_{i}^{2}} \\
& \sigma_{\text {radial }}=P \times \frac{R_{i}^{2}}{R_{o}^{2}-R_{i}^{2}}\left(1-\frac{R_{o}^{2}}{r^{2}}\right)
\end{aligned}
$$


When creep deformation is considered, the Lame equations may not be applicable depending on the wall thickness. During creep, high stresses can relax. When this happens, the stresses are transferred to lower stress areas within the structure. The speed and the degree at which this happens are governed by the creep properties of the material. For simplicity, Bailey assumed the material's creep behavior could be modeled using only steady-state creep with a power-law dependence. Using this assumption, for a power-law exponent of $n$, the stress distribution is described as follows [22]:

$$
\begin{aligned}
& \sigma_{\text {hoop }}=P \times \frac{[(2-n) / n]\left(R_{o} / r\right)^{2 / n}+1}{\left(R_{o} / R_{i}\right)^{2 / n}-1} \\
& \sigma_{\text {axial }}=P \times \frac{[(1-n) / n]\left(R_{o} / r\right)^{2 / n}+1}{\left(R_{o} / R_{i}\right)^{2 / n}-1} \\
& \sigma_{\text {radial }}=-P \times \frac{\left(R_{o} / r\right)^{2 / n}-1}{\left(R_{o} / R_{i}\right)^{2 / n}-1}
\end{aligned}
$$

equation 9

equation 10

equation 11

When $n$ equals 1 , i.e. when the creep-rate has a linear stress dependence, then the Bailey solution becomes the Lame solution.

In order to evaluate the internally pressurized tube rupture data using the Lame and Bailey equations, a single stress value for each test is needed. Two criteria (yield surfaces) were used; the Von Mises (VM) and the Stress Intensity (SI). The VM takes into account all three stresses (radial, axial, and hoop):

$$
\sigma_{V M}=\sqrt{\frac{\left(\sigma_{1}-\sigma_{2}\right)^{2}+\left(\sigma_{2}-\sigma_{3}\right)^{2}+\left(\sigma_{3}-\sigma_{1}\right)^{2}}{2}}
$$

equation 12

The SI is simply two times the Tresca stress or the maximum principal stress minus the minimum principal stress:

$$
\sigma_{S I}=\sigma_{\max }-\sigma_{\min }
$$

equation 13

An alternative approach to evaluating rupture in structures is the reference stress approach [23]. The reference stress approach is based on a limit load analysis of a perfectly plastic material. The basis assumption in this approach is that there are similarities between creep and plasticity. For a structure subjected to complex loading in creep, after sufficient time, internal stresses will redistribute and reach a steady-state condition that can be described by the plastic solution (limit load) for the structure. The result of the limit load analysis for a given geometry combined with a yield criteria (typically Tresca) is a single reference stress ( $\sigma_{\text {reference}}$ ), which governs the creep deformation in the structure and is independent of material (as long as the material is not creep brittle) [24]. For an infinitely long tube, the reference stress (Tresca) is [24]:

$$
\sigma_{\text {reference }}=\frac{P}{\ln \left(R_{o} / R_{i}\right)}
$$

equation 14 
This equation has been shown to give the best correlation with available experimental data compared to various ASME Boiler and Pressure Vessel (B\&PV) Code rules for cylindrical sections with varying wall thickness that have crept under internal pressure [25]. The use of the equation was recently (2005) accepted in the ASME B\&PV Code Section I as an alternative method for determining wall thickness of tubes and pipe in boilers.

The VM criterion was applied to the inner diameter (ID) and outer diameter (OD) stresses calculated for both the Lame and Bailey solutions. A value of $n=8$ was used for the creep calculations. This value was determined by evaluating the creep data for this heat of alloy 25 (discussed later in this section) and is consistent with other observations of creep in the alloy [29, 30]. Furthermore, the analysis is very sensitive to $n$ only in the range of $n=1$ to $n=4$. Changing $n$ from 6 to 10 has little effect on calculated stresses. The SI was applied to the ID and OD for the Bailey creep solution, and the reference stress was also evaluated. The rupture time for each stress calculated by each method was then compared with the predicted rupture life for that stress value by evaluation of the LMP fit of the uniaxial data. Figures 7.6 and 7.7 show the results for each analysis as actual life versus predicted life. A one-to-one correlation is a perfect fit of the data, and dashed lines at a factor of plus or minus two in life are included on each plot. Several ruptures are identified in each plot. For the standard tube without any pre-aging and exhibiting a longitudinal rupture originating in the tube, the identification is No Age. For a standard tube without preaging that had a rupture initiate in the tubular specimen weldment, the identification is No Age-WM. For a standard tube without pre-aging that had a rupture in the tubular specimen cap, the identification is "No Age - Cap”. For the tube specimens pre-aged for 6,000 hours at $675^{\circ} \mathrm{C}$, the identification is "Aged”.

Each plot also includes a fit of a straight line (power-law fit on log-log plot) to see how well each model followed a one-to-one correlation. This line was fit to a censored dataset. To censor the dataset, the nontypical ruptures were removed (No Age-WM and No Age-Cap) and the rupture results on aged capsule test conducted at $750^{\circ} \mathrm{C}$ were also removed due to observed aging effects in creep deformation. The aged capsules tested at 850 to $950^{\circ} \mathrm{C}$ were included in the censored dataset along with the typical ruptures of unaged material because it was judged that aging at $675^{\circ} \mathrm{C}$ had little effect on creep behavior at and above $850^{\circ} \mathrm{C}$. This was based on experimental observations of creep deformation of aged material in uniaxial creep tests where creep rates were similar at the highest testing temperatures $\left(850^{\circ} \mathrm{C}\right.$ and above) regardless of aging condition. A comparison of the tube ruptures, later in this section, with the uniaxial data shows that the $750^{\circ} \mathrm{C}$ test on aged material exhibited consistently longer life than expected compared to the aged tubes tested at $850^{\circ} \mathrm{C}$ and above which were within the scatter of the data. 

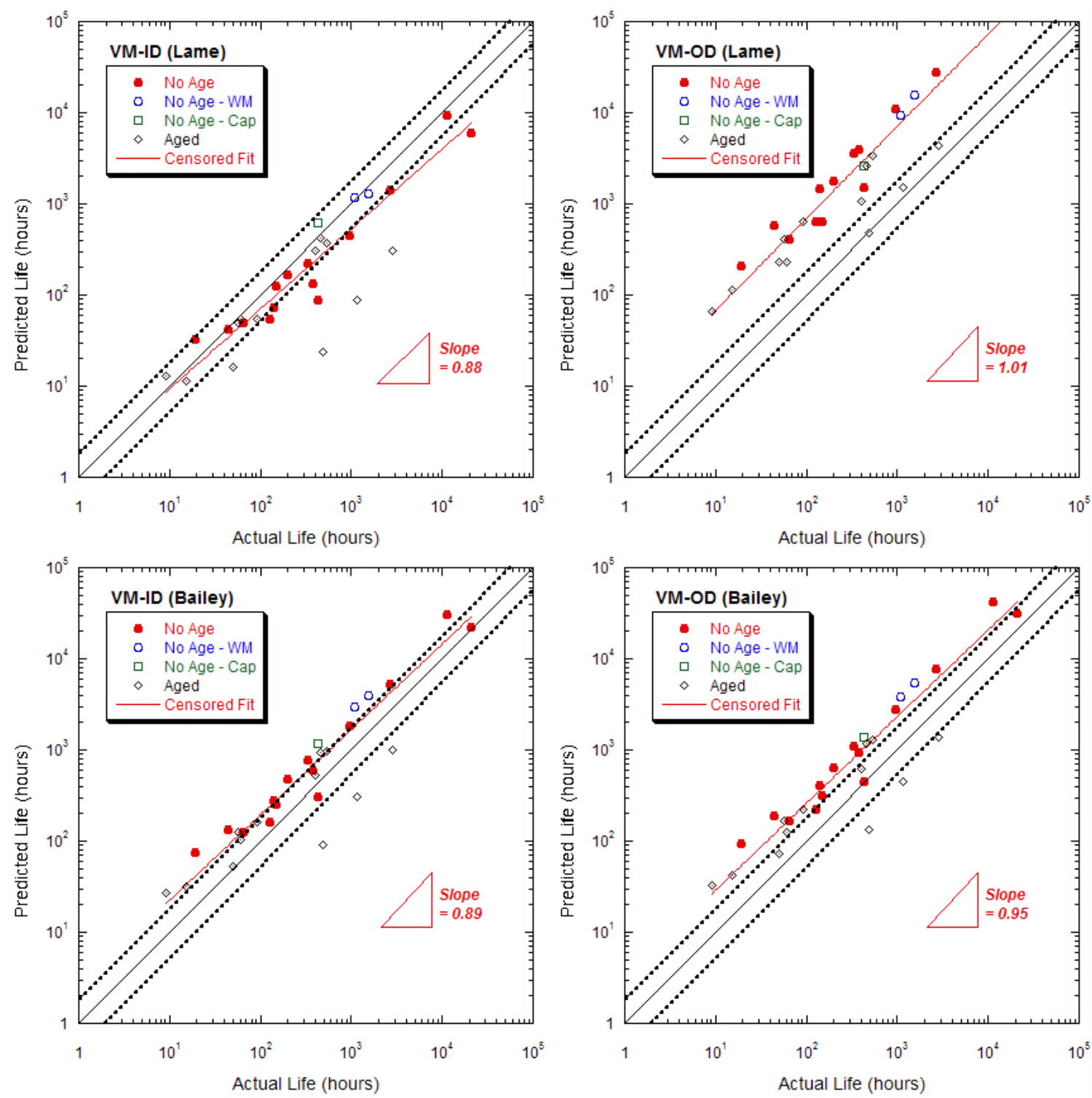

Figure 7.6. Actual vs. predicted life for pressurized tube creep-rupture tests analyzed using the Von Mises (VM) stress criterion for the inner (ID) and outer (OD) diameter elastic (Lame) and steady-state creep (Bailey) solutions. Slope is shown for a fit of the censored dataset. 

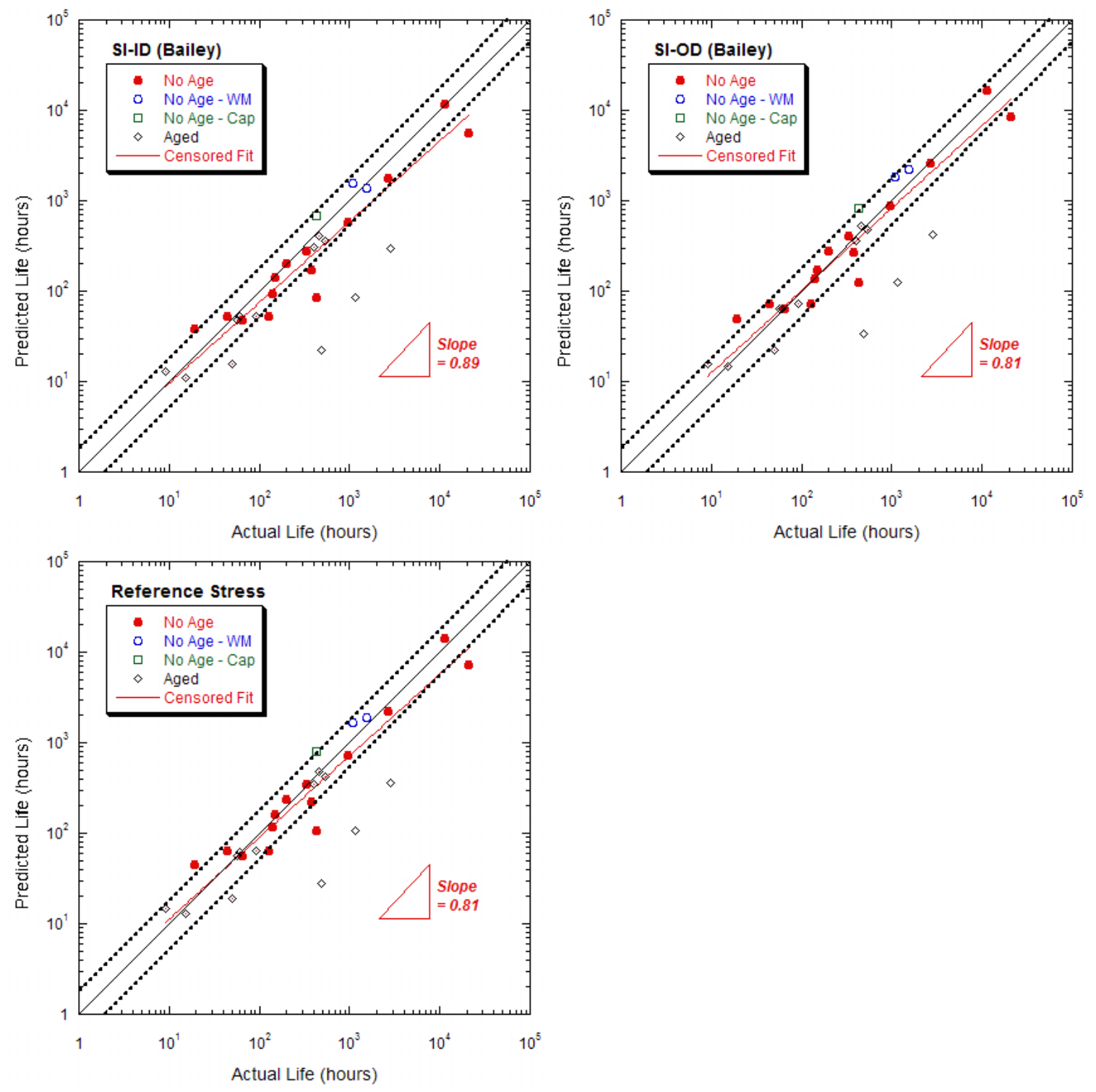

Figure 7.7. Actual vs. predicted life for pressurized tube creep-rupture tests analyzed using the stress intensity (SI) stress criterion (Tresca) for the inner (ID) and outer (OD) diameter steadystate creep (Bailey) solutions and for the reference stress solution (Tresca). Slope is shown for a fit of the censored dataset.

To evaluate the various stress criteria and models, the standard error of estimate (SEE) for log actual life and log predicted life was calculated for all of the rupture data and for the censored dataset. These results are tabulated with the calculated slopes for a fit of the censored dataset in Table 3. Visual examination of VM-OD (Lame), VM-ID (Bailey), and VM-OD (Bailey) plots show most of the data are above the one to one line and above the factor of two line. The VM-OD (Lame) showed the highest SEE for either dataset corroborating the visual inspection although it had the only slope close to one. The VM (Bailey) solutions appear to show good SEE for the entire dataset, but when the dataset is censored, little improvement is made in the SEE. This shows that the good SEE for the entire dataset is due to the location of the non-typical data and not due to a good representation of rupture data. 
Table 3. Standard error of estimate* (SEE) for tube rupture results

\begin{tabular}{lccccccc}
\hline & $\begin{array}{c}\text { VM-ID } \\
\text { (Lame) }\end{array}$ & $\begin{array}{c}\text { VM-OD } \\
\text { (Lame) }\end{array}$ & $\begin{array}{c}\text { VM-ID } \\
\text { (Bailey) }\end{array}$ & $\begin{array}{c}\text { VM-OD } \\
\text { (Bailey) }\end{array}$ & $\begin{array}{c}\text { SI-ID } \\
\text { (Bailey) }\end{array}$ & $\begin{array}{c}\text { SI-OD } \\
\text { (Bailey) }\end{array}$ & $\begin{array}{c}\text { Ref. } \\
\text { Stress }\end{array}$ \\
SEE & 0.45 & 0.83 & 0.37 & 0.44 & 0.45 & 0.38 & 0.40 \\
SEE (censored) & 0.29 & 0.87 & 0.31 & 0.43 & $\mathbf{0 . 2 7}$ & $\mathbf{0 . 2 1}$ & $\mathbf{0 . 2 3}$ \\
Slope & 0.88 & 1.01 & 0.89 & 0.95 & 0.89 & 0.81 & 0.81 \\
(censored) & & & & & & & \\
\hline
\end{tabular}

*SEE calculated for log actual life and log predicted life based on LMP fit of uniaxial data

The VM-ID (Lame) shows better correlation than the other VM results, but 8 censored data points fall below the factor of 2 band.

The SI-ID and -OD (Bailey) results show improved SEE for the entire dataset and for the censored datasets. For the ID, 5 censored data points fall below the factor of 2 band while for the OD 3 fall below and 1 falls above the band. The SEE for the SI-OD (Bailey) is the lowest of any analysis of the data, but the slope of the SI-ID (Bailey) censored dataset is slightly closer to one.

The reference stress approach results in a SEE between the SI (Bailey) solutions. Four censored data points fall below the band while one falls above the band. The slope and SEE is very close to the SI-OD (Bailey).

Based on these data, it is clear that the Lame solutions give a poor representation of the rupture data and the VM criteria, regardless of the stress calculation, gives a less accurate result compared to the Tresca based SI and reference stress solutions. The SI-ID (Bailey) gives a good fit of the data and a conservative estimation on life. The SI-OD (Bailey) and the reference stress (Tresca) give the best fits of the tubular creep data to the uniaxial creep data.

Microstructural observations of ruptured tubes appear to support the Tresca based creep solutions. Figure 7.8 shows the microstructure of a tube after pressurized creep testing. Extensive inner (ID) and outer (OD) diameter cracking are observed. Additionally, intergranular cavitation is observed through the entire wall of the tube. Although there is a stress gradient through the wall of the tube, the SI criteria for the creep (Bailey) solutions results in similar stress values on the ID and the OD of the tubes. In contrast, the Von Mises criteria applied to the elastic solution results in large differences in stress values at the OD and ID of the tube. Assuming that crack/cavitation initiation is controlled by the one of the chosen criteria, the Von Mises stress (elastic solution) supports crack initiation on the tube ID. The SI applied to the creep solution (Bailey) results in small through wall differences or a uniform controlling stress. The reference stress, by definition, supports a single relaxed stress value that controls rupture. The calculated reference stress is very similar to both the ID and OD SI Bailey stresses. The micrographs indicate that the controlling stress is not an ID or an OD localized effect.

The ID and OD crack depth and spacing was measured for a number of ruptured tubes by quantitative metallographic observations. As shown in figure 7.9, no obvious trend for spacing or depth was observed. From this, it appears the Tresca-based creep solutions have a better physical basis for controlling rupture than the Von Mises criteria applied to the elastic solutions. 


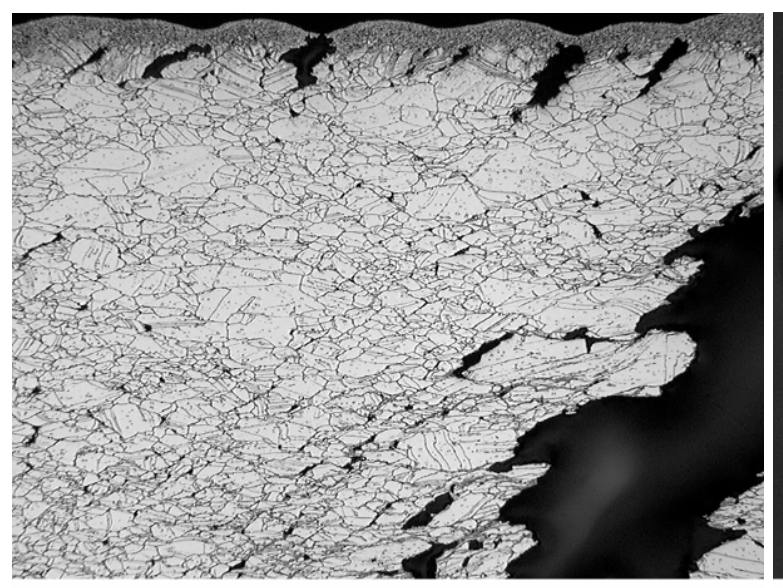

04-1625-02

IBD-130-01

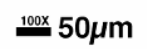

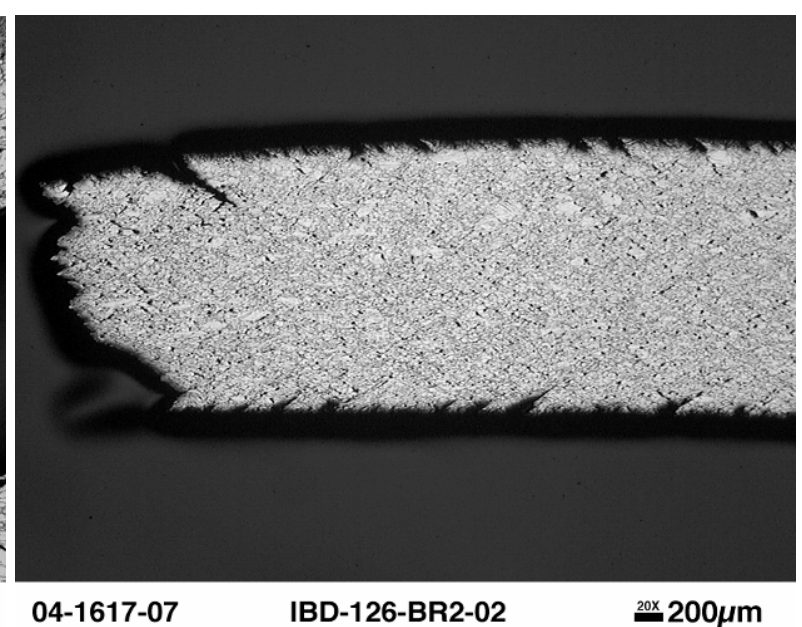

Figure 7.8. Typical micrograph of a region near the creep fracture of a pressurized tubular creep specimen. Extensive inner and outer diameter cracking is observed in addition to intergranular cavitation.
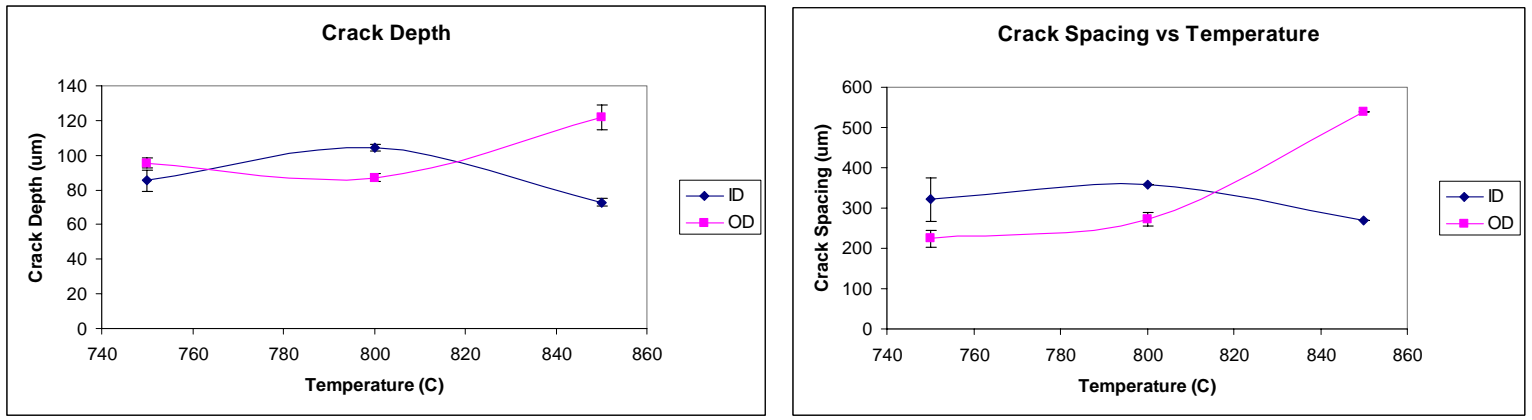

Figure 7.9. Quantitative metallographic results for crack depth (left) and crack spacing (right) as a function of test temperature and location (ID and OD) for selected tubular specimens.

\subsection{SUMMARY OF ALL RUPTURE RESULTS}

All of the rupture data produced on the program are plotted in figures 7.10, 7.11, and 7.12. The reference stress was used to calculate the stress for the internally pressurized tube tests. The nomenclature is as follows: "Unaged" - unaged sheet, "Aged" - sheet pre-aged for 6,000 hours at $675^{\circ} \mathrm{C}$, "Unaged WM" unaged sheet and bar cross-weldments, "Aged WM" - sheet cross-weldments pre-aged for 6,000 hours at $675^{\circ} \mathrm{C}$, "Unaged Tube” - unaged pressurized tubular tests (all rupture types), “Aged Tube” - pressurized tubular tests pre-aged for 6,000 hours at $675^{\circ} \mathrm{C}$, and "Isotherm" - isotherm from LMP fit of all uniaxial data. Ongoing tests are identified by arrows.

Evaluation of all the plots show the data scatter is very minimal for most temperatures. At $750^{\circ} \mathrm{C}$, the effect of aging on the pressurized tubular tests is clearly identified, but the longer-term uniaxial data on aged material show this is most likely a short-term effect. At 800 and $850^{\circ} \mathrm{C}$, a large amount of data is available which shows very good fits of the isothermal rupture curves, even for the non-typical ruptures in the tubular creep tests. The worst fit of the data is at $950^{\circ} \mathrm{C}$ where two of the tubular ruptures were at shorter-times than predicted. For the longest term test, this was due to a rupture in the cap of the specimen. Thus the fit is actually better than it appears. 

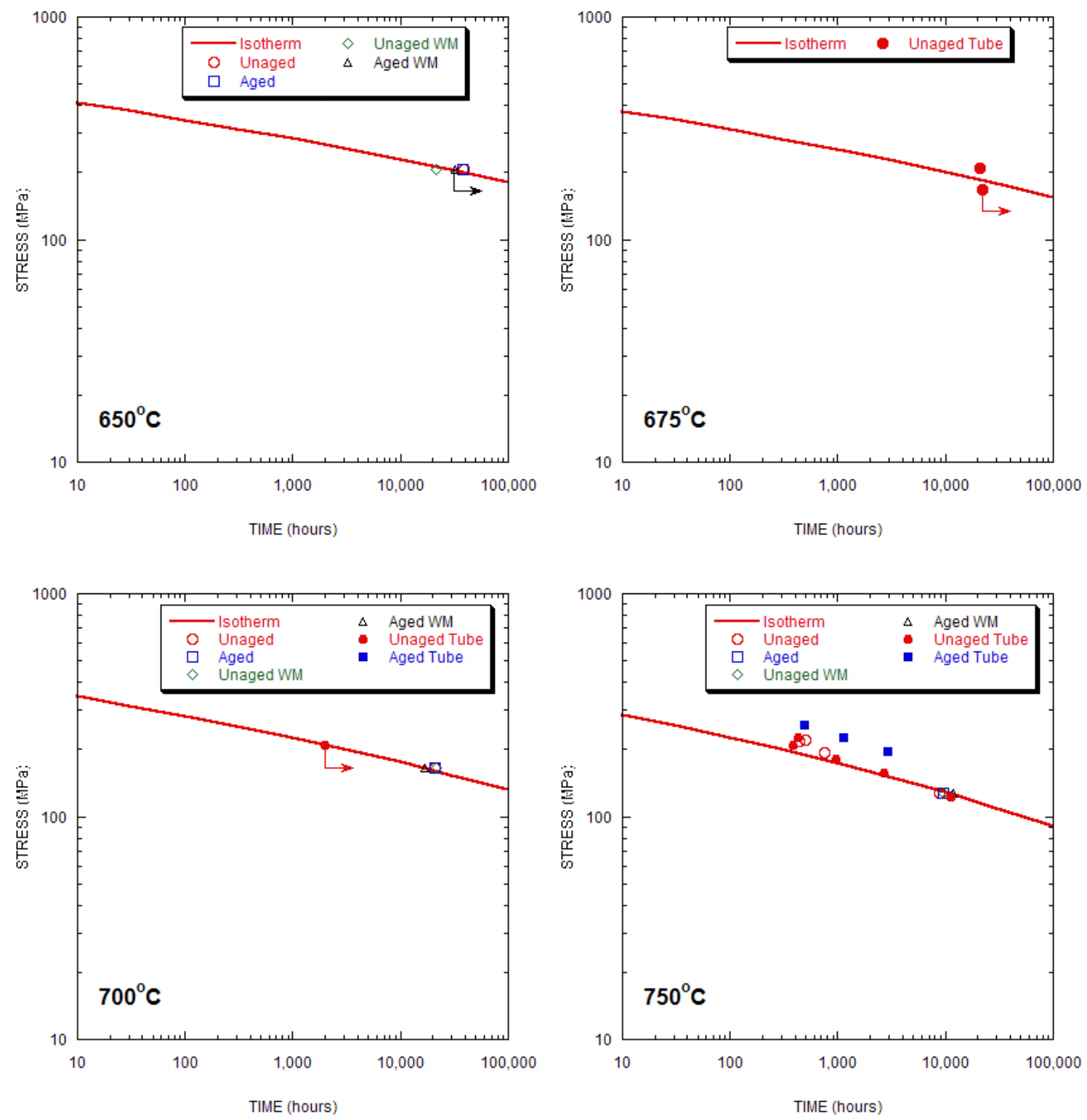

Figure 7.10. Plots of isothermal rupture data from 650 to $750^{\circ} \mathrm{C}$. The solid line is based on LMP analysis of entire dataset including historical data. 

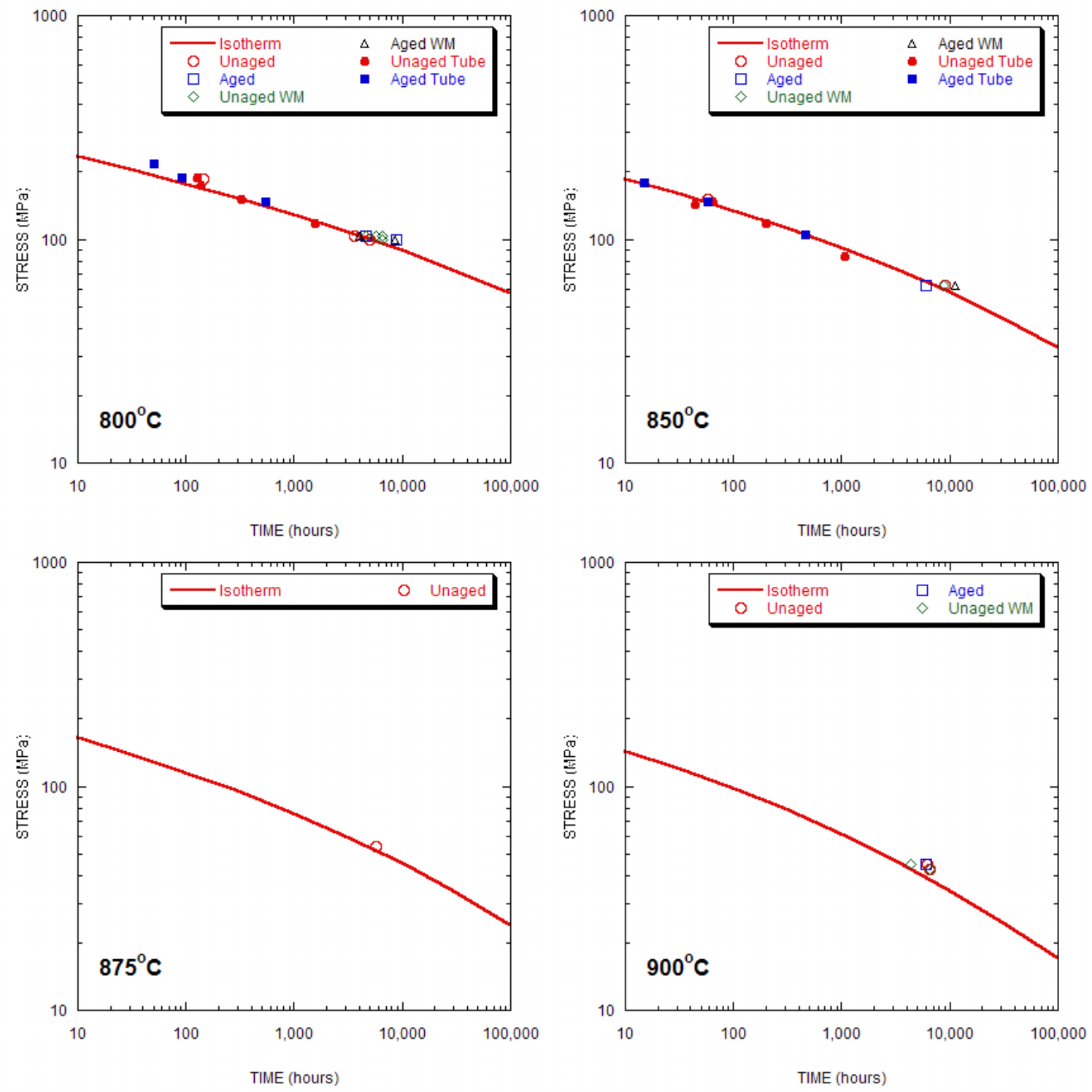

Figure 7.11. Plots of isothermal rupture data from 800 to $900^{\circ} \mathrm{C}$. The solid line is based on LMP analysis of entire dataset including historical data. 

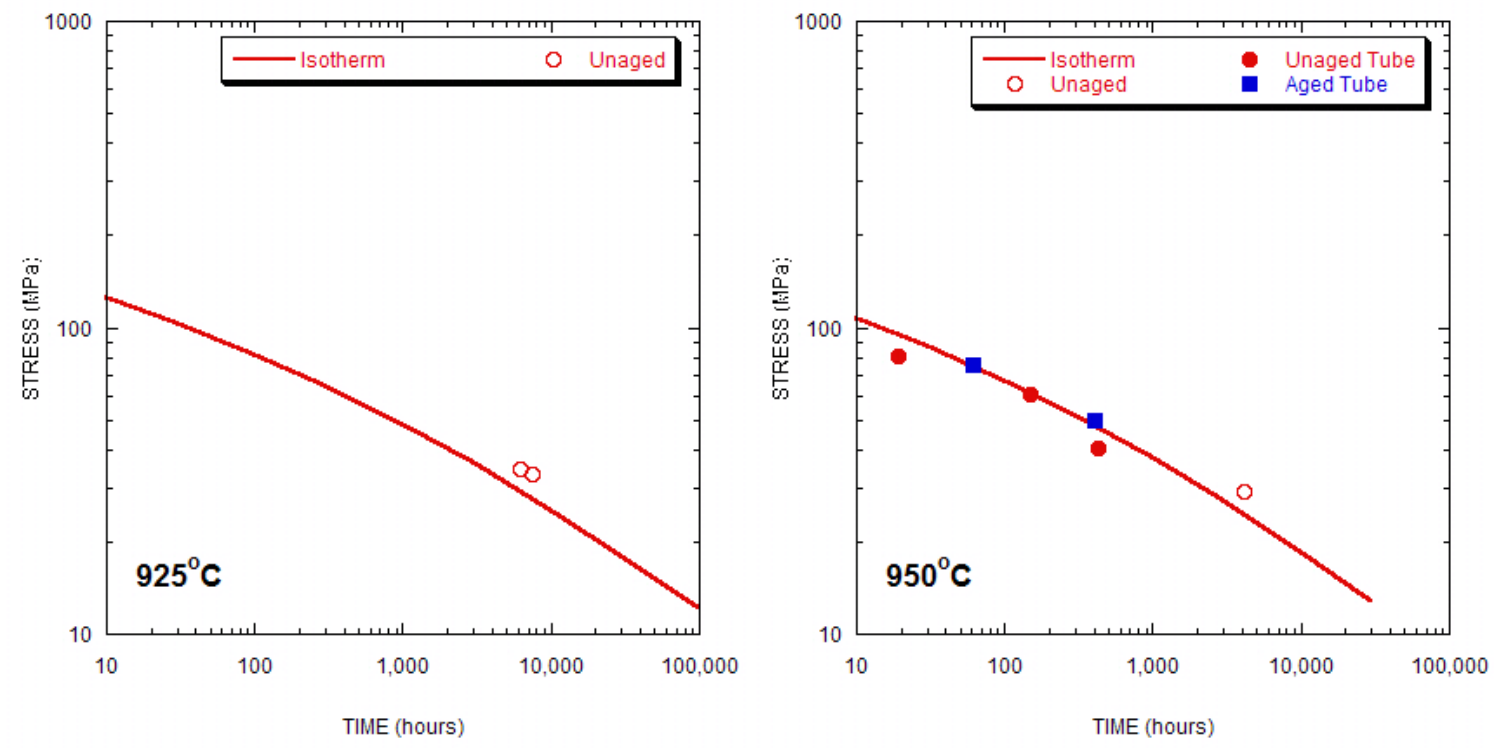

Figure 7.12. Plots of isothermal rupture data at 925 and $950^{\circ} \mathrm{C}$. The solid line is based on LMP analysis of entire dataset including historical data.

\subsection{CREEP-RATE ANALYSIS}

In addition to creep-rupture tests, creep tests to determine the steady state or minimum creep rates of alloy 25 at lower temperatures $\left(600\right.$ to $\left.700^{\circ} \mathrm{C}\right)$ were performed. The minimum creep rates are plotted as function of stress for various temperatures from the historical database in figure 7.13. 


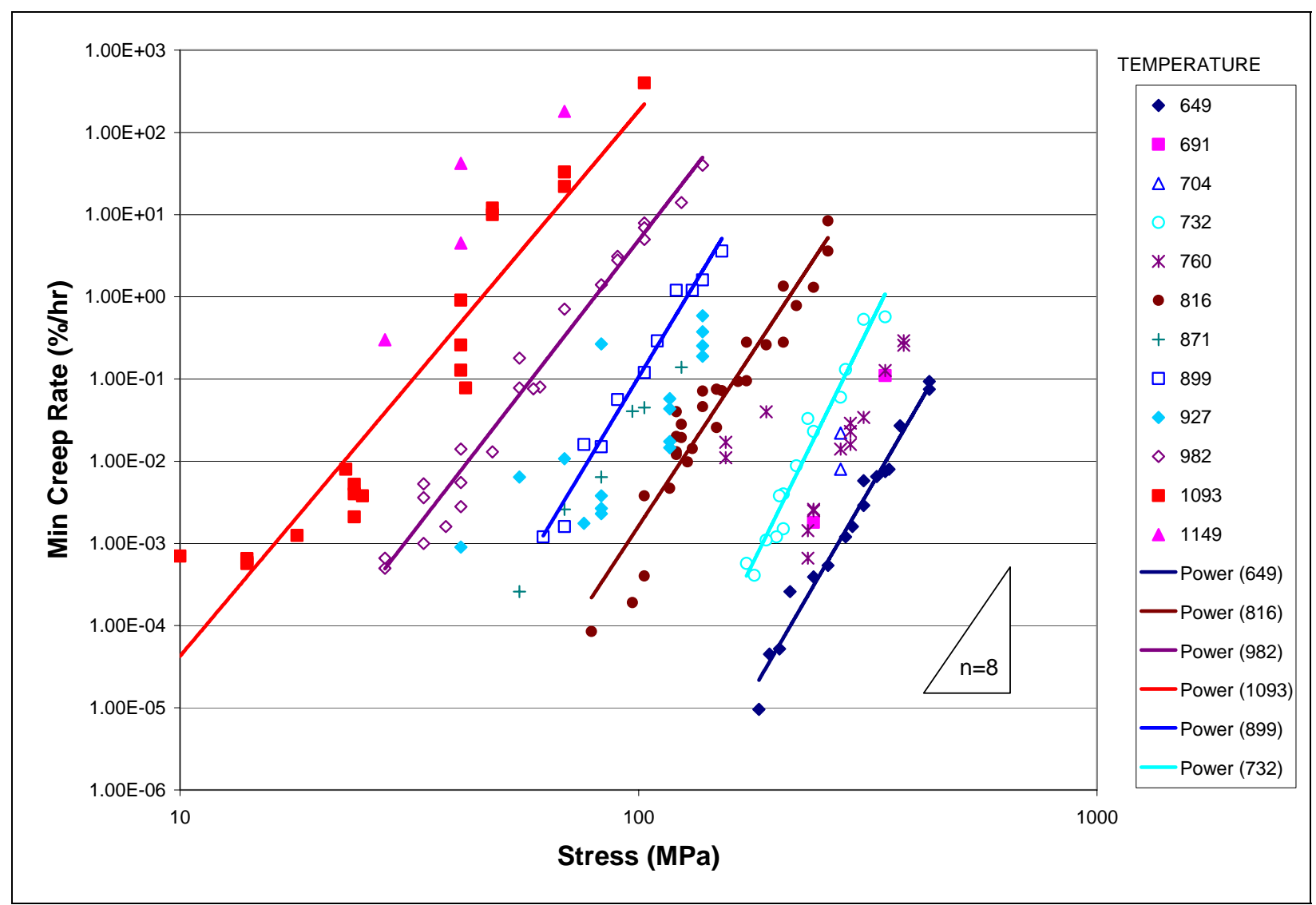

Figure 7.13. Minimum creep rate versus stress for various temperatures. All data taken from the historical dataset.

Some data are available for $649^{\circ} \mathrm{C}$, but most data is for $732^{\circ} \mathrm{C}$ and above. The power-law dependence of the isothermal minimum creep rate data $\left(\varepsilon_{\min }\right)$ data is variable and the power law exponent $(\mathrm{n})$, given by the relation:

$$
\dot{\varepsilon}_{\text {min }} \propto \sigma^{n}
$$

equation 15

varies between $n=6.5$ and $n=11.5$. In this study, creep testing was performed over a large range of temperatures and stresses for a variety of material conditions. Few isothermal creep conditions had more than two or three different stress levels for the same material condition, so a creep rate analysis was performed on the historical dataset for comparison with the current dataset.

It is assumed the temperature dependence of creep can be described by an Arrhenius relationship:

$$
\dot{\varepsilon}_{\text {min }} \propto D_{o} \exp (-Q / R T) \quad \text { equation } 16
$$

where $\mathrm{T}$ is absolute temperature, $\mathrm{D}_{\mathrm{o}}$ is the pre-exponential diffusion constant, $\mathrm{Q}$ is the activation energy for creep, and $\mathrm{R}$ is the universal gas constant. A phenomenological description of minimum creep rate as function of temperature $(T)$ and stress $(\sigma)$ can be developed from relations 15 and 16 as follows [26, 27]:

$$
\dot{\varepsilon}_{\min }=A \sigma^{n} \exp (-Q / R T)
$$

equation 17 
where $\mathrm{A}$ is constant, $\mathrm{n}$ is the power-law exponent, $\mathrm{Q}$ is the activation energy for creep, and $\mathrm{R}$ is the universal gas constant. Figure 7.14 is an Arrhenius plot of minimum creep rate divided by stress to the $\mathrm{n}$ power. From the analysis of these data, Q and A were determined, and, a diffusion compensated minimum creep rate parameter [min creep rate / Aexp(-Q/RT)] was calculated.

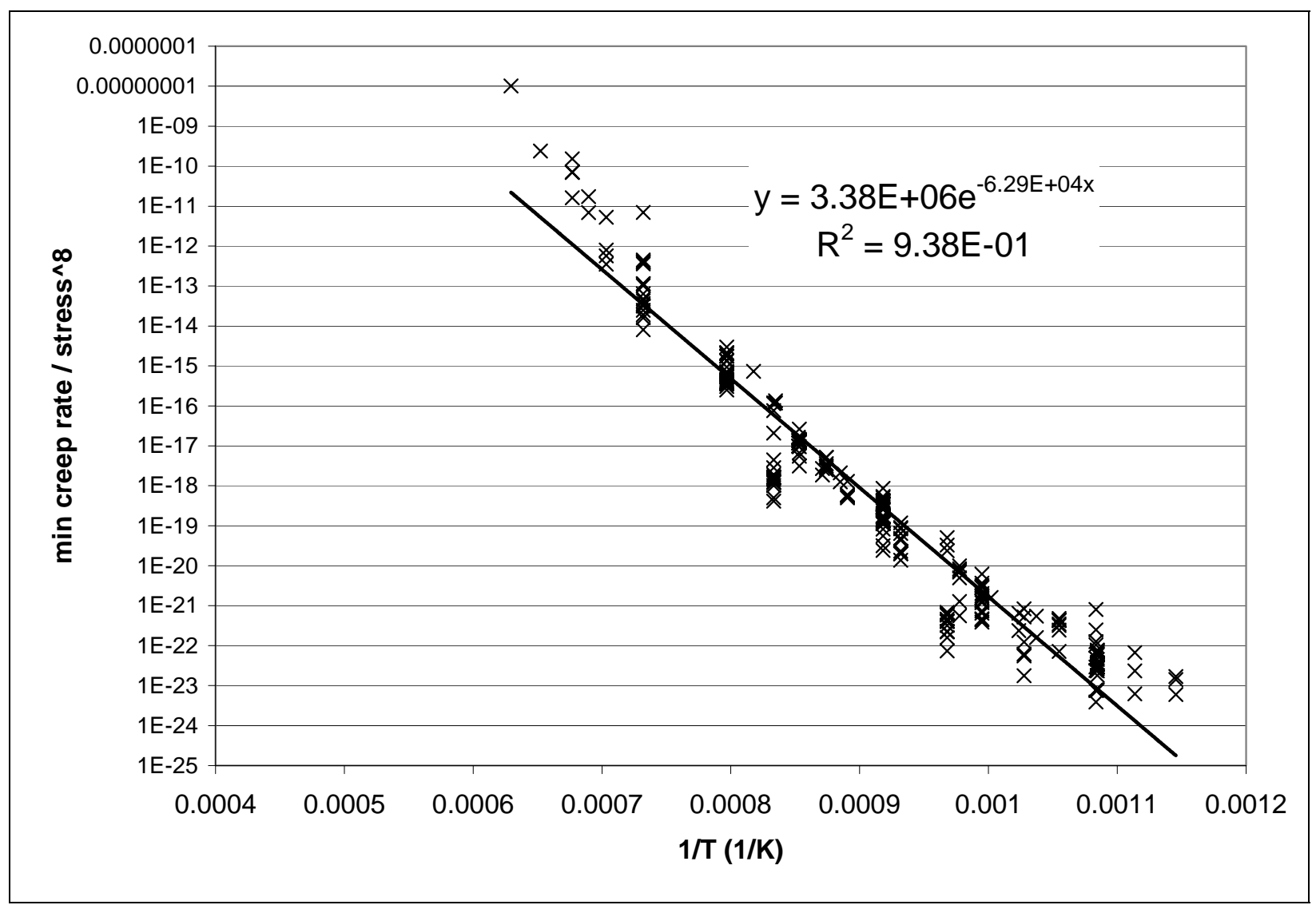

Figure 7.14. Activation energy determination plot of inverse absolute temperature versus minimum creep rate divided by $\operatorname{stress}^{\wedge} \mathbf{n}(\mathbf{n}=\mathbf{8})$.

This parameter is plotted versus stress for all data including all material conditions and the historical data in figure 7.15. 


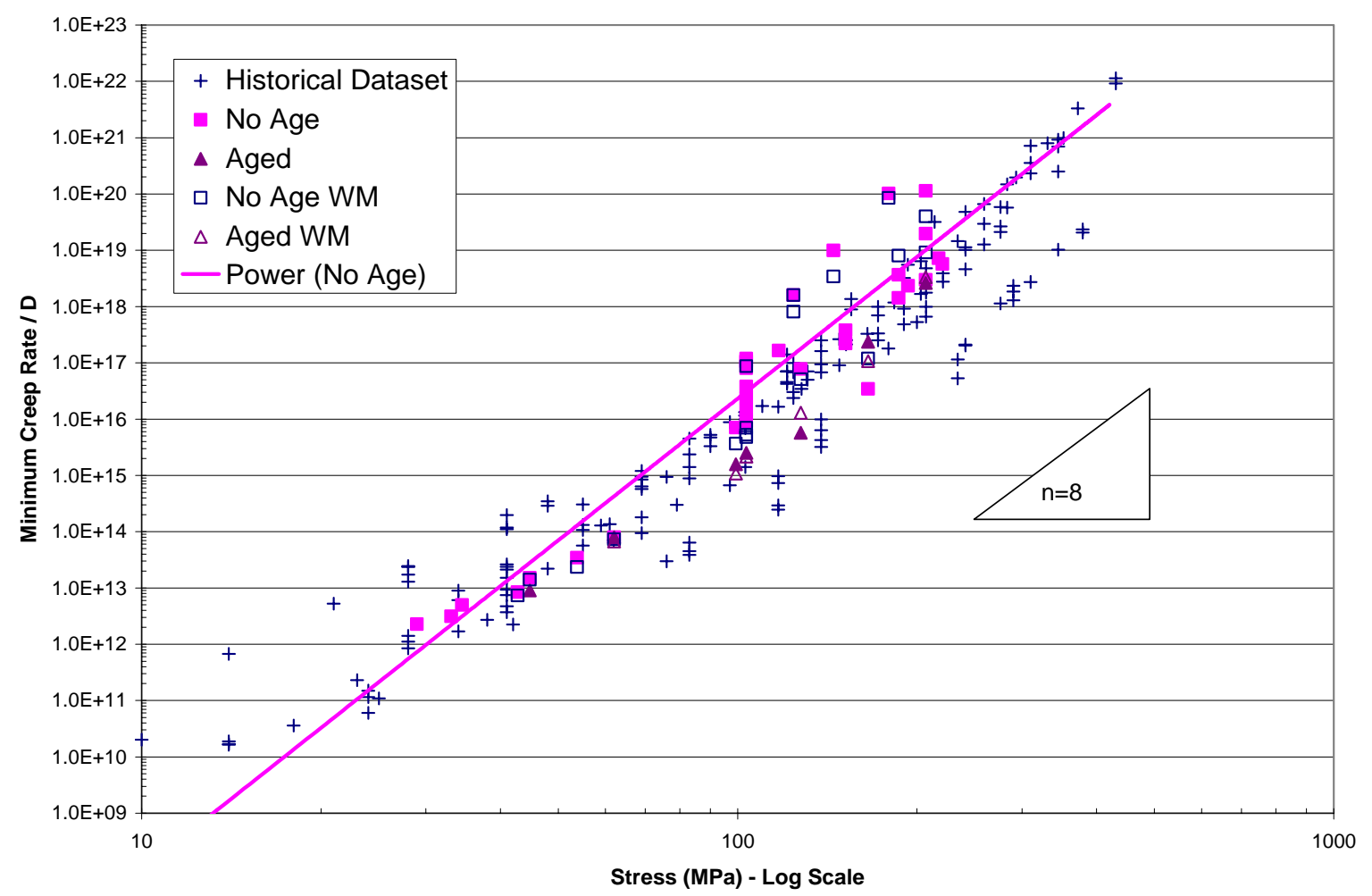

Figure 7.15. Stress versus diffusion compensated minimum creep rate (min. creep rate / $\mathbf{D}_{\mathbf{0}} \exp (-\mathbf{Q} / \mathbf{R T})$ for all material conditions. Fit of the data give a power-law exponent of $n=8.4$.

A power-law was fit to the No Age uniaxial creep data from the creep rate and creep-rupture tests in figure 7.15. The slope of fit matched the creep rates calculated from the historical dataset and the powerlaw exponent was found to be $n=8$ (fit value, $n=8.4$ ). This is in good agreement with literature results, were Tanaka et. al $[29,30]$ studied the effect of microstructure and aging heat-treatments on the creep behavior of alloy 25 at 816 to $1038^{\circ} \mathrm{C}$ and found that the power-law exponent was $\mathrm{n}=8$ regardless of heattreatment or test conditions. In general, the diffusion compensated creep rates for all material conditions matched those of the historical dataset. The aged data generally showed slightly lower creep rates at stress levels of $100 \mathrm{MPa}$ or greater. The data at lower stresses is limited but shows comparable results. From this analysis, a power-law exponent of $n=8$ was judged to be a good representation over a broad range of stresses and temperatures for alloy 25 , and this value was used in the analysis of the pressurized tube rupture results. 


\section{CONCLUSIONS}

An extensive tensile and creep study has produced a large database of high-temperature mechanical properties for a new heat of Haynes alloy 25. The database contains properties for sheet and bar products including material with GTAW weldments and material aged at 675 to $850^{\circ} \mathrm{C}$ for times up to 12,000 hours. An appendix is included in the report with all the data generated throughout the program as well as a collection of historical creep and tensile data on the alloy

Tensile results show this heat of alloy 25 to have yield strength and ultimate tensile strength values comparable to those reported in the historical database. Tensile ductility was comparable for lower temperatures and appears better than the historical database at $800^{\circ} \mathrm{C}$ and above. Welding did not cause a reduction in tensile properties (strength or ductility). Aging at $675^{\circ} \mathrm{C}$ caused a dramatic increase in yield strength, a modest increase in ultimate tensile strength, and a significant decrease in tensile ductility at both room temperature and at $650^{\circ} \mathrm{C}$. The strength and ductility changes with time were accurately described by a Johnson-Mehl-Avarmi (JMA) type equation, which indicated different phases and/or location of phases may be the source of changes in strength and ductility.

Creep-rupture tests showed welding and aging at $675^{\circ} \mathrm{C}$ for 6,000 hours did not effect uniaxial rupture life for tests conducted from $650^{\circ} \mathrm{C}$ to $950^{\circ} \mathrm{C}$. The Larson-Miller Parameter (LMP) was used to accurately describe the rupture strength for all material conditions. This heat showed much less scatter in rupture time compared to the historical database. The rupture ductility data matched the historical dataset where at long times ductility decreased. Tubular creep tests were conducted by internally pressurizing tubes of varying wall thicknesses. The rupture lives of these tests were evaluated by a number of methods which showed the steady-state creep analysis (Bailey) of I.D. and O.D. stresses and the reference stress solution for an infinitely long cylinder gave very good correlation with predicted life. Microstructural evaluation of ruptured tubes showed these fits have a physical basis. Evaluation of the creep-rates showed that for the broad range of stresses and temperatures, a power-law exponent of $n=8$ described the minimum creep rate behavior of the alloy. Overall, over 800,000 hours of creep data, with the longest test times exceeding 40,000 hours, were produced to augment the historical database which had less than 200,000 hours of creep data. 


\section{REFERENCES}

[1] R.W. Swindeman, “Some Creep-Rupture Data for Newer Heats of Haynes Alloy No. 25 (L-605)," ORNL-TM-3028, Oak Ridge National Laboratory, Oak Ridge, TN, 1970.

[2] R. W. Swindeman, "Review of the Mechanical Behavior of Haynes Alloy No. 25,” Attachment to Letter to J. P. Moore, Oak Ridge National Laboratory, July 1998.

[3] C. S. Slunder, "Short-Time Tensile Properties of the Co-20Cr-15W-10Ni Cobalt-Base Alloy (L-605)," DMIC-Memo-179, September, 1963.

[4] W.F. Simmons and H.C. Cross, "Report on The Elevated-Temperature Properties of Selected SuperStrength Alloys,” Spec. Tech. Publ. No. 160, American Society for Testing and Materials, Philadelphia, 1954.

[5] B.A. Baughman, “Gas Atmosphere Effects on Materials,” WASC-TR-59-511 (PB-161980), May 1960.

[6] A. Greene, H. Sieber, D. Wells, and T. Wolfe, "Research Investigations on Mechanical Properties of Nickel and Cobalt-Base Alloys for Inclusion in Military Handbook-5,” AD-418639, March 1963.

[7] G. D. Sandrock, R.L. Ashbrook, and J.C. Freche, "Effect of Variations in Silicon and Iron Content on Embrittlement of a Cobalt-Base Alloy (L-605),” NASA-TN-D-2989, September 1965.

[8] H. Conrad, E. Barnett, and J. White, "Correlation and Interpretation of High Temperature Mechanical Properties of Certain Superalloys,” pp. 1-9 to 1-29 in Joint International Conference on Creep, The Institute of Mechanical Engineers, London, 1963.

[9] P. N. Flagella and W. L. McCullough, "Stress-Rupture and Creep Behavior of Haynes Alloy No. 25 at 1440, 1700, and 2000F in Air,” TID-24045 (GE-NMP-67-181 AD-468683), June 1965.

[10] N. Yukawa and K. Sato, "The Correlation between Microstructure and Stress-Rupture Properties of a Co-Cr-Ni-W (HS-25) Alloy,” pp. 680-686 in Proceedings of the International Conference on the Strength of Metals and Alloys, The Japan Institute of Metals, Omachi, Japan, 1968.

[11] R. Widmer, J. M. Dhosi, A Mullendore, and N. J. Grant, "Mechanisms Associated with Long Time Creep Phenomena,” Part I, AFML-TR-65-181 (AD-468683), June 1965.

[12] R. Widmer, J.M. Dhosi, and N.J. Grant, "Mechanisms Associated with Long Time Creep Phenomena,” Part II, AFML-TR-65-181 (AD-815679), March 1967.

[13] S.T. Wlodek, “Embrittlement of a Co-Cr-W (L-605) Alloy,” Trans. ASM, American Society for Metals, 56, 287-303, 1963.

[14] D.T. Bourgette, "Effect of Aging Time and Temperature on the Impact and Tensile Behavior of L605 - A Cobalt Base Alloy,” ORNL-TM-3734, Oak Ridge National Laboratory, Oak Ridge, TN, 1973.

[15] H.E. McCoy and D.T. Bourgette, "Influence of Aging on the Impact Properties of Hastelloy N, Haynes Alloy No. 25, and Haynes Alloy No. 188,” ORNL-TM-4380, Oak Ridge National Laboratory, Oak Ridge, TN, 1973. 
[16] J. P. Hammond, "Effect of Long-Term Aging at $815^{\circ} \mathrm{C}$ on the Tensile Properties and Microstructural Stability of Four Cobalt- and Nickel-Base Superalloys,” ORNL-5174, Oak Ridge National Laboratory, Oak Ridge, TN, 1976.

[17] J. P. Shingledecker, L. Riester. ORNL/CF-05/10, Oak Ridge National Laboratory, Oak Ridge, TN, 2005.

[18] M. Radovic, E. Lara-Curzio, L. Riester. "Comparison of different experimental techniques for determination of elastic properties of solids.” Materials Science and Engineering A, A386 (2004) 56-70.

[19] “Haynes® 25 alloy Product Brochure.” H-3057D, 2004 Haynes, Intl., www.haynesintl.com.

[20] D. A Porter, K. E. Easterling. Phase Transformations in Metals and Alloys. Chapman \& Hall, London, 1992.

[21] C. McKamey, E. George. "Mechanical Properties of Haynes Alloy 25 Before and After Aging at 550-850C.” Attachment to letter No. 0706-14-05, J.F.King to John Dowicki, July 8, 2005.

[22] I.Finnie and W. R. Heller. Creep of Engineering Materials. McGraw-Hill 1959. 182-184.

[23] R. K. Penny, D .L. Marriott. Design for Creep. 1995 Chapman \& Hall, London, UK.

[24] Boiler Materials for Ultrasupercritical Coal Power Plants - Task 8, An Overview of Reference Stress Approach, NETL/DOE/OCDO, 2003. USC T-6.

[25] J. D. Fishburn. “A Single Technically Consistent Design Formula for the Thickness of Cylindrical Sections Under Internal Pressure.” Proceedings of 2005 ASME Pressure Vessels and Piping Division Conference, July 17-21, Denver, CO USA. PVP2005-71026.

[26] T. H. Courtney. Mechanical Behavior of Materials. 2nd Ed. McGraw-Hill 2000.

[27] F. R. N. Nabarro, H. L. deVilliers. The Physics of Creep. Taylor \& Francis Ltd 1995.

[28] W.D. Klopp. Aerospace Structural Metals Handbook. L-605, CODE 4302, March 1986. 1-37.

[29] M. Tanaka, H. Iizuka, M. Tagami. "Effects of grain-boundary configuration on the high-temperature creep strength of cobalt-base L-605 alloys.” Journal of Materials Science 24 (1989) 2421-2428.

[30] M. Tanaka, H. Iizuka "Effects of high-temperature ageing on the creep-rupture properties of cobaltbase L-605 alloys.” Journal of Materials Science 25 (1990) 5199-5206. 


\section{APPENDIX A. DATA TABLES AND FIGURES}

The appendix has eight sections. The first four sections (A.1-A.4) contain the tabular elastic, tensile, creep, and rupture data produced during this program (Haynes alloy 25 heat \# 1860-8-1391). The fifth and sixth sections (A.5, A.6) contain the stress-strain and the creep strain versus time curves used to generate the tabular data in the previous sections. The final two sections (A.7 and A.8) contain the historical tensile and creep data used throughout the report; these data are based largely on the work of Swindeman [2].

\section{A.1 TABULAR ELASTIC PROPERTIES}

Table A.1.1. Elastic properties of Haynes alloy 25 (Heat \# 1860-8-1391) before and after aging at $675^{\circ} \mathrm{C}$ for 6,000 hours

RUS Measured Properties of HS-25

\begin{tabular}{|c|c|c|c|c|c|c|c|c|}
\hline \multirow[b]{2}{*}{$\begin{array}{c}\text { Temperature } \\
\left({ }^{\circ} \mathrm{C}\right)\end{array}$} & \multicolumn{4}{|l|}{ Unaged } & \multicolumn{4}{|c|}{ Aged 6,000 hours $675^{\circ} \mathrm{C}$} \\
\hline & $\begin{array}{c}\text { Elastic } \\
\text { Modulus } \\
(\mathrm{GPa})\end{array}$ & $\begin{array}{c}\text { Shear } \\
\text { Modulus } \\
(\mathrm{GPa})\end{array}$ & $\begin{array}{c}\text { Bulk } \\
\text { Modulus } \\
(\mathrm{GPa})\end{array}$ & $\begin{array}{c}\text { Poisson's } \\
\text { Ratio }\end{array}$ & $\begin{array}{c}\text { Elastic } \\
\text { Modulus } \\
(\mathrm{GPa})\end{array}$ & $\begin{array}{c}\text { Shear } \\
\text { Modulus } \\
(\mathrm{GPa})\end{array}$ & $\begin{array}{c}\text { Bulk } \\
\text { Modulus } \\
\text { (GPa) }\end{array}$ & $\begin{array}{c}\text { Poisson's } \\
\text { Ratio } \\
\end{array}$ \\
\hline 25 & 234.7 & 90.6 & 190.8 & 0.295 & 241.5 & 93.5 & 192.7 & 0.291 \\
\hline 150 & 225.1 & 86.3 & 191.0 & 0.304 & 232.1 & 89.5 & 190.4 & 0.297 \\
\hline 300 & 213.4 & 81.6 & 185.2 & 0.308 & 220.7 & 84.6 & 187.7 & 0.304 \\
\hline 500 & 199.4 & 75.4 & 186.6 & 0.322 & 204.0 & 77.6 & 184.1 & 0.315 \\
\hline 650 & 184.3 & 69.5 & 176.2 & 0.326 & 185.6 & 70.0 & 177.8 & 0.326 \\
\hline 800 & 169.6 & 63.6 & 169.2 & 0.333 & 173.3 & 65.1 & 170.7 & 0.331 \\
\hline 900 & 160.4 & 59.7 & 169.5 & 0.342 & 162.4 & 60.4 & 173.8 & 0.344 \\
\hline 1000 & 151.2 & 56.1 & 166.6 & 0.349 & 153.0 & 56.7 & 169.3 & 0.349 \\
\hline 1100 & 143.0 & 52.8 & 163.3 & 0.354 & 143.3 & 52.9 & 163.2 & 0.354 \\
\hline
\end{tabular}

Note 1: Measurement made by Resonant Ultrasound Spectroscopy (RUS) 


\section{A.2 TABULAR TENSILE PROPERTIES}

Table A.2.1. Tensile properties of Haynes alloy 25 (Heat \# 1860-8-1391)

\begin{tabular}{|c|c|c|c|c|c|c|c|c|c|c|c|}
\hline Test ID & $\begin{array}{l}\text { Product } \\
\text { Form }\end{array}$ & $\begin{array}{l}\text { Aging } \\
\text { Temp. } \\
\left({ }^{\circ} \mathrm{C}\right)\end{array}$ & $\begin{array}{l}\text { Aging } \\
\text { Time } \\
\text { (hours) }\end{array}$ & $\begin{array}{l}\text { Test } \\
\text { Temp. } \\
\left({ }^{\circ} \mathrm{C}\right)\end{array}$ & $\begin{array}{l}\text { Prop. } \\
\text { Limit } \\
\text { (MPa) }\end{array}$ & $\begin{array}{c}\text { Yield } \\
\text { Strength } \\
\text { (MPa) }\end{array}$ & $\begin{array}{c}\text { Ultimate } \\
\text { Tensile } \\
\text { Strength } \\
\text { (MPa) }\end{array}$ & $\begin{array}{c}\text { Uniform } \\
\text { Elong. } \\
(\%)\end{array}$ & $\begin{array}{c}\text { Elong. } \\
(\%)\end{array}$ & $\begin{array}{l}\text { Red. } \\
\text { of } \\
\text { Area } \\
(\%)\end{array}$ & $\begin{array}{c}\text { Failure } \\
\text { Location }\end{array}$ \\
\hline TT-BM-01 & Sheet & none & none & 23 & 272 & 499 & 1000 & 56.6 & 56.6 & 39.9 & $\mathrm{GL}$ \\
\hline TT-BM-02 & Sheet & none & none & 300 & 196 & 308 & 884 & 72.5 & 74.9 & 56.6 & $\mathrm{GL}$ \\
\hline TT-BM-03 & Sheet & none & none & 500 & 165 & 276 & 806 & 64.6 & 68.7 & 54.4 & $\mathrm{GL}$ \\
\hline TT-BM-04 & Sheet & none & none & 650 & 218 & 261 & 778 & 54.1 & 57.2 & 35.1 & $\mathrm{GL}$ \\
\hline TT-BM-05 & Sheet & none & none & 800 & 187 & 232 & 477 & 26.2 & 59.1 & 41.6 & $\mathrm{GL}$ \\
\hline TT-BM-06 & Sheet & none & none & 1000 & 65 & 163 & 167 & 3.8 & 88.5 & 69.2 & $\mathrm{GL}$ \\
\hline TT-BM-07 & Sheet & none & none & 1100 & 27 & 86 & 92 & 1.7 & 70.4 & 61.7 & $\mathrm{GL}$ \\
\hline TT-BM-08 & Sheet & 675 & 6000 & 23 & 365 & 789 & 1053 & 7.3 & 7.3 & 4.4 & $\mathrm{GL}, \mathrm{GM}$ \\
\hline TT-BM-08B & Sheet & 675 & 6000 & 23 & 549 & 792 & 1045 & 8.4 & 8.4 & 5.8 & $\mathrm{GL}$ \\
\hline TT-BM-09 & Sheet & 675 & 6000 & 300 & 379 & 610 & 955 & 13.7 & 13.7 & 13.8 & GL \\
\hline TT-BM-10 & Sheet & 675 & 6000 & 500 & 421 & 558 & 945 & 17.3 & 17.3 & 16.1 & $\mathrm{GL}$ \\
\hline TT-BM-11 & Sheet & 675 & 6000 & 650 & 338 & 516 & 907 & 21.3 & 21.3 & 14.7 & GL \\
\hline TT-BM-12 & Sheet & 675 & 6000 & 800 & 269 & 445 & 565 & 3.6 & 17.3 & 16.6 & $\mathrm{GL}$ \\
\hline TT-BM-13 & Sheet & 675 & 6000 & 1000 & & 178 & 179 & & 45.2 & 39.0 & $\mathrm{GL}$ \\
\hline TT-BM-14 & Sheet & 675 & 6000 & 1100 & 62 & 101 & 101 & & 47.9 & 32.9 & $\mathrm{GL}$ \\
\hline TT-BM-15 & Sheet & 675 & 12000 & 23 & 483 & 778 & 1043 & 7.9 & 7.9 & 8.1 & $\mathrm{GL}$ \\
\hline TT-BM-16 & Sheet & 675 & 12000 & 300 & 379 & 585 & 969 & 14.3 & 14.3 & 13.8 & $\mathrm{GL}$ \\
\hline TT-BM-17 & Sheet & 675 & 12000 & 500 & 331 & 566 & 938 & 16.1 & 16.1 & 18.0 & $\mathrm{GL}$ \\
\hline TT-BM-18 & Sheet & 675 & 12000 & 650 & 276 & 536 & 897 & 17.3 & 17.3 & 17.5 & GL \\
\hline TT-BM-19 & Sheet & 675 & 12000 & 800 & 221 & 414 & 553 & 3.5 & 9.8 & 10.3 & $\mathrm{GL}$ \\
\hline TT-BM-20 & Sheet & 675 & 12000 & 1000 & 83 & 174 & 175 & 2.0 & 52.4 & 45.2 & $\mathrm{GL}$ \\
\hline TT-BM-21 & Sheet & 675 & 12000 & 1100 & 48 & 99 & 99 & 0.4 & 45.8 & 45.0 & $\mathrm{GL}$ \\
\hline HS-03-01a & Sheet & none & none & 23 & 386 & 518 & 978 & 56.0 & 57.5 & 45.6 & $\mathrm{GL}$ \\
\hline HS-03-02a & Sheet & 675 & 0.25 & 23 & 524 & 537 & 978 & 61.0 & 62.0 & 47.4 & GL \\
\hline HS-03-07a & Sheet & 675 & 2.4 & 23 & 462 & 532 & 1009 & 63.0 & 68.2 & 52.4 & GL \\
\hline HS-03-05a & Sheet & 675 & 24 & 23 & 476 & 536 & 1008 & 62.0 & 67.8 & 50.8 & $\mathrm{GL}$ \\
\hline HS-03-09a & Sheet & 675 & 100 & 23 & 434 & 552 & 969 & 53.0 & 53.5 & 53.4 & $\mathrm{GL}$ \\
\hline HS-03-03a & Sheet & 675 & 240 & 23 & 421 & 536 & 970 & 38.0 & 38.4 & 26.3 & $\mathrm{GL}$ \\
\hline HS-03-01b & Sheet & 675 & 1000 & 23 & 510 & 744 & 1047 & 20.9 & 20.9 & 17.4 & $\mathrm{GL}$ \\
\hline HS-03-01a & Sheet & 675 & 2000 & 23 & 496 & 756 & 1017 & 9.8 & 9.8 & 10.7 & GL \\
\hline HS-03-08a & Sheet & 675 & 2.4 & 650 & 207 & 260 & 776 & 56.6 & 56.6 & 37.9 & $\mathrm{GL}$ \\
\hline HS-03-06a & Sheet & 675 & 24 & 650 & 207 & 280 & 795 & 61.4 & 61.4 & 39.4 & $\mathrm{GL}$ \\
\hline HS-03-04a & Sheet & 675 & 240 & 650 & 221 & 328 & 818 & 44.2 & 44.2 & 38.0 & $\mathrm{GL}$ \\
\hline HS-03-02b & Sheet & 675 & 1000 & 650 & 345 & 445 & 837 & 38.6 & 38.6 & 28.6 & $\mathrm{GL}$ \\
\hline HS-03-02a & Sheet & 675 & 2000 & 650 & 345 & 568 & 891 & 23.6 & 23.6 & 22.9 & GL \\
\hline HS-03-10a & Sheet & 700 & 1000 & 23 & 503 & 744 & 1066 & 16.1 & 16.1 & 14.6 & GL \\
\hline HS-03-11a & Sheet & 750 & 1000 & 23 & 441 & 587 & 1014 & 19.6 & 19.6 & 18.3 & GL \\
\hline
\end{tabular}

*Failure Location: $G L=$ gauge length, $G M=$ gauge mark, WM=weld metal, BM=base metal, HAZ=heat affected zone 
Table A.2.2. Tensile properties of Haynes alloy 25 GTA weldments

\begin{tabular}{|c|c|c|c|c|c|c|c|c|c|c|c|}
\hline Test ID & $\begin{array}{l}\text { Product } \\
\text { Form }\end{array}$ & $\begin{array}{l}\text { Aging } \\
\text { Temp. } \\
\left({ }^{\circ} \mathrm{C}\right)\end{array}$ & $\begin{array}{l}\text { Aging } \\
\text { Time } \\
\text { (hours) }\end{array}$ & $\begin{array}{r}\text { Test } \\
\text { Temp. } \\
\left({ }^{\circ} \mathrm{C}\right) \\
\end{array}$ & $\begin{array}{r}\text { Prop. } \\
\text { Limit } \\
(\mathrm{MPa})\end{array}$ & $\begin{array}{r}\text { Yield } \\
\text { Strength } \\
(\mathrm{MPa}) \\
\end{array}$ & $\begin{array}{r}\text { Ultimate } \\
\text { Tensile } \\
\text { Strength } \\
(\mathrm{MPa})\end{array}$ & $\begin{array}{r}\text { Uniform } \\
\text { Elong. } \\
(\%) \\
\end{array}$ & $\begin{array}{r}\text { Elong. } \\
(\%)\end{array}$ & $\begin{array}{r}\text { Red. } \\
\text { of } \\
\text { Area } \\
(\%) \\
\end{array}$ & $\begin{array}{c}\text { Failure } \\
\text { Location }\end{array}$ \\
\hline TT-WM-01 & $\begin{array}{l}\text { Sheet } \\
\text { Weld }\end{array}$ & none & none & 23 & & 495 & 1008 & 50.0 & 50.0 & 40.7 & $\mathrm{BM}$ \\
\hline TT-WM-02 & $\begin{array}{l}\text { Sheet } \\
\text { Weld }\end{array}$ & none & none & 300 & 219 & 307 & 888 & 70.0 & 74.5 & 57.1 & BM \\
\hline TT-WM-03 & $\begin{array}{l}\text { Sheet } \\
\text { Weld }\end{array}$ & none & none & 500 & 196 & 289 & 809 & 66.2 & 72.5 & 51.7 & BM \\
\hline TT-WM-04 & $\begin{array}{l}\text { Sheet } \\
\text { Weld }\end{array}$ & none & none & 650 & 191 & 279 & 768 & 49.7 & 49.7 & 32.4 & $\mathrm{BM}$ \\
\hline TT-WM-05 & $\begin{array}{l}\text { Sheet } \\
\text { Weld }\end{array}$ & none & none & 800 & 153 & 245 & 480 & 22.5 & 50.0 & 45.7 & $\mathrm{BM}$ \\
\hline TT-WM-06 & $\begin{array}{l}\text { Sheet } \\
\text { Weld }\end{array}$ & none & none & 1000 & 90 & 165 & 170 & 4.0 & 72.8 & 62.0 & BM \\
\hline TT-WM-07 & $\begin{array}{l}\text { Sheet } \\
\text { Weld }\end{array}$ & none & none & 1100 & 54 & 94 & 96 & 1.5 & 53.0 & 58.7 & BM \\
\hline TT-WM-08 & $\begin{array}{l}\text { Sheet } \\
\text { Weld }\end{array}$ & 675 & 6000 & 23 & 552 & 762 & 1004 & 5.6 & 5.6 & 5.2 & BM \\
\hline TT-WM-09 & $\begin{array}{l}\text { Sheet } \\
\text { Weld }\end{array}$ & 675 & 6000 & 300 & 448 & 601 & 936 & 12.8 & 12.8 & 13.2 & BM \\
\hline TT-WM-10 & $\begin{array}{l}\text { Sheet } \\
\text { Weld }\end{array}$ & 675 & 6000 & 500 & 372 & 542 & 927 & 16.3 & 16.3 & 15.0 & $\mathrm{BM}$ \\
\hline TT-WM-11 & $\begin{array}{l}\text { Sheet } \\
\text { Weld }\end{array}$ & 675 & 6000 & 650 & 241 & 549 & 895 & 16.7 & 16.7 & 17.5 & BM \\
\hline TT-WM-12 & $\begin{array}{l}\text { Sheet } \\
\text { Weld }\end{array}$ & 675 & 6000 & 800 & & 402 & 554 & 7.2 & 13.4 & 18.3 & $\mathrm{BM}$ \\
\hline TT-WM-13 & $\begin{array}{l}\text { Sheet } \\
\text { Weld }\end{array}$ & 675 & 6000 & 1000 & 83 & 174 & 177 & 0.5 & 47.3 & 45.2 & $\mathrm{BM}$ \\
\hline TT-WM-14 & $\begin{array}{l}\text { Sheet } \\
\text { Weld }\end{array}$ & 675 & 6000 & 1100 & 48 & 99 & 99 & 0.5 & 44.5 & 45.5 & $\mathrm{BM}$ \\
\hline TT-WM-15 & $\begin{array}{l}\text { Sheet } \\
\text { Weld }\end{array}$ & 675 & 12000 & 23 & 414 & 753 & 1009 & 5.0 & 5.0 & 6.3 & BM \\
\hline TT-WM-16 & $\begin{array}{l}\text { Sheet } \\
\text { Weld }\end{array}$ & 675 & 12000 & 300 & 372 & 615 & 926 & 7.8 & 7.8 & 8.4 & $\mathrm{BM}$ \\
\hline TT-WM-17 & $\begin{array}{l}\text { Sheet } \\
\text { Weld }\end{array}$ & 675 & 12000 & 500 & 310 & 564 & 918 & 12.0 & 12.0 & 13.3 & BM \\
\hline TT-WM-18 & $\begin{array}{l}\text { Sheet } \\
\text { Weld }\end{array}$ & 675 & 12000 & 650 & 310 & 572 & 899 & 11.0 & 11.0 & 12.2 & BM \\
\hline TT-WM-19 & $\begin{array}{l}\text { Sheet } \\
\text { Weld }\end{array}$ & 675 & 12000 & 800 & 193 & 438 & 562 & 2.8 & 8.7 & 10.9 & $\mathrm{BM}$ \\
\hline TT-WM-20 & $\begin{array}{l}\text { Sheet } \\
\text { Weld }\end{array}$ & 675 & 12000 & 1000 & & 171 & 172 & 0.3 & 38.6 & 37.1 & BM \\
\hline TT-WM-21 & $\begin{array}{l}\text { Sheet } \\
\text { Weld }\end{array}$ & 675 & 12000 & 1100 & & 101 & 101 & 0.3 & 43.8 & 33.4 & $\mathrm{BM}$ \\
\hline LWT-1 & Bar Weld & none & none & 20 & & 595 & 1147 & 629.0 & 63.1 & & WM \\
\hline AWT-1 & Bar Weld & none & none & 20 & & 593 & 1122 & 53.7 & 56.8 & & WM \\
\hline LWT-2 & Bar Weld & none & none & 650 & & 330 & 736 & 25.5 & 26.2 & & WM \\
\hline AWT-2 & Bar Weld & none & none & 650 & & 367 & 851 & 47.7 & 47.4 & & WM \\
\hline LWT-3 & Bar Weld & 850 & 50 & 20 & & 533 & 1012 & 30.0 & 30.0 & & WM \\
\hline AWT-3 & Bar Weld & 850 & 50 & 20 & & 559 & 1051 & 37.2 & 37.3 & & WM \\
\hline LWT-4 & Bar Weld & 850 & 50 & 650 & & 538 & 831 & 31.7 & 31.7 & & WM \\
\hline AWT-4 & Bar Weld & 850 & 50 & 650 & & 352 & 873 & 49.2 & 49.3 & & WM \\
\hline LWT-5 & Bar Weld & 675 & 6000 & 20 & & 822 & 1058 & 4.5 & 4.5 & & $\mathrm{BM}$ \\
\hline AWT-5 & Bar Weld & 675 & 6000 & 20 & & 834 & 1073 & 4.3 & 4.3 & & $\mathrm{BM}$ \\
\hline LWT-6 & Bar Weld & 675 & 6000 & 650 & & 575 & 929 & 11.8 & 11.8 & & $\mathrm{BM}$ \\
\hline AWT-6 & Bar Weld & 675 & 6000 & 650 & & 564 & 931 & 15.1 & 15.4 & & BM \\
\hline
\end{tabular}

*Failure Location: $\mathrm{GL}=$ gauge length, $\mathrm{GM}=$ gauge mark, WM=weld metal, BM=base metal, HAZ=heat affected zone 


\section{A.3 TABULAR UNIAXIAL CREEP AND CREEP-RUPTURE DATA}

Table A.3.1. Creep and stress-rupture data for Haynes alloy 25 (Heat \# 1860-8-1391)

\begin{tabular}{|c|c|c|c|c|c|c|c|c|c|}
\hline Test ID & $\begin{array}{l}\text { Product } \\
\text { Form }\end{array}$ & $\begin{array}{l}\text { Aging } \\
\text { Temp. } \\
\left({ }^{\circ} \mathrm{C}\right)\end{array}$ & $\begin{array}{l}\text { Aging } \\
\text { Time } \\
\text { (hours) }\end{array}$ & $\begin{array}{c}\text { Test } \\
\text { Temp. } \\
\left({ }^{\circ} \mathrm{C}\right)\end{array}$ & $\begin{array}{l}\text { Stress } \\
(\mathrm{MPa})\end{array}$ & $\begin{array}{c}\text { Rupture } \\
\text { Life } \\
\text { (hours) } \\
\text { stopped } \\
\text { or } \\
\text { ongoing } \\
\end{array}$ & $\begin{array}{l}\text { Minimum } \\
\text { Creep } \\
\text { Rate } \\
\text { (\%/hr) }\end{array}$ & $\begin{array}{c}\text { Elong. } \\
(\%)\end{array}$ & $\begin{array}{l}\text { Red. } \\
\text { of } \\
\text { Area } \\
(\%)\end{array}$ \\
\hline $\begin{array}{l}\text { CR-BM- } \\
01\end{array}$ & sheet & none & none & 650 & 206.8 & 38557.0 & 2.60E-05 & 2.8 & 4.5 \\
\hline $\begin{array}{l}\text { CR-BM- } \\
02\end{array}$ & sheet & none & none & 700 & 165.5 & 20637.0 & $1.00 \mathrm{E}-05$ & 4.9 & 3.9 \\
\hline $\begin{array}{l}\text { CR-BM- } \\
03\end{array}$ & sheet & none & none & 750 & 127.6 & 8786.0 & 5.30E-04 & 10.9 & 8.3 \\
\hline $\begin{array}{l}\text { CR-BM- } \\
04\end{array}$ & sheet & none & none & 800 & 99.3 & 4983.0 & 8.50E-04 & 11.5 & 10.2 \\
\hline $\begin{array}{l}\text { CR-BM- } \\
05\end{array}$ & sheet & none & none & 800 & 103.4 & 3626.0 & $1.10 \mathrm{E}-03$ & 12.8 & 12.2 \\
\hline $\begin{array}{l}\text { CR-BM- } \\
06\end{array}$ & sheet & none & none & 850 & 62.1 & 8975.0 & 1.30E-04 & 6.9 & 2.7 \\
\hline $\begin{array}{l}\text { CR-BM- } \\
07\end{array}$ & sheet & none & none & 875 & 53.8 & 5763.0 & $1.90 \mathrm{E}-04$ & 7.0 & 5.0 \\
\hline $\begin{array}{l}\text { CR-BM- } \\
08\end{array}$ & sheet & none & none & 900 & 44.8 & 6232.0 & $2.70 \mathrm{E}-04$ & 12.0 & 8.4 \\
\hline $\begin{array}{l}\text { CR-BM- } \\
09\end{array}$ & sheet & none & none & 900 & 42.7 & 6585.0 & $1.50 \mathrm{E}-04$ & 6.1 & 5.7 \\
\hline $\begin{array}{l}\text { CR-BM- } \\
11^{*}\end{array}$ & sheet & none & none & 925 & 34.5 & 6253.0 & $2.70 E-04$ & 10.6 & 8.8 \\
\hline $\begin{array}{l}\text { CR-BM- } \\
12^{*}\end{array}$ & sheet & none & none & 925 & 33.1 & 7436.8 & 1.70E-04 & 9.0 & 6.5 \\
\hline $\begin{array}{l}\text { CR-BM- } \\
14^{*}\end{array}$ & sheet & none & none & 950 & 29.0 & 4095.0 & $3.60 E-04$ & 8.1 & 9.3 \\
\hline TN30440 & sheet & none & none & 750 & 220.6 & 498.4 & 3.90E-02 & 33.6 & 25.2 \\
\hline TN29885 & sheet & none & none & 800 & 186.2 & 144.4 & 1.70E-01 & 45.3 & 47.6 \\
\hline TN30215 & sheet & none & none & 750 & 217.2 & 436.8 & 4.90E-02 & 32.0 & 32.7 \\
\hline TN30420 & sheet & none & none & 850 & 151.7 & 57.6 & 3.60E-01 & 46.7 & 48.3 \\
\hline TN30138 & sheet & none & none & 750 & 193.1 & 745.0 & 1.60E-02 & 21.3 & 19.7 \\
\hline MG-13 & sheet & none & none & 600 & 179.3 & 9000.0 & $1.8 \mathrm{E}-05$ & & \\
\hline MG-14 & sheet & none & none & 600 & 206.8 & 12311.0 & 2.0E-05 & & \\
\hline MG-15 & sheet & none & none & 625 & 144.8 & 30000.0 & 1.3E-05 & & \\
\hline MG-17 & sheet & none & none & 625 & 206.8 & 12614.0 & 2.1E-05 & & \\
\hline MG-18 & sheet & none & none & 650 & 124.1 & 10507.0 & 4.5E-05 & & \\
\hline MG-21 & sheet & none & none & 650 & 186.2 & 11080.0 & 4.2E-05 & & \\
\hline MG-22 & sheet & none & none & 675 & 103.4 & 11117.0 & 4.2E-06 & & \\
\hline MG-24 & sheet & none & none & 675 & 151.7 & 38000.0 & 1.6E-05 & & \\
\hline \multirow[t]{8}{*}{ MG22b } & \multirow[t]{8}{*}{ sheet } & \multirow[t]{8}{*}{ none } & \multirow[t]{8}{*}{ none } & 675 & 103.4 & 15976.0 & 5.5E-06 & & \\
\hline & & & & 675 & 0.0 & 16262.0 & & & \\
\hline & & & & 675 & 103.4 & 20591.0 & 5.70E-06 & & \\
\hline & & & & 700 & 103.4 & 22892.0 & 6.80E-06 & & \\
\hline & & & & 725 & 103.4 & 24496.0 & 2.10E-05 & & \\
\hline & & & & 700 & 103.4 & 25574.0 & 1.10E-05 & & \\
\hline & & & & 675 & 103.4 & 39841.0 & $6.30 \mathrm{E}-06$ & & \\
\hline & & & & 675 & 117.2 & 42000.0 & 8.70E-06 & & \\
\hline
\end{tabular}

* Testing was performed in Argon, load line displacement was used to estimate minimum creep rate 
Table A.3.1. Creep and stress-rupture data for Haynes alloy 25 (continued)

\begin{tabular}{|c|c|c|c|c|c|c|c|c|c|}
\hline Test ID & $\begin{array}{l}\text { Product } \\
\text { Form }\end{array}$ & $\begin{array}{c}\text { Aging } \\
\text { Temp. } \\
\left({ }^{\circ} \mathrm{C}\right)\end{array}$ & $\begin{array}{l}\text { Aging } \\
\text { Time } \\
\text { (hours) }\end{array}$ & $\begin{array}{c}\text { Test } \\
\text { Temp. } \\
\left({ }^{\circ} \mathrm{C}\right)\end{array}$ & $\begin{array}{l}\text { Stress } \\
(\mathrm{MPa})\end{array}$ & $\begin{array}{r}\text { Rupture } \\
\text { Life } \\
\text { (hours) } \\
\text { stopped } \\
\text { or } \\
\text { ongoing }\end{array}$ & $\begin{array}{r}\text { Minimum } \\
\text { Creep } \\
\text { Rate } \\
(\% / h r)\end{array}$ & $\begin{array}{l}\text { Elong. } \\
(\%)\end{array}$ & $\begin{array}{l}\text { Red. } \\
\text { of } \\
\text { Area } \\
(\%)\end{array}$ \\
\hline $\begin{array}{l}\text { CR-BM- } \\
15\end{array}$ & sheet & 675 & 6000 & 650 & 206.8 & 38300.0 & $2.50 \mathrm{E}-05$ & & \\
\hline $\begin{array}{l}\text { CR-BM- } \\
16\end{array}$ & sheet & 675 & 6000 & 700 & 165.5 & 20670 & 6.90E-05 & 3.8 & 3.1 \\
\hline $\begin{array}{l}\text { CR-BM- } \\
17\end{array}$ & sheet & 675 & 6000 & 750 & 127.6 & 9536 & $3.90 \mathrm{E}-05$ & 5.8 & 4.8 \\
\hline $\begin{array}{l}\text { CR-BM- } \\
18\end{array}$ & sheet & 675 & 6000 & 800 & 99.3 & 8863 & $1.90 \mathrm{E}-04$ & 9.3 & 7.1 \\
\hline $\begin{array}{l}\text { CR-BM- } \\
19\end{array}$ & sheet & 675 & 6000 & 800 & 103.4 & 4626 & 3.00E-04 & 6.9 & 6.4 \\
\hline $\begin{array}{l}\text { CR-BM- } \\
20\end{array}$ & sheet & 675 & 6000 & 850 & 62.1 & 6092 & 1.30E-04 & 4.2 & 1.2 \\
\hline $\begin{array}{l}\text { CR-BM- } \\
22\end{array}$ & sheet & 675 & 6000 & 900 & 44.8 & 6105 & $1.60 \mathrm{E}-04$ & 11.0 & 5.1 \\
\hline
\end{tabular}


Table A.3.2. Creep* and stress-rupture data for Haynes alloy 25 weldments (Heat \# 1860-8-1391)

\begin{tabular}{|c|c|c|c|c|c|c|c|c|c|c|}
\hline Test ID & $\begin{array}{l}\text { Product } \\
\text { Form }\end{array}$ & $\begin{array}{l}\text { Aging } \\
\text { Temp. } \\
\left({ }^{\circ} \mathrm{C}\right)\end{array}$ & $\begin{array}{l}\text { Aging } \\
\text { Time } \\
\text { (hours) }\end{array}$ & $\begin{array}{c}\text { Test } \\
\text { Temp. } \\
\left({ }^{\circ} \mathrm{C}\right)\end{array}$ & $\begin{array}{l}\text { Stress } \\
(\mathrm{MPa})\end{array}$ & 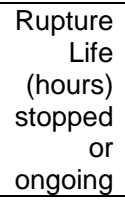 & $\begin{array}{r}\text { Minimum } \\
\text { Creep } \\
\text { Rate } \\
(\% / \mathrm{hr}) \\
\end{array}$ & $\begin{array}{r}\text { Elong. } \\
(\%)\end{array}$ & $\begin{array}{r}\text { Red. } \\
\text { of } \\
\text { Area } \\
(\%) \\
\end{array}$ & $\begin{array}{l}\text { Failure } \\
\text { Location }\end{array}$ \\
\hline $\begin{array}{l}\text { CR-WM- } \\
01\end{array}$ & $\begin{array}{l}\text { sheet } \\
\text { weld }\end{array}$ & none & none & 650 & 206.8 & 21532 & 3.48E-04 & 3.3 & 1.7 & $\mathrm{BM}$ \\
\hline $\begin{array}{l}\text { CR-WM- } \\
02\end{array}$ & $\begin{array}{l}\text { sheet } \\
\text { weld }\end{array}$ & none & none & 700 & 165.5 & 21339.3 & $3.45 \mathrm{E}-05$ & 4.4 & 1.9 & BM \\
\hline $\begin{array}{l}\text { CR-WM- } \\
03\end{array}$ & $\begin{array}{l}\text { sheet } \\
\text { weld }\end{array}$ & none & none & 750 & 127.6 & 9588 & $3.50 \mathrm{E}-04$ & 8.1 & 9.6 & BM \\
\hline $\begin{array}{l}\text { CR-WM- } \\
04\end{array}$ & $\begin{array}{l}\text { sheet } \\
\text { weld }\end{array}$ & none & none & 800 & 99.3 & 6620 & 4.40E-04 & 6.7 & 10.3 & $\mathrm{BM}$ \\
\hline $\begin{array}{l}\text { CR-WM- } \\
05\end{array}$ & $\begin{array}{l}\text { sheet } \\
\text { weld }\end{array}$ & none & none & 800 & 103.4 & 4550 & $8.40 \mathrm{E}-04$ & 9.2 & 5.4 & BM \\
\hline $\begin{array}{l}\text { CR-WM- } \\
06\end{array}$ & $\begin{array}{l}\text { sheet } \\
\text { weld }\end{array}$ & none & none & 850 & 62.1 & 8710 & 1.20E-04 & 6.5 & 4.1 & BM \\
\hline $\begin{array}{l}\text { CR-WM- } \\
07\end{array}$ & $\begin{array}{l}\text { sheet } \\
\text { weld }\end{array}$ & none & none & 875 & 53.8 & 6000 & 1.30E-04 & & & \\
\hline $\begin{array}{l}\text { CR-WM- } \\
08\end{array}$ & $\begin{array}{l}\text { sheet } \\
\text { weld }\end{array}$ & none & none & 900 & 44.8 & 4372 & $2.50 \mathrm{E}-04$ & 5.2 & 1.2 & BM \\
\hline $\begin{array}{l}\text { CR-WM- } \\
09\end{array}$ & $\begin{array}{l}\text { sheet } \\
\text { weld }\end{array}$ & none & none & 900 & 42.7 & 6470 & $1.30 \mathrm{E}-04$ & 9.8 & 7.2 & BM \\
\hline MG-01 & $\begin{array}{l}\text { sheet } \\
\text { weld }\end{array}$ & none & none & 600 & 179.3 & 32128 & 1.5E-05 & & & \\
\hline MG-03 & $\begin{array}{l}\text { sheet } \\
\text { weld }\end{array}$ & none & none & 625 & 144.8 & 32440 & 4.5E-06 & & & \\
\hline MG-06 & $\begin{array}{l}\text { sheet } \\
\text { weld }\end{array}$ & none & none & 650 & 124.1 & 11782 & 1.4E-05 & & & \\
\hline MG-09 & $\begin{array}{l}\text { sheet } \\
\text { weld }\end{array}$ & none & none & 650 & 186.2 & 10292 & 7.0E-05 & & & \\
\hline MG-10 & $\begin{array}{l}\text { sheet } \\
\text { weld }\end{array}$ & none & none & 675 & 103.4 & 11295 & 4.6E-06 & & & \\
\hline $\begin{array}{l}\text { CR-WM- } \\
15\end{array}$ & $\begin{array}{l}\text { sheet } \\
\text { weld }\end{array}$ & 675 & 6000 & 650 & 206.8 & 32136 & 1.30E-05 & 2.6 & 2.1 & BM \\
\hline $\begin{array}{l}\text { CR-WM- } \\
16\end{array}$ & $\begin{array}{l}\text { sheet } \\
\text { weld }\end{array}$ & 675 & 6000 & 700 & 165.5 & 16896 & 3.10E-05 & 1.8 & 1.0 & HAZ \\
\hline $\begin{array}{l}\text { CR-WM- } \\
17\end{array}$ & $\begin{array}{l}\text { sheet } \\
\text { weld }\end{array}$ & 675 & 6000 & 750 & 127.6 & 11990 & $8.10 \mathrm{E}-05$ & 4.5 & 3.1 & BM \\
\hline $\begin{array}{l}\text { CR-WM- } \\
18\end{array}$ & $\begin{array}{l}\text { sheet } \\
\text { weld }\end{array}$ & 675 & 6000 & 800 & 99.3 & 8568 & 1.30E-04 & & & BM \\
\hline $\begin{array}{l}\text { CR-WM- } \\
19\end{array}$ & $\begin{array}{l}\text { sheet } \\
\text { weld }\end{array}$ & 675 & 6000 & 800 & 103.4 & 4011 & $2.60 \mathrm{E}-04$ & 4.2 & 6.2 & BM \\
\hline $\begin{array}{l}\text { CR-WM- } \\
20\end{array}$ & $\begin{array}{l}\text { sheet } \\
\text { weld }\end{array}$ & 675 & 6000 & 850 & 62.1 & 11117 & 1.10E-04 & 5.2 & 2.4 & $\mathrm{BM}$ \\
\hline LWC-8 & bar weld & none & none & 650 & 206.8 & 8326.0 & & & & \\
\hline LWC-9 & bar weld & none & none & 800 & 103.4 & 6464.1 & 6.34E-04 & 11.2 & 27.3 & $\mathrm{BM}$ \\
\hline AWC-7 & bar weld & none & none & 650 & 124.1 & 8326.0 & 7.12E-06 & & & \\
\hline AWC-8 & bar weld & none & none & 650 & 206.8 & 8186.0 & 7.99E-05 & & & \\
\hline AWC-9 & bar weld & none & none & 800 & 103.4 & 5718.9 & 5.71E-04 & 14.5 & 19.2 & $\mathrm{BM}$ \\
\hline
\end{tabular}

*Note: Min. Creep Rate is based on displacement of a 2" specimen gauge length with a GTAW weldment in the center of the gauge 


\section{A.4 TABULAR PRESSURIZED TUBE RUPTURE DATA}

Table A.4.1. Rupture data for Haynes alloy 25 pressurized creep tests on tubes

\begin{tabular}{|c|c|c|c|c|c|c|c|c|}
\hline Test ID & $\begin{array}{l}\text { Diameter: } \\
\text { thickness } \\
\text { ratio }\end{array}$ & $\begin{array}{l}\text { Aging } \\
\text { Temp. } \\
\left({ }^{\circ} \mathrm{C}\right)\end{array}$ & $\begin{array}{l}\text { Aging } \\
\text { Time } \\
\text { (hours) }\end{array}$ & $\begin{array}{c}\text { Temperature } \\
\left({ }^{\circ} \mathrm{C}\right)\end{array}$ & $\begin{array}{c}\text { Pressure } \\
\text { (psi) }\end{array}$ & $\begin{array}{c}\text { Rupture } \\
\text { Life } \\
\text { (hours) } \\
\text { Ongoing }\end{array}$ & $\begin{array}{l}\text { Rupture } \\
\text { Location }\end{array}$ & $\begin{array}{c}\text { Hoop } \\
\text { Strain at } \\
\text { Failure } \\
(\%)\end{array}$ \\
\hline LTP-1 & 10.76 & none & none & 675 & 5,000 & 22114.0 & In Test & \\
\hline LTP-2 & 10.76 & none & none & 750 & 3,645 & 11147.8 & Tube & 7.1 \\
\hline PB-IM-01 & 10.76 & none & none & 750 & 4,700 & 2707.6 & Tube & 13.8 \\
\hline PB-IM-02 & 10.76 & none & none & 750 & 5,400 & 958.4 & Tube & 12.6 \\
\hline PB-IM-03 & 10.76 & none & none & 750 & 6,200 & 383.0 & Tube & 18.9 \\
\hline PB-IM-04 & 10.76 & none & none & 800 & 3,500 & 1550.2 & Weld & 11.8 \\
\hline PB-IM-05 & 10.76 & none & none & 800 & 4,500 & 328.8 & Tube & 26.4 \\
\hline PB-IM-06 & 10.76 & none & none & 800 & 5,200 & 138.1 & Tube & 38.2 \\
\hline PB-IM-07 & 10.76 & none & none & 850 & 2,500 & 1071.0 & Weld & 6.0 \\
\hline PB-IM-08 & 10.76 & none & none & 850 & 3,500 & 199.8 & Tube & 30.7 \\
\hline PB-IM-09 & 10.76 & none & none & 850 & 4,300 & 43.8 & Tube & 38.6 \\
\hline PB-IM-10 & 10.76 & none & none & 950 & 1,200 & 432.2 & End Cap & 9.8 \\
\hline PB-IM-11 & 10.76 & none & none & 950 & 1,800 & 147.2 & Tube & 42.4 \\
\hline PB-IM-12 & 10.76 & none & none & 950 & 2,400 & 19.4 & Tube & 56.2 \\
\hline LTS-1 & 13.15 & none & none & 675 & 5,000 & 21002.0 & Tube & \\
\hline LTS-2 & 13.15 & none & none & 700 & 5,000 & 2000.0 & In Test & \\
\hline PB-OM-01 & 13.15 & none & none & 750 & 5,400 & 426.3 & Tube & 21.9 \\
\hline PB-OM-02 & 13.15 & none & none & 800 & 4,500 & 125.7 & Tube & 38.9 \\
\hline PB-OM-03 & 13.15 & none & none & 850 & 3,500 & 65.0 & Tube & 38.4 \\
\hline PB-OM-04 & 13.15 & 675 & 6000 & 750 & 4,700 & 2880.0 & Tube & 2.9 \\
\hline PB-OM-05 & 13.15 & 675 & 6000 & 750 & 5,400 & 1143.3 & Tube & 1.6 \\
\hline PB-OM-06 & 13.15 & 675 & 6000 & 750 & 6,200 & 495.8 & Tube & 2.5 \\
\hline PB-OM-07 & 13.15 & 675 & 6000 & 800 & 3,500 & 545.9 & Tube & 12.3 \\
\hline PB-OM-08 & 13.15 & 675 & 6000 & 800 & 4,500 & 92.1 & Tube & 22.1 \\
\hline PB-OM-09 & 13.15 & 675 & 6000 & 800 & 5,200 & 50.3 & Tube & 24.0 \\
\hline PB-OM-10 & 13.15 & 675 & 6000 & 850 & 2,500 & 459.9 & Tube & 19.0 \\
\hline PB-OM-11 & 13.15 & 675 & 6000 & 850 & 3,500 & 57.8 & Tube & 23.5 \\
\hline PB-OM-12 & 13.15 & 675 & 6000 & 850 & 4,300 & 15.2 & Tube & 32.6 \\
\hline PB-OM-13 & 13.15 & 675 & 6000 & 950 & 1,200 & 404.5 & Tube & 14.0 \\
\hline PB-OM-14 & 13.15 & 675 & 6000 & 950 & 1,800 & 60.4 & Tube & 18.0 \\
\hline PB-OM-15 & 13.15 & 675 & 6000 & 950 & 2,400 & 9.1 & Tube & 29.3 \\
\hline
\end{tabular}




\section{A.5 STRESS-STRAIN CURVES}

\begin{tabular}{|c|c|c|c|c|c|c|c|c|c|c|c|}
\hline Test ID & $\begin{array}{l}\text { Product } \\
\text { Form }\end{array}$ & $\begin{array}{c}\text { Aging } \\
\text { Temp. } \\
\left({ }^{\circ} \mathrm{C}\right)\end{array}$ & $\begin{array}{c}\text { Aging } \\
\text { Time } \\
\text { (hours) }\end{array}$ & $\begin{array}{c}\text { Test } \\
\text { Temp. } \\
\left({ }^{\circ} \mathrm{C}\right)\end{array}$ & $\begin{array}{l}\text { Prop. } \\
\text { Limit } \\
\text { (MPa) }\end{array}$ & $\begin{array}{c}\text { Yield } \\
\text { Strength } \\
(\mathrm{MPa})\end{array}$ & $\begin{array}{l}\text { Ultimate } \\
\text { Tensile } \\
\text { Strength } \\
\text { (MPa) }\end{array}$ & $\begin{array}{c}\text { Uniform } \\
\text { Elong. } \\
(\%)\end{array}$ & $\begin{array}{c}\text { Elong. } \\
(\%)\end{array}$ & $\begin{array}{l}\text { Red. } \\
\text { of } \\
\text { Area } \\
(\%)\end{array}$ & $\begin{array}{c}\text { Failure } \\
\text { Location }\end{array}$ \\
\hline TT-BM-01 & Sheet & none & none & 23 & 272 & 499 & 1000 & 56.6 & 56.6 & 39.9 & GL \\
\hline
\end{tabular}

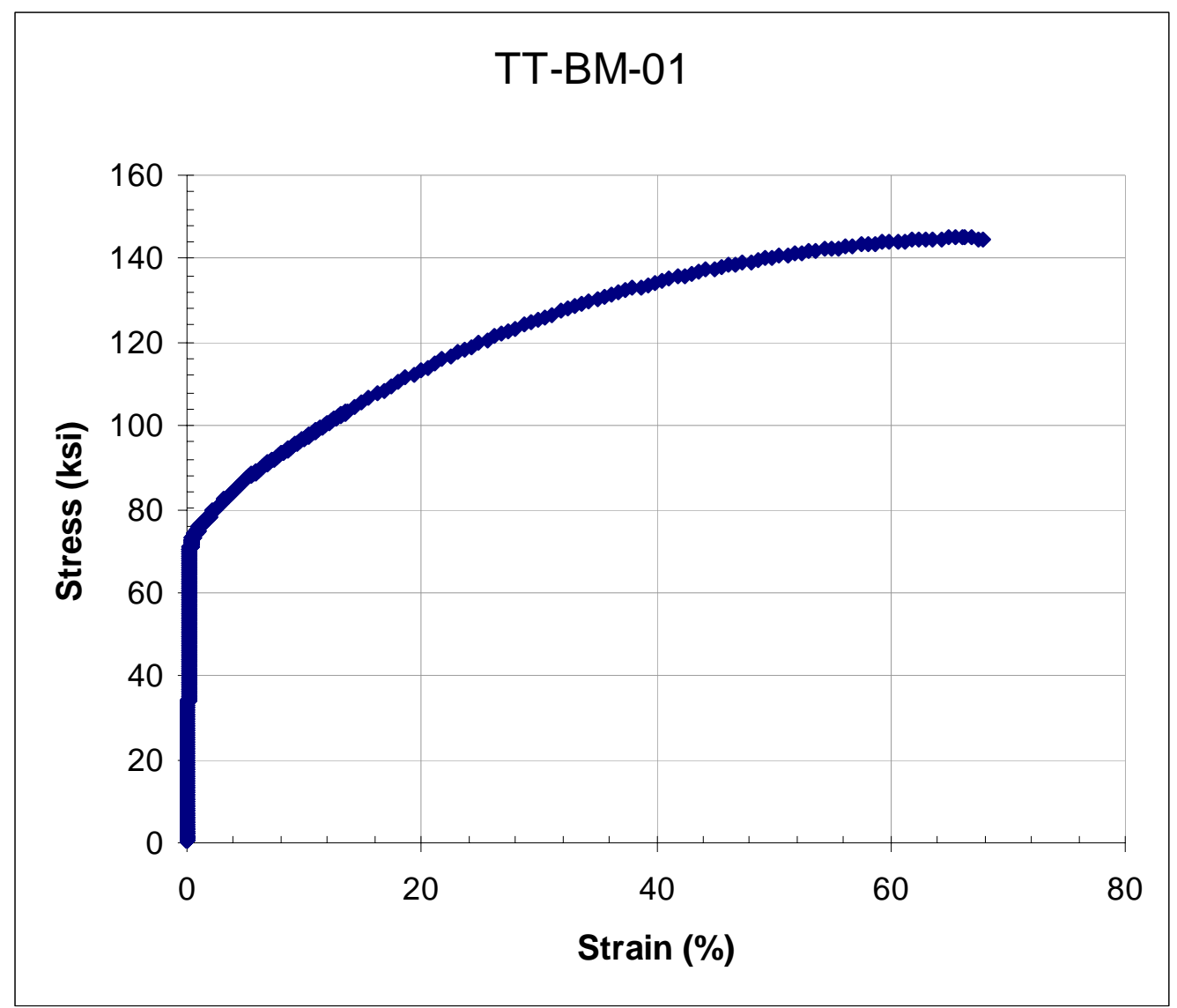




\begin{tabular}{|c|c|c|c|c|c|c|c|c|c|c|c|}
\hline Test ID & $\begin{array}{l}\text { Product } \\
\text { Form }\end{array}$ & $\begin{array}{l}\text { Aging } \\
\text { Temp. } \\
\left({ }^{\circ} \mathrm{C}\right)\end{array}$ & $\begin{array}{l}\text { Aging } \\
\text { Time } \\
\text { (hours) }\end{array}$ & $\begin{array}{c}\text { Test } \\
\text { Temp. } \\
\left({ }^{\circ} \mathrm{C}\right)\end{array}$ & $\begin{array}{c}\text { Prop. } \\
\text { Limit } \\
(\mathrm{MPa})\end{array}$ & $\begin{array}{c}\text { Yield } \\
\text { Strength } \\
\text { (MPa) }\end{array}$ & $\begin{array}{c}\text { Ultimate } \\
\text { Tensile } \\
\text { Strength } \\
\text { (MPa) }\end{array}$ & $\begin{array}{c}\text { Uniform } \\
\text { Elong. } \\
(\%)\end{array}$ & $\begin{array}{c}\text { Elong. } \\
(\%)\end{array}$ & $\begin{array}{c}\text { Red. } \\
\text { of } \\
\text { Area } \\
(\%)\end{array}$ & $\begin{array}{c}\text { Failure } \\
\text { Location }\end{array}$ \\
\hline TT-BM-02 & Sheet & none & none & 300 & 196 & 308 & 884 & 72.5 & 74.9 & 56.6 & $\mathrm{GL}$ \\
\hline
\end{tabular}

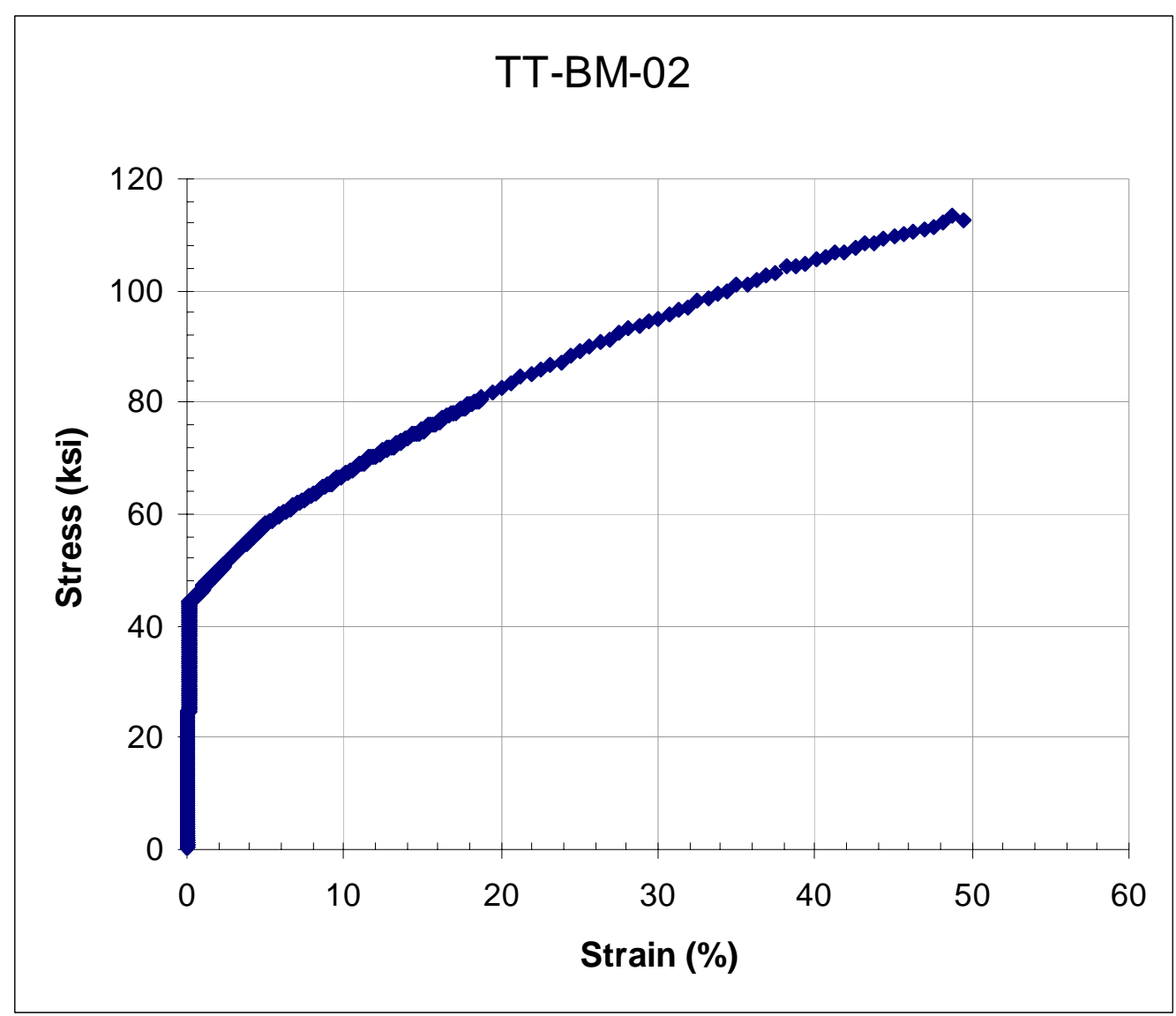




\begin{tabular}{|c|c|c|c|c|c|c|c|c|c|c|c|}
\hline Test ID & $\begin{array}{l}\text { Product } \\
\text { Form }\end{array}$ & $\begin{array}{l}\text { Aging } \\
\text { Temp. } \\
\left({ }^{\circ} \mathrm{C}\right)\end{array}$ & $\begin{array}{l}\text { Aging } \\
\text { Time } \\
\text { (hours) }\end{array}$ & $\begin{array}{c}\text { Test } \\
\text { Temp. } \\
\left({ }^{\circ} \mathrm{C}\right)\end{array}$ & $\begin{array}{c}\text { Prop. } \\
\text { Limit } \\
(\mathrm{MPa})\end{array}$ & $\begin{array}{c}\text { Yield } \\
\text { Strength } \\
\text { (MPa) }\end{array}$ & $\begin{array}{c}\text { Ultimate } \\
\text { Tensile } \\
\text { Strength } \\
\text { (MPa) }\end{array}$ & $\begin{array}{c}\text { Uniform } \\
\text { Elong. } \\
(\%)\end{array}$ & $\begin{array}{c}\text { Elong. } \\
(\%)\end{array}$ & $\begin{array}{c}\text { Red. } \\
\text { of } \\
\text { Area } \\
(\%) \\
\end{array}$ & $\begin{array}{c}\text { Failure } \\
\text { Location }\end{array}$ \\
\hline TT-BM-03 & Sheet & none & none & 500 & 165 & 276 & 806 & 64.6 & 68.7 & 54.4 & $\mathrm{GL}$ \\
\hline
\end{tabular}

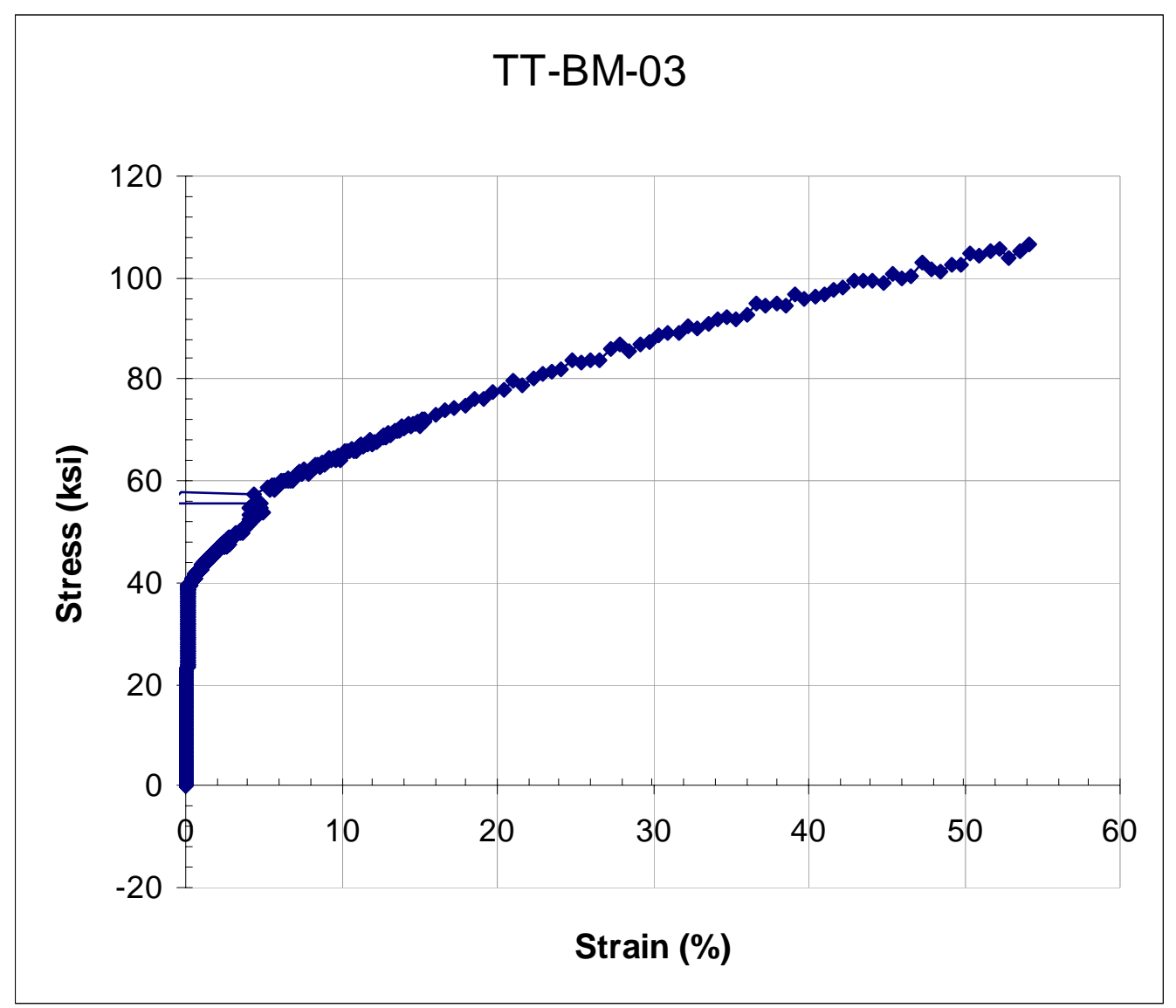




\begin{tabular}{|c|c|c|c|c|c|c|c|c|c|c|c|}
\hline Test ID & $\begin{array}{l}\text { Product } \\
\text { Form }\end{array}$ & $\begin{array}{l}\text { Aging } \\
\text { Temp. } \\
\left({ }^{\circ} \mathrm{C}\right)\end{array}$ & $\begin{array}{l}\text { Aging } \\
\text { Time } \\
\text { (hours) }\end{array}$ & $\begin{array}{c}\text { Test } \\
\text { Temp. } \\
\left({ }^{\circ} \mathrm{C}\right)\end{array}$ & $\begin{array}{c}\text { Prop. } \\
\text { Limit } \\
(\mathrm{MPa})\end{array}$ & $\begin{array}{c}\text { Yield } \\
\text { Strength } \\
\text { (MPa) }\end{array}$ & $\begin{array}{c}\text { Ultimate } \\
\text { Tensile } \\
\text { Strength } \\
\text { (MPa) }\end{array}$ & $\begin{array}{c}\text { Uniform } \\
\text { Elong. } \\
(\%)\end{array}$ & $\begin{array}{c}\text { Elong. } \\
(\%)\end{array}$ & $\begin{array}{c}\text { Red. } \\
\text { of } \\
\text { Area } \\
(\%)\end{array}$ & $\begin{array}{c}\text { Failure } \\
\text { Location }\end{array}$ \\
\hline TT-BM-04 & Sheet & none & none & 650 & 218 & 261 & 778 & 54.1 & 57.2 & 35.1 & $\mathrm{GL}$ \\
\hline
\end{tabular}

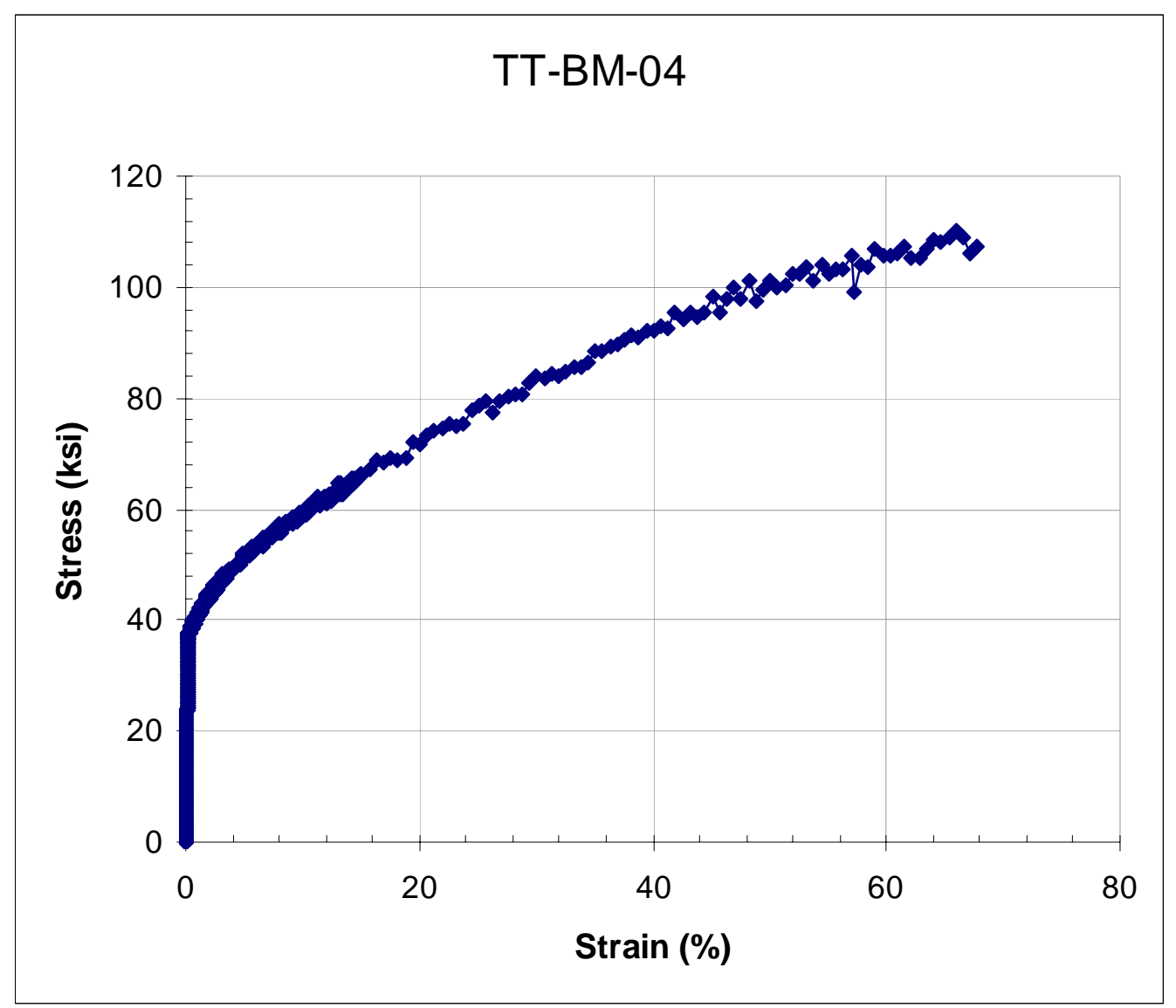




\begin{tabular}{|c|c|c|c|c|c|c|c|c|c|c|c|}
\hline Test ID & $\begin{array}{l}\text { Product } \\
\text { Form }\end{array}$ & $\begin{array}{l}\text { Aging } \\
\text { Temp. } \\
\left({ }^{\circ} \mathrm{C}\right)\end{array}$ & $\begin{array}{l}\text { Aging } \\
\text { Time } \\
\text { (hours) }\end{array}$ & $\begin{array}{c}\text { Test } \\
\text { Temp. } \\
\left({ }^{\circ} \mathrm{C}\right)\end{array}$ & $\begin{array}{c}\text { Prop. } \\
\text { Limit } \\
(\mathrm{MPa})\end{array}$ & $\begin{array}{c}\text { Yield } \\
\text { Strength } \\
\text { (MPa) }\end{array}$ & $\begin{array}{c}\text { Ultimate } \\
\text { Tensile } \\
\text { Strength } \\
\text { (MPa) }\end{array}$ & $\begin{array}{c}\text { Uniform } \\
\text { Elong. } \\
(\%)\end{array}$ & $\begin{array}{c}\text { Elong. } \\
(\%)\end{array}$ & $\begin{array}{c}\text { Red. } \\
\text { of } \\
\text { Area } \\
(\%)\end{array}$ & $\begin{array}{c}\text { Failure } \\
\text { Location }\end{array}$ \\
\hline TT-BM-05 & Sheet & none & none & 800 & 187 & 232 & 477 & 26.2 & 59.1 & 41.6 & $\mathrm{GL}$ \\
\hline
\end{tabular}

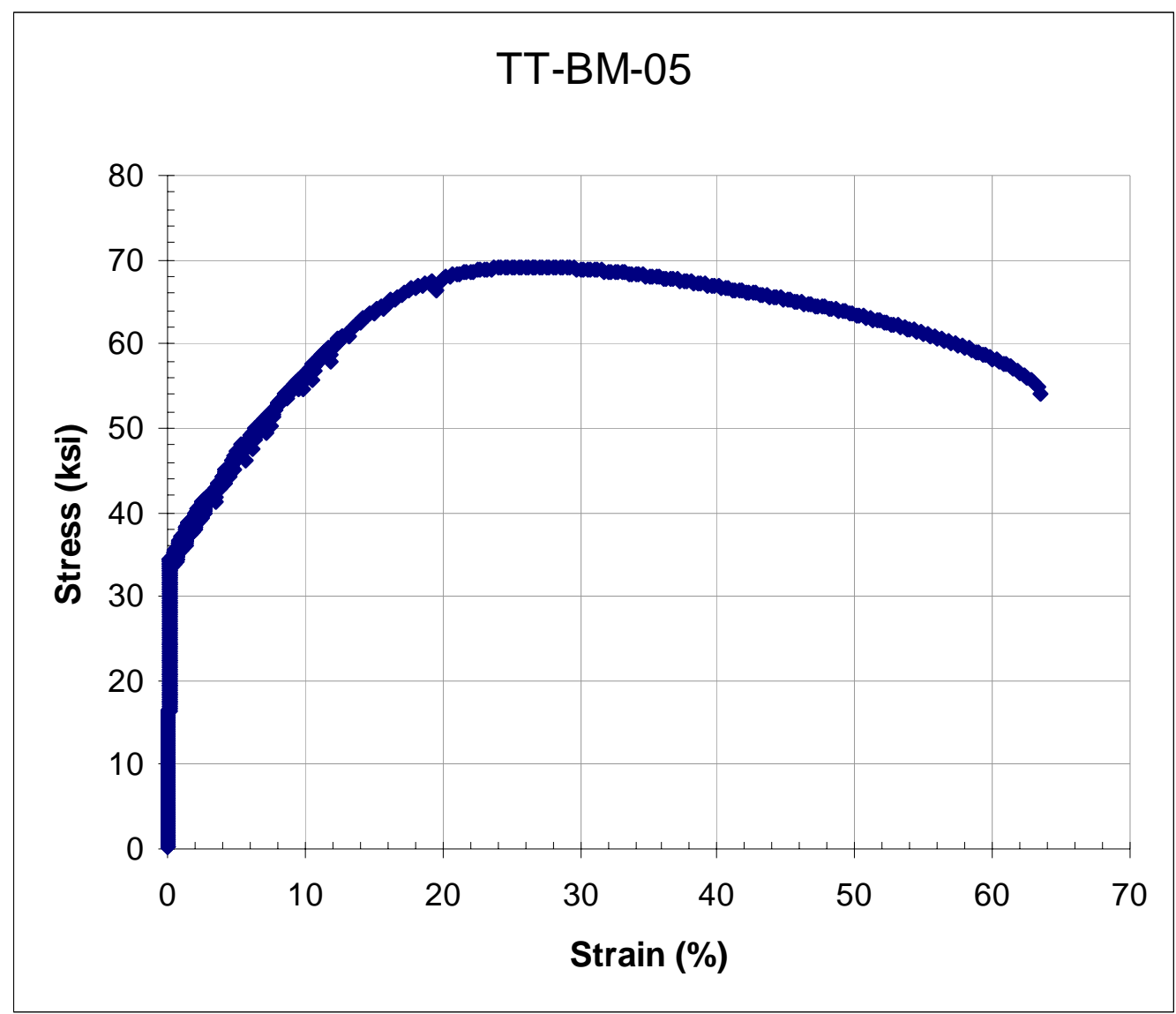




\begin{tabular}{|c|c|c|c|c|c|c|c|c|c|c|c|}
\hline Test ID & $\begin{array}{l}\text { Product } \\
\text { Form }\end{array}$ & $\begin{array}{l}\text { Aging } \\
\text { Temp. } \\
\left({ }^{\circ} \mathrm{C}\right)\end{array}$ & $\begin{array}{l}\text { Aging } \\
\text { Time } \\
\text { (hours) }\end{array}$ & $\begin{array}{c}\text { Test } \\
\text { Temp. } \\
\left({ }^{\circ} \mathrm{C}\right)\end{array}$ & $\begin{array}{c}\text { Prop. } \\
\text { Limit } \\
(\mathrm{MPa})\end{array}$ & $\begin{array}{c}\text { Yield } \\
\text { Strength } \\
\text { (MPa) }\end{array}$ & $\begin{array}{c}\text { Ultimate } \\
\text { Tensile } \\
\text { Strength } \\
\text { (MPa) }\end{array}$ & $\begin{array}{c}\text { Uniform } \\
\text { Elong. } \\
(\%)\end{array}$ & $\begin{array}{c}\text { Elong. } \\
(\%)\end{array}$ & $\begin{array}{c}\text { Red. } \\
\text { of } \\
\text { Area } \\
(\%)\end{array}$ & $\begin{array}{c}\text { Failure } \\
\text { Location }\end{array}$ \\
\hline TT-BM-06 & Sheet & none & none & 1000 & 65 & 163 & 167 & 3.8 & 88.5 & 69.2 & $\mathrm{GL}$ \\
\hline
\end{tabular}

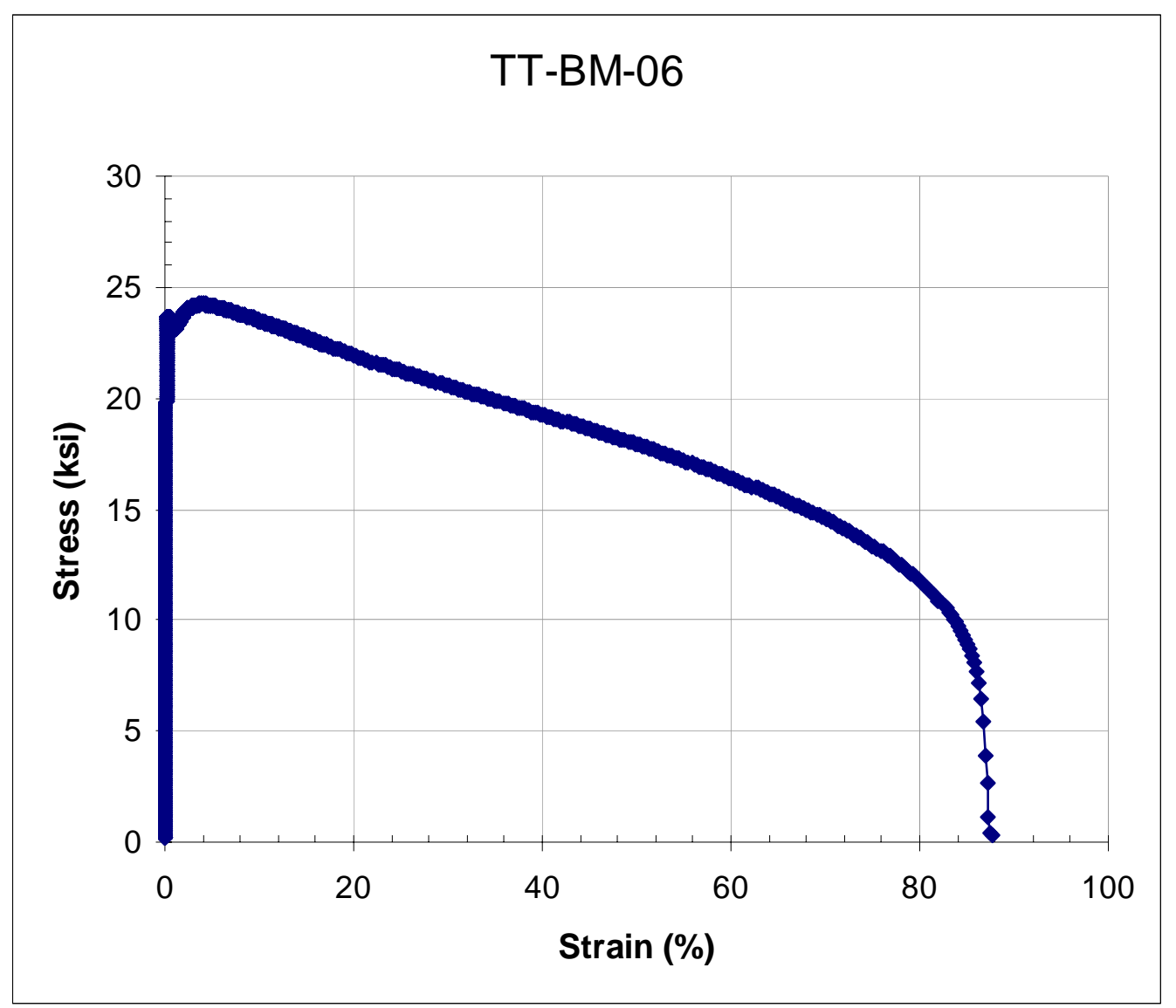




\begin{tabular}{|c|c|c|c|c|c|c|c|c|c|c|c|}
\hline Test ID & $\begin{array}{l}\text { Product } \\
\text { Form }\end{array}$ & $\begin{array}{l}\text { Aging } \\
\text { Temp. } \\
\left({ }^{\circ} \mathrm{C}\right)\end{array}$ & $\begin{array}{l}\text { Aging } \\
\text { Time } \\
\text { (hours) }\end{array}$ & $\begin{array}{c}\text { Test } \\
\text { Temp. } \\
\left({ }^{\circ} \mathrm{C}\right)\end{array}$ & $\begin{array}{c}\text { Prop. } \\
\text { Limit } \\
(\mathrm{MPa})\end{array}$ & $\begin{array}{c}\text { Yield } \\
\text { Strength } \\
\text { (MPa) }\end{array}$ & $\begin{array}{c}\text { Ultimate } \\
\text { Tensile } \\
\text { Strength } \\
\text { (MPa) }\end{array}$ & $\begin{array}{c}\text { Uniform } \\
\text { Elong. } \\
(\%)\end{array}$ & $\begin{array}{c}\text { Elong. } \\
(\%)\end{array}$ & $\begin{array}{c}\text { Red. } \\
\text { of } \\
\text { Area } \\
(\%)\end{array}$ & $\begin{array}{c}\text { Failure } \\
\text { Location }\end{array}$ \\
\hline TT-BM-07 & Sheet & none & none & 1100 & 27 & 86 & 92 & 1.7 & 70.4 & 61.7 & $\mathrm{GL}$ \\
\hline
\end{tabular}

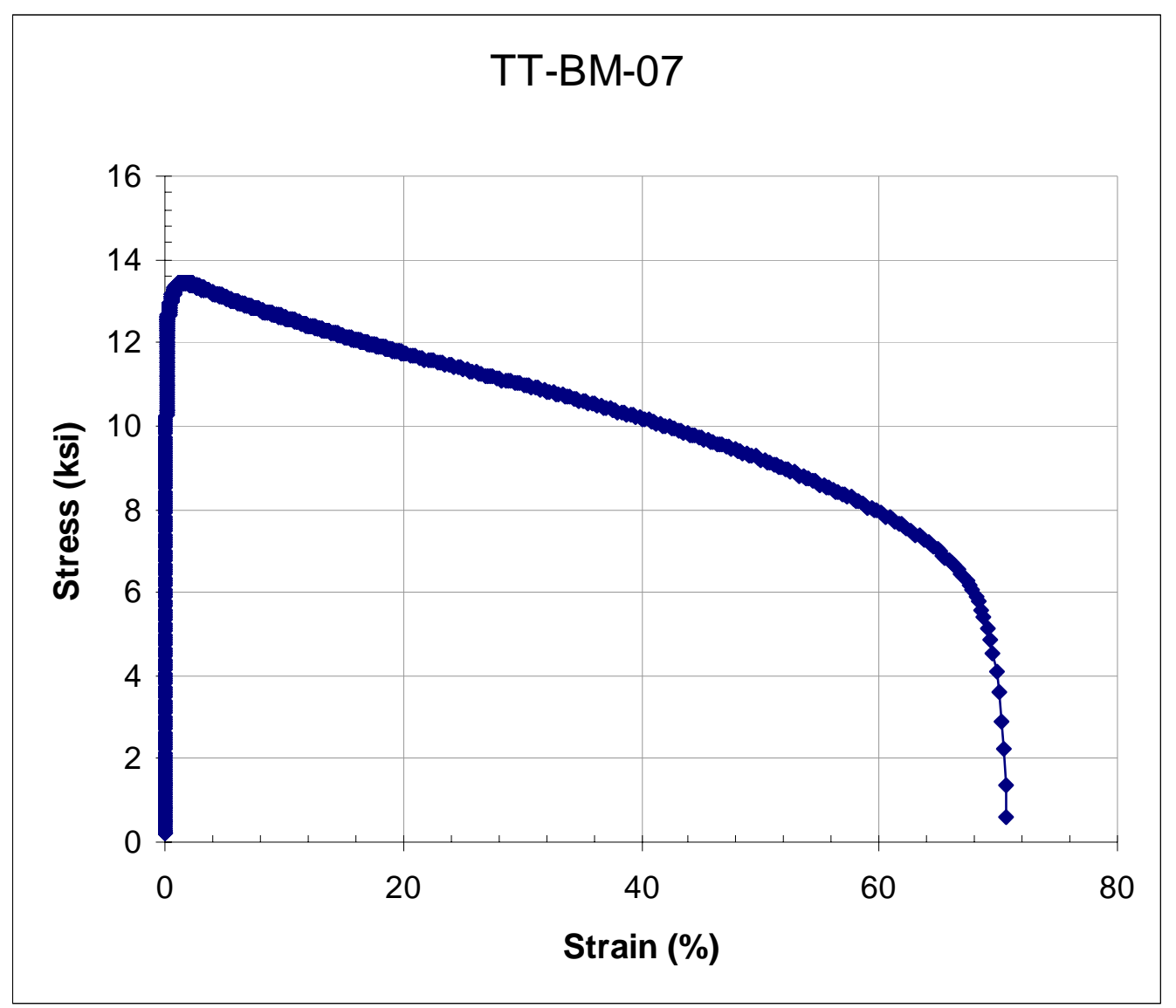




\begin{tabular}{|c|c|c|c|c|c|c|c|c|c|c|c|}
\hline Test ID & $\begin{array}{l}\text { Product } \\
\text { Form }\end{array}$ & $\begin{array}{l}\text { Aging } \\
\text { Temp. } \\
\left({ }^{\circ} \mathrm{C}\right)\end{array}$ & $\begin{array}{l}\text { Aging } \\
\text { Time } \\
\text { (hours) }\end{array}$ & $\begin{array}{l}\text { Test } \\
\text { Temp. } \\
\left({ }^{\circ} \mathrm{C}\right)\end{array}$ & $\begin{array}{c}\text { Prop. } \\
\text { Limit } \\
(\mathrm{MPa})\end{array}$ & $\begin{array}{c}\text { Yield } \\
\text { Strength } \\
\text { (MPa) }\end{array}$ & $\begin{array}{c}\text { Ultimate } \\
\text { Tensile } \\
\text { Strength } \\
\text { (MPa) }\end{array}$ & $\begin{array}{c}\text { Uniform } \\
\text { Elong. } \\
(\%)\end{array}$ & $\begin{array}{c}\text { Elong. } \\
(\%)\end{array}$ & $\begin{array}{c}\text { Red. } \\
\text { of } \\
\text { Area } \\
(\%) \\
\end{array}$ & $\begin{array}{c}\text { Failure } \\
\text { Location }\end{array}$ \\
\hline TT-BM-08 & Sheet & 675 & 6000 & 23 & 365 & 789 & 1053 & 7.3 & 7.3 & 4.4 & $\mathrm{GL}, \mathrm{GM}$ \\
\hline
\end{tabular}

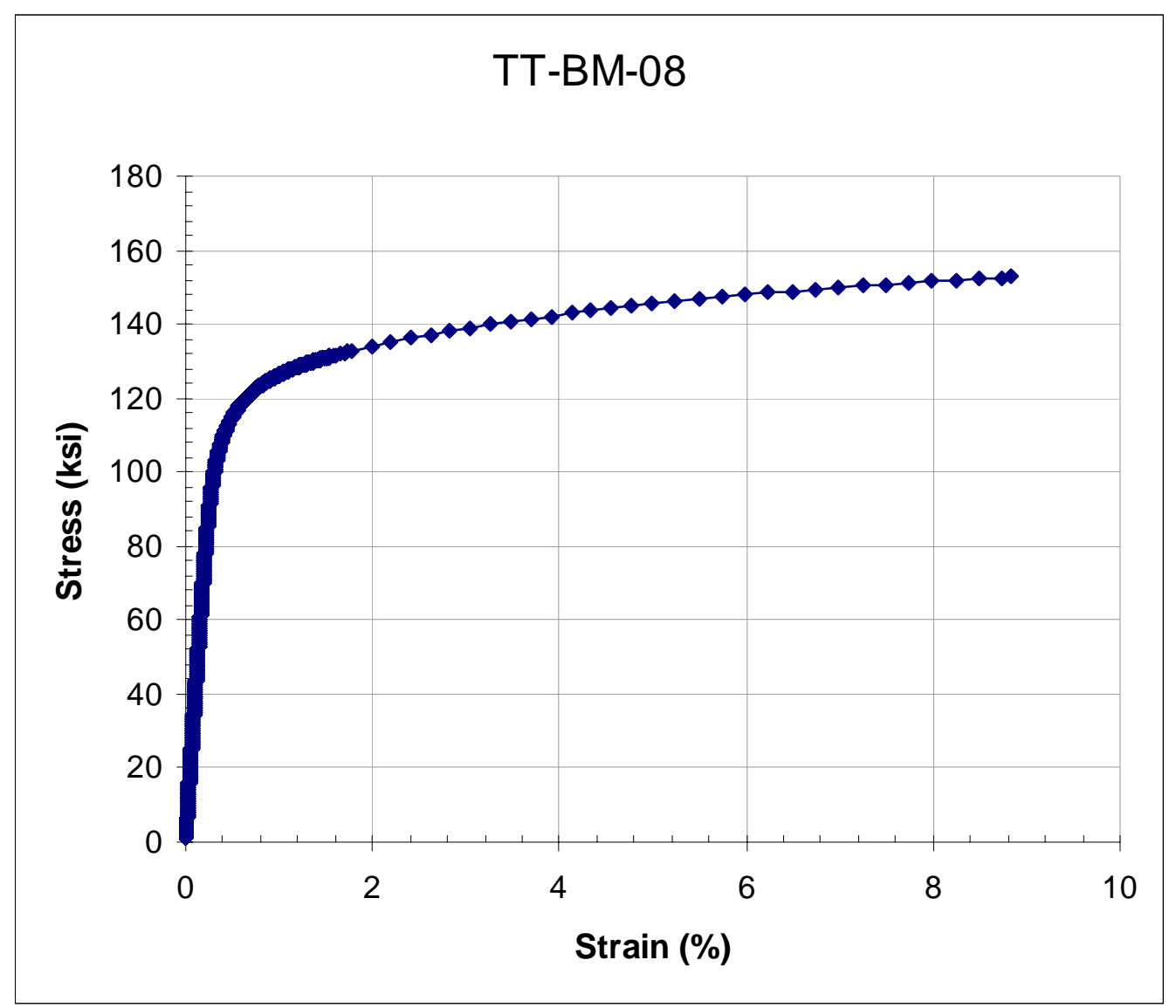




\begin{tabular}{|c|c|c|c|c|c|c|c|c|c|c|c|}
\hline Test ID & $\begin{array}{l}\text { Product } \\
\text { Form }\end{array}$ & $\begin{array}{l}\text { Aging } \\
\text { Temp. } \\
\left({ }^{\circ} \mathrm{C}\right)\end{array}$ & $\begin{array}{l}\text { Aging } \\
\text { Time } \\
\text { (hours) }\end{array}$ & $\begin{array}{l}\text { Test } \\
\text { Temp. } \\
\left({ }^{\circ} \mathrm{C}\right)\end{array}$ & $\begin{array}{c}\text { Prop. } \\
\text { Limit } \\
(\mathrm{MPa})\end{array}$ & $\begin{array}{c}\text { Yield } \\
\text { Strength } \\
\text { (MPa) }\end{array}$ & $\begin{array}{c}\text { Ultimate } \\
\text { Tensile } \\
\text { Strength } \\
\text { (MPa) }\end{array}$ & $\begin{array}{c}\text { Uniform } \\
\text { Elong. } \\
(\%)\end{array}$ & $\begin{array}{c}\text { Elong. } \\
(\%)\end{array}$ & $\begin{array}{c}\text { Red. } \\
\text { of } \\
\text { Area } \\
(\%) \\
\end{array}$ & $\begin{array}{c}\text { Failure } \\
\text { Location }\end{array}$ \\
\hline TT-BM-08B & Sheet & 675 & 6000 & 23 & 549 & 792 & 1045 & 8.4 & 8.4 & 5.8 & $\mathrm{GL}$ \\
\hline
\end{tabular}

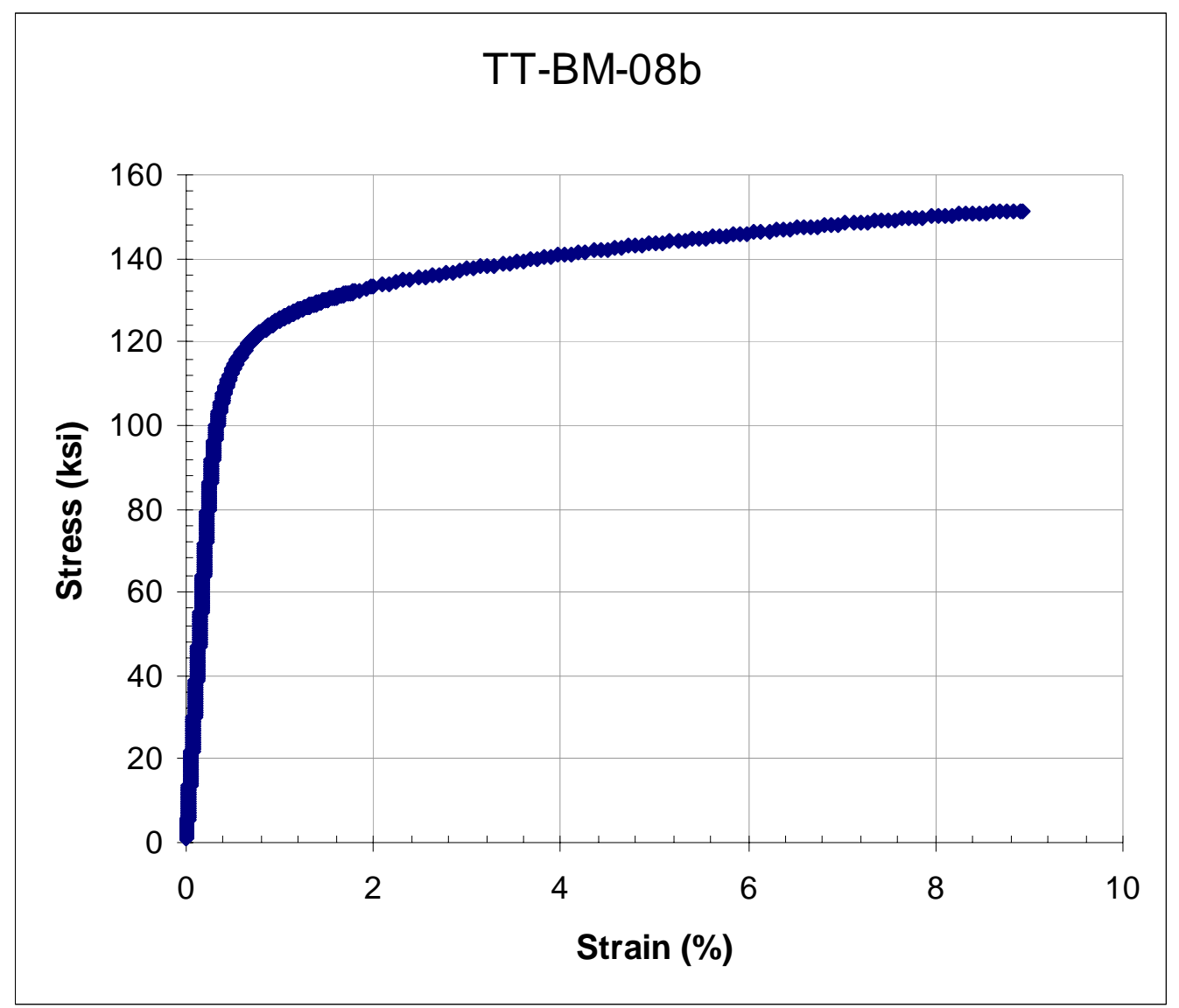




\begin{tabular}{|c|c|c|c|c|c|c|c|c|c|c|c|}
\hline Test ID & $\begin{array}{l}\text { Product } \\
\text { Form }\end{array}$ & $\begin{array}{l}\text { Aging } \\
\text { Temp. } \\
\left({ }^{\circ} \mathrm{C}\right)\end{array}$ & $\begin{array}{l}\text { Aging } \\
\text { Time } \\
\text { (hours) }\end{array}$ & $\begin{array}{l}\text { Test } \\
\text { Temp. } \\
\left({ }^{\circ} \mathrm{C}\right)\end{array}$ & $\begin{array}{c}\text { Prop. } \\
\text { Limit } \\
(\mathrm{MPa})\end{array}$ & $\begin{array}{c}\text { Yield } \\
\text { Strength } \\
\text { (MPa) }\end{array}$ & $\begin{array}{c}\text { Ultimate } \\
\text { Tensile } \\
\text { Strength } \\
\text { (MPa) }\end{array}$ & $\begin{array}{c}\text { Uniform } \\
\text { Elong. } \\
(\%)\end{array}$ & $\begin{array}{c}\text { Elong. } \\
(\%)\end{array}$ & $\begin{array}{c}\text { Red. } \\
\text { of } \\
\text { Area } \\
(\%) \\
\end{array}$ & $\begin{array}{c}\text { Failure } \\
\text { Location }\end{array}$ \\
\hline TT-BM-09 & Sheet & 675 & 6000 & 300 & 379 & 610 & 955 & 13.7 & 13.7 & 13.8 & $\mathrm{GL}$ \\
\hline
\end{tabular}

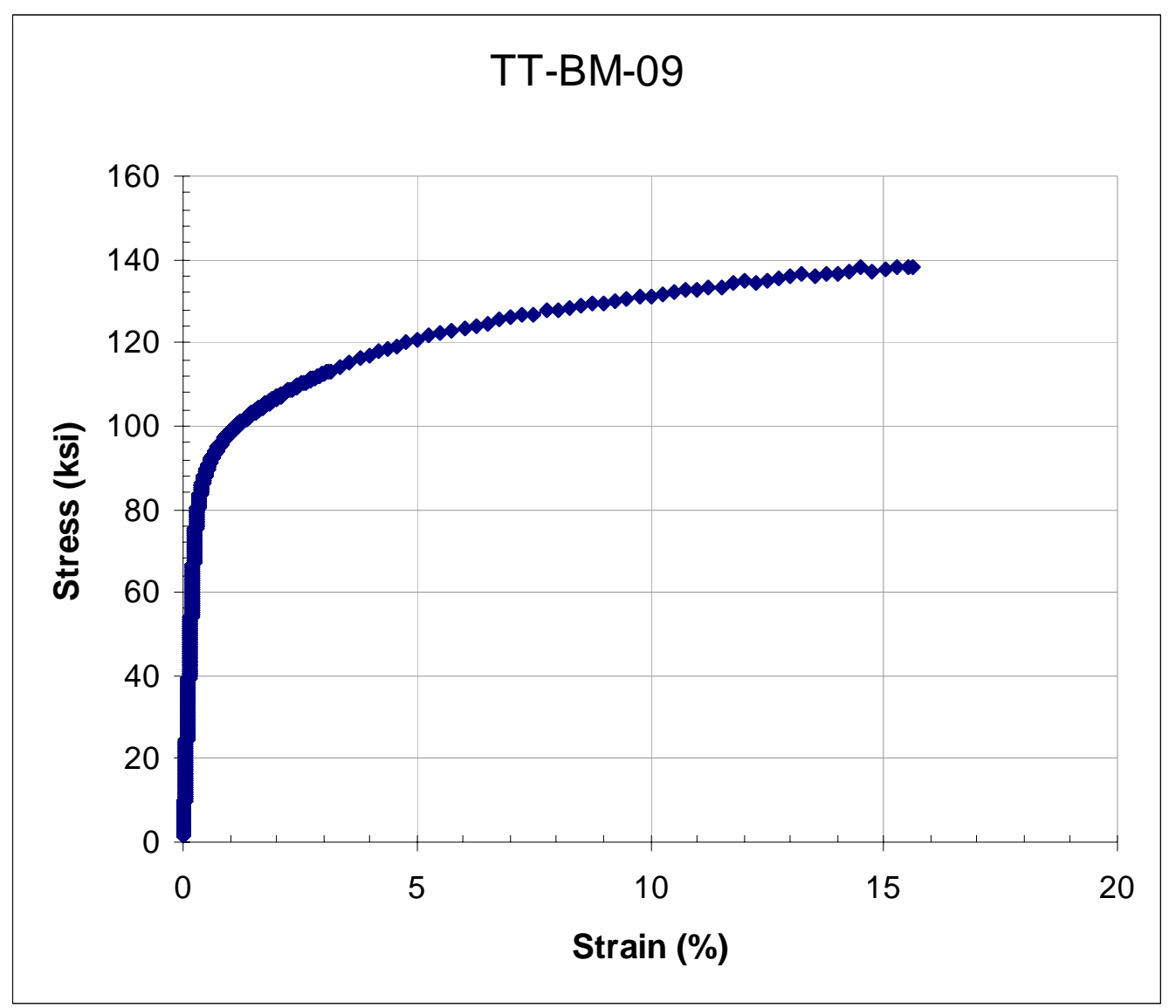




\begin{tabular}{|c|c|c|c|c|c|c|c|c|c|c|c|}
\hline Test ID & $\begin{array}{l}\text { Product } \\
\text { Form }\end{array}$ & $\begin{array}{l}\text { Aging } \\
\text { Temp. } \\
\left({ }^{\circ} \mathrm{C}\right)\end{array}$ & $\begin{array}{l}\text { Aging } \\
\text { Time } \\
\text { (hours) }\end{array}$ & $\begin{array}{l}\text { Test } \\
\text { Temp. } \\
\left({ }^{\circ} \mathrm{C}\right)\end{array}$ & $\begin{array}{c}\text { Prop. } \\
\text { Limit } \\
(\mathrm{MPa})\end{array}$ & $\begin{array}{c}\text { Yield } \\
\text { Strength } \\
\text { (MPa) }\end{array}$ & $\begin{array}{c}\text { Ultimate } \\
\text { Tensile } \\
\text { Strength } \\
\text { (MPa) }\end{array}$ & $\begin{array}{c}\text { Uniform } \\
\text { Elong. } \\
(\%)\end{array}$ & $\begin{array}{c}\text { Elong. } \\
(\%)\end{array}$ & $\begin{array}{c}\text { Red. } \\
\text { of } \\
\text { Area } \\
(\%) \\
\end{array}$ & $\begin{array}{c}\text { Failure } \\
\text { Location }\end{array}$ \\
\hline TT-BM-10 & Sheet & 675 & 6000 & 500 & 421 & 558 & 945 & 17.3 & 17.3 & 16.1 & $\mathrm{GL}$ \\
\hline
\end{tabular}

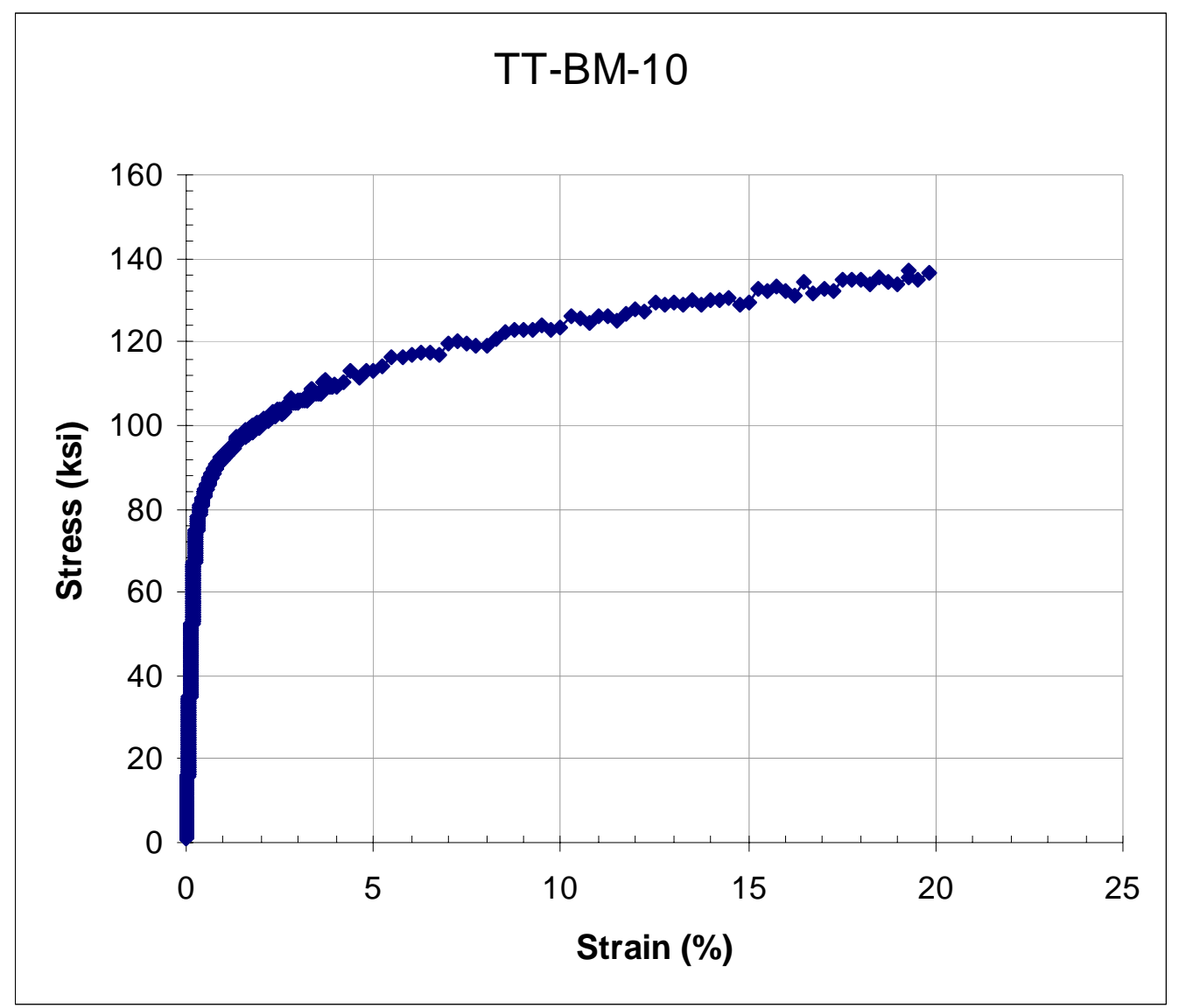




\begin{tabular}{|c|c|c|c|c|c|c|c|c|c|c|c|}
\hline Test ID & $\begin{array}{l}\text { Product } \\
\text { Form }\end{array}$ & $\begin{array}{l}\text { Aging } \\
\text { Temp. } \\
\left({ }^{\circ} \mathrm{C}\right)\end{array}$ & $\begin{array}{l}\text { Aging } \\
\text { Time } \\
\text { (hours) }\end{array}$ & $\begin{array}{l}\text { Test } \\
\text { Temp. } \\
\left({ }^{\circ} \mathrm{C}\right)\end{array}$ & $\begin{array}{l}\text { Prop. } \\
\text { Limit } \\
(\mathrm{MPa})\end{array}$ & $\begin{array}{c}\text { Yield } \\
\text { Strength } \\
\text { (MPa) }\end{array}$ & $\begin{array}{l}\text { Ultimate } \\
\text { Tensile } \\
\text { Strength } \\
\text { (MPa) }\end{array}$ & $\begin{array}{l}\text { Uniform } \\
\text { Elong. } \\
(\%)\end{array}$ & $\begin{array}{c}\text { Elong. } \\
(\%)\end{array}$ & $\begin{array}{c}\text { Red. } \\
\text { of } \\
\text { Area } \\
(\%) \\
\end{array}$ & $\begin{array}{c}\text { Failure } \\
\text { Location }\end{array}$ \\
\hline TT-BM-11 & Sheet & 675 & 6000 & 650 & 338 & 516 & 907 & 21.3 & 21.3 & 14.7 & $\mathrm{GL}$ \\
\hline
\end{tabular}

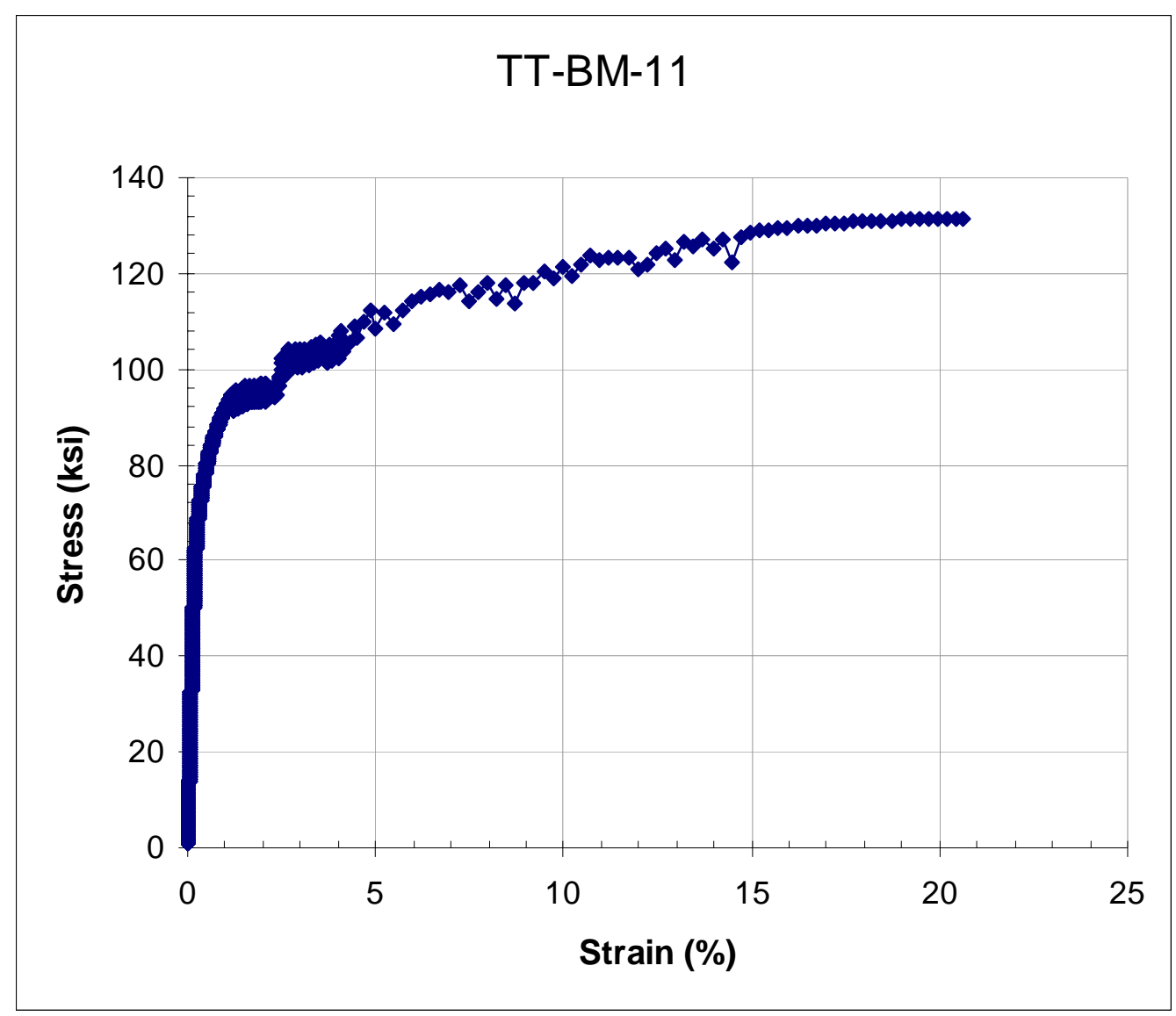




\begin{tabular}{|c|c|c|c|c|c|c|c|c|c|c|c|}
\hline Test ID & $\begin{array}{l}\text { Product } \\
\text { Form }\end{array}$ & $\begin{array}{l}\text { Aging } \\
\text { Temp. } \\
\left({ }^{\circ} \mathrm{C}\right)\end{array}$ & $\begin{array}{l}\text { Aging } \\
\text { Time } \\
\text { (hours) }\end{array}$ & $\begin{array}{c}\text { Test } \\
\text { Temp. } \\
\left({ }^{\circ} \mathrm{C}\right)\end{array}$ & $\begin{array}{c}\text { Prop. } \\
\text { Limit } \\
(\mathrm{MPa})\end{array}$ & $\begin{array}{c}\text { Yield } \\
\text { Strength } \\
\text { (MPa) }\end{array}$ & $\begin{array}{c}\text { Ultimate } \\
\text { Tensile } \\
\text { Strength } \\
\text { (MPa) }\end{array}$ & $\begin{array}{c}\text { Uniform } \\
\text { Elong. } \\
(\%)\end{array}$ & $\begin{array}{c}\text { Elong. } \\
(\%)\end{array}$ & $\begin{array}{c}\text { Red. } \\
\text { of } \\
\text { Area } \\
(\%) \\
\end{array}$ & $\begin{array}{c}\text { Failure } \\
\text { Location }\end{array}$ \\
\hline TT-BM-12 & Sheet & 675 & 6000 & 800 & 269 & 445 & 565 & 3.6 & 17.3 & 16.6 & $\mathrm{GL}$ \\
\hline
\end{tabular}

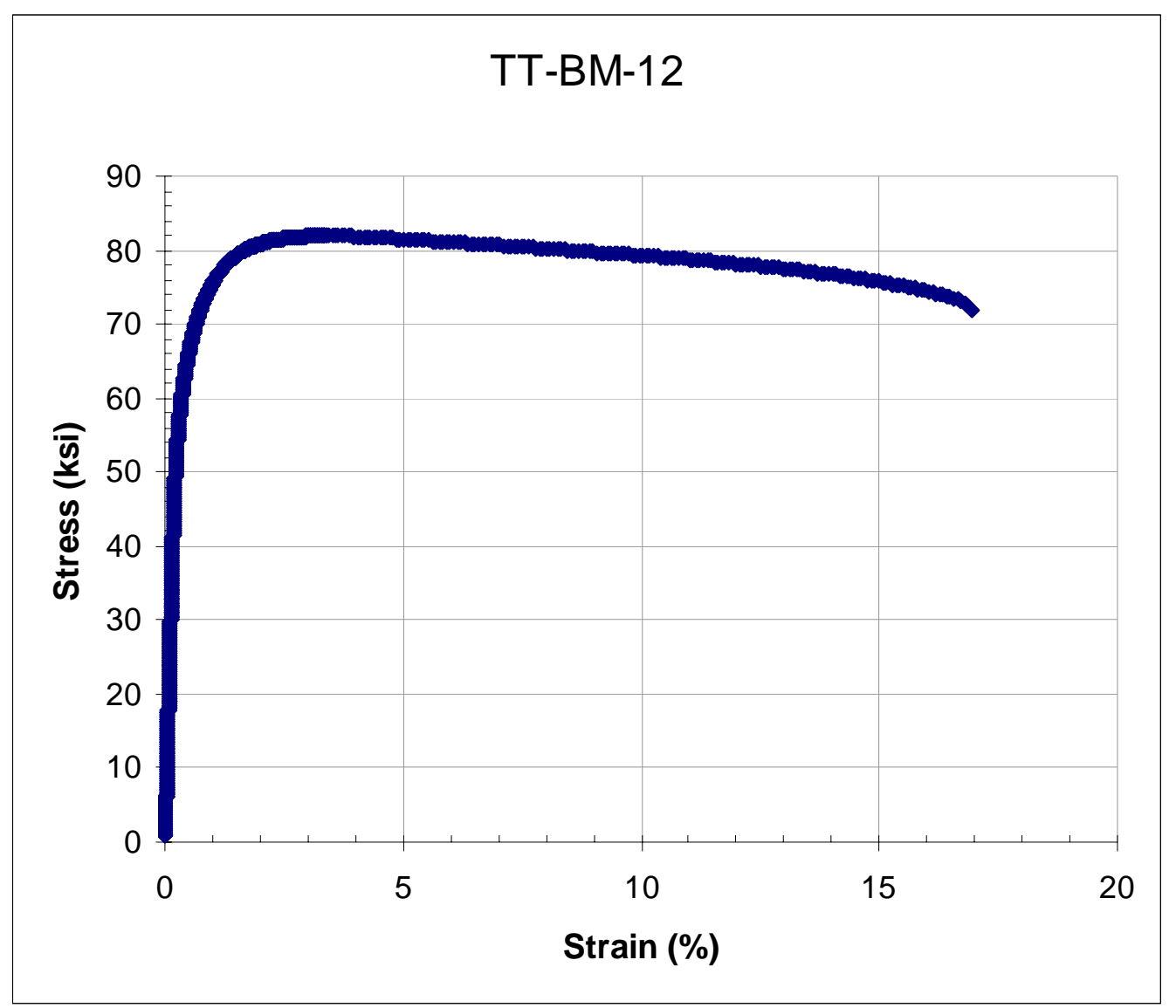




\begin{tabular}{|c|c|c|c|c|c|c|c|c|c|c|c|}
\hline Test ID & $\begin{array}{l}\text { Product } \\
\text { Form }\end{array}$ & $\begin{array}{l}\text { Aging } \\
\text { Temp. } \\
\left({ }^{\circ} \mathrm{C}\right)\end{array}$ & $\begin{array}{l}\text { Aging } \\
\text { Time } \\
\text { (hours) }\end{array}$ & $\begin{array}{c}\text { Test } \\
\text { Temp. } \\
\left({ }^{\circ} \mathrm{C}\right)\end{array}$ & $\begin{array}{c}\text { Prop. } \\
\text { Limit } \\
(\mathrm{MPa})\end{array}$ & $\begin{array}{c}\text { Yield } \\
\text { Strength } \\
\text { (MPa) }\end{array}$ & $\begin{array}{c}\text { Ultimate } \\
\text { Tensile } \\
\text { Strength } \\
\text { (MPa) }\end{array}$ & $\begin{array}{c}\text { Uniform } \\
\text { Elong. } \\
(\%)\end{array}$ & $\begin{array}{c}\text { Elong. } \\
(\%)\end{array}$ & $\begin{array}{c}\text { Red. } \\
\text { of } \\
\text { Area } \\
(\%) \\
\end{array}$ & $\begin{array}{c}\text { Failure } \\
\text { Location }\end{array}$ \\
\hline TT-BM-13 & Sheet & 675 & 6000 & 1000 & & 178 & 179 & & 45.2 & 39.0 & $\mathrm{GL}$ \\
\hline
\end{tabular}

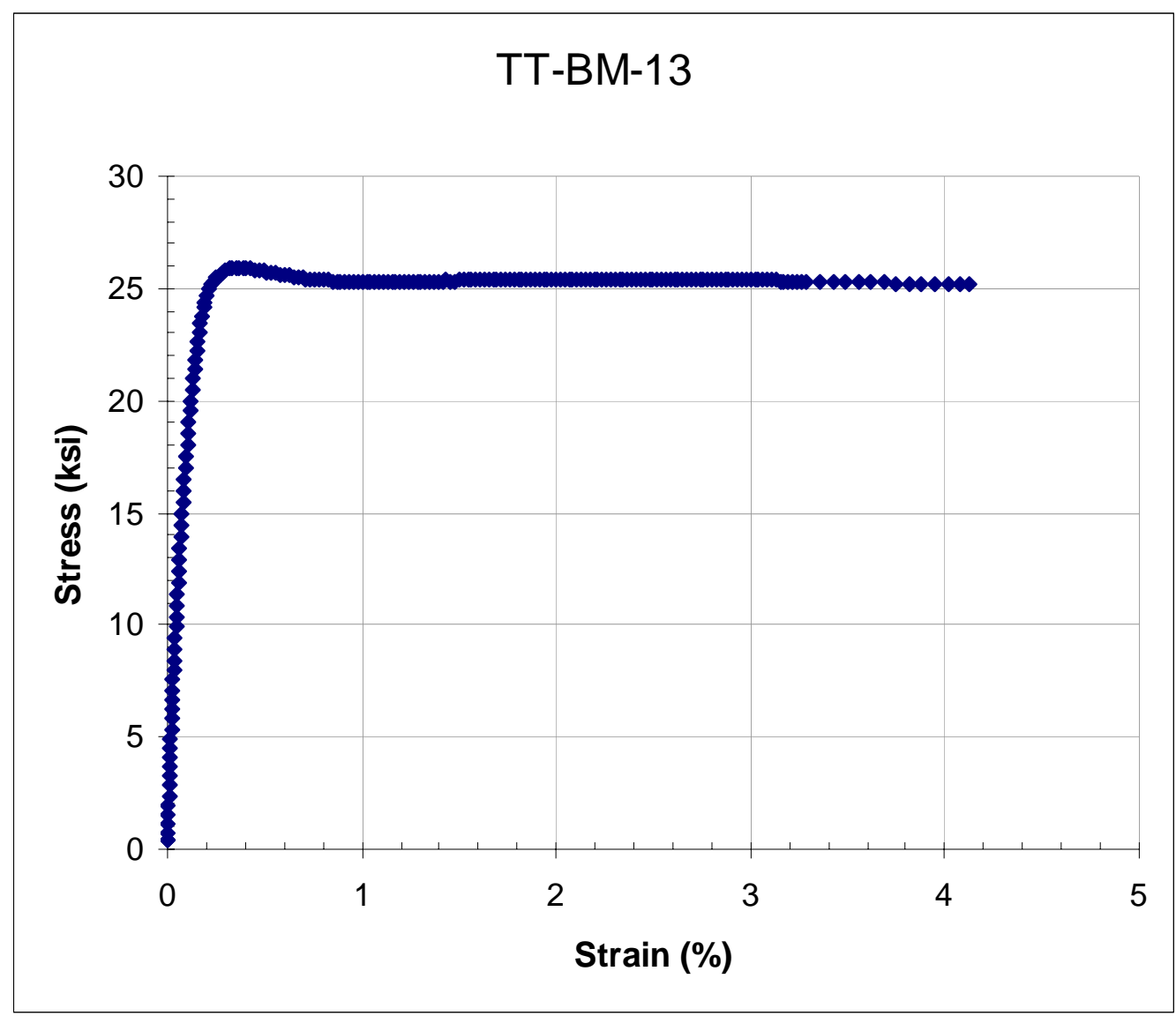




\begin{tabular}{|c|c|c|c|c|c|c|c|c|c|c|c|}
\hline Test ID & $\begin{array}{l}\text { Product } \\
\text { Form }\end{array}$ & $\begin{array}{l}\text { Aging } \\
\text { Temp. } \\
\left({ }^{\circ} \mathrm{C}\right)\end{array}$ & $\begin{array}{l}\text { Aging } \\
\text { Time } \\
\text { (hours) }\end{array}$ & $\begin{array}{c}\text { Test } \\
\text { Temp. } \\
\left({ }^{\circ} \mathrm{C}\right)\end{array}$ & $\begin{array}{c}\text { Prop. } \\
\text { Limit } \\
(\mathrm{MPa})\end{array}$ & $\begin{array}{c}\text { Yield } \\
\text { Strength } \\
\text { (MPa) }\end{array}$ & $\begin{array}{c}\text { Ultimate } \\
\text { Tensile } \\
\text { Strength } \\
\text { (MPa) }\end{array}$ & $\begin{array}{c}\text { Uniform } \\
\text { Elong. } \\
(\%)\end{array}$ & $\begin{array}{c}\text { Elong. } \\
(\%)\end{array}$ & $\begin{array}{c}\text { Red. } \\
\text { of } \\
\text { Area } \\
(\%)\end{array}$ & $\begin{array}{c}\text { Failure } \\
\text { Location }\end{array}$ \\
\hline TT-BM-14 & Sheet & 675 & 6000 & 1100 & 62 & 101 & 101 & & 47.9 & 32.9 & $\mathrm{GL}$ \\
\hline
\end{tabular}

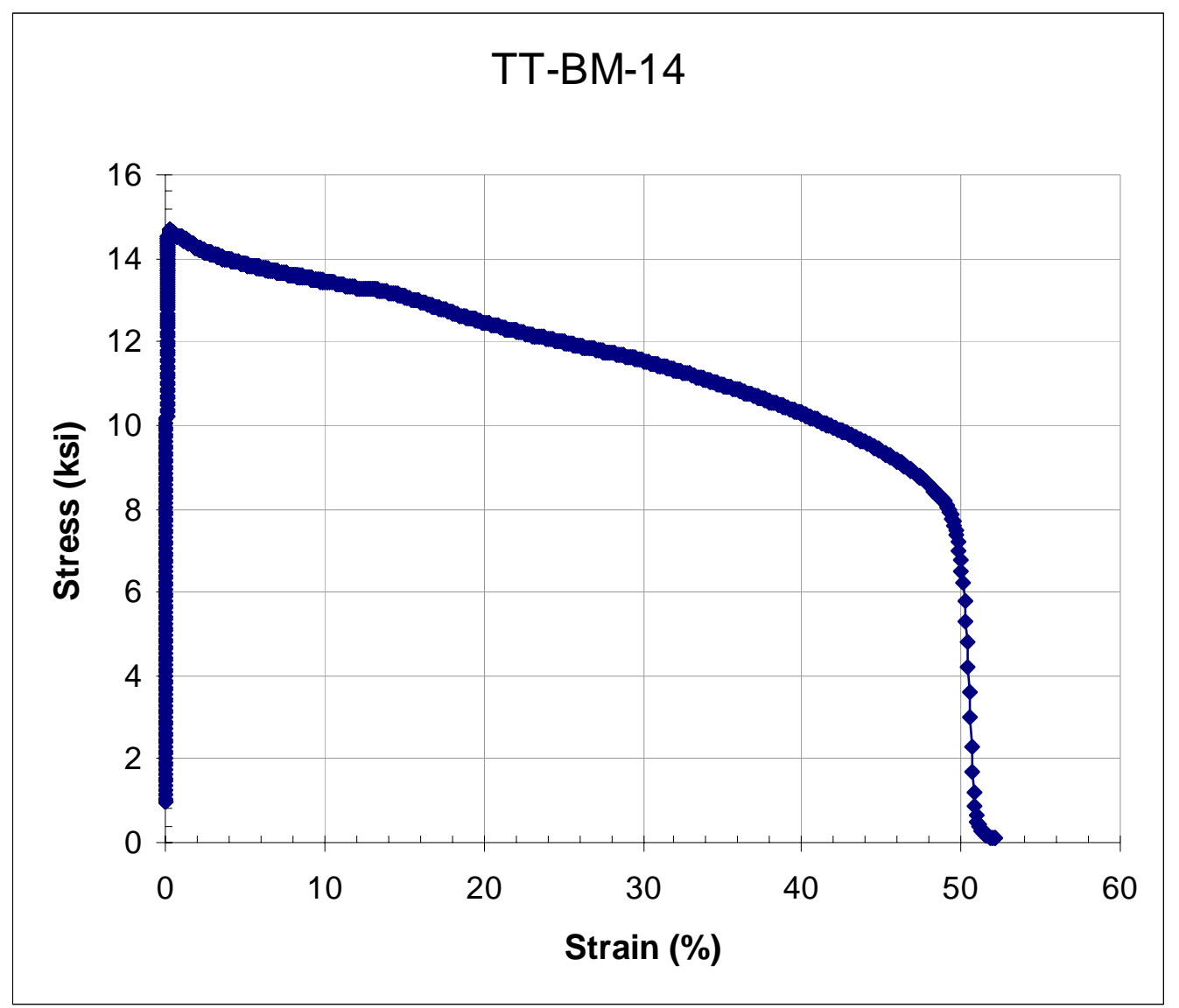




\begin{tabular}{|c|c|c|c|c|c|c|c|c|c|c|c|}
\hline Test ID & $\begin{array}{l}\text { Product } \\
\text { Form }\end{array}$ & $\begin{array}{l}\text { Aging } \\
\text { Temp. } \\
\left({ }^{\circ} \mathrm{C}\right)\end{array}$ & $\begin{array}{l}\text { Aging } \\
\text { Time } \\
\text { (hours) }\end{array}$ & $\begin{array}{l}\text { Test } \\
\text { Temp. } \\
\left({ }^{\circ} \mathrm{C}\right)\end{array}$ & $\begin{array}{c}\text { Prop. } \\
\text { Limit } \\
(\mathrm{MPa})\end{array}$ & $\begin{array}{c}\text { Yield } \\
\text { Strength } \\
\text { (MPa) }\end{array}$ & $\begin{array}{c}\text { Ultimate } \\
\text { Tensile } \\
\text { Strength } \\
\text { (MPa) }\end{array}$ & $\begin{array}{c}\text { Uniform } \\
\text { Elong. } \\
(\%)\end{array}$ & $\begin{array}{c}\text { Elong. } \\
(\%)\end{array}$ & $\begin{array}{c}\text { Red. } \\
\text { of } \\
\text { Area } \\
(\%) \\
\end{array}$ & $\begin{array}{c}\text { Failure } \\
\text { Location }\end{array}$ \\
\hline TT-BM-15 & Sheet & 675 & 12000 & 23 & 483 & 778 & 1043 & 7.9 & 7.9 & 8.1 & $\mathrm{GL}$ \\
\hline
\end{tabular}

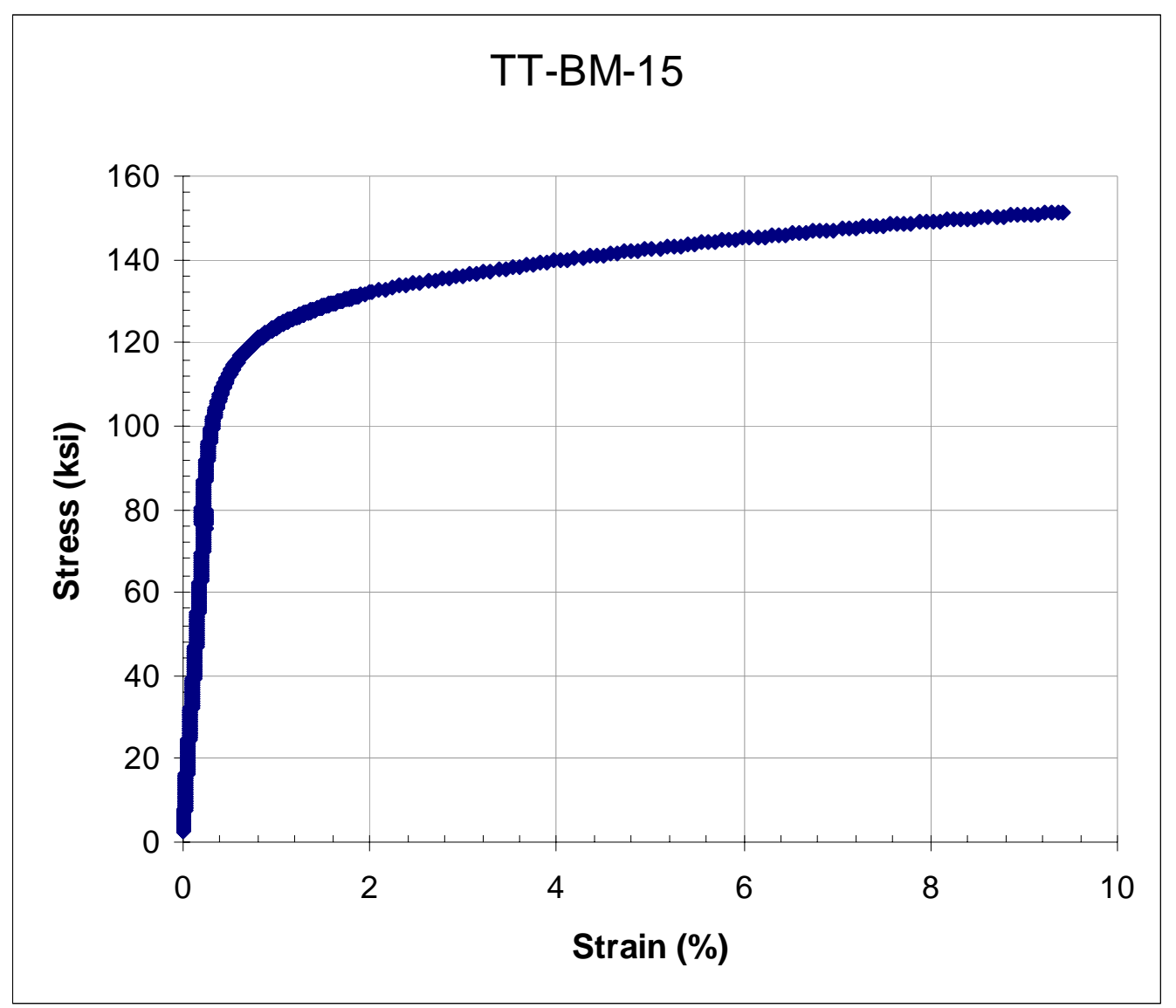




\begin{tabular}{|c|c|c|c|c|c|c|c|c|c|c|c|}
\hline Test ID & $\begin{array}{l}\text { Product } \\
\text { Form }\end{array}$ & $\begin{array}{l}\text { Aging } \\
\text { Temp. } \\
\left({ }^{\circ} \mathrm{C}\right)\end{array}$ & $\begin{array}{l}\text { Aging } \\
\text { Time } \\
\text { (hours) }\end{array}$ & $\begin{array}{l}\text { Test } \\
\text { Temp. } \\
\left({ }^{\circ} \mathrm{C}\right)\end{array}$ & $\begin{array}{c}\text { Prop. } \\
\text { Limit } \\
(\mathrm{MPa})\end{array}$ & $\begin{array}{c}\text { Yield } \\
\text { Strength } \\
\text { (MPa) }\end{array}$ & $\begin{array}{c}\text { Ultimate } \\
\text { Tensile } \\
\text { Strength } \\
\text { (MPa) }\end{array}$ & $\begin{array}{c}\text { Uniform } \\
\text { Elong. } \\
(\%)\end{array}$ & $\begin{array}{c}\text { Elong. } \\
(\%)\end{array}$ & $\begin{array}{c}\text { Red. } \\
\text { of } \\
\text { Area } \\
(\%) \\
\end{array}$ & $\begin{array}{c}\text { Failure } \\
\text { Location }\end{array}$ \\
\hline TT-BM-16 & Sheet & 675 & 12000 & 300 & 379 & 585 & 969 & 14.3 & 14.3 & 13.8 & $\mathrm{GL}$ \\
\hline
\end{tabular}

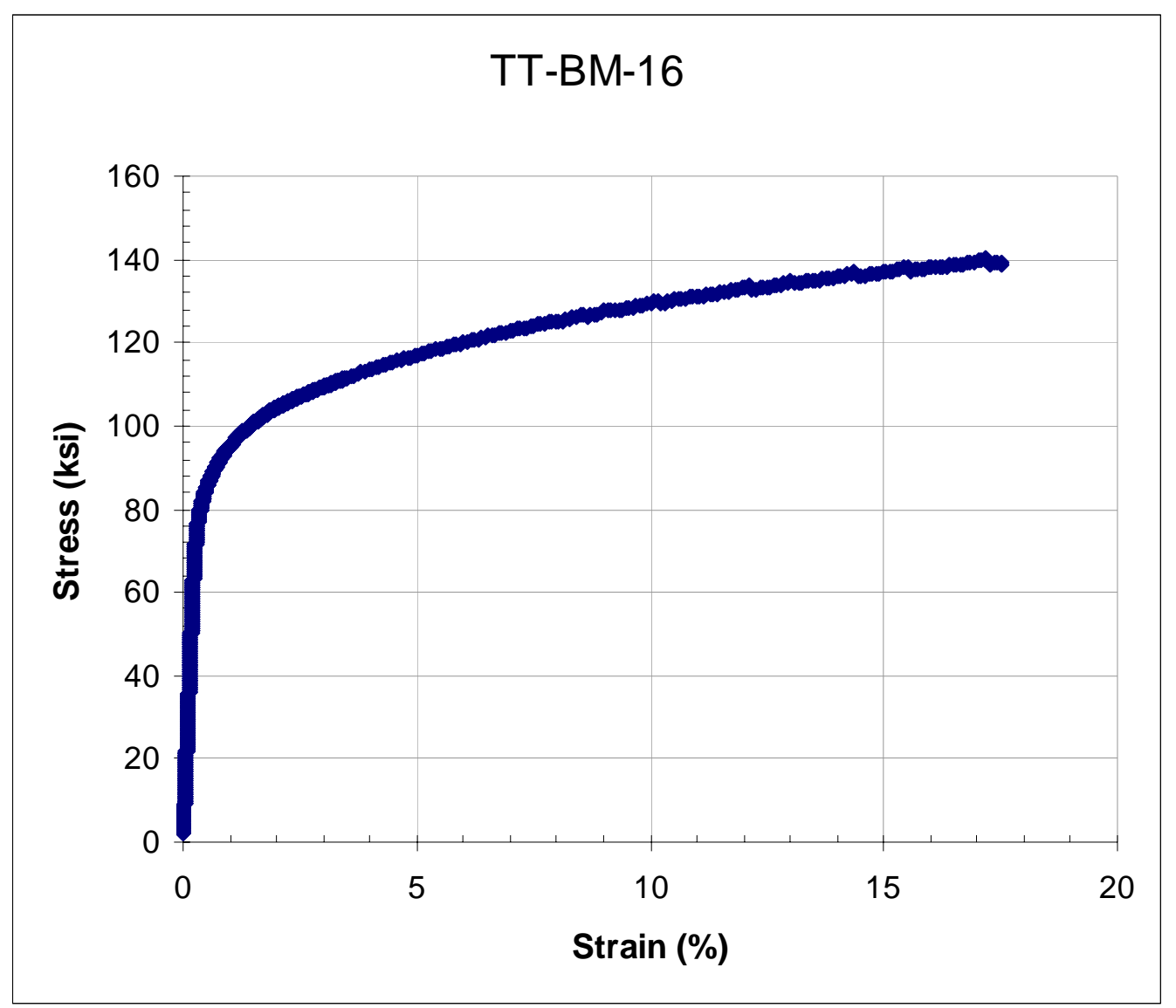




\begin{tabular}{|c|c|c|c|c|c|c|c|c|c|c|c|}
\hline Test ID & $\begin{array}{l}\text { Product } \\
\text { Form }\end{array}$ & $\begin{array}{l}\text { Aging } \\
\text { Temp. } \\
\left({ }^{\circ} \mathrm{C}\right)\end{array}$ & $\begin{array}{l}\text { Aging } \\
\text { Time } \\
\text { (hours) }\end{array}$ & $\begin{array}{l}\text { Test } \\
\text { Temp. } \\
\left({ }^{\circ} \mathrm{C}\right)\end{array}$ & $\begin{array}{c}\text { Prop. } \\
\text { Limit } \\
(\mathrm{MPa})\end{array}$ & $\begin{array}{c}\text { Yield } \\
\text { Strength } \\
\text { (MPa) }\end{array}$ & $\begin{array}{c}\text { Ultimate } \\
\text { Tensile } \\
\text { Strength } \\
\text { (MPa) }\end{array}$ & $\begin{array}{c}\text { Uniform } \\
\text { Elong. } \\
(\%)\end{array}$ & $\begin{array}{c}\text { Elong. } \\
(\%)\end{array}$ & $\begin{array}{c}\text { Red. } \\
\text { of } \\
\text { Area } \\
(\%)\end{array}$ & $\begin{array}{c}\text { Failure } \\
\text { Location }\end{array}$ \\
\hline TT-BM-17 & Sheet & 675 & 12000 & 500 & 331 & 566 & 938 & 16.1 & 16.1 & 18.0 & $\mathrm{GL}$ \\
\hline
\end{tabular}

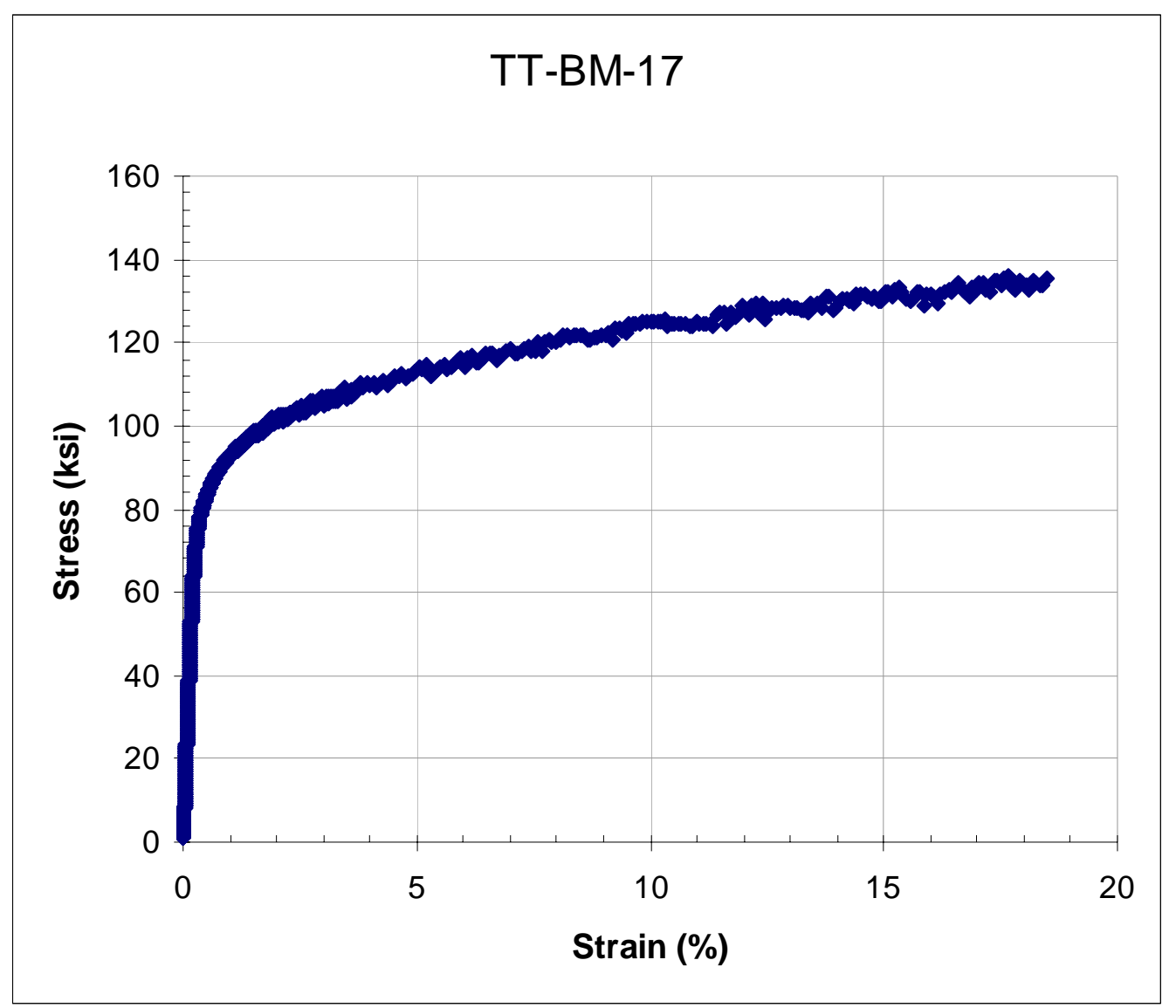




\begin{tabular}{|c|c|c|c|c|c|c|c|c|c|c|c|}
\hline Test ID & $\begin{array}{l}\text { Product } \\
\text { Form }\end{array}$ & $\begin{array}{l}\text { Aging } \\
\text { Temp. } \\
\left({ }^{\circ} \mathrm{C}\right)\end{array}$ & $\begin{array}{l}\text { Aging } \\
\text { Time } \\
\text { (hours) }\end{array}$ & $\begin{array}{l}\text { Test } \\
\text { Temp. } \\
\left({ }^{\circ} \mathrm{C}\right)\end{array}$ & $\begin{array}{c}\text { Prop. } \\
\text { Limit } \\
(\mathrm{MPa})\end{array}$ & $\begin{array}{c}\text { Yield } \\
\text { Strength } \\
\text { (MPa) }\end{array}$ & $\begin{array}{c}\text { Ultimate } \\
\text { Tensile } \\
\text { Strength } \\
\text { (MPa) }\end{array}$ & $\begin{array}{c}\text { Uniform } \\
\text { Elong. } \\
(\%)\end{array}$ & $\begin{array}{c}\text { Elong. } \\
(\%)\end{array}$ & $\begin{array}{c}\text { Red. } \\
\text { of } \\
\text { Area } \\
(\%) \\
\end{array}$ & $\begin{array}{c}\text { Failure } \\
\text { Location }\end{array}$ \\
\hline TT-BM-18 & Sheet & 675 & 12000 & 650 & 276 & 536 & 897 & 17.3 & 17.3 & 17.5 & $\mathrm{GL}$ \\
\hline
\end{tabular}

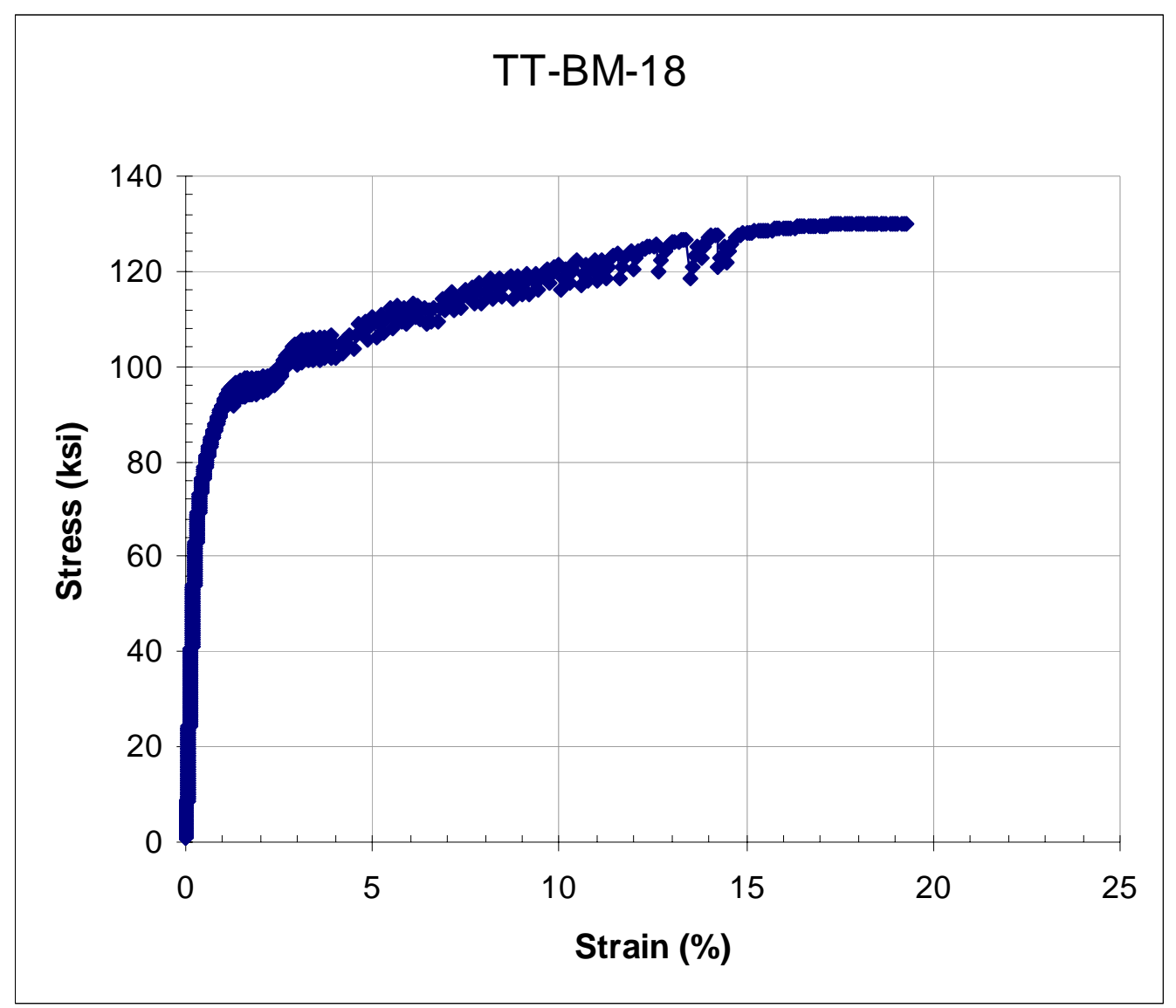




\begin{tabular}{|c|c|c|c|c|c|c|c|c|c|c|c|}
\hline Test ID & $\begin{array}{l}\text { Product } \\
\text { Form }\end{array}$ & $\begin{array}{l}\text { Aging } \\
\text { Temp. } \\
\left({ }^{\circ} \mathrm{C}\right)\end{array}$ & $\begin{array}{l}\text { Aging } \\
\text { Time } \\
\text { (hours) }\end{array}$ & $\begin{array}{c}\text { Test } \\
\text { Temp. } \\
\left({ }^{\circ} \mathrm{C}\right)\end{array}$ & $\begin{array}{c}\text { Prop. } \\
\text { Limit } \\
(\mathrm{MPa})\end{array}$ & $\begin{array}{c}\text { Yield } \\
\text { Strength } \\
\text { (MPa) }\end{array}$ & $\begin{array}{c}\text { Ultimate } \\
\text { Tensile } \\
\text { Strength } \\
\text { (MPa) }\end{array}$ & $\begin{array}{c}\text { Uniform } \\
\text { Elong. } \\
(\%)\end{array}$ & $\begin{array}{c}\text { Elong. } \\
(\%)\end{array}$ & $\begin{array}{c}\text { Red. } \\
\text { of } \\
\text { Area } \\
(\%) \\
\end{array}$ & $\begin{array}{c}\text { Failure } \\
\text { Location }\end{array}$ \\
\hline TT-BM-19 & Sheet & 675 & 12000 & 800 & 221 & 414 & 553 & 3.5 & 9.8 & 10.3 & $\mathrm{GL}$ \\
\hline
\end{tabular}

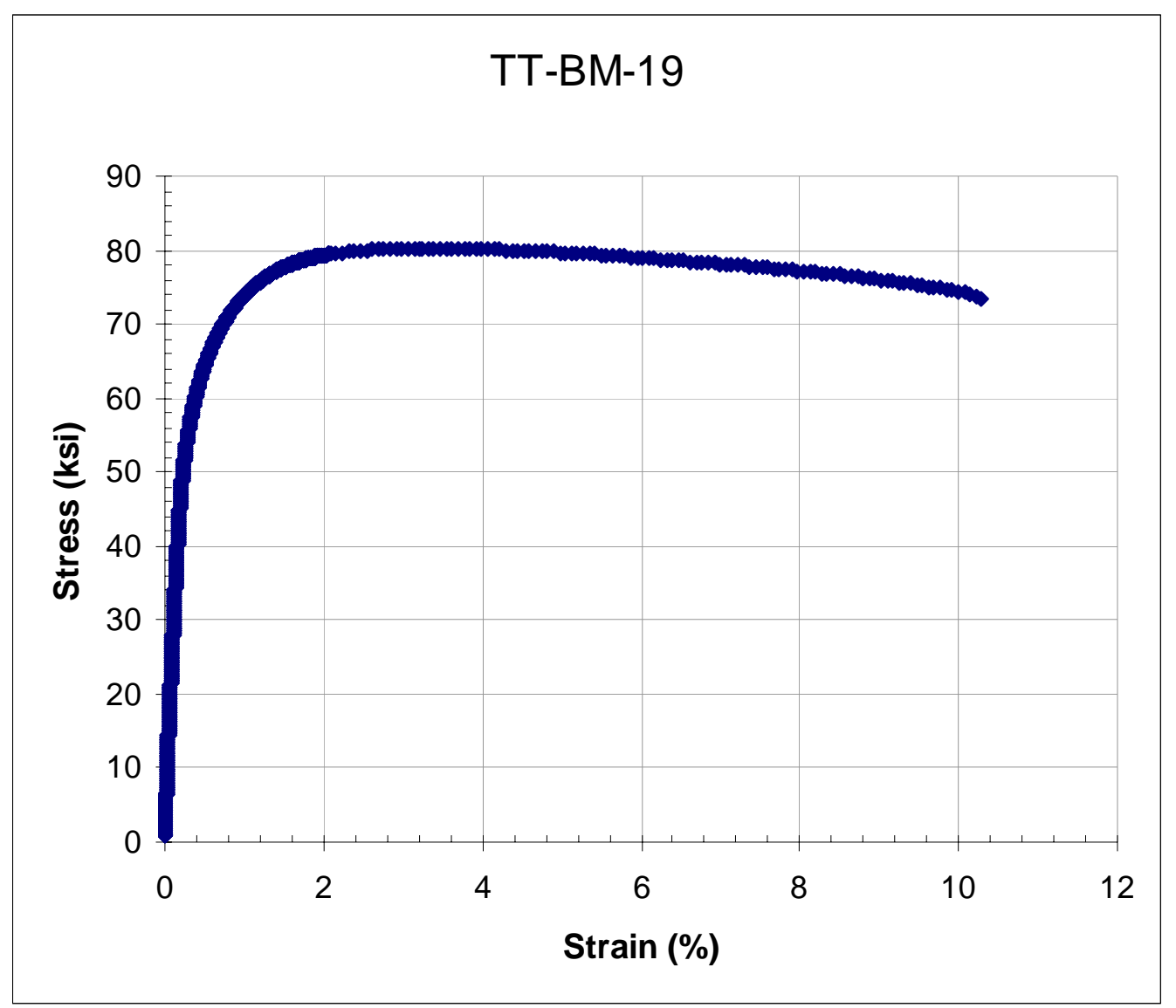




\begin{tabular}{|c|c|c|c|c|c|c|c|c|c|c|c|}
\hline Test ID & $\begin{array}{l}\text { Product } \\
\text { Form }\end{array}$ & $\begin{array}{l}\text { Aging } \\
\text { Temp. } \\
\left({ }^{\circ} \mathrm{C}\right)\end{array}$ & $\begin{array}{l}\text { Aging } \\
\text { Time } \\
\text { (hours) }\end{array}$ & $\begin{array}{l}\text { Test } \\
\text { Temp. } \\
\left({ }^{\circ} \mathrm{C}\right)\end{array}$ & $\begin{array}{c}\text { Prop. } \\
\text { Limit } \\
(\mathrm{MPa})\end{array}$ & $\begin{array}{c}\text { Yield } \\
\text { Strength } \\
\text { (MPa) }\end{array}$ & $\begin{array}{c}\text { Ultimate } \\
\text { Tensile } \\
\text { Strength } \\
\text { (MPa) }\end{array}$ & $\begin{array}{c}\text { Uniform } \\
\text { Elong. } \\
(\%)\end{array}$ & $\begin{array}{c}\text { Elong. } \\
(\%)\end{array}$ & $\begin{array}{c}\text { Red. } \\
\text { of } \\
\text { Area } \\
(\%)\end{array}$ & $\begin{array}{c}\text { Failure } \\
\text { Location }\end{array}$ \\
\hline TT-BM-20 & Sheet & 675 & 12000 & 1000 & 83 & 174 & 175 & 2.0 & 52.4 & 45.2 & $\mathrm{GL}$ \\
\hline
\end{tabular}

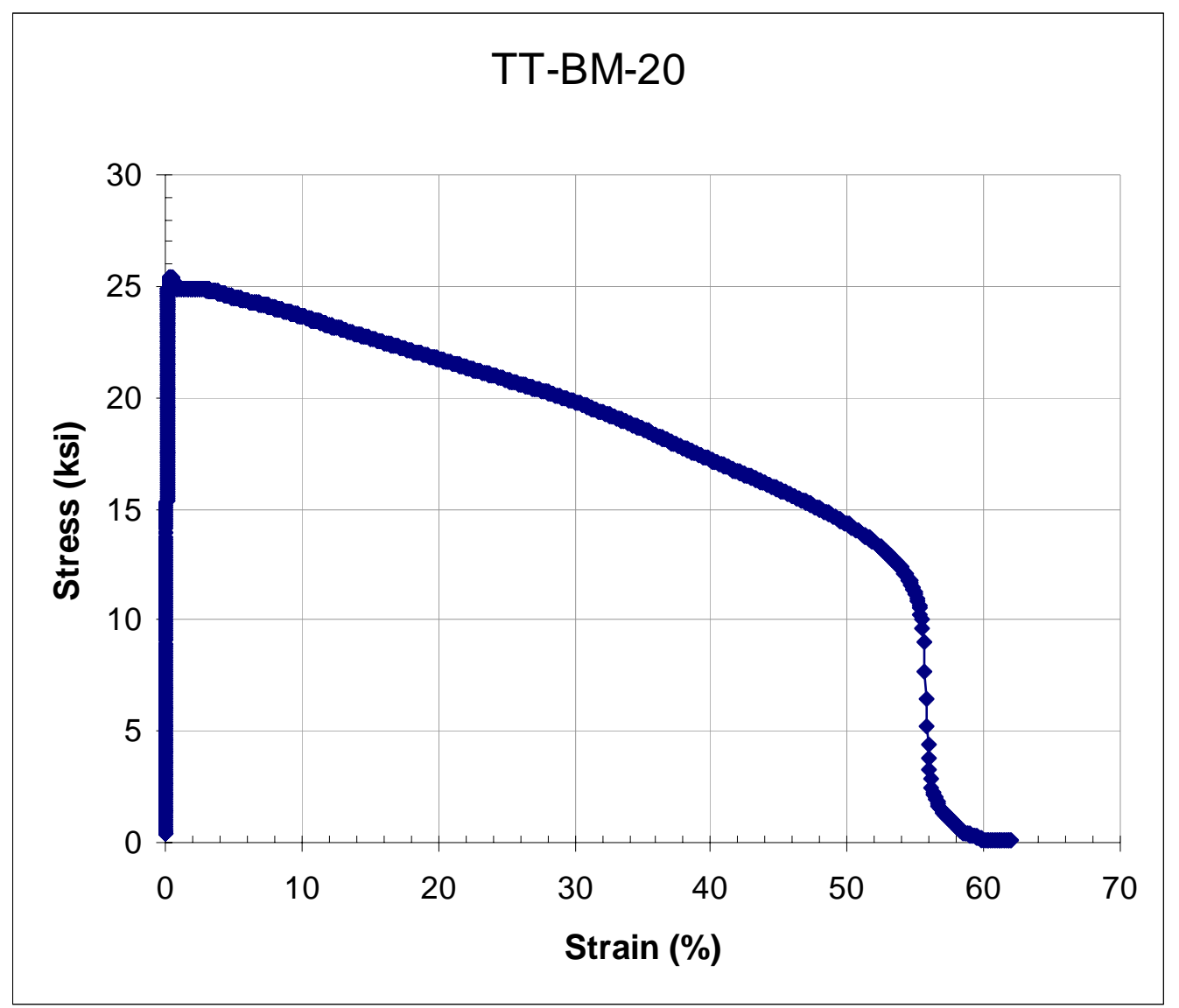




\begin{tabular}{|c|c|c|c|c|c|c|c|c|c|c|c|}
\hline Test ID & $\begin{array}{l}\text { Product } \\
\text { Form }\end{array}$ & $\begin{array}{l}\text { Aging } \\
\text { Temp. } \\
\left({ }^{\circ} \mathrm{C}\right)\end{array}$ & $\begin{array}{l}\text { Aging } \\
\text { Time } \\
\text { (hours) }\end{array}$ & $\begin{array}{c}\text { Test } \\
\text { Temp. } \\
\left({ }^{\circ} \mathrm{C}\right)\end{array}$ & $\begin{array}{c}\text { Prop. } \\
\text { Limit } \\
(\mathrm{MPa})\end{array}$ & $\begin{array}{c}\text { Yield } \\
\text { Strength } \\
\text { (MPa) }\end{array}$ & $\begin{array}{c}\text { Ultimate } \\
\text { Tensile } \\
\text { Strength } \\
\text { (MPa) }\end{array}$ & $\begin{array}{c}\text { Uniform } \\
\text { Elong. } \\
(\%)\end{array}$ & $\begin{array}{c}\text { Elong. } \\
(\%)\end{array}$ & $\begin{array}{c}\text { Red. } \\
\text { of } \\
\text { Area } \\
(\%) \\
\end{array}$ & $\begin{array}{c}\text { Failure } \\
\text { Location }\end{array}$ \\
\hline TT-BM-21 & Sheet & 675 & 12000 & 1100 & 48 & 99 & 99 & 0.4 & 45.8 & 45.0 & $\mathrm{GL}$ \\
\hline
\end{tabular}

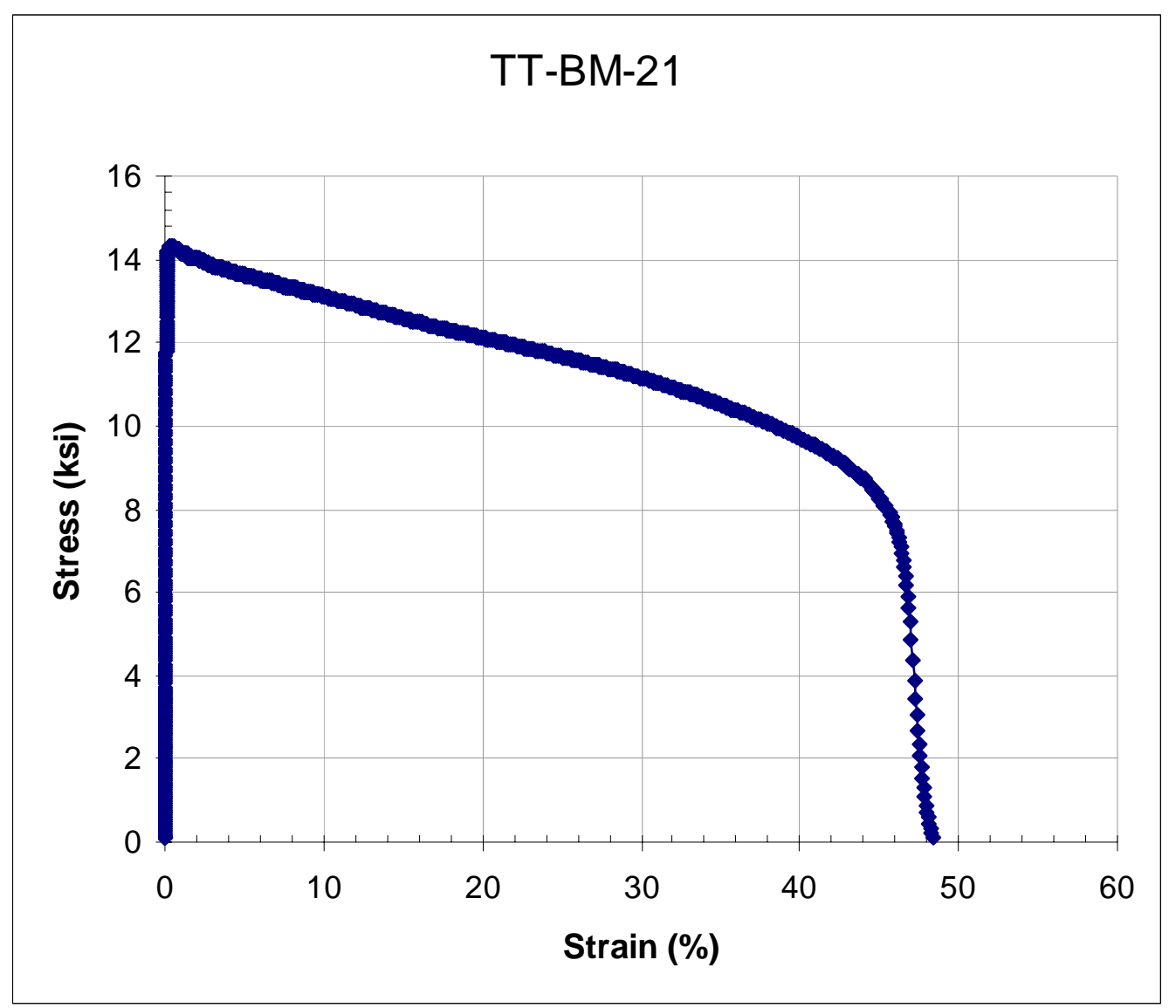




\begin{tabular}{|c|c|c|c|c|c|c|c|c|c|c|c|}
\hline Test ID & $\begin{array}{l}\text { Product } \\
\text { Form }\end{array}$ & $\begin{array}{l}\text { Aging } \\
\text { Temp. } \\
\left({ }^{\circ} \mathrm{C}\right)\end{array}$ & $\begin{array}{l}\text { Aging } \\
\text { Time } \\
\text { (hours) }\end{array}$ & $\begin{array}{l}\text { Test } \\
\text { Temp. } \\
\left({ }^{\circ} \mathrm{C}\right)\end{array}$ & $\begin{array}{c}\text { Prop. } \\
\text { Limit } \\
(\mathrm{MPa})\end{array}$ & $\begin{array}{c}\text { Yield } \\
\text { Strength } \\
\text { (MPa) }\end{array}$ & $\begin{array}{c}\text { Ultimate } \\
\text { Tensile } \\
\text { Strength } \\
\text { (MPa) }\end{array}$ & $\begin{array}{c}\text { Uniform } \\
\text { Elong. } \\
(\%)\end{array}$ & $\begin{array}{c}\text { Elong. } \\
(\%)\end{array}$ & $\begin{array}{c}\text { Red. } \\
\text { of } \\
\text { Area } \\
(\%) \\
\end{array}$ & $\begin{array}{c}\text { Failure } \\
\text { Location }\end{array}$ \\
\hline HS-03-07a & Sheet & 675 & 2.4 & 23 & 462 & 532 & 1009 & 63.0 & 68.2 & 52.4 & $\mathrm{GL}$ \\
\hline
\end{tabular}

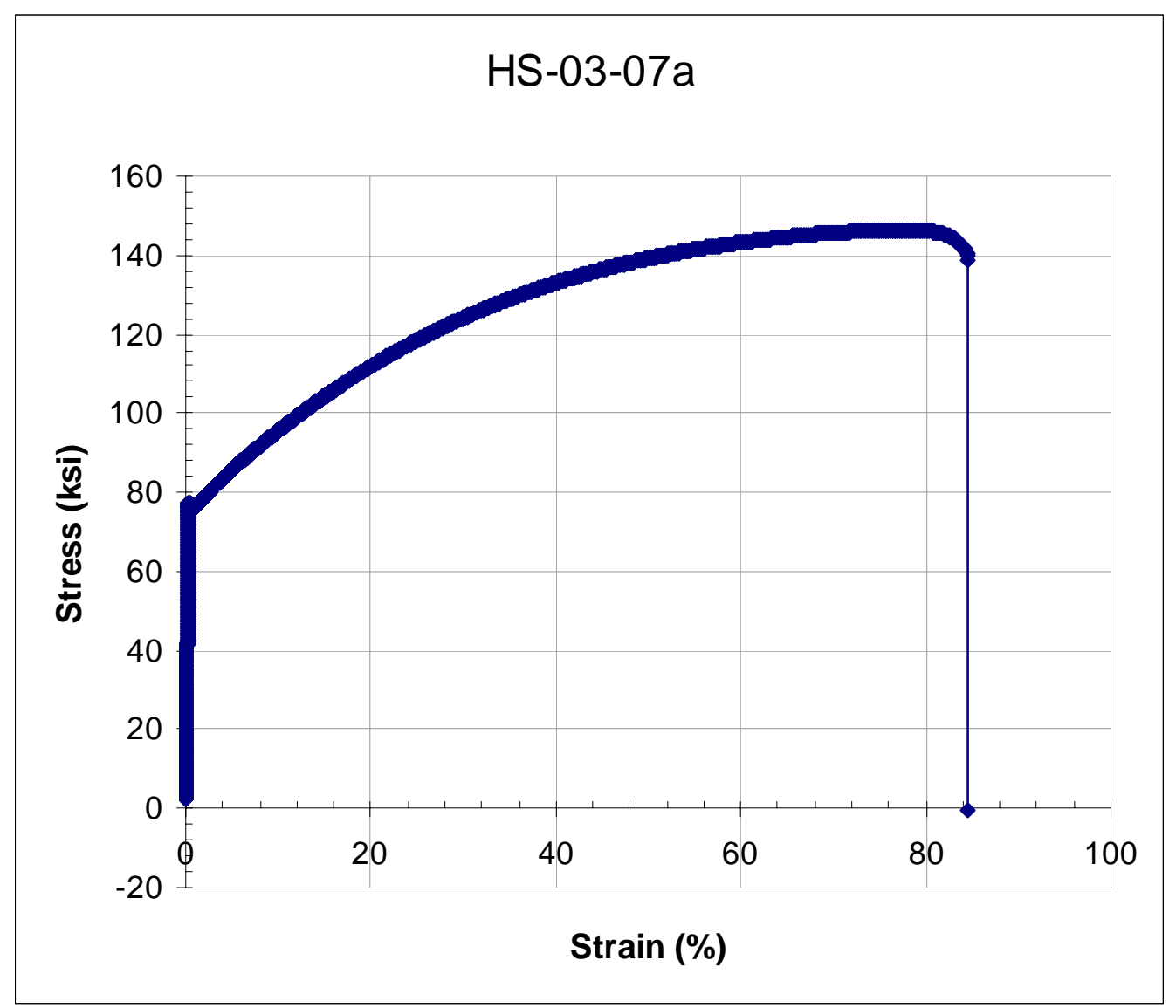




\begin{tabular}{|c|c|c|c|c|c|c|c|c|c|c|c|}
\hline Test ID & $\begin{array}{l}\text { Product } \\
\text { Form }\end{array}$ & $\begin{array}{l}\text { Aging } \\
\text { Temp. } \\
\left({ }^{\circ} \mathrm{C}\right)\end{array}$ & $\begin{array}{l}\text { Aging } \\
\text { Time } \\
\text { (hours) }\end{array}$ & $\begin{array}{l}\text { Test } \\
\text { Temp. } \\
\left({ }^{\circ} \mathrm{C}\right)\end{array}$ & $\begin{array}{c}\text { Prop. } \\
\text { Limit } \\
(\mathrm{MPa})\end{array}$ & $\begin{array}{c}\text { Yield } \\
\text { Strength } \\
\text { (MPa) }\end{array}$ & $\begin{array}{c}\text { Ultimate } \\
\text { Tensile } \\
\text { Strength } \\
\text { (MPa) }\end{array}$ & $\begin{array}{c}\text { Uniform } \\
\text { Elong. } \\
(\%)\end{array}$ & $\begin{array}{c}\text { Elong. } \\
(\%)\end{array}$ & $\begin{array}{c}\text { Red. } \\
\text { of } \\
\text { Area } \\
(\%) \\
\end{array}$ & $\begin{array}{c}\text { Failure } \\
\text { Location }\end{array}$ \\
\hline HS-03-05a & Sheet & 675 & 24 & 23 & 476 & 536 & 1008 & 62.0 & 67.8 & 50.8 & $\mathrm{GL}$ \\
\hline
\end{tabular}

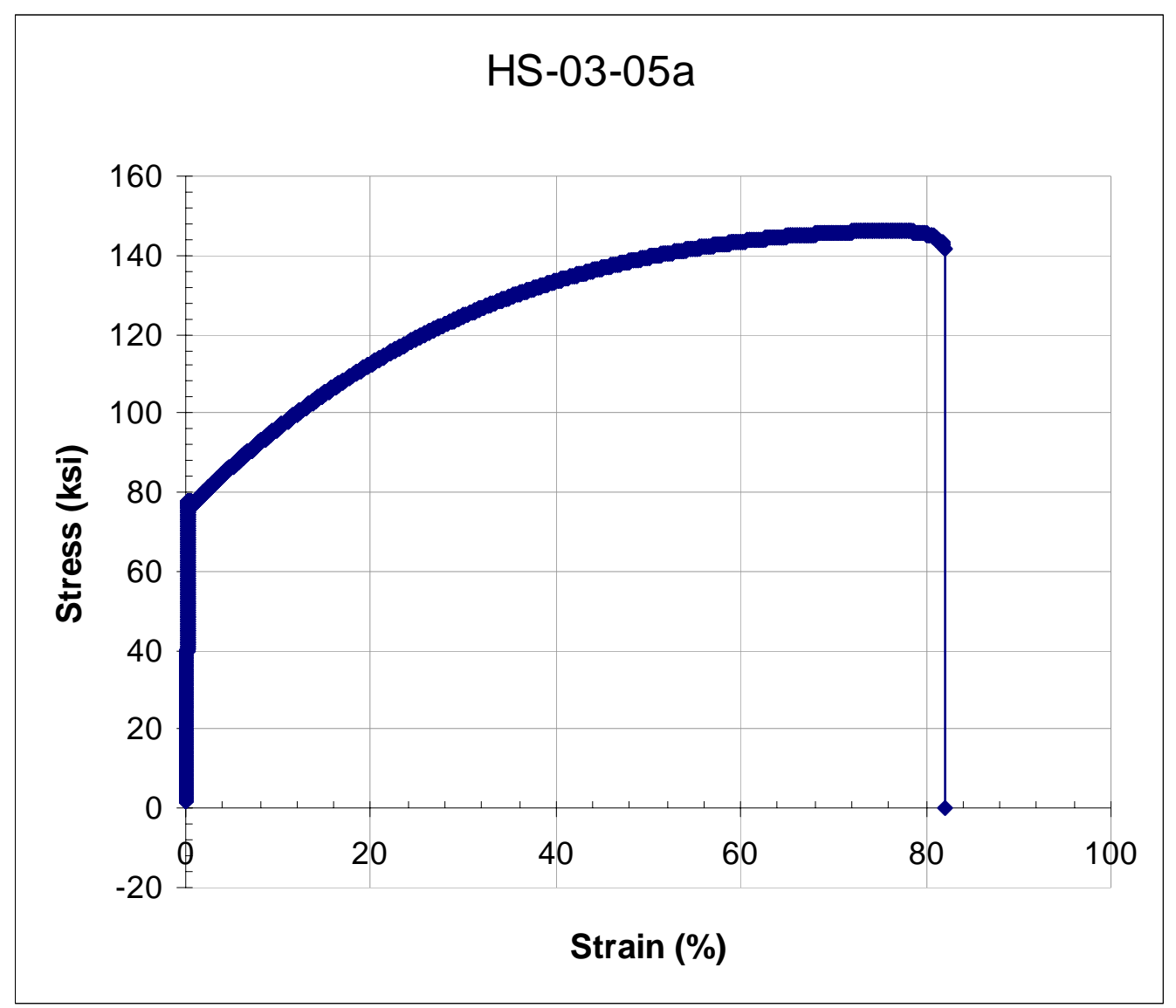




\begin{tabular}{|c|c|c|c|c|c|c|c|c|c|c|c|}
\hline Test ID & $\begin{array}{l}\text { Product } \\
\text { Form }\end{array}$ & $\begin{array}{l}\text { Aging } \\
\text { Temp. } \\
\left({ }^{\circ} \mathrm{C}\right)\end{array}$ & $\begin{array}{l}\text { Aging } \\
\text { Time } \\
\text { (hours) }\end{array}$ & $\begin{array}{l}\text { Test } \\
\text { Temp. } \\
\left({ }^{\circ} \mathrm{C}\right)\end{array}$ & $\begin{array}{l}\text { Prop. } \\
\text { Limit } \\
\text { (MPa) }\end{array}$ & $\begin{array}{c}\text { Yield } \\
\text { Strength } \\
\text { (MPa) }\end{array}$ & $\begin{array}{l}\text { Ultimate } \\
\text { Tensile } \\
\text { Strength } \\
\text { (MPa) }\end{array}$ & $\begin{array}{c}\text { Uniform } \\
\text { Elong. } \\
(\%)\end{array}$ & $\begin{array}{c}\text { Elong. } \\
(\%)\end{array}$ & $\begin{array}{c}\text { Red. } \\
\text { of } \\
\text { Area } \\
(\%) \\
\end{array}$ & $\begin{array}{c}\text { Failure } \\
\text { Location }\end{array}$ \\
\hline HS-03-03a & Sheet & 675 & 240 & 23 & 421 & 536 & 970 & 38.0 & 38.4 & 26.3 & $\mathrm{GL}$ \\
\hline
\end{tabular}

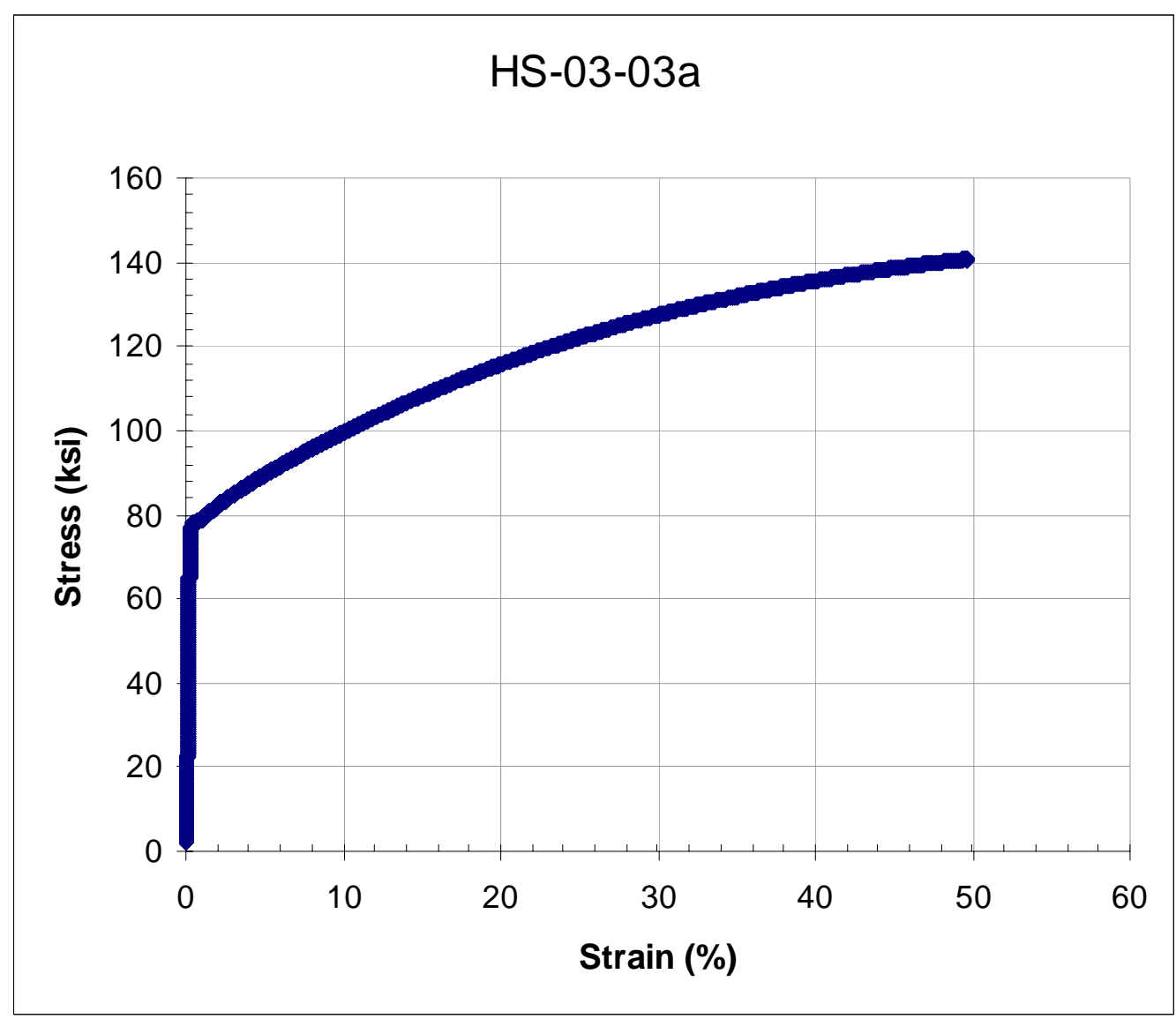




\begin{tabular}{|c|c|c|c|c|c|c|c|c|c|c|c|}
\hline Test ID & $\begin{array}{l}\text { Product } \\
\text { Form }\end{array}$ & $\begin{array}{l}\text { Aging } \\
\text { Temp. } \\
\left({ }^{\circ} \mathrm{C}\right)\end{array}$ & $\begin{array}{l}\text { Aging } \\
\text { Time } \\
\text { (hours) }\end{array}$ & $\begin{array}{l}\text { Test } \\
\text { Temp. } \\
\left({ }^{\circ} \mathrm{C}\right)\end{array}$ & $\begin{array}{c}\text { Prop. } \\
\text { Limit } \\
(\mathrm{MPa})\end{array}$ & $\begin{array}{c}\text { Yield } \\
\text { Strength } \\
\text { (MPa) }\end{array}$ & $\begin{array}{c}\text { Ultimate } \\
\text { Tensile } \\
\text { Strength } \\
\text { (MPa) }\end{array}$ & $\begin{array}{c}\text { Uniform } \\
\text { Elong. } \\
(\%)\end{array}$ & $\begin{array}{c}\text { Elong. } \\
(\%)\end{array}$ & $\begin{array}{c}\text { Red. } \\
\text { of } \\
\text { Area } \\
(\%) \\
\end{array}$ & $\begin{array}{c}\text { Failure } \\
\text { Location }\end{array}$ \\
\hline HS-03-01b & Sheet & 675 & 1000 & 23 & 510 & 744 & 1047 & 20.9 & 20.9 & 17.4 & $\mathrm{GL}$ \\
\hline
\end{tabular}

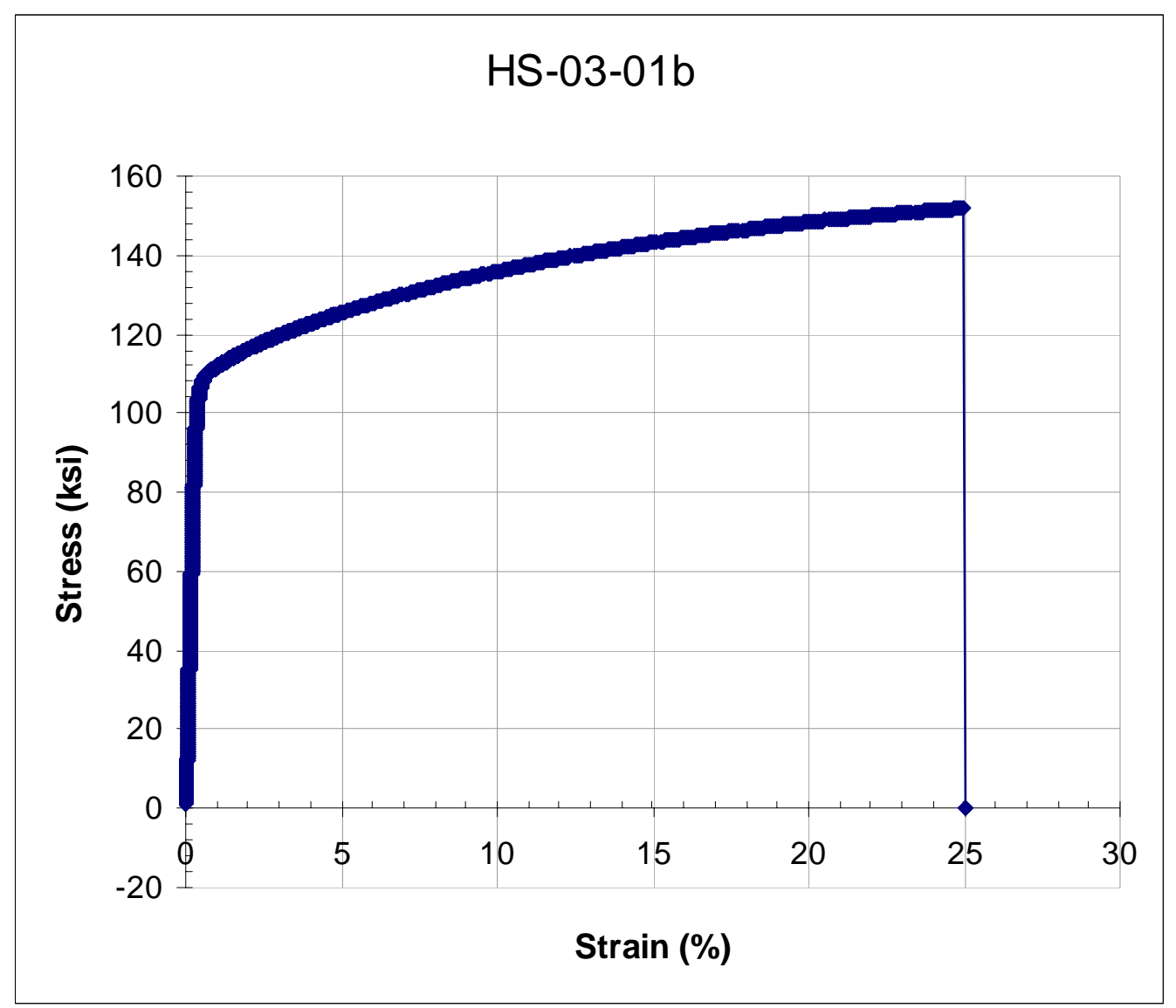




\begin{tabular}{|c|c|c|c|c|c|c|c|c|c|c|c|}
\hline Test ID & $\begin{array}{l}\text { Product } \\
\text { Form }\end{array}$ & $\begin{array}{l}\text { Aging } \\
\text { Temp. } \\
\left({ }^{\circ} \mathrm{C}\right)\end{array}$ & $\begin{array}{l}\text { Aging } \\
\text { Time } \\
\text { (hours) }\end{array}$ & $\begin{array}{l}\text { Test } \\
\text { Temp. } \\
\left({ }^{\circ} \mathrm{C}\right)\end{array}$ & $\begin{array}{c}\text { Prop. } \\
\text { Limit } \\
(\mathrm{MPa})\end{array}$ & $\begin{array}{c}\text { Yield } \\
\text { Strength } \\
\text { (MPa) }\end{array}$ & $\begin{array}{c}\text { Ultimate } \\
\text { Tensile } \\
\text { Strength } \\
\text { (MPa) }\end{array}$ & $\begin{array}{c}\text { Uniform } \\
\text { Elong. } \\
(\%)\end{array}$ & $\begin{array}{c}\text { Elong. } \\
(\%)\end{array}$ & $\begin{array}{c}\text { Red. } \\
\text { of } \\
\text { Area } \\
(\%) \\
\end{array}$ & $\begin{array}{c}\text { Failure } \\
\text { Location }\end{array}$ \\
\hline HS-03-01a & Sheet & 675 & 2000 & 23 & 496 & 756 & 1017 & 9.8 & 9.8 & 10.7 & $\mathrm{GL}$ \\
\hline
\end{tabular}

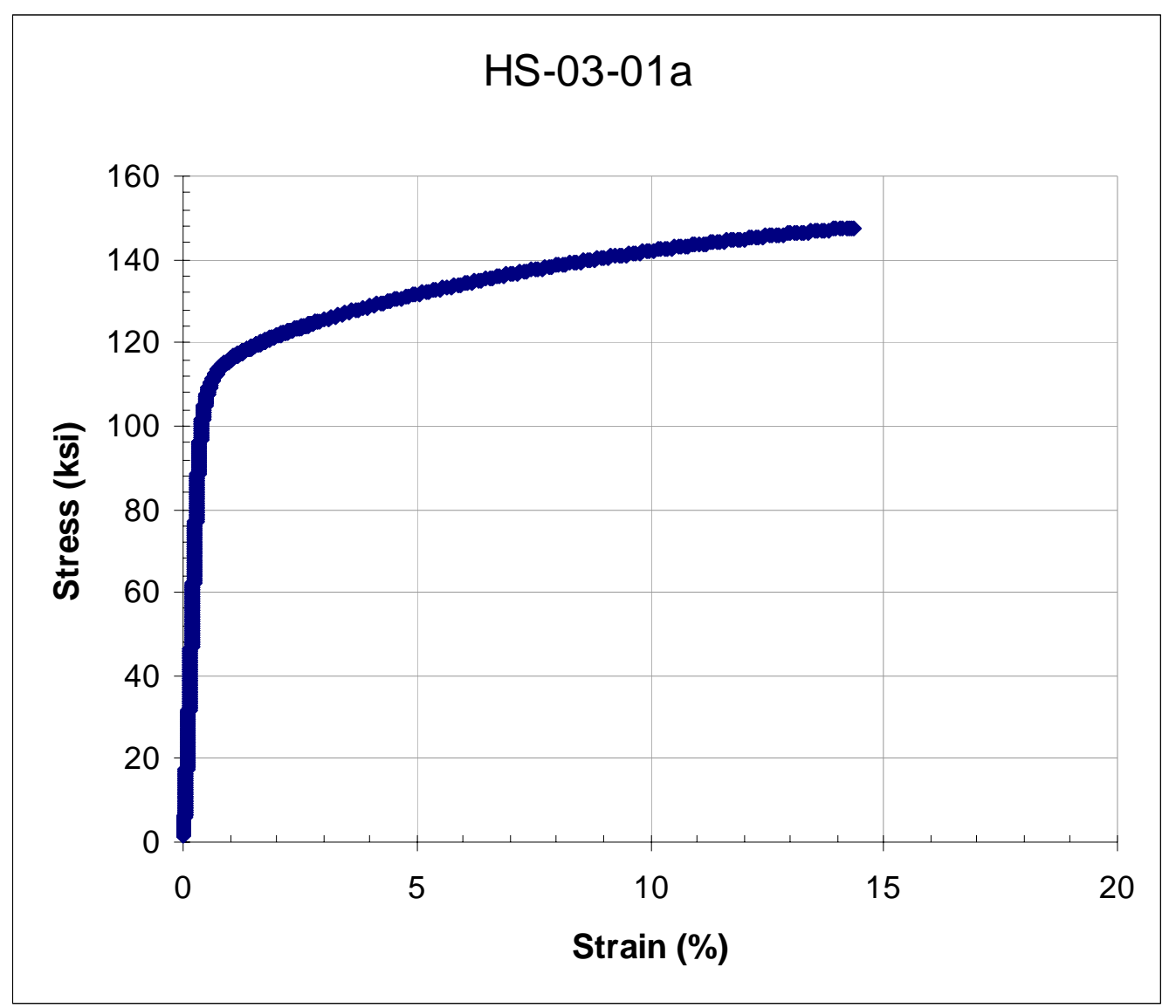




\begin{tabular}{|c|c|c|c|c|c|c|c|c|c|c|c|}
\hline Test ID & $\begin{array}{l}\text { Product } \\
\text { Form }\end{array}$ & $\begin{array}{l}\text { Aging } \\
\text { Temp. } \\
\left({ }^{\circ} \mathrm{C}\right)\end{array}$ & $\begin{array}{l}\text { Aging } \\
\text { Time } \\
\text { (hours) }\end{array}$ & $\begin{array}{c}\text { Test } \\
\text { Temp. } \\
\left({ }^{\circ} \mathrm{C}\right)\end{array}$ & $\begin{array}{c}\text { Prop. } \\
\text { Limit } \\
(\mathrm{MPa})\end{array}$ & $\begin{array}{c}\text { Yield } \\
\text { Strength } \\
\text { (MPa) }\end{array}$ & $\begin{array}{c}\text { Ultimate } \\
\text { Tensile } \\
\text { Strength } \\
\text { (MPa) }\end{array}$ & $\begin{array}{c}\text { Uniform } \\
\text { Elong. } \\
(\%)\end{array}$ & $\begin{array}{c}\text { Elong. } \\
(\%)\end{array}$ & $\begin{array}{c}\text { Red. } \\
\text { of } \\
\text { Area } \\
(\%) \\
\end{array}$ & $\begin{array}{c}\text { Failure } \\
\text { Location }\end{array}$ \\
\hline HS-03-08a & Sheet & 675 & 2.4 & 650 & 207 & 260 & 776 & 56.6 & 56.6 & 37.9 & $\mathrm{GL}$ \\
\hline
\end{tabular}

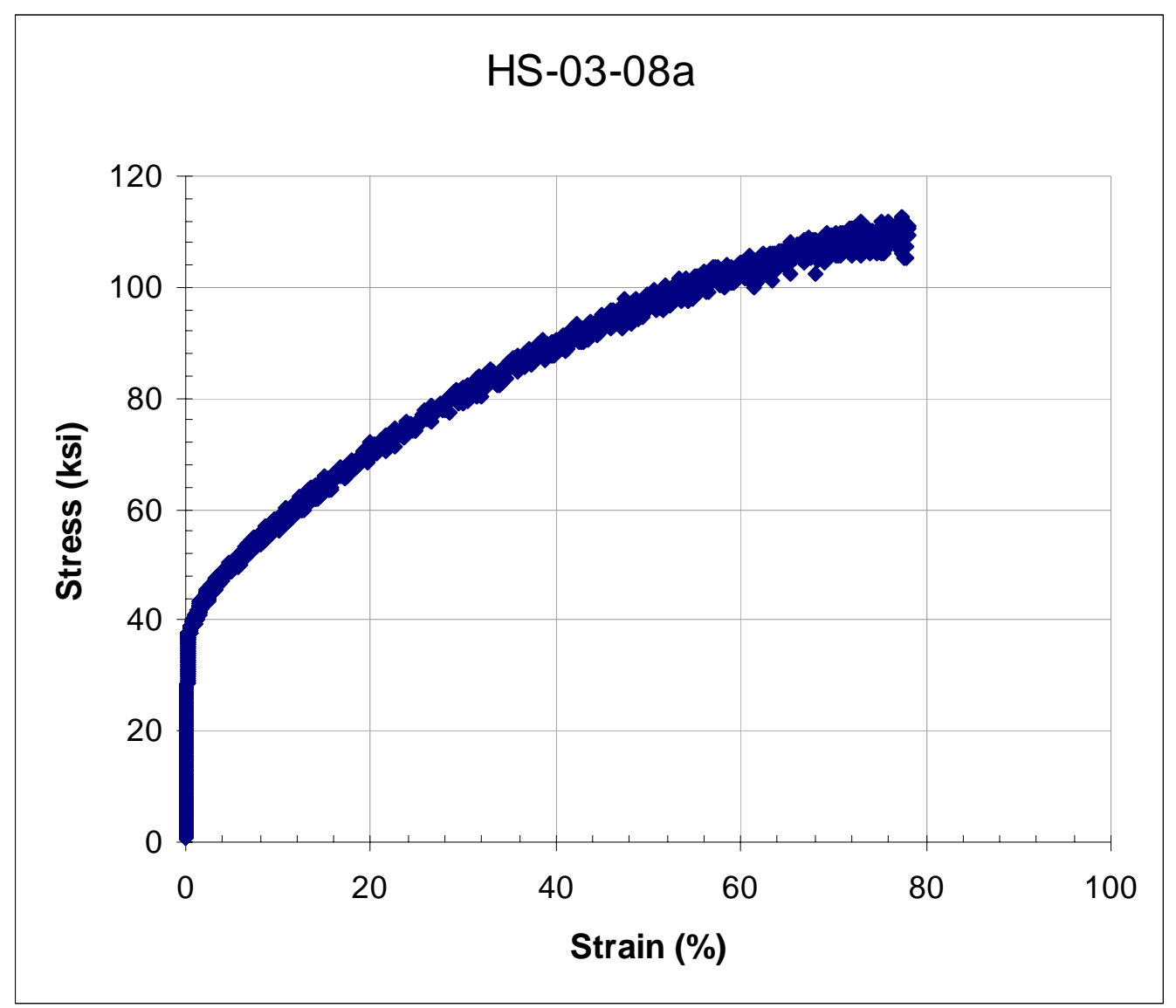




\begin{tabular}{|c|c|c|c|c|c|c|c|c|c|c|c|}
\hline Test ID & $\begin{array}{l}\text { Product } \\
\text { Form }\end{array}$ & $\begin{array}{l}\text { Aging } \\
\text { Temp. } \\
\left({ }^{\circ} \mathrm{C}\right)\end{array}$ & $\begin{array}{l}\text { Aging } \\
\text { Time } \\
\text { (hours) }\end{array}$ & $\begin{array}{l}\text { Test } \\
\text { Temp. } \\
\left({ }^{\circ} \mathrm{C}\right)\end{array}$ & $\begin{array}{c}\text { Prop. } \\
\text { Limit } \\
(\mathrm{MPa})\end{array}$ & $\begin{array}{c}\text { Yield } \\
\text { Strength } \\
\text { (MPa) }\end{array}$ & $\begin{array}{c}\text { Ultimate } \\
\text { Tensile } \\
\text { Strength } \\
(\mathrm{MPa})\end{array}$ & $\begin{array}{c}\text { Uniform } \\
\text { Elong. } \\
(\%)\end{array}$ & $\begin{array}{c}\text { Elong. } \\
(\%)\end{array}$ & $\begin{array}{c}\text { Red. } \\
\text { of } \\
\text { Area } \\
(\%) \\
\end{array}$ & $\begin{array}{c}\text { Failure } \\
\text { Location }\end{array}$ \\
\hline HS-03-06a & Sheet & 675 & 24 & 650 & 207 & 280 & 795 & 61.4 & 61.4 & 39.4 & $\mathrm{GL}$ \\
\hline
\end{tabular}

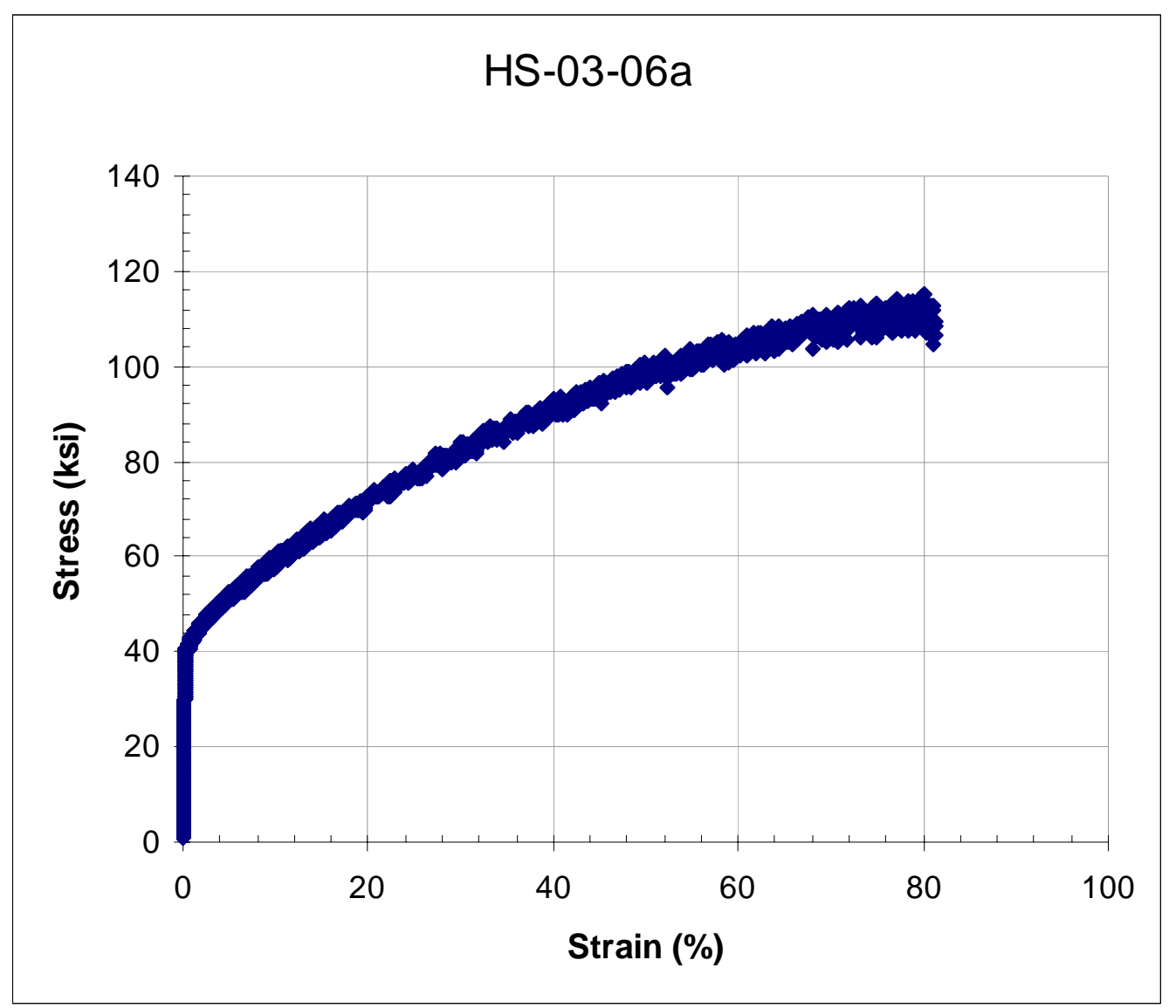




\begin{tabular}{|c|c|c|c|c|c|c|c|c|c|c|c|}
\hline Test ID & $\begin{array}{l}\text { Product } \\
\text { Form }\end{array}$ & $\begin{array}{l}\text { Aging } \\
\text { Temp. } \\
\left({ }^{\circ} \mathrm{C}\right)\end{array}$ & $\begin{array}{l}\text { Aging } \\
\text { Time } \\
\text { (hours) }\end{array}$ & $\begin{array}{c}\text { Test } \\
\text { Temp. } \\
\left({ }^{\circ} \mathrm{C}\right)\end{array}$ & $\begin{array}{c}\text { Prop. } \\
\text { Limit } \\
(\mathrm{MPa})\end{array}$ & $\begin{array}{c}\text { Yield } \\
\text { Strength } \\
\text { (MPa) }\end{array}$ & $\begin{array}{c}\text { Ultimate } \\
\text { Tensile } \\
\text { Strength } \\
\text { (MPa) }\end{array}$ & $\begin{array}{c}\text { Uniform } \\
\text { Elong. } \\
(\%)\end{array}$ & $\begin{array}{c}\text { Elong. } \\
(\%)\end{array}$ & $\begin{array}{c}\text { Red. } \\
\text { of } \\
\text { Area } \\
(\%) \\
\end{array}$ & $\begin{array}{c}\text { Failure } \\
\text { Location }\end{array}$ \\
\hline HS-03-04a & Sheet & 675 & 240 & 650 & 221 & 328 & 818 & 44.2 & 44.2 & 38.0 & $\mathrm{GL}$ \\
\hline
\end{tabular}

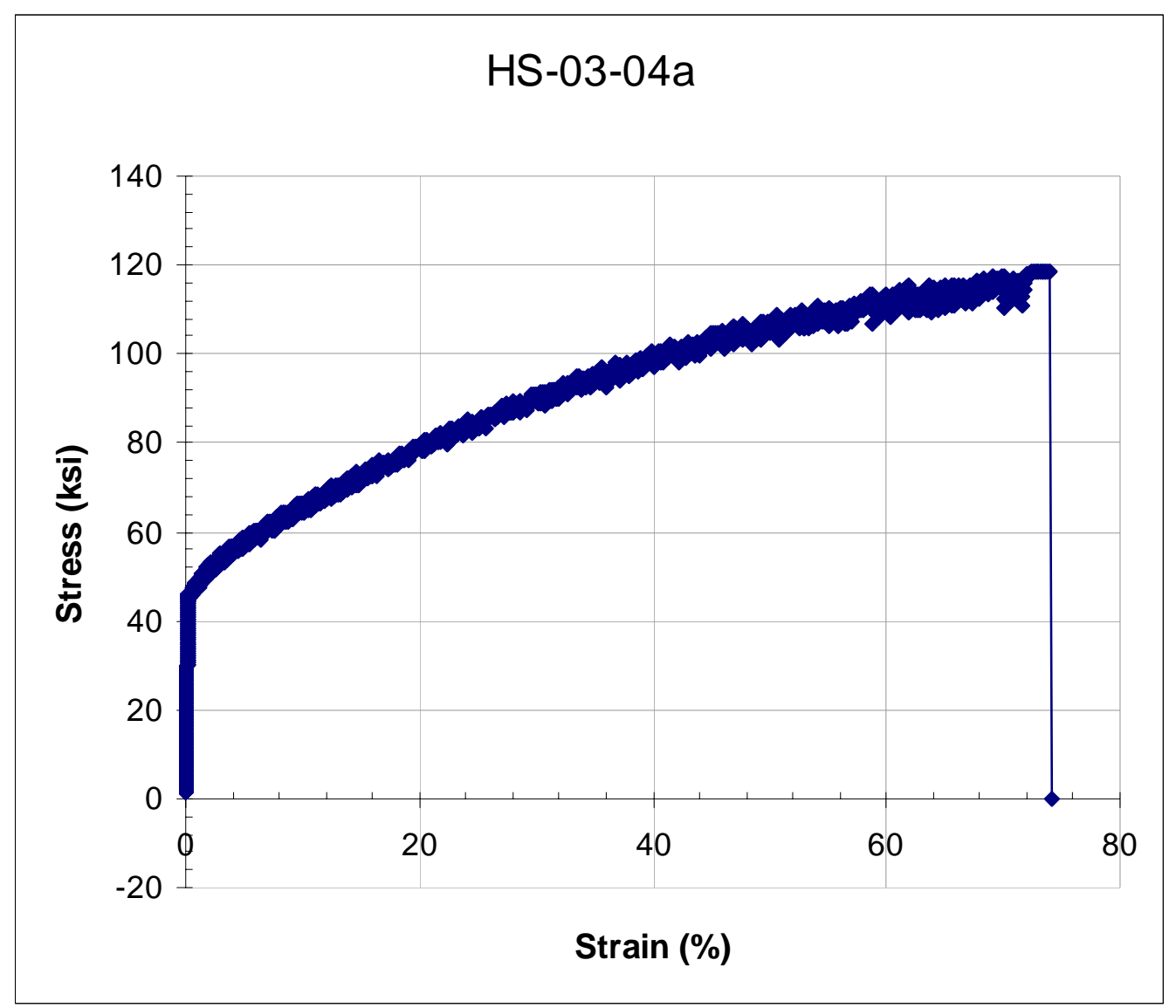




\begin{tabular}{|c|c|c|c|c|c|c|c|c|c|c|c|}
\hline Test ID & $\begin{array}{l}\text { Product } \\
\text { Form }\end{array}$ & $\begin{array}{l}\text { Aging } \\
\text { Temp. } \\
\left({ }^{\circ} \mathrm{C}\right)\end{array}$ & $\begin{array}{l}\text { Aging } \\
\text { Time } \\
\text { (hours) }\end{array}$ & $\begin{array}{c}\text { Test } \\
\text { Temp. } \\
\left({ }^{\circ} \mathrm{C}\right)\end{array}$ & $\begin{array}{c}\text { Prop. } \\
\text { Limit } \\
(\mathrm{MPa})\end{array}$ & $\begin{array}{c}\text { Yield } \\
\text { Strength } \\
\text { (MPa) }\end{array}$ & $\begin{array}{c}\text { Ultimate } \\
\text { Tensile } \\
\text { Strength } \\
\text { (MPa) }\end{array}$ & $\begin{array}{c}\text { Uniform } \\
\text { Elong. } \\
(\%)\end{array}$ & $\begin{array}{c}\text { Elong. } \\
(\%)\end{array}$ & $\begin{array}{c}\text { Red. } \\
\text { of } \\
\text { Area } \\
(\%)\end{array}$ & $\begin{array}{c}\text { Failure } \\
\text { Location }\end{array}$ \\
\hline $\mathrm{HS}-03-02 \mathrm{~b}$ & Sheet & 675 & 1000 & 650 & 345 & 445 & 837 & 38.6 & 38.6 & 28.6 & $\mathrm{GL}$ \\
\hline
\end{tabular}

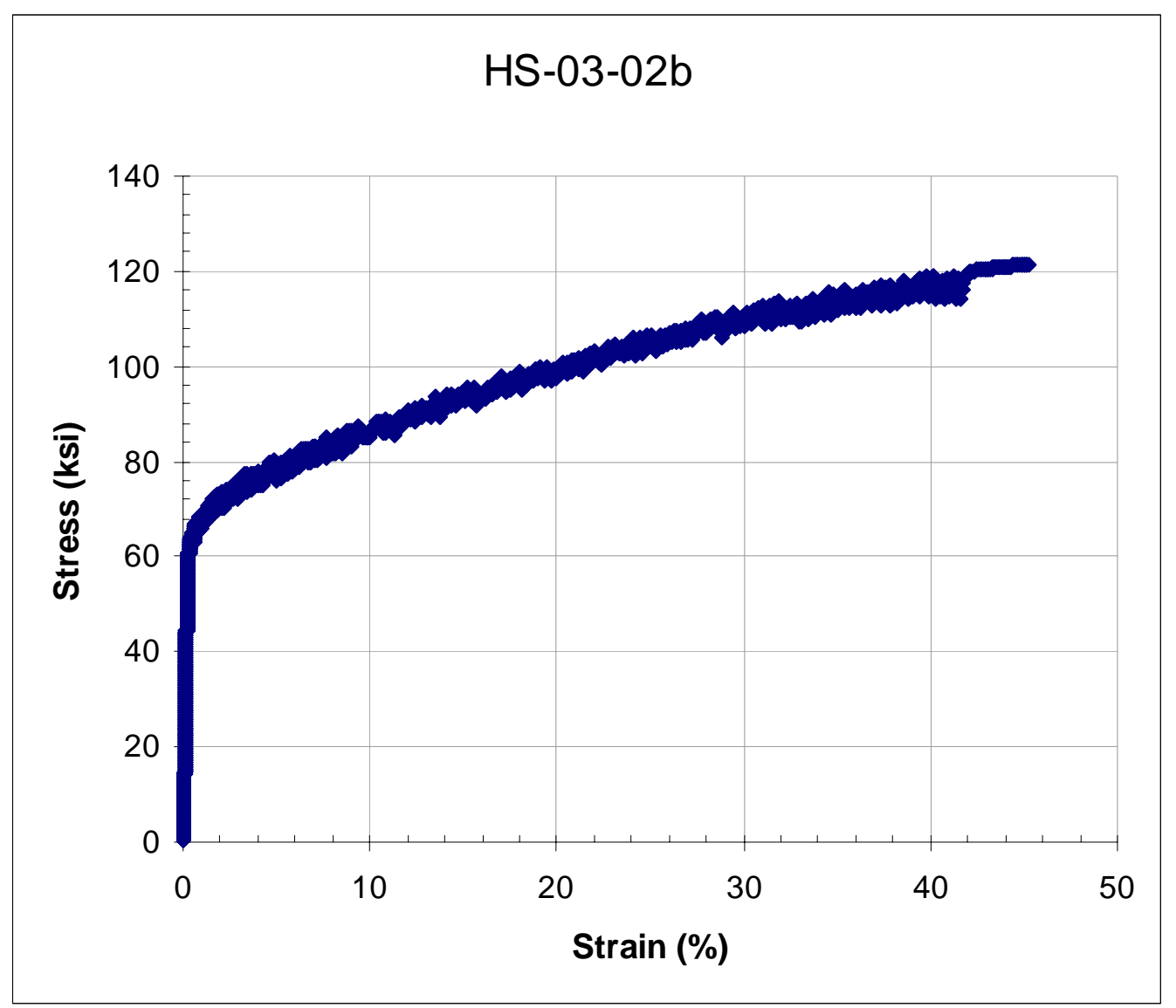




\begin{tabular}{|c|c|c|c|c|c|c|c|c|c|c|c|}
\hline Test ID & $\begin{array}{l}\text { Product } \\
\text { Form }\end{array}$ & $\begin{array}{l}\text { Aging } \\
\text { Temp. } \\
\left({ }^{\circ} \mathrm{C}\right)\end{array}$ & $\begin{array}{l}\text { Aging } \\
\text { Time } \\
\text { (hours) }\end{array}$ & $\begin{array}{c}\text { Test } \\
\text { Temp. } \\
\left({ }^{\circ} \mathrm{C}\right)\end{array}$ & $\begin{array}{c}\text { Prop. } \\
\text { Limit } \\
(\mathrm{MPa})\end{array}$ & $\begin{array}{c}\text { Yield } \\
\text { Strength } \\
\text { (MPa) }\end{array}$ & $\begin{array}{c}\text { Ultimate } \\
\text { Tensile } \\
\text { Strength } \\
\text { (MPa) }\end{array}$ & $\begin{array}{c}\text { Uniform } \\
\text { Elong. } \\
(\%)\end{array}$ & $\begin{array}{c}\text { Elong. } \\
(\%)\end{array}$ & $\begin{array}{c}\text { Red. } \\
\text { of } \\
\text { Area } \\
(\%)\end{array}$ & $\begin{array}{c}\text { Failure } \\
\text { Location }\end{array}$ \\
\hline HS-03-02a & Sheet & 675 & 2000 & 650 & 345 & 568 & 891 & 23.6 & 23.6 & 22.9 & $\mathrm{GL}$ \\
\hline
\end{tabular}

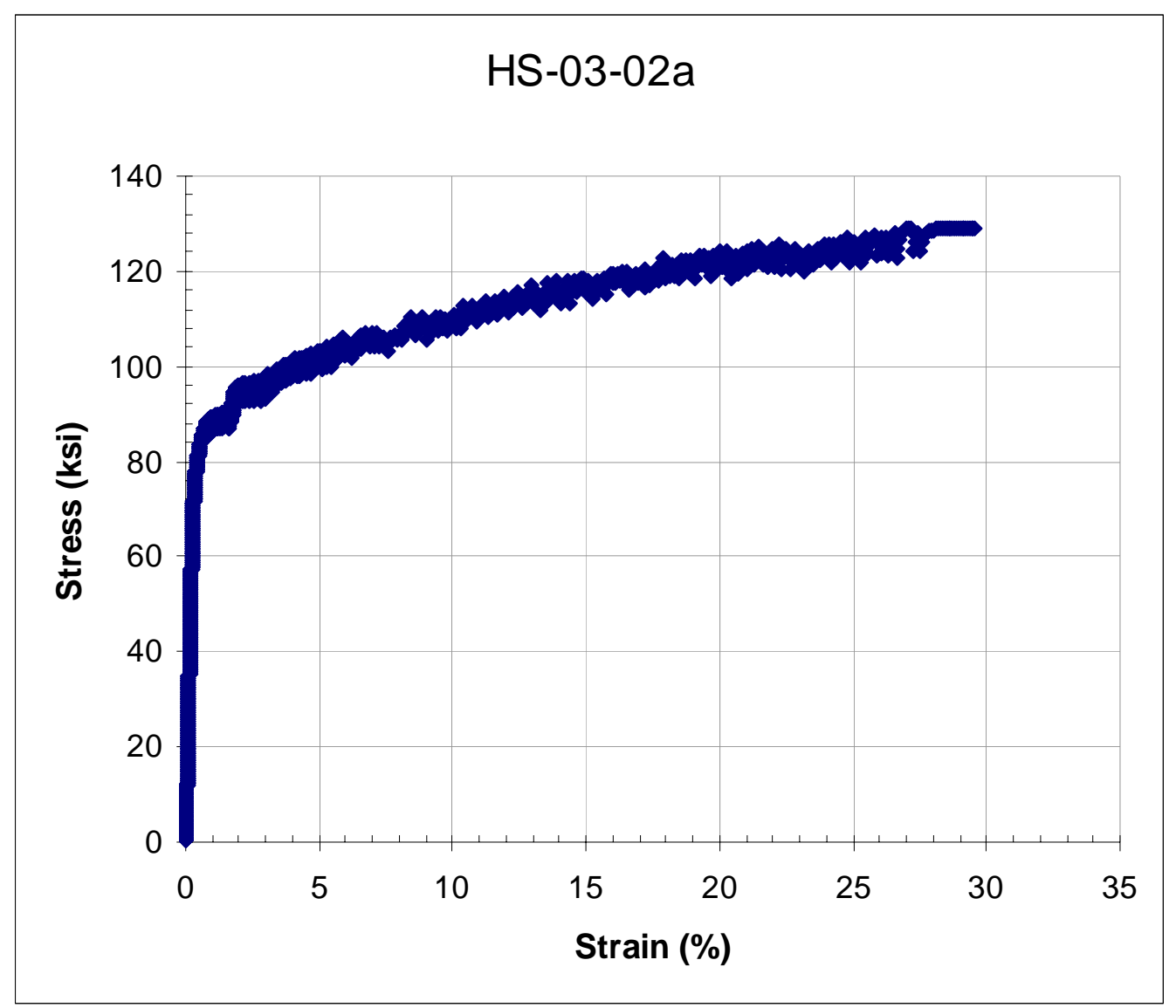




\begin{tabular}{|c|c|c|c|c|c|c|c|c|c|c|c|}
\hline Test ID & $\begin{array}{l}\text { Product } \\
\text { Form }\end{array}$ & $\begin{array}{l}\text { Aging } \\
\text { Temp. } \\
\left({ }^{\circ} \mathrm{C}\right)\end{array}$ & $\begin{array}{l}\text { Aging } \\
\text { Time } \\
\text { (hours) }\end{array}$ & $\begin{array}{r}\text { Test } \\
\text { Temp. } \\
\left({ }^{\circ} \mathrm{C}\right) \\
\end{array}$ & $\begin{array}{l}\text { Prop. } \\
\text { Limit } \\
(\mathrm{MPa})\end{array}$ & $\begin{array}{r}\text { Yield } \\
\text { Strength } \\
(\mathrm{MPa}) \\
\end{array}$ & $\begin{array}{r}\text { Ultimate } \\
\text { Tensile } \\
\text { Strength } \\
(\mathrm{MPa})\end{array}$ & $\begin{array}{r}\text { Uniform } \\
\text { Elong. } \\
(\%)\end{array}$ & $\begin{array}{r}\text { Elong. } \\
(\%)\end{array}$ & $\begin{array}{r}\text { Red. } \\
\text { of } \\
\text { Area } \\
(\%) \\
\end{array}$ & $\begin{array}{c}\text { Failure } \\
\text { Location }\end{array}$ \\
\hline TT-WM-01 & $\begin{array}{l}\text { Sheet } \\
\text { Weld }\end{array}$ & none & none & 23 & & 495 & 1008 & 50.0 & 50.0 & 40.7 & BM \\
\hline
\end{tabular}

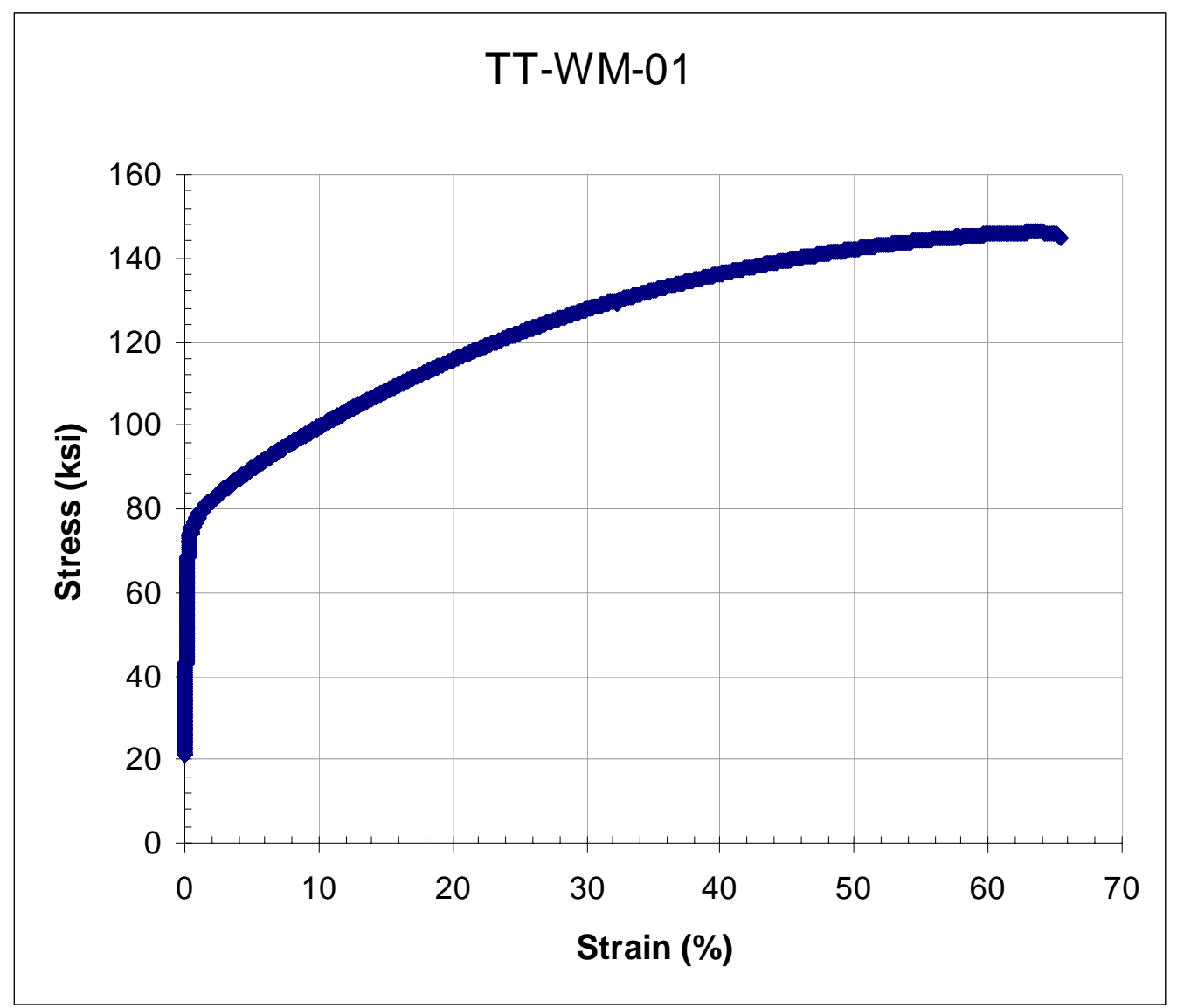




\begin{tabular}{|c|c|c|c|r|r|r|r|r|r|r|r|}
\hline Test ID & $\begin{array}{c}\text { Product } \\
\text { Form }\end{array}$ & $\begin{array}{c}\text { Aging } \\
\text { Temp. } \\
\left({ }^{\circ} \mathrm{C}\right)\end{array}$ & $\begin{array}{c}\text { Aging } \\
\text { Time } \\
\text { (hours) }\end{array}$ & $\begin{array}{r}\text { Test } \\
\text { Temp. } \\
\left({ }^{\circ} \mathrm{C}\right)\end{array}$ & $\begin{array}{r}\text { Prop. } \\
\text { Limit } \\
(\mathrm{MPa})\end{array}$ & $\begin{array}{r}\text { Strength } \\
(\mathrm{MPa})\end{array}$ & $\begin{array}{r}\text { Strimate } \\
\text { Sensile } \\
(\mathrm{MPa})\end{array}$ & $\begin{array}{r}\text { Uniform } \\
\text { Elong. } \\
(\%)\end{array}$ & $\begin{array}{r}\text { Red. } \\
\text { of } \\
\text { Elong. } \\
(\%)\end{array}$ & $\begin{array}{r}\text { Area } \\
(\%)\end{array}$ & $\begin{array}{r}\text { Failure } \\
\text { Location }\end{array}$ \\
\hline TT-WM-02 & $\begin{array}{l}\text { Sheet } \\
\text { Weld }\end{array}$ & none & none & 300 & 219 & 307 & 888 & 70.0 & 74.5 & 57.1 & BM \\
\hline
\end{tabular}

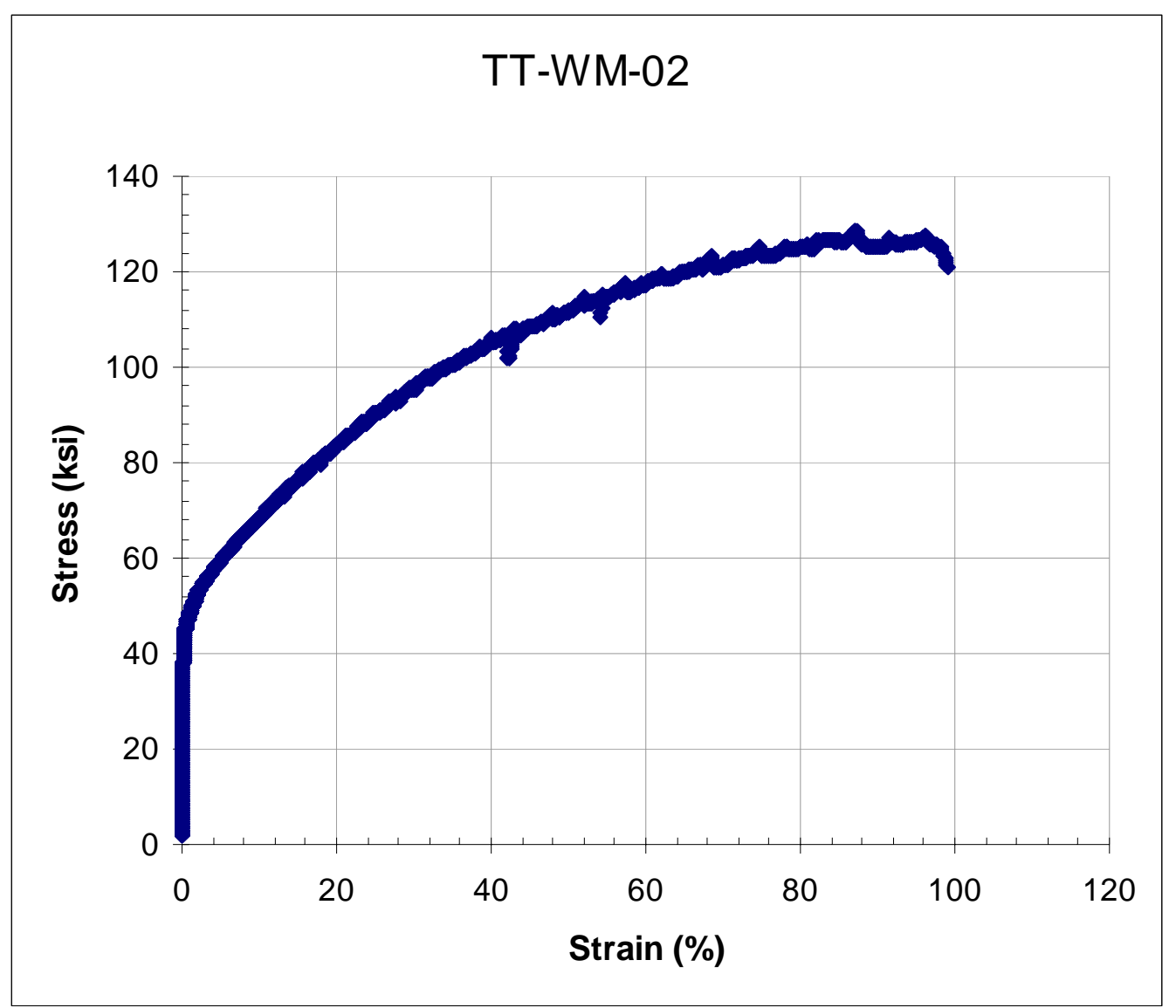




\begin{tabular}{|c|c|c|c|r|r|r|r|r|r|r|r|}
\hline Test ID & $\begin{array}{c}\text { Product } \\
\text { Form }\end{array}$ & $\begin{array}{c}\text { Aging } \\
\text { Temp. } \\
\left({ }^{\circ} \mathrm{C}\right)\end{array}$ & $\begin{array}{c}\text { Aging } \\
\text { Time } \\
\text { (hours) }\end{array}$ & $\begin{array}{r}\text { Test } \\
\text { Temp. } \\
\left({ }^{\circ} \mathrm{C}\right)\end{array}$ & $\begin{array}{r}\text { Prop. } \\
\text { Limit } \\
(\mathrm{MPa})\end{array}$ & $\begin{array}{r}\text { Strength } \\
(\mathrm{MPa})\end{array}$ & $\begin{array}{r}\text { Stimate } \\
\text { Sensile } \\
(\mathrm{MPa})\end{array}$ & $\begin{array}{r}\text { Uniform } \\
\text { Elong. } \\
(\%)\end{array}$ & $\begin{array}{r}\text { Red. } \\
\text { of } \\
\text { Elong. } \\
(\%)\end{array}$ & $\begin{array}{r}\text { Area } \\
(\%)\end{array}$ & $\begin{array}{r}\text { Failure } \\
\text { Location }\end{array}$ \\
\hline TT-WM-03 & $\begin{array}{l}\text { Sheet } \\
\text { Weld }\end{array}$ & none & none & 500 & 196 & 289 & 809 & 66.2 & 72.5 & 51.7 & BM \\
\hline
\end{tabular}

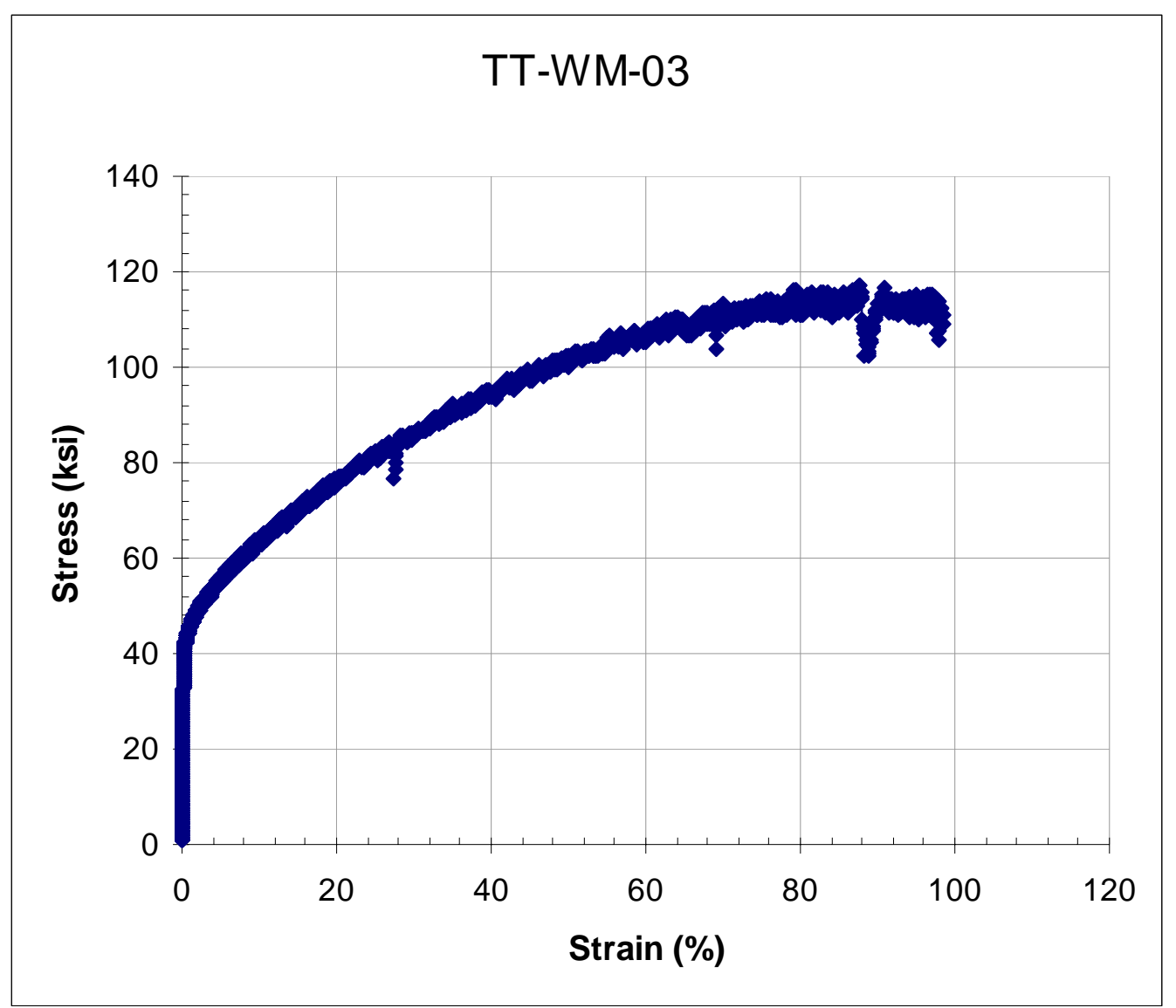




\begin{tabular}{|c|c|c|c|r|r|r|r|r|r|r|r|}
\hline Test ID & $\begin{array}{c}\text { Product } \\
\text { Form }\end{array}$ & $\begin{array}{c}\text { Aging } \\
\text { Temp. } \\
\left({ }^{\circ} \mathrm{C}\right)\end{array}$ & $\begin{array}{c}\text { Aging } \\
\text { Time } \\
\text { (hours) }\end{array}$ & $\begin{array}{r}\text { Test } \\
\text { Temp. } \\
\left({ }^{\circ} \mathrm{C}\right)\end{array}$ & $\begin{array}{r}\text { Prop. } \\
\text { Limit } \\
(\mathrm{MPa})\end{array}$ & $\begin{array}{r}\text { Strength } \\
(\mathrm{MPa})\end{array}$ & $\begin{array}{r}\text { Strimate } \\
\text { Sensile } \\
(\mathrm{MPa})\end{array}$ & $\begin{array}{r}\text { Uniform } \\
\text { Elong. } \\
(\%)\end{array}$ & $\begin{array}{r}\text { Red. } \\
\text { of } \\
\text { Elong. } \\
(\%)\end{array}$ & $\begin{array}{r}\text { Area } \\
(\%)\end{array}$ & $\begin{array}{r}\text { Failure } \\
\text { Location }\end{array}$ \\
\hline TT-WM-04 & $\begin{array}{l}\text { Sheet } \\
\text { Weld }\end{array}$ & none & none & 650 & 191 & 279 & 768 & 49.7 & 49.7 & 32.4 & BM \\
\hline
\end{tabular}

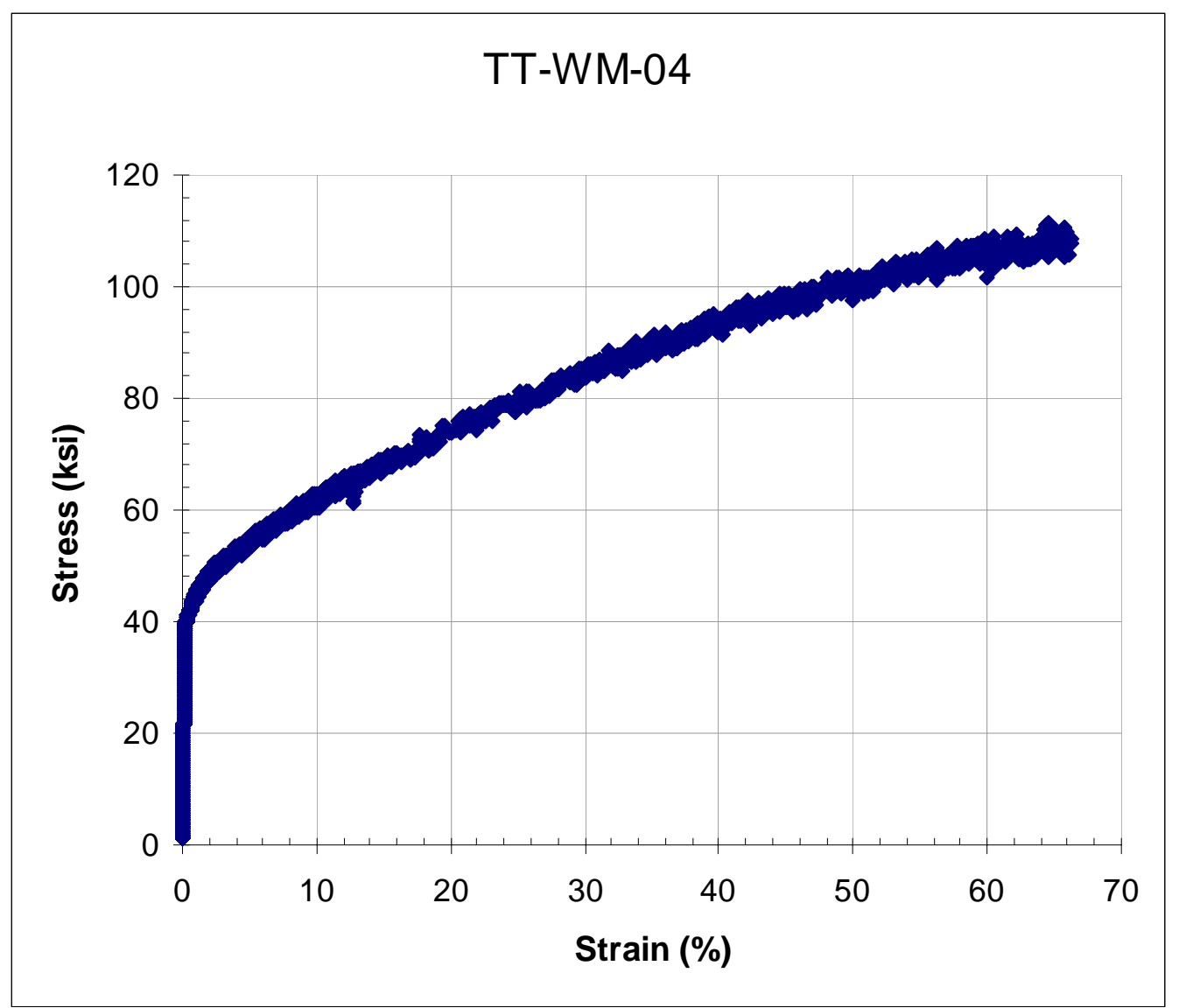




\begin{tabular}{|c|c|c|c|r|r|r|r|r|r|r|r|}
\hline Test ID & $\begin{array}{c}\text { Product } \\
\text { Form }\end{array}$ & $\begin{array}{c}\text { Aging } \\
\text { Temp. } \\
\left({ }^{\circ} \mathrm{C}\right)\end{array}$ & $\begin{array}{c}\text { Aging } \\
\text { Time } \\
\text { (hours) }\end{array}$ & $\begin{array}{r}\text { Test } \\
\text { Temp. } \\
\left({ }^{\circ} \mathrm{C}\right)\end{array}$ & $\begin{array}{r}\text { Prop. } \\
\text { Limit } \\
(\mathrm{MPa})\end{array}$ & $\begin{array}{r}\text { Strength } \\
(\mathrm{MPa})\end{array}$ & $\begin{array}{r}\text { Stimate } \\
\text { Sensile } \\
(\mathrm{MPa})\end{array}$ & $\begin{array}{r}\text { Uniform } \\
\text { Elong. } \\
(\%)\end{array}$ & $\begin{array}{r}\text { Red. } \\
\text { of } \\
\text { Elong. } \\
(\%)\end{array}$ & $\begin{array}{r}\text { Area } \\
(\%)\end{array}$ & $\begin{array}{r}\text { Failure } \\
\text { Location }\end{array}$ \\
\hline TT-WM-05 & $\begin{array}{l}\text { Sheet } \\
\text { Weld }\end{array}$ & none & none & 800 & 153 & 245 & 480 & 22.5 & 50.0 & 45.7 & BM \\
\hline
\end{tabular}

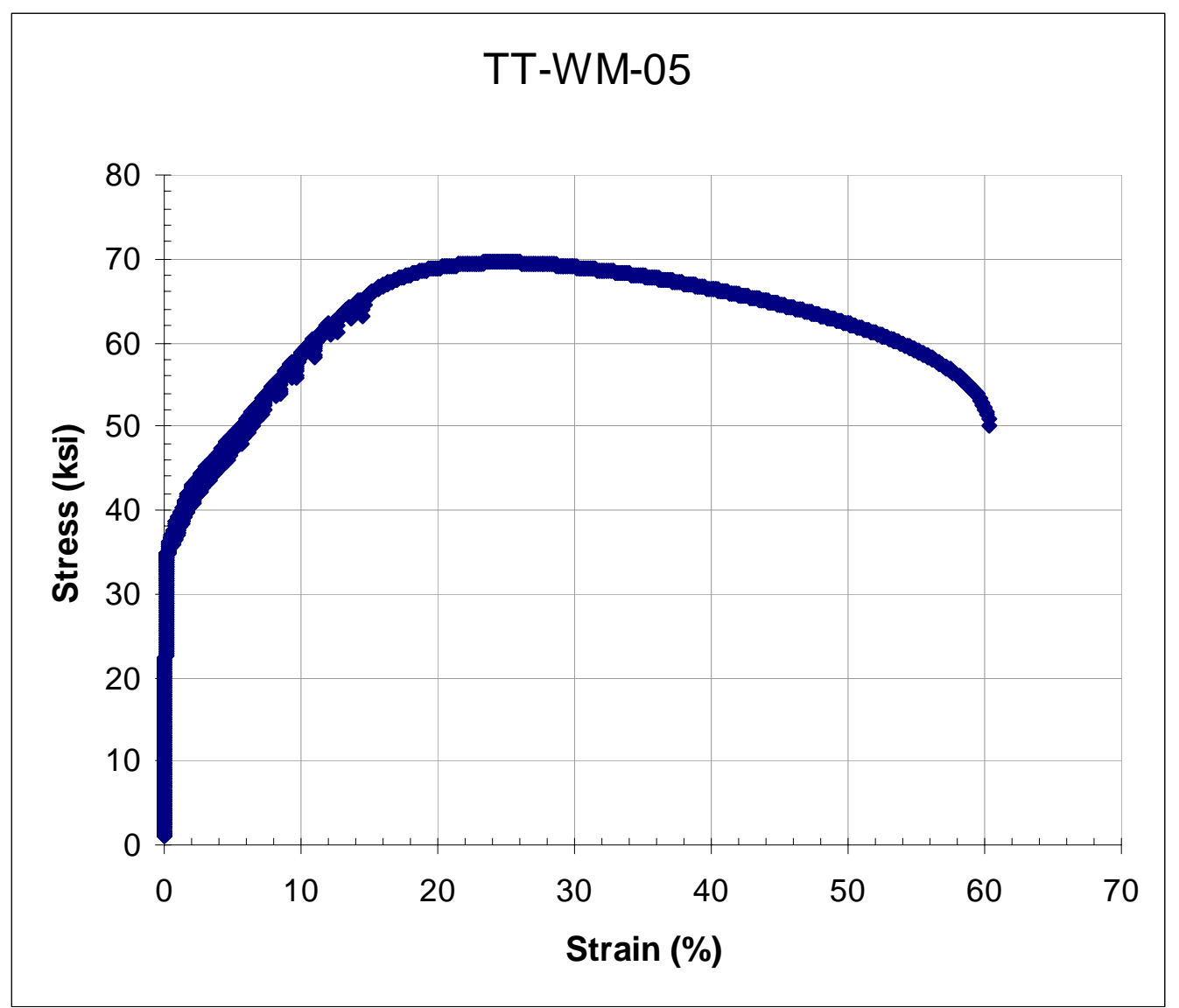




\begin{tabular}{|c|c|c|c|c|c|c|c|c|c|c|c|}
\hline Test ID & $\begin{array}{c}\text { Product } \\
\text { Form }\end{array}$ & $\begin{array}{l}\text { Aging } \\
\text { Temp. } \\
\left({ }^{\circ} \mathrm{C}\right)\end{array}$ & $\begin{array}{l}\text { Aging } \\
\text { Time } \\
\text { (hours) }\end{array}$ & $\begin{array}{r}\text { Test } \\
\text { Temp. } \\
\left({ }^{\circ} \mathrm{C}\right) \\
\end{array}$ & $\begin{array}{l}\text { Prop. } \\
\text { Limit } \\
(\mathrm{MPa})\end{array}$ & $\begin{array}{r}\text { Yield } \\
\text { Strength } \\
(\mathrm{MPa})\end{array}$ & $\begin{array}{r}\text { Ultimate } \\
\text { Tensile } \\
\text { Strength } \\
(\mathrm{MPa})\end{array}$ & $\begin{array}{r}\text { Uniform } \\
\text { Elong. } \\
(\%)\end{array}$ & $\begin{array}{r}\text { Elong. } \\
(\%)\end{array}$ & $\begin{array}{r}\text { Red. } \\
\text { of } \\
\text { Area } \\
(\%)\end{array}$ & $\begin{array}{c}\text { Failure } \\
\text { Location }\end{array}$ \\
\hline TT-WM-06 & $\begin{array}{l}\text { Sheet } \\
\text { Weld }\end{array}$ & none & none & 1000 & 90 & 165 & 170 & 4.0 & 72.8 & 62.0 & $\mathrm{BM}$ \\
\hline
\end{tabular}

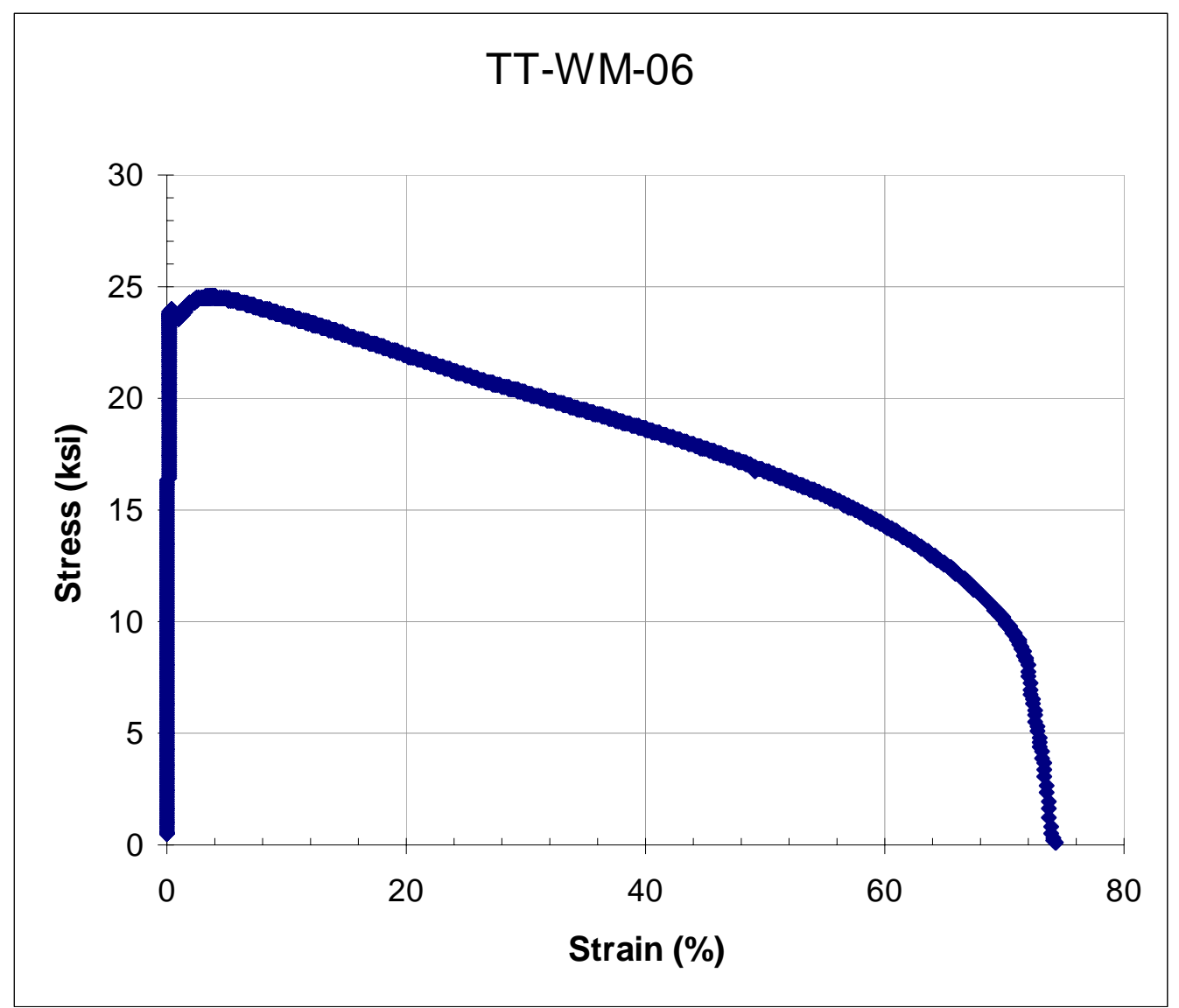




\begin{tabular}{|c|c|c|r|r|r|r|r|r|r|r|r|}
\hline Test ID & $\begin{array}{c}\text { Product } \\
\text { Form }\end{array}$ & $\begin{array}{c}\text { Aging } \\
\text { Temp. } \\
\left({ }^{\circ} \mathrm{C}\right)\end{array}$ & $\begin{array}{c}\text { Aging } \\
\text { Time } \\
\text { (hours) }\end{array}$ & $\begin{array}{r}\text { Test } \\
\text { Temp. } \\
\left({ }^{\circ} \mathrm{C}\right)\end{array}$ & $\begin{array}{r}\text { Prop. } \\
\text { Limit } \\
(\mathrm{MPa})\end{array}$ & $\begin{array}{r}\text { Strength } \\
(\mathrm{MPa})\end{array}$ & $\begin{array}{r}\text { Strimate } \\
\text { Sensile } \\
(\mathrm{MPa})\end{array}$ & $\begin{array}{r}\text { Uniform } \\
\text { Elong. } \\
(\%)\end{array}$ & $\begin{array}{r}\text { Red. } \\
\text { of } \\
\text { Elong. } \\
(\%)\end{array}$ & $\begin{array}{r}\text { Area } \\
(\%)\end{array}$ & $\begin{array}{r}\text { Failure } \\
\text { Location }\end{array}$ \\
\hline TT-WM-07 & $\begin{array}{l}\text { Sheet } \\
\text { Weld }\end{array}$ & none & none & 1100 & 54 & 94 & 96 & 1.5 & 53.0 & 58.7 & BM \\
\hline
\end{tabular}

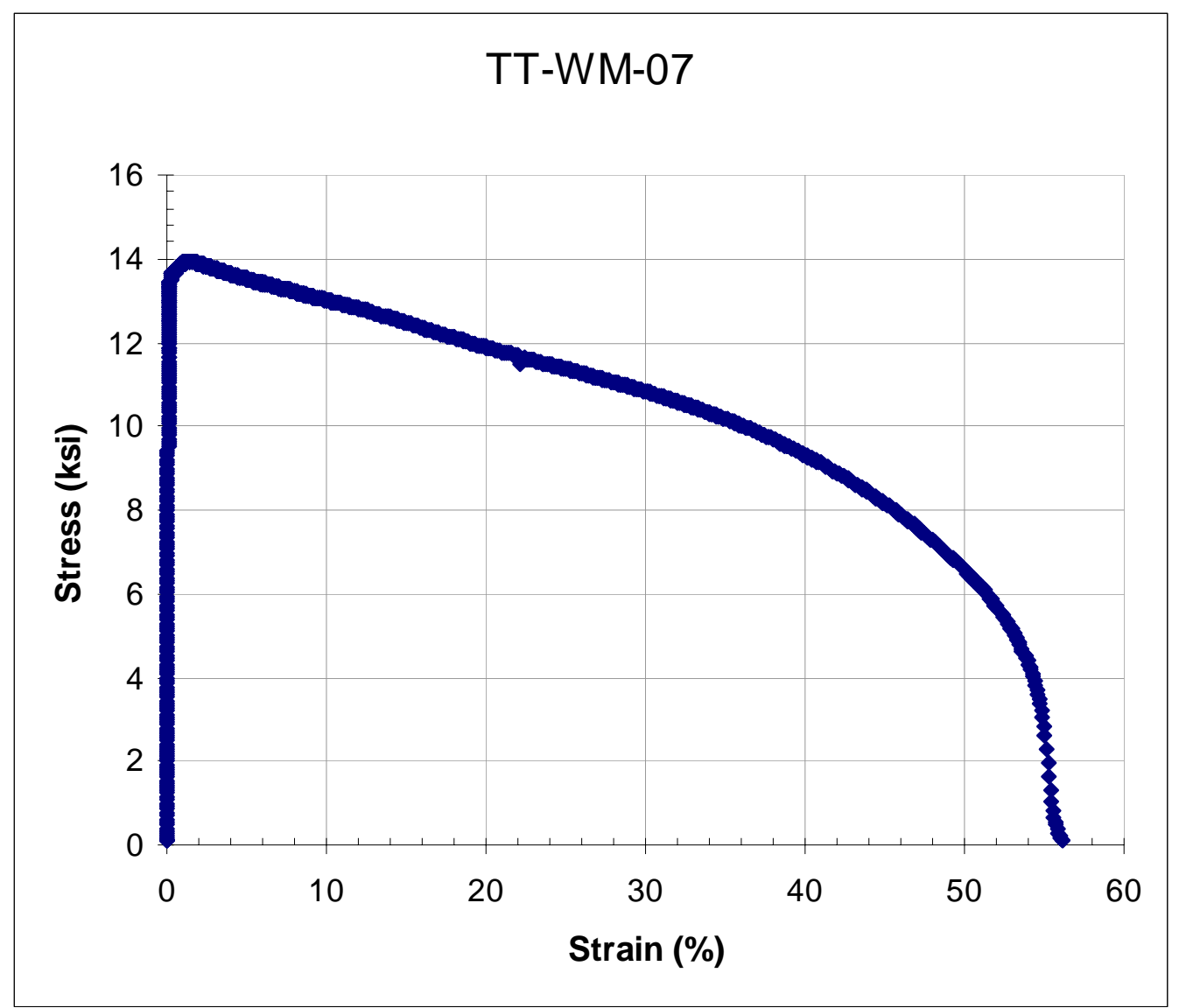




\begin{tabular}{|c|c|c|c|c|c|c|c|c|c|c|c|}
\hline Test ID & $\begin{array}{c}\text { Product } \\
\text { Form }\end{array}$ & $\begin{array}{l}\text { Aging } \\
\text { Temp. } \\
\left({ }^{\circ} \mathrm{C}\right)\end{array}$ & $\begin{array}{l}\text { Aging } \\
\text { Time } \\
\text { (hours) }\end{array}$ & $\begin{array}{r}\text { Test } \\
\text { Temp. } \\
\left({ }^{\circ} \mathrm{C}\right) \\
\end{array}$ & $\begin{array}{r}\text { Prop. } \\
\text { Limit } \\
(\mathrm{MPa})\end{array}$ & $\begin{array}{r}\text { Yield } \\
\text { Strength } \\
(\mathrm{MPa})\end{array}$ & $\begin{array}{r}\text { Ultimate } \\
\text { Tensile } \\
\text { Strength } \\
(\mathrm{MPa})\end{array}$ & $\begin{array}{r}\text { Uniform } \\
\text { Elong. } \\
(\%)\end{array}$ & $\begin{array}{r}\text { Elong. } \\
(\%)\end{array}$ & $\begin{array}{r}\text { Red. } \\
\text { of } \\
\text { Area } \\
(\%) \\
\end{array}$ & $\begin{array}{c}\text { Failure } \\
\text { Location }\end{array}$ \\
\hline TT-WM-08 & $\begin{array}{l}\text { Sheet } \\
\text { Weld }\end{array}$ & 675 & 6000 & 23 & 552 & 762 & 1004 & 5.6 & 5.6 & 5.2 & BM \\
\hline
\end{tabular}

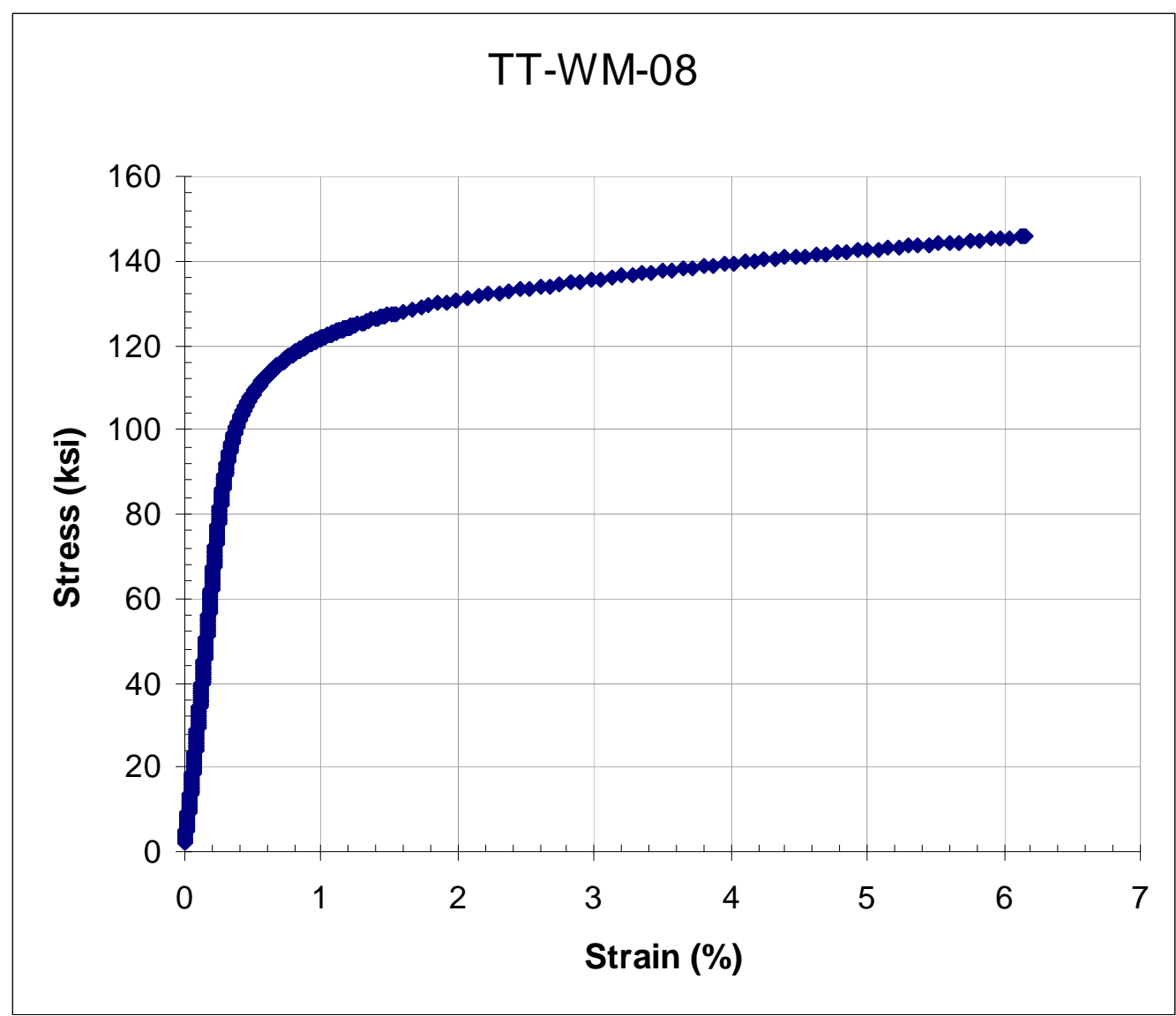




\begin{tabular}{|c|c|c|c|r|r|r|r|r|r|r|r|}
\hline Test ID & $\begin{array}{c}\text { Product } \\
\text { Form }\end{array}$ & $\begin{array}{c}\text { Aging } \\
\text { Temp. } \\
\left({ }^{\circ} \mathrm{C}\right)\end{array}$ & $\begin{array}{c}\text { Aging } \\
\text { Time } \\
(\text { hours })\end{array}$ & $\begin{array}{r}\text { Test } \\
\text { Temp. } \\
\left({ }^{\circ} \mathrm{C}\right)\end{array}$ & $\begin{array}{r}\text { Prop. } \\
\text { Limit } \\
(\mathrm{MPa})\end{array}$ & $\begin{array}{r}\text { Yield } \\
\text { Strength } \\
(\mathrm{MPa})\end{array}$ & $\begin{array}{r}\text { Ultimate } \\
\text { Tensile } \\
\text { Strength } \\
(\mathrm{MPa})\end{array}$ & $\begin{array}{r}\text { Uniform } \\
\text { Elong. } \\
(\%)\end{array}$ & $\begin{array}{r}\text { Red. } \\
\text { of } \\
\text { Elong. } \\
(\%)\end{array}$ & $\begin{array}{r}\text { Area } \\
(\%)\end{array}$ & $\begin{array}{r}\text { Failure } \\
\text { Location }\end{array}$ \\
\hline TT-WM-09 & $\begin{array}{l}\text { Sheet } \\
\text { Weld }\end{array}$ & 675 & 6000 & 300 & 448 & 601 & 936 & 12.8 & 12.8 & 13.2 & BM \\
\hline
\end{tabular}

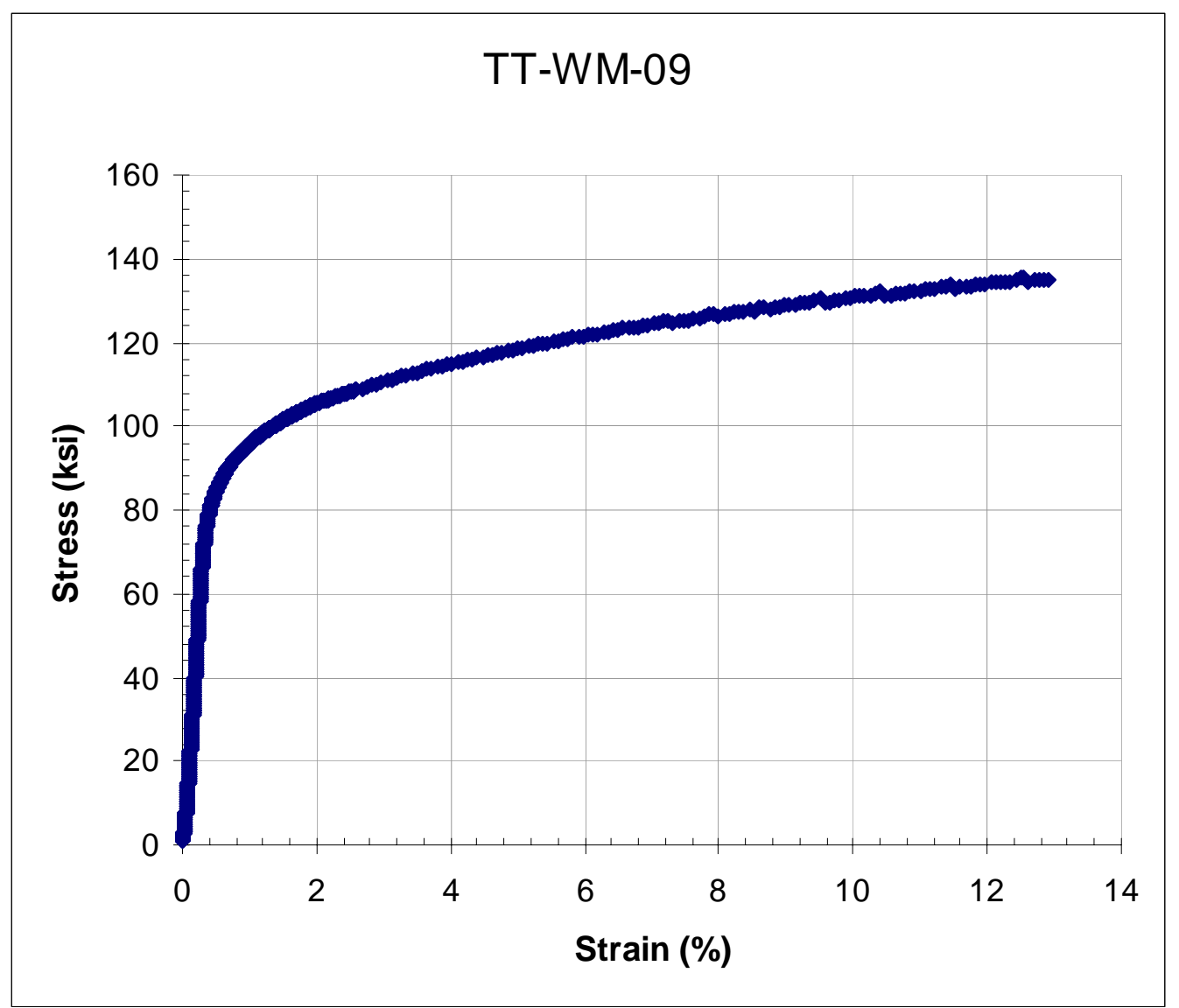




\begin{tabular}{|c|c|c|c|c|c|c|c|c|c|c|c|}
\hline Test ID & $\begin{array}{c}\text { Product } \\
\text { Form }\end{array}$ & $\begin{array}{l}\text { Aging } \\
\text { Temp. } \\
\left({ }^{\circ} \mathrm{C}\right)\end{array}$ & $\begin{array}{l}\text { Aging } \\
\text { Time } \\
\text { (hours) }\end{array}$ & $\begin{array}{r}\text { Test } \\
\text { Temp. } \\
\left({ }^{\circ} \mathrm{C}\right) \\
\end{array}$ & $\begin{array}{r}\text { Prop. } \\
\text { Limit } \\
(\mathrm{MPa})\end{array}$ & $\begin{array}{r}\text { Yield } \\
\text { Strength } \\
(\mathrm{MPa})\end{array}$ & $\begin{array}{r}\text { Ultimate } \\
\text { Tensile } \\
\text { Strength } \\
(\mathrm{MPa})\end{array}$ & $\begin{array}{r}\text { Uniform } \\
\text { Elong. } \\
(\%)\end{array}$ & $\begin{array}{r}\text { Elong. } \\
(\%)\end{array}$ & $\begin{array}{r}\text { Red. } \\
\text { of } \\
\text { Area } \\
(\%)\end{array}$ & $\begin{array}{c}\text { Failure } \\
\text { Location }\end{array}$ \\
\hline TT-WM-10 & $\begin{array}{l}\text { Sheet } \\
\text { Weld }\end{array}$ & 675 & 6000 & 500 & 372 & 542 & 927 & 16.3 & 16.3 & 15.0 & $\mathrm{BM}$ \\
\hline
\end{tabular}

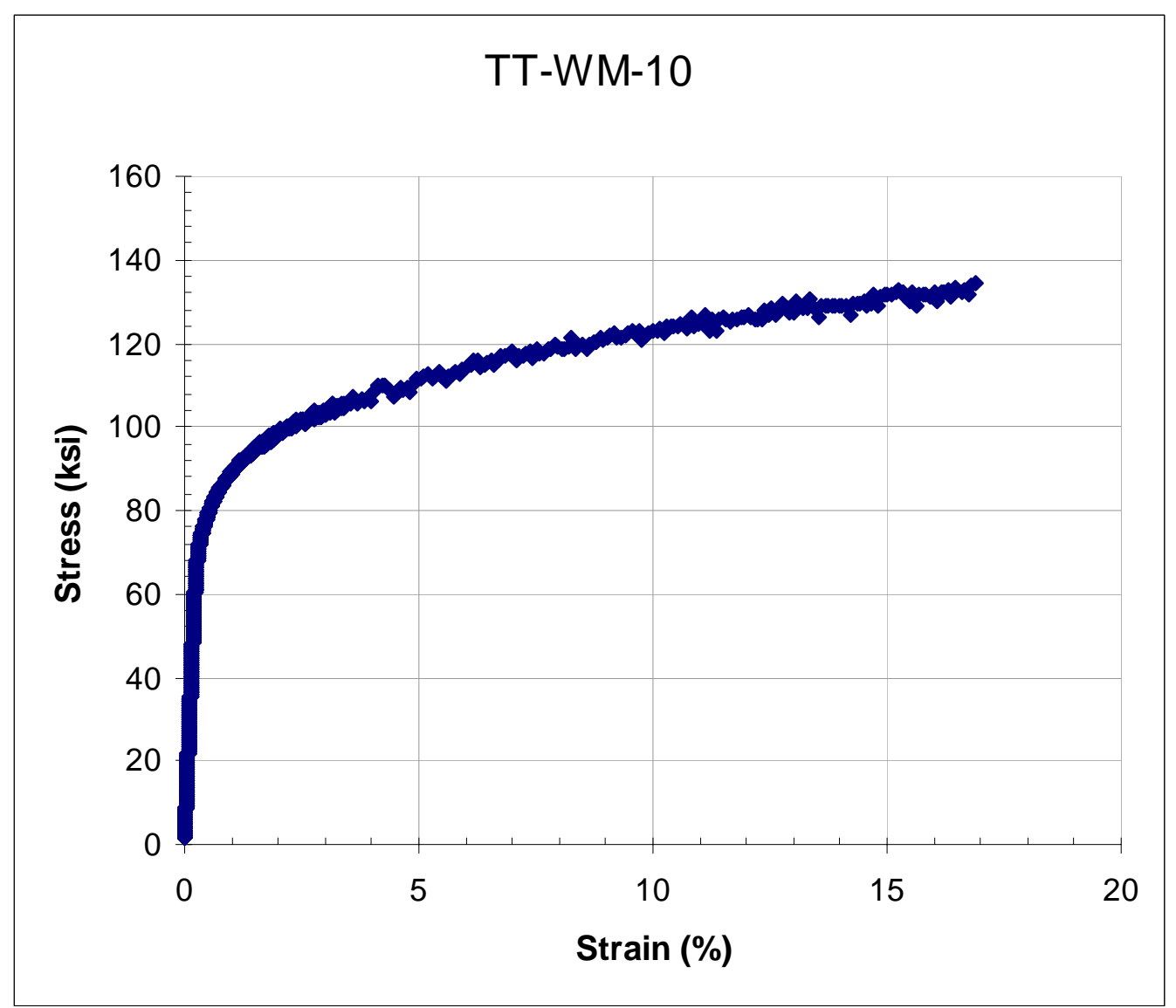




\begin{tabular}{|c|c|c|c|c|c|c|c|c|c|c|c|}
\hline Test ID & $\begin{array}{c}\text { Product } \\
\text { Form }\end{array}$ & $\begin{array}{l}\text { Aging } \\
\text { Temp. } \\
\left({ }^{\circ} \mathrm{C}\right)\end{array}$ & $\begin{array}{l}\text { Aging } \\
\text { Time } \\
\text { (hours) }\end{array}$ & $\begin{array}{r}\text { Test } \\
\text { Temp. } \\
\left({ }^{\circ} \mathrm{C}\right) \\
\end{array}$ & $\begin{array}{r}\text { Prop. } \\
\text { Limit } \\
(\mathrm{MPa})\end{array}$ & $\begin{array}{r}\text { Yield } \\
\text { Strength } \\
(\mathrm{MPa})\end{array}$ & $\begin{array}{r}\text { Ultimate } \\
\text { Tensile } \\
\text { Strength } \\
(\mathrm{MPa})\end{array}$ & $\begin{array}{r}\text { Uniform } \\
\text { Elong. } \\
(\%)\end{array}$ & $\begin{array}{r}\text { Elong. } \\
(\%)\end{array}$ & $\begin{array}{r}\text { Red. } \\
\text { of } \\
\text { Area } \\
(\%) \\
\end{array}$ & $\begin{array}{c}\text { Failure } \\
\text { Location }\end{array}$ \\
\hline TT-WM-11 & $\begin{array}{l}\text { Sheet } \\
\text { Weld }\end{array}$ & 675 & 6000 & 650 & 241 & 549 & 895 & 16.7 & 16.7 & 17.5 & $\mathrm{BM}$ \\
\hline
\end{tabular}

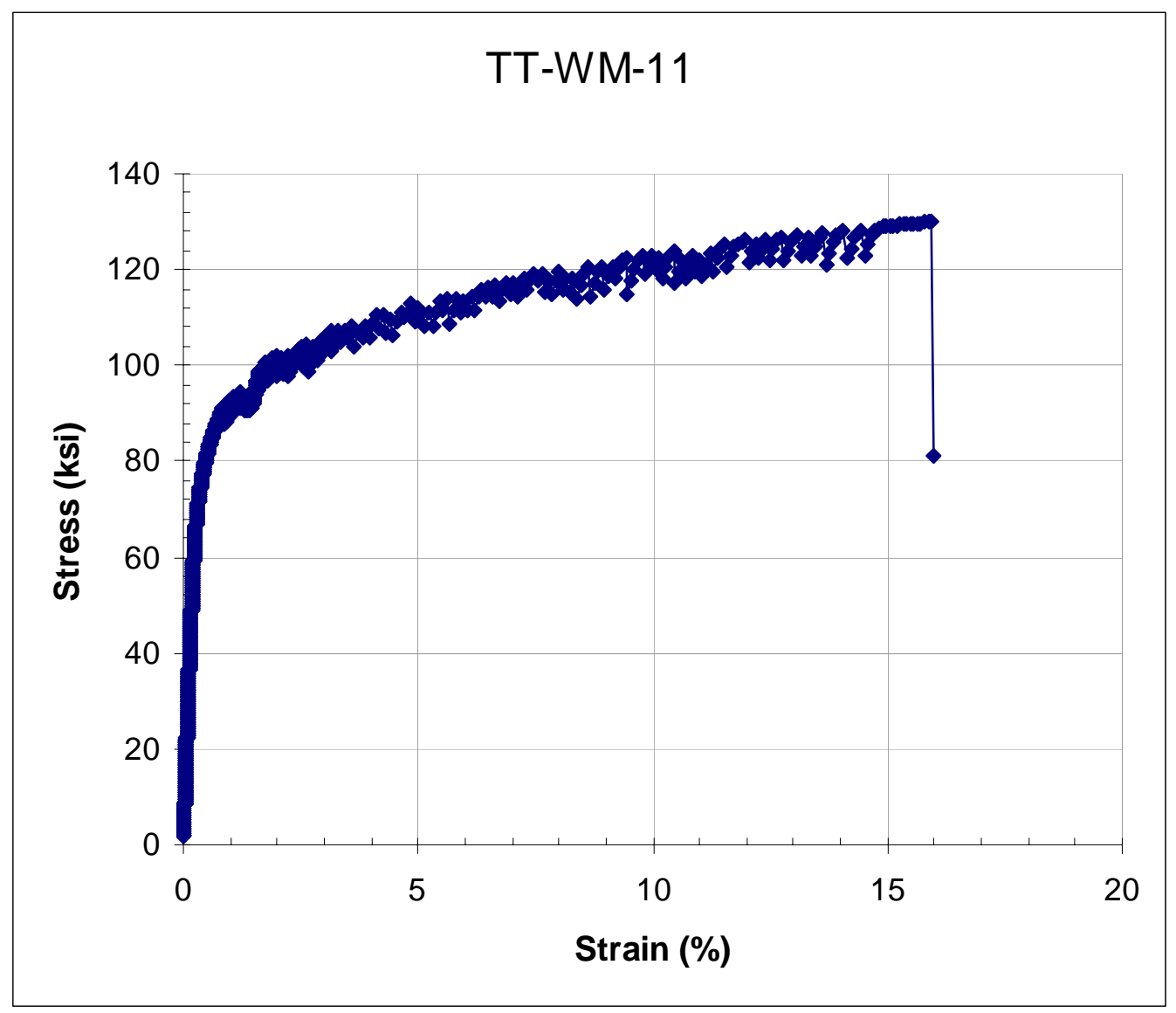




\begin{tabular}{|c|c|c|c|c|c|c|c|c|c|c|c|}
\hline Test ID & $\begin{array}{c}\text { Product } \\
\text { Form }\end{array}$ & $\begin{array}{l}\text { Aging } \\
\text { Temp. } \\
\left({ }^{\circ} \mathrm{C}\right)\end{array}$ & $\begin{array}{l}\text { Aging } \\
\text { Time } \\
\text { (hours) }\end{array}$ & $\begin{array}{r}\text { Test } \\
\text { Temp. } \\
\left({ }^{\circ} \mathrm{C}\right) \\
\end{array}$ & $\begin{array}{l}\text { Prop. } \\
\text { Limit } \\
(\mathrm{MPa})\end{array}$ & $\begin{array}{r}\text { Yield } \\
\text { Strength } \\
(\mathrm{MPa})\end{array}$ & $\begin{array}{r}\text { Ultimate } \\
\text { Tensile } \\
\text { Strength } \\
(\mathrm{MPa})\end{array}$ & $\begin{array}{r}\text { Uniform } \\
\text { Elong. } \\
(\%)\end{array}$ & $\begin{array}{r}\text { Elong. } \\
(\%)\end{array}$ & $\begin{array}{r}\text { Red. } \\
\text { of } \\
\text { Area } \\
(\%)\end{array}$ & $\begin{array}{c}\text { Failure } \\
\text { Location }\end{array}$ \\
\hline TT-WM-12 & $\begin{array}{l}\text { Sheet } \\
\text { Weld }\end{array}$ & 675 & 6000 & 800 & & 402 & 554 & 7.2 & 13.4 & 18.3 & $\mathrm{BM}$ \\
\hline
\end{tabular}

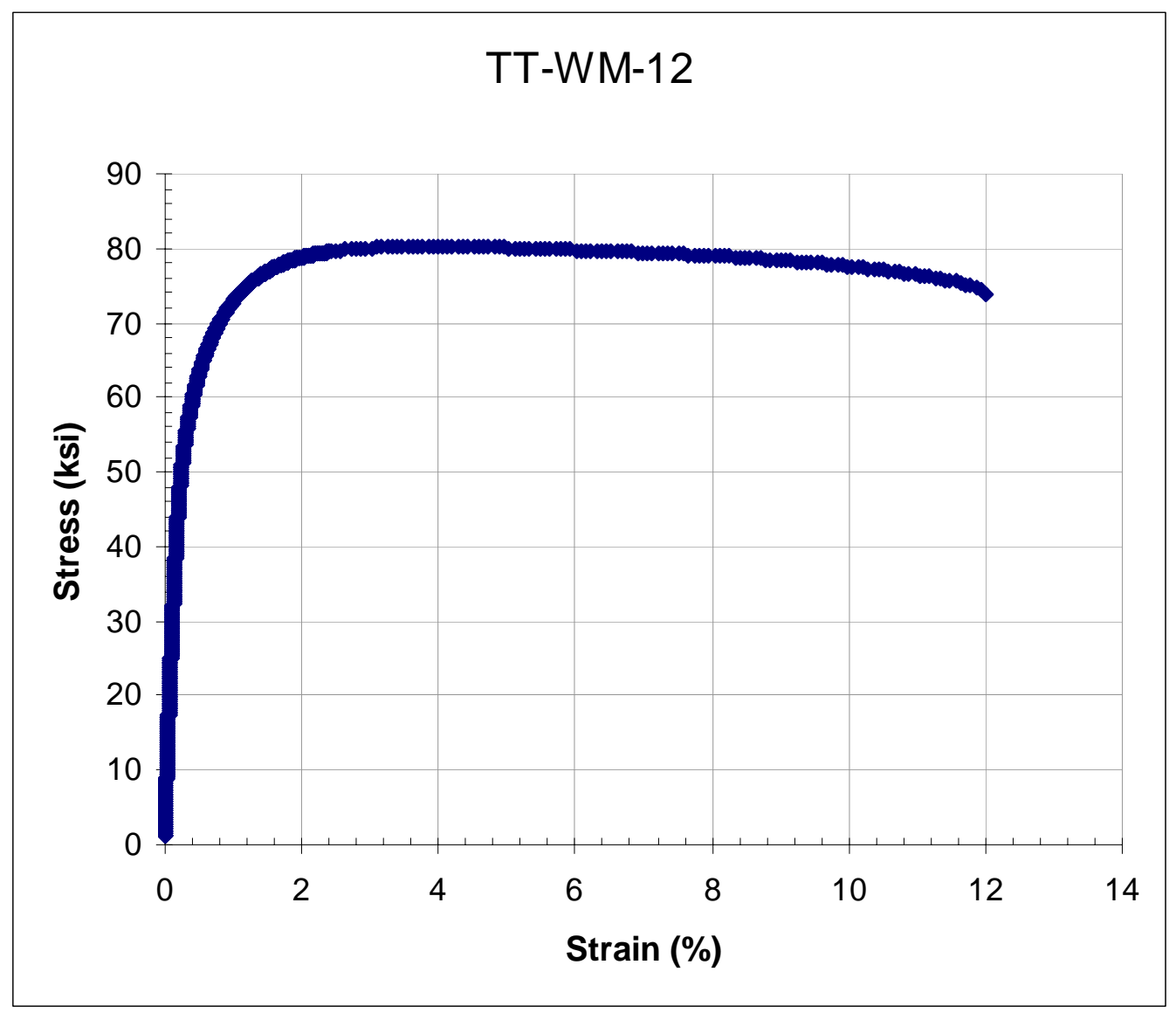




\begin{tabular}{|c|c|c|r|r|r|r|r|r|r|r|r|}
\hline Test ID & $\begin{array}{c}\text { Product } \\
\text { Form }\end{array}$ & $\begin{array}{c}\text { Aging } \\
\text { Temp. } \\
\left({ }^{\circ} \mathrm{C}\right)\end{array}$ & $\begin{array}{c}\text { Aging } \\
\text { Time } \\
(\text { hours })\end{array}$ & $\begin{array}{r}\text { Test } \\
\text { Temp. } \\
\left({ }^{\circ} \mathrm{C}\right)\end{array}$ & $\begin{array}{r}\text { Prop. } \\
\text { Limit } \\
(\mathrm{MPa})\end{array}$ & $\begin{array}{r}\text { Yield } \\
\text { Strength } \\
(\mathrm{MPa})\end{array}$ & $\begin{array}{r}\text { Ultimate } \\
\text { Tensile } \\
\text { Strength } \\
(\mathrm{MPa})\end{array}$ & $\begin{array}{r}\text { Uniform } \\
\text { Elong. } \\
(\%)\end{array}$ & $\begin{array}{r}\text { Red. } \\
\text { of } \\
\text { Elong. } \\
(\%)\end{array}$ & $\begin{array}{r}\text { Area } \\
(\%)\end{array}$ & $\begin{array}{r}\text { Failure } \\
\text { Location }\end{array}$ \\
\hline TT-WM-13 & $\begin{array}{l}\text { Sheet } \\
\text { Weld }\end{array}$ & 675 & 6000 & 1000 & 83 & 174 & 177 & 0.5 & 47.3 & 45.2 & BM \\
\hline
\end{tabular}

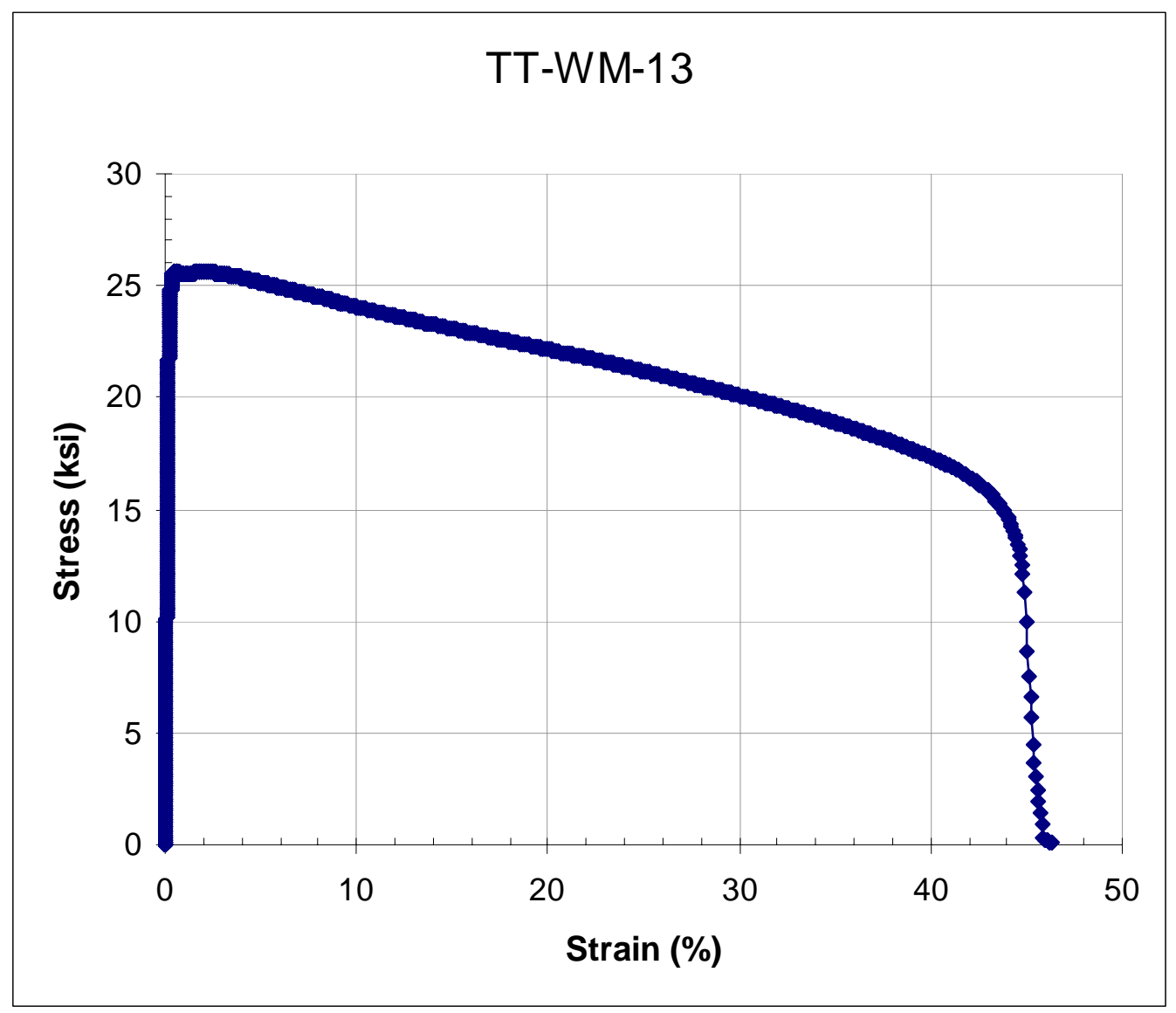




\begin{tabular}{|c|c|c|r|r|r|r|r|r|r|r|r|}
\hline Test ID & $\begin{array}{c}\text { Product } \\
\text { Form }\end{array}$ & $\begin{array}{c}\text { Aging } \\
\text { Temp. } \\
\left({ }^{\circ} \mathrm{C}\right)\end{array}$ & $\begin{array}{c}\text { Aging } \\
\text { Time } \\
(\text { hours })\end{array}$ & $\begin{array}{r}\text { Test } \\
\text { Temp. } \\
\left({ }^{\circ} \mathrm{C}\right)\end{array}$ & $\begin{array}{r}\text { Prop. } \\
\text { Limit } \\
(\mathrm{MPa})\end{array}$ & $\begin{array}{r}\text { Yield } \\
\text { Strength } \\
(\mathrm{MPa})\end{array}$ & $\begin{array}{r}\text { Ultimate } \\
\text { Tensile } \\
\text { Strength } \\
(\mathrm{MPa})\end{array}$ & $\begin{array}{r}\text { Uniform } \\
\text { Elong. } \\
(\%)\end{array}$ & $\begin{array}{r}\text { Red. } \\
\text { of } \\
\text { Elong. } \\
(\%)\end{array}$ & $\begin{array}{r}\text { Area } \\
(\%)\end{array}$ & $\begin{array}{r}\text { Failure } \\
\text { Location }\end{array}$ \\
\hline TT-WM-14 & $\begin{array}{l}\text { Sheet } \\
\text { Weld }\end{array}$ & 675 & 6000 & 1100 & 48 & 99 & 99 & 0.5 & 44.5 & 45.5 & BM \\
\hline
\end{tabular}

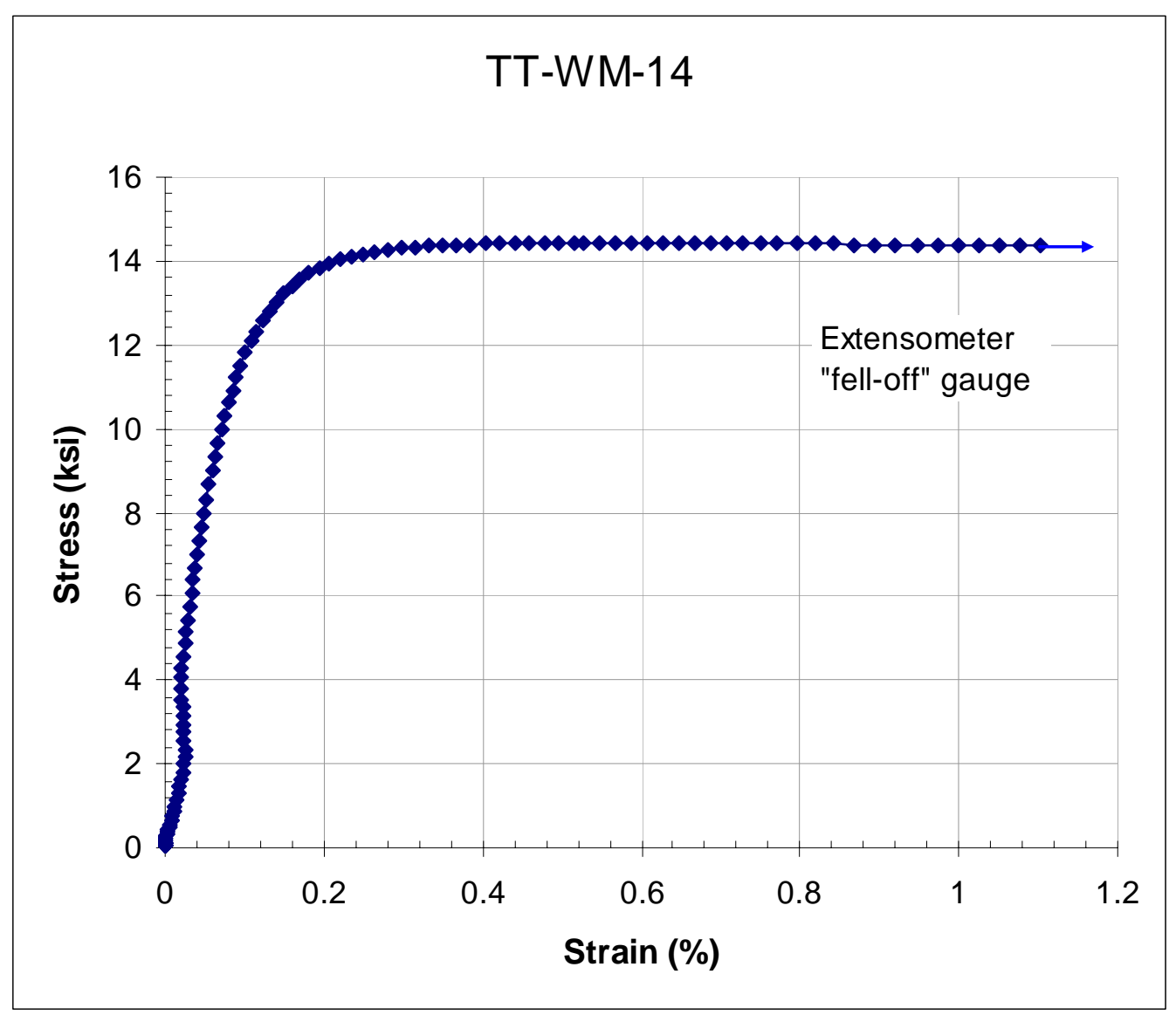




\begin{tabular}{|c|c|c|c|c|c|c|c|c|c|c|c|}
\hline Test ID & $\begin{array}{c}\text { Product } \\
\text { Form }\end{array}$ & $\begin{array}{l}\text { Aging } \\
\text { Temp. } \\
\left({ }^{\circ} \mathrm{C}\right)\end{array}$ & $\begin{array}{l}\text { Aging } \\
\text { Time } \\
\text { (hours) }\end{array}$ & $\begin{array}{r}\text { Test } \\
\text { Temp. } \\
\left({ }^{\circ} \mathrm{C}\right) \\
\end{array}$ & $\begin{array}{r}\text { Prop. } \\
\text { Limit } \\
(\mathrm{MPa})\end{array}$ & $\begin{array}{r}\text { Yield } \\
\text { Strength } \\
(\mathrm{MPa})\end{array}$ & $\begin{array}{r}\text { Ultimate } \\
\text { Tensile } \\
\text { Strength } \\
(\mathrm{MPa})\end{array}$ & $\begin{array}{r}\text { Uniform } \\
\text { Elong. } \\
(\%)\end{array}$ & $\begin{array}{r}\text { Elong. } \\
(\%)\end{array}$ & $\begin{array}{r}\text { Red. } \\
\text { of } \\
\text { Area } \\
(\%) \\
\end{array}$ & $\begin{array}{c}\text { Failure } \\
\text { Location }\end{array}$ \\
\hline TT-WM-15 & $\begin{array}{l}\text { Sheet } \\
\text { Weld }\end{array}$ & 675 & 12000 & 23 & 414 & 753 & 1009 & 5.0 & 5.0 & 6.3 & $\mathrm{BM}$ \\
\hline
\end{tabular}

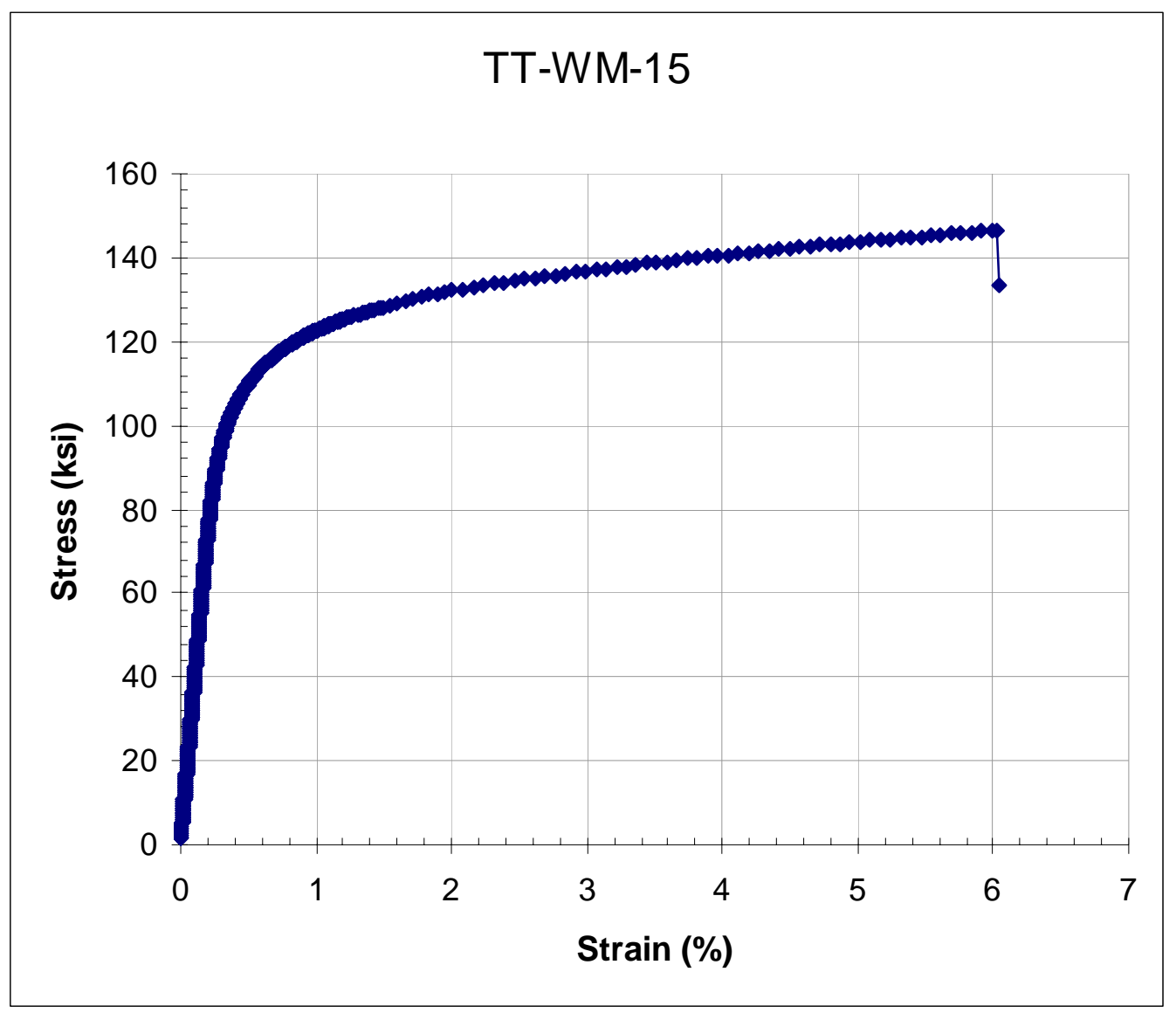




\begin{tabular}{|c|c|c|c|c|c|c|c|c|c|c|c|}
\hline Test ID & $\begin{array}{c}\text { Product } \\
\text { Form }\end{array}$ & $\begin{array}{l}\text { Aging } \\
\text { Temp. } \\
\left({ }^{\circ} \mathrm{C}\right)\end{array}$ & $\begin{array}{l}\text { Aging } \\
\text { Time } \\
\text { (hours) }\end{array}$ & $\begin{array}{r}\text { Test } \\
\text { Temp. } \\
\left({ }^{\circ} \mathrm{C}\right) \\
\end{array}$ & $\begin{array}{r}\text { Prop. } \\
\text { Limit } \\
(\mathrm{MPa})\end{array}$ & $\begin{array}{r}\text { Yield } \\
\text { Strength } \\
(\mathrm{MPa})\end{array}$ & $\begin{array}{r}\text { Ultimate } \\
\text { Tensile } \\
\text { Strength } \\
(\mathrm{MPa})\end{array}$ & $\begin{array}{r}\text { Uniform } \\
\text { Elong. } \\
(\%)\end{array}$ & $\begin{array}{r}\text { Elong. } \\
(\%)\end{array}$ & $\begin{array}{r}\text { Red. } \\
\text { of } \\
\text { Area } \\
(\%)\end{array}$ & $\begin{array}{c}\text { Failure } \\
\text { Location }\end{array}$ \\
\hline TT-WM-16 & $\begin{array}{l}\text { Sheet } \\
\text { Weld }\end{array}$ & 675 & 12000 & 300 & 372 & 615 & 926 & 7.8 & 7.8 & 8.4 & $\mathrm{BM}$ \\
\hline
\end{tabular}

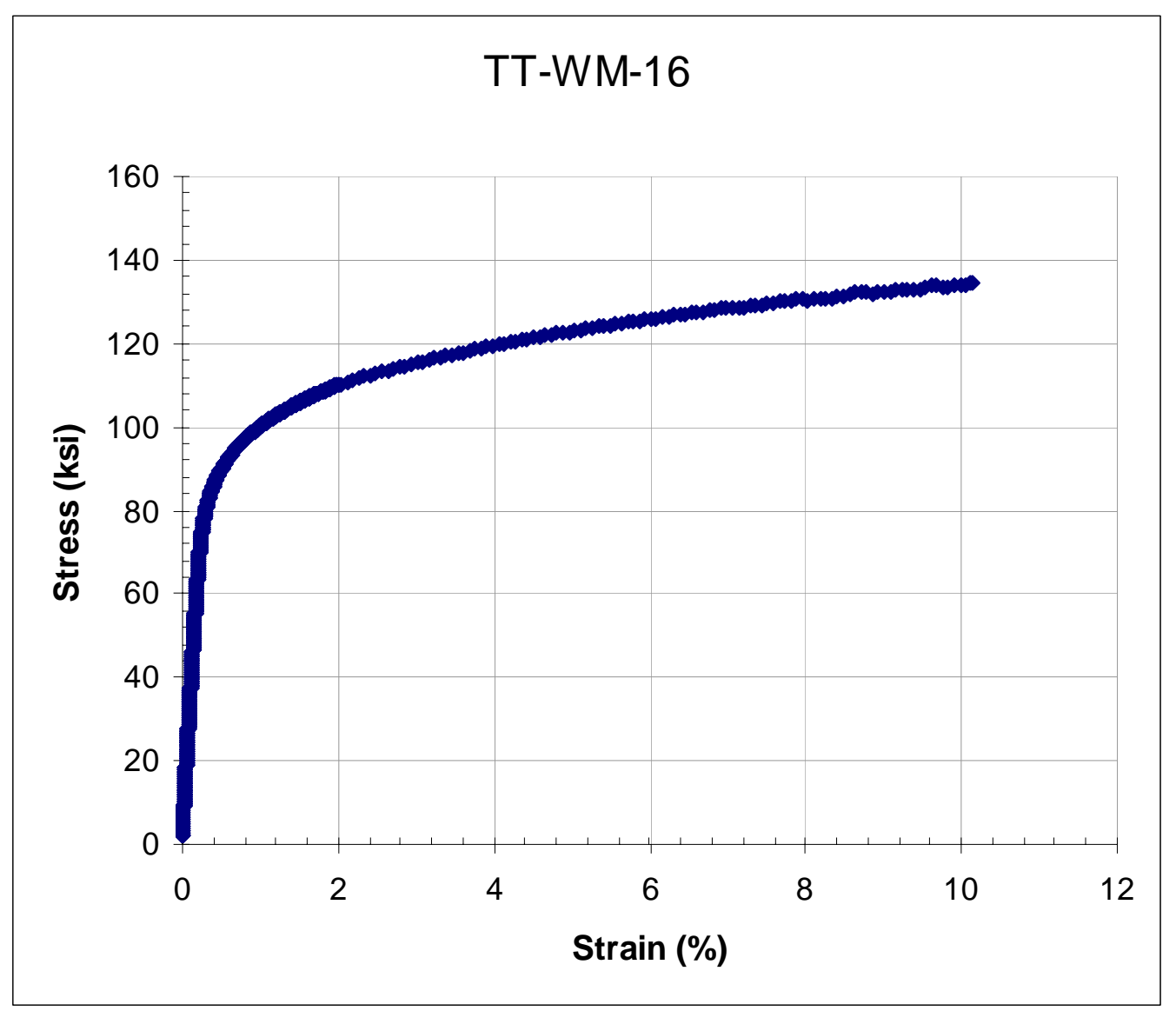




\begin{tabular}{|c|c|c|c|c|c|c|c|c|c|c|c|}
\hline Test ID & $\begin{array}{c}\text { Product } \\
\text { Form }\end{array}$ & $\begin{array}{l}\text { Aging } \\
\text { Temp. } \\
\left({ }^{\circ} \mathrm{C}\right)\end{array}$ & $\begin{array}{l}\text { Aging } \\
\text { Time } \\
\text { (hours) }\end{array}$ & $\begin{array}{r}\text { Test } \\
\text { Temp. } \\
\left({ }^{\circ} \mathrm{C}\right) \\
\end{array}$ & $\begin{array}{r}\text { Prop. } \\
\text { Limit } \\
(\mathrm{MPa})\end{array}$ & $\begin{array}{r}\text { Yield } \\
\text { Strength } \\
(\mathrm{MPa})\end{array}$ & $\begin{array}{r}\text { Ultimate } \\
\text { Tensile } \\
\text { Strength } \\
(\mathrm{MPa})\end{array}$ & $\begin{array}{r}\text { Uniform } \\
\text { Elong. } \\
(\%)\end{array}$ & $\begin{array}{r}\text { Elong. } \\
(\%)\end{array}$ & $\begin{array}{r}\text { Red. } \\
\text { of } \\
\text { Area } \\
(\%) \\
\end{array}$ & $\begin{array}{c}\text { Failure } \\
\text { Location }\end{array}$ \\
\hline TT-WM-17 & $\begin{array}{l}\text { Sheet } \\
\text { Weld }\end{array}$ & 675 & 12000 & 500 & 310 & 564 & 918 & 12.0 & 12.0 & 13.3 & $\mathrm{BM}$ \\
\hline
\end{tabular}

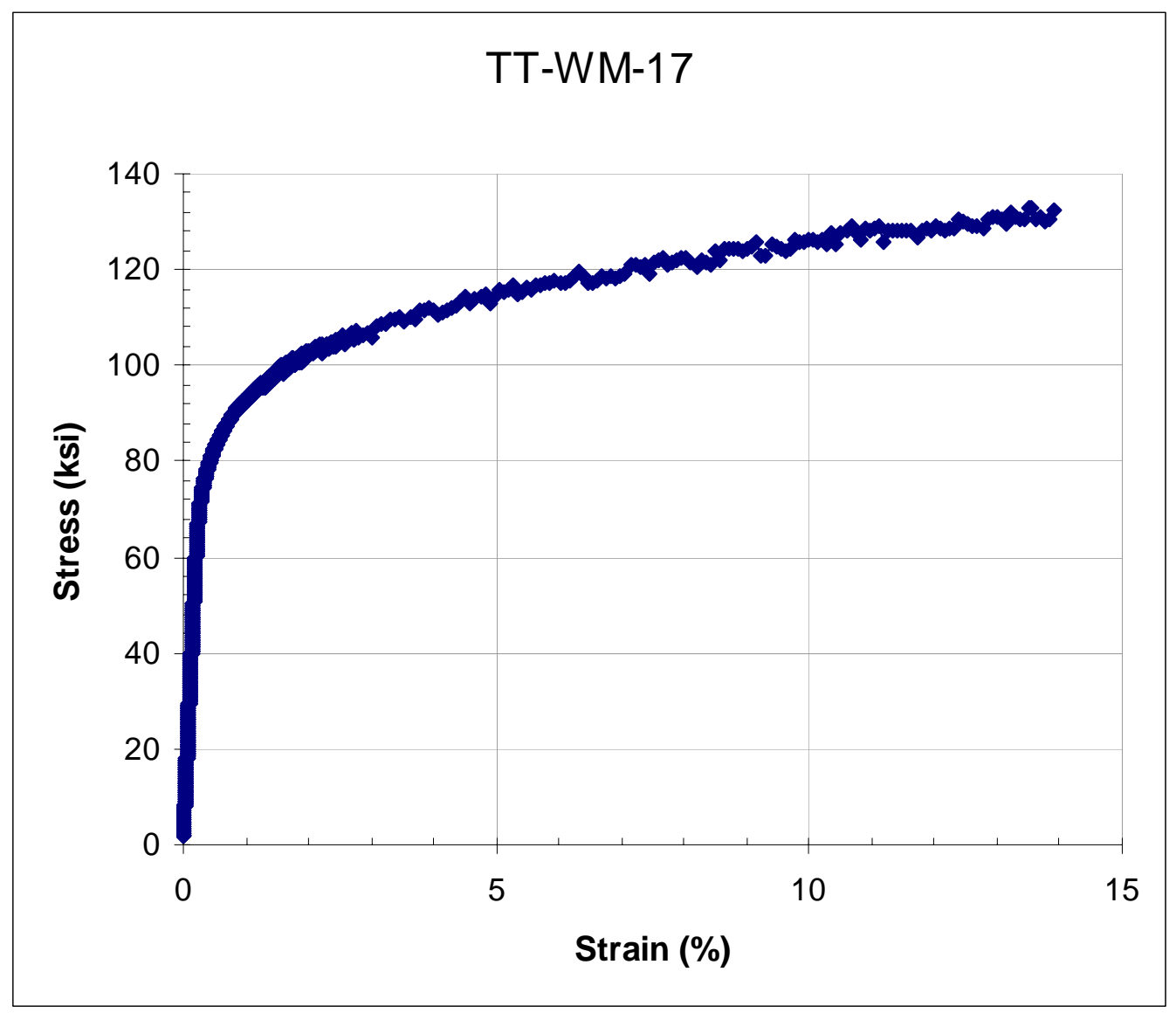




\begin{tabular}{|c|c|c|c|c|c|c|c|c|c|c|c|}
\hline Test ID & $\begin{array}{c}\text { Product } \\
\text { Form }\end{array}$ & $\begin{array}{l}\text { Aging } \\
\text { Temp. } \\
\left({ }^{\circ} \mathrm{C}\right)\end{array}$ & $\begin{array}{l}\text { Aging } \\
\text { Time } \\
\text { (hours) }\end{array}$ & $\begin{array}{r}\text { Test } \\
\text { Temp. } \\
\left({ }^{\circ} \mathrm{C}\right) \\
\end{array}$ & $\begin{array}{r}\text { Prop. } \\
\text { Limit } \\
(\mathrm{MPa})\end{array}$ & $\begin{array}{r}\text { Yield } \\
\text { Strength } \\
(\mathrm{MPa})\end{array}$ & $\begin{array}{r}\text { Ultimate } \\
\text { Tensile } \\
\text { Strength } \\
(\mathrm{MPa})\end{array}$ & $\begin{array}{r}\text { Uniform } \\
\text { Elong. } \\
(\%)\end{array}$ & $\begin{array}{r}\text { Elong. } \\
(\%)\end{array}$ & $\begin{array}{r}\text { Red. } \\
\text { of } \\
\text { Area } \\
(\%) \\
\end{array}$ & $\begin{array}{c}\text { Failure } \\
\text { Location }\end{array}$ \\
\hline TT-WM-18 & $\begin{array}{l}\text { Sheet } \\
\text { Weld }\end{array}$ & 675 & 12000 & 650 & 310 & 572 & 899 & 11.0 & 11.0 & 12.2 & $\mathrm{BM}$ \\
\hline
\end{tabular}

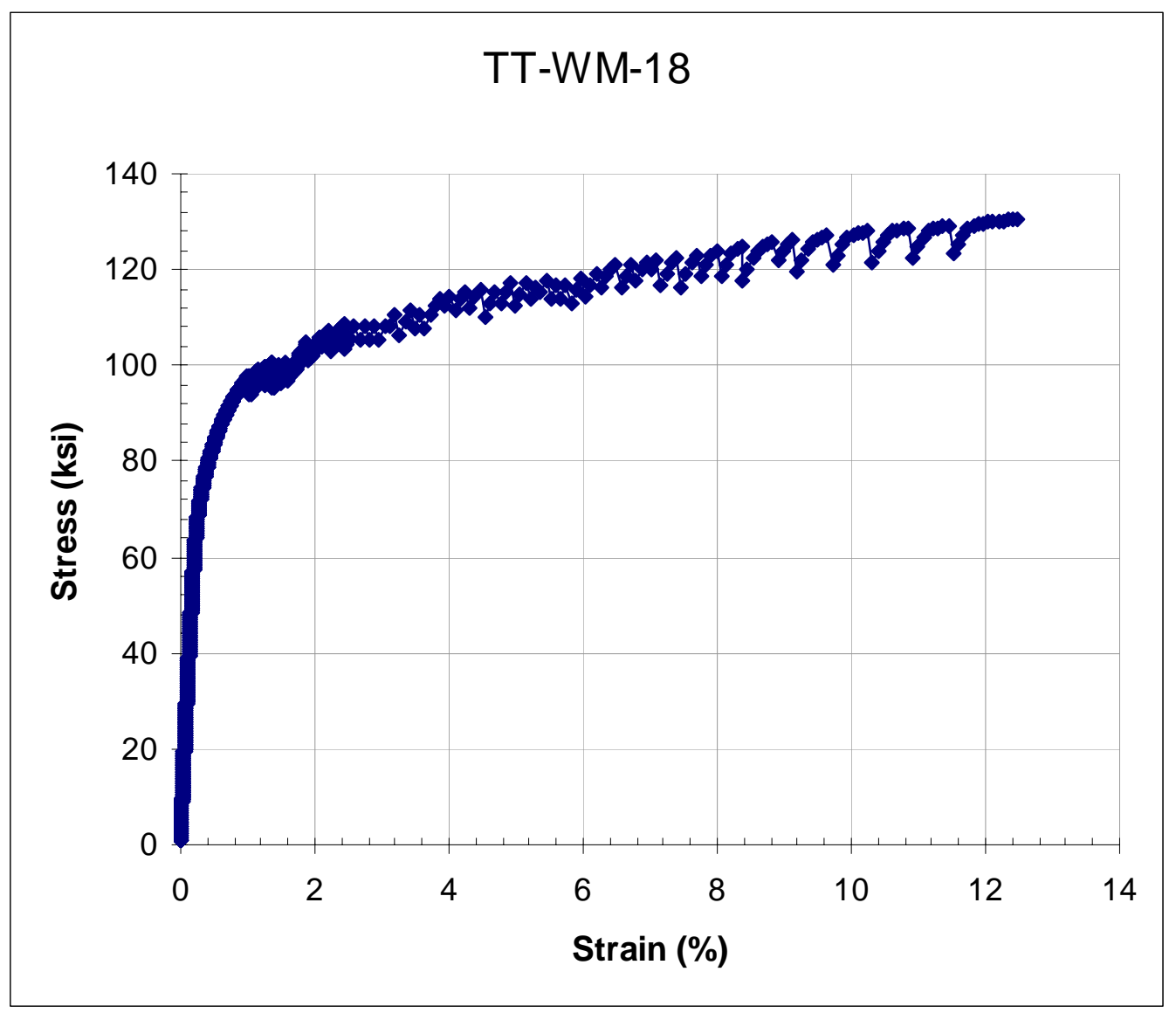




\begin{tabular}{|c|c|c|c|c|c|c|c|c|c|c|c|}
\hline Test ID & $\begin{array}{c}\text { Product } \\
\text { Form }\end{array}$ & $\begin{array}{l}\text { Aging } \\
\text { Temp. } \\
\left({ }^{\circ} \mathrm{C}\right)\end{array}$ & $\begin{array}{l}\text { Aging } \\
\text { Time } \\
\text { (hours) }\end{array}$ & $\begin{array}{r}\text { Test } \\
\text { Temp. } \\
\left({ }^{\circ} \mathrm{C}\right) \\
\end{array}$ & $\begin{array}{r}\text { Prop. } \\
\text { Limit } \\
(\mathrm{MPa})\end{array}$ & $\begin{array}{r}\text { Yield } \\
\text { Strength } \\
(\mathrm{MPa})\end{array}$ & $\begin{array}{r}\text { Ultimate } \\
\text { Tensile } \\
\text { Strength } \\
(\mathrm{MPa})\end{array}$ & $\begin{array}{r}\text { Uniform } \\
\text { Elong. } \\
(\%)\end{array}$ & $\begin{array}{r}\text { Elong. } \\
(\%)\end{array}$ & $\begin{array}{r}\text { Red. } \\
\text { of } \\
\text { Area } \\
(\%)\end{array}$ & $\begin{array}{c}\text { Failure } \\
\text { Location }\end{array}$ \\
\hline TT-WM-19 & $\begin{array}{l}\text { Sheet } \\
\text { Weld }\end{array}$ & 675 & 12000 & 800 & 193 & 438 & 562 & 2.8 & 8.7 & 10.9 & $\mathrm{BM}$ \\
\hline
\end{tabular}

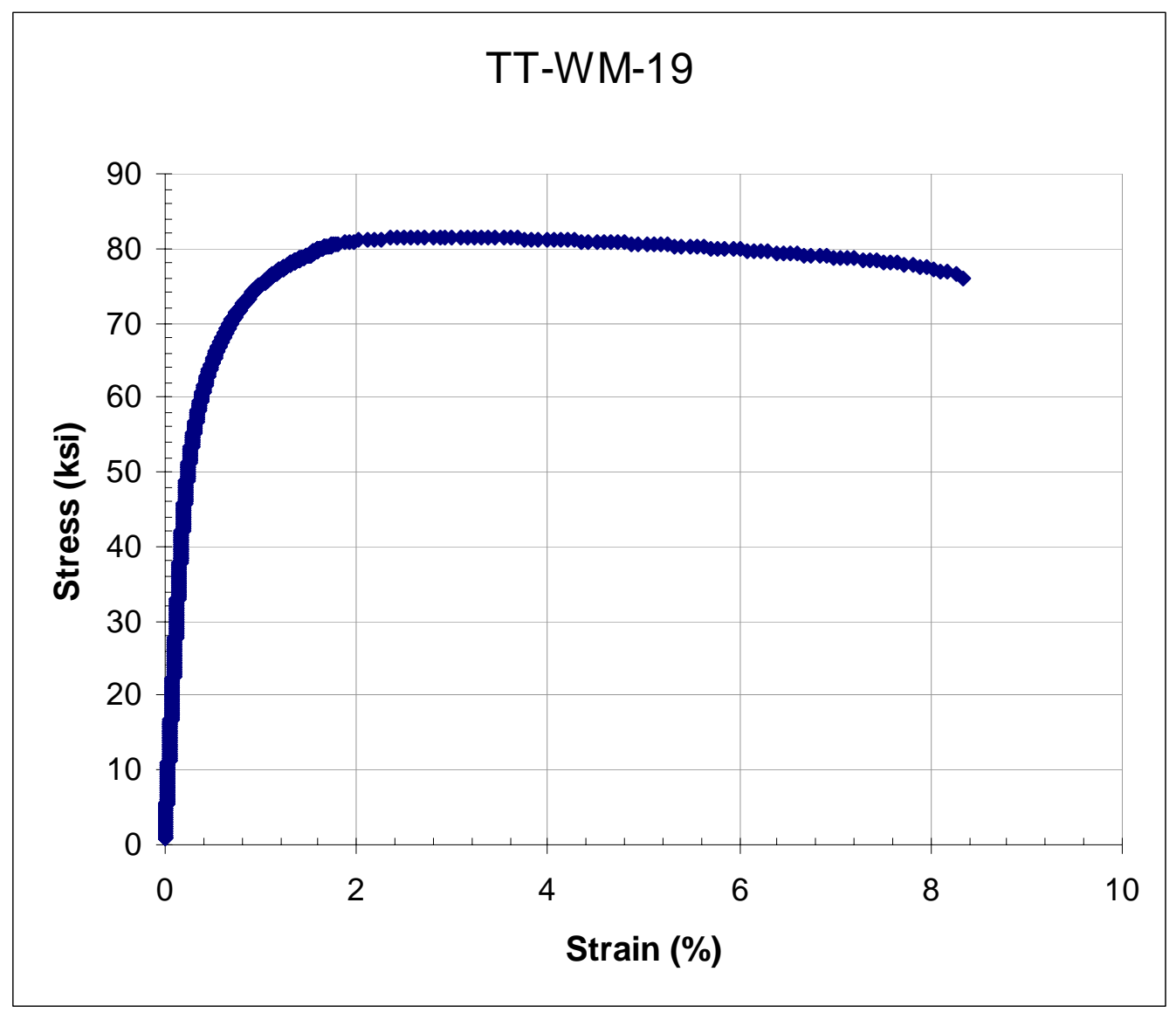




\begin{tabular}{|c|c|c|c|r|r|r|r|r|r|r|r|}
\hline Test ID & $\begin{array}{c}\text { Product } \\
\text { Form }\end{array}$ & $\begin{array}{c}\text { Aging } \\
\text { Temp. } \\
\left({ }^{\circ} \mathrm{C}\right)\end{array}$ & $\begin{array}{c}\text { Aging } \\
\text { Time } \\
\text { (hours) }\end{array}$ & $\begin{array}{r}\text { Test } \\
\text { Temp. } \\
\left({ }^{\circ} \mathrm{C}\right)\end{array}$ & $\begin{array}{r}\text { Prop. } \\
\text { Limit } \\
(\mathrm{MPa})\end{array}$ & $\begin{array}{r}\text { Yield } \\
\text { Strength } \\
(\mathrm{MPa})\end{array}$ & $\begin{array}{r}\text { Ultimate } \\
\text { Tensile } \\
\text { Strength } \\
(\mathrm{MPa})\end{array}$ & $\begin{array}{r}\text { Uniform } \\
\text { Elong. } \\
(\%)\end{array}$ & $\begin{array}{r}\text { Red. } \\
\text { of } \\
\text { Elong. } \\
(\%)\end{array}$ & $\begin{array}{r}\text { Area } \\
(\%)\end{array}$ & $\begin{array}{r}\text { Failure } \\
\text { Location }\end{array}$ \\
\hline TT-WM-20 & $\begin{array}{l}\text { Sheet } \\
\text { Weld }\end{array}$ & 675 & 12000 & 1000 & & 171 & 172 & 0.3 & 38.6 & 37.1 & BM \\
\hline
\end{tabular}

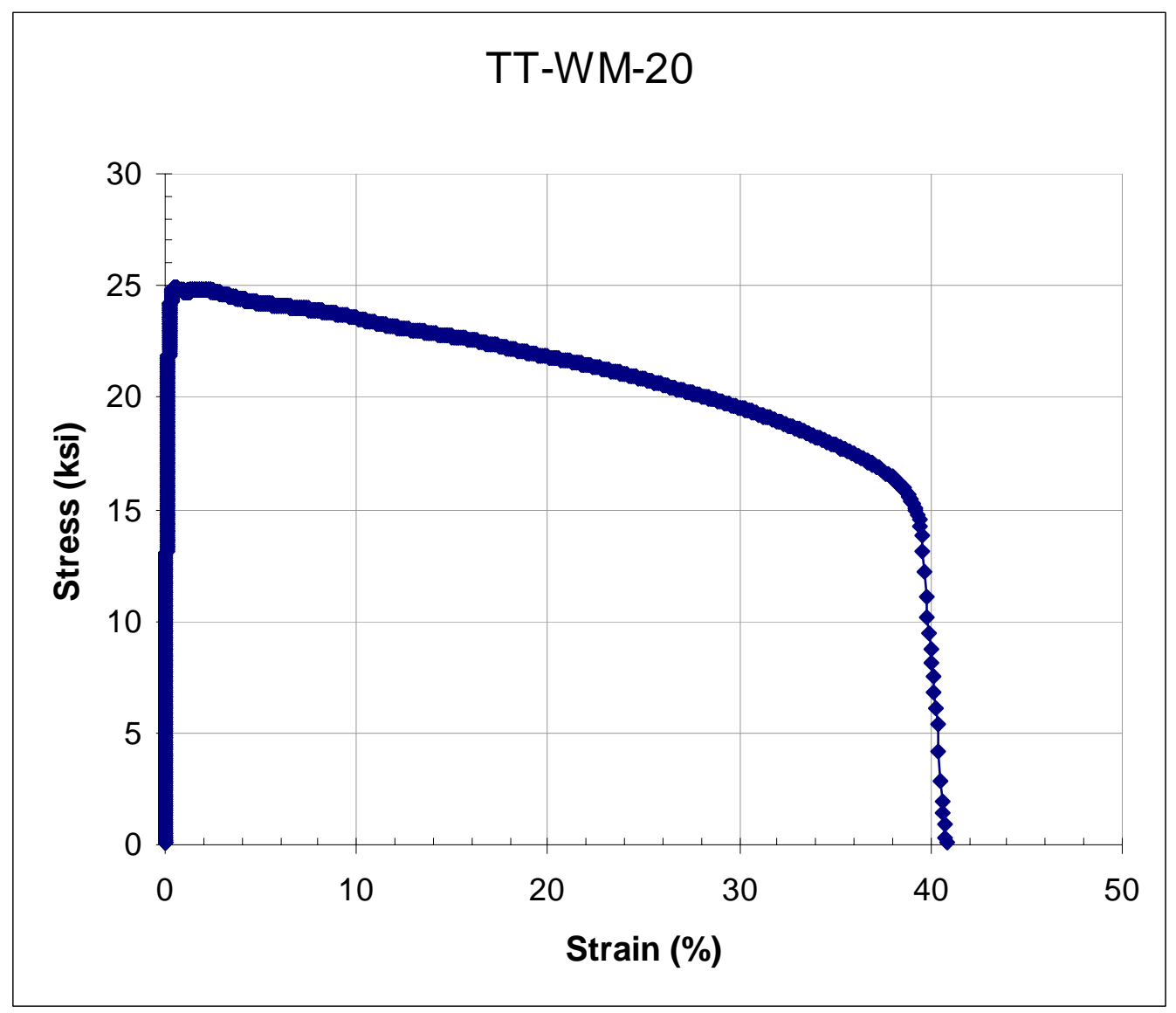




\begin{tabular}{|c|c|c|c|c|c|c|c|c|c|c|c|}
\hline Test ID & $\begin{array}{c}\text { Product } \\
\text { Form }\end{array}$ & $\begin{array}{l}\text { Aging } \\
\text { Temp. } \\
\left({ }^{\circ} \mathrm{C}\right)\end{array}$ & $\begin{array}{l}\text { Aging } \\
\text { Time } \\
\text { (hours) }\end{array}$ & $\begin{array}{r}\text { Test } \\
\text { Temp. } \\
\left({ }^{\circ} \mathrm{C}\right) \\
\end{array}$ & $\begin{array}{l}\text { Prop. } \\
\text { Limit } \\
(\mathrm{MPa})\end{array}$ & $\begin{array}{r}\text { Yield } \\
\text { Strength } \\
(\mathrm{MPa})\end{array}$ & $\begin{array}{r}\text { Ultimate } \\
\text { Tensile } \\
\text { Strength } \\
(\mathrm{MPa})\end{array}$ & $\begin{array}{r}\text { Uniform } \\
\text { Elong. } \\
(\%)\end{array}$ & $\begin{array}{r}\text { Elong. } \\
(\%)\end{array}$ & $\begin{array}{r}\text { Red. } \\
\text { of } \\
\text { Area } \\
(\%)\end{array}$ & $\begin{array}{c}\text { Failure } \\
\text { Location }\end{array}$ \\
\hline TT-WM-21 & $\begin{array}{l}\text { Sheet } \\
\text { Weld }\end{array}$ & 675 & 12000 & 1100 & & 101 & 101 & 0.3 & 43.8 & 33.4 & BM \\
\hline
\end{tabular}

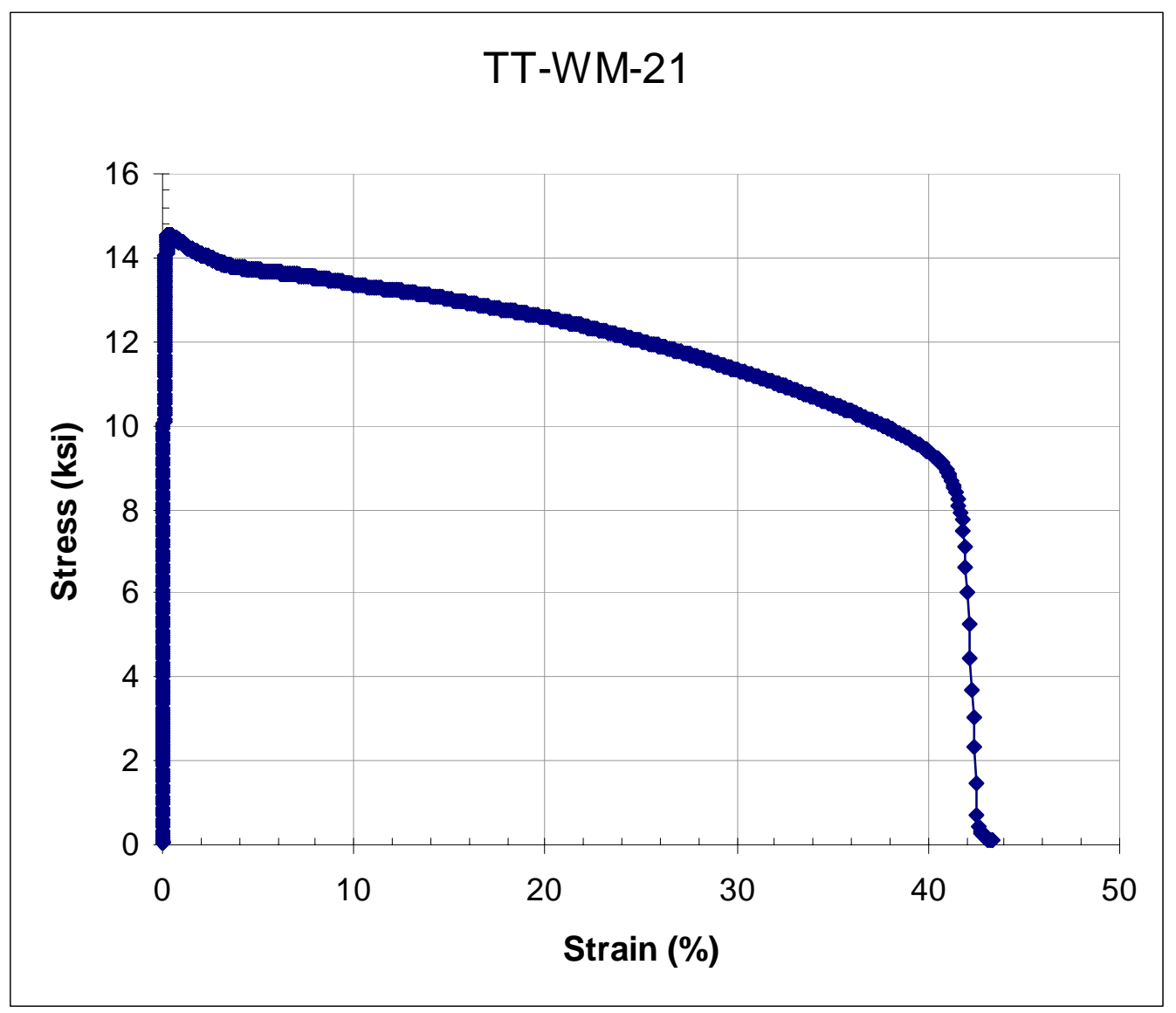




\begin{tabular}{|c|c|c|c|c|c|c|c|c|c|c|c|}
\hline Test ID & $\begin{array}{l}\text { Product } \\
\text { Form }\end{array}$ & $\begin{array}{l}\text { Aging } \\
\text { Temp. } \\
\left({ }^{\circ} \mathrm{C}\right)\end{array}$ & $\begin{array}{l}\text { Aging } \\
\text { Time } \\
\text { (hours) }\end{array}$ & $\begin{array}{r}\text { Test } \\
\text { Temp. } \\
\left({ }^{\circ} \mathrm{C}\right) \\
\end{array}$ & $\begin{array}{r}\text { Prop. } \\
\text { Limit } \\
(\mathrm{MPa})\end{array}$ & $\begin{array}{r}\text { Yield } \\
\text { Strength } \\
(\mathrm{MPa}) \\
\end{array}$ & $\begin{array}{r}\text { Ultimate } \\
\text { Tensile } \\
\text { Strength } \\
(\mathrm{MPa})\end{array}$ & $\begin{array}{r}\text { Uniform } \\
\text { Elong. } \\
(\%)\end{array}$ & $\begin{array}{r}\text { Elong. } \\
(\%)\end{array}$ & $\begin{array}{r}\text { Red. } \\
\text { of } \\
\text { Area } \\
(\%) \\
\end{array}$ & $\begin{array}{c}\text { Failure } \\
\text { Location }\end{array}$ \\
\hline LWT-1 & Bar Weld & none & none & 20 & & 595 & 1147 & 629.0 & 63.1 & & WM \\
\hline
\end{tabular}

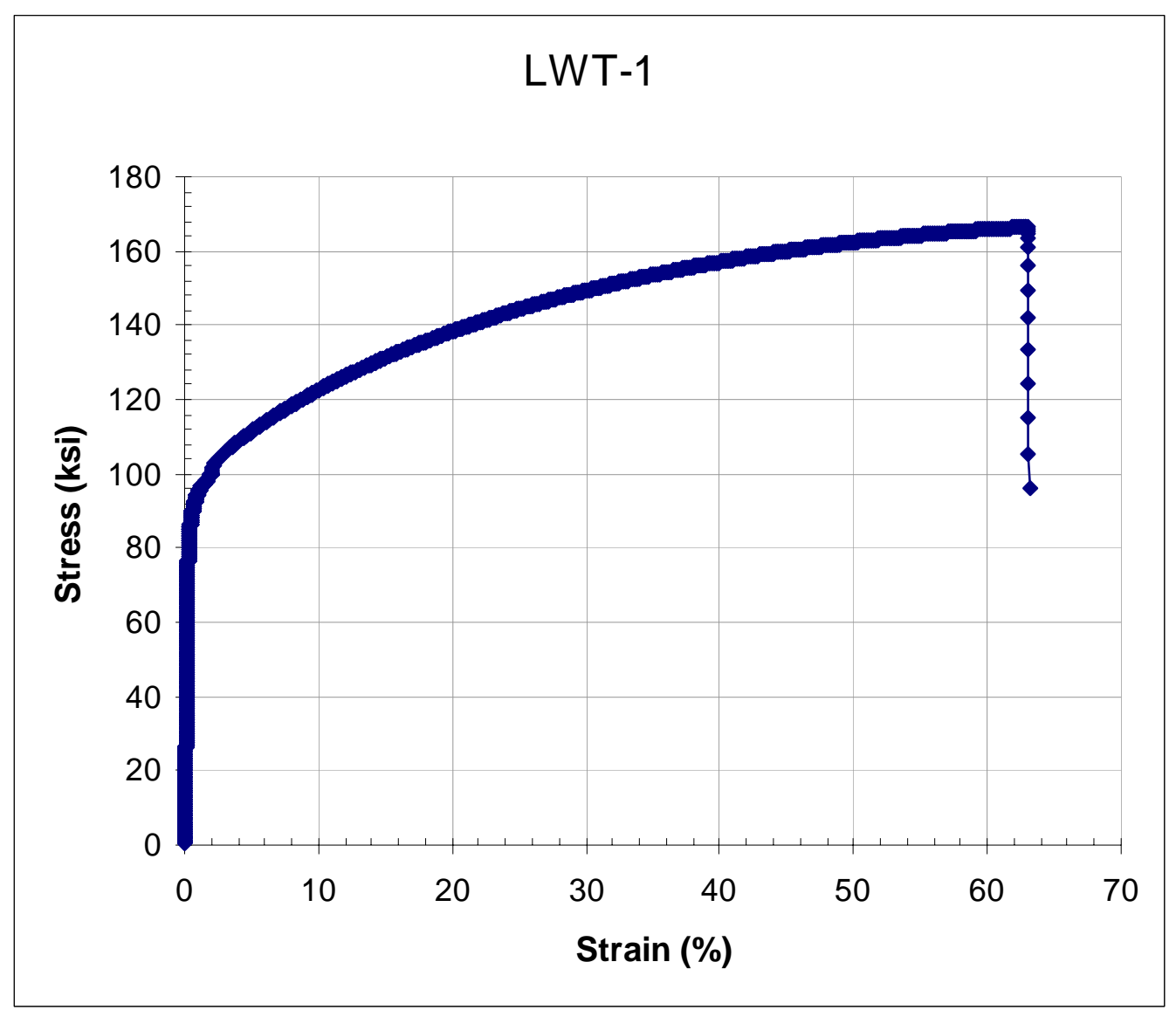




\begin{tabular}{|c|c|c|c|c|c|c|c|c|c|c|c|}
\hline Test ID & $\begin{array}{l}\text { Product } \\
\text { Form }\end{array}$ & $\begin{array}{l}\text { Aging } \\
\text { Temp. } \\
\left({ }^{\circ} \mathrm{C}\right)\end{array}$ & $\begin{array}{l}\text { Aging } \\
\text { Time } \\
\text { (hours) }\end{array}$ & $\begin{array}{r}\text { Test } \\
\text { Temp. } \\
\left({ }^{\circ} \mathrm{C}\right)\end{array}$ & $\begin{array}{l}\text { Prop. } \\
\text { Limit } \\
(\mathrm{MPa})\end{array}$ & $\begin{array}{r}\text { Yield } \\
\text { Strength } \\
(\mathrm{MPa}) \\
\end{array}$ & $\begin{array}{r}\text { Ultimate } \\
\text { Tensile } \\
\text { Strength } \\
(\mathrm{MPa})\end{array}$ & $\begin{array}{r}\text { Uniform } \\
\text { Elong. } \\
(\%)\end{array}$ & $\begin{array}{r}\text { Elong. } \\
(\%)\end{array}$ & $\begin{array}{r}\text { Red. } \\
\text { of } \\
\text { Area } \\
(\%) \\
\end{array}$ & $\begin{array}{c}\text { Failure } \\
\text { Location }\end{array}$ \\
\hline AWT-1 & Bar Weld & none & none & 20 & & 593 & 1122 & 53.7 & 56.8 & & WM \\
\hline
\end{tabular}

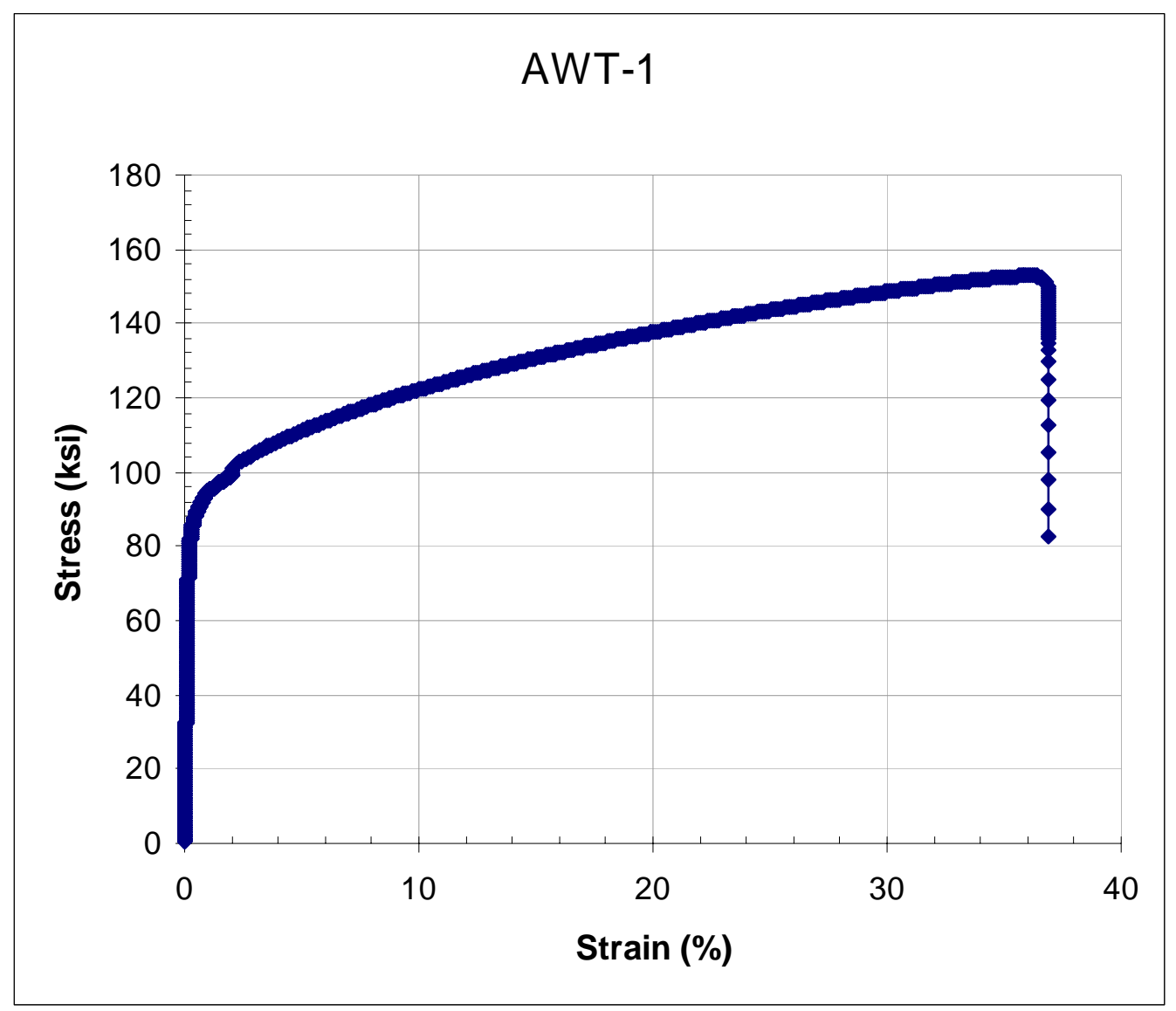




\begin{tabular}{|c|c|c|c|c|c|c|c|c|c|c|c|}
\hline Test ID & $\begin{array}{l}\text { Product } \\
\text { Form }\end{array}$ & $\begin{array}{l}\text { Aging } \\
\text { Temp. } \\
\left({ }^{\circ} \mathrm{C}\right)\end{array}$ & $\begin{array}{l}\text { Aging } \\
\text { Time } \\
\text { (hours) }\end{array}$ & $\begin{array}{r}\text { Test } \\
\text { Temp. } \\
\left({ }^{\circ} \mathrm{C}\right) \\
\end{array}$ & $\begin{array}{r}\text { Prop. } \\
\text { Limit } \\
(\mathrm{MPa})\end{array}$ & $\begin{array}{r}\text { Yield } \\
\text { Strength } \\
(\mathrm{MPa}) \\
\end{array}$ & $\begin{array}{r}\text { Ultimate } \\
\text { Tensile } \\
\text { Strength } \\
(\mathrm{MPa})\end{array}$ & $\begin{array}{r}\text { Uniform } \\
\text { Elong. } \\
(\%) \\
\end{array}$ & $\begin{array}{r}\text { Elong. } \\
(\%)\end{array}$ & $\begin{array}{r}\text { Red. } \\
\text { of } \\
\text { Area } \\
(\%) \\
\end{array}$ & $\begin{array}{c}\text { Failure } \\
\text { Location }\end{array}$ \\
\hline LWT-2 & Bar Weld & none & none & 650 & & 330 & 736 & 25.5 & 26.2 & & WM \\
\hline
\end{tabular}

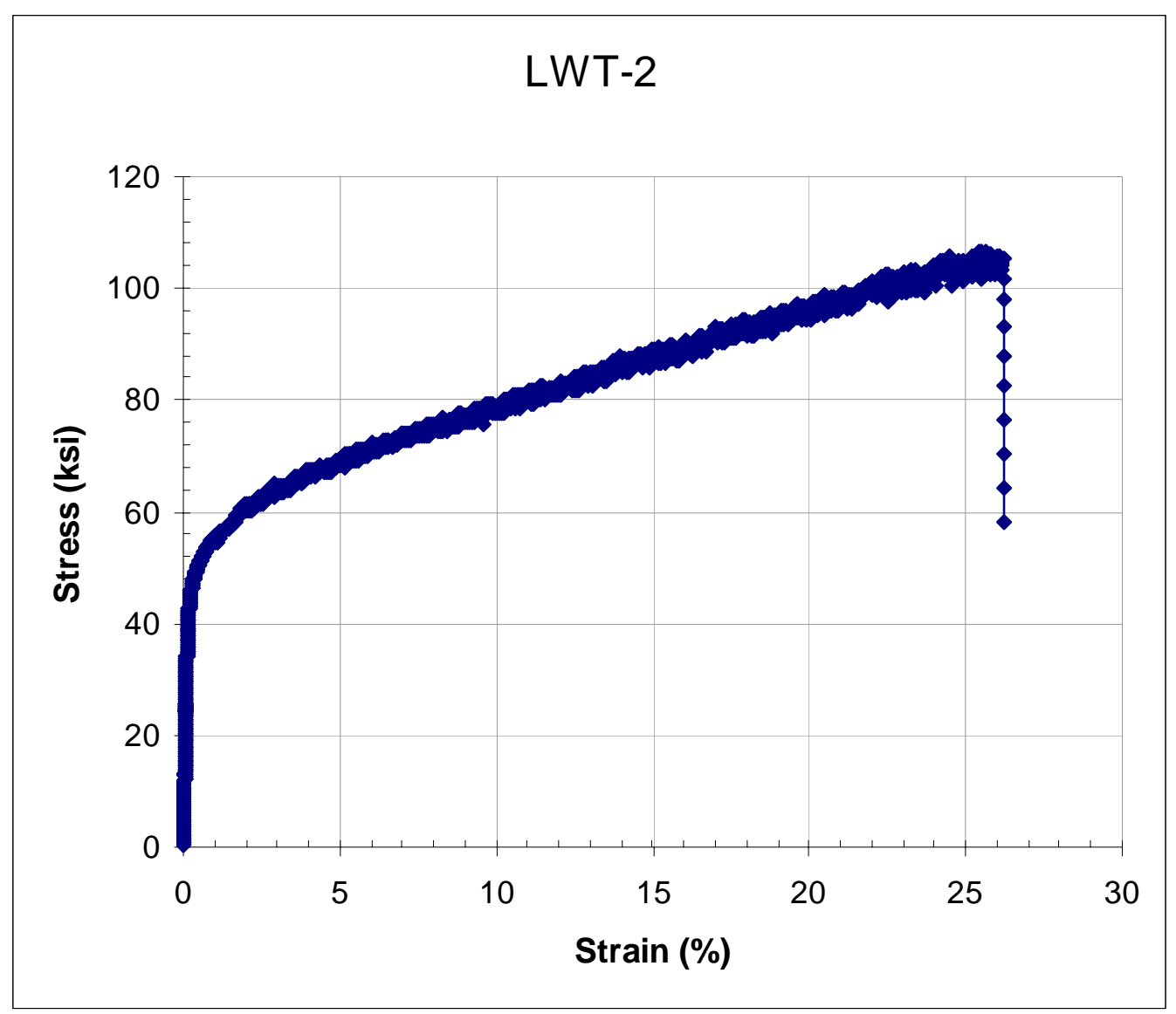




\begin{tabular}{|c|c|c|c|c|c|c|c|c|c|c|c|}
\hline Test ID & $\begin{array}{l}\text { Product } \\
\text { Form }\end{array}$ & $\begin{array}{l}\text { Aging } \\
\text { Temp. } \\
\left({ }^{\circ} \mathrm{C}\right)\end{array}$ & $\begin{array}{l}\text { Aging } \\
\text { Time } \\
\text { (hours) }\end{array}$ & $\begin{array}{r}\text { Test } \\
\text { Temp. } \\
\left({ }^{\circ} \mathrm{C}\right)\end{array}$ & $\begin{array}{l}\text { Prop. } \\
\text { Limit } \\
(\mathrm{MPa})\end{array}$ & $\begin{array}{r}\text { Yield } \\
\text { Strength } \\
(\mathrm{MPa}) \\
\end{array}$ & $\begin{array}{r}\text { Ultimate } \\
\text { Tensile } \\
\text { Strength } \\
(\mathrm{MPa})\end{array}$ & $\begin{array}{r}\text { Uniform } \\
\text { Elong. } \\
(\%)\end{array}$ & $\begin{array}{r}\text { Elong. } \\
(\%)\end{array}$ & $\begin{array}{r}\text { Red. } \\
\text { of } \\
\text { Area } \\
(\%) \\
\end{array}$ & $\begin{array}{c}\text { Failure } \\
\text { Location }\end{array}$ \\
\hline AWT-2 & Bar Weld & none & none & 650 & & 367 & 851 & 47.7 & 47.4 & & WM \\
\hline
\end{tabular}

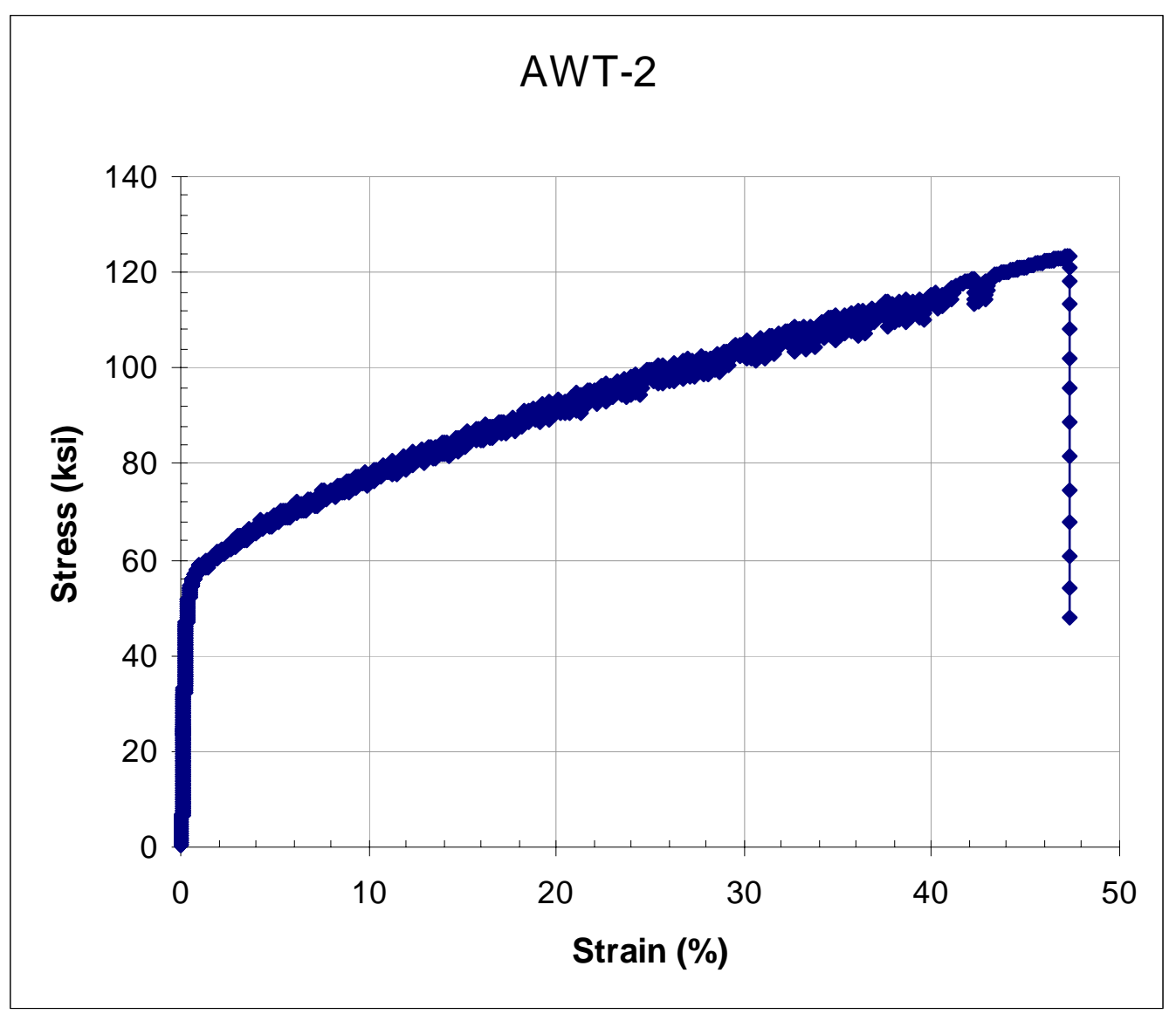




\begin{tabular}{|c|c|c|c|c|c|c|c|c|c|c|c|}
\hline Test ID & $\begin{array}{l}\text { Product } \\
\text { Form }\end{array}$ & $\begin{array}{l}\text { Aging } \\
\text { Temp. } \\
\left({ }^{\circ} \mathrm{C}\right)\end{array}$ & $\begin{array}{l}\text { Aging } \\
\text { Time } \\
\text { (hours) }\end{array}$ & $\begin{array}{r}\text { Test } \\
\text { Temp. } \\
\left({ }^{\circ} \mathrm{C}\right) \\
\end{array}$ & $\begin{array}{r}\text { Prop. } \\
\text { Limit } \\
(\mathrm{MPa})\end{array}$ & $\begin{array}{r}\text { Yield } \\
\text { Strength } \\
(\mathrm{MPa}) \\
\end{array}$ & $\begin{array}{r}\text { Ultimate } \\
\text { Tensile } \\
\text { Strength } \\
(\mathrm{MPa})\end{array}$ & $\begin{array}{r}\text { Uniform } \\
\text { Elong. } \\
(\%) \\
\end{array}$ & $\begin{array}{r}\text { Elong. } \\
(\%)\end{array}$ & $\begin{array}{r}\text { Red. } \\
\text { of } \\
\text { Area } \\
(\%) \\
\end{array}$ & $\begin{array}{c}\text { Failure } \\
\text { Location }\end{array}$ \\
\hline LWT-3 & Bar Weld & 850 & 50 & 20 & & 533 & 1012 & 30.0 & 30.0 & & WM \\
\hline
\end{tabular}

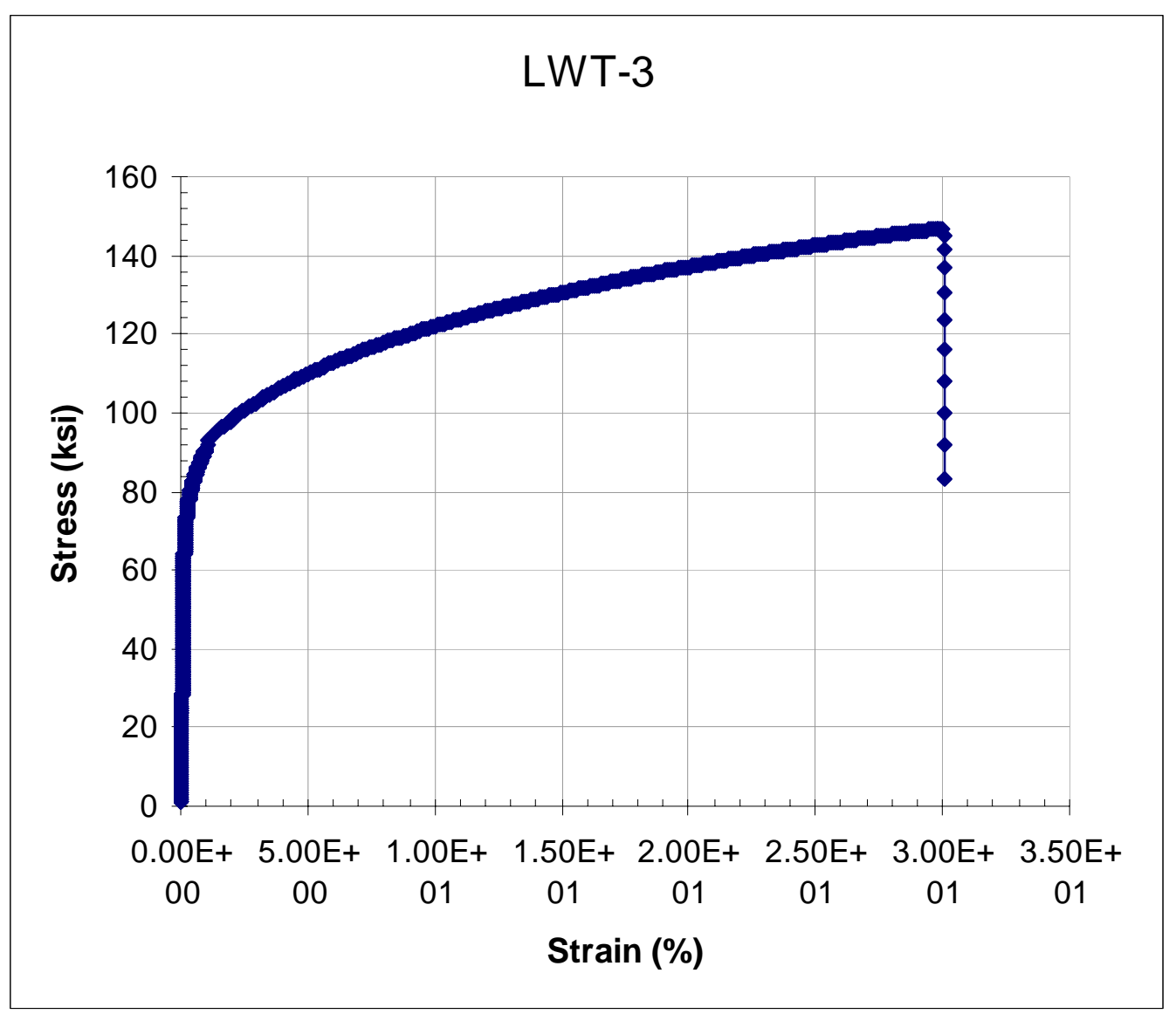




\begin{tabular}{|c|c|c|c|c|c|c|c|c|c|c|c|}
\hline Test ID & $\begin{array}{l}\text { Product } \\
\text { Form }\end{array}$ & $\begin{array}{l}\text { Aging } \\
\text { Temp. } \\
\left({ }^{\circ} \mathrm{C}\right)\end{array}$ & $\begin{array}{l}\text { Aging } \\
\text { Time } \\
\text { (hours) }\end{array}$ & $\begin{array}{r}\text { Test } \\
\text { Temp. } \\
\left({ }^{\circ} \mathrm{C}\right)\end{array}$ & $\begin{array}{l}\text { Prop. } \\
\text { Limit } \\
(\mathrm{MPa})\end{array}$ & $\begin{array}{r}\text { Yield } \\
\text { Strength } \\
(\mathrm{MPa}) \\
\end{array}$ & $\begin{array}{r}\text { Ultimate } \\
\text { Tensile } \\
\text { Strength } \\
(\mathrm{MPa})\end{array}$ & $\begin{array}{r}\text { Uniform } \\
\text { Elong. } \\
(\%)\end{array}$ & $\begin{array}{r}\text { Elong. } \\
(\%)\end{array}$ & $\begin{array}{r}\text { Red. } \\
\text { of } \\
\text { Area } \\
(\%) \\
\end{array}$ & $\begin{array}{c}\text { Failure } \\
\text { Location }\end{array}$ \\
\hline AWT-3 & Bar Weld & 850 & 50 & 20 & & 559 & 1051 & 37.2 & 37.3 & & WM \\
\hline
\end{tabular}

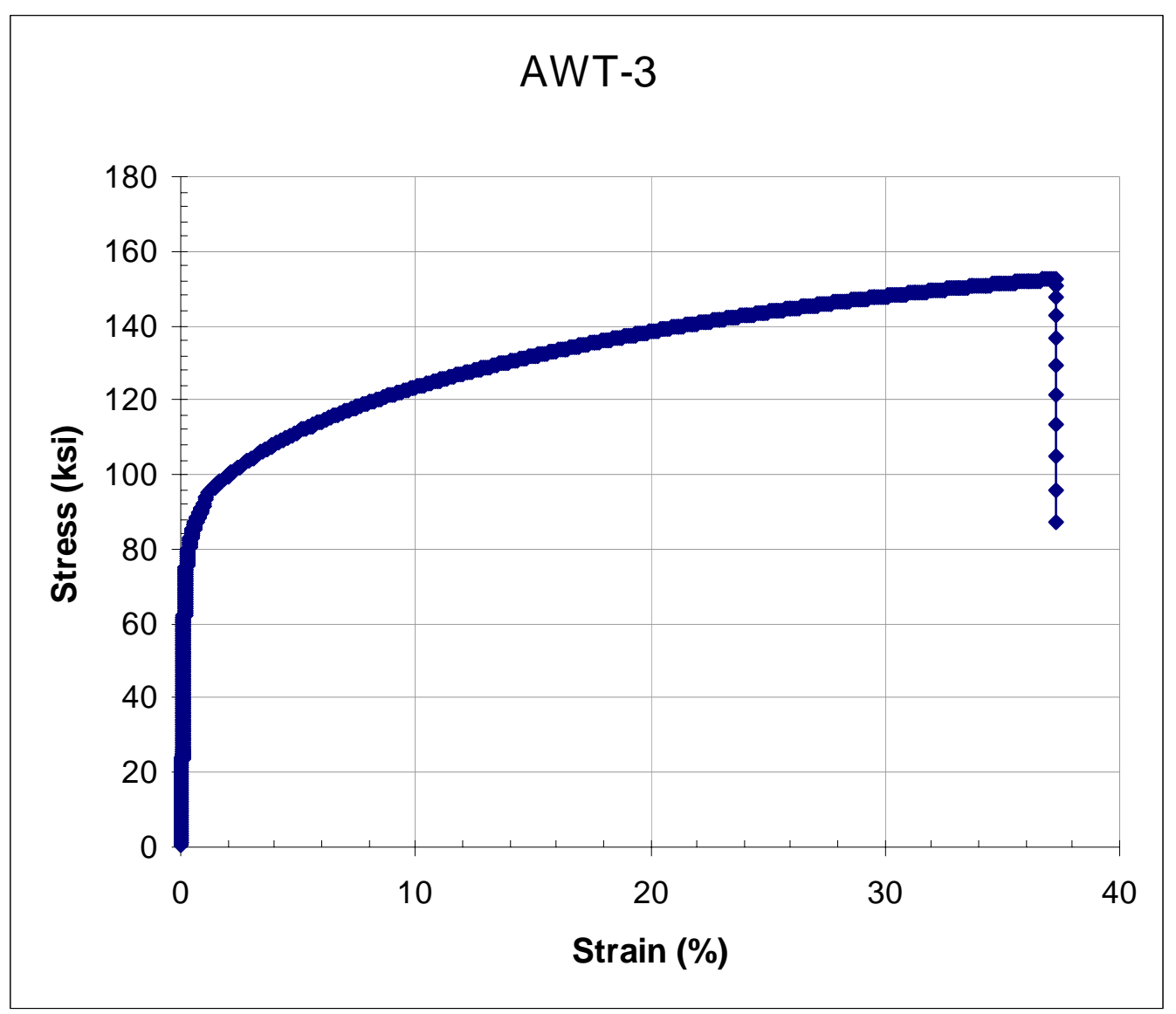




\begin{tabular}{|c|c|c|c|c|c|c|c|c|c|c|c|}
\hline Test ID & $\begin{array}{l}\text { Product } \\
\text { Form }\end{array}$ & $\begin{array}{l}\text { Aging } \\
\text { Temp. } \\
\left({ }^{\circ} \mathrm{C}\right)\end{array}$ & $\begin{array}{l}\text { Aging } \\
\text { Time } \\
\text { (hours) }\end{array}$ & $\begin{array}{r}\text { Test } \\
\text { Temp. } \\
\left({ }^{\circ} \mathrm{C}\right) \\
\end{array}$ & $\begin{array}{r}\text { Prop. } \\
\text { Limit } \\
(\mathrm{MPa})\end{array}$ & $\begin{array}{r}\text { Yield } \\
\text { Strength } \\
(\mathrm{MPa}) \\
\end{array}$ & $\begin{array}{r}\text { Ultimate } \\
\text { Tensile } \\
\text { Strength } \\
(\mathrm{MPa})\end{array}$ & $\begin{array}{r}\text { Uniform } \\
\text { Elong. } \\
(\%)\end{array}$ & $\begin{array}{r}\text { Elong. } \\
(\%)\end{array}$ & $\begin{array}{r}\text { Red. } \\
\text { of } \\
\text { Area } \\
(\%) \\
\end{array}$ & $\begin{array}{c}\text { Failure } \\
\text { Location }\end{array}$ \\
\hline LWT-4 & Bar Weld & 850 & 50 & 650 & & 538 & 831 & 31.7 & 31.7 & & WM \\
\hline
\end{tabular}

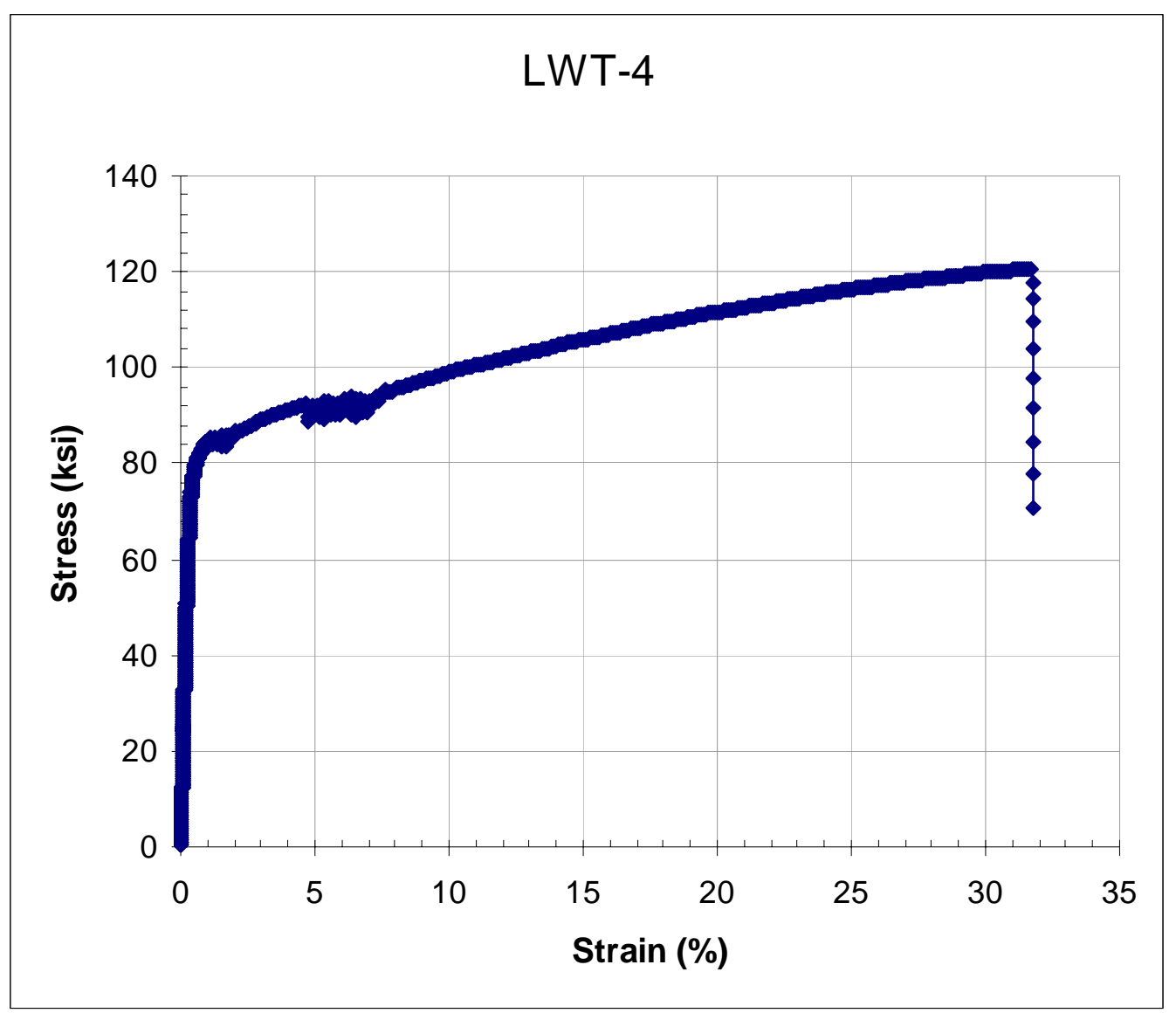




\begin{tabular}{|c|c|c|c|c|c|c|c|c|c|c|c|}
\hline Test ID & $\begin{array}{l}\text { Product } \\
\text { Form }\end{array}$ & $\begin{array}{l}\text { Aging } \\
\text { Temp. } \\
\left({ }^{\circ} \mathrm{C}\right)\end{array}$ & $\begin{array}{l}\text { Aging } \\
\text { Time } \\
\text { (hours) }\end{array}$ & $\begin{array}{r}\text { Test } \\
\text { Temp. } \\
\left({ }^{\circ} \mathrm{C}\right)\end{array}$ & $\begin{array}{l}\text { Prop. } \\
\text { Limit } \\
(\mathrm{MPa})\end{array}$ & $\begin{array}{r}\text { Yield } \\
\text { Strength } \\
(\mathrm{MPa}) \\
\end{array}$ & $\begin{array}{r}\text { Ultimate } \\
\text { Tensile } \\
\text { Strength } \\
(\mathrm{MPa})\end{array}$ & $\begin{array}{r}\text { Uniform } \\
\text { Elong. } \\
(\%)\end{array}$ & $\begin{array}{r}\text { Elong. } \\
(\%)\end{array}$ & $\begin{array}{r}\text { Red. } \\
\text { of } \\
\text { Area } \\
(\%) \\
\end{array}$ & $\begin{array}{c}\text { Failure } \\
\text { Location }\end{array}$ \\
\hline AWT-4 & Bar Weld & 850 & 50 & 650 & & 352 & 873 & 49.2 & 49.3 & & WM \\
\hline
\end{tabular}

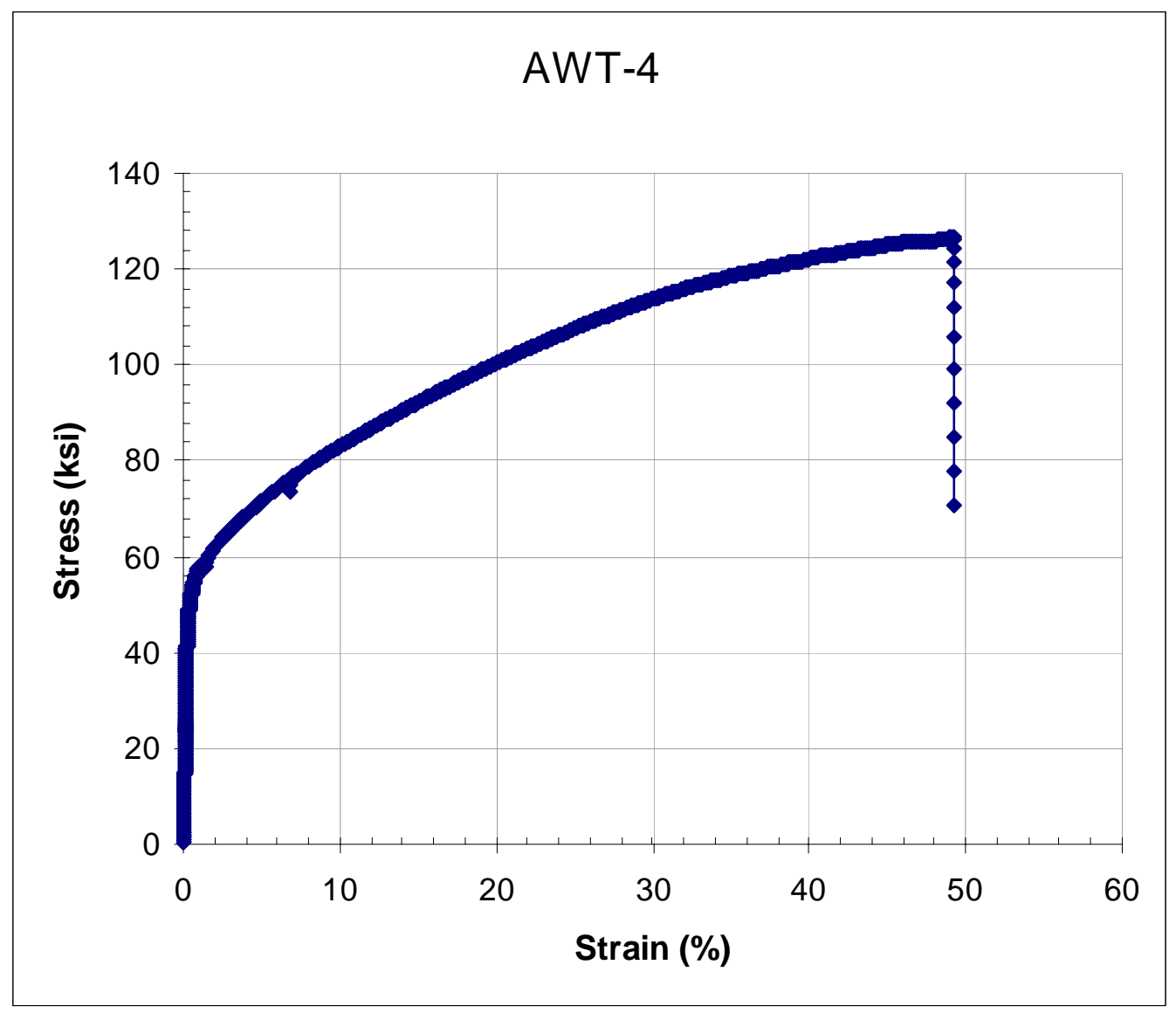




\begin{tabular}{|c|c|c|c|c|c|c|c|c|c|c|c|}
\hline Test ID & $\begin{array}{l}\text { Product } \\
\text { Form }\end{array}$ & $\begin{array}{l}\text { Aging } \\
\text { Temp. } \\
\left({ }^{\circ} \mathrm{C}\right)\end{array}$ & $\begin{array}{l}\text { Aging } \\
\text { Time } \\
\text { (hours) }\end{array}$ & $\begin{array}{r}\text { Test } \\
\text { Temp. } \\
\left({ }^{\circ} \mathrm{C}\right) \\
\end{array}$ & $\begin{array}{r}\text { Prop. } \\
\text { Limit } \\
(\mathrm{MPa})\end{array}$ & $\begin{array}{r}\text { Yield } \\
\text { Strength } \\
(\mathrm{MPa}) \\
\end{array}$ & $\begin{array}{r}\text { Ultimate } \\
\text { Tensile } \\
\text { Strength } \\
(\mathrm{MPa})\end{array}$ & $\begin{array}{r}\text { Uniform } \\
\text { Elong. } \\
(\%) \\
\end{array}$ & $\begin{array}{r}\text { Elong. } \\
(\%)\end{array}$ & $\begin{array}{r}\text { Red. } \\
\text { of } \\
\text { Area } \\
(\%) \\
\end{array}$ & $\begin{array}{c}\text { Failure } \\
\text { Location }\end{array}$ \\
\hline LWT-5 & Bar Weld & 675 & 6000 & 20 & & 822 & 1058 & 4.5 & 4.5 & & $\mathrm{BM}$ \\
\hline
\end{tabular}

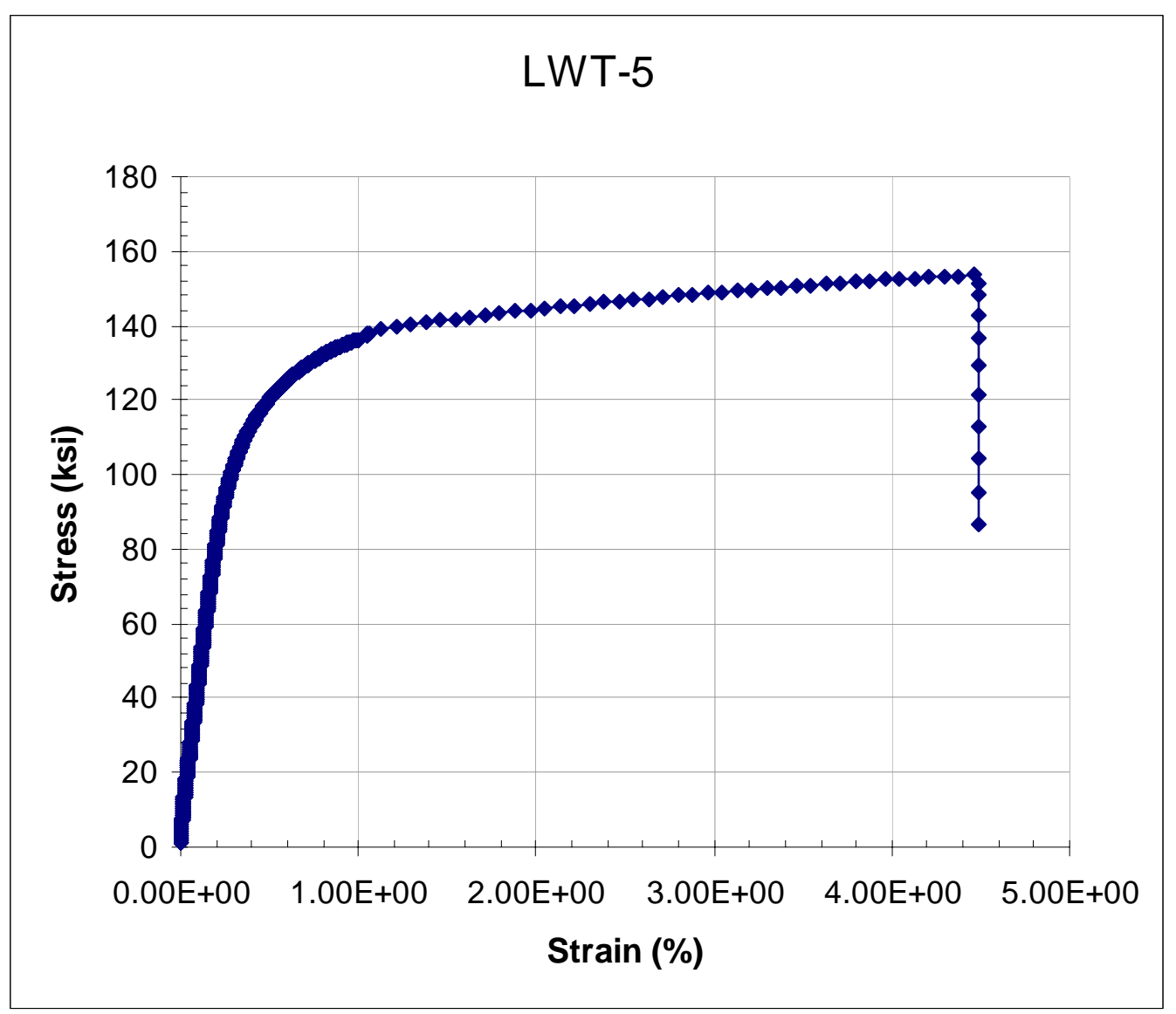




\begin{tabular}{|c|c|c|c|c|c|c|c|c|c|c|c|}
\hline Test ID & $\begin{array}{l}\text { Product } \\
\text { Form }\end{array}$ & $\begin{array}{l}\text { Aging } \\
\text { Temp. } \\
\left({ }^{\circ} \mathrm{C}\right)\end{array}$ & $\begin{array}{l}\text { Aging } \\
\text { Time } \\
\text { (hours) }\end{array}$ & $\begin{array}{r}\text { Test } \\
\text { Temp. } \\
\left({ }^{\circ} \mathrm{C}\right) \\
\end{array}$ & $\begin{array}{r}\text { Prop. } \\
\text { Limit } \\
(\mathrm{MPa})\end{array}$ & $\begin{array}{r}\text { Yield } \\
\text { Strength } \\
(\mathrm{MPa}) \\
\end{array}$ & $\begin{array}{r}\text { Ultimate } \\
\text { Tensile } \\
\text { Strength } \\
(\mathrm{MPa})\end{array}$ & $\begin{array}{r}\text { Uniform } \\
\text { Elong. } \\
(\%)\end{array}$ & $\begin{array}{r}\text { Elong. } \\
(\%)\end{array}$ & $\begin{array}{r}\text { Red. } \\
\text { of } \\
\text { Area } \\
(\%) \\
\end{array}$ & $\begin{array}{c}\text { Failure } \\
\text { Location }\end{array}$ \\
\hline AWT-5 & Bar Weld & 675 & 6000 & 20 & & 834 & 1073 & 4.3 & 4.3 & & BM \\
\hline
\end{tabular}

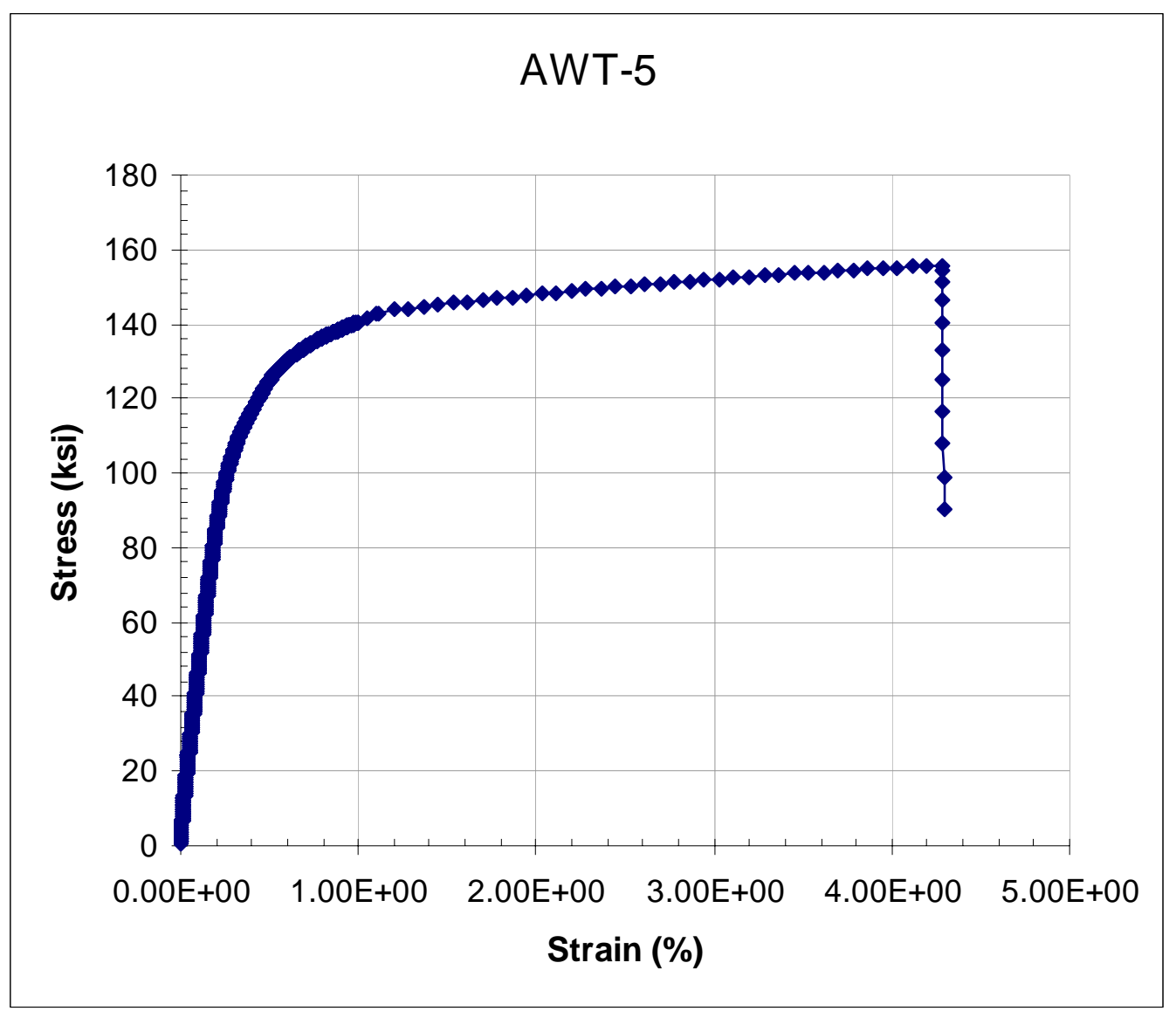




\begin{tabular}{|c|c|c|c|c|c|c|c|c|c|c|c|}
\hline Test ID & $\begin{array}{l}\text { Product } \\
\text { Form }\end{array}$ & $\begin{array}{l}\text { Aging } \\
\text { Temp. } \\
\left({ }^{\circ} \mathrm{C}\right)\end{array}$ & $\begin{array}{l}\text { Aging } \\
\text { Time } \\
\text { (hours) }\end{array}$ & $\begin{array}{r}\text { Test } \\
\text { Temp. } \\
\left({ }^{\circ} \mathrm{C}\right) \\
\end{array}$ & $\begin{array}{r}\text { Prop. } \\
\text { Limit } \\
(\mathrm{MPa})\end{array}$ & $\begin{array}{r}\text { Yield } \\
\text { Strength } \\
(\mathrm{MPa}) \\
\end{array}$ & $\begin{array}{r}\text { Ultimate } \\
\text { Tensile } \\
\text { Strength } \\
(\mathrm{MPa})\end{array}$ & $\begin{array}{r}\text { Uniform } \\
\text { Elong. } \\
(\%)\end{array}$ & $\begin{array}{r}\text { Elong. } \\
(\%)\end{array}$ & $\begin{array}{r}\text { Red. } \\
\text { of } \\
\text { Area } \\
(\%) \\
\end{array}$ & $\begin{array}{c}\text { Failure } \\
\text { Location }\end{array}$ \\
\hline LWT-6 & Bar Weld & 675 & 6000 & 650 & & 575 & 929 & 11.8 & 11.8 & & BM \\
\hline
\end{tabular}

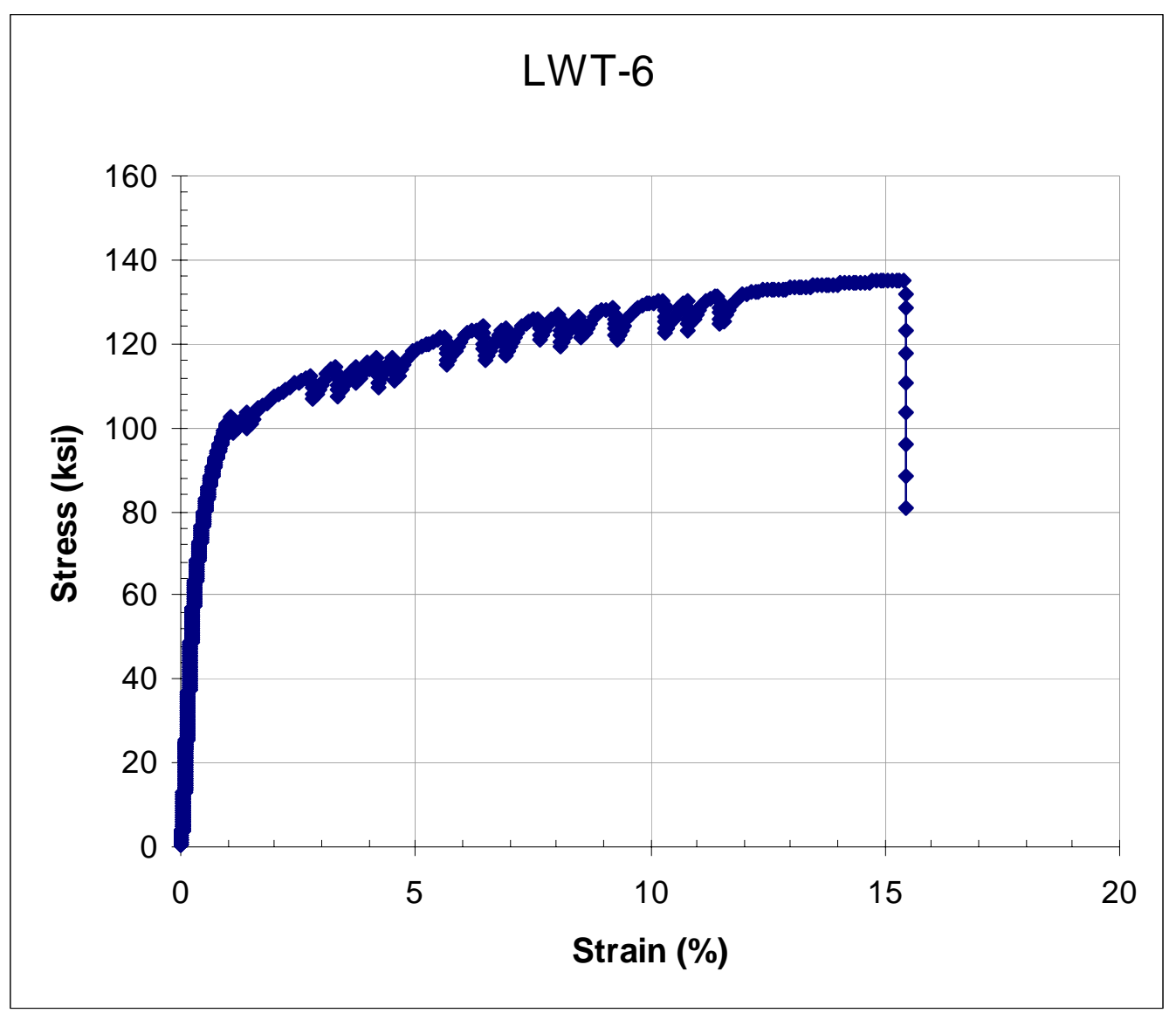




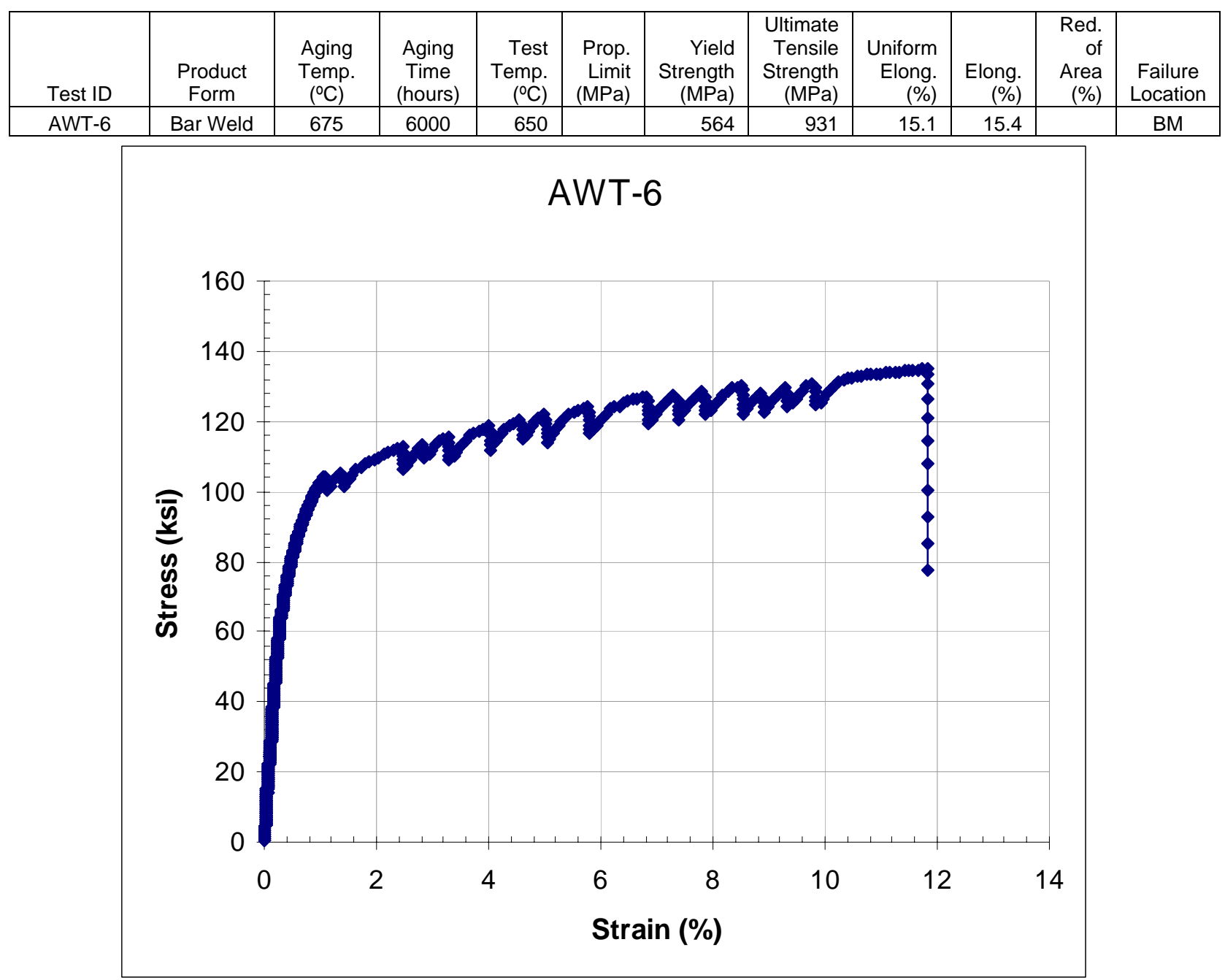




\section{A.6 CREEP STRAIN VS. TIME CURVES}

\begin{tabular}{|c|c|c|c|c|c|c|c|c|c|c|}
\hline Test ID & $\begin{array}{c}\text { Product } \\
\text { Form }\end{array}$ & $\begin{array}{c}\text { Aging } \\
\text { Temp. } \\
\left({ }^{\circ} \mathrm{C}\right)\end{array}$ & $\begin{array}{l}\text { Aging } \\
\text { Time } \\
\text { (hours) }\end{array}$ & $\begin{array}{c}\text { Test } \\
\text { Temp. } \\
\left({ }^{\circ} \mathrm{C}\right)\end{array}$ & $\begin{array}{l}\text { Stress } \\
(\mathrm{MPa})\end{array}$ & $\begin{array}{c}\text { Rupture } \\
\text { Life } \\
\text { (hours) } \\
\text { stopped } \\
\text { or } \\
\text { ongoing }\end{array}$ & $\begin{array}{c}\text { Minimum } \\
\text { Creep } \\
\text { Rate } \\
(\% / h r)\end{array}$ & $\begin{array}{c}\text { Elong. } \\
(\%)\end{array}$ & $\begin{array}{c}\text { Red. } \\
\text { of } \\
\text { Area } \\
(\%) \\
\end{array}$ & $\begin{array}{c}\text { Failure } \\
\text { Location }\end{array}$ \\
\hline $\begin{array}{l}\text { CR-BM- } \\
01\end{array}$ & sheet & none & none & 650 & 206.8 & 38557.0 & $2.60 \mathrm{E}-05$ & 2.8 & 4.5 & \\
\hline
\end{tabular}

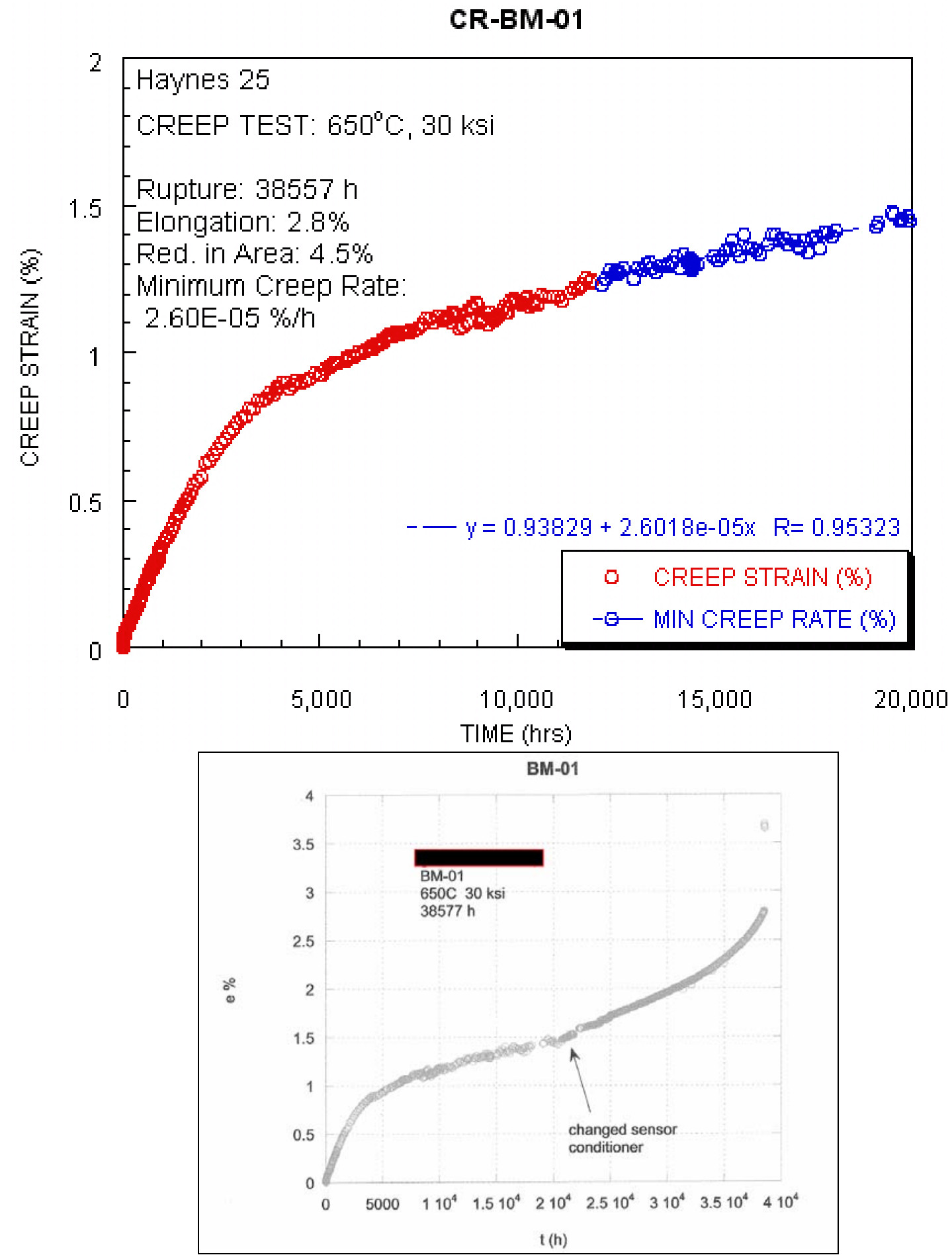




\begin{tabular}{|c|c|c|c|c|c|c|c|c|c|c|}
\hline Test ID & $\begin{array}{l}\text { Product } \\
\text { Form }\end{array}$ & $\begin{array}{c}\text { Aging } \\
\text { Temp. } \\
\left({ }^{\circ} \mathrm{C}\right)\end{array}$ & $\begin{array}{l}\text { Aging } \\
\text { Time } \\
\text { (hours) }\end{array}$ & $\begin{array}{c}\text { Test } \\
\text { Temp. } \\
\left({ }^{\circ} \mathrm{C}\right)\end{array}$ & $\begin{array}{l}\text { Stress } \\
\text { (MPa) }\end{array}$ & $\begin{array}{r}\text { Rupture } \\
\text { Life } \\
\text { (hours) } \\
\text { stopped } \\
\text { or } \\
\text { ongoing }\end{array}$ & $\begin{array}{r}\text { Minimum } \\
\text { Creep } \\
\text { Rate } \\
(\% / h r)\end{array}$ & $\begin{array}{r}\text { Elong. } \\
(\%)\end{array}$ & $\begin{array}{r}\text { Red. } \\
\text { of } \\
\text { Area } \\
(\%) \\
\end{array}$ & $\begin{array}{l}\text { Failure } \\
\text { Location }\end{array}$ \\
\hline $\begin{array}{l}\text { CR-BM- } \\
02\end{array}$ & sheet & none & none & 700 & 165.5 & 20637.0 & $1.00 \mathrm{E}-05$ & 4.9 & 3.9 & \\
\hline
\end{tabular}

CR-BM-02

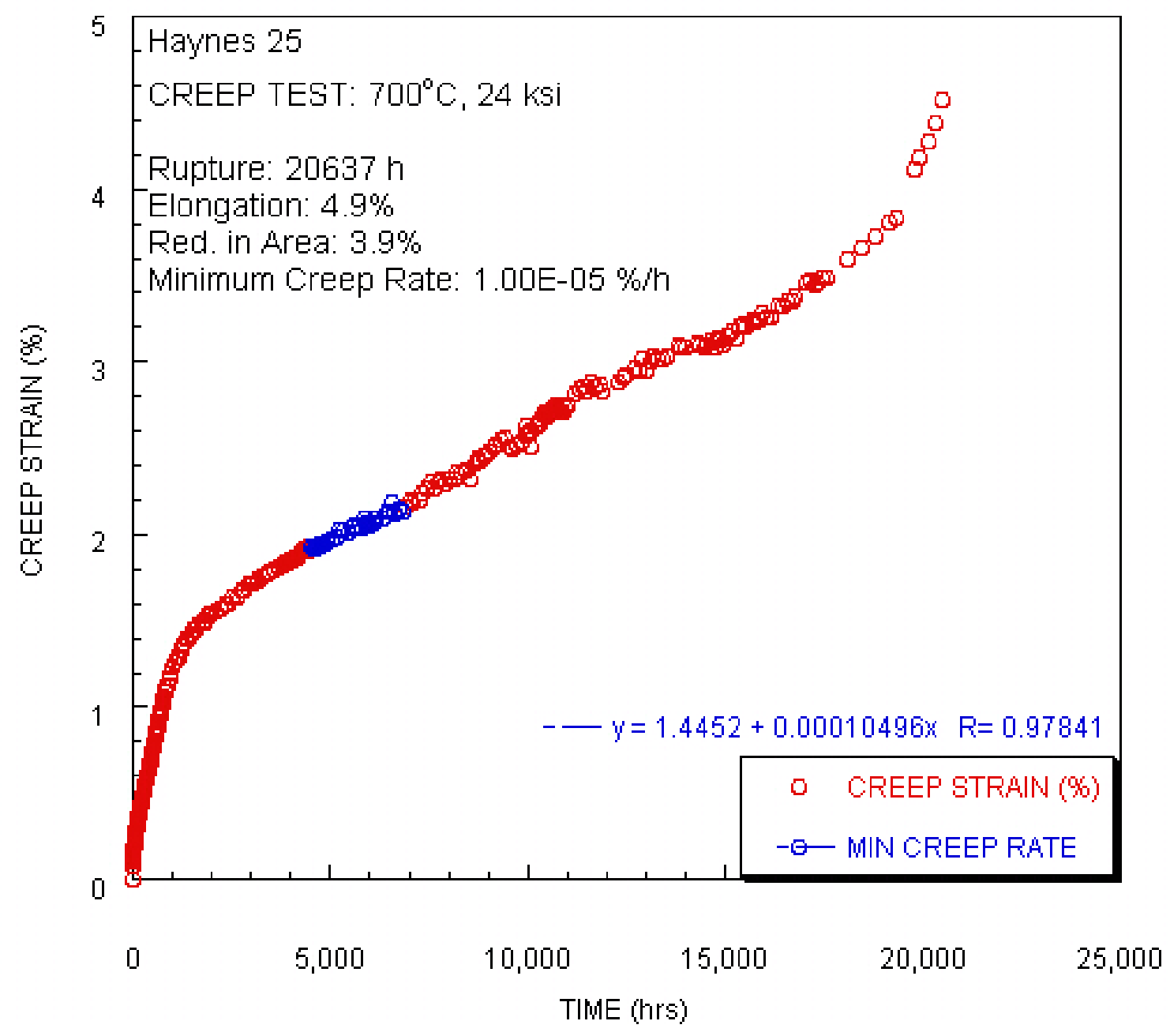




\begin{tabular}{|c|c|c|c|c|c|c|c|c|c|c|}
\hline Test ID & $\begin{array}{c}\text { Product } \\
\text { Form }\end{array}$ & $\begin{array}{c}\text { Aging } \\
\text { Temp. } \\
\left({ }^{\circ} \mathrm{C}\right)\end{array}$ & $\begin{array}{c}\text { Aging } \\
\text { Time } \\
\text { (hours) }\end{array}$ & $\begin{array}{c}\text { Test } \\
\text { Temp. } \\
\left({ }^{\circ} \mathrm{C}\right)\end{array}$ & $\begin{array}{l}\text { Stress } \\
(\mathrm{MPa})\end{array}$ & $\begin{array}{r}\text { Rupture } \\
\text { Life } \\
\text { (hours) } \\
\text { stopped } \\
\text { or } \\
\text { ongoing } \\
\end{array}$ & $\begin{array}{r}\text { Minimum } \\
\text { Creep } \\
\text { Rate } \\
(\% / h r) \\
\end{array}$ & $\begin{array}{r}\text { Elong. } \\
(\%)\end{array}$ & $\begin{array}{r}\text { Red. } \\
\text { of } \\
\text { Area } \\
(\%) \\
\end{array}$ & $\begin{array}{l}\text { Failure } \\
\text { Location }\end{array}$ \\
\hline $\begin{array}{l}\text { CR-BM- } \\
03\end{array}$ & sheet & none & none & 750 & 127.6 & 8786.0 & $5.30 \mathrm{E}-04$ & 10.9 & 8.3 & \\
\hline
\end{tabular}

\section{CR-BM-03}

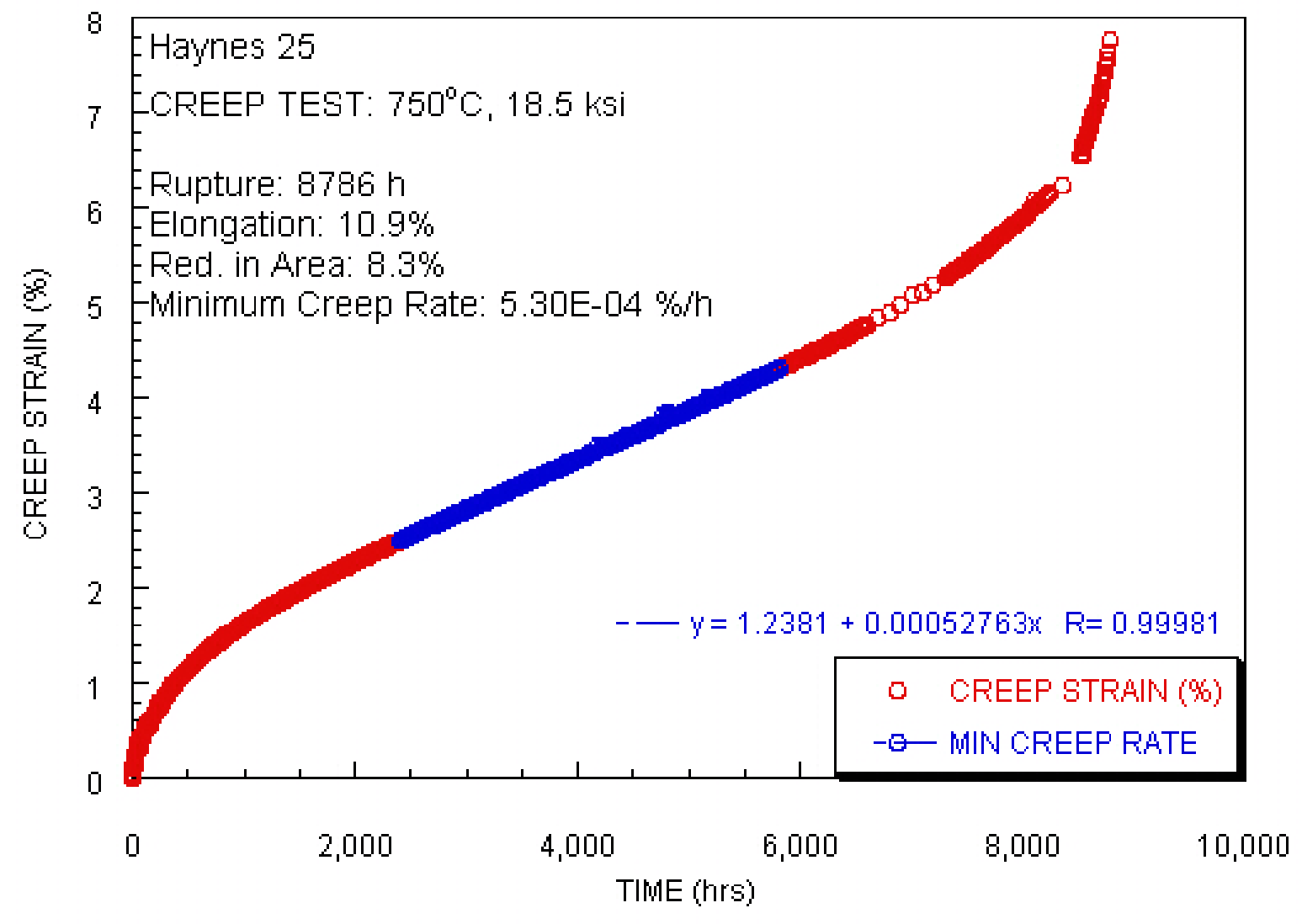




\begin{tabular}{|c|c|c|c|c|c|c|c|c|c|c|}
\hline Test ID & $\begin{array}{l}\text { Product } \\
\text { Form }\end{array}$ & $\begin{array}{c}\text { Aging } \\
\text { Temp. } \\
\left({ }^{\circ} \mathrm{C}\right)\end{array}$ & $\begin{array}{l}\text { Aging } \\
\text { Time } \\
\text { (hours) }\end{array}$ & $\begin{array}{c}\text { Test } \\
\text { Temp. } \\
\left({ }^{\circ} \mathrm{C}\right)\end{array}$ & $\begin{array}{l}\text { Stress } \\
\text { (MPa) }\end{array}$ & $\begin{array}{r}\text { Rupture } \\
\text { Life } \\
\text { (hours) } \\
\text { stopped } \\
\text { or } \\
\text { ongoing }\end{array}$ & $\begin{array}{r}\text { Minimum } \\
\text { Creep } \\
\text { Rate } \\
(\% / h r)\end{array}$ & $\begin{array}{r}\text { Elong. } \\
(\%)\end{array}$ & $\begin{array}{r}\text { Red. } \\
\text { of } \\
\text { Area } \\
(\%) \\
\end{array}$ & $\begin{array}{l}\text { Failure } \\
\text { Location }\end{array}$ \\
\hline $\begin{array}{l}\text { CR-BM- } \\
04\end{array}$ & sheet & none & none & 800 & 99.3 & 4983.0 & $8.50 \mathrm{E}-04$ & 11.5 & 10.2 & \\
\hline
\end{tabular}

CR-BM-04

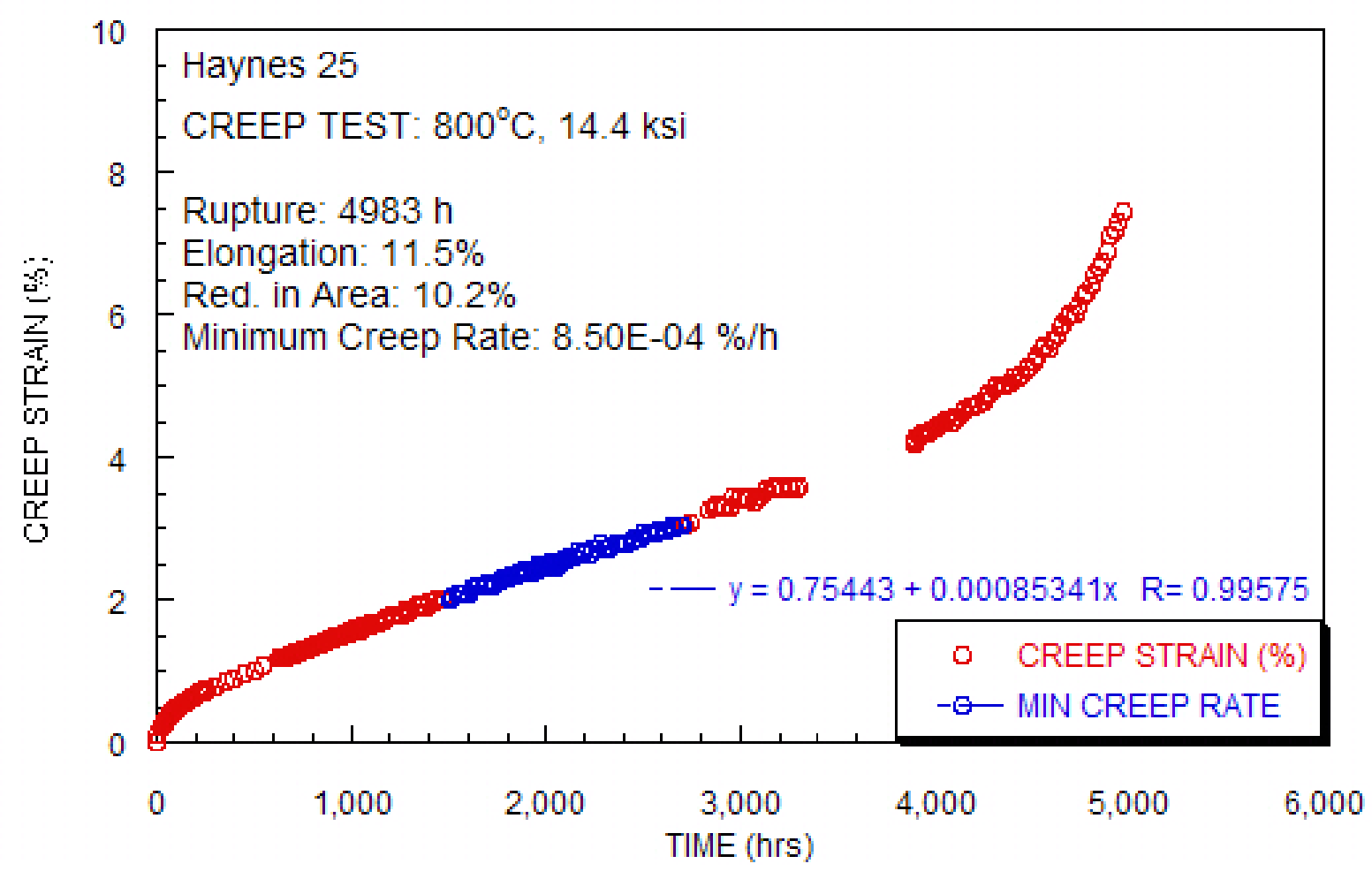




\begin{tabular}{|c|c|c|c|c|c|c|c|c|c|c|}
\hline Test ID & $\begin{array}{l}\text { Product } \\
\text { Form }\end{array}$ & $\begin{array}{c}\text { Aging } \\
\text { Temp. } \\
\left({ }^{\circ} \mathrm{C}\right)\end{array}$ & $\begin{array}{l}\text { Aging } \\
\text { Time } \\
\text { (hours) }\end{array}$ & $\begin{array}{c}\text { Test } \\
\text { Temp. } \\
\left({ }^{\circ} \mathrm{C}\right)\end{array}$ & $\begin{array}{l}\text { Stress } \\
(\mathrm{MPa})\end{array}$ & $\begin{array}{r}\text { Rupture } \\
\text { Life } \\
\text { (hours) } \\
\text { stopped } \\
\text { or } \\
\text { ongoing } \\
\end{array}$ & $\begin{array}{r}\text { Minimum } \\
\text { Creep } \\
\text { Rate } \\
(\% / h r) \\
\end{array}$ & $\begin{array}{r}\text { Elong. } \\
(\%)\end{array}$ & $\begin{array}{r}\text { Red. } \\
\text { of } \\
\text { Area } \\
(\%) \\
\end{array}$ & $\begin{array}{l}\text { Failure } \\
\text { Location }\end{array}$ \\
\hline $\begin{array}{l}\text { CR-BM- } \\
05\end{array}$ & sheet & none & none & 800 & 103.4 & 3626.0 & 1.10E-03 & 12.8 & 12.2 & \\
\hline
\end{tabular}

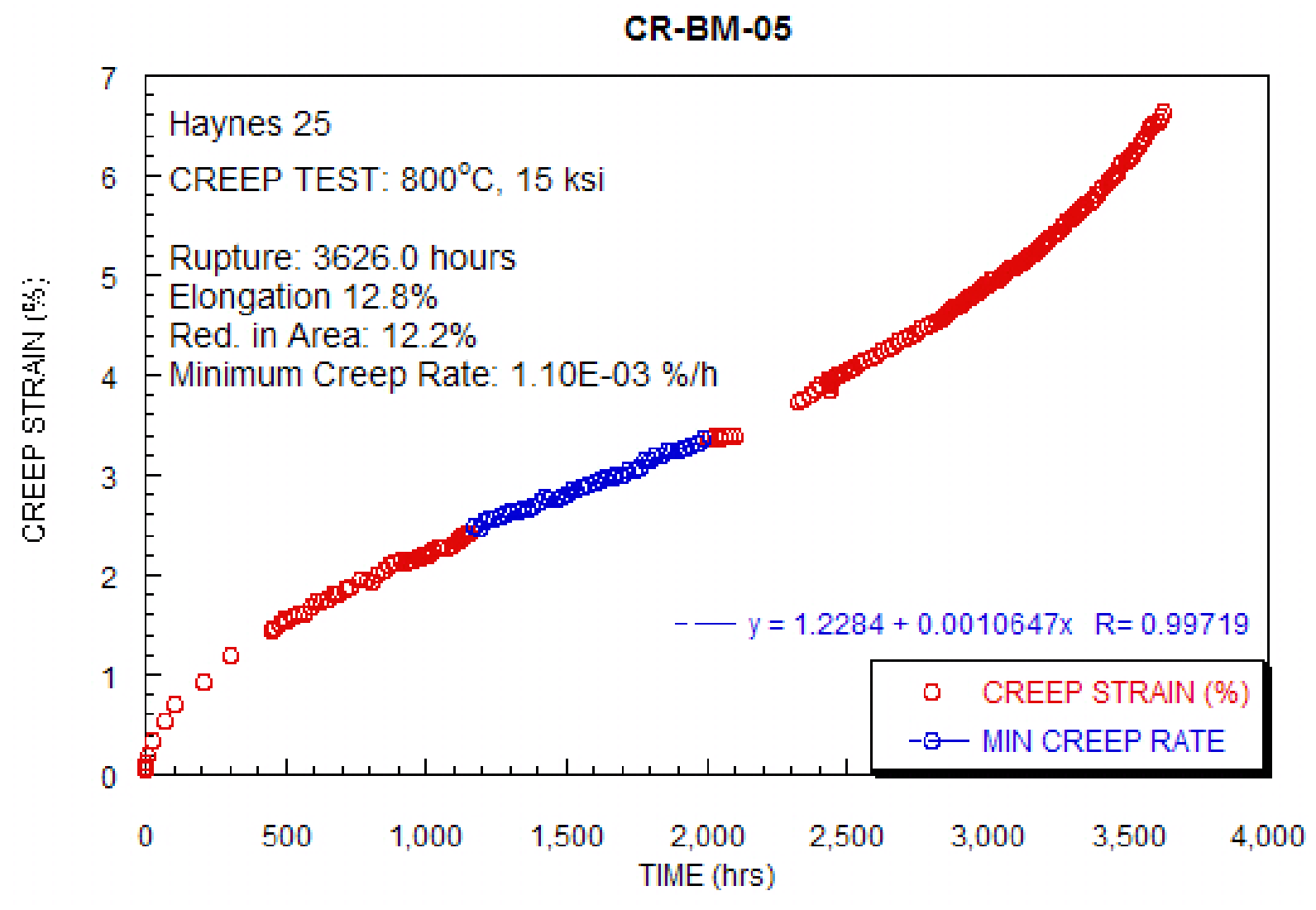




\begin{tabular}{|c|c|c|c|c|c|c|c|c|c|c|}
\hline Test ID & $\begin{array}{l}\text { Product } \\
\text { Form }\end{array}$ & $\begin{array}{c}\text { Aging } \\
\text { Temp. } \\
\left({ }^{\circ} \mathrm{C}\right)\end{array}$ & $\begin{array}{l}\text { Aging } \\
\text { Time } \\
\text { (hours) }\end{array}$ & $\begin{array}{c}\text { Test } \\
\text { Temp. } \\
\left({ }^{\circ} \mathrm{C}\right)\end{array}$ & $\begin{array}{l}\text { Stress } \\
\text { (MPa) }\end{array}$ & $\begin{array}{r}\text { Rupture } \\
\text { Life } \\
\text { (hours) } \\
\text { stopped } \\
\text { or } \\
\text { ongoing }\end{array}$ & $\begin{array}{r}\text { Minimum } \\
\text { Creep } \\
\text { Rate } \\
(\% / h r)\end{array}$ & $\begin{array}{r}\text { Elong. } \\
(\%)\end{array}$ & $\begin{array}{r}\text { Red. } \\
\text { of } \\
\text { Area } \\
(\%) \\
\end{array}$ & $\begin{array}{l}\text { Failure } \\
\text { Location }\end{array}$ \\
\hline $\begin{array}{l}\text { CR-BM- } \\
06\end{array}$ & sheet & none & none & 850 & 62.1 & 8975.0 & $1.30 \mathrm{E}-04$ & 6.9 & 2.7 & \\
\hline
\end{tabular}

CR-BM-06

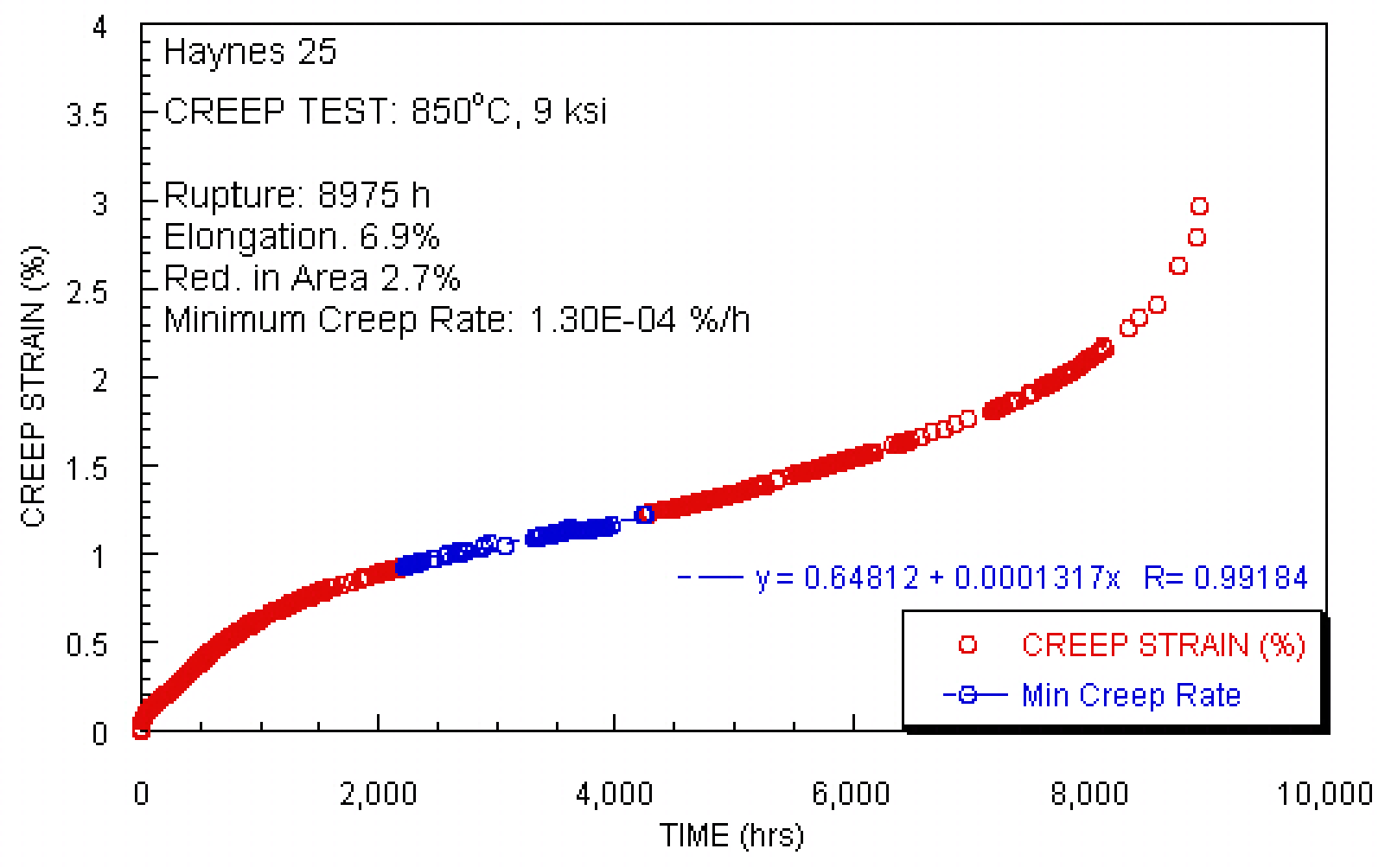




\begin{tabular}{|c|c|c|c|c|c|c|c|c|c|c|}
\hline Test ID & $\begin{array}{c}\text { Product } \\
\text { Form }\end{array}$ & $\begin{array}{c}\text { Aging } \\
\text { Temp. } \\
\left({ }^{\circ} \mathrm{C}\right)\end{array}$ & $\begin{array}{l}\text { Aging } \\
\text { Time } \\
\text { (hours) }\end{array}$ & $\begin{array}{c}\text { Test } \\
\text { Temp. } \\
\left({ }^{\circ} \mathrm{C}\right)\end{array}$ & $\begin{array}{l}\text { Stress } \\
(\mathrm{MPa})\end{array}$ & $\begin{array}{r}\text { Rupture } \\
\text { Life } \\
\text { (hours) } \\
\text { stopped } \\
\text { or } \\
\text { ongoing } \\
\end{array}$ & $\begin{array}{r}\text { Minimum } \\
\text { Creep } \\
\text { Rate } \\
(\% / h r) \\
\end{array}$ & $\begin{array}{r}\text { Elong. } \\
(\%)\end{array}$ & $\begin{array}{r}\text { Red. } \\
\text { of } \\
\text { Area } \\
(\%) \\
\end{array}$ & $\begin{array}{l}\text { Failure } \\
\text { Location }\end{array}$ \\
\hline $\begin{array}{l}\text { CR-BM- } \\
07\end{array}$ & sheet & none & none & 875 & 53.8 & 5763.0 & $1.90 \mathrm{E}-04$ & 7.0 & 5.0 & \\
\hline
\end{tabular}

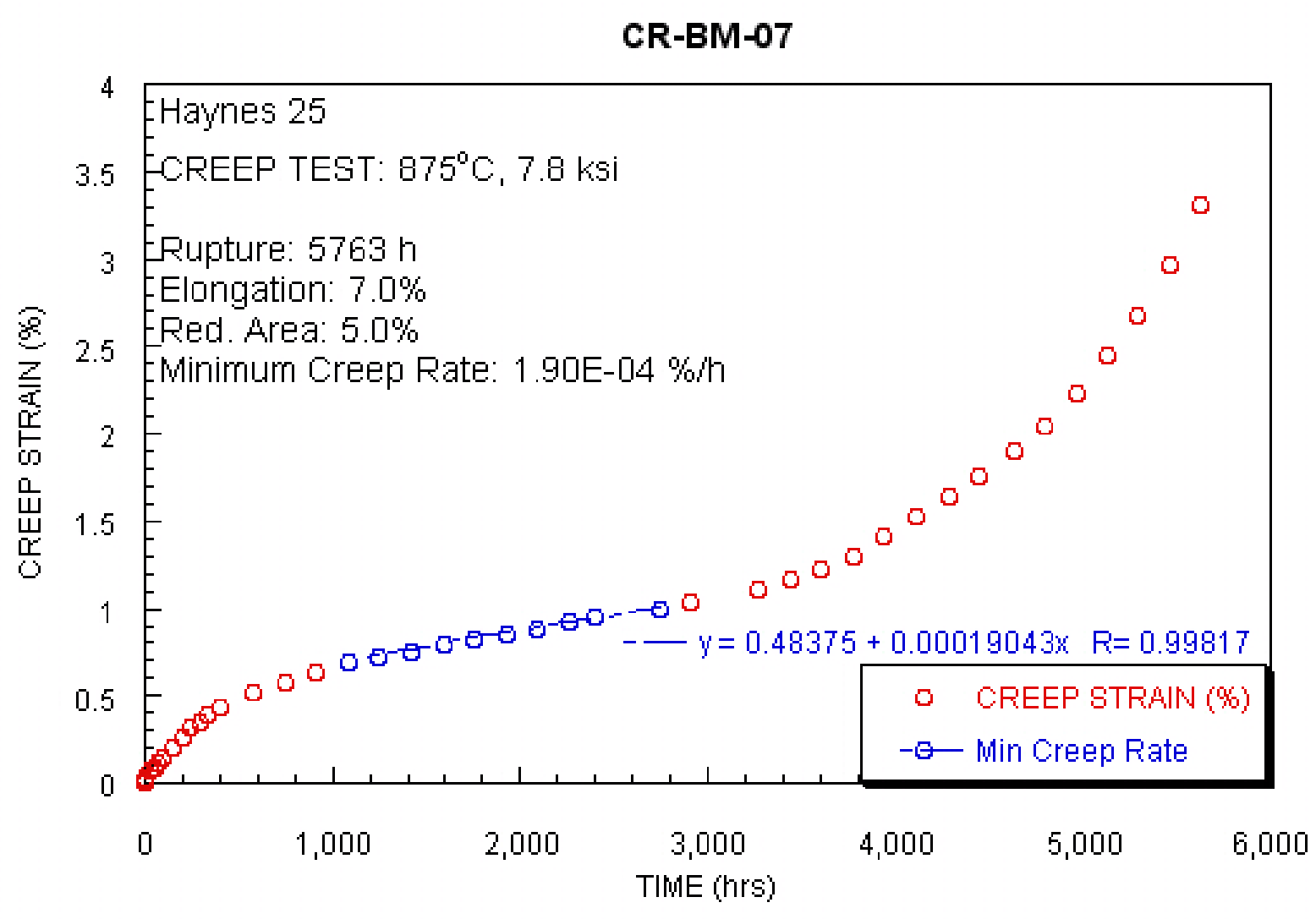




\begin{tabular}{|c|c|c|c|c|c|c|c|c|c|c|}
\hline Test ID & $\begin{array}{c}\text { Product } \\
\text { Form }\end{array}$ & $\begin{array}{c}\text { Aging } \\
\text { Temp. } \\
\left({ }^{\circ} \mathrm{C}\right)\end{array}$ & $\begin{array}{l}\text { Aging } \\
\text { Time } \\
\text { (hours) }\end{array}$ & $\begin{array}{c}\text { Test } \\
\text { Temp. } \\
\left({ }^{\circ} \mathrm{C}\right)\end{array}$ & $\begin{array}{l}\text { Stress } \\
(\mathrm{MPa})\end{array}$ & $\begin{array}{r}\text { Rupture } \\
\text { Life } \\
\text { (hours) } \\
\text { stopped } \\
\text { or } \\
\text { ongoing } \\
\end{array}$ & $\begin{array}{r}\text { Minimum } \\
\text { Creep } \\
\text { Rate } \\
(\% / h r) \\
\end{array}$ & $\begin{array}{r}\text { Elong. } \\
(\%)\end{array}$ & $\begin{array}{r}\text { Red. } \\
\text { of } \\
\text { Area } \\
(\%) \\
\end{array}$ & $\begin{array}{l}\text { Failure } \\
\text { Location }\end{array}$ \\
\hline $\begin{array}{l}\text { CR-BM- } \\
08\end{array}$ & sheet & none & none & 900 & 44.8 & 6232.0 & $2.70 \mathrm{E}-04$ & 12.0 & 8.4 & \\
\hline
\end{tabular}

CR-BM-08

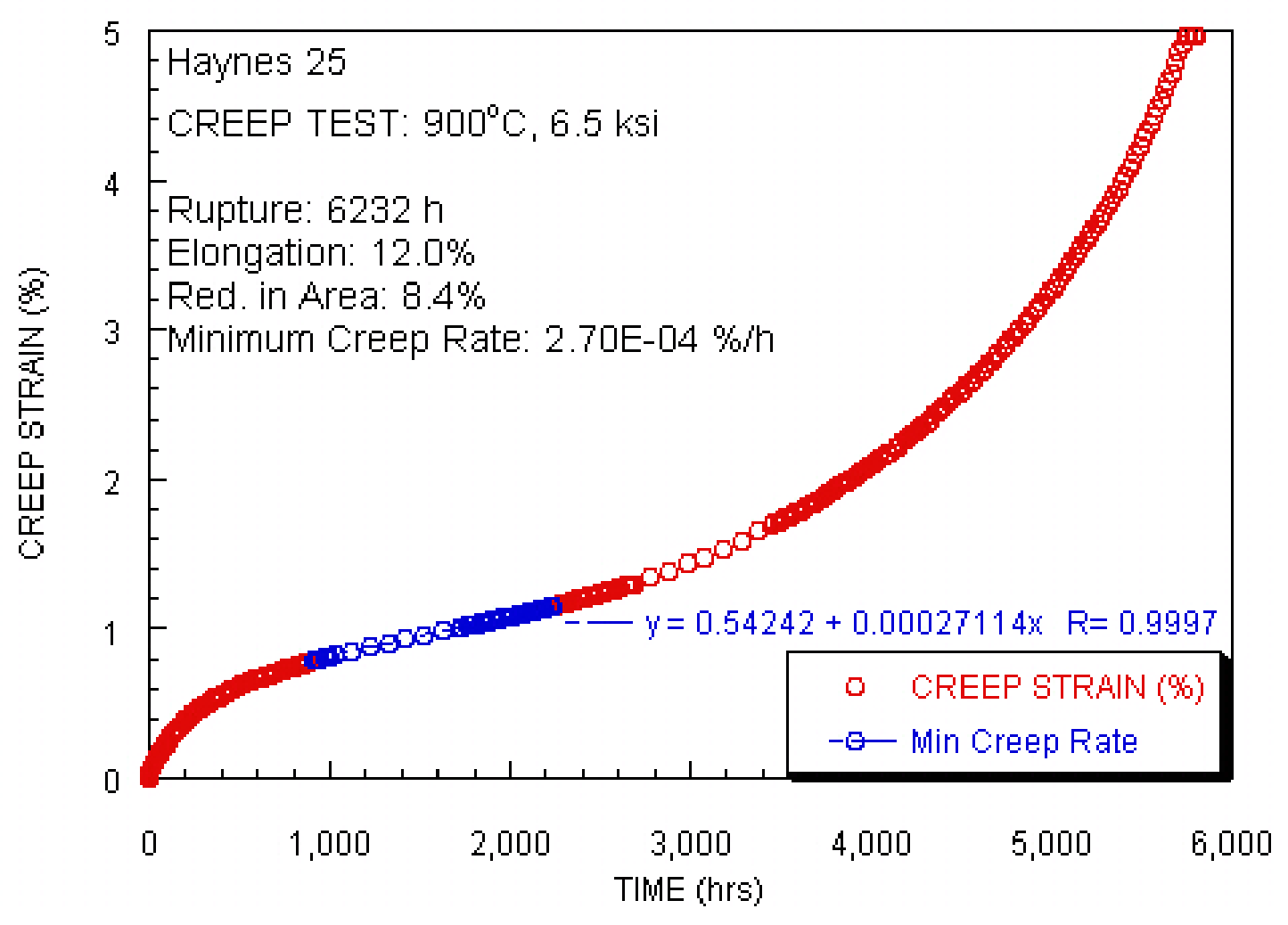




\begin{tabular}{|c|c|c|c|c|c|c|c|c|c|c|}
\hline Test ID & $\begin{array}{l}\text { Product } \\
\text { Form }\end{array}$ & $\begin{array}{c}\text { Aging } \\
\text { Temp. } \\
\left({ }^{\circ} \mathrm{C}\right)\end{array}$ & $\begin{array}{l}\text { Aging } \\
\text { Time } \\
\text { (hours) }\end{array}$ & $\begin{array}{c}\text { Test } \\
\text { Temp. } \\
\left({ }^{\circ} \mathrm{C}\right)\end{array}$ & $\begin{array}{l}\text { Stress } \\
(\mathrm{MPa})\end{array}$ & $\begin{array}{r}\text { Rupture } \\
\text { Life } \\
\text { (hours) } \\
\text { stopped } \\
\text { or } \\
\text { ongoing } \\
\end{array}$ & $\begin{array}{r}\text { Minimum } \\
\text { Creep } \\
\text { Rate } \\
(\% / h r) \\
\end{array}$ & $\begin{array}{r}\text { Elong. } \\
(\%)\end{array}$ & $\begin{array}{r}\text { Red. } \\
\text { of } \\
\text { Area } \\
(\%) \\
\end{array}$ & $\begin{array}{l}\text { Failure } \\
\text { Location }\end{array}$ \\
\hline $\begin{array}{l}\text { CR-BM- } \\
09\end{array}$ & sheet & none & none & 900 & 42.7 & 6585.0 & $1.50 \mathrm{E}-04$ & 6.1 & 5.7 & \\
\hline
\end{tabular}

\section{CR-BM-09}

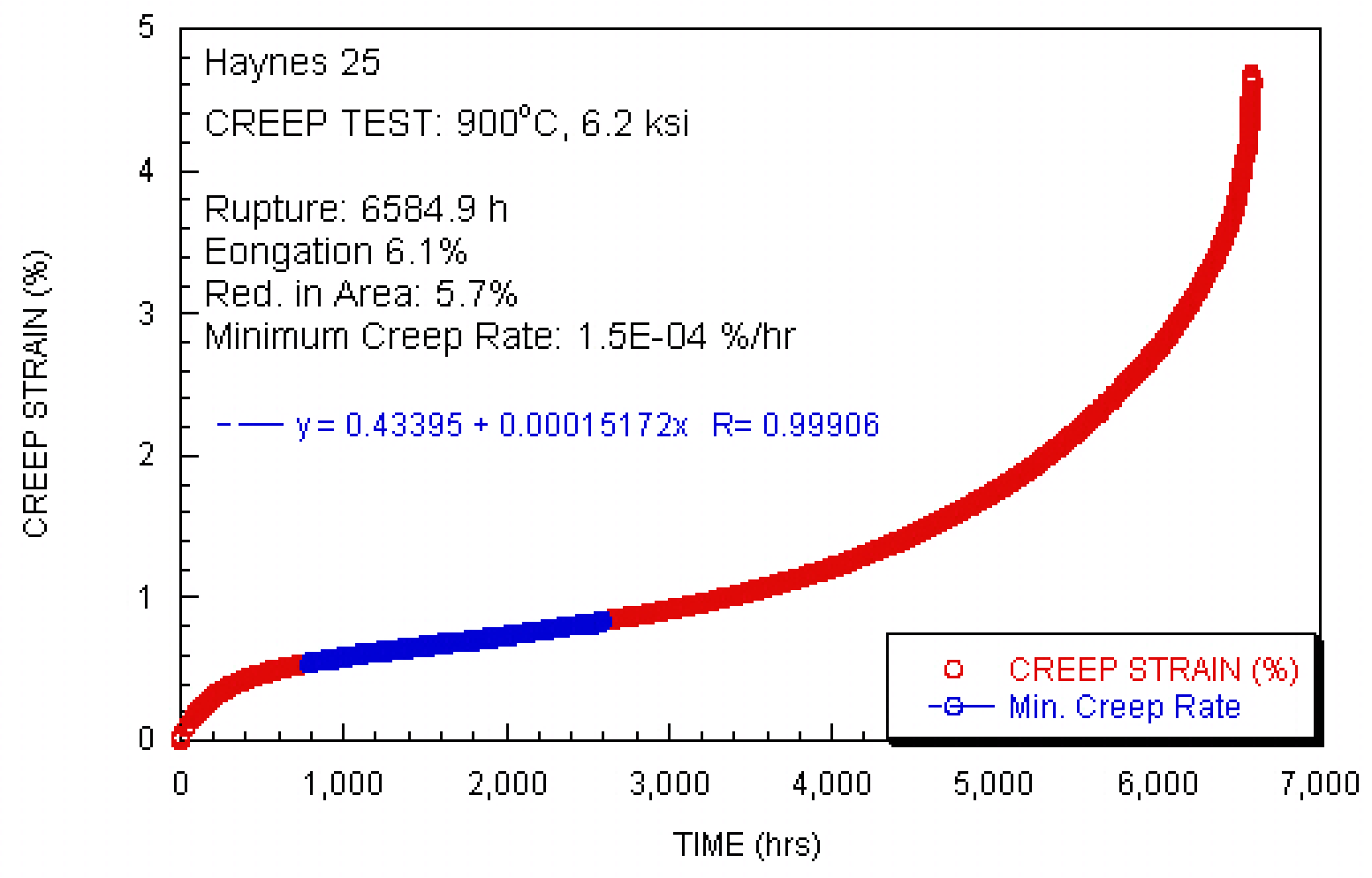




\begin{tabular}{|c|c|c|c|c|c|c|c|c|c|c|}
\hline Test ID & $\begin{array}{c}\text { Product } \\
\text { Form }\end{array}$ & $\begin{array}{c}\text { Aging } \\
\text { Temp. } \\
\left({ }^{\circ} \mathrm{C}\right)\end{array}$ & $\begin{array}{l}\text { Aging } \\
\text { Time } \\
\text { (hours) }\end{array}$ & $\begin{array}{c}\text { Test } \\
\text { Temp. } \\
\left({ }^{\circ} \mathrm{C}\right)\end{array}$ & $\begin{array}{l}\text { Stress } \\
(\mathrm{MPa})\end{array}$ & $\begin{array}{r}\text { Rupture } \\
\text { Life } \\
\text { (hours) } \\
\text { stopped } \\
\text { or } \\
\text { ongoing } \\
\end{array}$ & $\begin{array}{r}\text { Minimum } \\
\text { Creep } \\
\text { Rate } \\
(\% / h r)\end{array}$ & $\begin{array}{r}\text { Elong. } \\
(\%)\end{array}$ & $\begin{array}{r}\text { Red. } \\
\text { of } \\
\text { Area } \\
(\%) \\
\end{array}$ & $\begin{array}{l}\text { Failure } \\
\text { Location }\end{array}$ \\
\hline $\begin{array}{l}\text { CR-BM- } \\
11^{*}\end{array}$ & sheet & none & none & 925 & 34.5 & 6253.0 & 2.7E-04 & 10.6 & 8.8 & \\
\hline
\end{tabular}

CR-BM-11

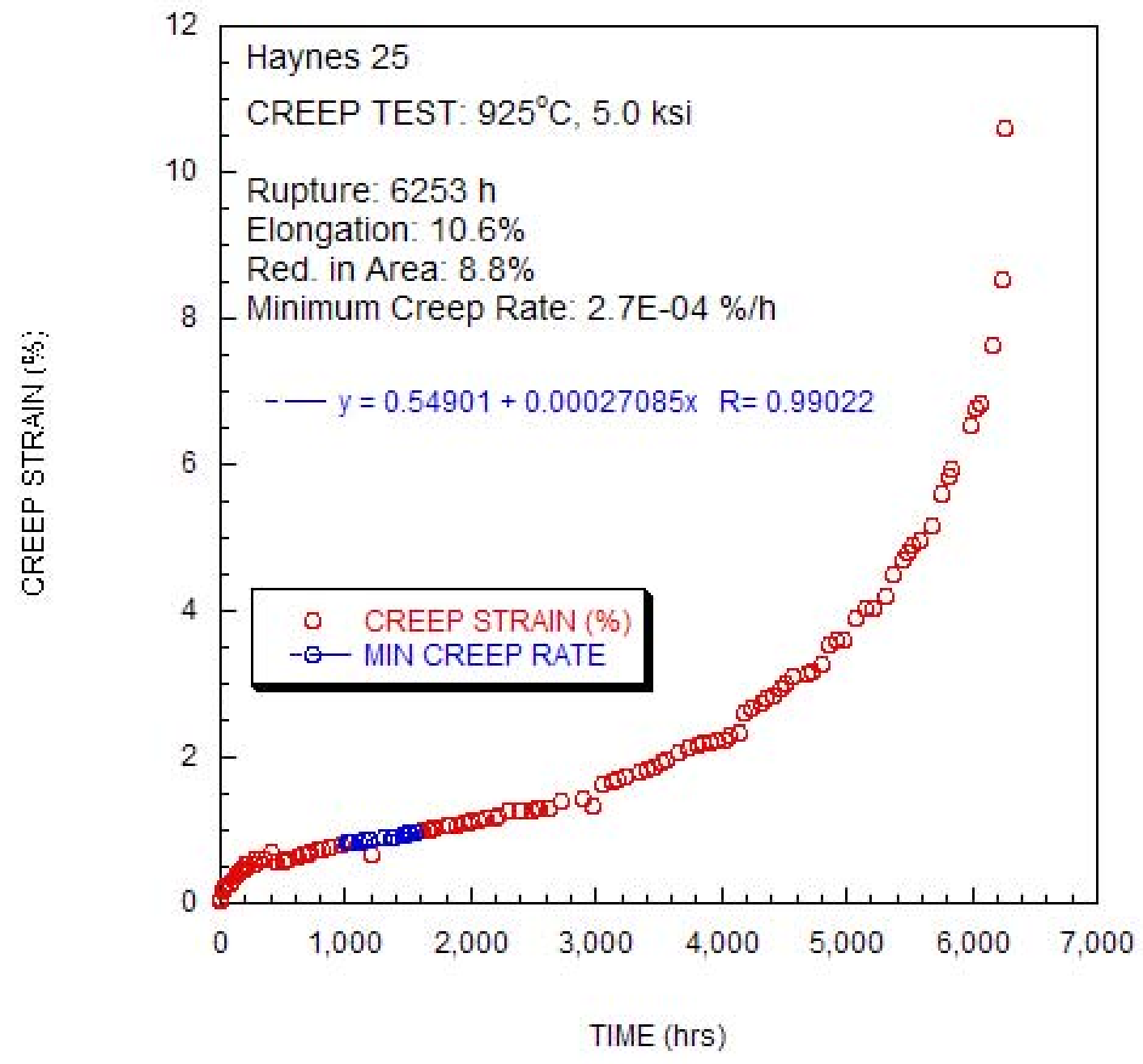

* Test performed in Argon, creep strain and minimum creep rate based on load-line displacement 


\begin{tabular}{|c|c|c|c|c|c|c|c|c|c|c|}
\hline Test ID & $\begin{array}{l}\text { Product } \\
\text { Form }\end{array}$ & $\begin{array}{c}\text { Aging } \\
\text { Temp. } \\
\left({ }^{\circ} \mathrm{C}\right)\end{array}$ & $\begin{array}{l}\text { Aging } \\
\text { Time } \\
\text { (hours) }\end{array}$ & $\begin{array}{c}\text { Test } \\
\text { Temp. } \\
\left({ }^{\circ} \mathrm{C}\right)\end{array}$ & $\begin{array}{l}\text { Stress } \\
\text { (MPa) }\end{array}$ & $\begin{array}{r}\text { Rupture } \\
\text { Life } \\
\text { (hours) } \\
\text { stopped } \\
\text { or } \\
\text { ongoing }\end{array}$ & $\begin{array}{r}\text { Minimum } \\
\text { Creep } \\
\text { Rate } \\
(\% / h r)\end{array}$ & $\begin{array}{r}\text { Elong. } \\
(\%)\end{array}$ & $\begin{array}{r}\text { Red. } \\
\text { of } \\
\text { Area } \\
(\%) \\
\end{array}$ & $\begin{array}{l}\text { Failure } \\
\text { Location }\end{array}$ \\
\hline $\begin{array}{l}\text { CR-BM- } \\
12^{*}\end{array}$ & sheet & none & none & 925 & 33.1 & 7436.8 & $1.70 E-04$ & 9.0 & 6.5 & \\
\hline
\end{tabular}

\section{CR-BM-12}

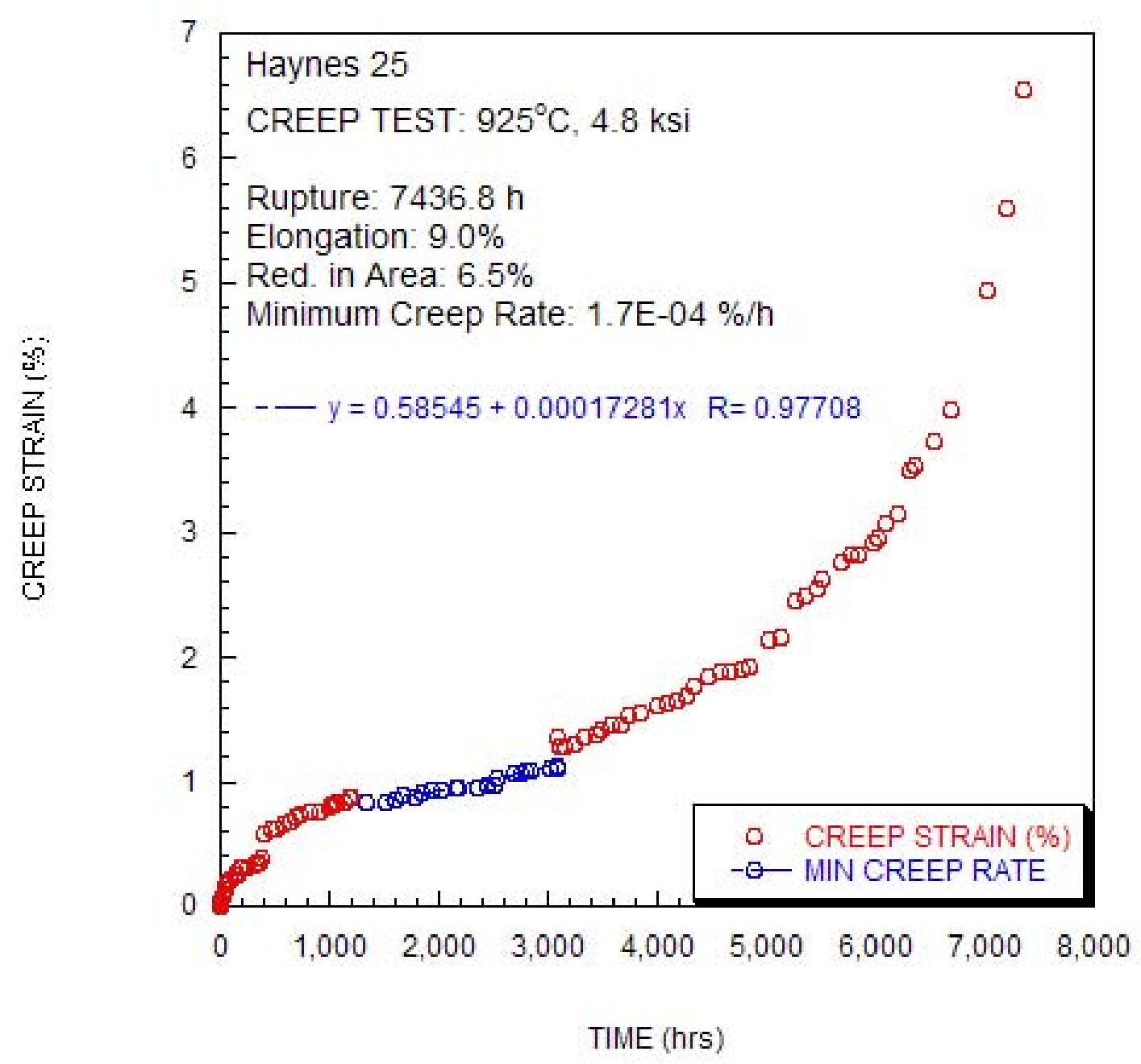

* Test performed in Argon, creep strain and minimum creep rate based on load-line displacement 


\begin{tabular}{|c|c|c|c|c|c|c|c|c|c|c|}
\hline Test ID & $\begin{array}{c}\text { Product } \\
\text { Form }\end{array}$ & $\begin{array}{c}\text { Aging } \\
\text { Temp. } \\
\left({ }^{\circ} \mathrm{C}\right)\end{array}$ & $\begin{array}{l}\text { Aging } \\
\text { Time } \\
\text { (hours) }\end{array}$ & $\begin{array}{c}\text { Test } \\
\text { Temp. } \\
\left({ }^{\circ} \mathrm{C}\right)\end{array}$ & $\begin{array}{l}\text { Stress } \\
(\mathrm{MPa})\end{array}$ & $\begin{array}{r}\text { Rupture } \\
\text { Life } \\
\text { (hours) } \\
\text { stopped } \\
\text { or } \\
\text { ongoing } \\
\end{array}$ & $\begin{array}{r}\text { Minimum } \\
\text { Creep } \\
\text { Rate } \\
(\% / h r) \\
\end{array}$ & $\begin{array}{r}\text { Elong. } \\
(\%)\end{array}$ & $\begin{array}{r}\text { Red. } \\
\text { of } \\
\text { Area } \\
(\%) \\
\end{array}$ & $\begin{array}{l}\text { Failure } \\
\text { Location }\end{array}$ \\
\hline $\begin{array}{l}\text { CR-BM- } \\
14^{*}\end{array}$ & sheet & none & none & 950 & 29.0 & 4095.0 & 3.60E-04 & 8.1 & 9.3 & \\
\hline
\end{tabular}

CR-BM-14

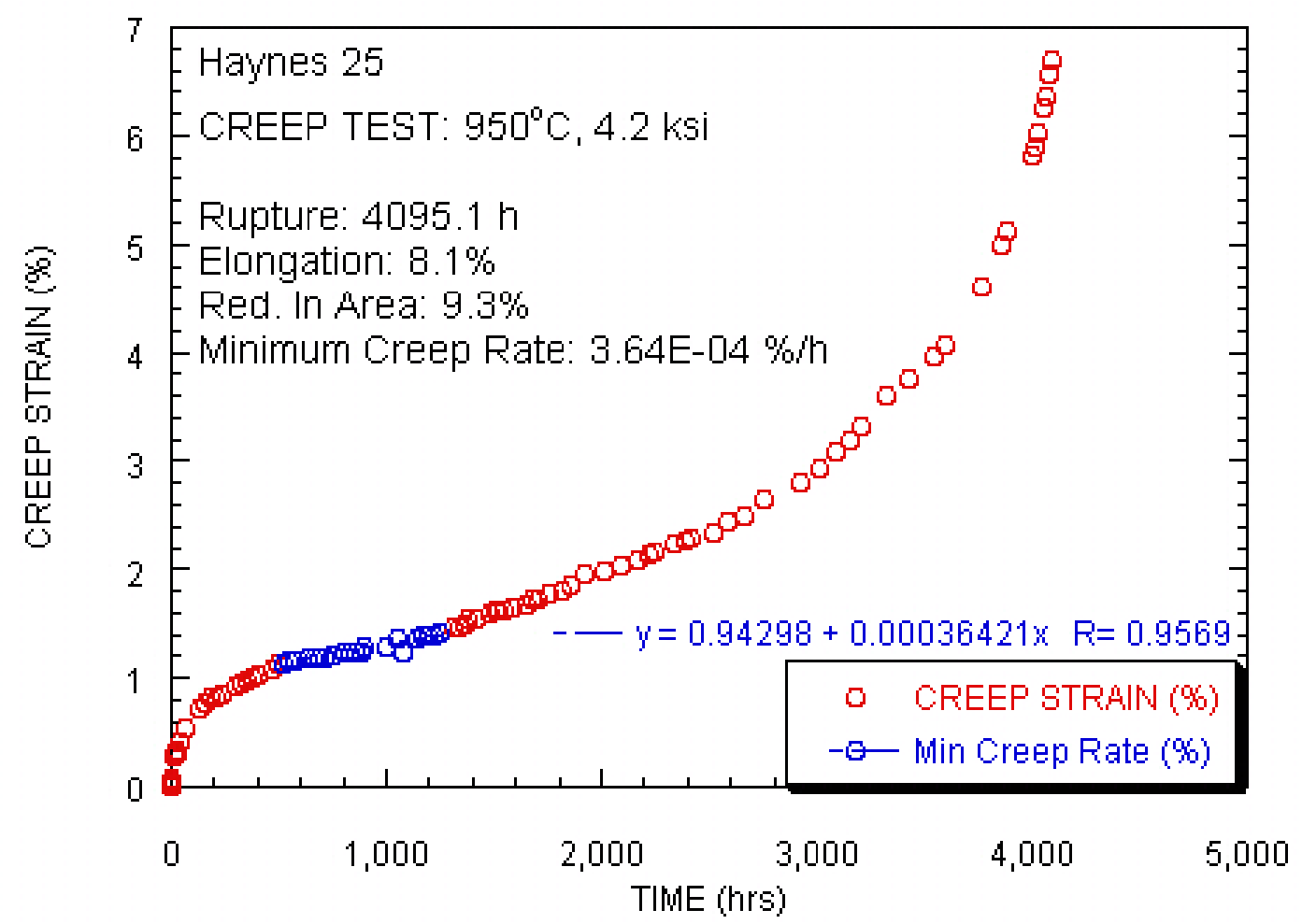

* Test performed in Argon, creep strain and minimum creep rate based on load-line displacement 


\begin{tabular}{|c|c|c|c|c|c|c|c|c|c|c|}
\hline Test ID & $\begin{array}{l}\text { Product } \\
\text { Form }\end{array}$ & $\begin{array}{l}\text { Aging } \\
\text { Temp. } \\
\left({ }^{\circ} \mathrm{C}\right)\end{array}$ & $\begin{array}{l}\text { Aging } \\
\text { Time } \\
\text { (hours) }\end{array}$ & $\begin{array}{l}\text { Test } \\
\text { Temp. } \\
\left({ }^{\circ} \mathrm{C}\right)\end{array}$ & $\begin{array}{l}\text { Stress } \\
(\mathrm{MPa})\end{array}$ & $\begin{array}{r}\text { Rupture } \\
\text { Life } \\
\text { (hours) } \\
\text { stopped } \\
\text { or } \\
\text { ongoing } \\
\end{array}$ & $\begin{array}{r}\text { Minimum } \\
\text { Creep } \\
\text { Rate } \\
(\% / h r) \\
\end{array}$ & $\begin{array}{r}\text { Elong. } \\
(\%)\end{array}$ & $\begin{array}{r}\text { Red. } \\
\text { of } \\
\text { Area } \\
(\%) \\
\end{array}$ & $\begin{array}{l}\text { Failure } \\
\text { Location }\end{array}$ \\
\hline TN30440 & sheet & none & none & 750 & 220.6 & 498.4 & 3.90E-02 & 33.6 & 25.2 & \\
\hline
\end{tabular}

TN30440

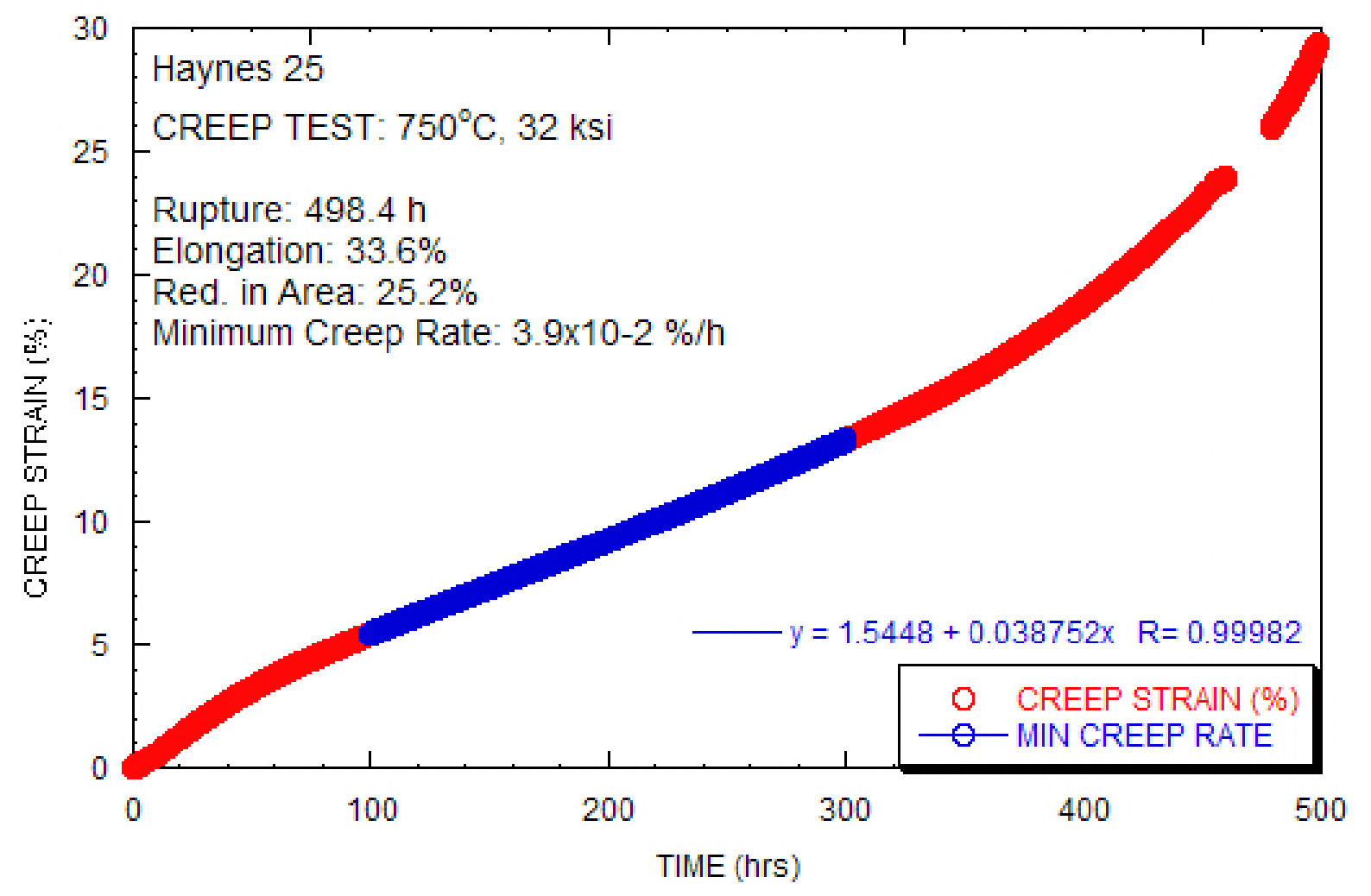




\begin{tabular}{|c|c|c|c|c|c|c|c|c|c|c|}
\hline Test ID & $\begin{array}{c}\text { Product } \\
\text { Form }\end{array}$ & $\begin{array}{l}\text { Aging } \\
\text { Temp. } \\
\left({ }^{\circ} \mathrm{C}\right)\end{array}$ & $\begin{array}{l}\text { Aging } \\
\text { Time } \\
\text { (hours) }\end{array}$ & $\begin{array}{c}\text { Test } \\
\text { Temp. } \\
\left({ }^{\circ} \mathrm{C}\right)\end{array}$ & $\begin{array}{l}\text { Stress } \\
(\mathrm{MPa})\end{array}$ & $\begin{array}{r}\text { Rupture } \\
\text { Life } \\
\text { (hours) } \\
\text { stopped } \\
\text { or } \\
\text { ongoing } \\
\end{array}$ & $\begin{array}{r}\text { Minimum } \\
\text { Creep } \\
\text { Rate } \\
(\% / h r) \\
\end{array}$ & $\begin{array}{r}\text { Elong. } \\
(\%)\end{array}$ & $\begin{array}{r}\text { Red. } \\
\text { of } \\
\text { Area } \\
(\%) \\
\end{array}$ & $\begin{array}{l}\text { Failure } \\
\text { Location }\end{array}$ \\
\hline TN29885 & sheet & none & none & 800 & 186.2 & 144.4 & 1.70E-01 & 45.3 & 47.6 & \\
\hline
\end{tabular}

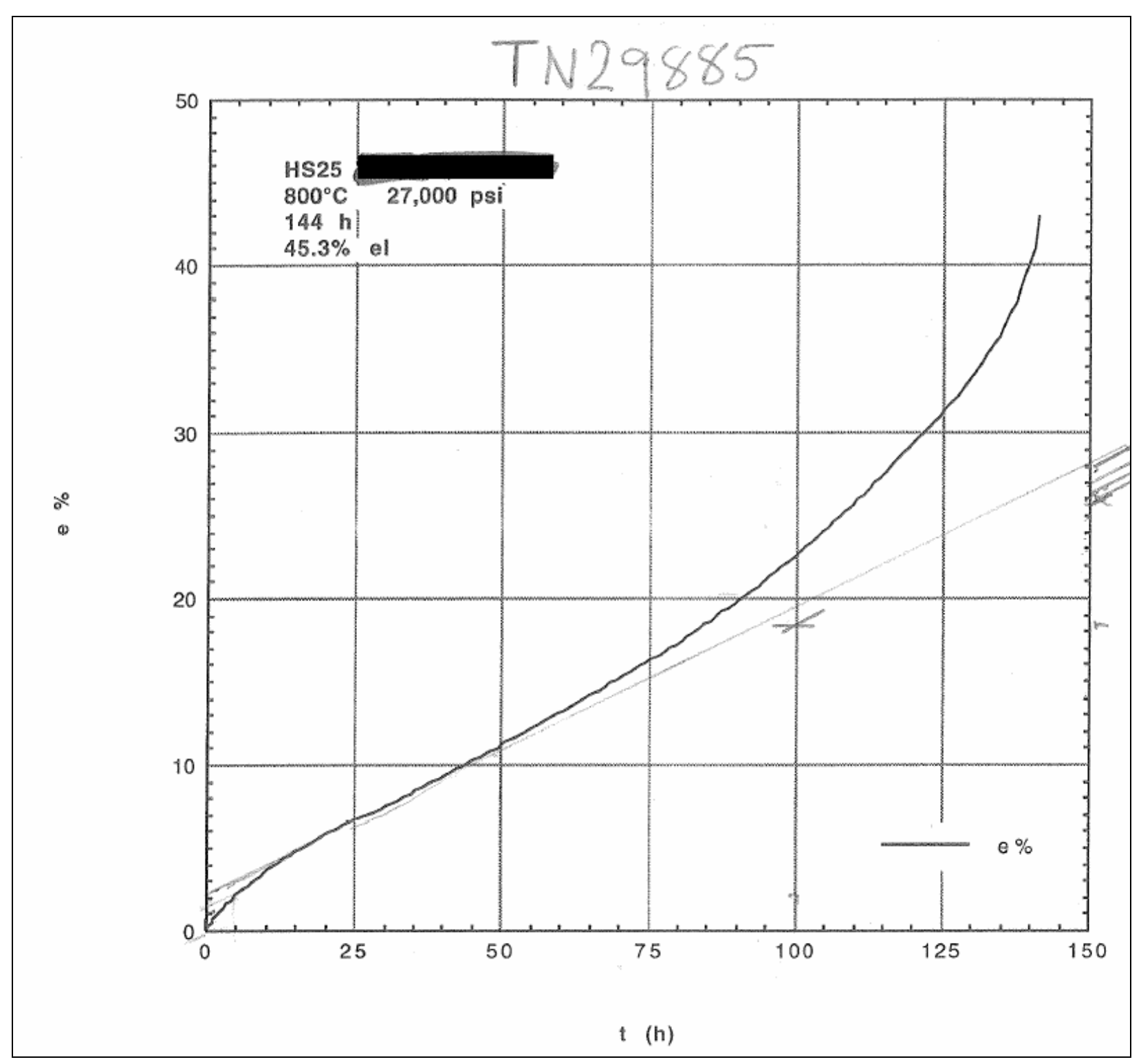




\begin{tabular}{|c|c|c|c|c|c|c|c|c|c|c|}
\hline Test ID & $\begin{array}{l}\text { Product } \\
\text { Form }\end{array}$ & $\begin{array}{l}\text { Aging } \\
\text { Temp. } \\
\left({ }^{\circ} \mathrm{C}\right)\end{array}$ & $\begin{array}{l}\text { Aging } \\
\text { Time } \\
\text { (hours) }\end{array}$ & $\begin{array}{l}\text { Test } \\
\text { Temp. } \\
\left({ }^{\circ} \mathrm{C}\right)\end{array}$ & $\begin{array}{l}\text { Stress } \\
(\mathrm{MPa})\end{array}$ & $\begin{array}{r}\text { Rupture } \\
\text { Life } \\
\text { (hours) } \\
\text { stopped } \\
\text { or } \\
\text { ongoing } \\
\end{array}$ & $\begin{array}{r}\text { Minimum } \\
\text { Creep } \\
\text { Rate } \\
(\% / h r) \\
\end{array}$ & $\begin{array}{r}\text { Elong. } \\
(\%)\end{array}$ & $\begin{array}{r}\text { Red. } \\
\text { of } \\
\text { Area } \\
(\%) \\
\end{array}$ & $\begin{array}{l}\text { Failure } \\
\text { Location }\end{array}$ \\
\hline TN30215 & sheet & none & none & 750 & 217.2 & 436.8 & 4.90E-02 & 32.0 & 32.7 & \\
\hline
\end{tabular}

TN30215

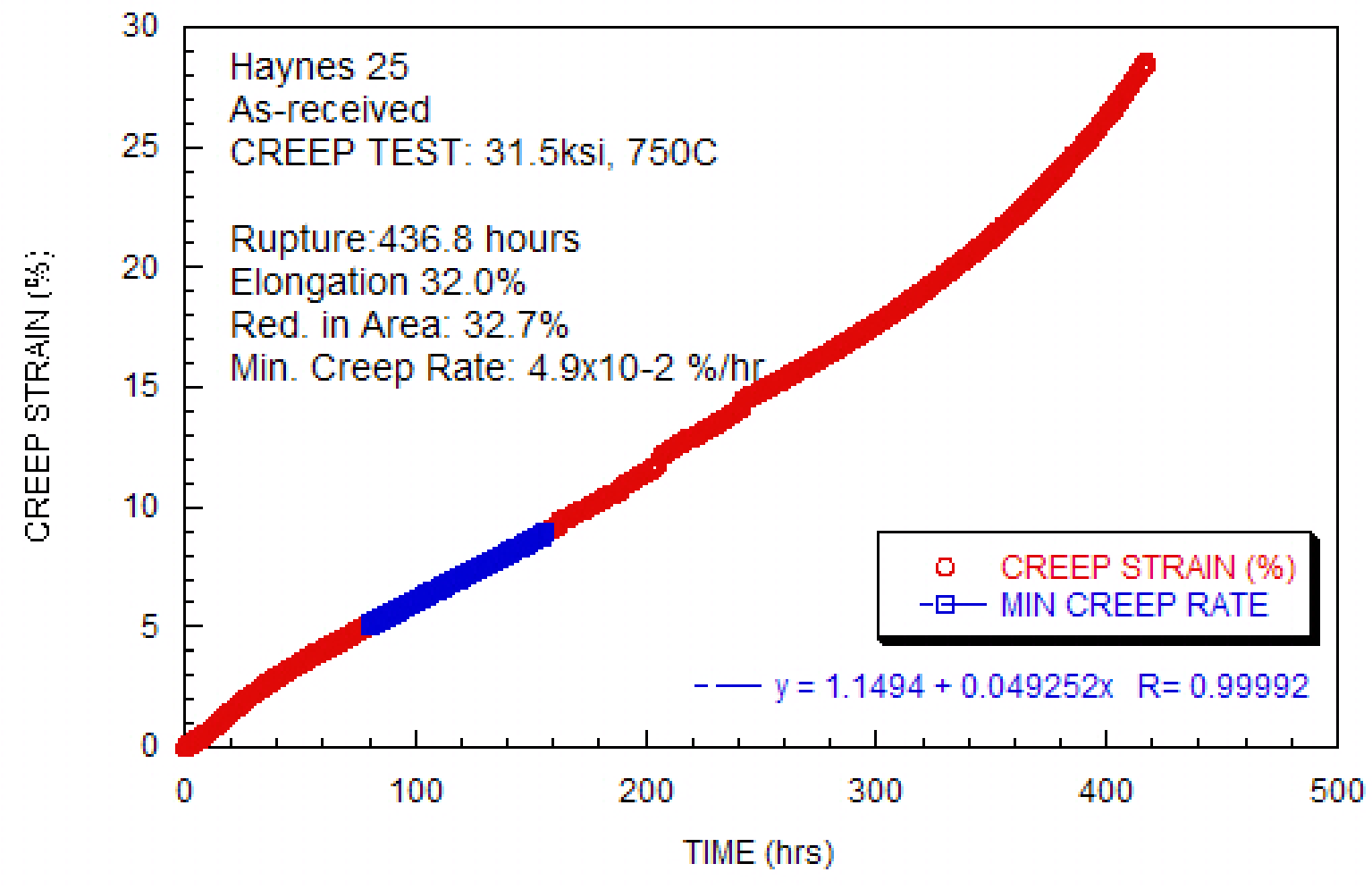




\begin{tabular}{|c|c|c|c|c|c|c|c|c|c|c|}
\hline Test ID & $\begin{array}{l}\text { Product } \\
\text { Form }\end{array}$ & $\begin{array}{l}\text { Aging } \\
\text { Temp. } \\
\left({ }^{\circ} \mathrm{C}\right)\end{array}$ & $\begin{array}{l}\text { Aging } \\
\text { Time } \\
\text { (hours) }\end{array}$ & $\begin{array}{l}\text { Test } \\
\text { Temp. } \\
\left({ }^{\circ} \mathrm{C}\right)\end{array}$ & $\begin{array}{l}\text { Stress } \\
(\mathrm{MPa})\end{array}$ & $\begin{array}{r}\text { Rupture } \\
\text { Life } \\
\text { (hours) } \\
\text { stopped } \\
\text { or } \\
\text { ongoing } \\
\end{array}$ & $\begin{array}{r}\text { Minimum } \\
\text { Creep } \\
\text { Rate } \\
(\% / h r) \\
\end{array}$ & $\begin{array}{r}\text { Elong. } \\
(\%)\end{array}$ & $\begin{array}{r}\text { Red. } \\
\text { of } \\
\text { Area } \\
(\%) \\
\end{array}$ & $\begin{array}{l}\text { Failure } \\
\text { Location }\end{array}$ \\
\hline TN30420 & sheet & none & none & 850 & 151.7 & 57.6 & 3.60E-01 & 46.7 & 48.3 & \\
\hline
\end{tabular}

TN30420

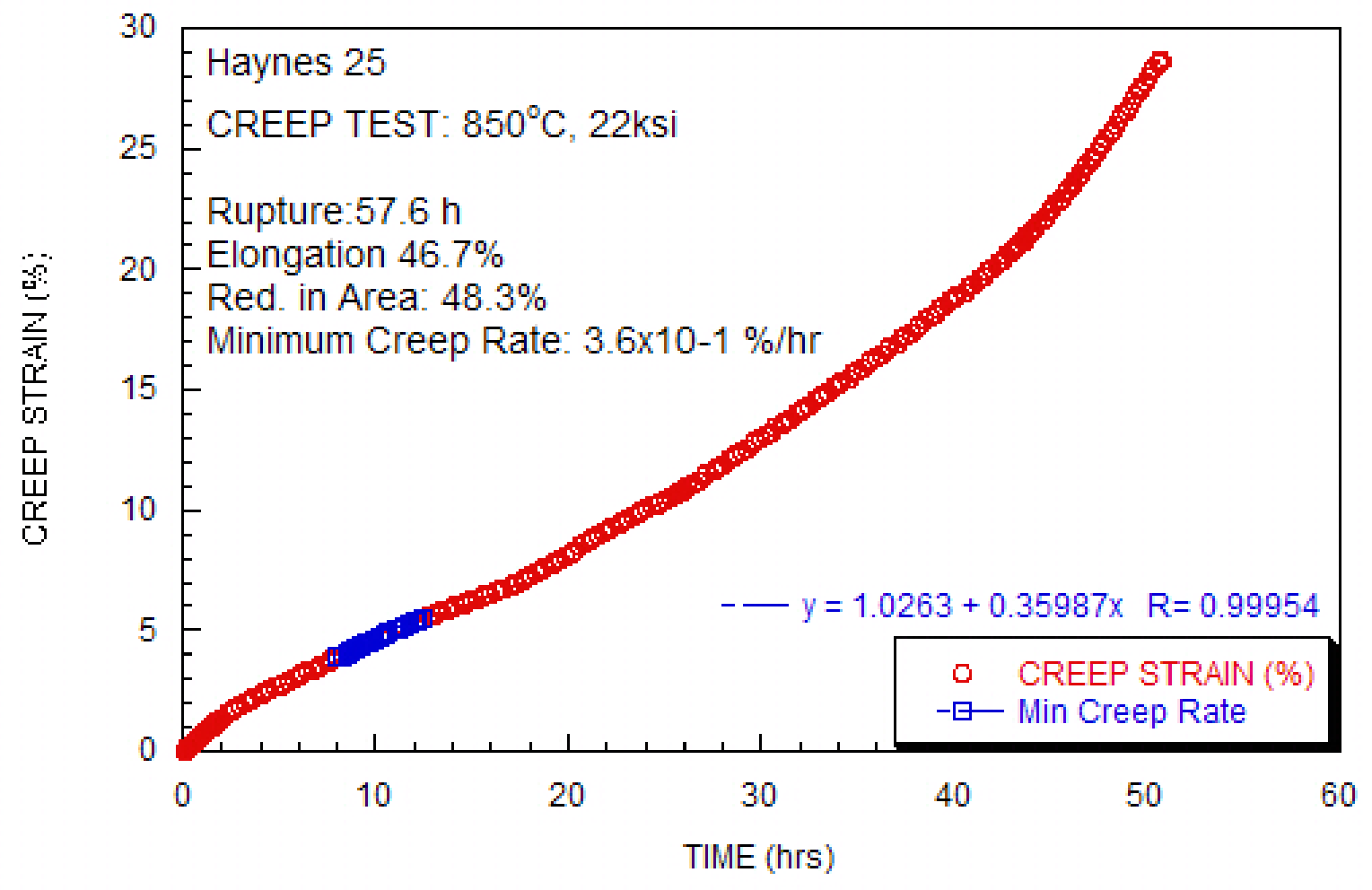




\begin{tabular}{|c|c|c|c|c|c|c|c|c|c|c|}
\hline Test ID & $\begin{array}{l}\text { Product } \\
\text { Form }\end{array}$ & $\begin{array}{l}\text { Aging } \\
\text { Temp. } \\
\left({ }^{\circ} \mathrm{C}\right)\end{array}$ & $\begin{array}{l}\text { Aging } \\
\text { Time } \\
\text { (hours) }\end{array}$ & $\begin{array}{c}\text { Test } \\
\text { Temp. } \\
\left({ }^{\circ} \mathrm{C}\right)\end{array}$ & $\begin{array}{l}\text { Stress } \\
(\mathrm{MPa})\end{array}$ & $\begin{array}{r}\text { Rupture } \\
\text { Life } \\
\text { (hours) } \\
\text { stopped } \\
\text { or } \\
\text { ongoing } \\
\end{array}$ & $\begin{array}{r}\text { Minimum } \\
\text { Creep } \\
\text { Rate } \\
(\% / \mathrm{hr}) \\
\end{array}$ & $\begin{array}{r}\text { Elong. } \\
(\%)\end{array}$ & $\begin{array}{r}\text { Red. } \\
\text { of } \\
\text { Area } \\
(\%) \\
\end{array}$ & $\begin{array}{l}\text { Failure } \\
\text { Location }\end{array}$ \\
\hline TN30138 & sheet & none & none & 750 & 193.1 & 745.0 & 1.60E-02 & 21.3 & 19.7 & \\
\hline
\end{tabular}

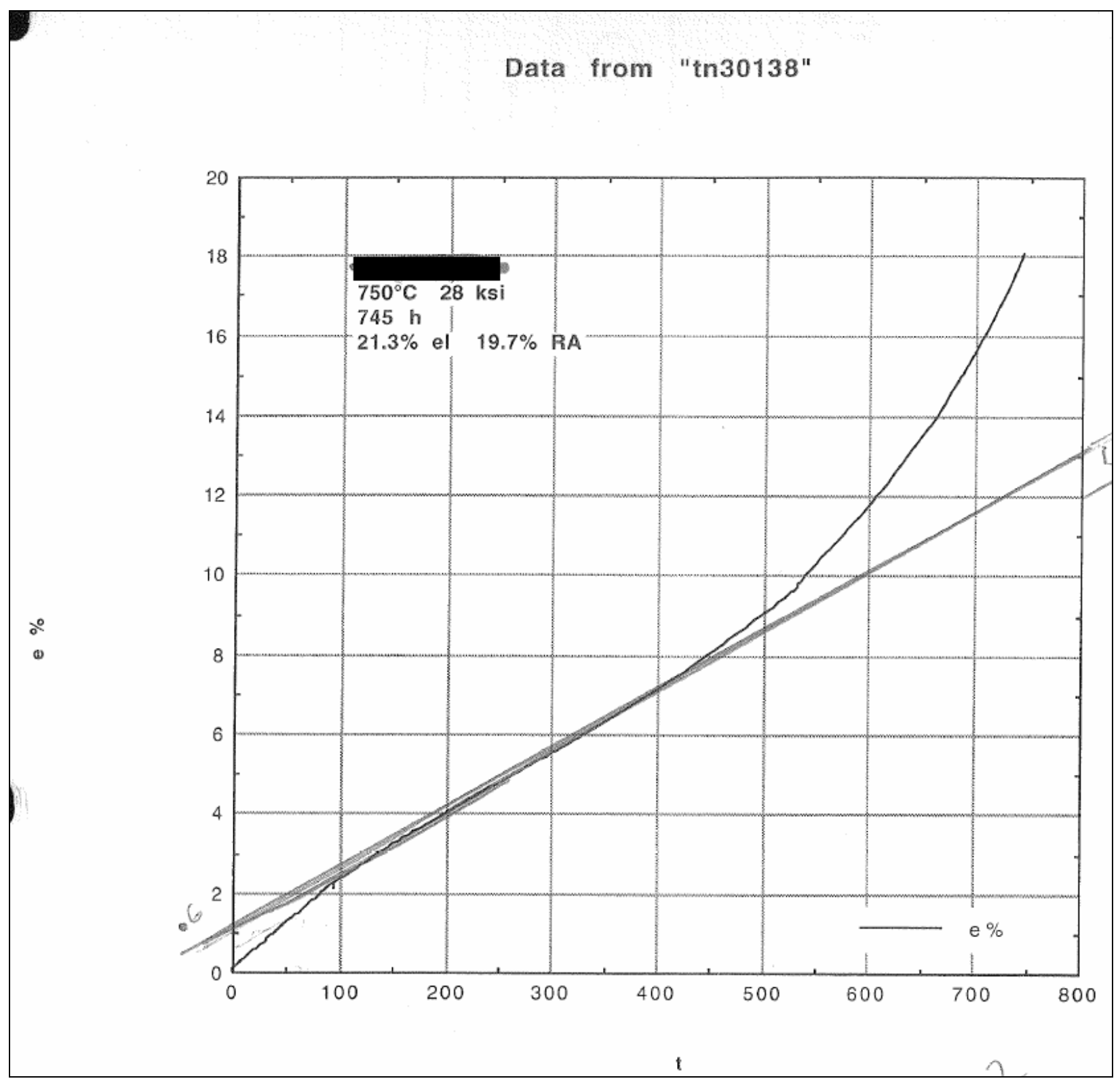




\begin{tabular}{|c|c|c|c|c|c|c|c|c|c|c|}
\hline Test ID & $\begin{array}{l}\text { Product } \\
\text { Form }\end{array}$ & $\begin{array}{l}\text { Aging } \\
\text { Temp. } \\
\left({ }^{\circ} \mathrm{C}\right)\end{array}$ & $\begin{array}{l}\text { Aging } \\
\text { Time } \\
\text { (hours) }\end{array}$ & $\begin{array}{l}\text { Test } \\
\text { Temp. } \\
\left({ }^{\circ} \mathrm{C}\right)\end{array}$ & $\begin{array}{l}\text { Stress } \\
(\mathrm{MPa})\end{array}$ & $\begin{array}{r}\text { Rupture } \\
\text { Life } \\
\text { (hours) } \\
\text { stopped } \\
\text { or } \\
\text { ongoing }\end{array}$ & $\begin{array}{r}\text { Minimum } \\
\text { Creep } \\
\text { Rate } \\
(\% / h r)\end{array}$ & $\begin{array}{l}\text { Elong. } \\
(\%)\end{array}$ & $\begin{array}{l}\text { Red. } \\
\text { of } \\
\text { Area } \\
(\%)\end{array}$ & $\begin{array}{l}\text { Failure } \\
\text { Location }\end{array}$ \\
\hline MG-13 & sheet & none & none & 600 & 179.3 & 9000.0 & 1.8E-05 & & & \\
\hline
\end{tabular}

MG-13

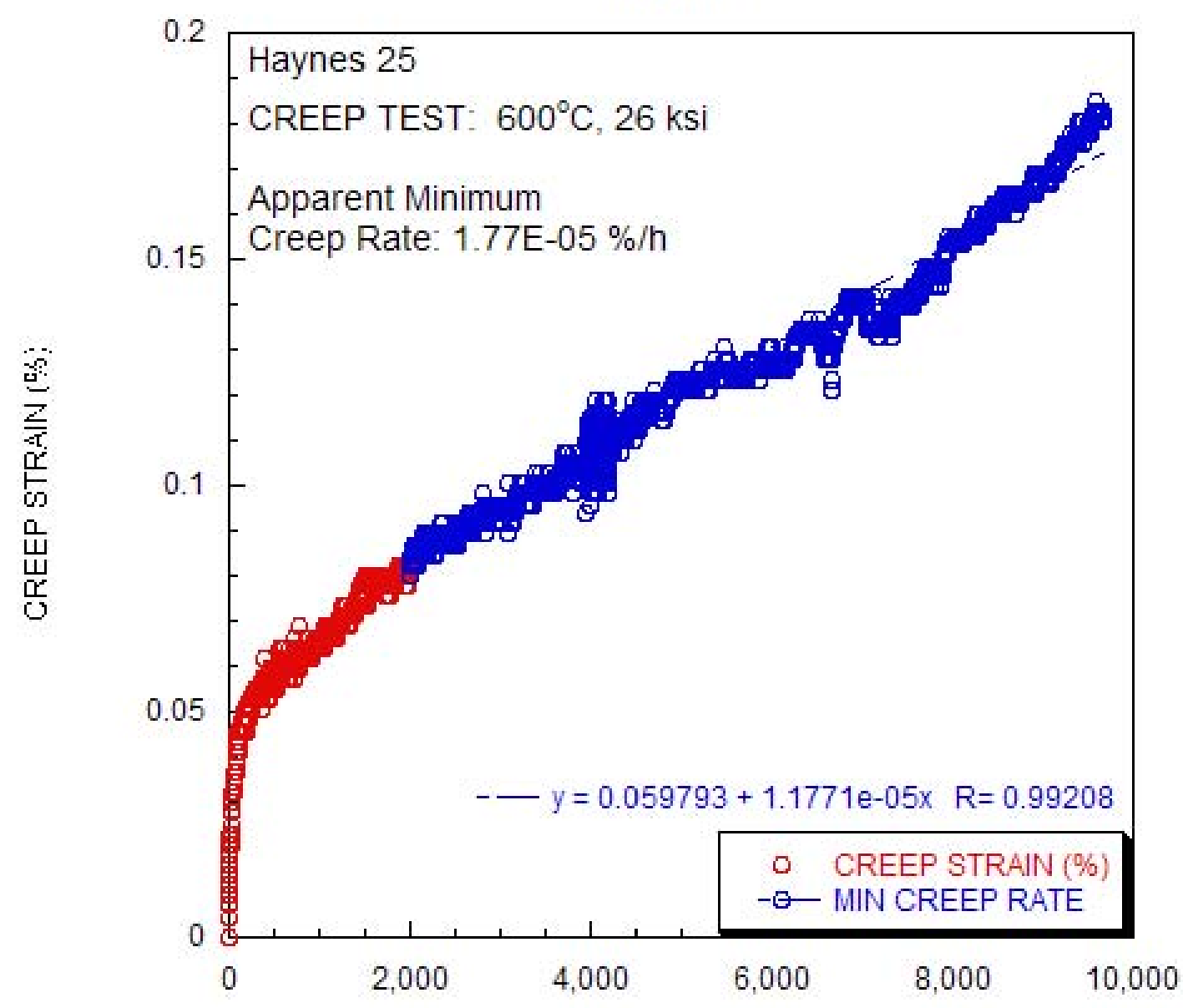

TIME (hrs) 


\begin{tabular}{|c|c|c|c|c|c|c|c|c|c|c|}
\hline Test ID & $\begin{array}{l}\text { Product } \\
\text { Form }\end{array}$ & $\begin{array}{l}\text { Aging } \\
\text { Temp. } \\
\left({ }^{\circ} \mathrm{C}\right)\end{array}$ & $\begin{array}{l}\text { Aging } \\
\text { Time } \\
\text { (hours) }\end{array}$ & $\begin{array}{l}\text { Test } \\
\text { Temp. } \\
\left({ }^{\circ} \mathrm{C}\right)\end{array}$ & $\begin{array}{l}\text { Stress } \\
(\mathrm{MPa})\end{array}$ & $\begin{array}{r}\text { Rupture } \\
\text { Life } \\
\text { (hours) } \\
\text { stopped } \\
\text { or } \\
\text { ongoing } \\
\end{array}$ & $\begin{array}{r}\text { Minimum } \\
\text { Creep } \\
\text { Rate } \\
(\% / h r) \\
\end{array}$ & $\begin{array}{l}\text { Elong. } \\
(\%)\end{array}$ & $\begin{array}{l}\text { Red. } \\
\text { of } \\
\text { Area } \\
(\%) \\
\end{array}$ & $\begin{array}{l}\text { Failure } \\
\text { Location }\end{array}$ \\
\hline MG-14 & sheet & none & none & 600 & 206.8 & 12311.0 & 2.0E-05 & & & \\
\hline
\end{tabular}

MG-14

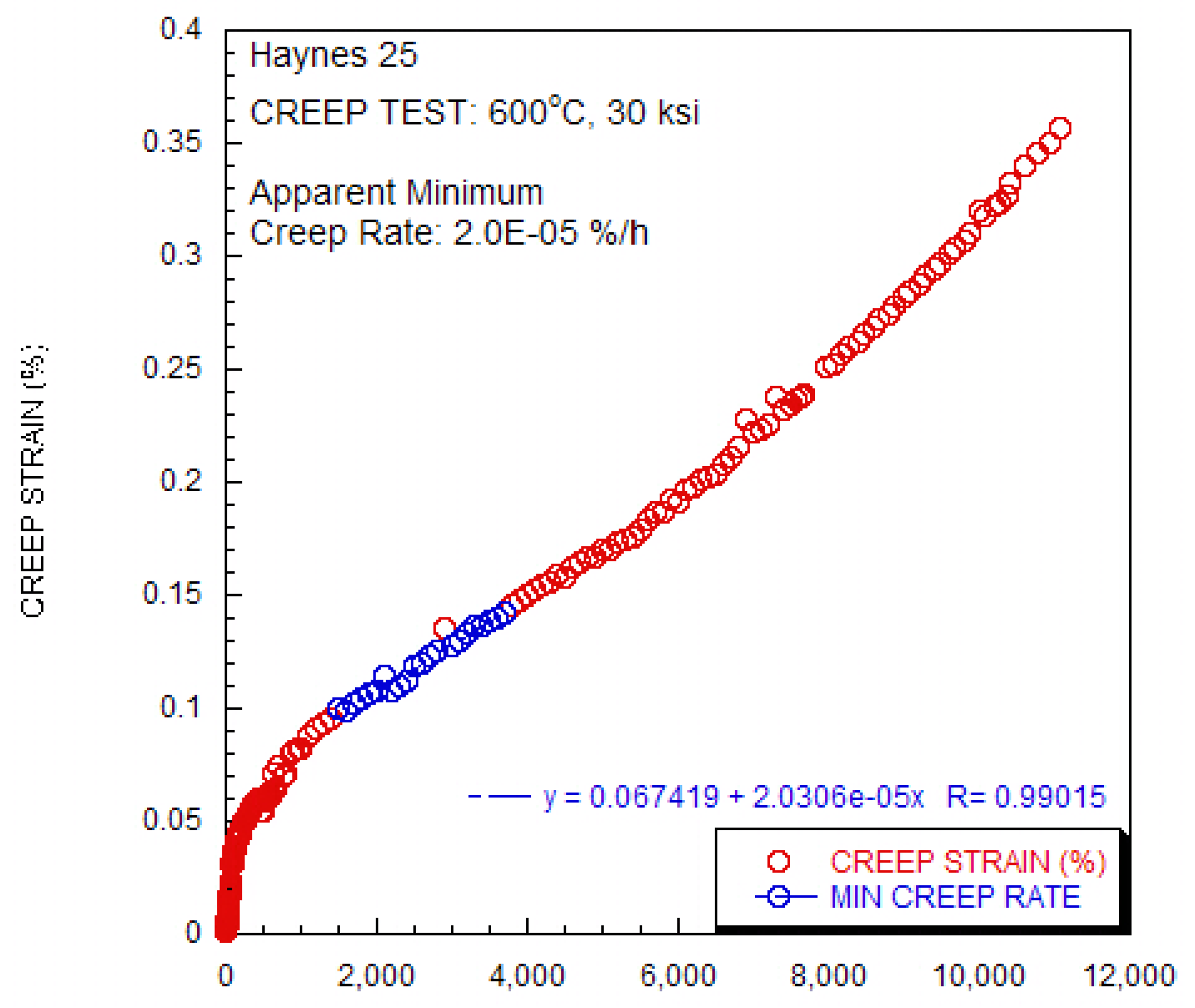

TIME (hrs) 


\begin{tabular}{|c|c|c|c|c|c|c|c|c|c|c|}
\hline Test ID & $\begin{array}{l}\text { Product } \\
\text { Form }\end{array}$ & $\begin{array}{l}\text { Aging } \\
\text { Temp. } \\
\left({ }^{\circ} \mathrm{C}\right)\end{array}$ & $\begin{array}{l}\text { Aging } \\
\text { Time } \\
\text { (hours) }\end{array}$ & $\begin{array}{l}\text { Test } \\
\text { Temp. } \\
\left({ }^{\circ} \mathrm{C}\right)\end{array}$ & $\begin{array}{l}\text { Stress } \\
(\mathrm{MPa})\end{array}$ & $\begin{array}{r}\text { Rupture } \\
\text { Life } \\
\text { (hours) } \\
\text { stopped } \\
\text { or } \\
\text { ongoing }\end{array}$ & $\begin{array}{r}\text { Minimum } \\
\text { Creep } \\
\text { Rate } \\
(\% / h r)\end{array}$ & $\begin{array}{l}\text { Elong. } \\
(\%)\end{array}$ & $\begin{array}{l}\text { Red. } \\
\text { of } \\
\text { Area } \\
(\%)\end{array}$ & $\begin{array}{l}\text { Failure } \\
\text { Location }\end{array}$ \\
\hline MG-15 & sheet & none & none & 625 & 144.8 & 30000.0 & 1.3E-05 & & & \\
\hline
\end{tabular}

\section{MG-15}

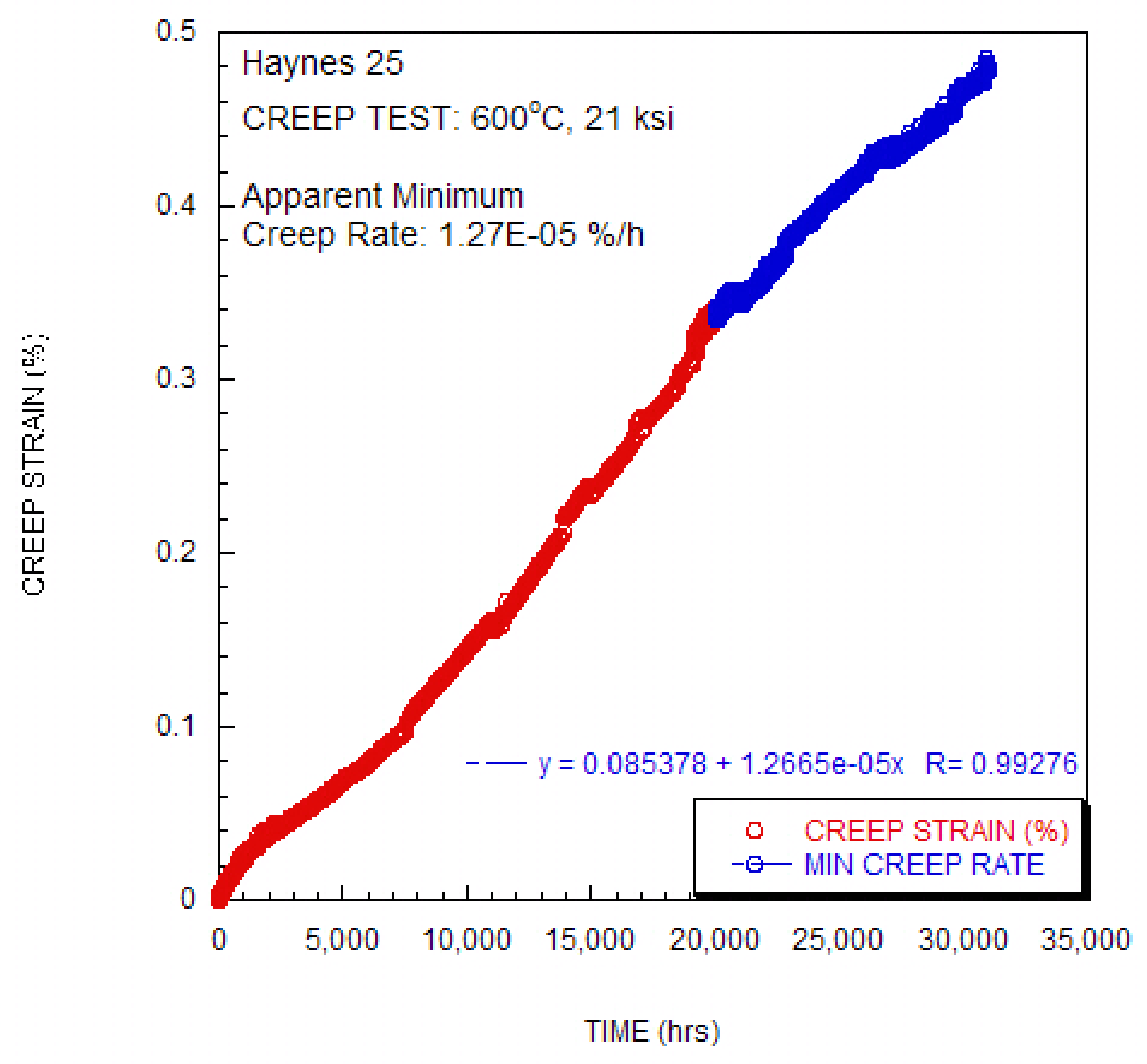




\begin{tabular}{|c|c|c|c|c|c|c|c|c|c|c|}
\hline Test ID & $\begin{array}{c}\text { Product } \\
\text { Form }\end{array}$ & $\begin{array}{c}\text { Aging } \\
\text { Temp. } \\
\left({ }^{\circ} \mathrm{C}\right)\end{array}$ & $\begin{array}{l}\text { Aging } \\
\text { Time } \\
\text { (hours) }\end{array}$ & $\begin{array}{l}\text { Test } \\
\text { Temp. } \\
\left({ }^{\circ} \mathrm{C}\right)\end{array}$ & $\begin{array}{l}\text { Stress } \\
(\mathrm{MPa})\end{array}$ & $\begin{array}{r}\text { Rupture } \\
\text { Life } \\
\text { (hours) } \\
\text { stopped } \\
\text { or } \\
\text { ongoing }\end{array}$ & $\begin{array}{r}\text { Minimum } \\
\text { Creep } \\
\text { Rate } \\
(\% / h r)\end{array}$ & $\begin{array}{l}\text { Elong. } \\
(\%)\end{array}$ & $\begin{array}{l}\text { Red. } \\
\text { of } \\
\text { Area } \\
(\%)\end{array}$ & $\begin{array}{l}\text { Failure } \\
\text { Location }\end{array}$ \\
\hline MG-17 & sheet & none & none & 625 & 206.8 & 12614.0 & 2.1E-05 & & & \\
\hline
\end{tabular}

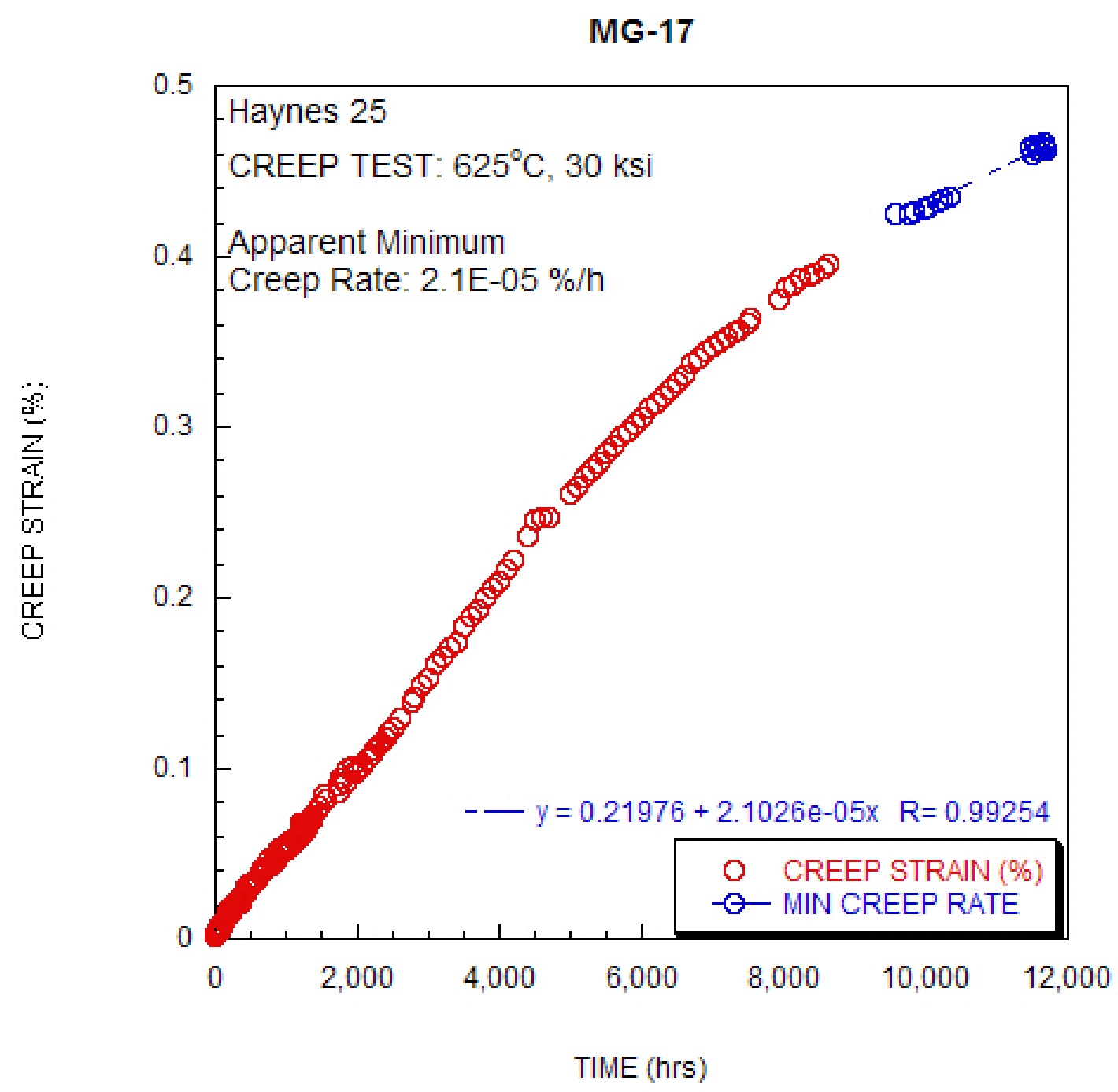




\begin{tabular}{|c|c|c|c|c|c|c|c|c|c|c|}
\hline Test ID & $\begin{array}{l}\text { Product } \\
\text { Form }\end{array}$ & $\begin{array}{l}\text { Aging } \\
\text { Temp. } \\
\left({ }^{\circ} \mathrm{C}\right)\end{array}$ & $\begin{array}{l}\text { Aging } \\
\text { Time } \\
\text { (hours) }\end{array}$ & $\begin{array}{l}\text { Test } \\
\text { Temp. } \\
\left({ }^{\circ} \mathrm{C}\right)\end{array}$ & $\begin{array}{l}\text { Stress } \\
(\mathrm{MPa})\end{array}$ & $\begin{array}{r}\text { Rupture } \\
\text { Life } \\
\text { (hours) } \\
\text { stopped } \\
\text { or } \\
\text { ongoing } \\
\end{array}$ & $\begin{array}{r}\text { Minimum } \\
\text { Creep } \\
\text { Rate } \\
(\% / h r) \\
\end{array}$ & $\begin{array}{l}\text { Elong. } \\
(\%)\end{array}$ & $\begin{array}{l}\text { Red. } \\
\text { of } \\
\text { Area } \\
(\%) \\
\end{array}$ & $\begin{array}{l}\text { Failure } \\
\text { Location }\end{array}$ \\
\hline MG-18 & sheet & none & none & 650 & 124.1 & 10507.0 & 4.5E-05 & & & \\
\hline
\end{tabular}

MG-18

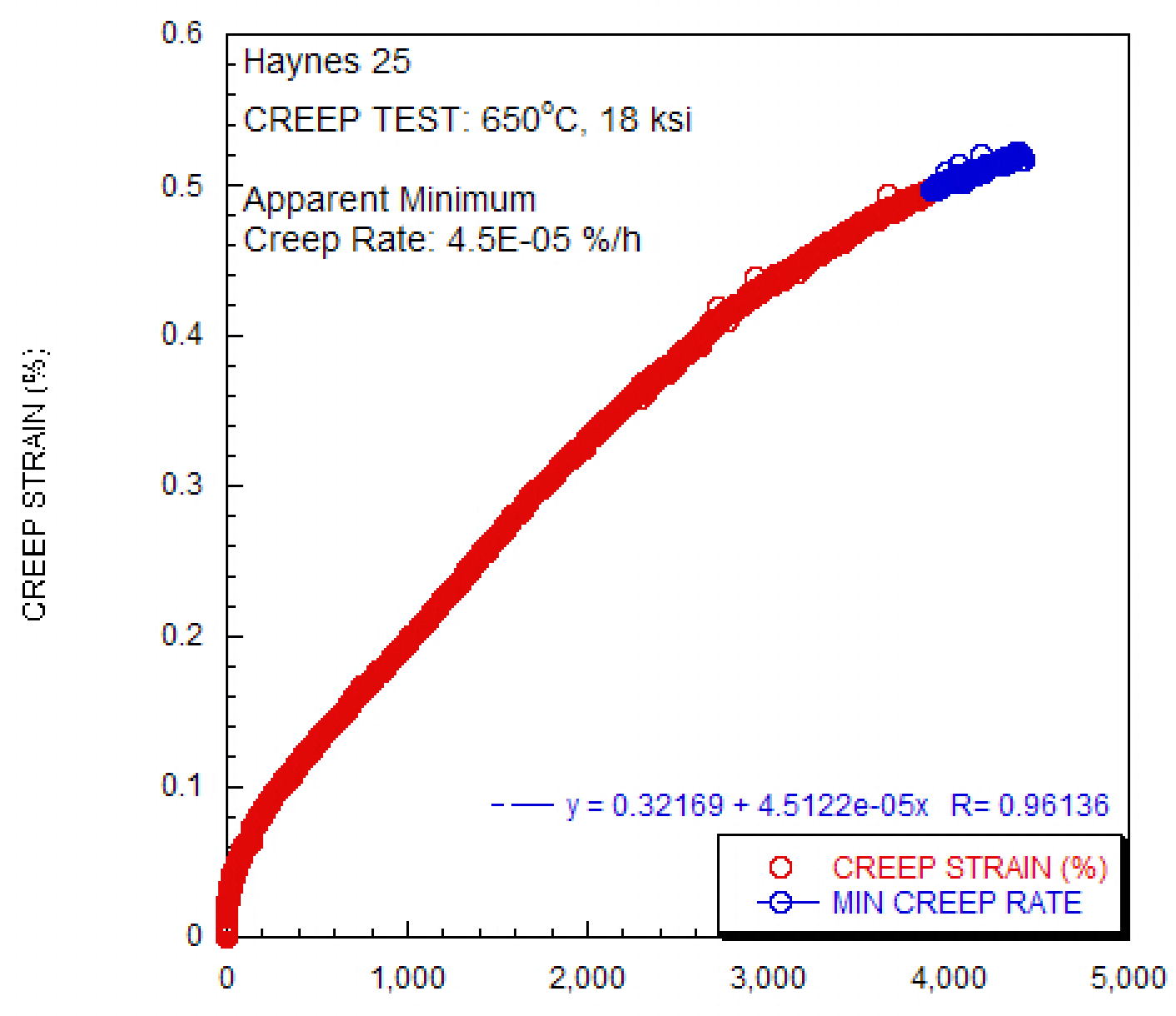

TIME (hrs) 


\begin{tabular}{|c|c|c|c|c|c|c|c|c|c|c|}
\hline Test ID & $\begin{array}{c}\text { Product } \\
\text { Form }\end{array}$ & $\begin{array}{c}\text { Aging } \\
\text { Temp. } \\
\left({ }^{\circ} \mathrm{C}\right)\end{array}$ & $\begin{array}{l}\text { Aging } \\
\text { Time } \\
\text { (hours) }\end{array}$ & $\begin{array}{l}\text { Test } \\
\text { Temp. } \\
\left({ }^{\circ} \mathrm{C}\right)\end{array}$ & $\begin{array}{l}\text { Stress } \\
(\mathrm{MPa})\end{array}$ & $\begin{array}{r}\text { Rupture } \\
\text { Life } \\
\text { (hours) } \\
\text { stopped } \\
\text { or } \\
\text { ongoing }\end{array}$ & $\begin{array}{r}\text { Minimum } \\
\text { Creep } \\
\text { Rate } \\
(\% / h r)\end{array}$ & $\begin{array}{l}\text { Elong. } \\
(\%)\end{array}$ & $\begin{array}{l}\text { Red. } \\
\text { of } \\
\text { Area } \\
(\%)\end{array}$ & $\begin{array}{l}\text { Failure } \\
\text { Location }\end{array}$ \\
\hline MG-21 & sheet & none & none & 650 & 186.2 & 11080.0 & 4.2E-05 & & & \\
\hline
\end{tabular}

\section{MG-21}

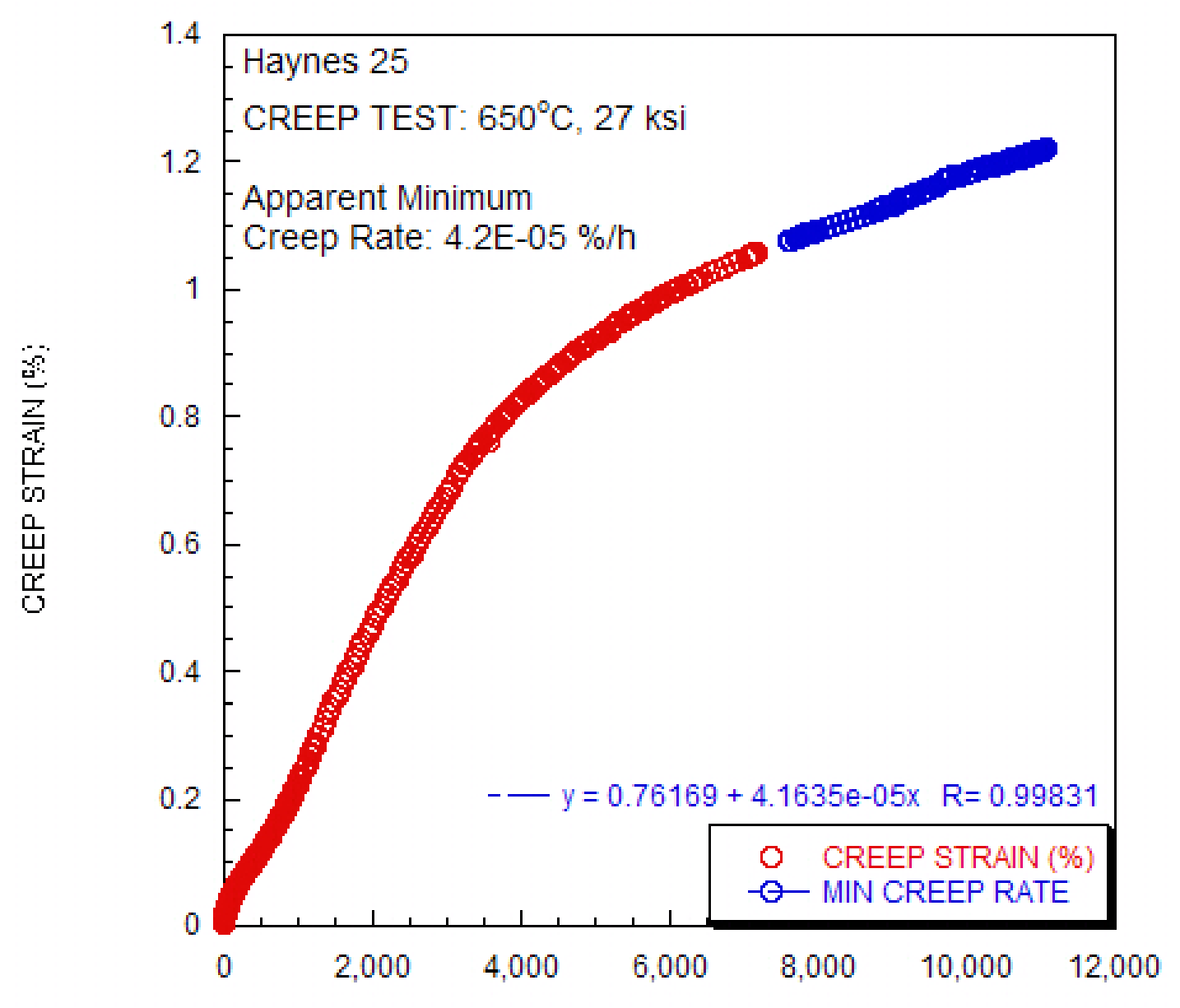

TIME (h) 


\begin{tabular}{|c|c|c|c|c|c|c|c|c|c|c|}
\hline Test ID & $\begin{array}{c}\text { Product } \\
\text { Form }\end{array}$ & $\begin{array}{l}\text { Aging } \\
\text { Temp. } \\
\left({ }^{\circ} \mathrm{C}\right)\end{array}$ & $\begin{array}{l}\text { Aging } \\
\text { Time } \\
\text { (hours) }\end{array}$ & $\begin{array}{l}\text { Test } \\
\text { Temp. } \\
\left({ }^{\circ} \mathrm{C}\right)\end{array}$ & $\begin{array}{l}\text { Stress } \\
(\mathrm{MPa})\end{array}$ & $\begin{array}{r}\text { Rupture } \\
\text { Life } \\
\text { (hours) } \\
\text { stopped } \\
\text { or } \\
\text { ongoing } \\
\end{array}$ & $\begin{array}{r}\text { Minimum } \\
\text { Creep } \\
\text { Rate } \\
(\% / h r) \\
\end{array}$ & $\begin{array}{l}\text { Elong. } \\
(\%)\end{array}$ & $\begin{array}{l}\text { Red. } \\
\text { of } \\
\text { Area } \\
(\%)\end{array}$ & $\begin{array}{l}\text { Failure } \\
\text { Location }\end{array}$ \\
\hline MG-22 & sheet & none & none & 675 & 103.4 & 11117.0 & 4.2E-06 & & & \\
\hline
\end{tabular}

\section{MG-22}

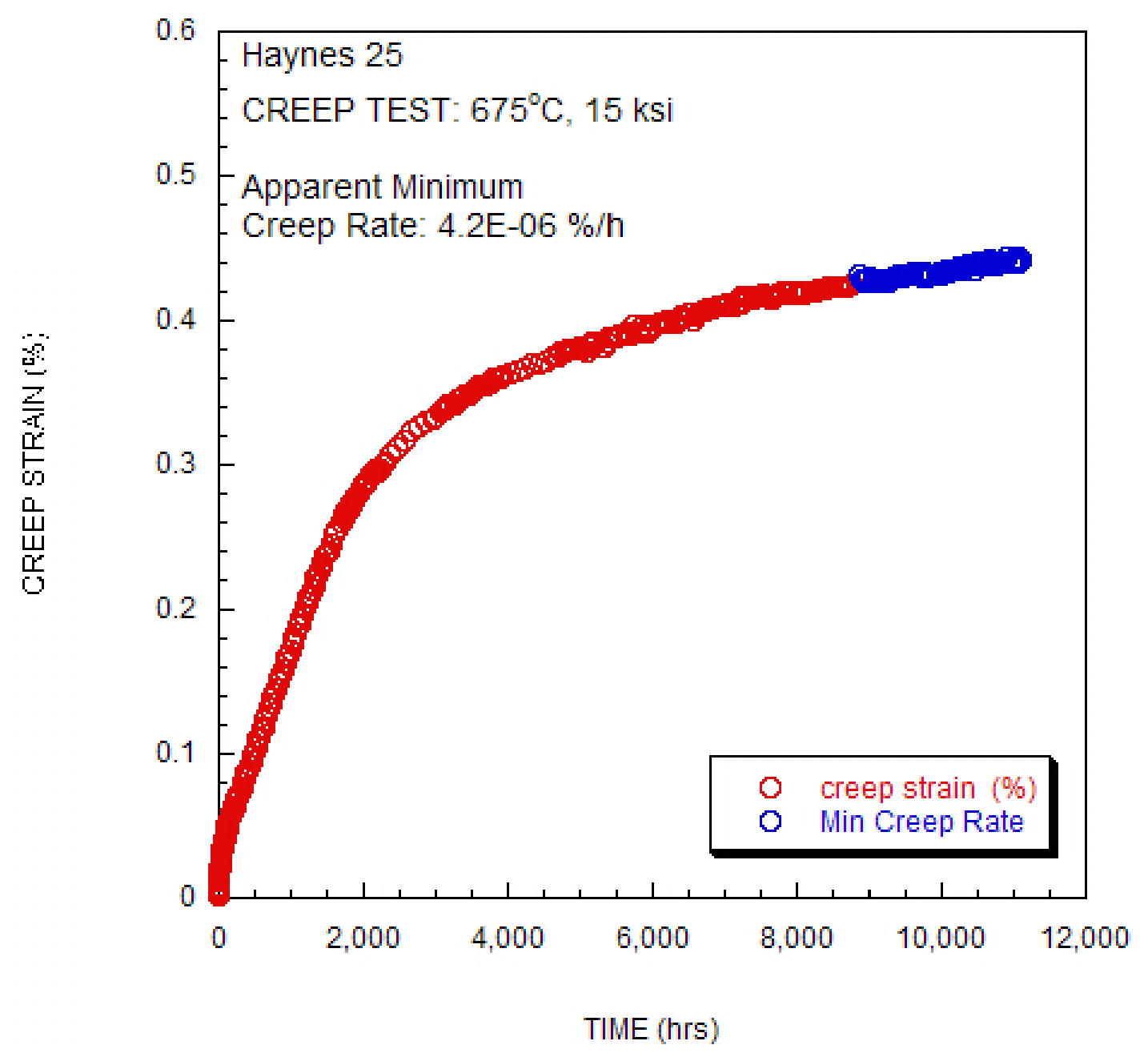




\begin{tabular}{|c|c|c|c|c|c|c|c|c|c|c|}
\hline Test ID & $\begin{array}{l}\text { Product } \\
\text { Form }\end{array}$ & $\begin{array}{c}\text { Aging } \\
\text { Temp. } \\
\left({ }^{\circ} \mathrm{C}\right)\end{array}$ & $\begin{array}{l}\text { Aging } \\
\text { Time } \\
\text { (hours) }\end{array}$ & $\begin{array}{c}\text { Test } \\
\text { Temp. } \\
\left({ }^{\circ} \mathrm{C}\right)\end{array}$ & $\begin{array}{l}\text { Stress } \\
(\mathrm{MPa})\end{array}$ & $\begin{array}{r}\text { Rupture } \\
\text { Life } \\
\text { (hours) } \\
\text { stopped } \\
\text { or } \\
\text { ongoing }\end{array}$ & $\begin{array}{r}\text { Minimum } \\
\text { Creep } \\
\text { Rate } \\
(\% / h r)\end{array}$ & $\begin{array}{l}\text { Elong. } \\
(\%)\end{array}$ & $\begin{array}{l}\text { Red. } \\
\text { of } \\
\text { Area } \\
(\%) \\
\end{array}$ & $\begin{array}{l}\text { Failure } \\
\text { Location }\end{array}$ \\
\hline MG-24 & sheet & none & none & 675 & 151.7 & 38000.0 & 1.6E-05 & & & \\
\hline
\end{tabular}

MG-24

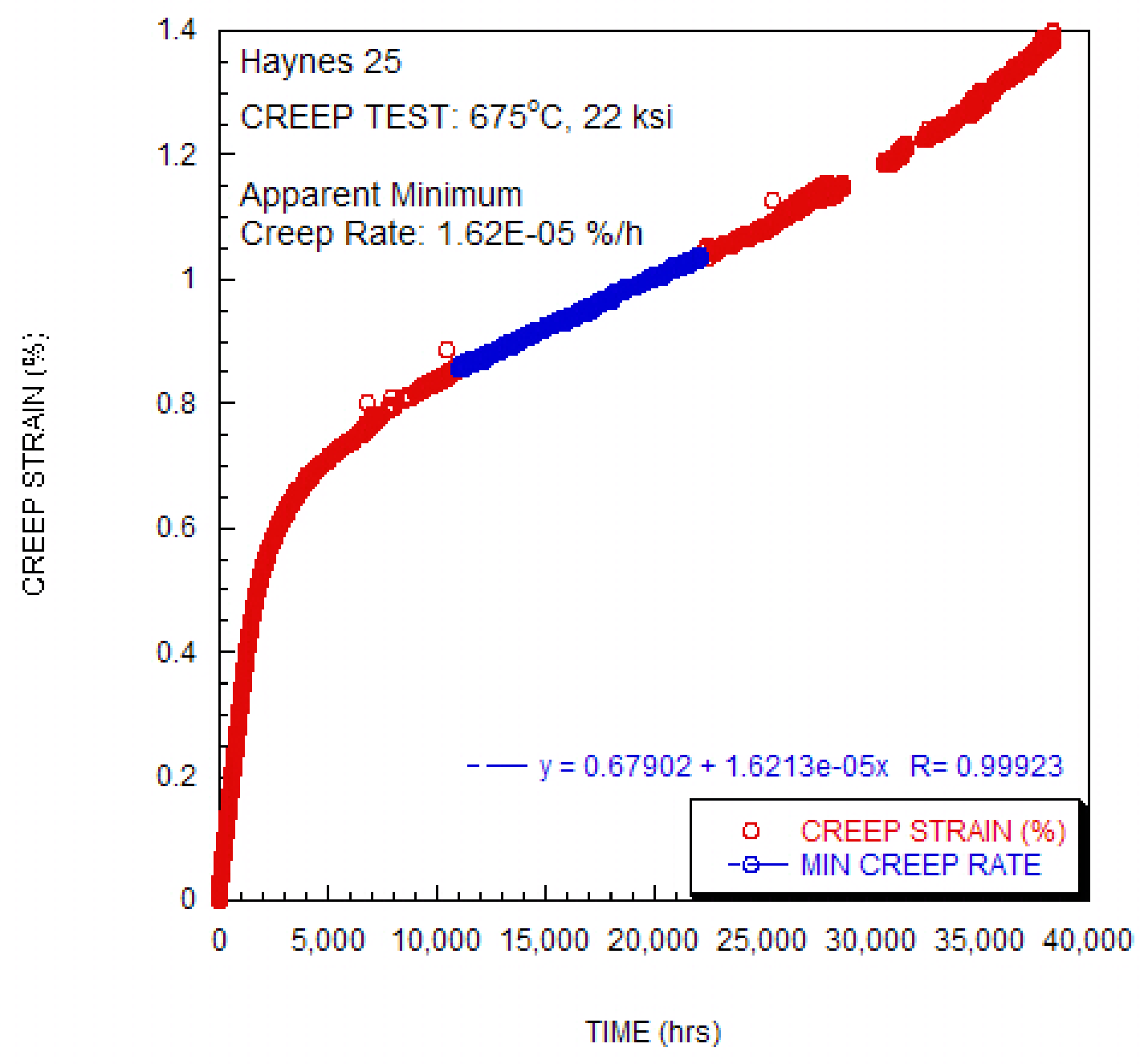




\begin{tabular}{|c|c|c|c|c|c|c|c|c|c|c|}
\hline Test ID & $\begin{array}{c}\text { Product } \\
\text { Form }\end{array}$ & $\begin{array}{c}\text { Aging } \\
\text { Temp. } \\
\left({ }^{\circ} \mathrm{C}\right)\end{array}$ & $\begin{array}{l}\text { Aging } \\
\text { Time } \\
\text { (hours) }\end{array}$ & $\begin{array}{c}\text { Test } \\
\text { Temp. } \\
\left({ }^{\circ} \mathrm{C}\right)\end{array}$ & $\begin{array}{l}\text { Stress } \\
(\mathrm{MPa})\end{array}$ & $\begin{array}{r}\text { Rupture } \\
\text { Life } \\
\text { (hours) } \\
\text { stopped } \\
\text { or } \\
\text { ongoing }\end{array}$ & $\begin{array}{r}\text { Minimum } \\
\text { Creep } \\
\text { Rate } \\
(\% / h r)\end{array}$ & $\begin{array}{l}\text { Elong. } \\
(\%)\end{array}$ & $\begin{array}{l}\text { Red. } \\
\text { of } \\
\text { Area } \\
(\%) \\
\end{array}$ & $\begin{array}{l}\text { Failure } \\
\text { Location }\end{array}$ \\
\hline \multirow[t]{8}{*}{ MG22b } & \multirow[t]{8}{*}{ sheet } & \multirow[t]{8}{*}{ none } & \multirow[t]{8}{*}{ none } & 675 & 103.4 & 15976.0 & 5.5E-06 & & & \\
\hline & & & & 675 & 0.0 & 16262.0 & & & & \\
\hline & & & & 675 & 103.4 & 20591.0 & 5.70E-06 & & & \\
\hline & & & & 700 & 103.4 & 22892.0 & $6.80 \mathrm{E}-06$ & & & \\
\hline & & & & 725 & 103.4 & 24496.0 & 2.10E-05 & & & \\
\hline & & & & 700 & 103.4 & 25574.0 & 1.10E-05 & & & \\
\hline & & & & 675 & 103.4 & 39841.0 & 6.30E-06 & & & \\
\hline & & & & 675 & 117.2 & 42000.0 & 8.70E-06 & & & \\
\hline
\end{tabular}

MG-22b

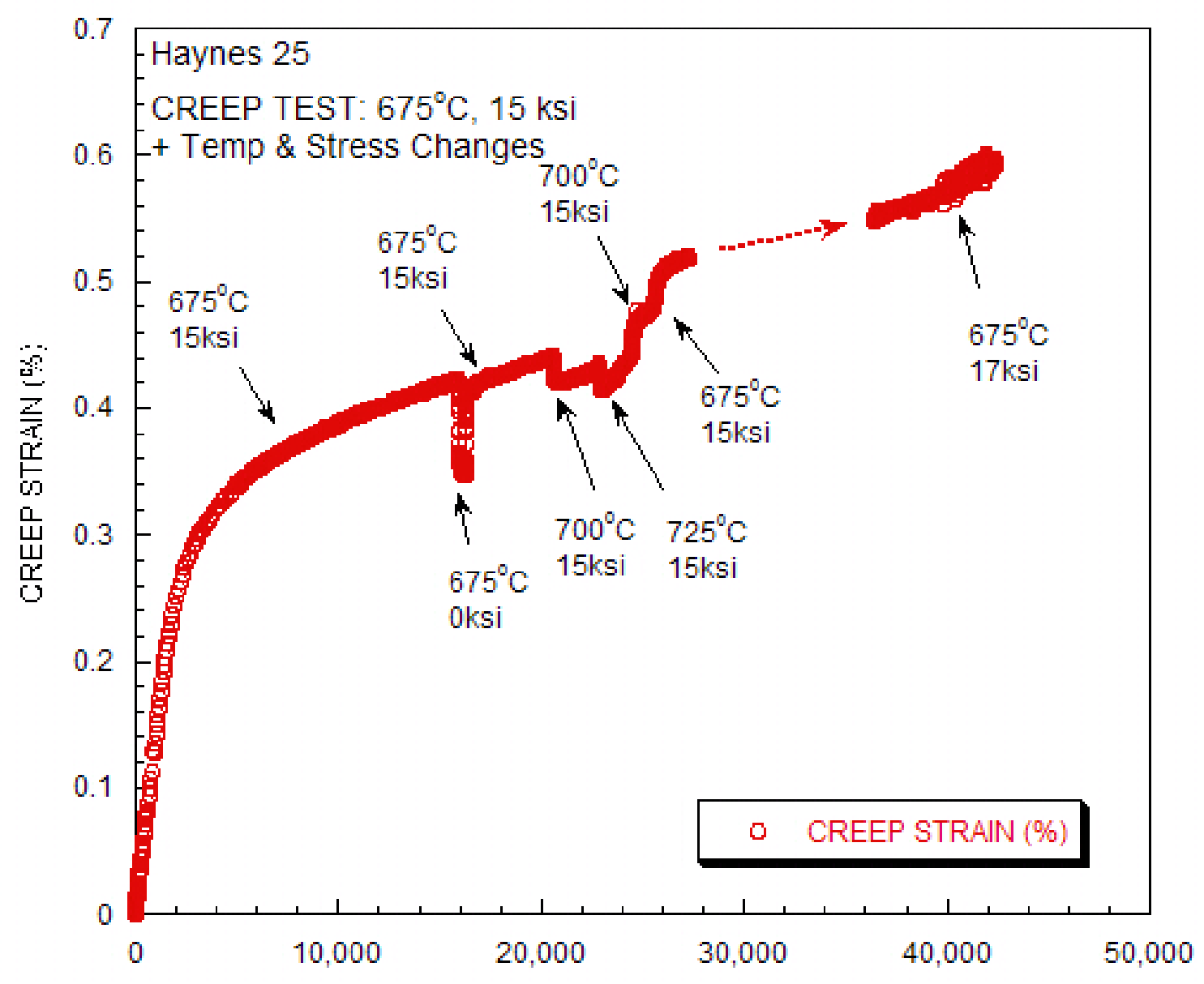

time (h) 


\begin{tabular}{|c|c|c|c|c|c|c|c|c|c|c|}
\hline Test ID & $\begin{array}{l}\text { Product } \\
\text { Form }\end{array}$ & $\begin{array}{c}\text { Aging } \\
\text { Temp. } \\
\left({ }^{\circ} \mathrm{C}\right)\end{array}$ & $\begin{array}{l}\text { Aging } \\
\text { Time } \\
\text { (hours) }\end{array}$ & $\begin{array}{c}\text { Test } \\
\text { Temp. } \\
\left({ }^{\circ} \mathrm{C}\right)\end{array}$ & $\begin{array}{l}\text { Stress } \\
(\mathrm{MPa})\end{array}$ & $\begin{array}{r}\text { Rupture } \\
\text { Life } \\
\text { (hours) } \\
\text { stopped } \\
\text { or } \\
\text { ongoing } \\
\end{array}$ & $\begin{array}{r}\text { Minimum } \\
\text { Creep } \\
\text { Rate } \\
(\% / h r) \\
\end{array}$ & $\begin{array}{l}\text { Elong. } \\
(\%)\end{array}$ & $\begin{array}{l}\text { Red. } \\
\text { of } \\
\text { Area } \\
(\%) \\
\end{array}$ & $\begin{array}{l}\text { Failure } \\
\text { Location }\end{array}$ \\
\hline $\begin{array}{l}\text { CR-BM- } \\
15\end{array}$ & sheet & 675 & 6000 & 650 & 206.8 & 38300.0 & $2.50 \mathrm{E}-05$ & & & \\
\hline
\end{tabular}

CR-BM-15

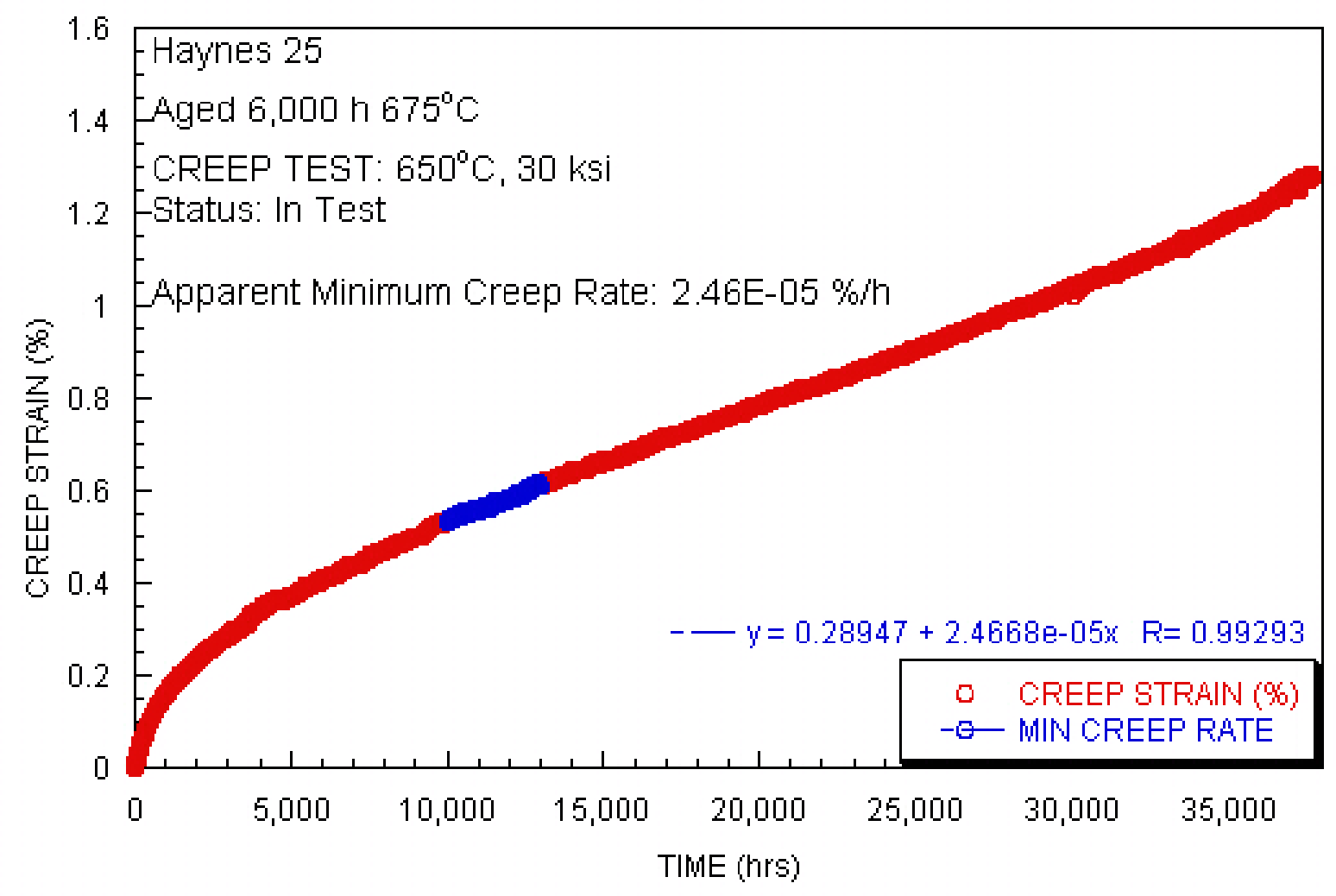




\begin{tabular}{|c|c|c|c|c|c|c|c|c|c|c|}
\hline Test ID & $\begin{array}{l}\text { Product } \\
\text { Form }\end{array}$ & $\begin{array}{c}\text { Aging } \\
\text { Temp. } \\
\left({ }^{\circ} \mathrm{C}\right)\end{array}$ & $\begin{array}{l}\text { Aging } \\
\text { Time } \\
\text { (hours) }\end{array}$ & $\begin{array}{c}\text { Test } \\
\text { Temp. } \\
\left({ }^{\circ} \mathrm{C}\right)\end{array}$ & $\begin{array}{l}\text { Stress } \\
(\mathrm{MPa})\end{array}$ & $\begin{array}{r}\text { Rupture } \\
\text { Life } \\
\text { (hours) } \\
\text { stopped } \\
\text { or } \\
\text { ongoing } \\
\end{array}$ & $\begin{array}{r}\text { Minimum } \\
\text { Creep } \\
\text { Rate } \\
(\% / h r) \\
\end{array}$ & $\begin{array}{r}\text { Elong. } \\
(\%)\end{array}$ & $\begin{array}{r}\text { Red. } \\
\text { of } \\
\text { Area } \\
(\%) \\
\end{array}$ & $\begin{array}{l}\text { Failure } \\
\text { Location }\end{array}$ \\
\hline $\begin{array}{l}\text { CR-BM- } \\
16\end{array}$ & sheet & 675 & 6000 & 700 & 165.5 & 20670 & 6.90E-05 & 3.8 & 3.1 & \\
\hline
\end{tabular}

CR-BM-16

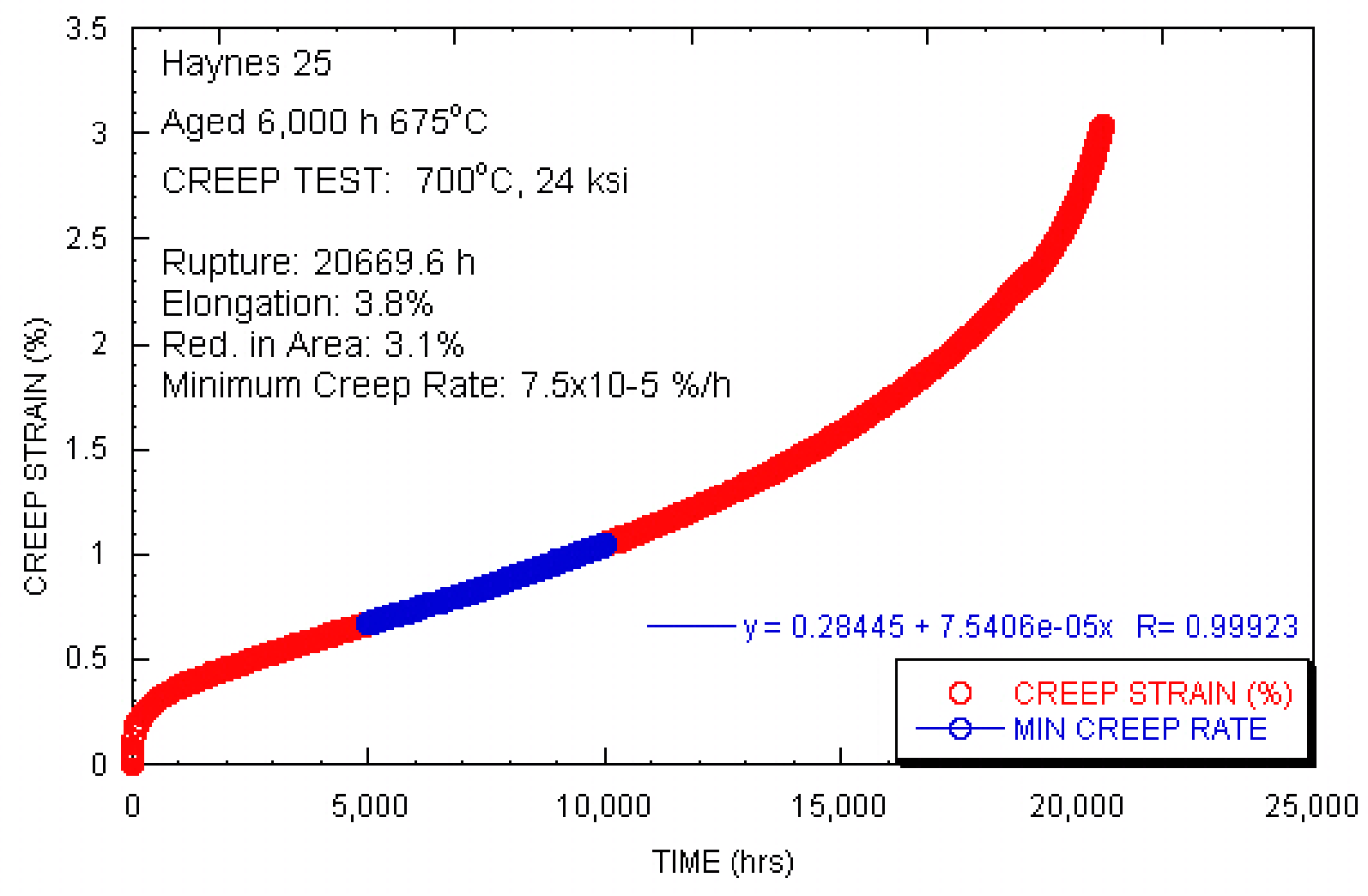




\begin{tabular}{|c|c|c|c|c|c|c|c|c|c|c|}
\hline Test ID & $\begin{array}{c}\text { Product } \\
\text { Form }\end{array}$ & $\begin{array}{c}\text { Aging } \\
\text { Temp. } \\
\left({ }^{\circ} \mathrm{C}\right)\end{array}$ & $\begin{array}{l}\text { Aging } \\
\text { Time } \\
\text { (hours) }\end{array}$ & $\begin{array}{c}\text { Test } \\
\text { Temp. } \\
\left({ }^{\circ} \mathrm{C}\right)\end{array}$ & $\begin{array}{l}\text { Stress } \\
(\mathrm{MPa})\end{array}$ & $\begin{array}{r}\text { Rupture } \\
\text { Life } \\
\text { (hours) } \\
\text { stopped } \\
\text { or } \\
\text { ongoing } \\
\end{array}$ & $\begin{array}{r}\text { Minimum } \\
\text { Creep } \\
\text { Rate } \\
(\% / h r) \\
\end{array}$ & $\begin{array}{r}\text { Elong. } \\
(\%)\end{array}$ & $\begin{array}{r}\text { Red. } \\
\text { of } \\
\text { Area } \\
(\%) \\
\end{array}$ & $\begin{array}{l}\text { Failure } \\
\text { Location }\end{array}$ \\
\hline $\begin{array}{l}\text { CR-BM- } \\
17\end{array}$ & sheet & 675 & 6000 & 750 & 127.6 & 9536 & 3.90E-05 & 5.8 & 4.8 & \\
\hline
\end{tabular}

CR-BM-17

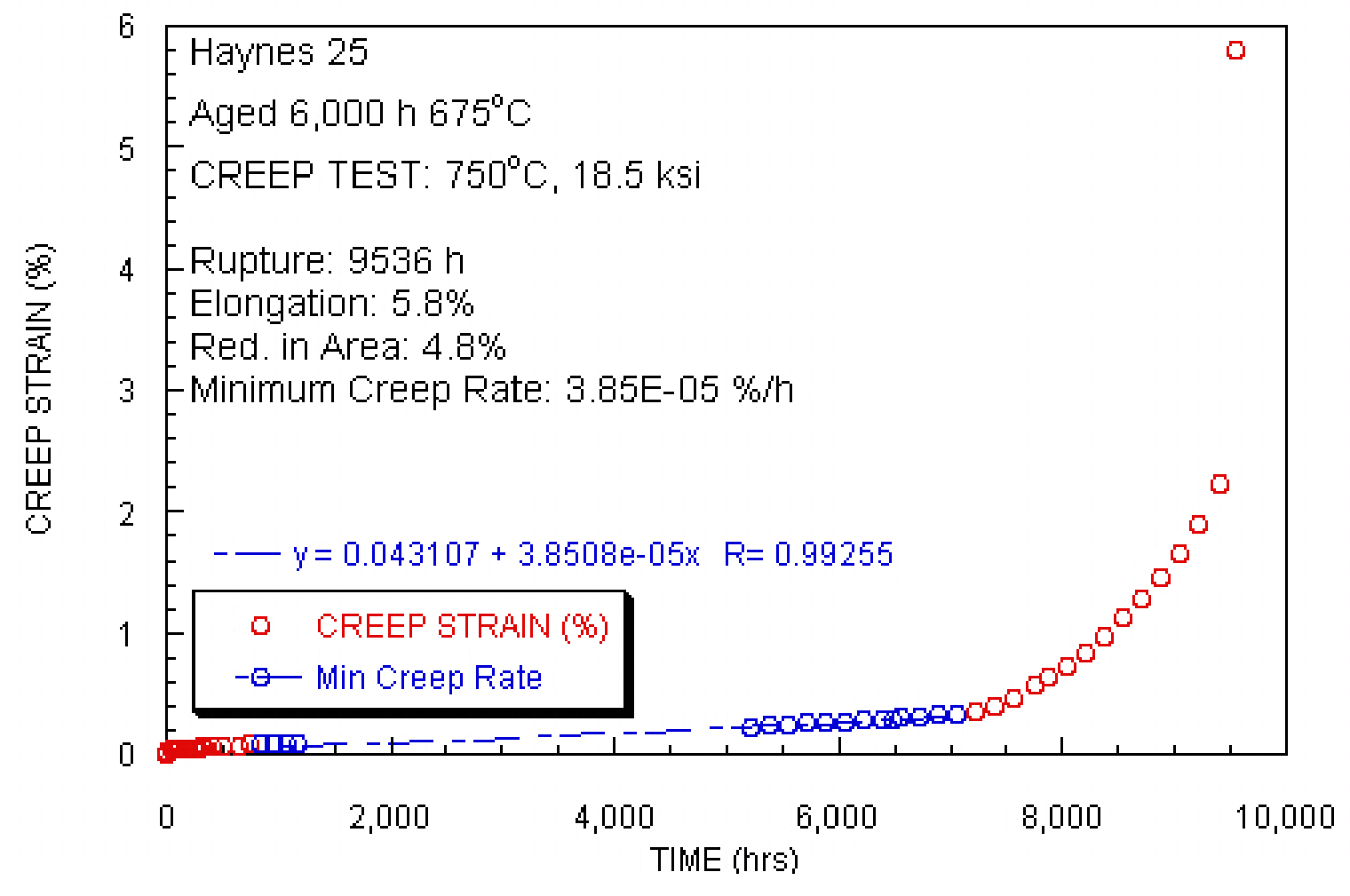




\begin{tabular}{|c|c|c|c|c|c|c|c|c|c|c|}
\hline Test ID & $\begin{array}{c}\text { Product } \\
\text { Form }\end{array}$ & $\begin{array}{c}\text { Aging } \\
\text { Temp. } \\
\left({ }^{\circ} \mathrm{C}\right)\end{array}$ & $\begin{array}{l}\text { Aging } \\
\text { Time } \\
\text { (hours) }\end{array}$ & $\begin{array}{c}\text { Test } \\
\text { Temp. } \\
\left({ }^{\circ} \mathrm{C}\right)\end{array}$ & $\begin{array}{l}\text { Stress } \\
(\mathrm{MPa})\end{array}$ & $\begin{array}{r}\text { Rupture } \\
\text { Life } \\
\text { (hours) } \\
\text { stopped } \\
\text { or } \\
\text { ongoing } \\
\end{array}$ & $\begin{array}{r}\text { Minimum } \\
\text { Creep } \\
\text { Rate } \\
(\% / \mathrm{hr}) \\
\end{array}$ & $\begin{array}{r}\text { Elong. } \\
(\%)\end{array}$ & $\begin{array}{r}\text { Red. } \\
\text { of } \\
\text { Area } \\
(\%) \\
\end{array}$ & $\begin{array}{l}\text { Failure } \\
\text { Location }\end{array}$ \\
\hline $\begin{array}{l}\text { CR-BM- } \\
18\end{array}$ & sheet & 675 & 6000 & 800 & 99.3 & 8863 & 1.90E-04 & 9.3 & 7.1 & \\
\hline
\end{tabular}

CR-BM-18

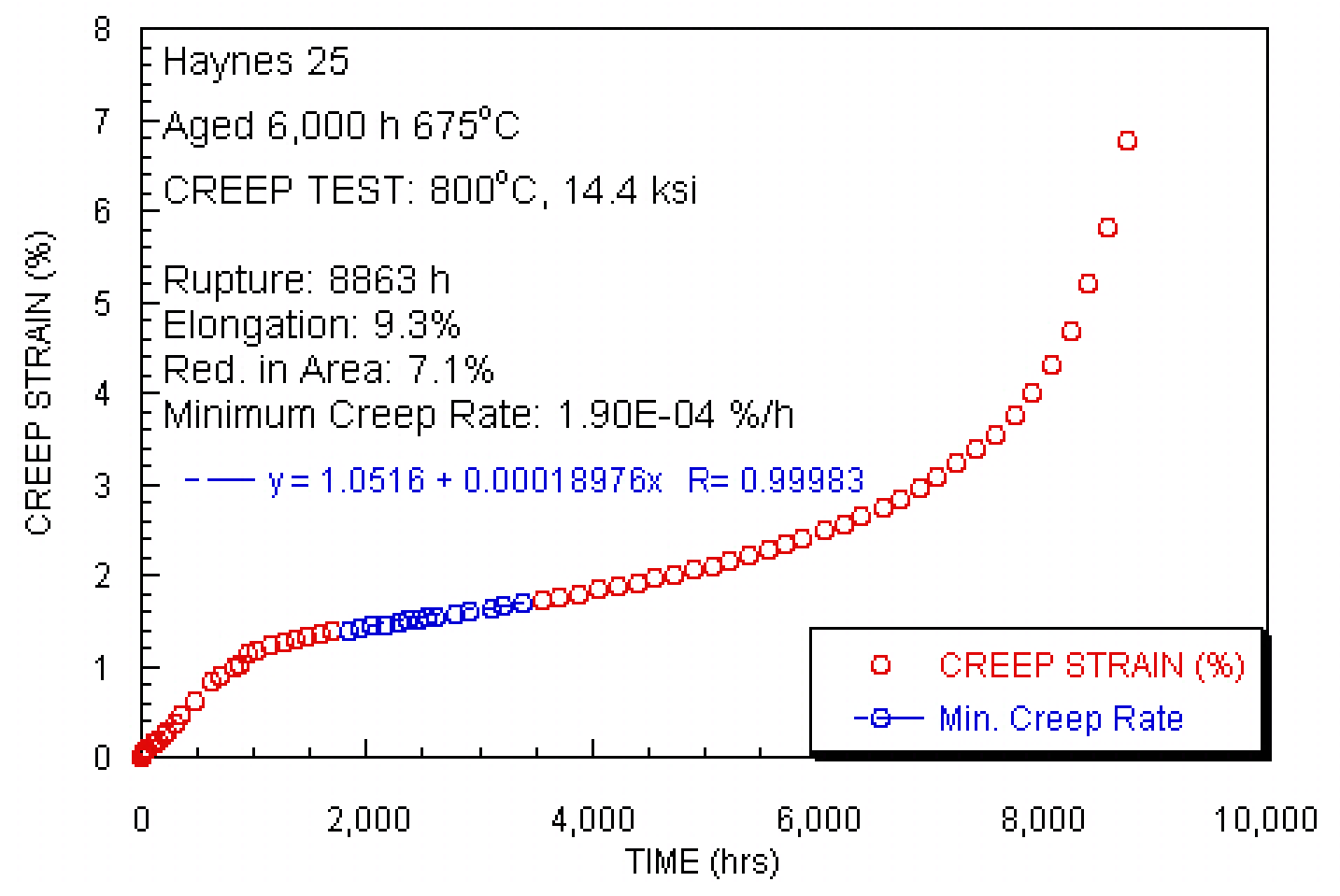




\begin{tabular}{|c|c|c|c|c|c|c|c|c|c|c|}
\hline Test ID & $\begin{array}{l}\text { Product } \\
\text { Form }\end{array}$ & $\begin{array}{c}\text { Aging } \\
\text { Temp. } \\
\left({ }^{\circ} \mathrm{C}\right)\end{array}$ & $\begin{array}{l}\text { Aging } \\
\text { Time } \\
\text { (hours) }\end{array}$ & $\begin{array}{c}\text { Test } \\
\text { Temp. } \\
\left({ }^{\circ} \mathrm{C}\right)\end{array}$ & $\begin{array}{l}\text { Stress } \\
\text { (MPa) }\end{array}$ & $\begin{array}{r}\text { Rupture } \\
\text { Life } \\
\text { (hours) } \\
\text { stopped } \\
\text { or } \\
\text { ongoing }\end{array}$ & $\begin{array}{r}\text { Minimum } \\
\text { Creep } \\
\text { Rate } \\
(\% / h r)\end{array}$ & $\begin{array}{r}\text { Elong. } \\
(\%)\end{array}$ & $\begin{array}{r}\text { Red. } \\
\text { of } \\
\text { Area } \\
(\%) \\
\end{array}$ & $\begin{array}{l}\text { Failure } \\
\text { Location }\end{array}$ \\
\hline $\begin{array}{l}\text { CR-BM- } \\
19\end{array}$ & sheet & 675 & 6000 & 800 & 103.4 & 4626 & $3.00 \mathrm{E}-04$ & 6.9 & 6.4 & \\
\hline
\end{tabular}

CR-BM-19

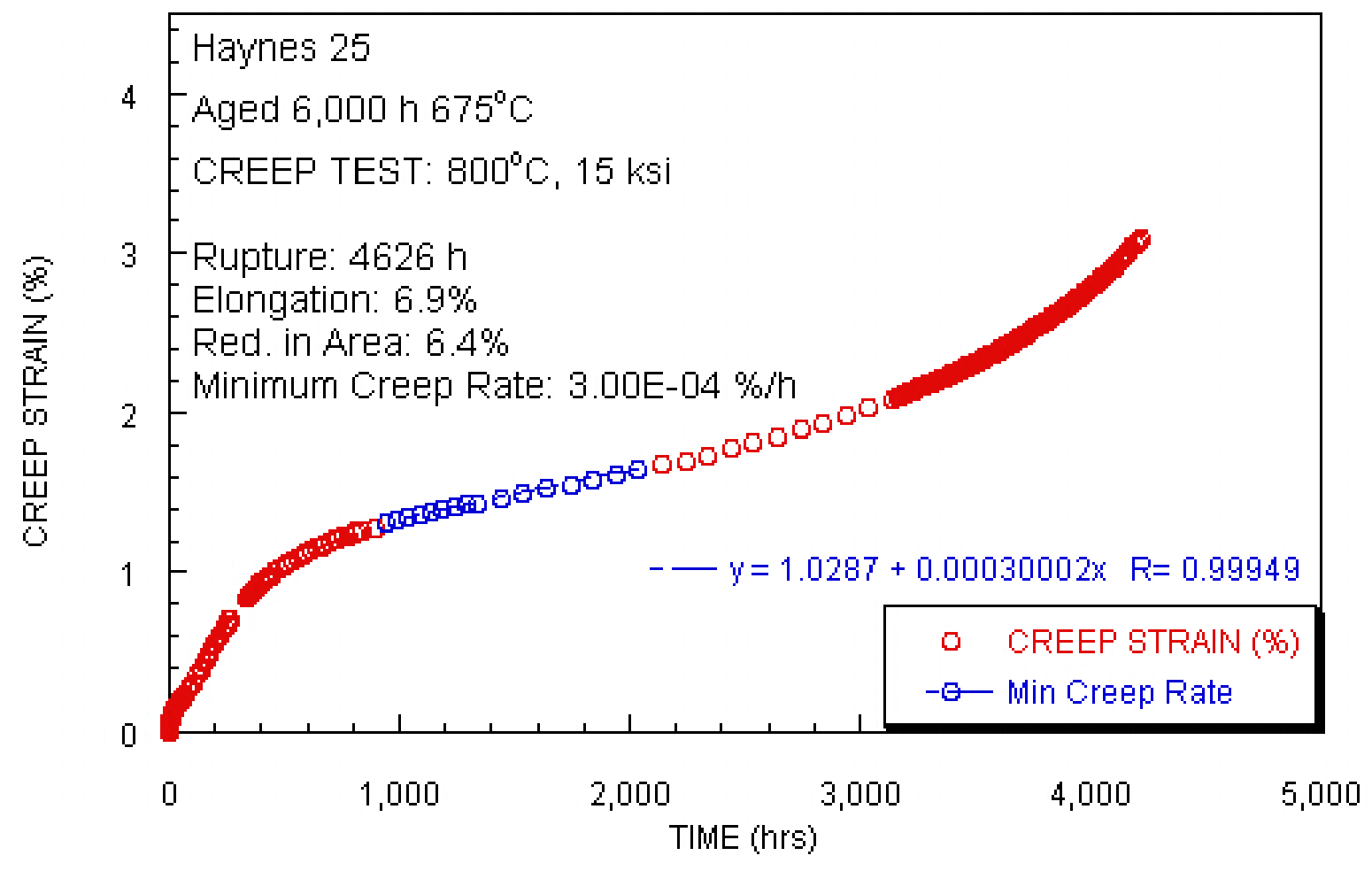




\begin{tabular}{|c|c|c|c|c|c|c|c|c|c|c|}
\hline Test ID & $\begin{array}{c}\text { Product } \\
\text { Form }\end{array}$ & $\begin{array}{c}\text { Aging } \\
\text { Temp. } \\
\left({ }^{\circ} \mathrm{C}\right)\end{array}$ & $\begin{array}{l}\text { Aging } \\
\text { Time } \\
\text { (hours) }\end{array}$ & $\begin{array}{c}\text { Test } \\
\text { Temp. } \\
\left({ }^{\circ} \mathrm{C}\right)\end{array}$ & $\begin{array}{l}\text { Stress } \\
(\mathrm{MPa})\end{array}$ & $\begin{array}{r}\text { Rupture } \\
\text { Life } \\
\text { (hours) } \\
\text { stopped } \\
\text { or } \\
\text { ongoing } \\
\end{array}$ & $\begin{array}{r}\text { Minimum } \\
\text { Creep } \\
\text { Rate } \\
(\% / h r) \\
\end{array}$ & $\begin{array}{r}\text { Elong. } \\
(\%)\end{array}$ & $\begin{array}{r}\text { Red. } \\
\text { of } \\
\text { Area } \\
(\%) \\
\end{array}$ & $\begin{array}{l}\text { Failure } \\
\text { Location }\end{array}$ \\
\hline $\begin{array}{l}\text { CR-BM- } \\
20\end{array}$ & sheet & 675 & 6000 & 850 & 62.1 & 6092 & 1.30E-04 & 4.2 & 1.2 & \\
\hline
\end{tabular}

\section{CR-BM-20}

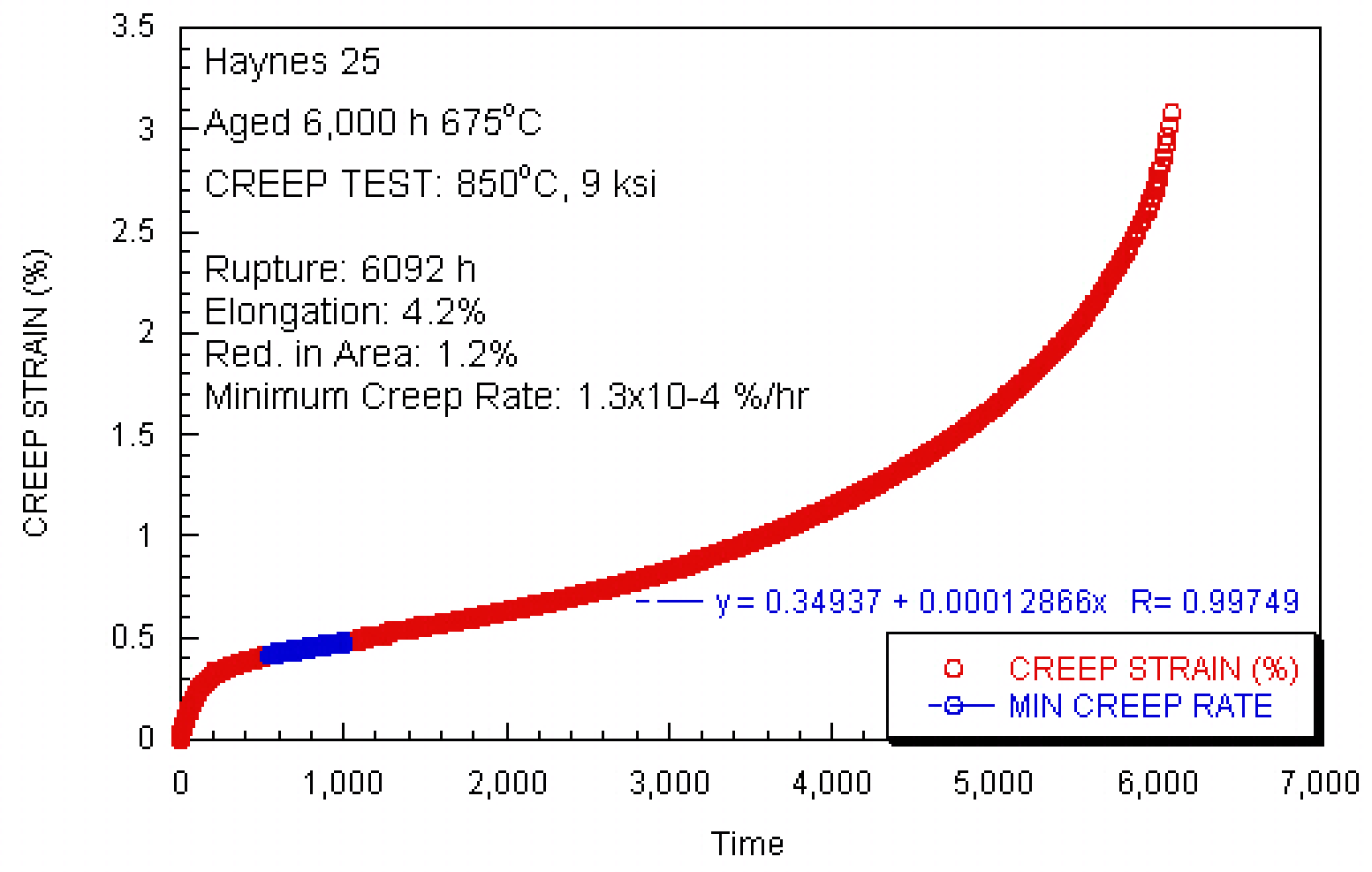




\begin{tabular}{|c|c|c|c|c|c|c|c|c|c|c|}
\hline Test ID & $\begin{array}{l}\text { Product } \\
\text { Form }\end{array}$ & $\begin{array}{c}\text { Aging } \\
\text { Temp. } \\
\left({ }^{\circ} \mathrm{C}\right)\end{array}$ & $\begin{array}{l}\text { Aging } \\
\text { Time } \\
\text { (hours) }\end{array}$ & $\begin{array}{c}\text { Test } \\
\text { Temp. } \\
\left({ }^{\circ} \mathrm{C}\right)\end{array}$ & $\begin{array}{l}\text { Stress } \\
\text { (MPa) }\end{array}$ & $\begin{array}{r}\text { Rupture } \\
\text { Life } \\
\text { (hours) } \\
\text { stopped } \\
\text { or } \\
\text { ongoing }\end{array}$ & $\begin{array}{r}\text { Minimum } \\
\text { Creep } \\
\text { Rate } \\
(\% / h r)\end{array}$ & $\begin{array}{r}\text { Elong. } \\
(\%)\end{array}$ & $\begin{array}{r}\text { Red. } \\
\text { of } \\
\text { Area } \\
(\%) \\
\end{array}$ & $\begin{array}{l}\text { Failure } \\
\text { Location }\end{array}$ \\
\hline $\begin{array}{l}\text { CR-BM- } \\
22\end{array}$ & sheet & 675 & 6000 & 900 & 44.8 & 6105 & $1.60 \mathrm{E}-04$ & 11.0 & 5.1 & \\
\hline
\end{tabular}

\section{CR-BM-22}

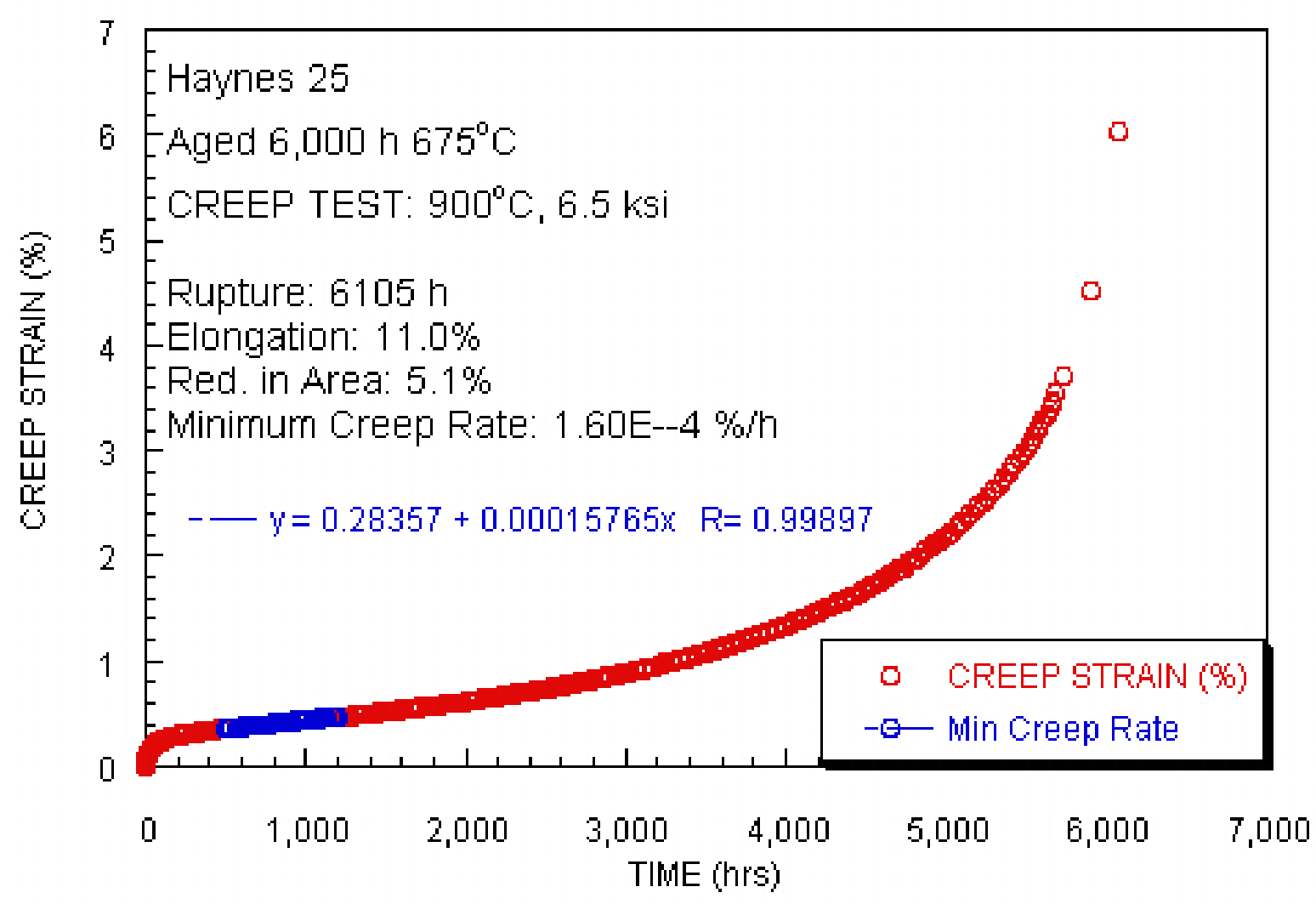




\begin{tabular}{|c|c|c|c|c|c|c|c|c|c|c|}
\hline Test ID & $\begin{array}{l}\text { Product } \\
\text { Form }\end{array}$ & $\begin{array}{c}\text { Aging } \\
\text { Temp. } \\
\left({ }^{\circ} \mathrm{C}\right)\end{array}$ & $\begin{array}{l}\text { Aging } \\
\text { Time } \\
\text { (hours) }\end{array}$ & $\begin{array}{c}\text { Test } \\
\text { Temp. } \\
\left({ }^{\circ} \mathrm{C}\right)\end{array}$ & $\begin{array}{l}\text { Stress } \\
(\mathrm{MPa})\end{array}$ & $\begin{array}{r}\text { Rupture } \\
\text { Life } \\
\text { (hours) } \\
\text { stopped } \\
\text { or } \\
\text { ongoing }\end{array}$ & $\begin{array}{r}\text { Minimum } \\
\text { Creep } \\
\text { Rate } \\
(\% / h r)\end{array}$ & $\begin{array}{r}\text { Elong. } \\
(\%)\end{array}$ & $\begin{array}{r}\text { Red. } \\
\text { of } \\
\text { Area } \\
(\%)\end{array}$ & $\begin{array}{l}\text { Failure } \\
\text { Location }\end{array}$ \\
\hline $\begin{array}{l}\text { CR-WM- } \\
02\end{array}$ & $\begin{array}{l}\text { sheet } \\
\text { weld }\end{array}$ & none & none & 700 & 165.5 & 21339.3 & $3.45 \mathrm{E}-05$ & 4.4 & 1.9 & BM \\
\hline
\end{tabular}

CR-WM-02

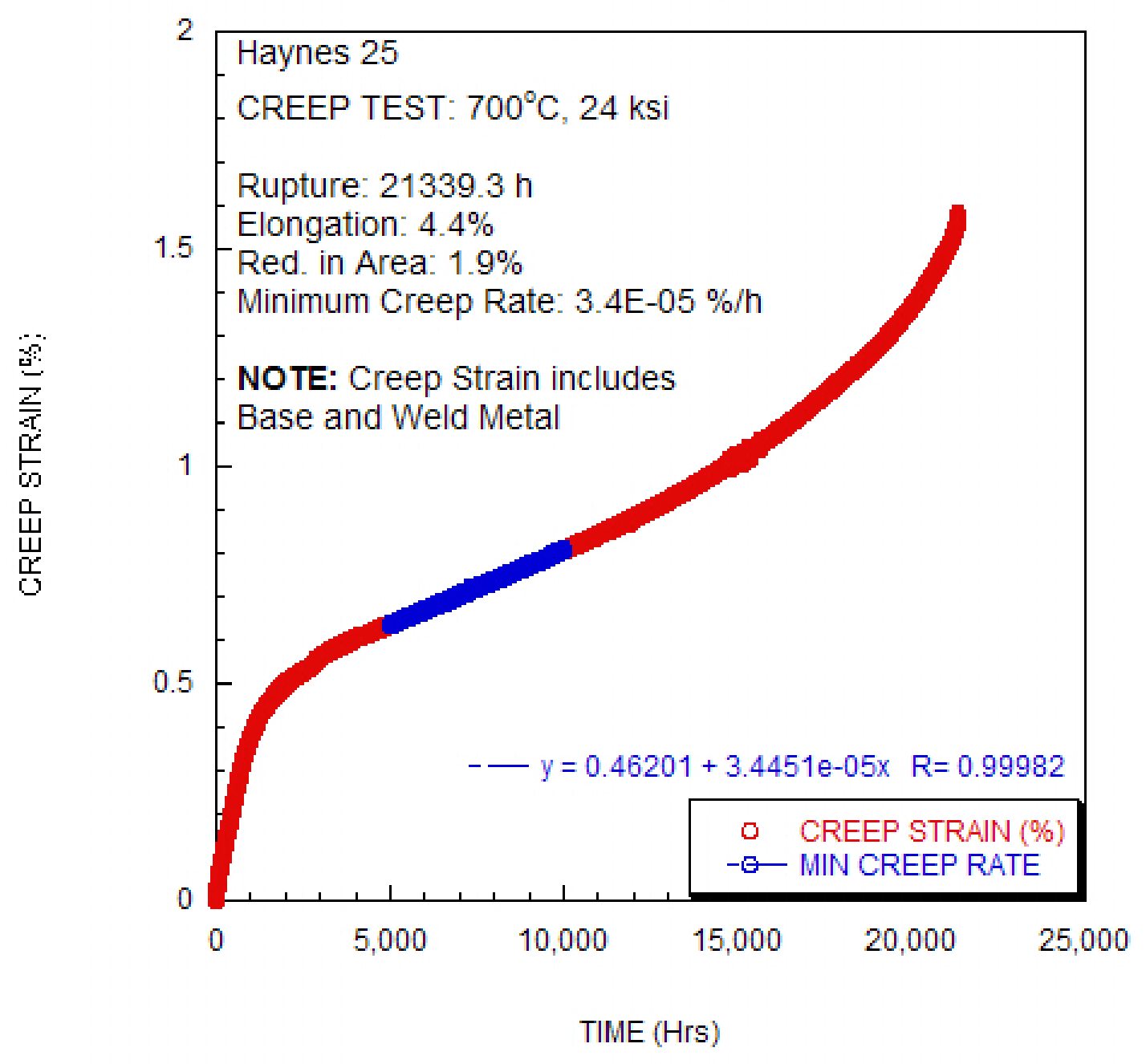




\begin{tabular}{|c|c|c|c|c|c|c|c|c|c|c|}
\hline Test ID & $\begin{array}{l}\text { Product } \\
\text { Form }\end{array}$ & $\begin{array}{c}\text { Aging } \\
\text { Temp. } \\
\left({ }^{\circ} \mathrm{C}\right)\end{array}$ & $\begin{array}{l}\text { Aging } \\
\text { Time } \\
\text { (hours) }\end{array}$ & $\begin{array}{c}\text { Test } \\
\text { Temp. } \\
\left({ }^{\circ} \mathrm{C}\right)\end{array}$ & $\begin{array}{l}\text { Stress } \\
(\mathrm{MPa})\end{array}$ & $\begin{array}{r}\text { Rupture } \\
\text { Life } \\
\text { (hours) } \\
\text { stopped } \\
\text { or } \\
\text { ongoing }\end{array}$ & $\begin{array}{r}\text { Minimum } \\
\text { Creep } \\
\text { Rate } \\
(\% / h r)\end{array}$ & $\begin{array}{r}\text { Elong. } \\
(\%)\end{array}$ & $\begin{array}{r}\text { Red. } \\
\text { of } \\
\text { Area } \\
(\%) \\
\end{array}$ & $\begin{array}{l}\text { Failure } \\
\text { Location }\end{array}$ \\
\hline $\begin{array}{l}\text { CR-WM- } \\
03\end{array}$ & $\begin{array}{l}\text { sheet } \\
\text { weld }\end{array}$ & none & none & 750 & 127.6 & 9588 & $3.50 \mathrm{E}-04$ & 8.1 & 9.6 & BM \\
\hline
\end{tabular}

CR-WM-03

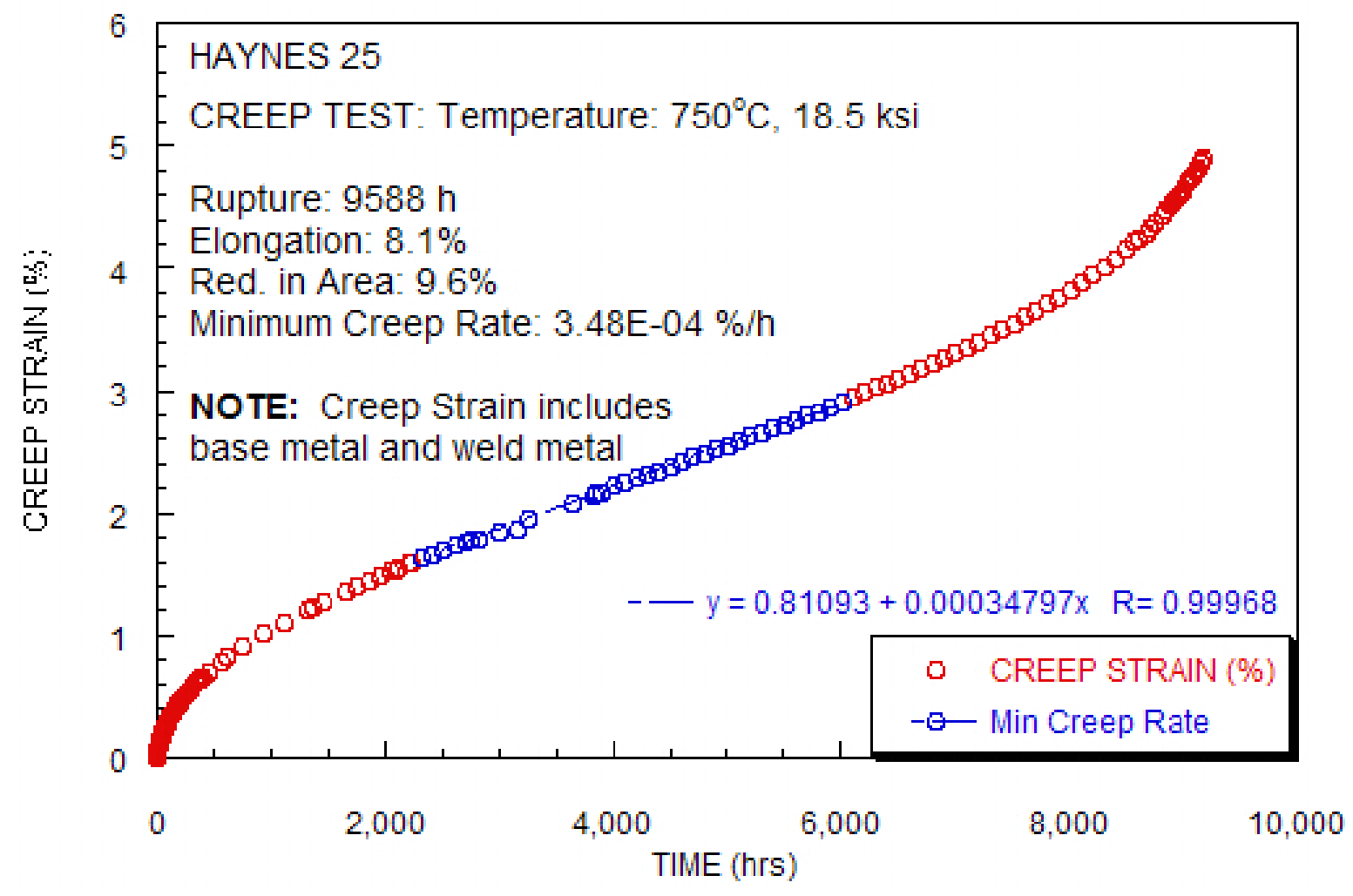




\begin{tabular}{|c|c|c|c|c|c|c|c|c|c|c|}
\hline Test ID & $\begin{array}{c}\text { Product } \\
\text { Form }\end{array}$ & $\begin{array}{l}\text { Aging } \\
\text { Temp. } \\
\left({ }^{\circ} \mathrm{C}\right)\end{array}$ & $\begin{array}{l}\text { Aging } \\
\text { Time } \\
\text { (hours) }\end{array}$ & $\begin{array}{c}\text { Test } \\
\text { Temp. } \\
\left({ }^{\circ} \mathrm{C}\right)\end{array}$ & $\begin{array}{l}\text { Stress } \\
(\mathrm{MPa})\end{array}$ & 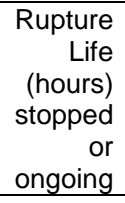 & $\begin{array}{r}\text { Minimum } \\
\text { Creep } \\
\text { Rate } \\
(\% / h r) \\
\end{array}$ & $\begin{array}{r}\text { Elong. } \\
(\%)\end{array}$ & $\begin{array}{r}\text { Red. } \\
\text { of } \\
\text { Area } \\
(\%) \\
\end{array}$ & $\begin{array}{l}\text { Failure } \\
\text { Location }\end{array}$ \\
\hline $\begin{array}{l}\text { CR-WM- } \\
04\end{array}$ & $\begin{array}{l}\text { sheet } \\
\text { weld }\end{array}$ & none & none & 800 & 99.3 & 6620 & $4.40 \mathrm{E}-04$ & 6.7 & 10.3 & BM \\
\hline
\end{tabular}

CR-WM-04

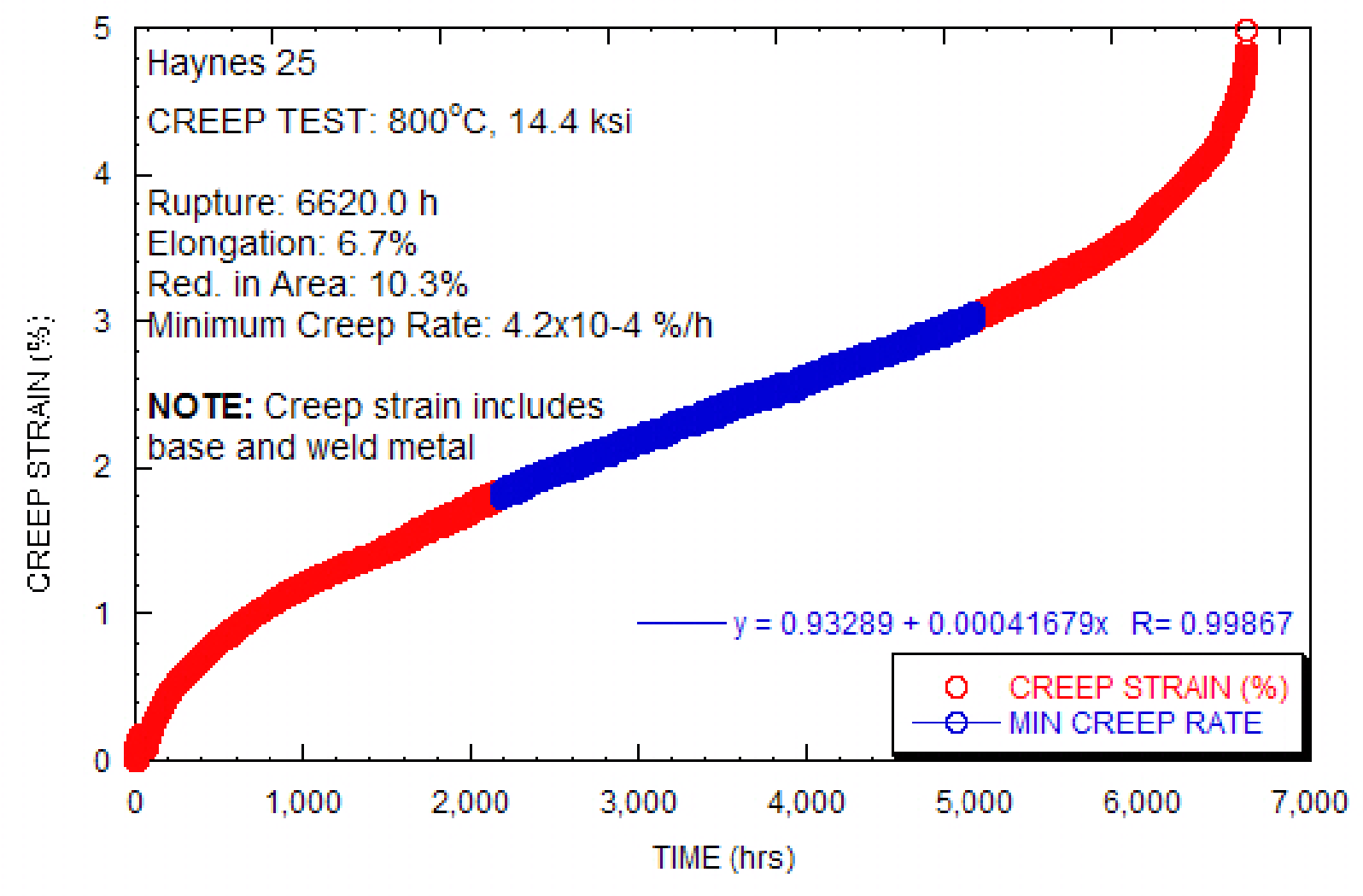




\begin{tabular}{|c|c|c|c|c|c|c|c|c|c|c|}
\hline Test ID & $\begin{array}{l}\text { Product } \\
\text { Form }\end{array}$ & $\begin{array}{c}\text { Aging } \\
\text { Temp. } \\
\left({ }^{\circ} \mathrm{C}\right)\end{array}$ & $\begin{array}{l}\text { Aging } \\
\text { Time } \\
\text { (hours) }\end{array}$ & $\begin{array}{c}\text { Test } \\
\text { Temp. } \\
\left({ }^{\circ} \mathrm{C}\right)\end{array}$ & $\begin{array}{l}\text { Stress } \\
(\mathrm{MPa})\end{array}$ & $\begin{array}{r}\text { Rupture } \\
\text { Life } \\
\text { (hours) } \\
\text { stopped } \\
\text { or } \\
\text { ongoing }\end{array}$ & $\begin{array}{r}\text { Minimum } \\
\text { Creep } \\
\text { Rate } \\
(\% / h r)\end{array}$ & $\begin{array}{r}\text { Elong. } \\
(\%)\end{array}$ & $\begin{array}{r}\text { Red. } \\
\text { of } \\
\text { Area } \\
(\%)\end{array}$ & $\begin{array}{l}\text { Failure } \\
\text { Location }\end{array}$ \\
\hline $\begin{array}{l}\text { CR-WM- } \\
05\end{array}$ & $\begin{array}{l}\text { sheet } \\
\text { weld }\end{array}$ & none & none & 800 & 103.4 & 4550 & $8.40 \mathrm{E}-04$ & 9.2 & 5.4 & BM \\
\hline
\end{tabular}

CR-WM-05

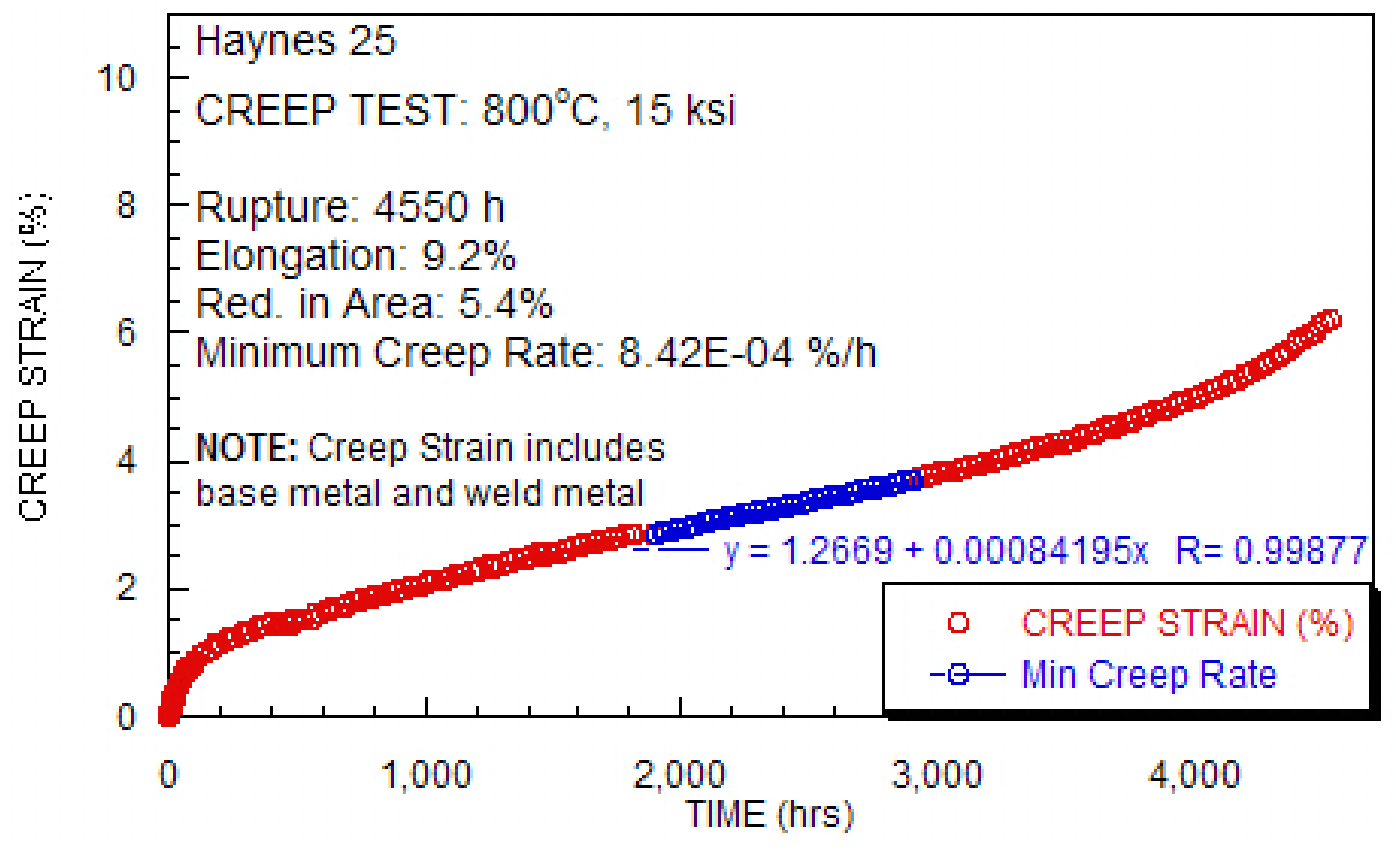




\begin{tabular}{|c|c|c|c|c|c|c|c|c|c|c|}
\hline Test ID & $\begin{array}{l}\text { Product } \\
\text { Form }\end{array}$ & $\begin{array}{c}\text { Aging } \\
\text { Temp. } \\
\left({ }^{\circ} \mathrm{C}\right)\end{array}$ & $\begin{array}{l}\text { Aging } \\
\text { Time } \\
\text { (hours) }\end{array}$ & $\begin{array}{c}\text { Test } \\
\text { Temp. } \\
\left({ }^{\circ} \mathrm{C}\right)\end{array}$ & $\begin{array}{l}\text { Stress } \\
(\mathrm{MPa})\end{array}$ & $\begin{array}{r}\text { Rupture } \\
\text { Life } \\
\text { (hours) } \\
\text { stopped } \\
\text { or } \\
\text { ongoing }\end{array}$ & $\begin{array}{r}\text { Minimum } \\
\text { Creep } \\
\text { Rate } \\
(\% / h r)\end{array}$ & $\begin{array}{r}\text { Elong. } \\
(\%)\end{array}$ & $\begin{array}{r}\text { Red. } \\
\text { of } \\
\text { Area } \\
(\%) \\
\end{array}$ & $\begin{array}{l}\text { Failure } \\
\text { Location }\end{array}$ \\
\hline $\begin{array}{l}\text { CR-WM- } \\
06\end{array}$ & $\begin{array}{l}\text { sheet } \\
\text { weld }\end{array}$ & none & none & 850 & 62.1 & 8710 & $1.20 \mathrm{E}-04$ & 6.5 & 4.1 & BM \\
\hline
\end{tabular}

CR-WM-06

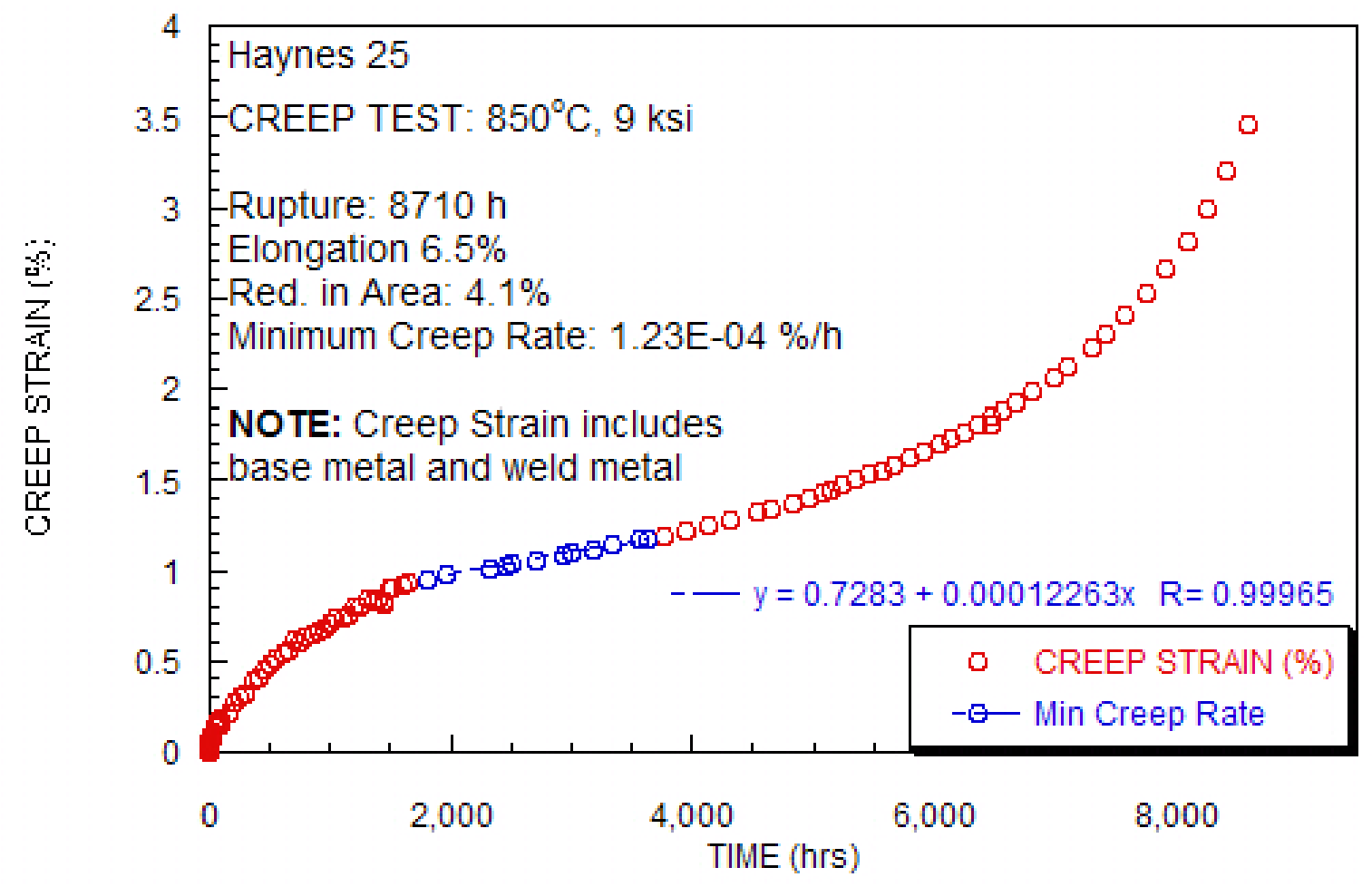




\begin{tabular}{|c|c|c|c|c|c|c|c|c|c|c|}
\hline Test ID & $\begin{array}{l}\text { Product } \\
\text { Form }\end{array}$ & $\begin{array}{l}\text { Aging } \\
\text { Temp. } \\
\left({ }^{\circ} \mathrm{C}\right)\end{array}$ & $\begin{array}{l}\text { Aging } \\
\text { Time } \\
\text { (hours) }\end{array}$ & $\begin{array}{c}\text { Test } \\
\text { Temp. } \\
\left({ }^{\circ} \mathrm{C}\right)\end{array}$ & $\begin{array}{l}\text { Stress } \\
(\mathrm{MPa})\end{array}$ & $\begin{array}{r}\text { Rupture } \\
\text { Life } \\
\text { (hours) } \\
\text { stopped } \\
\text { or } \\
\text { ongoing } \\
\end{array}$ & $\begin{array}{r}\text { Minimum } \\
\text { Creep } \\
\text { Rate } \\
(\% / \mathrm{hr}) \\
\end{array}$ & $\begin{array}{l}\text { Elong. } \\
(\%)\end{array}$ & $\begin{array}{l}\text { Red. } \\
\text { of } \\
\text { Area } \\
(\%)\end{array}$ & $\begin{array}{l}\text { Failure } \\
\text { Location }\end{array}$ \\
\hline $\begin{array}{l}\text { CR-WM- } \\
07\end{array}$ & $\begin{array}{l}\text { sheet } \\
\text { weld }\end{array}$ & none & none & 875 & 53.8 & 6000 & $1.30 \mathrm{E}-04$ & & & \\
\hline
\end{tabular}

\section{CR-WM-07}

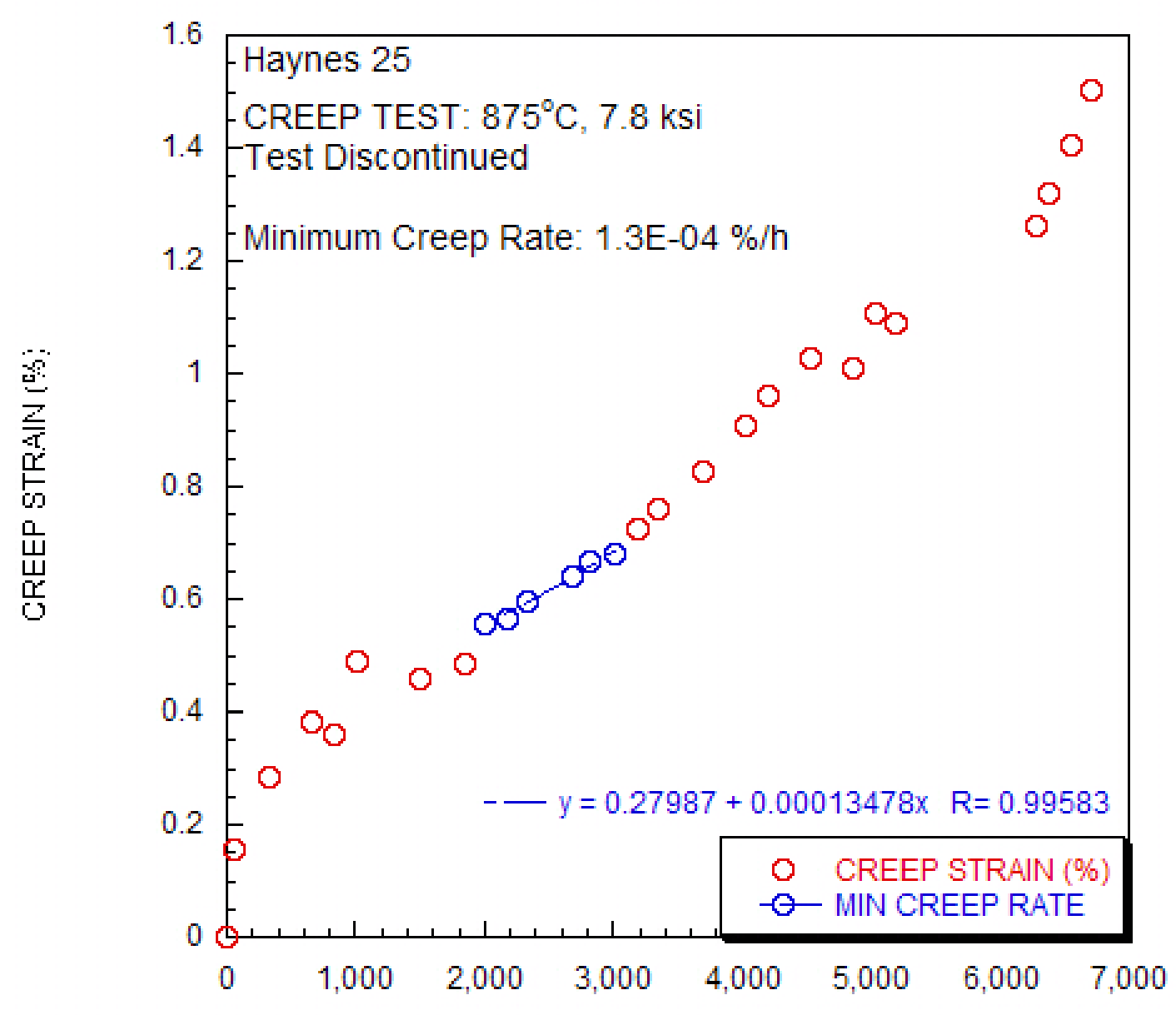

TIME (hrs) 


\begin{tabular}{|c|c|c|c|c|c|c|c|c|c|c|}
\hline Test ID & $\begin{array}{c}\text { Product } \\
\text { Form }\end{array}$ & $\begin{array}{c}\text { Aging } \\
\text { Temp. } \\
\left({ }^{\circ} \mathrm{C}\right)\end{array}$ & $\begin{array}{l}\text { Aging } \\
\text { Time } \\
\text { (hours) }\end{array}$ & $\begin{array}{c}\text { Test } \\
\text { Temp. } \\
\left({ }^{\circ} \mathrm{C}\right)\end{array}$ & $\begin{array}{l}\text { Stress } \\
(\mathrm{MPa})\end{array}$ & $\begin{array}{r}\text { Rupture } \\
\text { Life } \\
\text { (hours) } \\
\text { stopped } \\
\text { or } \\
\text { ongoing } \\
\end{array}$ & $\begin{array}{r}\text { Minimum } \\
\text { Creep } \\
\text { Rate } \\
(\% / \mathrm{hr}) \\
\end{array}$ & $\begin{array}{r}\text { Elong. } \\
(\%)\end{array}$ & $\begin{array}{r}\text { Red. } \\
\text { of } \\
\text { Area } \\
(\%) \\
\end{array}$ & $\begin{array}{l}\text { Failure } \\
\text { Location }\end{array}$ \\
\hline $\begin{array}{l}\text { CR-WM- } \\
08\end{array}$ & $\begin{array}{l}\text { sheet } \\
\text { weld }\end{array}$ & none & none & 900 & 44.8 & 4372 & $2.50 \mathrm{E}-04$ & 5.2 & 1.2 & BM \\
\hline
\end{tabular}

CR-WM-08

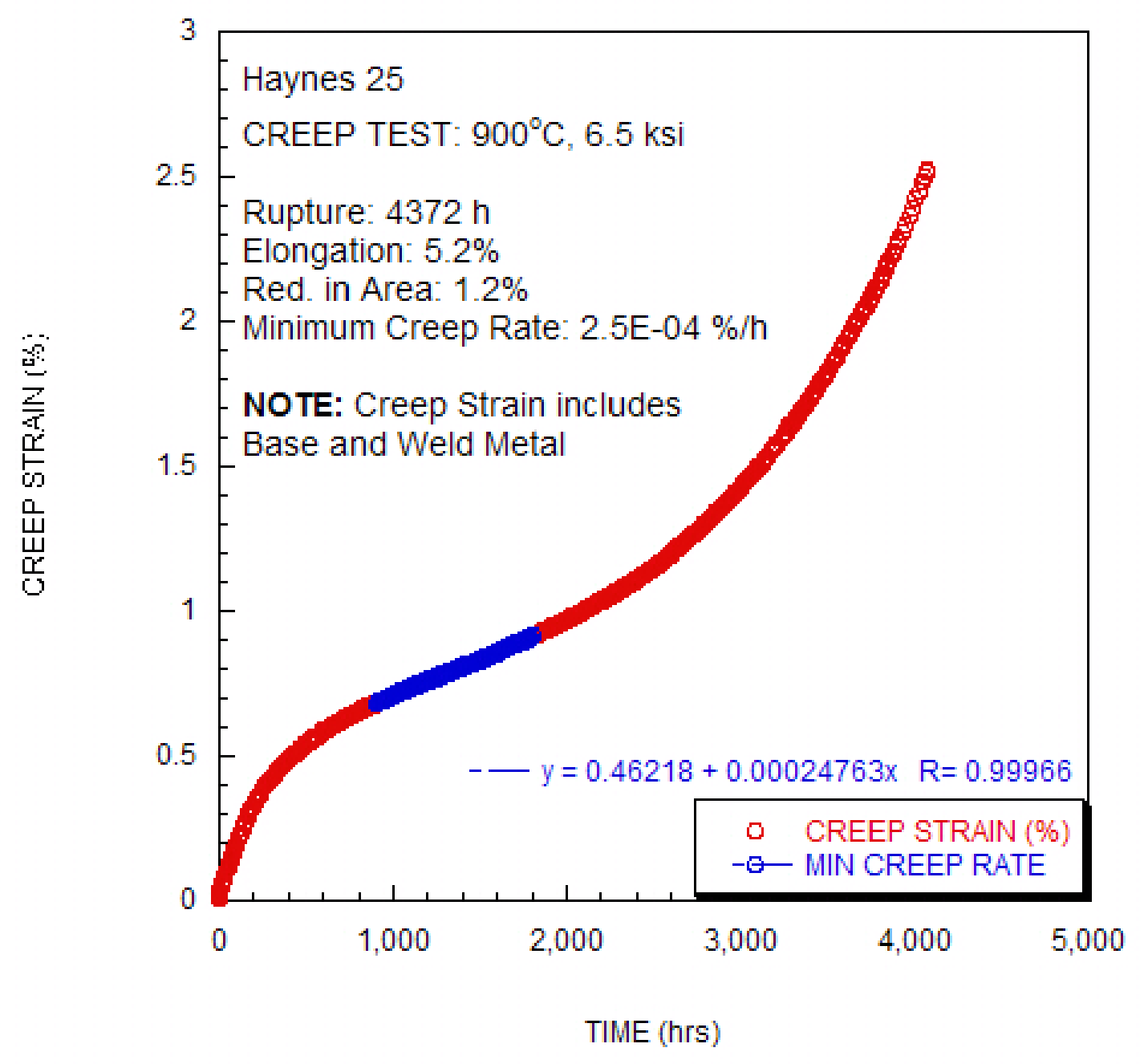




\begin{tabular}{|c|c|c|c|c|c|c|c|c|c|c|}
\hline Test ID & $\begin{array}{c}\text { Product } \\
\text { Form }\end{array}$ & $\begin{array}{c}\text { Aging } \\
\text { Temp. } \\
\left({ }^{\circ} \mathrm{C}\right)\end{array}$ & $\begin{array}{l}\text { Aging } \\
\text { Time } \\
\text { (hours) }\end{array}$ & $\begin{array}{c}\text { Test } \\
\text { Temp. } \\
\left({ }^{\circ} \mathrm{C}\right)\end{array}$ & $\begin{array}{l}\text { Stress } \\
(\mathrm{MPa})\end{array}$ & $\begin{array}{r}\text { Rupture } \\
\text { Life } \\
\text { (hours) } \\
\text { stopped } \\
\text { or } \\
\text { ongoing }\end{array}$ & $\begin{array}{r}\text { Minimum } \\
\text { Creep } \\
\text { Rate } \\
(\% / h r)\end{array}$ & $\begin{array}{r}\text { Elong. } \\
(\%)\end{array}$ & $\begin{array}{r}\text { Red. } \\
\text { of } \\
\text { Area } \\
(\%) \\
\end{array}$ & $\begin{array}{l}\text { Failure } \\
\text { Location }\end{array}$ \\
\hline $\begin{array}{l}\text { CR-WM- } \\
09\end{array}$ & $\begin{array}{l}\text { sheet } \\
\text { weld }\end{array}$ & none & none & 900 & 42.7 & 6470 & 1.30E-04 & 9.8 & 7.2 & BM \\
\hline
\end{tabular}

\section{CR-WM-09}

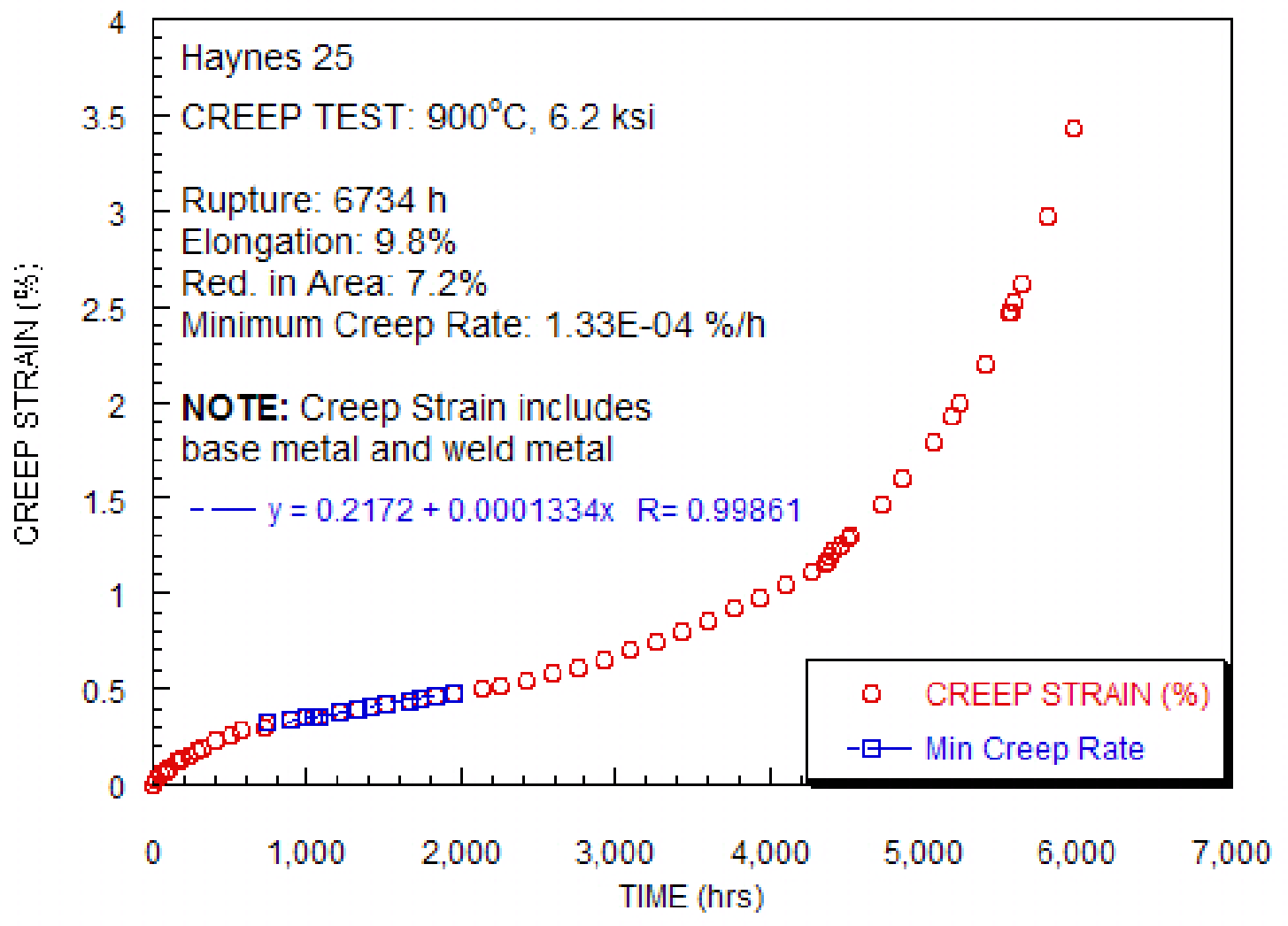




\begin{tabular}{|c|c|c|c|c|c|c|c|c|c|c|}
\hline Test ID & $\begin{array}{c}\text { Product } \\
\text { Form }\end{array}$ & $\begin{array}{c}\text { Aging } \\
\text { Temp. } \\
\left({ }^{\circ} \mathrm{C}\right)\end{array}$ & $\begin{array}{l}\text { Aging } \\
\text { Time } \\
\text { (hours) }\end{array}$ & $\begin{array}{c}\text { Test } \\
\text { Temp. } \\
\left({ }^{\circ} \mathrm{C}\right)\end{array}$ & $\begin{array}{l}\text { Stress } \\
(\mathrm{MPa})\end{array}$ & $\begin{array}{r}\text { Rupture } \\
\text { Life } \\
\text { (hours) } \\
\text { stopped } \\
\text { or } \\
\text { ongoing }\end{array}$ & $\begin{array}{r}\text { Minimum } \\
\text { Creep } \\
\text { Rate } \\
(\% / h r)\end{array}$ & $\begin{array}{l}\text { Elong. } \\
(\%)\end{array}$ & $\begin{array}{l}\text { Red. } \\
\text { of } \\
\text { Area } \\
(\%)\end{array}$ & $\begin{array}{l}\text { Failure } \\
\text { Location }\end{array}$ \\
\hline MG-01 & $\begin{array}{l}\text { sheet } \\
\text { weld }\end{array}$ & none & none & 600 & 179.3 & 32128 & $1.5 \mathrm{E}-05$ & & & \\
\hline
\end{tabular}

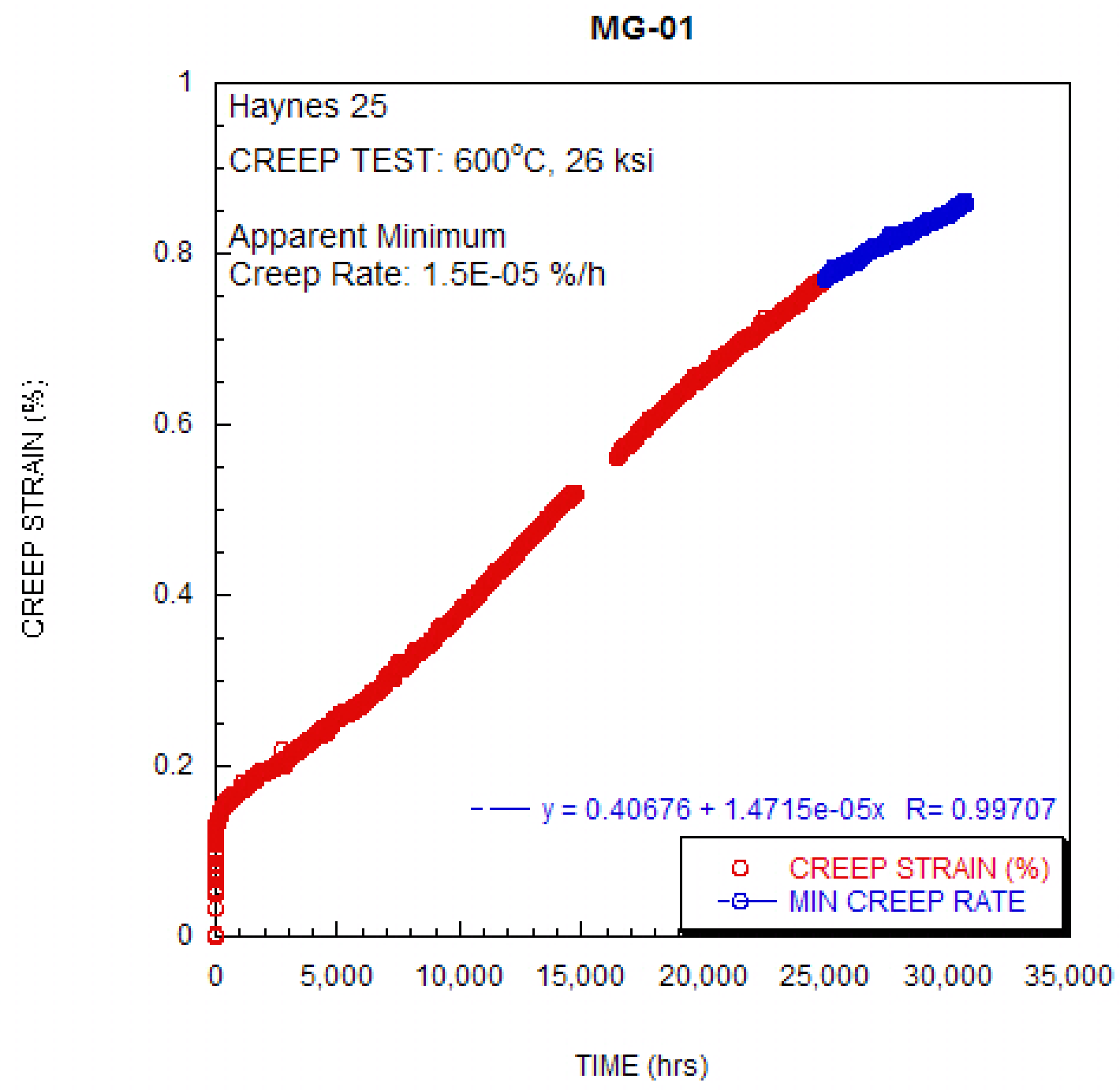




\begin{tabular}{|c|c|c|c|c|c|c|c|c|c|c|}
\hline Test ID & $\begin{array}{c}\text { Product } \\
\text { Form }\end{array}$ & $\begin{array}{c}\text { Aging } \\
\text { Temp. } \\
\left({ }^{\circ} \mathrm{C}\right)\end{array}$ & $\begin{array}{l}\text { Aging } \\
\text { Time } \\
\text { (hours) }\end{array}$ & $\begin{array}{c}\text { Test } \\
\text { Temp. } \\
\left({ }^{\circ} \mathrm{C}\right)\end{array}$ & $\begin{array}{l}\text { Stress } \\
(\mathrm{MPa})\end{array}$ & $\begin{array}{r}\text { Rupture } \\
\text { Life } \\
\text { (hours) } \\
\text { stopped } \\
\text { or } \\
\text { ongoing }\end{array}$ & $\begin{array}{r}\text { Minimum } \\
\text { Creep } \\
\text { Rate } \\
(\% / h r)\end{array}$ & $\begin{array}{l}\text { Elong. } \\
(\%)\end{array}$ & $\begin{array}{l}\text { Red. } \\
\text { of } \\
\text { Area } \\
(\%)\end{array}$ & $\begin{array}{l}\text { Failure } \\
\text { Location }\end{array}$ \\
\hline MG-03 & $\begin{array}{l}\text { sheet } \\
\text { weld }\end{array}$ & none & none & 625 & 144.8 & 32440 & 4.5E-06 & & & \\
\hline
\end{tabular}

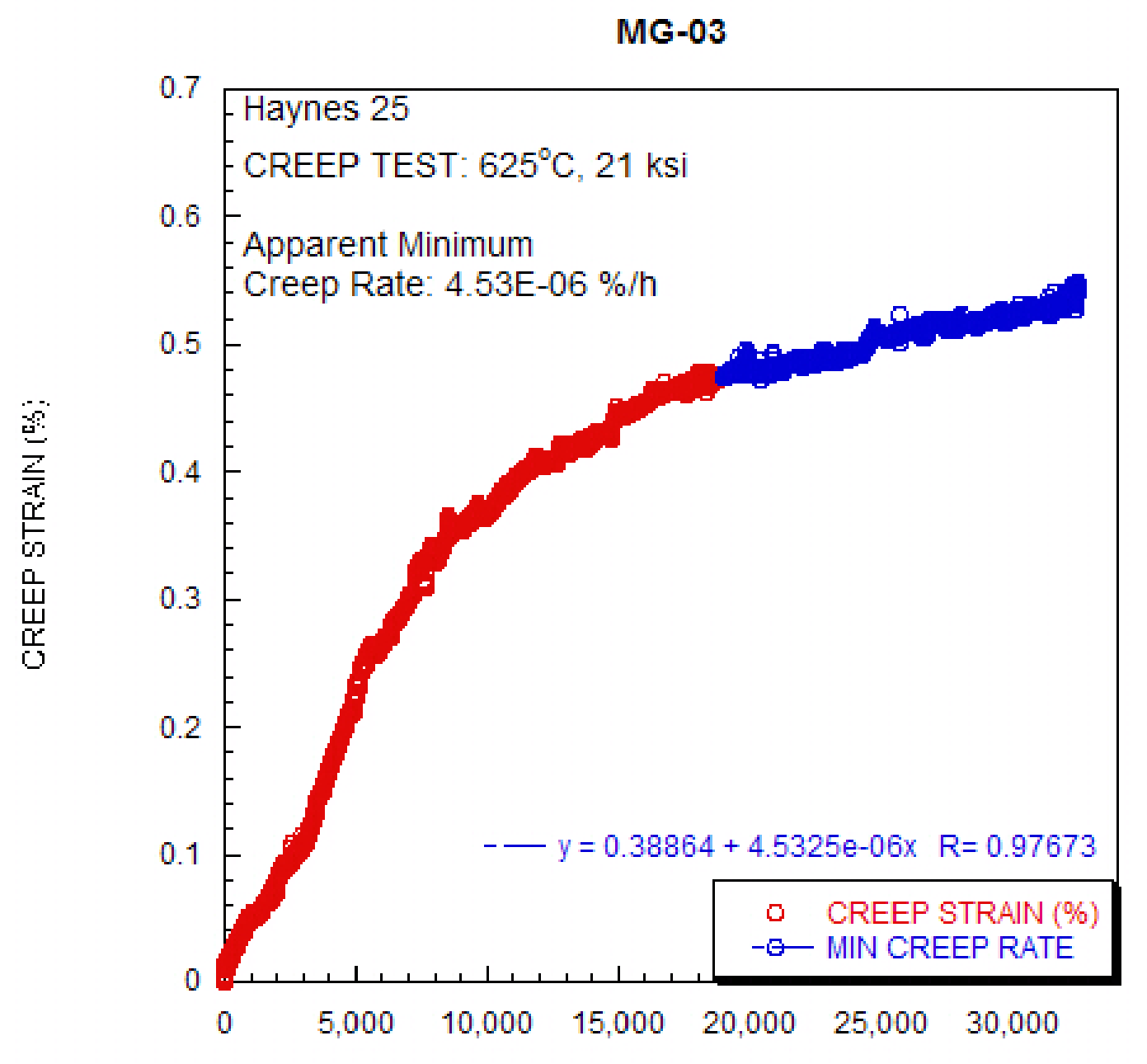

TIME (hrs) 


\begin{tabular}{|c|c|c|c|c|c|c|c|c|c|c|}
\hline Test ID & $\begin{array}{c}\text { Product } \\
\text { Form } \\
\end{array}$ & $\begin{array}{c}\text { Aging } \\
\text { Temp. } \\
\left({ }^{\circ} \mathrm{C}\right)\end{array}$ & $\begin{array}{l}\text { Aging } \\
\text { Time } \\
\text { (hours) }\end{array}$ & $\begin{array}{c}\text { Test } \\
\text { Temp. } \\
\left({ }^{\circ} \mathrm{C}\right)\end{array}$ & $\begin{array}{l}\text { Stress } \\
(\mathrm{MPa})\end{array}$ & $\begin{array}{r}\text { Rupture } \\
\text { Life } \\
\text { (hours) } \\
\text { stopped } \\
\text { or } \\
\text { ongoing } \\
\end{array}$ & $\begin{array}{r}\text { Minimum } \\
\text { Creep } \\
\text { Rate } \\
(\% / \mathrm{hr}) \\
\end{array}$ & $\begin{array}{l}\text { Elong. } \\
(\%)\end{array}$ & $\begin{array}{l}\text { Red. } \\
\text { of } \\
\text { Area } \\
(\%)\end{array}$ & $\begin{array}{l}\text { Failure } \\
\text { Location }\end{array}$ \\
\hline MG-06 & $\begin{array}{l}\text { sheet } \\
\text { weld }\end{array}$ & none & none & 650 & 124.1 & 11782 & 1.4E-05 & & & \\
\hline
\end{tabular}

\section{MG-06}

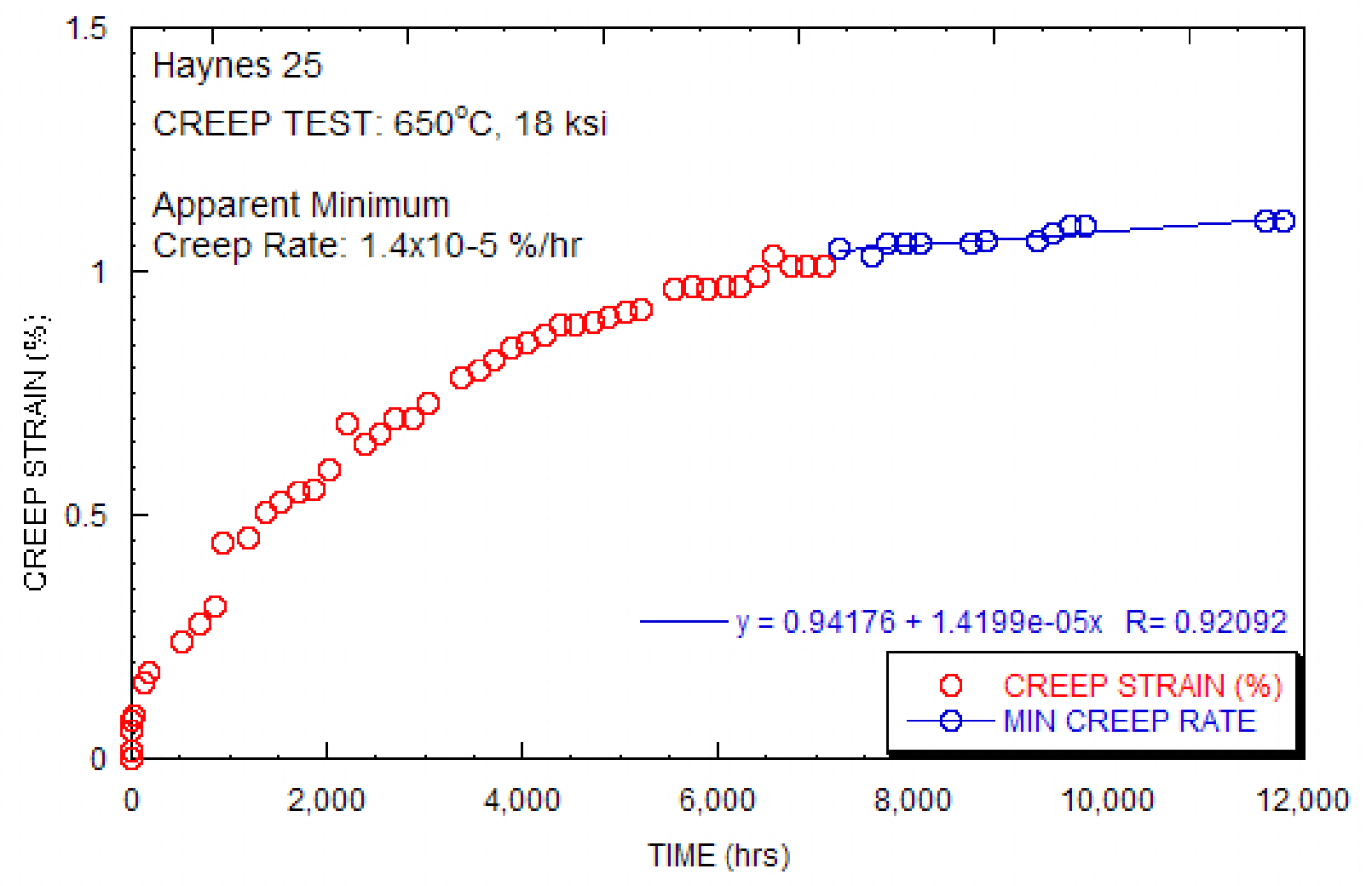




\begin{tabular}{|c|c|c|c|c|c|c|c|c|c|c|}
\hline Test ID & $\begin{array}{c}\text { Product } \\
\text { Form } \\
\end{array}$ & $\begin{array}{l}\text { Aging } \\
\text { Temp. } \\
\left({ }^{\circ} \mathrm{C}\right)\end{array}$ & $\begin{array}{l}\text { Aging } \\
\text { Time } \\
\text { (hours) }\end{array}$ & $\begin{array}{c}\text { Test } \\
\text { Temp. } \\
\left({ }^{\circ} \mathrm{C}\right)\end{array}$ & $\begin{array}{l}\text { Stress } \\
(\mathrm{MPa})\end{array}$ & $\begin{array}{r}\text { Rupture } \\
\text { Life } \\
\text { (hours) } \\
\text { stopped } \\
\text { or } \\
\text { ongoing } \\
\end{array}$ & $\begin{array}{r}\text { Minimum } \\
\text { Creep } \\
\text { Rate } \\
(\% / \mathrm{hr}) \\
\end{array}$ & $\begin{array}{l}\text { Elong. } \\
(\%)\end{array}$ & $\begin{array}{l}\text { Red. } \\
\text { of } \\
\text { Area } \\
(\%)\end{array}$ & $\begin{array}{l}\text { Failure } \\
\text { Location }\end{array}$ \\
\hline MG-09 & $\begin{array}{l}\text { sheet } \\
\text { weld }\end{array}$ & none & none & 650 & 186.2 & 10292 & 7.0E-05 & & & \\
\hline
\end{tabular}

MG-09

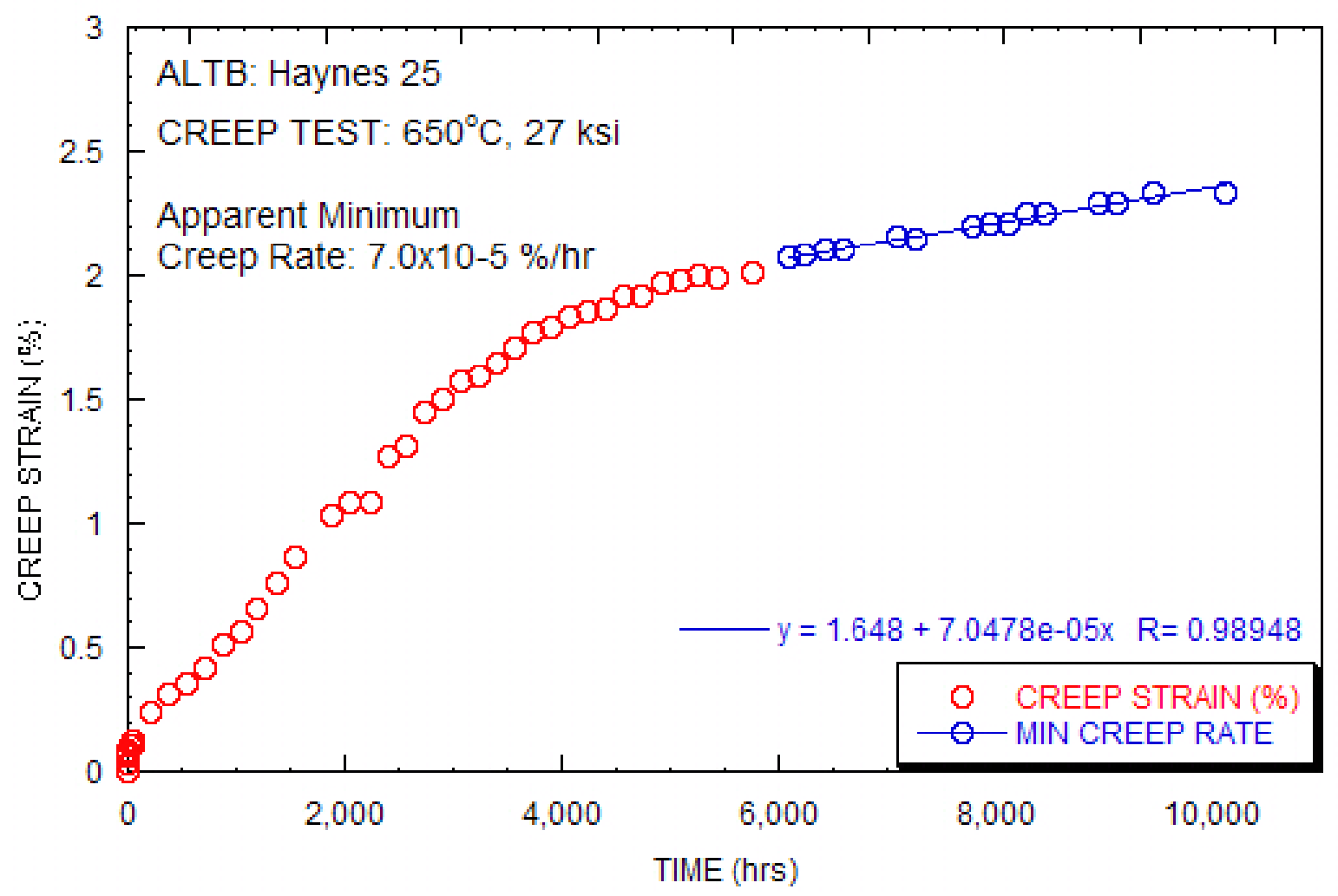




\begin{tabular}{|c|c|c|c|c|c|c|c|c|c|c|}
\hline Test ID & $\begin{array}{c}\text { Product } \\
\text { Form } \\
\end{array}$ & $\begin{array}{c}\text { Aging } \\
\text { Temp. } \\
\left({ }^{\circ} \mathrm{C}\right)\end{array}$ & $\begin{array}{l}\text { Aging } \\
\text { Time } \\
\text { (hours) }\end{array}$ & $\begin{array}{c}\text { Test } \\
\text { Temp. } \\
\left({ }^{\circ} \mathrm{C}\right)\end{array}$ & $\begin{array}{l}\text { Stress } \\
(\mathrm{MPa})\end{array}$ & $\begin{array}{r}\text { Rupture } \\
\text { Life } \\
\text { (hours) } \\
\text { stopped } \\
\text { or } \\
\text { ongoing } \\
\end{array}$ & $\begin{array}{r}\text { Minimum } \\
\text { Creep } \\
\text { Rate } \\
(\% / \mathrm{hr}) \\
\end{array}$ & $\begin{array}{l}\text { Elong. } \\
(\%)\end{array}$ & $\begin{array}{l}\text { Red. } \\
\text { of } \\
\text { Area } \\
(\%)\end{array}$ & $\begin{array}{l}\text { Failure } \\
\text { Location }\end{array}$ \\
\hline MG-10 & $\begin{array}{l}\text { sheet } \\
\text { weld }\end{array}$ & none & none & 675 & 103.4 & 11295 & 4.6E-06 & & & \\
\hline
\end{tabular}

MG-10

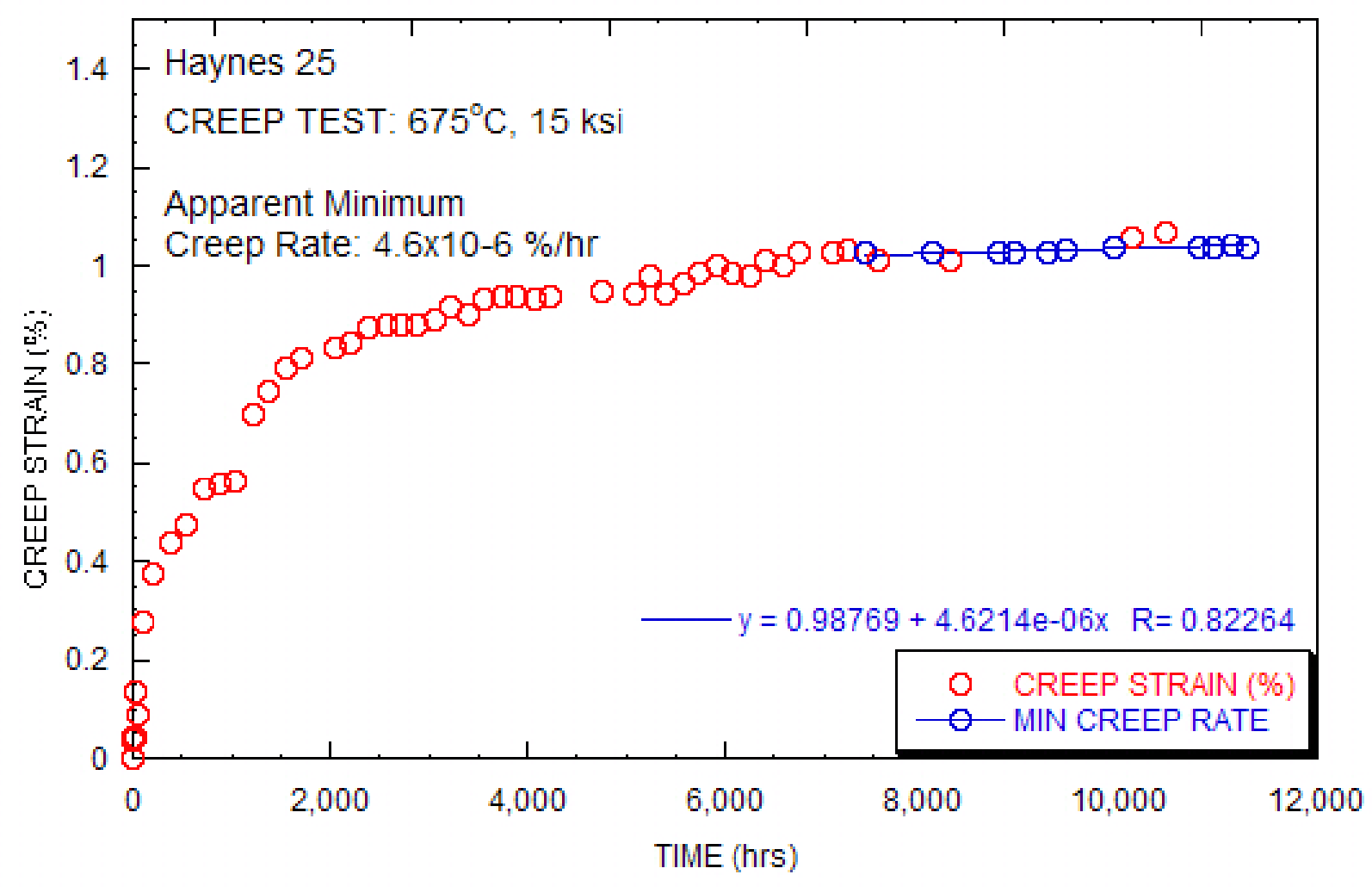




\begin{tabular}{|c|c|c|c|c|c|c|c|c|c|c|}
\hline Test ID & $\begin{array}{l}\text { Product } \\
\text { Form }\end{array}$ & $\begin{array}{c}\text { Aging } \\
\text { Temp. } \\
\left({ }^{\circ} \mathrm{C}\right)\end{array}$ & $\begin{array}{l}\text { Aging } \\
\text { Time } \\
\text { (hours) }\end{array}$ & $\begin{array}{c}\text { Test } \\
\text { Temp. } \\
\left({ }^{\circ} \mathrm{C}\right)\end{array}$ & $\begin{array}{l}\text { Stress } \\
(\mathrm{MPa})\end{array}$ & $\begin{array}{r}\text { Rupture } \\
\text { Life } \\
\text { (hours) } \\
\text { stopped } \\
\text { or } \\
\text { ongoing }\end{array}$ & $\begin{array}{r}\text { Minimum } \\
\text { Creep } \\
\text { Rate } \\
(\% / h r)\end{array}$ & $\begin{array}{r}\text { Elong. } \\
(\%)\end{array}$ & $\begin{array}{r}\text { Red. } \\
\text { of } \\
\text { Area } \\
(\%) \\
\end{array}$ & $\begin{array}{l}\text { Failure } \\
\text { Location }\end{array}$ \\
\hline $\begin{array}{l}\text { CR-WM- } \\
15\end{array}$ & $\begin{array}{l}\text { sheet } \\
\text { weld }\end{array}$ & 675 & 6000 & 650 & 206.8 & 32136 & $1.30 \mathrm{E}-05$ & 2.6 & 2.1 & BM \\
\hline
\end{tabular}

CR-WM-15

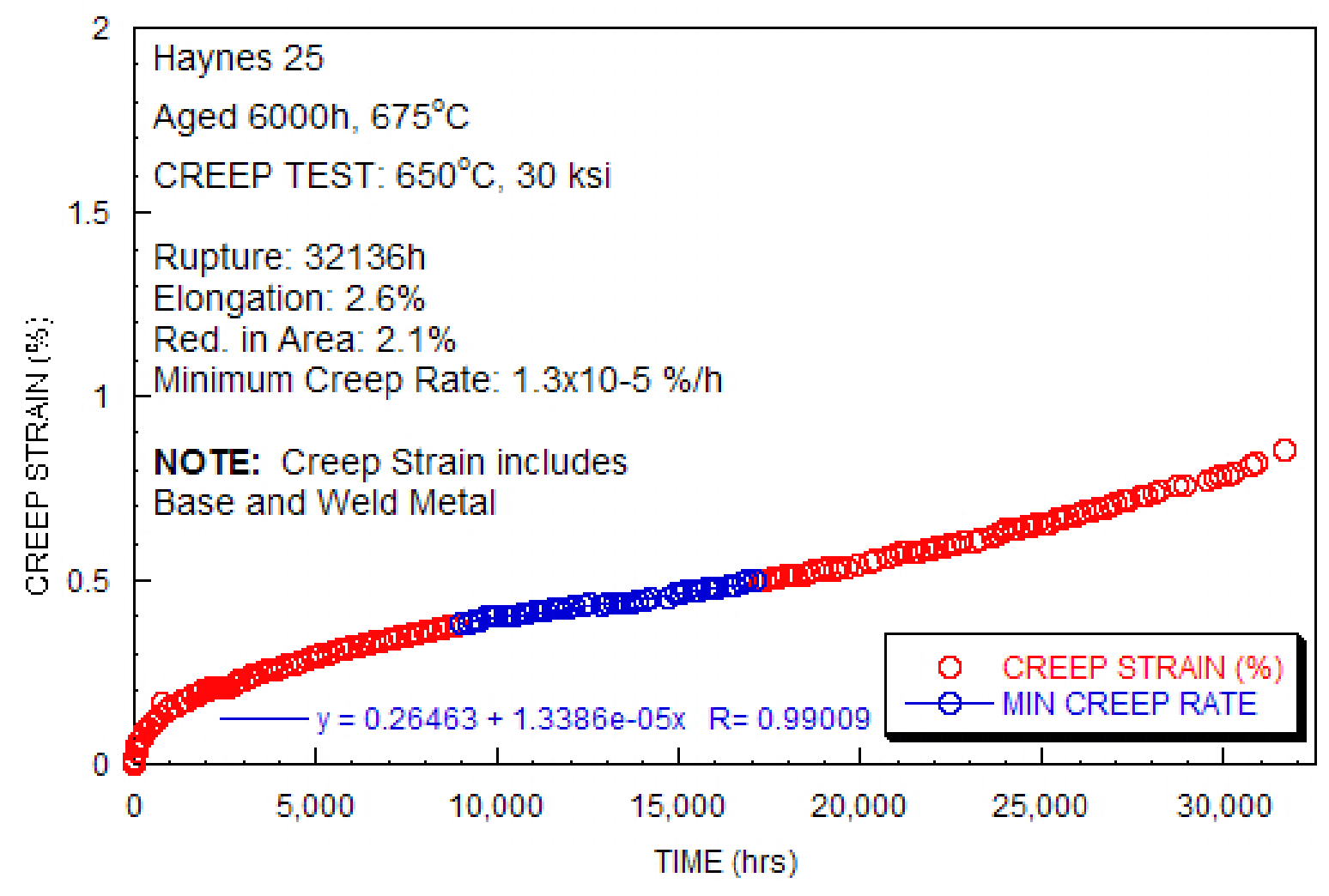




\begin{tabular}{|c|c|c|c|c|c|c|c|c|c|c|}
\hline Test ID & $\begin{array}{l}\text { Product } \\
\text { Form }\end{array}$ & $\begin{array}{c}\text { Aging } \\
\text { Temp. } \\
\left({ }^{\circ} \mathrm{C}\right)\end{array}$ & $\begin{array}{l}\text { Aging } \\
\text { Time } \\
\text { (hours) }\end{array}$ & $\begin{array}{c}\text { Test } \\
\text { Temp. } \\
\left({ }^{\circ} \mathrm{C}\right)\end{array}$ & $\begin{array}{l}\text { Stress } \\
(\mathrm{MPa})\end{array}$ & $\begin{array}{r}\text { Rupture } \\
\text { Life } \\
\text { (hours) } \\
\text { stopped } \\
\text { or } \\
\text { ongoing }\end{array}$ & $\begin{array}{r}\text { Minimum } \\
\text { Creep } \\
\text { Rate } \\
(\% / h r)\end{array}$ & $\begin{array}{r}\text { Elong. } \\
(\%)\end{array}$ & $\begin{array}{r}\text { Red. } \\
\text { of } \\
\text { Area } \\
(\%) \\
\end{array}$ & $\begin{array}{l}\text { Failure } \\
\text { Location }\end{array}$ \\
\hline $\begin{array}{l}\text { CR-WM- } \\
16\end{array}$ & $\begin{array}{l}\text { sheet } \\
\text { weld }\end{array}$ & 675 & 6000 & 700 & 165.5 & 16896 & $3.10 \mathrm{E}-05$ & 1.8 & 1.0 & HAZ \\
\hline
\end{tabular}

CR-WM-16

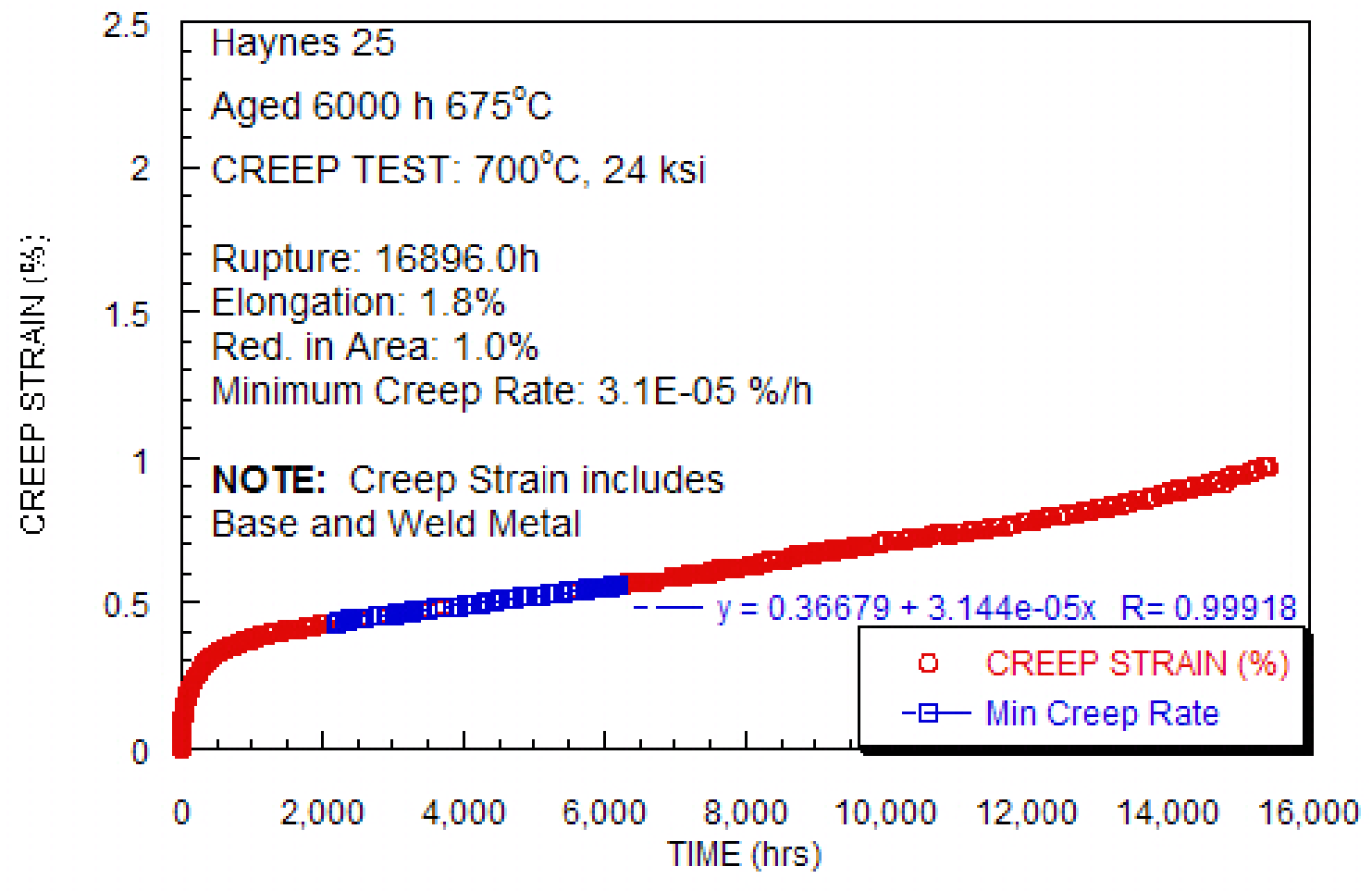




\begin{tabular}{|c|c|c|c|c|c|c|c|c|c|c|}
\hline Test ID & $\begin{array}{c}\text { Product } \\
\text { Form }\end{array}$ & $\begin{array}{l}\text { Aging } \\
\text { Temp. } \\
\left({ }^{\circ} \mathrm{C}\right)\end{array}$ & $\begin{array}{l}\text { Aging } \\
\text { Time } \\
\text { (hours) }\end{array}$ & $\begin{array}{c}\text { Test } \\
\text { Temp. } \\
\left({ }^{\circ} \mathrm{C}\right)\end{array}$ & $\begin{array}{l}\text { Stress } \\
(\mathrm{MPa})\end{array}$ & $\begin{array}{r}\text { Rupture } \\
\text { Life } \\
\text { (hours) } \\
\text { stopped } \\
\text { or } \\
\text { ongoing } \\
\end{array}$ & $\begin{array}{r}\text { Minimum } \\
\text { Creep } \\
\text { Rate } \\
(\% / \mathrm{hr}) \\
\end{array}$ & $\begin{array}{r}\text { Elong. } \\
(\%)\end{array}$ & $\begin{array}{r}\text { Red. } \\
\text { of } \\
\text { Area } \\
(\%) \\
\end{array}$ & $\begin{array}{l}\text { Failure } \\
\text { Location }\end{array}$ \\
\hline $\begin{array}{l}\text { CR-WM- } \\
17\end{array}$ & $\begin{array}{l}\text { sheet } \\
\text { weld }\end{array}$ & 675 & 6000 & 750 & 127.6 & 11990 & 8.10E-05 & 4.5 & 3.1 & BM \\
\hline
\end{tabular}

CR-WM-17

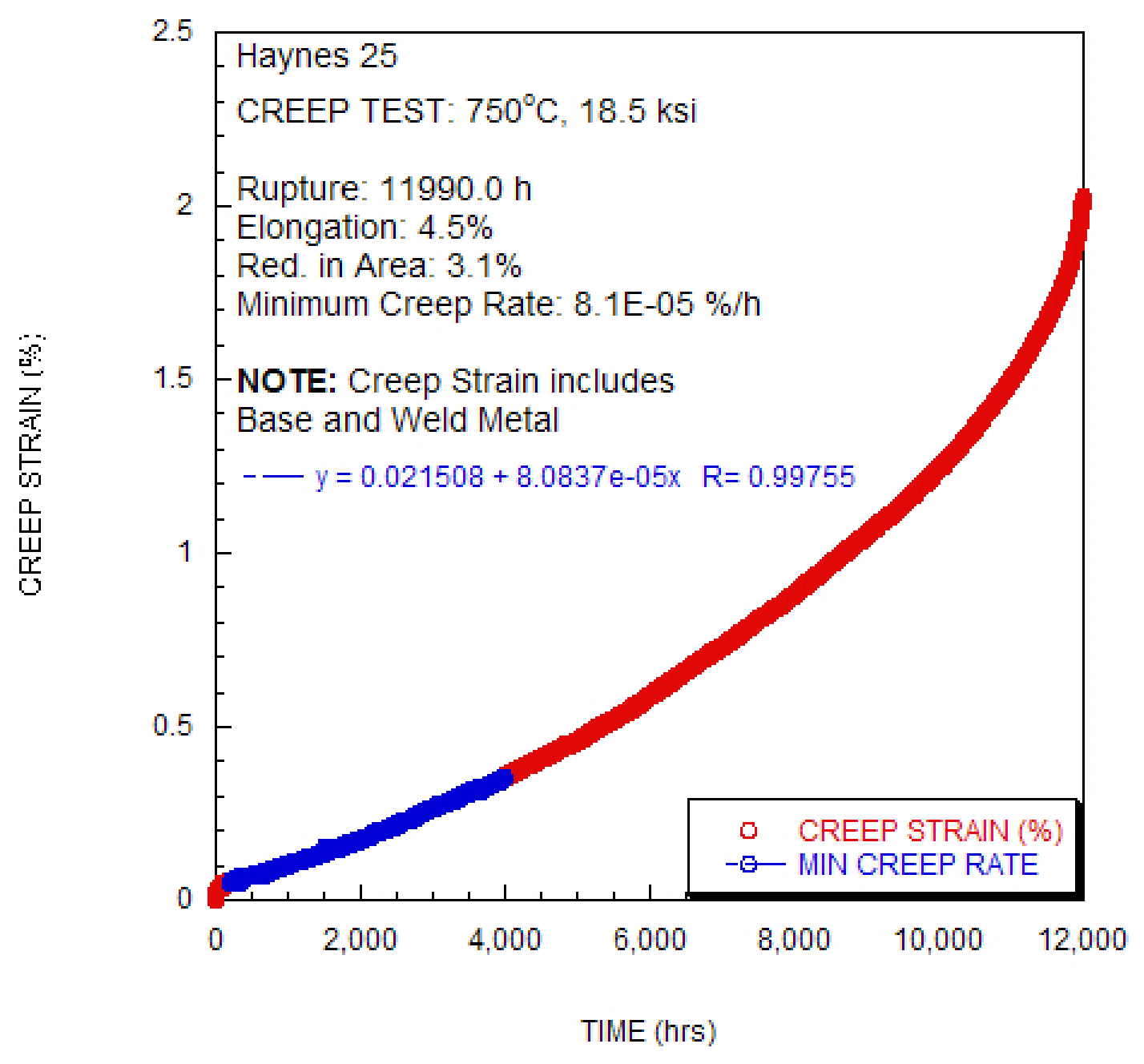




\begin{tabular}{|c|c|c|c|c|c|c|c|c|c|c|}
\hline Test ID & $\begin{array}{l}\text { Product } \\
\text { Form }\end{array}$ & $\begin{array}{l}\text { Aging } \\
\text { Temp. } \\
\left({ }^{\circ} \mathrm{C}\right)\end{array}$ & $\begin{array}{l}\text { Aging } \\
\text { Time } \\
\text { (hours) }\end{array}$ & $\begin{array}{c}\text { Test } \\
\text { Temp. } \\
\left({ }^{\circ} \mathrm{C}\right)\end{array}$ & $\begin{array}{l}\text { Stress } \\
(\mathrm{MPa})\end{array}$ & 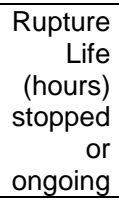 & $\begin{array}{r}\text { Minimum } \\
\text { Creep } \\
\text { Rate } \\
(\% / h r) \\
\end{array}$ & $\begin{array}{l}\text { Elong. } \\
(\%)\end{array}$ & $\begin{array}{l}\text { Red. } \\
\text { of } \\
\text { Area } \\
(\%) \\
\end{array}$ & $\begin{array}{l}\text { Failure } \\
\text { Location }\end{array}$ \\
\hline $\begin{array}{l}\text { CR-WM- } \\
18\end{array}$ & $\begin{array}{l}\text { sheet } \\
\text { weld }\end{array}$ & 675 & 6000 & 800 & 99.3 & 8568 & 1.30E-04 & & & BM \\
\hline
\end{tabular}




\begin{tabular}{|c|c|c|c|c|c|c|c|c|c|c|}
\hline Test ID & $\begin{array}{l}\text { Product } \\
\text { Form }\end{array}$ & $\begin{array}{c}\text { Aging } \\
\text { Temp. } \\
\left({ }^{\circ} \mathrm{C}\right)\end{array}$ & $\begin{array}{l}\text { Aging } \\
\text { Time } \\
\text { (hours) }\end{array}$ & $\begin{array}{c}\text { Test } \\
\text { Temp. } \\
\left({ }^{\circ} \mathrm{C}\right)\end{array}$ & $\begin{array}{l}\text { Stress } \\
(\mathrm{MPa})\end{array}$ & $\begin{array}{r}\text { Rupture } \\
\text { Life } \\
\text { (hours) } \\
\text { stopped } \\
\text { or } \\
\text { ongoing } \\
\end{array}$ & $\begin{array}{r}\text { Minimum } \\
\text { Creep } \\
\text { Rate } \\
(\% / h r) \\
\end{array}$ & $\begin{array}{r}\text { Elong. } \\
(\%)\end{array}$ & $\begin{array}{r}\text { Red. } \\
\text { of } \\
\text { Area } \\
(\%) \\
\end{array}$ & $\begin{array}{l}\text { Failure } \\
\text { Location }\end{array}$ \\
\hline $\begin{array}{l}\text { CR-WM- } \\
19\end{array}$ & $\begin{array}{l}\text { sheet } \\
\text { weld }\end{array}$ & 675 & 6000 & 800 & 103.4 & 4011 & $2.60 \mathrm{E}-04$ & 4.2 & 6.2 & BM \\
\hline
\end{tabular}

\section{CR-WM-19}

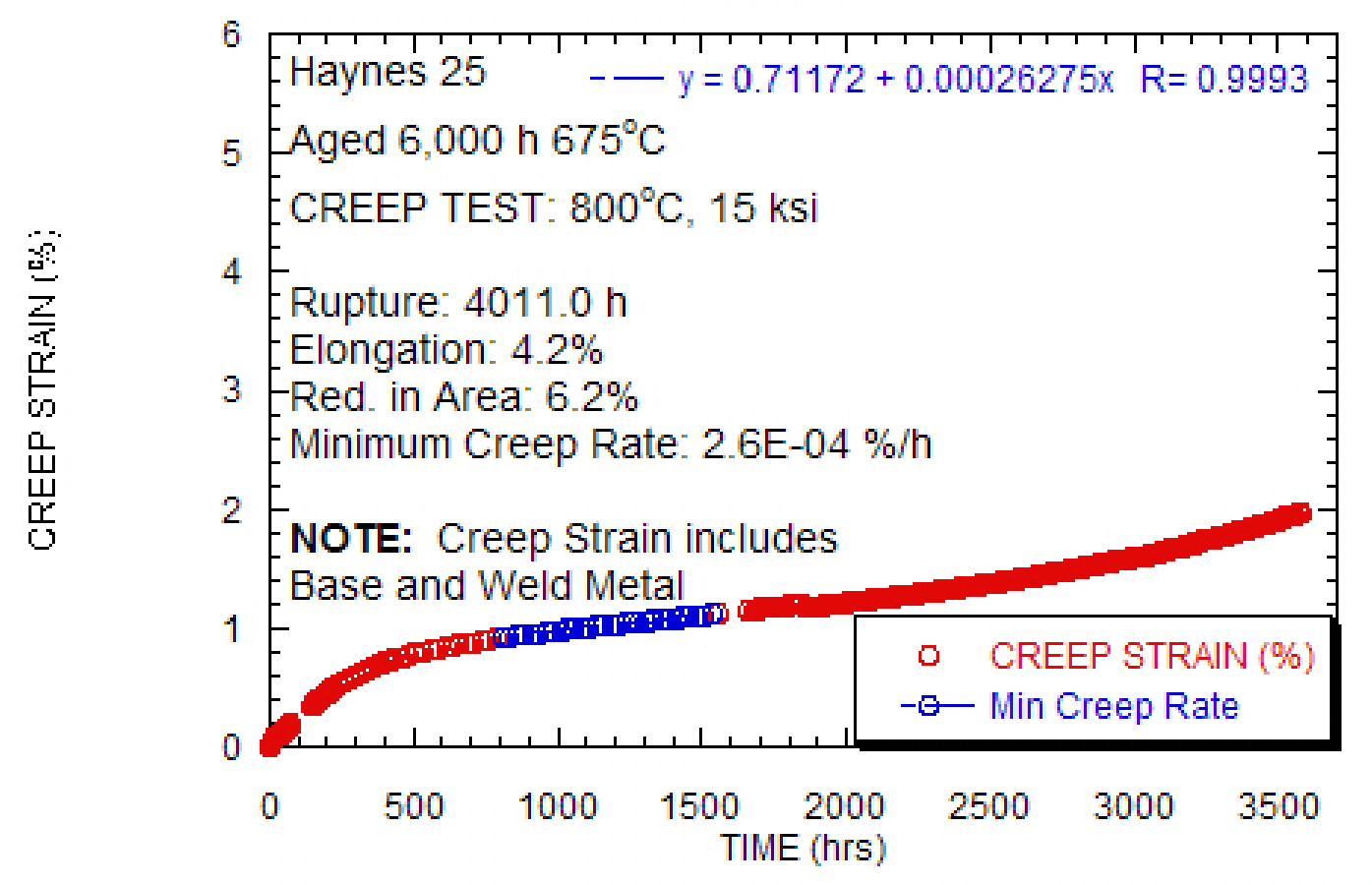




\begin{tabular}{|c|c|c|c|c|c|c|c|c|c|c|}
\hline Test ID & $\begin{array}{l}\text { Product } \\
\text { Form }\end{array}$ & $\begin{array}{c}\text { Aging } \\
\text { Temp. } \\
\left({ }^{\circ} \mathrm{C}\right)\end{array}$ & $\begin{array}{l}\text { Aging } \\
\text { Time } \\
\text { (hours) }\end{array}$ & $\begin{array}{c}\text { Test } \\
\text { Temp. } \\
\left({ }^{\circ} \mathrm{C}\right)\end{array}$ & $\begin{array}{l}\text { Stress } \\
(\mathrm{MPa})\end{array}$ & $\begin{array}{r}\text { Rupture } \\
\text { Life } \\
\text { (hours) } \\
\text { stopped } \\
\text { or } \\
\text { ongoing }\end{array}$ & $\begin{array}{r}\text { Minimum } \\
\text { Creep } \\
\text { Rate } \\
(\% / h r)\end{array}$ & $\begin{array}{r}\text { Elong. } \\
(\%)\end{array}$ & $\begin{array}{r}\text { Red. } \\
\text { of } \\
\text { Area } \\
(\%)\end{array}$ & $\begin{array}{l}\text { Failure } \\
\text { Location }\end{array}$ \\
\hline $\begin{array}{l}\text { CR-WM- } \\
20\end{array}$ & $\begin{array}{l}\text { sheet } \\
\text { weld }\end{array}$ & 675 & 6000 & 850 & 62.1 & 11117 & 1.10E-04 & 5.2 & 2.4 & $\mathrm{BM}$ \\
\hline
\end{tabular}

CR-WM-20

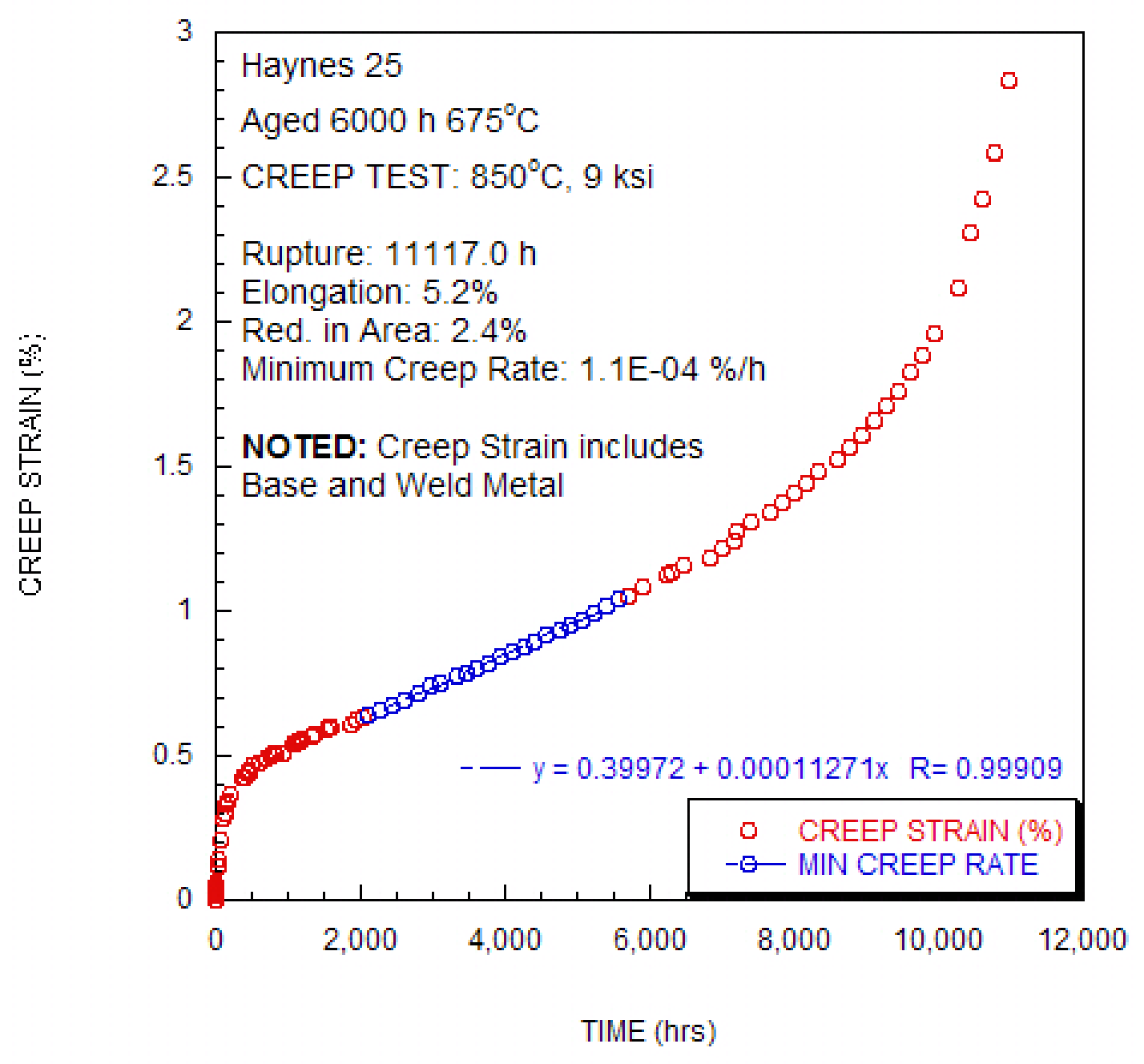




\begin{tabular}{|c|c|c|c|c|c|c|c|c|c|c|}
\hline Test ID & $\begin{array}{c}\text { Product } \\
\text { Form }\end{array}$ & $\begin{array}{l}\text { Aging } \\
\text { Temp. } \\
\left({ }^{\circ} \mathrm{C}\right)\end{array}$ & $\begin{array}{l}\text { Aging } \\
\text { Time } \\
\text { (hours) }\end{array}$ & $\begin{array}{l}\text { Test } \\
\text { Temp. } \\
\left({ }^{\circ} \mathrm{C}\right)\end{array}$ & $\begin{array}{l}\text { Stress } \\
(\mathrm{MPa})\end{array}$ & $\begin{array}{r}\text { Rupture } \\
\text { Life } \\
\text { (hours) } \\
\text { stopped } \\
\text { or } \\
\text { ongoing } \\
\end{array}$ & $\begin{array}{r}\text { Minimum } \\
\text { Creep } \\
\text { Rate } \\
(\% / h r) \\
\end{array}$ & $\begin{array}{r}\text { Elong. } \\
(\%)\end{array}$ & $\begin{array}{r}\text { Red. } \\
\text { of } \\
\text { Area } \\
(\%) \\
\end{array}$ & $\begin{array}{l}\text { Failure } \\
\text { Location }\end{array}$ \\
\hline LWC-9 & bar weld & none & none & 800 & 103.4 & 6464.1 & 6.34E-04 & 11.2 & 27.3 & $\mathrm{BM}$ \\
\hline
\end{tabular}

\section{LWC-9}

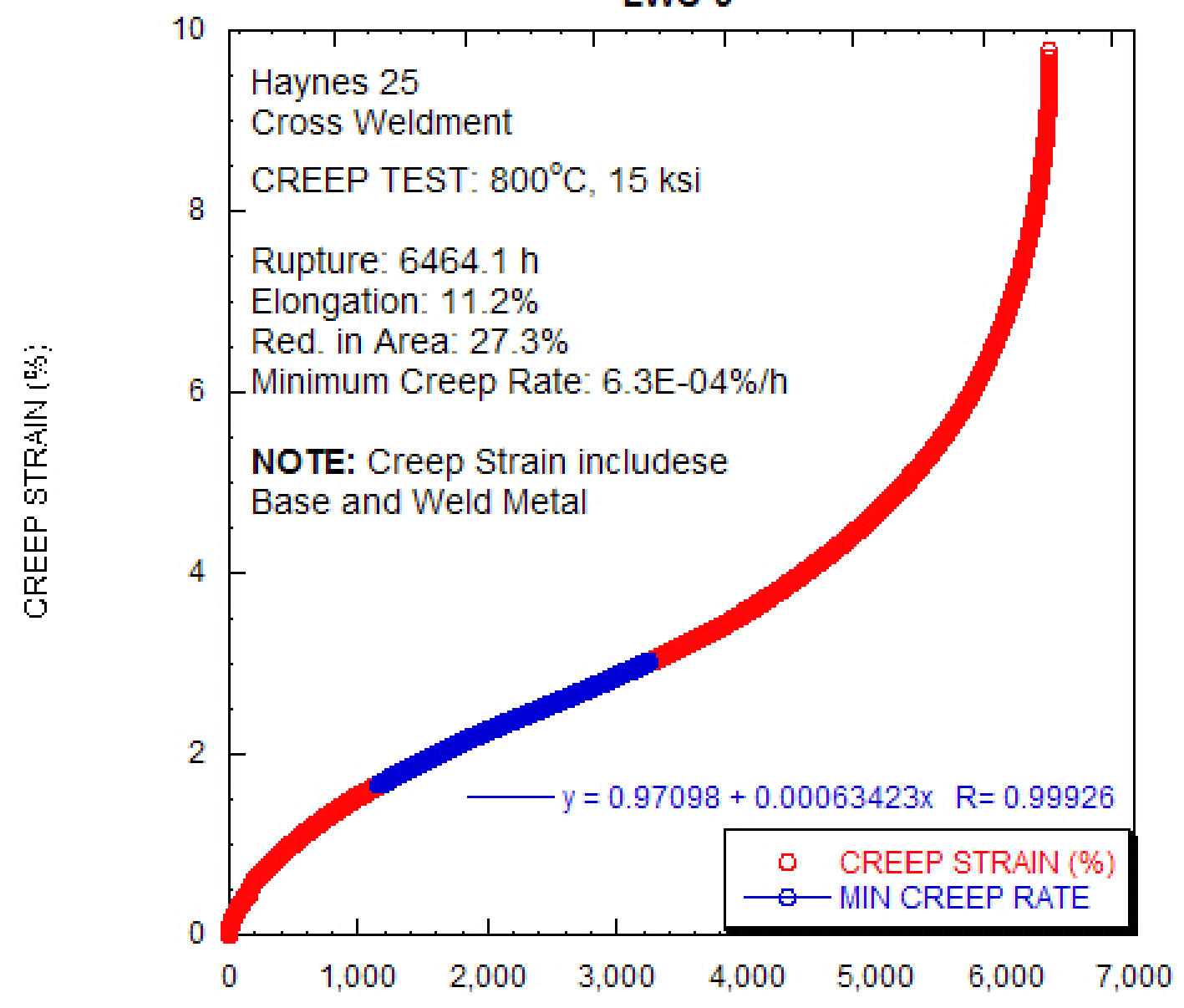

Time 


\begin{tabular}{|c|c|c|c|c|c|c|c|c|c|c|}
\hline Test ID & $\begin{array}{l}\text { Product } \\
\text { Form }\end{array}$ & $\begin{array}{l}\text { Aging } \\
\text { Temp. } \\
\left({ }^{\circ} \mathrm{C}\right)\end{array}$ & $\begin{array}{l}\text { Aging } \\
\text { Time } \\
\text { (hours) }\end{array}$ & $\begin{array}{c}\text { Test } \\
\text { Temp. } \\
\left({ }^{\circ} \mathrm{C}\right)\end{array}$ & $\begin{array}{l}\text { Stress } \\
(\mathrm{MPa})\end{array}$ & $\begin{array}{r}\text { Rupture } \\
\text { Life } \\
\text { (hours) } \\
\text { stopped } \\
\text { or } \\
\text { ongoing } \\
\end{array}$ & $\begin{array}{r}\text { Minimum } \\
\text { Creep } \\
\text { Rate } \\
(\% / h r) \\
\end{array}$ & $\begin{array}{l}\text { Elong. } \\
(\%)\end{array}$ & $\begin{array}{l}\text { Red. } \\
\text { of } \\
\text { Area } \\
(\%) \\
\end{array}$ & $\begin{array}{l}\text { Failure } \\
\text { Location }\end{array}$ \\
\hline AWC-7 & bar weld & none & none & 650 & 124.1 & 8326.0 & 7.12E-06 & & & \\
\hline
\end{tabular}

AWC-7 (TN30693)

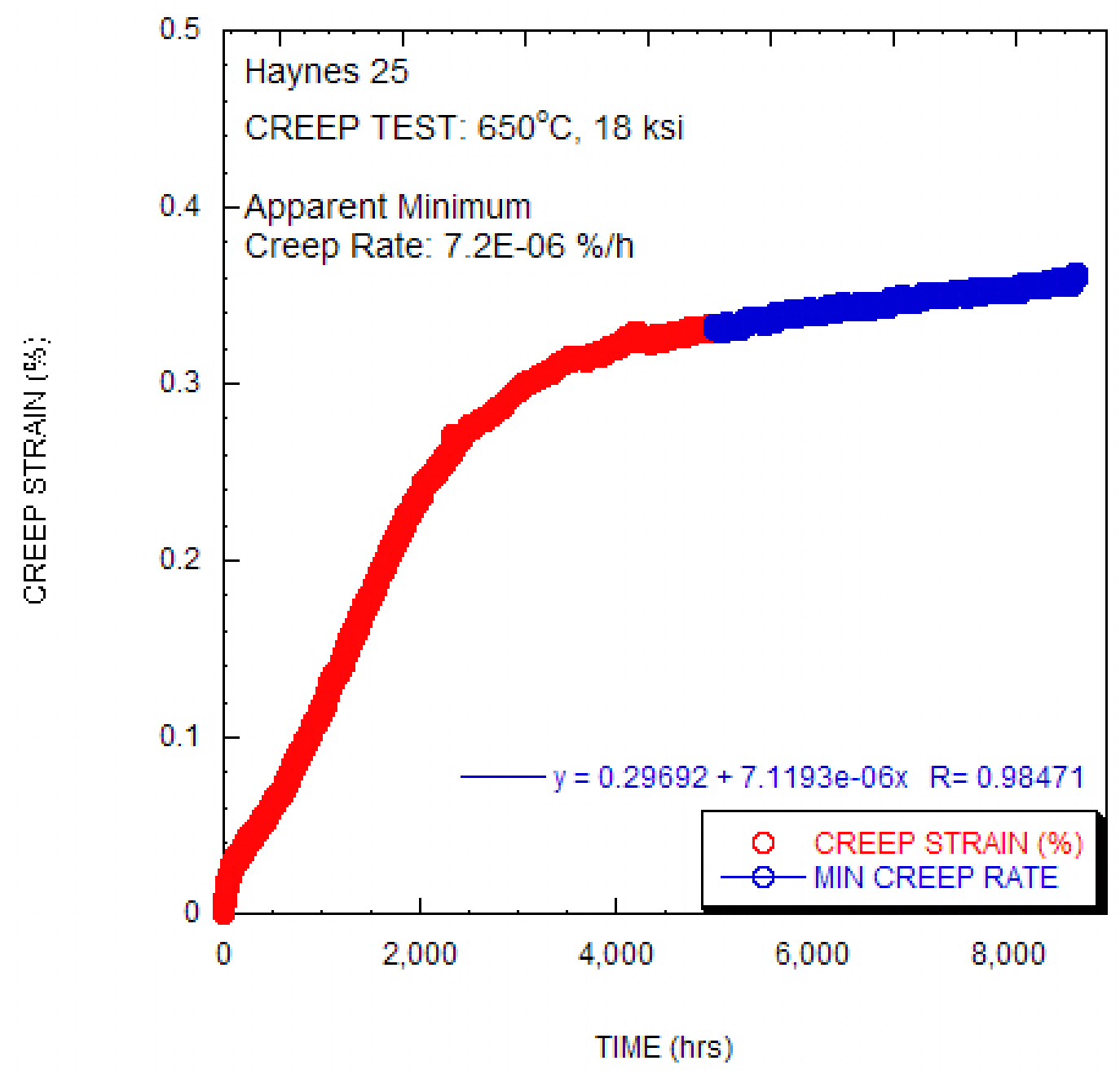




\begin{tabular}{|c|c|c|c|c|c|c|c|c|c|c|}
\hline Test ID & $\begin{array}{l}\text { Product } \\
\text { Form }\end{array}$ & $\begin{array}{l}\text { Aging } \\
\text { Temp. } \\
\left({ }^{\circ} \mathrm{C}\right)\end{array}$ & $\begin{array}{l}\text { Aging } \\
\text { Time } \\
\text { (hours) }\end{array}$ & $\begin{array}{c}\text { Test } \\
\text { Temp. } \\
\left({ }^{\circ} \mathrm{C}\right)\end{array}$ & $\begin{array}{l}\text { Stress } \\
(\mathrm{MPa})\end{array}$ & $\begin{array}{r}\text { Rupture } \\
\text { Life } \\
\text { (hours) } \\
\text { stopped } \\
\text { or } \\
\text { ongoing } \\
\end{array}$ & $\begin{array}{r}\text { Minimum } \\
\text { Creep } \\
\text { Rate } \\
(\% / h r) \\
\end{array}$ & $\begin{array}{l}\text { Elong. } \\
(\%)\end{array}$ & $\begin{array}{l}\text { Red. } \\
\text { of } \\
\text { Area } \\
(\%) \\
\end{array}$ & $\begin{array}{l}\text { Failure } \\
\text { Location }\end{array}$ \\
\hline AWC-8 & bar weld & none & none & 650 & 206.8 & 8186.0 & 7.99E-05 & & & \\
\hline
\end{tabular}

\section{AWC-8}

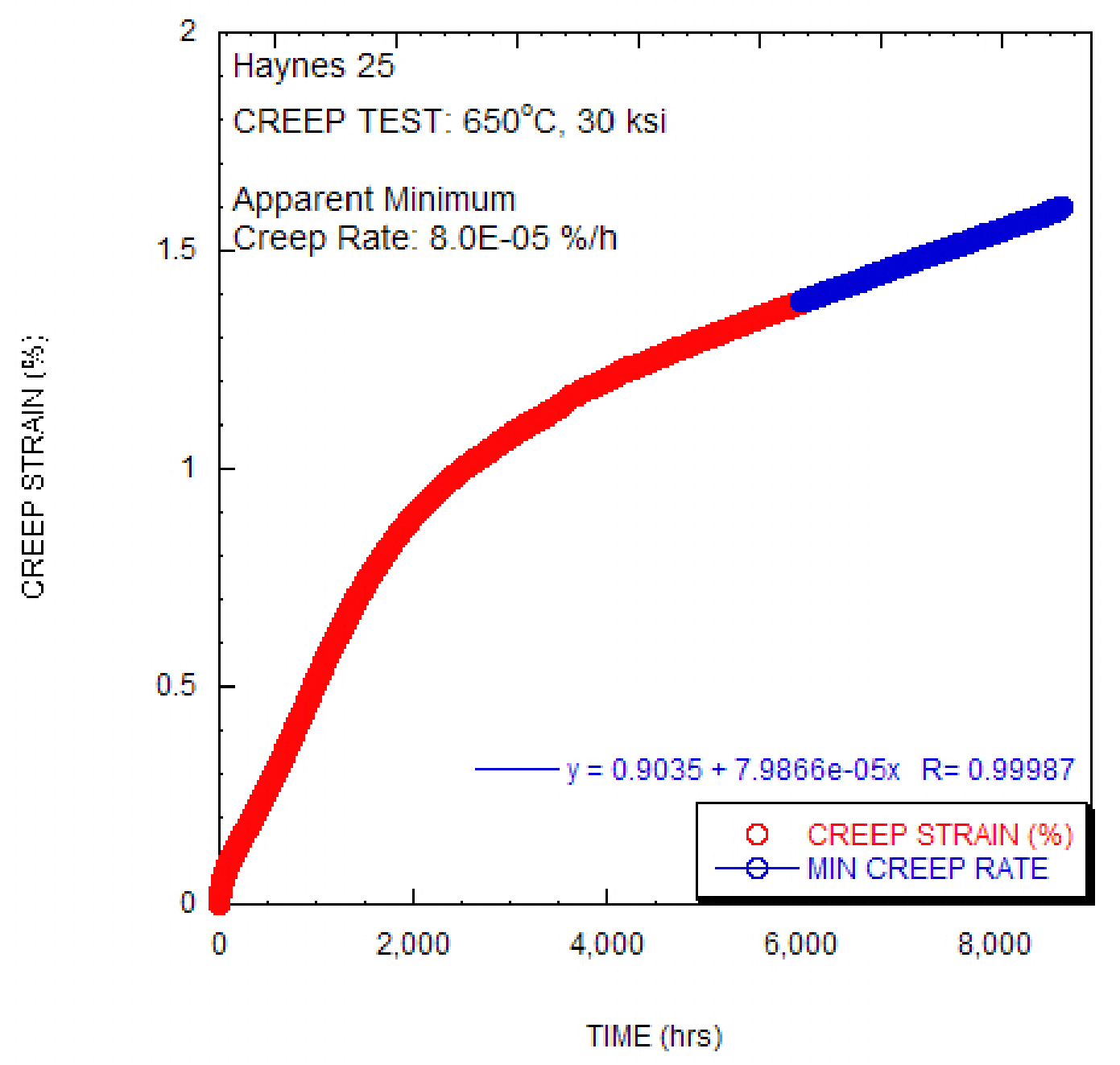




\begin{tabular}{|c|c|c|c|c|c|c|c|c|c|c|}
\hline Test ID & $\begin{array}{c}\text { Product } \\
\text { Form }\end{array}$ & $\begin{array}{l}\text { Aging } \\
\text { Temp. } \\
\left({ }^{\circ} \mathrm{C}\right)\end{array}$ & $\begin{array}{l}\text { Aging } \\
\text { Time } \\
\text { (hours) }\end{array}$ & $\begin{array}{l}\text { Test } \\
\text { Temp. } \\
\left({ }^{\circ} \mathrm{C}\right)\end{array}$ & $\begin{array}{l}\text { Stress } \\
(\mathrm{MPa})\end{array}$ & $\begin{array}{r}\text { Rupture } \\
\text { Life } \\
\text { (hours) } \\
\text { stopped } \\
\text { or } \\
\text { ongoing } \\
\end{array}$ & $\begin{array}{r}\text { Minimum } \\
\text { Creep } \\
\text { Rate } \\
(\% / h r) \\
\end{array}$ & $\begin{array}{r}\text { Elong. } \\
(\%)\end{array}$ & $\begin{array}{r}\text { Red. } \\
\text { of } \\
\text { Area } \\
(\%) \\
\end{array}$ & $\begin{array}{l}\text { Failure } \\
\text { Location }\end{array}$ \\
\hline AWC-9 & bar weld & none & none & 800 & 103.4 & 5718.9 & 5.71E-04 & 14.5 & 19.2 & $\mathrm{BM}$ \\
\hline
\end{tabular}

AWC-9

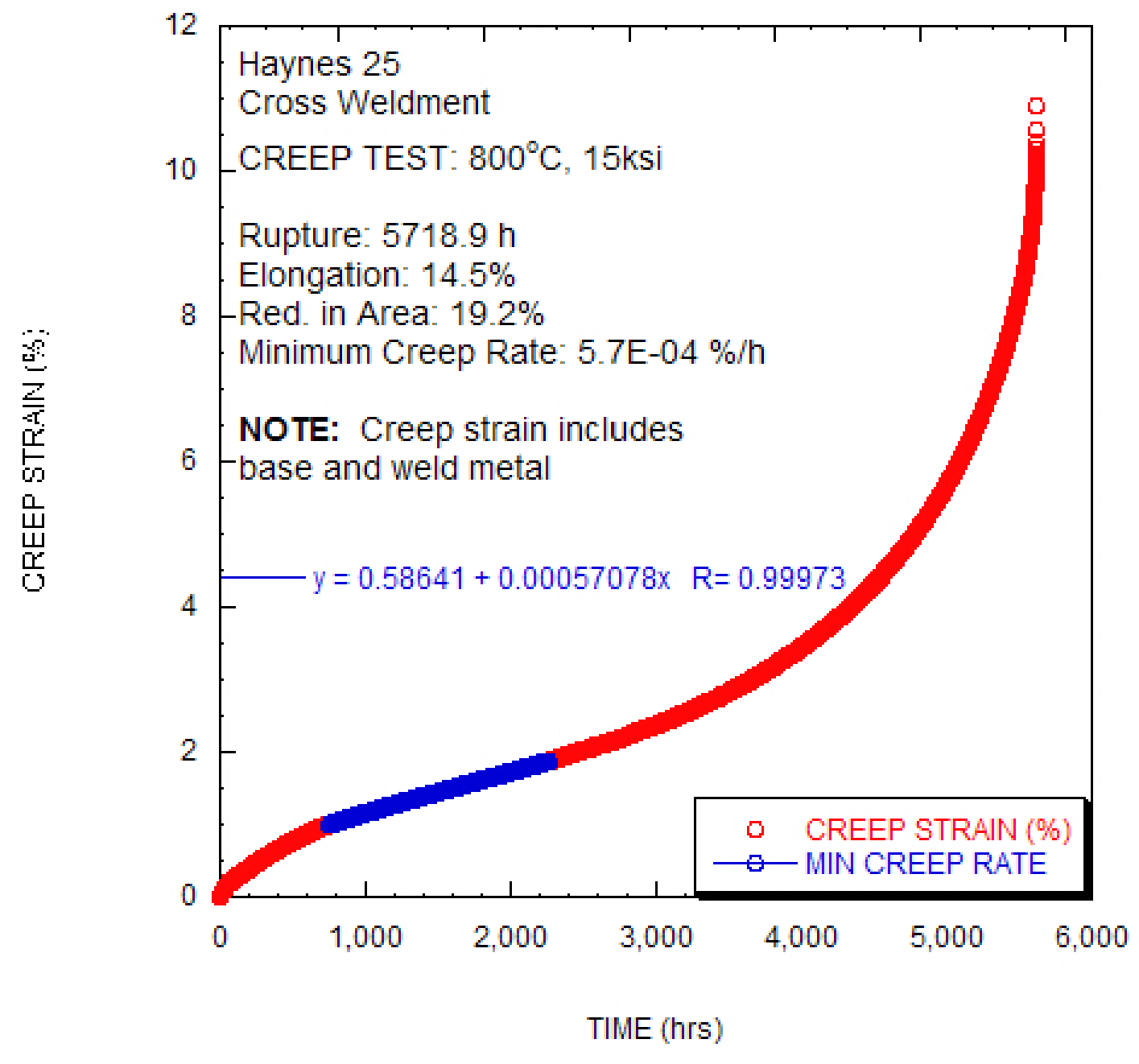




\section{A.7 HISTORICAL SUMMARY OF HAYNES 25 TENSILE DATA}

Table A.7.1. Alloy 25 (L-605) historical tensile data for annealed material

\begin{tabular}{|c|c|c|c|c|c|}
\hline $\begin{array}{c}\text { Heat ID / } \\
\text { Source }\end{array}$ & $\begin{array}{c}\text { Product } \\
\text { Form }\end{array}$ & $\begin{array}{c}\text { Temperature } \\
\left({ }^{\circ} \mathrm{C}\right)\end{array}$ & $\begin{array}{c}\text { Yield } \\
\text { Strength } \\
(\mathrm{MPa})\end{array}$ & $\begin{array}{c}\text { Ultimate } \\
\text { Tensile } \\
\text { Strength } \\
(\mathrm{MPa})\end{array}$ & $\begin{array}{c}\text { Elongation } \\
(\%)\end{array}$ \\
\hline astm 1 & & 24 & 483 & 1069 & 55 \\
\hline astm 1 & & 649 & 272 & 514 & 25 \\
\hline astm 1 & & 816 & 241 & 345 & 15 \\
\hline astm 1 & & 982 & 145 & 157 & 16 \\
\hline astm 1 & & 1149 & & 62 & 24 \\
\hline astm 2 & & 24 & 592 & 1110 & 47 \\
\hline astm 2 & & 399 & 385 & 952 & 40 \\
\hline astm 2 & & 538 & 372 & 903 & 40 \\
\hline astm 2 & & 649 & 379 & 648 & 29 \\
\hline astm 2 & & 732 & 354 & 578 & 11 \\
\hline astm 2 & & 816 & 310 & 381 & 16 \\
\hline astm 2 & & 899 & 220 & 236 & 30 \\
\hline astm 2 & & 982 & 190 & 201 & 37 \\
\hline astm 4 & & 24 & 396 & 1020 & 36 \\
\hline astm 4 & & 649 & & 731 & 34 \\
\hline astm 4 & & 816 & & 477 & 42 \\
\hline astm 5 & & 24 & 407 & 958 & \\
\hline ht 1716 & sheet & 24 & 492 & 869 & 43 \\
\hline ht 1931 & sheet & 24 & 459 & 993 & 68 \\
\hline ht 1843 & sheet & 24 & 385 & 876 & 77 \\
\hline ht 1335 & sheet & 24 & 476 & 1034 & 65 \\
\hline ht 1813 & sheet & 24 & 494 & 952 & 43.6 \\
\hline ht 1816 & sheet & 24 & 448 & 931 & 60 \\
\hline ht 1816 & sheet & 316 & 305 & 827 & 80 \\
\hline ht 1816 & sheet & 760 & 242 & 583 & 28 \\
\hline ht 1816 & sheet & 982 & 125 & 231 & 40 \\
\hline Xxx & sheet & 649 & 241 & 483 & 24 \\
\hline Xxx & sheet & 982 & 159 & 179 & 39 \\
\hline Xxx & sheet & 24 & 424 & 993 & 85 \\
\hline Xxx & sheet & 24 & 385 & 896 & 94 \\
\hline Xxx & sheet & 650 & 195 & 686 & 64 \\
\hline Xxx & sheet & 700 & 191 & 636 & 50 \\
\hline Xxx & sheet & 800 & 183 & 388 & 28.8 \\
\hline Xxx & sheet & 850 & 186 & 300 & 20.8 \\
\hline DMIC-32 & sheet & 24 & 462 & 1007 & 64 \\
\hline DMIC-32 & sheet & 316 & & 814 & 77.5 \\
\hline DMIC-32 & Sheet & 427 & & 772 & 72 \\
\hline DMIC-32 & sheet & 538 & & 690 & 68 \\
\hline DMIC-32 & sheet & 593 & & 669 & 53.5 \\
\hline
\end{tabular}


Table A.7.1. Alloy 25 (L-605) historical tensile data for annealed material (Continued)

\begin{tabular}{|c|c|c|c|c|c|}
\hline $\begin{array}{c}\text { Heat ID / } \\
\text { Source }\end{array}$ & $\begin{array}{c}\text { Product } \\
\text { Form }\end{array}$ & $\begin{array}{c}\text { Temperature } \\
\left({ }^{\circ} \mathrm{C}\right)\end{array}$ & $\begin{array}{c}\text { Yield } \\
\text { Strength } \\
(\mathrm{MPa})\end{array}$ & $\begin{array}{c}\text { Ultimate } \\
\text { Tensile } \\
\text { Strength } \\
(\mathrm{MPa})\end{array}$ & $\begin{array}{c}\text { Elongation } \\
(\%)\end{array}$ \\
\hline DMIC-32 & sheet & 649 & & 514 & 25 \\
\hline DMIC-32 & sheet & 732 & & 372 & 13 \\
\hline DMIC-32 & sheet & 816 & & 345 & 15 \\
\hline DMIC-32 & sheet & 899 & & 228 & 16 \\
\hline DMIC-32 & sheet & 982 & & 157 & 16 \\
\hline DMIC-32 & sheet & 1093 & & 97 & 23.3 \\
\hline DMIC-32 & sheet & 1149 & & 62 & 24 \\
\hline DMIC-32 & sheet & 1204 & & 50 & 22.6 \\
\hline DMIC-32 & sheet & 1260 & & 35 & 18.6 \\
\hline DMIC-33 & sheet & 24 & 483 & 1069 & 55 \\
\hline DMIC-33 & sheet & 93 & & 979 & 62 \\
\hline DMIC-33 & sheet & 149 & & 924 & 67 \\
\hline DMIC-33 & sheet & 204 & & 876 & 71 \\
\hline DMIC-33 & sheet & 260 & & 841 & 75 \\
\hline DMIC-33 & sheet & 316 & & 814 & 77 \\
\hline DMIC-33 & sheet & 371 & & 786 & 75 \\
\hline DMIC-33 & sheet & 427 & & 772 & 72 \\
\hline DMIC-33 & sheet & 482 & & 745 & 71 \\
\hline DMIC-33 & sheet & 538 & 241 & 703 & 68 \\
\hline DMIC-33 & sheet & 760 & 255 & 365 & 13 \\
\hline DMIC-33 & sheet & 871 & 234 & 276 & 14 \\
\hline DMIC-33 & sheet & 982 & & 159 & 18 \\
\hline DMIC-33 & sheet & 649 & 241 & 524 & 25 \\
\hline DMIC-33 & sheet & 1093 & & 90 & 23 \\
\hline DMIC-34 & sheet & 24 & 463 & 1007 & 64 \\
\hline
\end{tabular}


Table A.7.1 Alloy 25 (L-605) historical tensile data for annealed material (Continued)

\begin{tabular}{|c|c|c|c|c|c|}
\hline $\begin{array}{c}\text { Heat ID / } \\
\text { Source }\end{array}$ & $\begin{array}{c}\text { Product } \\
\text { Form }\end{array}$ & $\begin{array}{c}\text { Temperature } \\
\left({ }^{\circ} \mathrm{C}\right)\end{array}$ & $\begin{array}{c}\text { Yield } \\
\text { Strength } \\
(\mathrm{MPa})\end{array}$ & $\begin{array}{c}\text { Ultimate } \\
\text { Tensile } \\
\text { Strength } \\
(\mathrm{MPa})\end{array}$ & $\begin{array}{c}\text { Elongation } \\
(\%)\end{array}$ \\
\hline DMIC-34 & sheet & 316 & 279 & 883 & 72 \\
\hline DMIC-34 & sheet & 427 & 269 & 855 & 74 \\
\hline DMIC-34 & sheet & 538 & 247 & 800 & 59 \\
\hline DMIC-34 & sheet & 649 & 244 & 710 & 35 \\
\hline DMIC-34 & sheet & 760 & 260 & 455 & 12 \\
\hline DMIC-34 & sheet & 871 & 238 & 321 & 30 \\
\hline DMIC-34 & sheet & 982 & 159 & 237 & 41 \\
\hline DMIC-34 & sheet & 1093 & 83 & 135 & 34 \\
\hline DMIC-34 & sheet & 1149 & 61 & 72 & 21 \\
\hline DMIC-34 & sheet & 1204 & 39 & 47 & 14 \\
\hline DMIC-34 & sheet & 1260 & & 32 & 13 \\
\hline DMIC-34 & sheet & 1316 & & 21 & 6 \\
\hline DMIC-39 & sheet & 24 & 592 & 1110 & 47 \\
\hline DMIC-39 & sheet & 399 & 385 & 952 & 40 \\
\hline DMIC-39 & sheet & 538 & 372 & 903 & 40 \\
\hline DMIC-39 & sheet & 649 & 379 & 648 & 29 \\
\hline DMIC-39 & sheet & 732 & 354 & 578 & 11 \\
\hline DMIC-39 & sheet & 816 & 310 & 381 & 16 \\
\hline DMIC-39 & sheet & 899 & 219 & 236 & 30 \\
\hline DMIC-39 & sheet & 982 & 190 & 201 & 37 \\
\hline DMIC-39 & sheet & 1149 & & 62 & 24 \\
\hline DMIC-38 & sheet & 24 & 474 & 972 & 43 \\
\hline DMIC-38 & sheet & 538 & 245 & 758 & 59 \\
\hline DMIC-38 & sheet & 538 & 249 & 710 & 45 \\
\hline DMIC-38 & sheet & 649 & 230 & 651 & 40 \\
\hline
\end{tabular}


Table A.7.1. Alloy 25 (L-605) historical tensile data for annealed material (Continued)

\begin{tabular}{|c|c|c|c|c|c|}
\hline $\begin{array}{c}\text { Heat ID / } \\
\text { Source }\end{array}$ & $\begin{array}{c}\text { Product } \\
\text { Form }\end{array}$ & $\begin{array}{c}\text { Temperature } \\
\left({ }^{\circ} \mathrm{C}\right)\end{array}$ & $\begin{array}{c}\text { Yield } \\
\text { Strength } \\
(\mathrm{MPa})\end{array}$ & $\begin{array}{c}\text { Ultimate } \\
\text { Tensile } \\
\text { Strength } \\
(\mathrm{MPa})\end{array}$ & $\begin{array}{c}\text { Elongation } \\
(\%)\end{array}$ \\
\hline DMIC-38 & sheet & 649 & 239 & 696 & 43.5 \\
\hline DMIC-38 & sheet & 732 & 208 & 520 & 23 \\
\hline DMIC-38 & sheet & 732 & 228 & 556 & 28 \\
\hline DMIC-38 & sheet & 816 & 220 & 445 & 27 \\
\hline DMIC-38 & sheet & 816 & 227 & 441 & 27.5 \\
\hline DMIC-38 & sheet & 899 & 226 & 328 & 28 \\
\hline DMIC-38 & sheet & 899 & 223 & 300 & 26 \\
\hline DMIC-38 & sheet & 982 & 151 & 169 & 35 \\
\hline DMIC-38 & sheet & 982 & 183 & 219 & 35 \\
\hline DMIC-38 & sheet & 1038 & 51 & 85 & 18 \\
\hline DMIC-38 & sheet & 1038 & 79 & 103 & 16.5 \\
\hline DMIC-38 & sheet & 1093 & 68 & 90 & 17 \\
\hline DMIC-38 & sheet & 1093 & 48 & 73 & 22.5 \\
\hline DMIC-38 & sheet & 1149 & 32 & 55 & 13 \\
\hline DMIC-38 & sheet & 1149 & 40 & 54 & 22 \\
\hline DMIC-56 & sheet & 24 & 496 & 938 & 59 \\
\hline DMIC-56 & sheet & 649 & 234 & 621 & 66 \\
\hline DMIC-56 & sheet & 649 & 254 & 696 & 70 \\
\hline DMIC-56 & sheet & 871 & 217 & 433 & 31 \\
\hline DMIC-56 & sheet & 871 & 200 & 410 & 40 \\
\hline DMIC-56 & sheet & 982 & 200 & 270 & 35 \\
\hline DMIC-56 & sheet & 982 & 155 & 227 & 25 \\
\hline DMIC-56 & sheet & 1149 & 54 & 103 & 25 \\
\hline DMIC-56 & sheet & 1149 & 66 & 109 & 25 \\
\hline
\end{tabular}


Table A.7.2. Alloy 25 (L-605) historical tensile data for welded material

\begin{tabular}{|c|c|c|c|c|c|c|c|}
\hline $\begin{array}{l}\text { Heat ID } \\
\text { / Source }\end{array}$ & $\begin{array}{l}\text { Product } \\
\text { Form } \\
\text { (Thickness } \\
\text { in inches) }\end{array}$ & $\begin{array}{c}\text { Weld } \\
\text { Process }\end{array}$ & $\begin{array}{c}\text { Temperature } \\
\left({ }^{\circ} \mathrm{C}\right)\end{array}$ & $\begin{array}{c}\text { Yield } \\
\text { Strength } \\
\text { (MPa) }\end{array}$ & $\begin{array}{l}\text { Ultimate } \\
\text { Tensile } \\
\text { Strength } \\
\text { (MPa) }\end{array}$ & $\begin{array}{c}\text { Elongation } \\
(\%)\end{array}$ & $\begin{array}{l}\text { Failure } \\
\text { Location }\end{array}$ \\
\hline haynes & .094 sht & sma & 24 & 505 & 898 & 30 & \\
\hline haynes & $.094 \mathrm{sht}$ & sma & 816 & 247 & 452 & 16 & \\
\hline haynes & .125 sht & sma & 24 & 486 & 920 & 35 & \\
\hline haynes & $.125 \mathrm{sht}$ & sma & 816 & 232 & 445 & 15 & \\
\hline haynes & $.094 \mathrm{sht}$ & gta & 24 & 512 & 935 & 38 & \\
\hline haynes & $.094 \mathrm{sht}$ & gta & 816 & 249 & 472 & 19 & \\
\hline haynes & $.125 \mathrm{sht}$ & gta & 24 & 496 & 945 & 40 & \\
\hline haynes & $.125 \mathrm{sht}$ & gta & 816 & 232 & 477 & 23 & \\
\hline $\begin{array}{c}\text { DMIC } \\
25\end{array}$ & $.062 \mathrm{sht}$ & gta & 24 & 402 & 958 & 58.5 & weldment \\
\hline $\begin{array}{c}\text { DMIC } \\
25\end{array}$ & $.062 \mathrm{sht}$ & gta & 24 & 461 & 949 & 55 & weldment \\
\hline $\begin{array}{c}\text { DMIC } \\
25 \\
\end{array}$ & $.062 \mathrm{sht}$ & gta & 538 & 248 & 696 & 50.5 & weldment \\
\hline $\begin{array}{c}\text { DMIC } \\
25\end{array}$ & $.062 \mathrm{sht}$ & gta & 538 & 250 & 667 & & \\
\hline $\begin{array}{l}\text { DMIC } \\
25 \\
\end{array}$ & $.062 \mathrm{sht}$ & gta & 649 & 261 & 605 & 25 & weldment \\
\hline $\begin{array}{c}\text { DMIC } \\
25 \\
\end{array}$ & $.062 \mathrm{sht}$ & gta & 649 & 261 & 618 & & \\
\hline $\begin{array}{l}\text { DMIC } \\
25\end{array}$ & $.062 \mathrm{sht}$ & gta & 732 & 226 & 527 & 18.5 & weldment \\
\hline $\begin{array}{l}\text { DMIC } \\
25\end{array}$ & $.062 \mathrm{sht}$ & gta & 732 & 233 & 583 & 22 & weldment \\
\hline $\begin{array}{c}\text { DMIC } \\
25 \\
\end{array}$ & $.062 \mathrm{sht}$ & gta & 816 & 220 & 419 & 23 & \\
\hline $\begin{array}{c}\text { DMIC } \\
25\end{array}$ & $.062 \mathrm{sht}$ & gta & 816 & 206 & 416 & 22 & weldment \\
\hline $\begin{array}{l}\text { DMIC } \\
25\end{array}$ & $.062 \mathrm{sht}$ & gta & 900 & 220 & 241 & 30 & weldment \\
\hline $\begin{array}{c}\text { DMIC } \\
25\end{array}$ & $.062 \mathrm{sht}$ & gta & 900 & 225 & 239 & 30 & weldment \\
\hline $\begin{array}{l}\text { DMIC } \\
25 \\
\end{array}$ & $.062 \mathrm{sht}$ & gta & 982 & 14.4 & 158 & 17 & weldment \\
\hline $\begin{array}{l}\text { DMIC } \\
25\end{array}$ & $.062 \mathrm{sht}$ & gta & 982 & 152 & 181 & 22 & weldment \\
\hline $\begin{array}{c}\text { DMIC } \\
25\end{array}$ & $.062 \mathrm{sht}$ & gta & 1038 & 68 & 119 & 15 & weldment \\
\hline $\begin{array}{c}\text { DMIC } \\
25\end{array}$ & $.062 \mathrm{sht}$ & gta & 1038 & 66 & 128 & 14 & weldment \\
\hline $\begin{array}{l}\text { DMIC } \\
25\end{array}$ & $.062 \mathrm{sht}$ & gta & 1038 & 54 & 68 & 14 & weldment \\
\hline $\begin{array}{c}\text { DMIC } \\
25 \\
\end{array}$ & $.062 \mathrm{sht}$ & gta & 1038 & 55 & 63 & 15.5 & \\
\hline $\begin{array}{c}\text { DMIC } \\
25\end{array}$ & $.062 \mathrm{sht}$ & gta & 1149 & & 57 & 6.5 & weldment \\
\hline $\begin{array}{l}\text { DMIC } \\
25\end{array}$ & $.062 \mathrm{sht}$ & gta & 1149 & 32 & 41 & 7 & weldment \\
\hline
\end{tabular}


Table A.7.2. Alloy 25 (L-605) historical tensile data for welded material (Continued)

\begin{tabular}{|c|c|c|c|c|c|c|c|}
\hline $\begin{array}{c}\text { Heat ID } \\
\text { / Source }\end{array}$ & $\begin{array}{c}\text { Product } \\
\text { Form } \\
\text { (Thickness } \\
\text { in inches) }\end{array}$ & $\begin{array}{c}\text { Weld } \\
\text { Process }\end{array}$ & $\begin{array}{c}\text { Temperature } \\
\left({ }^{\circ} \mathrm{C}\right)\end{array}$ & $\begin{array}{c}\text { Yield } \\
\text { Strength } \\
(\mathrm{MPa})\end{array}$ & $\begin{array}{c}\text { Ultimate } \\
\text { Tensile } \\
\text { Strength } \\
(\mathrm{MPa})\end{array}$ & $\begin{array}{c}\text { Elongation } \\
(\%)\end{array}$ & $\begin{array}{c}\text { Failure } \\
\text { Location }\end{array}$ \\
\hline DMIC 6 & $0.04 \mathrm{sht}$ & gta & 24 & 505 & 787 & 18.2 & \\
\hline DMIC 6 & $0.04 \mathrm{sht}$ & gta & 871 & 237 & 245 & 9.6 & \\
\hline DMIC 6 & $0.04 \mathrm{sht}$ & gta & 1093 & 75 & 80 & 12.4 & \\
\hline 1931 & $.062 \mathrm{sht}$ & gta & 24 & 481 & 910 & 35 & \\
\hline 1843 & $.062 \mathrm{sht}$ & gia & 24 & 432 & 864 & 34 & \\
\hline 1335 & $.060 \mathrm{sht}$ & gta & 24 & 490 & 972 & 40 & \\
\hline
\end{tabular}


Table A.7.3. Alloy 25 (L-605) historical tensile data for aged material

\begin{tabular}{|c|c|c|c|c|c|c|c|}
\hline $\begin{array}{l}\text { Heat ID / } \\
\text { Source }\end{array}$ & $\begin{array}{c}\text { Aging } \\
\text { Temperature } \\
\left({ }^{\circ} \mathrm{C}\right)\end{array}$ & $\begin{array}{l}\text { Aging } \\
\text { Time } \\
\text { (hours) }\end{array}$ & $\begin{array}{c}\text { Test } \\
\text { Temperature } \\
\left({ }^{\circ} \mathrm{C}\right)\end{array}$ & $\begin{array}{c}\text { Yield } \\
\text { Strength } \\
\text { (MPa) }\end{array}$ & $\begin{array}{c}\text { Ultimate } \\
\text { Tensile } \\
\text { Strength } \\
(\mathrm{MPa})\end{array}$ & $\begin{array}{c}\text { Elongation } \\
(\%)\end{array}$ & $\begin{array}{l}\text { Reduction } \\
\text { of Area } \\
(\%)\end{array}$ \\
\hline DMIC 39 & 760 & 0 & 760 & 228 & 324 & 9 & \\
\hline DMIC 39 & 760 & 0 & 760 & 193 & 386 & 18 & \\
\hline DMIC 39 & 760 & 120 & 760 & 283 & 579 & 24 & \\
\hline DMIC 39 & 760 & 120 & 760 & 214 & 510 & 31 & \\
\hline DMIC 39 & 760 & 350 & 760 & 421 & 641 & 10 & \\
\hline DMIC 39 & 760 & 350 & 760 & 393 & 676 & 18 & \\
\hline DMIC 39 & 871 & 0 & 871 & 172 & 324 & 19 & \\
\hline DMIC 39 & 871 & 0 & 871 & 179 & 386 & 19 & \\
\hline DMIC 39 & 871 & 120 & 871 & 186 & 414 & 38 & \\
\hline DMIC 39 & 871 & 120 & 871 & 269 & 372 & 25 & \\
\hline DMIC 39 & 871 & 350 & 871 & 186 & 386 & 30 & \\
\hline DMIC 39 & 871 & 350 & 871 & 179 & 386 & 37 & \\
\hline DMIC39 & 982 & 0 & 982 & 103 & 200 & 17 & \\
\hline DMIC 39 & 982 & 0 & 982 & 110 & 248 & 12 & \\
\hline DMIC 39 & 982 & 120 & 982 & 103 & 179 & 22 & \\
\hline DMIC 39 & 982 & 120 & 982 & 138 & 248 & 35 & \\
\hline DMIC39 & 982 & 350 & 982 & 83 & 228 & 35 & \\
\hline DMIC 39 & 982 & 350 & 982 & 110 & 248 & 32 & \\
\hline $\begin{array}{l}\text { ORNL } \\
1816\end{array}$ & 816 & 0 & 24 & 448 & 931 & 60 & \\
\hline $\begin{array}{l}\text { ORNL } \\
1816\end{array}$ & 816 & 11448 & 24 & 427 & 821 & 7.9 & 7.9 \\
\hline $\begin{array}{l}\text { ORNL } \\
1816\end{array}$ & 816 & 11448 & 24 & 427 & 848 & 8.8 & 8.8 \\
\hline $\begin{array}{l}\text { ORNL } \\
1816 \\
\end{array}$ & 816 & 0 & 316 & 303 & 827 & 80 & \\
\hline $\begin{array}{l}\text { ORNL } \\
1816 \\
\end{array}$ & 816 & 11448 & 316 & 317 & 772 & 20 & 20 \\
\hline $\begin{array}{l}\text { ORNL } \\
1816\end{array}$ & 816 & 11448 & 316 & 303 & 758 & 18.3 & 18.3 \\
\hline $\begin{array}{l}\text { ORNL } \\
1816 \\
\end{array}$ & 816 & 0 & 760 & 241 & 586 & 28 & \\
\hline $\begin{array}{l}\text { ORNL } \\
1816\end{array}$ & 816 & 11448 & 760 & 241 & 552 & 53.1 & 20 \\
\hline $\begin{array}{l}\text { ORNL } \\
1816 \\
\end{array}$ & 816 & 11448 & 760 & 255 & 558 & 53 & 18.4 \\
\hline $\begin{array}{l}\text { ORNL } \\
1816\end{array}$ & 816 & 0 & 982 & 124 & 234 & 40 & \\
\hline $\begin{array}{l}\text { ORNL } \\
1816\end{array}$ & 816 & 11448 & 982 & 152 & 179 & 48 & 6 \\
\hline $\begin{array}{l}\text { ORNL } \\
1816\end{array}$ & 816 & 0 & 24 & 448 & 931 & 60 & \\
\hline $\begin{array}{l}\text { ORNL } \\
1816\end{array}$ & 816 & 11448 & 24 & 400 & 931 & 10.2 & 10.2 \\
\hline $\begin{array}{l}\text { ORNL } \\
1816\end{array}$ & 816 & 11448 & 24 & 379 & 1020 & 10.8 & 10.8 \\
\hline $\begin{array}{l}\text { ORNL } \\
1816\end{array}$ & 816 & 0 & 316 & 303 & 827 & 80 & \\
\hline
\end{tabular}


Table A.7.3. Alloy 25 (L-605) historical tensile data for aged material (continued)

\begin{tabular}{|c|c|c|c|c|c|c|c|}
\hline $\begin{array}{l}\text { Heat ID / } \\
\text { Source }\end{array}$ & $\begin{array}{c}\text { Aging } \\
\text { Temperature } \\
\left({ }^{\circ} \mathrm{C}\right)\end{array}$ & $\begin{array}{l}\text { Aging } \\
\text { Time } \\
\text { (hours) }\end{array}$ & $\begin{array}{c}\text { Test } \\
\text { Temperature } \\
\left({ }^{\circ} \mathrm{C}\right) \\
\end{array}$ & $\begin{array}{l}\text { Yield } \\
\text { Strength } \\
\text { (MPa) }\end{array}$ & $\begin{array}{c}\text { Ultimate } \\
\text { Tensile } \\
\text { Strength } \\
(\mathrm{MPa})\end{array}$ & $\begin{array}{c}\text { Elongation } \\
(\%)\end{array}$ & $\begin{array}{c}\text { Reduction } \\
\text { of Area } \\
(\%)\end{array}$ \\
\hline $\begin{array}{l}\text { ORNL } \\
1816\end{array}$ & 816 & 11448 & 316 & 331 & 821 & 20.2 & 20.2 \\
\hline $\begin{array}{l}\text { ORNL } \\
1816\end{array}$ & 816 & 11448 & 316 & 324 & 765 & 13.8 & 13.8 \\
\hline $\begin{array}{l}\text { ORNL } \\
1816\end{array}$ & 816 & 0 & 760 & 241 & 586 & 28 & \\
\hline $\begin{array}{l}\text { ORNL } \\
1816 \\
\end{array}$ & 816 & 11448 & 760 & 262 & 586 & 57.7 & 16.7 \\
\hline $\begin{array}{l}\text { ORNL } \\
1816\end{array}$ & 816 & 11448 & 760 & 262 & 586 & 59.4 & 16.6 \\
\hline $\begin{array}{l}\text { ORNL } \\
1816\end{array}$ & 816 & 0 & 982 & 124 & 234 & 40 & \\
\hline $\begin{array}{l}\text { ORNL } \\
1816\end{array}$ & 816 & 11448 & 982 & 152 & 179 & 47.1 & 6 \\
\hline $\begin{array}{l}\text { ORNL } \\
1816\end{array}$ & 816 & 11448 & 982 & 76 & 90 & 75 & 7.7 \\
\hline $\begin{array}{l}\text { ORNL } \\
1813\end{array}$ & 850 & 0 & 24 & 496 & 952 & 43.6 & 43.2 \\
\hline $\begin{array}{l}\text { ORNL } \\
1813\end{array}$ & 850 & 50 & 24 & 552 & 779 & 14.6 & \\
\hline $\begin{array}{l}\text { ORNL } \\
1813 \\
\end{array}$ & 850 & 4843 & 24 & 607 & 917 & 12.9 & 12.7 \\
\hline SNAP 29 & 760 & 0 & 24 & 407 & 883 & 56.6 & \\
\hline SNAP 29 & 760 & 500 & 24 & 427 & 724 & 17 & \\
\hline SNAP 29 & 760 & 1000 & 24 & 483 & 793 & 10 & \\
\hline SNAP 29 & 760 & 4000 & 24 & & 793 & 2 & \\
\hline SNAP 29 & 760 & 0 & 538 & 179 & 655 & 71.2 & \\
\hline SNAP 29 & 760 & 500 & 538 & 200 & 600 & 41.3 & \\
\hline SNAP 29 & 760 & 1000 & 538 & 296 & 690 & 27.8 & \\
\hline SNAP 29 & 760 & 4000 & 538 & 359 & 752 & 10 & \\
\hline SNAP 29 & 816 & 0 & 24 & 407 & 883 & 56.6 & \\
\hline SNAP 29 & 816 & 500 & 24 & 462 & 765 & 8 & \\
\hline SNAP 29 & 816 & 1000 & 24 & 522 & 851 & 3 & \\
\hline SNAP 29 & 816 & 4000 & 24 & 490 & 821 & 2 & \\
\hline SNAP 29 & 816 & 0 & 538 & 179 & 655 & 71.2 & \\
\hline SNAP 29 & 816 & 500 & 538 & 262 & 621 & 15 & \\
\hline SNAP 29 & 816 & 1000 & 538 & 359 & & & \\
\hline SNAP 29 & 816 & 4000 & 538 & 338 & 627 & 5 & \\
\hline SNAP 29 & 871 & 0 & 24 & 407 & 883 & 56.6 & \\
\hline SNAP 29 & 871 & 500 & 24 & 517 & 876 & 8 & \\
\hline SNAP 29 & 871 & 1000 & 24 & 476 & 807 & 3 & \\
\hline SNAP 29 & 871 & 4000 & 24 & 462 & 731 & 2 & \\
\hline SNAP 29 & 871 & 0 & 538 & 179 & 655 & 71.2 & \\
\hline SNAP 29 & 871 & 500 & 538 & 317 & 765 & 10 & \\
\hline SNAP 29 & 871 & 1000 & 538 & 310 & 676 & 8.3 & \\
\hline SNAP 29 & 871 & 4000 & 538 & 296 & 607 & 4 & \\
\hline
\end{tabular}


Table A.7.3. Alloy 25 (L-605) historical tensile data for aged material (continued)

\begin{tabular}{|c|c|c|c|c|c|c|c|}
\hline $\begin{array}{l}\text { Heat ID / } \\
\text { Source }\end{array}$ & $\begin{array}{c}\text { Aging } \\
\text { Temperature } \\
\left({ }^{\circ} \mathrm{C}\right)\end{array}$ & $\begin{array}{l}\text { Aging } \\
\text { Time } \\
\text { (hours) }\end{array}$ & $\begin{array}{c}\text { Test } \\
\text { Temperature } \\
\left({ }^{\circ} \mathrm{C}\right)\end{array}$ & $\begin{array}{l}\text { Yield } \\
\text { Strength } \\
\text { (MPa) }\end{array}$ & $\begin{array}{l}\text { Ultimate } \\
\text { Tensile } \\
\text { Strength } \\
\text { (MPa) }\end{array}$ & $\begin{array}{c}\text { Elongation } \\
(\%)\end{array}$ & $\begin{array}{l}\text { Reduction } \\
\text { of Area } \\
\text { (\%) }\end{array}$ \\
\hline Wlodek A & 871 & 4 & 24 & 600 & & 35 & \\
\hline Wlodek A & 871 & 15 & 24 & 607 & & 27 & \\
\hline Wlodek A & 871 & 25 & 24 & 614 & & 18 & \\
\hline Wlodek A & 871 & 50 & 24 & 607 & & 18 & \\
\hline Wlodek A & 871 & 100 & 24 & 565 & & 12 & \\
\hline Wlodek A & 871 & 1000 & 24 & 586 & 1117 & 9 & \\
\hline Wlodek B & 871 & 1000 & 24 & 531 & 1034 & 7 & \\
\hline Wlodek C & 871 & 1000 & 24 & 565 & 1069 & 5 & \\
\hline Wlodek C & 871 & 1000 & 260 & 414 & & 12 & \\
\hline Wlodek C & 871 & 1000 & 538 & 372 & & 15 & \\
\hline Wlodek D & 871 & 1000 & 24 & 586 & 1055 & 5 & \\
\hline Wlodek E & 871 & 15 & 24 & 469 & & 16 & \\
\hline Wlodek E & 871 & 25 & 24 & 469 & & 10 & \\
\hline Wlodek E & 871 & 50 & 24 & 496 & & 10 & \\
\hline Wlodek E & 871 & 100 & 24 & 538 & & 10 & \\
\hline Wlodek E & 871 & 1000 & 24 & 565 & 979 & 5 & \\
\hline Wlodek F & 871 & 1000 & 24 & 531 & 910 & 2 & \\
\hline Wlodek F & 871 & 1000 & 260 & 365 & & 7 & \\
\hline Wlodek F & 871 & 1000 & 538 & 331 & & 11 & \\
\hline Wlodek F & 871 & 1000 & 871 & 179 & & 34 & \\
\hline Wlodek G & 871 & 1000 & 24 & 593 & 917 & 1 & \\
\hline Wlodek G & 871 & 1000 & 260 & 496 & & 1 & \\
\hline Wlodek G & 871 & 1000 & 538 & 434 & & 2 & \\
\hline Bourgette & 650 & 0 & 24 & 386 & 896 & 94 & 91 \\
\hline Bourgette & 650 & 1000 & 24 & 393 & 786 & 53 & 53 \\
\hline Bourgette & 650 & 1000 & 24 & 386 & 834 & 60 & 60 \\
\hline Bourgette & 650 & 2000 & 24 & 427 & 841 & 34 & 34 \\
\hline Bourgette & 650 & 2000 & 650 & 255 & 724 & 47 & 47 \\
\hline Bourgette & 700 & 0 & 24 & 386 & 896 & 94 & 91 \\
\hline Bourgette & 700 & 1000 & 24 & 758 & 917 & 5 & 5 \\
\hline Bourgette & 700 & 1000 & 24 & 758 & 952 & 8 & 8 \\
\hline Bourgette & 700 & 2000 & 24 & 917 & 1027 & 2.5 & 2.5 \\
\hline Bourgette & 700 & 2000 & 700 & 703 & 855 & 16 & 6.5 \\
\hline Bourgette & 800 & 0 & 24 & 386 & 896 & 94 & 91 \\
\hline Bourgette & 800 & 1000 & 24 & 545 & 938 & 15 & 15 \\
\hline Bourgette & 800 & 1000 & 800 & & 648 & 20.5 & 20.5 \\
\hline Bourgette & 800 & 2000 & 24 & 545 & 924 & 10.5 & 10.5 \\
\hline Bourgette & 800 & 2000 & 800 & 310 & 483 & 33.5 & 12 \\
\hline Bourgette & 850 & 0 & 24 & 386 & 896 & 94 & 91 \\
\hline Bourgette & 850 & 1000 & 650 & 193 & 690 & 64 & 63 \\
\hline Bourgette & 850 & 1000 & 700 & 193 & 634 & 50 & 50 \\
\hline Bourgette & 850 & 1000 & 850 & & 352 & 44.5 & 7.5 \\
\hline Bourgette & 850 & 2000 & 24 & 483 & 772 & 5.2 & 5.2 \\
\hline Bourgette & 850 & 2000 & 850 & 255 & 290 & 43.5 & 8 \\
\hline
\end{tabular}




\section{A.8 HISTORICAL SUMMARY OF HAYNES 25 CREEP-RUPTURE DATA}

Table A.8.1. Alloy 25 (L-605) historical creep and stress-rupture data

\begin{tabular}{|c|c|c|c|c|c|}
\hline $\begin{array}{l}\text { Heat ID / } \\
\text { Source }\end{array}$ & $\begin{array}{c}\text { Temperature } \\
\left({ }^{\circ} \mathrm{C}\right) \\
\end{array}$ & $\begin{array}{l}\text { Stress } \\
(\mathrm{MPa})\end{array}$ & $\begin{array}{c}\text { Rupture } \\
\text { Life } \\
\text { (MPa) }\end{array}$ & $\begin{array}{c}\text { Minimum } \\
\text { Creep Rate } \\
(\% / \mathrm{hr})\end{array}$ & $\begin{array}{c}\text { Elongation } \\
(\%)\end{array}$ \\
\hline astm1 & 982 & 28 & 686 & 5.00E-04 & 4.0 \\
\hline astm1 & 982 & 34 & 269 & 3.60E-03 & 4.0 \\
\hline astm1 & 927 & 41 & 569 & 9.00E-04 & 6.0 \\
\hline astm1 & 982 & 41 & 198 & 5.50E-03 & 2.0 \\
\hline astm1 & 871 & 55 & 1671 & 2.60E-04 & 6.0 \\
\hline astm1 & 927 & 55 & 283 & $6.40 \mathrm{E}-03$ & 13.0 \\
\hline astm1 & 871 & 69 & 582 & 2.60E-03 & 10.0 \\
\hline astm1 & 927 & 69 & 123 & 1.07E-02 & 13.0 \\
\hline astm1 & 871 & 83 & 506 & 6.40E-03 & 7.6 \\
\hline astm1 & 927 & 83 & 73.2 & 2.67E-01 & 10.0 \\
\hline astm1 & 816 & 97 & 2850 & $1.90 \mathrm{E}-04$ & 4.0 \\
\hline astm1 & 871 & 97 & 186 & 4.04E-02 & 10.0 \\
\hline astm1 & 871 & 103 & 139 & 4.50E-02 & 19.0 \\
\hline astm1 & 816 & 124 & 389 & 1.93E-02 & 15.0 \\
\hline astm1 & 816 & 124 & 324 & 2.81E-02 & 11.0 \\
\hline astm1 & 871 & 124 & 51.5 & 1.39E-01 & 17.5 \\
\hline astm1 & 816 & 131 & 431 & $1.42 \mathrm{E}-02$ & 20.0 \\
\hline astm1 & 816 & 148 & 269 & 2.57E-02 & 17.0 \\
\hline astm1 & 816 & 165 & 107 & 9.33E-02 & 17.0 \\
\hline astm1 & 649 & 310 & 121 & 5.80E-03 & 7.0 \\
\hline astm2 & 899 & 69 & 324 & & 6.0 \\
\hline astm2 & 899 & 103 & 36 & & 16.0 \\
\hline astm2 & 816 & 138 & 437 & & 15.0 \\
\hline astm2 & 899 & 138 & 10.7 & & 20.0 \\
\hline astm2 & 816 & 172 & 128 & & 21.0 \\
\hline astm2 & 899 & 172 & 2 & & 24.0 \\
\hline astm2 & 816 & 241 & 9.1 & & 28.0 \\
\hline astm2 & 649 & 345 & 71.9 & & 6.0 \\
\hline astm2 & 649 & 394 & 4.4 & & 7.0 \\
\hline astm2 & 649 & 446 & 4 & & 8.0 \\
\hline astm2 & 649 & 483 & 1.2 & & 11.0 \\
\hline astm3 & 982 & 34 & 420 & 5.30E-03 & 3.5 \\
\hline astm3 & 982 & 41 & 165 & $1.40 \mathrm{E}-02$ & 4.0 \\
\hline astm3 & 982 & 55 & 30 & 1.80E-01 & 9.0 \\
\hline astm3 & 982 & 69 & 11.5 & 7.10E-01 & 9.0 \\
\hline astm3 & 982 & 90 & 1.9 & $3.10 \mathrm{E}+00$ & 13.5 \\
\hline astm3 & 816 & 103 & 752 & 3.80E-03 & 5.0 \\
\hline astm3 & 816 & 138 & 90 & 4.60E-02 & 6.0 \\
\hline astm3 & 816 & 172 & 20 & 2.80E-01 & 7.5 \\
\hline astm3 & 816 & 207 & 5 & $1.35 E+00$ & 10.5 \\
\hline astm4 & 816 & 129 & 302.9 & & 14.0 \\
\hline astm4 & 816 & 150 & 115.5 & & 22.0 \\
\hline astm4 & 816 & 172 & 64.5 & & 15.0 \\
\hline
\end{tabular}


Table A.8.1. Alloy 25 (L-605) historical creep and stress-rupture data (continued)

\begin{tabular}{|c|c|c|c|c|c|}
\hline $\begin{array}{l}\text { Heat ID / } \\
\text { Source }\end{array}$ & $\begin{array}{c}\text { Temperature } \\
\left({ }^{\circ} \mathrm{C}\right)\end{array}$ & $\begin{array}{l}\text { Stress } \\
(\mathrm{MPa})\end{array}$ & $\begin{array}{c}\text { Rupture } \\
\text { Life } \\
\text { (MPa) }\end{array}$ & $\begin{array}{l}\text { Minimum } \\
\text { Creep Rate } \\
(\% / h r)\end{array}$ & $\begin{array}{c}\text { Elongation } \\
(\%)\end{array}$ \\
\hline astm4 & 816 & 207 & 15.4 & & 20.0 \\
\hline astm4 & 649 & 455 & 193.5 & & 8.0 \\
\hline astm4 & 649 & 481 & 113.5 & & 9.0 \\
\hline Baughman & 1038 & 34 & 6.8 & & 11.0 \\
\hline Baughman & 982 & 55 & 5 & & 9.0 \\
\hline Baughman & 982 & 69 & 1.6 & & 14.0 \\
\hline Baughman & 982 & 69 & 1.4 & & 13.0 \\
\hline Baughman & 1038 & 69 & 0.2 & & 19.0 \\
\hline Baughman & 982 & 103 & 0.2 & & 22.0 \\
\hline Flagella & 1093 & 10 & 595 & 7.00E-04 & \\
\hline Flagella & 1093 & 14 & 424.6 & 5.67E-04 & 4.1 \\
\hline Flagella & 1093 & 14 & 329.7 & 5.88E-04 & 3.7 \\
\hline Flagella & 1093 & 14 & 219.8 & $6.55 \mathrm{E}-04$ & 4.0 \\
\hline Flagella & 1093 & 18 & 223 & $1.25 E-03$ & \\
\hline Flagella & 1093 & 23 & 150.8 & 8.00E-03 & 6.2 \\
\hline Flagella & 1093 & 24 & 170 & $2.10 \mathrm{E}-03$ & 3.8 \\
\hline Flagella & 1093 & 24 & 39.6 & 4.00E-03 & \\
\hline Flagella & 1093 & 24 & 132 & 5.21E-03 & 7.0 \\
\hline Flagella & 1093 & 25 & 64 & 3.80E-03 & \\
\hline Flagella & 1093 & 41 & 13.6 & $1.28 \mathrm{E}-01$ & 12.1 \\
\hline Flagella & 1093 & 41 & 9.8 & 2.59E-01 & 10.6 \\
\hline Flagella & 1093 & 41 & 5.4 & 9.12E-01 & \\
\hline Flagella & 1093 & 42 & 14.5 & 7.78E-02 & 10.5 \\
\hline Flagella & 927 & 76 & 1057 & 1.76E-03 & 15.9 \\
\hline Flagella & 927 & 83 & 729 & $2.30 \mathrm{E}-03$ & 21.3 \\
\hline Flagella & 927 & 83 & 652 & 3.80E-03 & 26.6 \\
\hline Flagella & 927 & 83 & 554 & 2.67E-03 & 23.8 \\
\hline Flagella & 927 & 117 & 92.7 & 1.74E-02 & 22.3 \\
\hline Flagella & 927 & 117 & 81.3 & 4.35E-02 & 21.0 \\
\hline Flagella & 927 & 117 & 79.2 & 1.46E-02 & 28.0 \\
\hline Flagella & 927 & 117 & 74.9 & 5.77E-02 & 20.0 \\
\hline Flagella & 927 & 138 & 24.1 & 2.53E-01 & 33.3 \\
\hline Flagella & 927 & 138 & 23.6 & 1.89E-01 & 22.9 \\
\hline Flagella & 927 & 138 & 17 & 5.87E-01 & 23.5 \\
\hline Flagella & 927 & 138 & 13.6 & 3.76E-01 & 25.2 \\
\hline Flagella & 760 & 234 & 2053 & 6.60E-04 & 11.5 \\
\hline Flagella & 760 & 234 & 1584 & $1.43 E-03$ & 10.2 \\
\hline Flagella & 760 & 241 & 1289 & $2.50 \mathrm{E}-03$ & 12.6 \\
\hline Flagella & 760 & 241 & 1002 & $2.60 \mathrm{E}-03$ & 6.9 \\
\hline Flagella & 760 & 276 & 184 & 1.40E-02 & 7.7 \\
\hline Flagella & 760 & 290 & 103 & 2.90E-02 & 6.8 \\
\hline Flagella & 760 & 290 & 194 & 1.60E-02 & 6.5 \\
\hline Flagella & 760 & 290 & 152.5 & 2.30E-02 & 5.1 \\
\hline Flagella & 760 & 310 & 83.1 & 3.40E-02 & 6.4 \\
\hline Flagella & 760 & 345 & 29.2 & 1.27E-01 & 4.0 \\
\hline Flagella & 760 & 379 & 16.9 & 2.57E-01 & 7.4 \\
\hline
\end{tabular}


Table A.8.1. Alloy 25 (L-605) historical creep and stress-rupture data (continued)

\begin{tabular}{|c|c|c|c|c|c|}
\hline $\begin{array}{l}\text { Heat ID / } \\
\text { Source }\end{array}$ & $\begin{array}{c}\text { Temperature } \\
\left({ }^{\circ} \mathrm{C}\right)\end{array}$ & $\begin{array}{l}\text { Stress } \\
(\mathrm{MPa})\end{array}$ & $\begin{array}{c}\text { Rupture } \\
\text { Life } \\
\text { (MPa) }\end{array}$ & $\begin{array}{l}\text { Minimum } \\
\text { Creep Rate } \\
(\% / h r)\end{array}$ & $\begin{array}{c}\text { Elongation } \\
(\%)\end{array}$ \\
\hline Flagella & 760 & 379 & 9.1 & 2.93E-01 & 4.3 \\
\hline Greene & 982 & 40 & 87 & & 5.0 \\
\hline Greene & 982 & 59 & 58 & & 9.0 \\
\hline Greene & 982 & 69 & 14 & & 19.0 \\
\hline Greene & 982 & 76 & 7.1 & & 16.0 \\
\hline Greene & 982 & 79 & 8.8 & & 21.0 \\
\hline Greene & 982 & 79 & 7.8 & & 14.0 \\
\hline Greene & 982 & 79 & 5 & & 18.0 \\
\hline Greene & 982 & 103 & 1.8 & & 32.0 \\
\hline Greene & 982 & 138 & 0.3 & & 30.0 \\
\hline Greene & 982 & 159 & 0.2 & & 31.0 \\
\hline HW80794 & 1149 & 17 & 10 & & \\
\hline HW80794 & 1108 & 21 & 46 & & \\
\hline HW80794 & 1149 & 21 & 3.6 & & \\
\hline HW80794 & 1108 & 22 & 34 & & \\
\hline HW80794 & 1108 & 26 & 10 & & \\
\hline HW80794 & 1149 & 26 & 1.6 & & \\
\hline HW80794 & 1108 & 29 & 8.2 & & \\
\hline HW80794 & 1108 & 30 & 7 & & \\
\hline HW80794 & 1149 & 30 & 0.8 & & \\
\hline HW80794 & 1108 & 33 & 6 & & \\
\hline HW80794 & 1108 & 38 & 2.7 & & \\
\hline HW80794 & 1108 & 41 & 0.7 & & \\
\hline ORNL 1335 & 816 & 121 & 474 & $2.00 \mathrm{E}-02$ & 15.0 \\
\hline ORNL 1335 & 760 & 155 & 522 & $1.70 \mathrm{E}-02$ & 13.0 \\
\hline ORNL 1335 & 704 & 276 & 151 & 8.00E-03 & 5.0 \\
\hline ORNL 1716 & 1316 & 14 & 0.6 & $1.50 \mathrm{E}+01$ & 12.5 \\
\hline ORNL 1716 & 1204 & 21 & 1.3 & $5.80 \mathrm{E}+00$ & 10.0 \\
\hline ORNL 1716 & 1149 & 28 & 3 & 3.00E-01 & 4.0 \\
\hline ORNL 1716 & 1177 & 28 & 0.8 & $6.50 \mathrm{E}+00$ & 7.0 \\
\hline ORNL 1716 & 1204 & 28 & 0.4 & $2.70 \mathrm{E}+01$ & 11.0 \\
\hline ORNL 1716 & 1260 & 28 & 0.2 & $9.00 \mathrm{E}+01$ & 15.0 \\
\hline ORNL 1716 & 1149 & 41 & 0.5 & $4.50 \mathrm{E}+00$ & 5.0 \\
\hline ORNL 1716 & 1177 & 41 & 0.2 & $5.50 \mathrm{E}+01$ & 15.0 \\
\hline ORNL 1716 & 1204 & 41 & 0.1 & $1.30 \mathrm{E}+02$ & 16.0 \\
\hline ORNL 1716 & 1093 & 48 & 2.4 & $1.20 \mathrm{E}+01$ & 6.0 \\
\hline ORNL 1716 & 1093 & 69 & 0.3 & $2.20 \mathrm{E}+01$ & 12.0 \\
\hline ORNL 1716 & 1149 & 69 & 0 & $1.80 \mathrm{E}+02$ & 7.5 \\
\hline ORNL 1716 & 871 & 79 & 164 & & 3.5 \\
\hline ORNL 1716 & 982 & 103 & 1 & $5.00 \mathrm{E}+00$ & 9.0 \\
\hline ORNL 1716 & 1093 & 103 & 0 & $4.00 \mathrm{E}+02$ & 13.0 \\
\hline ORNL 1716 & 816 & 121 & 386 & 1.20E-02 & 6.0 \\
\hline ORNL 1716 & 982 & 138 & 0.3 & $4.00 E+01$ & 16.0 \\
\hline ORNL 1716 & 760 & 190 & 33 & & 3.0 \\
\hline ORNL 1843 & 871 & 79 & 515 & & 20.0 \\
\hline ORNL 1843 & 816 & 121 & 382 & 4.00E-02 & 23.0 \\
\hline
\end{tabular}


Table A.8.1. Alloy 25 (L-605) historical creep and stress-rupture data (continued)

\begin{tabular}{|c|c|c|c|c|c|}
\hline $\begin{array}{l}\text { Heat ID / } \\
\text { Source }\end{array}$ & $\begin{array}{l}\text { Temperature } \\
\left({ }^{\circ} \mathrm{C}\right)\end{array}$ & $\begin{array}{l}\text { Stress } \\
\text { (MPa) }\end{array}$ & $\begin{array}{c}\text { Rupture } \\
\text { Life } \\
\text { (MPa) }\end{array}$ & $\begin{array}{l}\text { Minimum } \\
\text { Creep Rate } \\
(\% / h r)\end{array}$ & $\begin{array}{c}\text { Elongation } \\
(\%)\end{array}$ \\
\hline ORNL 1843 & 760 & 155 & 1296 & 1.10E-02 & 20.0 \\
\hline ORNL 1931 & 1204 & 28 & 0.6 & $2.60 \mathrm{E}+01$ & 22.0 \\
\hline ORNL 1931 & 1149 & 41 & 0.3 & $4.20 \mathrm{E}+01$ & 17.0 \\
\hline ORNL 1931 & 1093 & 48 & 0.8 & $1.00 \mathrm{E}+01$ & 9.0 \\
\hline ORNL 1931 & 1093 & 69 & 0.2 & $3.30 \mathrm{E}+01$ & 14.0 \\
\hline ORNL 1931 & 982 & 103 & 1.5 & $7.90 \mathrm{E}+00$ & 15.0 \\
\hline ORNL 1931 & 816 & 121 & 595 & 1.30E-02 & 10.0 \\
\hline ORNL 1931 & 760 & 190 & 155 & 4.00E-02 & 8.0 \\
\hline ORNL 1931 & 704 & 276 & 248 & $2.20 \mathrm{E}-02$ & 5.0 \\
\hline Widmer & 982 & 28 & 1463.5 & 6.60E-04 & 5.2 \\
\hline Widmer & 982 & 34 & 921.9 & 1.00E-03 & 9.1 \\
\hline Widmer & 982 & 38 & 528 & 1.60E-03 & 9.3 \\
\hline Widmer & 982 & 41 & 447.2 & 2.80E-03 & 10.0 \\
\hline Widmer & 982 & 48 & 160 & 1.30E-02 & 9.6 \\
\hline Widmer & 982 & 55 & 51 & 7.80E-02 & 6.3 \\
\hline Widmer & 982 & 59 & 65.8 & 7.60E-02 & 10.7 \\
\hline Widmer & 982 & 61 & 56.6 & 8.00E-02 & 7.8 \\
\hline Widmer & 899 & 62 & 892 & 1.20E-03 & 4.0 \\
\hline Widmer & 899 & 69 & 965.9 & 1.60E-03 & 6.4 \\
\hline Widmer & 982 & 69 & 28.6 & & 19.1 \\
\hline Widmer & 899 & 76 & 287.8 & 1.60E-02 & 8.0 \\
\hline Widmer & 816 & 79 & 13018 & 8.50E-05 & 4.9 \\
\hline Widmer & 899 & 83 & 235 & 1.50E-02 & 8.9 \\
\hline Widmer & 982 & 83 & 7.8 & $1.40 \mathrm{E}+00$ & 20.8 \\
\hline Widmer & 899 & 90 & 123.5 & $5.60 \mathrm{E}-02$ & 12.7 \\
\hline Widmer & 982 & 90 & 5.2 & $2.80 \mathrm{E}+00$ & 32.4 \\
\hline Widmer & 816 & 103 & 3883.8 & 4.00E-04 & 10.0 \\
\hline Widmer & 857 & 103 & 368.4 & 1.60E-02 & 10.3 \\
\hline Widmer & 899 & 103 & 70.9 & 1.20E-01 & 11.0 \\
\hline Widmer & 982 & 103 & 2.1 & $6.90 \mathrm{E}+00$ & 29.4 \\
\hline Widmer & 899 & 110 & 46.6 & 2.90E-01 & 27.0 \\
\hline Widmer & 816 & 117 & 1157 & 4.70E-03 & 9.4 \\
\hline Widmer & 816 & 117 & 1203 & & 11.1 \\
\hline Widmer & 816 & 117 & 1661.8 & & 15.3 \\
\hline Widmer & 816 & 117 & 1729.4 & & 8.2 \\
\hline Widmer & 816 & 117 & 1764.7 & & 10.3 \\
\hline Widmer & 816 & 117 & 1802 & & 14.5 \\
\hline Widmer & 816 & 117 & 2010 & & 11.7 \\
\hline Widmer & 899 & 121 & 15.3 & $1.20 \mathrm{E}+00$ & 26.6 \\
\hline Widmer & 982 & 124 & 0.8 & $1.40 \mathrm{E}+01$ & 32.9 \\
\hline Widmer & 816 & 128 & 748.3 & 9.80E-03 & 15.1 \\
\hline Widmer & 899 & 131 & 12.7 & $1.20 \mathrm{E}+00$ & 23.6 \\
\hline Widmer & 816 & 138 & 305.7 & 7.10E-02 & 13.9 \\
\hline Widmer & 899 & 138 & 8.7 & $1.60 \mathrm{E}+00$ & 23.5 \\
\hline Widmer & 816 & 148 & 301 & 7.50E-02 & 16.5 \\
\hline Widmer & 816 & 152 & 146 & $7.20 \mathrm{E}-02$ & 14.5 \\
\hline
\end{tabular}


Table A.8.1. Alloy 25 (L-605) historical creep and stress-rupture data (continued)

\begin{tabular}{|c|c|c|c|c|c|}
\hline $\begin{array}{l}\text { Heat ID / } \\
\text { Source }\end{array}$ & $\begin{array}{c}\text { Temperature } \\
\left({ }^{\circ} \mathrm{C}\right)\end{array}$ & $\begin{array}{l}\text { Stress } \\
(\mathrm{MPa})\end{array}$ & $\begin{array}{c}\text { Rupture } \\
\text { Life } \\
\text { (MPa) }\end{array}$ & $\begin{array}{l}\text { Minimum } \\
\text { Creep Rate } \\
(\% / h r)\end{array}$ & $\begin{array}{c}\text { Elongation } \\
(\%)\end{array}$ \\
\hline Widmer & 899 & 152 & 4.2 & $3.60 \mathrm{E}+00$ & 19.9 \\
\hline Widmer & 732 & 172 & 6055 & 5.70E-04 & 7.2 \\
\hline Widmer & 816 & 172 & 96.5 & $9.50 \mathrm{E}-02$ & 23.4 \\
\hline Widmer & 857 & 172 & 9.6 & $1.60 \mathrm{E}+00$ & 19.7 \\
\hline Widmer & 732 & 179 & 5654 & 4.10E-04 & 7.0 \\
\hline Widmer & 649 & 183 & 21789 & $9.60 \mathrm{E}-06$ & 1.2 \\
\hline Widmer & 732 & 190 & 2098.8 & 1.10E-03 & 5.0 \\
\hline Widmer & 816 & 190 & 25.7 & $2.60 \mathrm{E}-01$ & 15.0 \\
\hline Widmer & 649 & 193 & 10192 & 4.50E-05 & 1.4 \\
\hline Widmer & 732 & 200 & 1969.1 & $1.20 \mathrm{E}-03$ & 5.6 \\
\hline Widmer & 649 & 203 & 17867 & 5.20E-05 & 2.2 \\
\hline Widmer & 732 & 203 & 374.6 & 3.80E-03 & 2.4 \\
\hline Widmer & 732 & 207 & 218.2 & 4.00E-03 & 8.5 \\
\hline Widmer & 732 & 207 & 815.9 & 1.50E-03 & 3.7 \\
\hline Widmer & 816 & 207 & 13.8 & 2.80E-01 & 12.1 \\
\hline Widmer & 816 & 207 & 16.2 & & 22.7 \\
\hline Widmer & 816 & 207 & 10.4 & & 12.8 \\
\hline Widmer & 816 & 207 & 11.3 & & 11.7 \\
\hline Widmer & 816 & 207 & 11.9 & & 14.9 \\
\hline Widmer & 816 & 207 & 13.4 & & 14.1 \\
\hline Widmer & 816 & 207 & 15.2 & & 15.0 \\
\hline Widmer & 816 & 207 & 23.4 & & 12.4 \\
\hline Widmer & 649 & 214 & 3294 & 2.60E-04 & 1.6 \\
\hline Widmer & 732 & 221 & 243.7 & 8.80E-03 & 3.9 \\
\hline Widmer & 816 & 221 & 5.5 & 7.80E-01 & 18.3 \\
\hline Widmer & 732 & 234 & 114.2 & 3.30E-02 & 5.7 \\
\hline Widmer & 649 & 241 & 3445 & 3.90E-04 & 3.2 \\
\hline Widmer & 691 & 241 & 539.7 & 1.80E-03 & 2.0 \\
\hline Widmer & 732 & 241 & 40.7 & $2.30 \mathrm{E}-02$ & 2.7 \\
\hline Widmer & 816 & 241 & 2.7 & $1.30 \mathrm{E}+00$ & 12.3 \\
\hline Widmer & 649 & 259 & 1693 & $5.40 \mathrm{E}-04$ & 2.1 \\
\hline Widmer & 816 & 259 & 1.7 & $3.60 \mathrm{E}+00$ & 17.1 \\
\hline Widmer & 816 & 259 & 1.1 & $8.40 \mathrm{E}+00$ & 15.1 \\
\hline Widmer & 649 & 276 & 686 & & 3.7 \\
\hline Widmer & 649 & 276 & 797 & & 5.1 \\
\hline Widmer & 649 & 276 & 1160 & & 2.0 \\
\hline Widmer & 649 & 276 & 1200 & & 4.0 \\
\hline Widmer & 649 & 276 & 1295 & & 4.0 \\
\hline Widmer & 649 & 276 & 1636 & & 3.8 \\
\hline Widmer & 732 & 276 & 18 & 6.00E-02 & 4.1 \\
\hline Widmer & 649 & 283 & 823 & 1.20E-03 & 4.3 \\
\hline Widmer & 732 & 283 & 10.2 & 1.30E-01 & 5.3 \\
\hline Widmer & 649 & 293 & 200 & 1.60E-03 & 4.3 \\
\hline Widmer & 732 & 296 & 5.9 & & 7.6 \\
\hline Widmer & 649 & 310 & 136.9 & 2.90E-03 & 8.2 \\
\hline Widmer & 732 & 310 & 3.7 & 5.30E-01 & 7.5 \\
\hline
\end{tabular}


Table A.8.1. Alloy 25 (L-605) historical creep and stress-rupture data (continued)

\begin{tabular}{|l|r|r|r|r|r|}
\hline $\begin{array}{c}\text { Heat ID / } \\
\text { Source }\end{array}$ & $\begin{array}{c}\text { Temperature } \\
\left({ }^{\circ} \mathrm{C}\right)\end{array}$ & $\begin{array}{c}\text { Stress } \\
(\mathrm{MPa})\end{array}$ & $\begin{array}{c}\text { Rupture } \\
\text { Life } \\
(\mathrm{MPa})\end{array}$ & $\begin{array}{c}\text { Minimum } \\
\text { Creep Rate } \\
(\% / \mathrm{hr})\end{array}$ & $\begin{array}{c}\text { Elongation } \\
(\%)\end{array}$ \\
\hline Widmer & 649 & 331 & 74.9 & $6.50 \mathrm{E}-03$ & 7.9 \\
\hline Widmer & 649 & 345 & 51.6 & $7.50 \mathrm{E}-03$ & 5.3 \\
\hline Widmer & 691 & 345 & 5.3 & $1.10 \mathrm{E}-01$ & 10.1 \\
\hline Widmer & 732 & 345 & 1.3 & $5.70 \mathrm{E}-01$ & 8.7 \\
\hline Widmer & 649 & 352 & 64.4 & $8.00 \mathrm{E}-03$ & 8.3 \\
\hline Widmer & 649 & 372 & 23.1 & $2.70 \mathrm{E}-02$ & 14.1 \\
\hline Widmer & 649 & 414 & 3.9 & & 24.8 \\
\hline Widmer & 649 & 414 & 5.4 & & 13.5 \\
\hline Widmer & 649 & 414 & 5.6 & & 16.0 \\
\hline Widmer & 649 & 414 & 6.2 & & 16.4 \\
\hline Widmer & 649 & 414 & 8 & & 13.8 \\
\hline Widmer & 649 & 414 & 8.6 & & 16.5 \\
\hline Widmer & 649 & 414 & 10.1 & & 16.7 \\
\hline Widmer & 649 & 414 & 11.8 & & 13.4 \\
\hline Widmer & 649 & 414 & 12.7 & & 14.3 \\
\hline Widmer & 649 & 431 & 12 & $9.30 \mathrm{E}-02$ & 18.4 \\
\hline Widmer & 649 & 431 & 8.5 & $7.50 \mathrm{E}-02$ & 19.9 \\
\hline Widmer & 649 & 448 & 5.1 & & 20.8 \\
\hline
\end{tabular}


Table A.8.2. Alloy 25 (L-605) historical creep and stress-rupture data for weldments

\begin{tabular}{|c|c|c|c|c|c|c|}
\hline $\begin{array}{l}\text { Heat ID / } \\
\text { Source }\end{array}$ & $\begin{array}{c}\text { Temperature } \\
\left({ }^{\circ} \mathrm{C}\right)\end{array}$ & $\begin{array}{l}\text { Stress } \\
(\mathrm{MPa})\end{array}$ & $\begin{array}{l}\text { Rupture } \\
\text { Life } \\
\text { (MPa) }\end{array}$ & $\begin{array}{c}\text { Minimum } \\
\text { Creep Rate } \\
(\% / \mathrm{hr})\end{array}$ & $\begin{array}{c}\text { Elongation } \\
(\%)\end{array}$ & $\begin{array}{l}\text { Rupture } \\
\text { Location }\end{array}$ \\
\hline flagella & 760 & 241 & 532.9 & $3.50 \mathrm{E}-03$ & 22.5 & \\
\hline flagella & 760 & 241 & 315.7 & 1.69E-02 & 8.8 & \\
\hline flagella & 760 & 290 & 150.1 & 4.70E-02 & 11.3 & \\
\hline flagella & 760 & 290 & 24.1 & 7.40E-02 & 6.3 & \\
\hline flagella & 760 & 379 & 1.9 & $1.51 E-01$ & 37.5 & \\
\hline flagella & 760 & 379 & 0.2 & & 21.0 & \\
\hline flagella & 760 & 234 & 555.0 & & 36.3 & \\
\hline flagella & 760 & 241 & 300.5 & 4.34E-03 & 13.8 & \\
\hline flagella & 760 & 290 & 16.8 & & 22.5 & \\
\hline flagella & 760 & 290 & 11.0 & 1.25E-01 & 32.5 & \\
\hline flagella & 760 & 379 & 5.0 & 9.70E-01 & 21.3 & \\
\hline flagella & 760 & 379 & 1.6 & $1.34 \mathrm{E}+00$ & 16.3 & \\
\hline flagella & 760 & 379 & 1.4 & $6.25 \mathrm{E}-01$ & 8.8 & \\
\hline flagella & 927 & 83 & 392.9 & 3.30E-02 & 31.3 & \\
\hline flagella & 927 & 83 & 320.9 & $1.55 \mathrm{E}-03$ & 10.0 & \\
\hline flagella & 927 & 117 & 27.4 & 9.37E-02 & 2.5 & \\
\hline flagella & 927 & 117 & 15.6 & & 21.3 & \\
\hline flagella & 927 & 138 & 26.9 & $2.91 \mathrm{E}-01$ & 7.1 & \\
\hline flagella & 927 & 138 & 17.9 & 4.48E-01 & 17.5 & \\
\hline flagella & 927 & 83 & 364.9 & $3.27 \mathrm{E}-02$ & 35.0 & \\
\hline flagella & 927 & 83 & 81.2 & & 16.3 & \\
\hline flagella & 927 & 117 & 66.1 & 1.28E-01 & 42.5 & \\
\hline flagella & 927 & 117 & 31.5 & 1.57E-01 & 27.5 & \\
\hline flagella & 927 & 117 & 5.8 & & 27.5 & \\
\hline flagella & 927 & 138 & 21.4 & 4.07E-01 & 61.3 & \\
\hline flagella & 927 & 165 & 4.3 & $1.66 \mathrm{E}+00$ & 21.0 & \\
\hline flagella & 1093 & 10 & 1614.2 & 5.77E-04 & & \\
\hline flagella & 1093 & 10 & 874.4 & 8.75E-03 & & \\
\hline flagella & 1093 & 24 & 74.6 & 1.99E-02 & 7.5 & \\
\hline flagella & 1093 & 24 & 38.3 & & & \\
\hline flagella & 1093 & 41 & 7.2 & 8.20E-01 & 38.8 & \\
\hline flagella & 1093 & 41 & 1.0 & & 34.0 & \\
\hline flagella & 1093 & 10 & 424.3 & 6.91E-03 & & \\
\hline flagella & 1093 & 13 & 129.8 & & 20.0 & \\
\hline flagella & 1093 & 24 & 75.1 & 8.00E-02 & 22.5 & \\
\hline flagella & 1093 & 24 & 17.6 & & 18.8 & \\
\hline flagella & 1093 & 24 & 17.0 & & 23.8 & \\
\hline flagella & 1093 & 41 & 6.1 & 9.11E-01 & 25.0 & \\
\hline flagella & 1093 & 41 & 2.8 & $1.44 \mathrm{E}+00$ & & \\
\hline flagella & 1093 & 41 & 2.1 & $2.21 E+00$ & 21.3 & \\
\hline ht 1931 & 649 & 345 & 105.0 & $2.50 \mathrm{E}-02$ & 5.0 & base \\
\hline ht 1931 & 649 & 293 & & 2.00E-03 & & \\
\hline ht 1931 & 704 & 276 & 173.0 & $1.50 \mathrm{E}-02$ & 2.0 & haz \\
\hline ht 1931 & 704 & 248 & 432.0 & 1.00E-02 & 2.0 & haz \\
\hline ht 1931 & 760 & 190 & 226.0 & $3.50 \mathrm{E}-02$ & 10.0 & haz \\
\hline
\end{tabular}


Table A.8.2. Alloy 25 (L-605) historical creep and stress-rupture data for weldments (continued)

\begin{tabular}{|c|c|c|c|c|c|c|}
\hline $\begin{array}{l}\text { Heat ID / } \\
\text { Source }\end{array}$ & $\begin{array}{c}\text { Temperature } \\
\left({ }^{\circ} \mathrm{C}\right)\end{array}$ & $\begin{array}{l}\text { Stress } \\
(\mathrm{MPa})\end{array}$ & $\begin{array}{c}\text { Rupture } \\
\text { Life } \\
\text { (MPa) }\end{array}$ & $\begin{array}{l}\text { Minimum } \\
\text { Creep Rate } \\
(\% / h r)\end{array}$ & $\begin{array}{c}\text { Elongation } \\
(\%)\end{array}$ & $\begin{array}{l}\text { Rupture } \\
\text { Location }\end{array}$ \\
\hline ht 1931 & 816 & 121 & 296.0 & 1.50E-02 & 7.5 & haz \\
\hline ht 1931 & 816 & 103 & 897.0 & 6.00E-03 & 7.0 & haz \\
\hline ht 1931 & 871 & 93 & 143.0 & & 4.0 & haz \\
\hline ht 1931 & 871 & 79 & 558.0 & & 7.0 & haz \\
\hline ht 1931 & 982 & 138 & 0.2 & 3.30E+01 & 9.0 & haz \\
\hline ht 1931 & 982 & 103 & 1.2 & $8.40 \mathrm{E}+00$ & 15.0 & base \\
\hline ht 1931 & 1093 & 69 & 0.1 & & 17.0 & base \\
\hline ht 1931 & 1093 & 69 & 0.1 & & 15.0 & base \\
\hline ht 1931 & 1093 & 48 & 0.9 & $5.00 \mathrm{E}+00$ & 17.0 & base \\
\hline ht 1931 & 1149 & 41 & 0.3 & $2.20 \mathrm{E}+01$ & 10.0 & base \\
\hline ht 1931 & 1204 & 28 & 0.5 & $3.00 \mathrm{E}+01$ & 30.0 & base \\
\hline ht 1843 & 760 & 155 & 1693.0 & 1.00E-02 & 9.0 & base \\
\hline ht 1843 & 816 & 121 & 1798.0 & 5.00E-03 & 10.0 & base \\
\hline ht 1843 & 871 & 79 & 1194.0 & & 10.0 & base \\
\hline ht 1843 & 816 & 121 & 1374.0 & 4.00E-03 & 6.0 & haz \\
\hline ht 1335 & 649 & 345 & 372.0 & 4.00E-03 & 6.0 & base \\
\hline ht 1335 & 704 & 276 & 20.0 & & 20.0 & base \\
\hline ht 1335 & 704 & 276 & 86.0 & $2.50 \mathrm{E}-02$ & 3.0 & weld \\
\hline ht 1335 & 760 & 190 & 106.0 & 8.00E-02 & 9.0 & base \\
\hline ht 1335 & 760 & 155 & 755.0 & 1.00E-02 & 12.0 & base \\
\hline ht 1335 & 816 & 121 & 269.0 & 3.00E-02 & 11.0 & base \\
\hline ht 1335 & 816 & 103 & 542.0 & & 11.0 & base \\
\hline ht 1335 & 871 & 78 & 410.0 & & & base \\
\hline astm & 816 & 207 & 28.5 & & 16.0 & base \\
\hline astm & 816 & 148 & 409.7 & & 15.0 & base \\
\hline astm & 816 & 138 & 19.0 & & 13.0 & base \\
\hline astm & 871 & 96.5 & 369.7 & & 5.0 & base \\
\hline astm & 927 & 96.5 & 41.7 & & 10.0 & base \\
\hline astm & 927 & 55.7 & 405.8 & & 5.0 & base \\
\hline astm & 982 & 69 & 43.1 & & 10.0 & base \\
\hline astm & 982 & 41.4 & 135.0 & & & \\
\hline
\end{tabular}




\section{INTERNAL DISTRIBUTION}
1. E. P. George
2. D. B. Glanton
3-4. J. F. King
5. E. Lara-Curzio
6. R. L. Martin
7. T. E. McGreevy

\author{
8. R. G. Miller \\ 9. W. Ren \\ 10-11. J. P. Shingledecker \\ 12. B. L. Sparks \\ 13. R. W. Swindeman \\ 14. G. B. Ulrich \\ 15. ORNL Technical Information Office \\ (RC)
}

\section{EXTERNAL DISTRIBUTION}

16. Robert T. Carpenter, Orbital Sciences Corporation 20030 Century Blvd., Suite 102, Germantown, MD 20874

17. John Dowicki, Office of Radioisotope Power Systems, NE-34/GTN

U. S. Department of Energy, 1000 Independence Avenue SW, Washington, DC 20585-1290

18. Lloyd. Edgerly, Office of Radioisotope Power Systems, NE-34/GTN

U. S. Department of Energy, 1000 Independence Avenue SW, Washington, DC 20585-1290

19. R. G. Hanson, Idaho National Laboratory, P. O. Box 1625, MS-6122, Idaho Falls, ID 83415

20. Stephen G. Johnson, Idaho National Laboratory, P. O. Box 1625, MS-6122, Idaho Falls, ID 83415

21. Robert Lange, Office of Radioisotope Power Systems, NE-34/GTN

U. S. Department of Energy, 1000 Independence Avenue SW, Washington, DC 20585-1290

22. Andrew Leanna, Teledyne Energy Systems, 10707 Gilroy Road, Hunt Valley, MD 21031-1311

23. Michael Katcher, Haynes International, P.O. Box 9013, Kokomo, IN 46904-9013

24. Dwaine Klarstrom, Haynes International, P.O. Box 9013, Kokomo, IN 46904-9013

25-26. Michael McKittrick, Teledyne Energy Systems, 10707 Gilroy Road, Hunt Valley, MD 210311311

27. Office of Scientific and Technical Information (PDF file to ORNL Releasing Official, D. R. Hamrin)

28. Emil Skrabek, Orbital Sciences Corporation 20030 Century Blvd., Suite 102, Germantown, MD 20874

29. Craig E. Van Pelt, Los Alamos National Laboratory, P. O. Box 1633, Los Alamos, NM 87545

30. John Vogt, Teledyne Energy Systems, 10707 Gilroy Road, Hunt Valley, MD 21031-1311 